\title{
Institutional Decolonization: The Internationalization of the Conflict Over Organized Labor in British Guiana, 1946-1961
}

Joshua David Esposito

Follow this and additional works at: https://researchrepository.wvu.edu/etd

\section{Recommended Citation}

Esposito, Joshua David, "Institutional Decolonization: The Internationalization of the Conflict Over Organized Labor in British Guiana, 1946-1961" (2015). Graduate Theses, Dissertations, and Problem Reports. 5551.

https://researchrepository.wvu.edu/etd/5551

This Dissertation is protected by copyright and/or related rights. It has been brought to you by the The Research Repository @ WVU with permission from the rights-holder(s). You are free to use this Dissertation in any way that is permitted by the copyright and related rights legislation that applies to your use. For other uses you must obtain permission from the rights-holder(s) directly, unless additional rights are indicated by a Creative Commons license in the record and/ or on the work itself. This Dissertation has been accepted for inclusion in WVU Graduate Theses, Dissertations, and Problem Reports collection by an authorized administrator of The Research Repository @ WVU.

For more information, please contact researchrepository@mail.wvu.edu. 


\title{
Institutional Decolonization: The Internationalization of the Conflict Over Organized Labor in British Guiana, 1946-1961
}

\author{
Joshua David Esposito
}

Dissertation submitted to the College of Arts and Sciences at West Virginia University in partial fulfillment of requirements for the degree of

\author{
Doctor of Philosophy in History \\ James Siekmeier, Ph.D., Chair \\ Joseph Hodge, Ph.D. \\ Elizabeth Fones-Wolf, Ph.D. \\ Kenneth Fones-Wolf, Ph.D. \\ Alan McPherson, Ph.D. \\ Department of History
}

Morgantown, West Virginia

2015

Keywords: Decolonization, Cold War, AFL-CIO, TUC, British Guiana, Guyana, Cheddi Jagan, People's Progressive Party, Manpower Citizens' Association

Copyright 2015, Joshua David Esposito 


\title{
Institutional Decolonization: The Internationalization of the Conflict Over Organized Labor in British Guiana, 1946-1961
}

\begin{abstract}
This dissertation argues that an internationalized struggle for control of British Guiana's trade unions after 1946 resulted in institutional dysfunction and violence in the early 1960s. Some Guianese nationalists, who eventually became leaders of the People's Progressive Party (PPP), wanted to replace the institutions imported from Great Britain with trade unionism geared towards a Guianese version of communism. Conversely, reformist Guianese labor leaders were intent on establishing a left-leaning capitalist framework of labor relations, primarily based on a British model of unionism. Guianese unionists' ideological proclivities shaped their international affiliations, adding a transnational dimension to the struggle between the colony's nationalist leaders. Thus, this dissertation argues that key British, American, and Eastern-bloc trade union connections were established in the colony in the late 1940s, well before the violent conclusion to Guianese decolonization.
\end{abstract}

Meanwhile, economic weakness, international pressure, and strategic calculations, convinced British policymakers to allow self-government in the colonies after assuring the territories were integrated into a British-led capitalist system. United States policymakers turned their attention to British Guiana when it became evident that the PPP represented a threat to break the colony's connections with the West and undermine American hegemony at the height of the Cold War. Thus, this dissertation analyzes decolonization and the Cold War through a single analytical frame, arguing that the two dynamics were mutually reinforcing.

In response to the PPP's pursuit of social revolution, the Colonial Office engaged in institutionbuilding projects to preserve pro-British capitalism in the colony. Simultaneously, American trade unionists and policymakers pursued institution-building to replace British influence and design Guiana's post-colonial labor relations based on American trade union practices. This dissertation demonstrates that British trade unionists deferred to American labor leaders in British Guiana after 1960, and argues that the colony's transition into the American sphere of influence among non-governmental actors preceded the end of formal British rule in the colony. 


\section{Acknowledgments}

Over the past few years I sent about a dozen unsolicited emails to scholars with various questions relating to my dissertation. Almost without exception their responses included comments letting me know how lucky I was to have the opportunity to work with James Siekmeier. Dr. Siekmeier, generously shared his knowledge of archival research and provided feedback on more than a dozen papers that evolved into this dissertation over the course of seven years. Perhaps more importantly, Dr. Siekmeier went above and beyond in offering guidance on teaching, advising, obtaining grants, giving conference papers, and choosing and pursuing a career path. When I reflect on my time in Morgantown, the friendship we developed and our lunches at the Daily Grind will be among my fondest memories. To him I extend a heartfelt thank you.

My first day of graduate school I walked across the hall after Dr. Siekmeier's class and into a course on British Empire with Joseph Hodge — and their combined influences shaped my thinking on international relations ever since. I would like to thank Dr. Hodge, who guided the development of my dissertation topic in its most embryonic stages. He also provided me with a wealth of information on researching in and maneuvering around London, where much of the research for this dissertation was conducted. I owe Dr. Hodge a final note of appreciation. I was first accepted into WVU's MA program for the 2007 academic year, and Dr. Hodge agreed to defer my enrollment so I could complete my enlistment in the Navy. His willingness to work with me to ensure I could attend WVU solidified my at-the-time uncertain notion of going to graduate school.

I would like to extend a special thank you to Elizabeth Fones-Wolf for her tireless dedication to the WVU history department. Dr. Fones-Wolf ran the history department at WVU with impressive precision. She offered me the opportunity to advise and mentor undergraduates, and 
provided guidance for me along the way, giving me another venue through which to engage the academic experience while generating much appreciated extra income. Perhaps most importantly, Dr. Fones-Wolf offered reassurance and advice during the most intense part of my job search. I would also like to thank Ken Fones-Wolf, who provided constant encouragement over the past seven years and a positive presence in Woodburn Hall day in and day out. He also offered insightful feedback on this dissertation and served as a valued resource whose door was always open whenever I needed direction in examining labor history.

I would also like to express a great deal of appreciation for Alan McPherson, with whom I have had the pleasure of working for the past year. Dr. McPherson's comments, suggestions, criticisms, and questions helped me think more deeply about my writing style and more broadly about how to turn research material into a historical argument. His influence far surpassed the time we worked together and it continues to guide the work I've engaged in since this dissertation's completion. I am also appreciative of Robert Waters, who offered research advice, provided feedback on several dissertation chapters, and who served as a sounding board for the arguments developed in this project. Most importantly, Dr. Waters proved an invaluable resource on Guyana-specific issues while offering encouragement throughout the writing process. It is my humble hope that this dissertation complements his work in some small way. I would like to offer an additional thank you to Hilbourne Watson, who offered valuable advice on Guyanaspecific research questions and whose work on the subject helped me to understand the broader dynamics in which the Guianese experience unfolded.

Historical studies are the reflection of countless hours sifting through historical records. Given the overwhelming amount of archival material available to Cold War scholars, research would be impossible without the help of knowledgeable, patient archivists willing to give of their time to navigate researchers through vast holdings. Therefore, I would like to express my 
appreciation for the archivists who ensured that I found the most useful material for this dissertation. I would especially like to thank Mr. Kevin Bailey at the Dwight D. Eisenhower Presidential Library, Mr. James Goddard at the Trade Union Congress Library Collections at London Metropolitan University, and Ms. Linda DeLoach at the George Meany Memorial Archives (formerly in Silver Spring, MD). Mr. Bailey, Mr. Goddard, and Ms. DeLoach all took the time to help me locate material in their collections prior to and during my visits to their libraries. They also offered assistance in understanding their reference systems, navigating countless boxes of material, and ultimately pointed me toward a cache of documents that form the base of this dissertation. I would also like to thank Mr. Daniel Gilfoyle at The National Archives of the United Kingdom. Mr. Gilfoyle helped me identify the most useful material for this project prior to my visit to London, which allowed me to maximize the short time I had to research overseas. Finally, I would like to thank Ms. Sharon Thayer at the University of Vermont and Ms. Patrizia Sione at the Kheel Center, Cornell, who took the time to digitize and send me material from their collections since I was unable to visit them. I would also like to thank West Virginia University Provost's Office for a generous Fellowship that funded the last year of this dissertation, and the committee that awarded me the Wesley M. Bagby, III Scholarship, which also provided important financing for this project.

Joel Christenson has played the role of mentor and friend ever since we took Dr. Siekmeier's foreign policy course together in the fall of 2008. Over the years he has offered advice, both requested and unsolicited when necessary, given feedback on countless papers and job materials, shared hotel rooms at conferences, and answered all variations of every possible question a graduate student (or new government historian) could possible contrive-usually more than once. I'm extremely excited at the prospect of collaborating professionally in the coming years. I would be remiss if I did not also thank Emily Christenson for her hospitality whenever Karina 
and I needed shelter during research trips, and for Teddy and Sylvia's willingness to share their parents' time.

I would also like to thank Joe Rizzo, with whom I had the pleasure of sharing a very unsecure cubicle for several years. Joe and I came into WVU together and went through the major hurdles of obtaining a doctoral degree at roughly the same time. As a result, his counsel was much appreciated as we talked through the frustrations of preparing for comprehensive exams and completing our dissertations. Bob and Shannon Tinnell are two of the most inspiring people I've had the opportunity to meet and their friendship during my time in Morgantown will be among my most cherished memories. Trevor Wolfe deserves a great deal of thanks for waking up at four in the morning to share our research over coffee, and to banter about philosophy. Trevor's companionship during morning workouts, and his cooking when Karina was away on research, kept my body and mind operational during the long days preparing for comprehensive exams and in the early stages of dissertation research.

I would also like to thank Billy Feeney, David Goldberg, Rich Hulver, Jake Ivey, Jordan Lieser, Jinny Turman, Brandon Williams, and Adam Zucconi. They are all impressive scholars and good friends. I look forward to reading their work as it is published. In particular, I want to thank Brandon for reminding me that historical works are not stories frozen in time, but tools for understanding and activism in the present. I expect his work in particular to make a powerful contribution to the future of our profession, and I hope to contribute in whatever manner possible. Tim Schultz and Isadora Cipolletta made it possible to finish this dissertation by opening their home as I transitioned to a full-time position while defending and revising this dissertation. Tim is an impressive historian and they are good friends who made the completion of this process possible. Marc Walter also went out of his way to offer encouragement at crucial times - before and during this process. 
The appreciation I have for the family that offered Karina and I support over the past seven years goes beyond words. Chase Merritt, Chad Borek, Caleb Foreman, Leon McCleary, Jody Judson, Jeremy Boyd, and Matt Harder may not have a biological connection, but they are my brothers. Obstacles seem minor when you have seven guys behind you pushing you forward. I am grateful for the love and support of Dulce and Rick Rittner since I met their daughter. The long road to a Ph.D. would be impossible to travel without an understanding family encouraging you along the way. Adam, Patricia, Julia, and Collin Wood also offered reassurance over the years. Long conversations by the fire while sharing cigars and scotch with Adam were valued respites during our far-too-infrequent visits. Thank you also to Anderson Faria Garcia and Zack Rittner, who have been wonderful brothers-in-law, and to Michael Oliveira for his all-important Portuguese lessons. My parents, Doug and Deb Esposito, deserve more thanks than I can begin to offer. I was able to pursue my dream because of their resolute desire to give their children that opportunity. My pursuit of a Ph.D. would never have begun without their love, hard work, and self-sacrifice. I would also like to thank my sisters, Shannan and Whitney Esposito, for their love and reassurance. No brother has ever been blessed with two more amazing little sisters. I would like to thank my godmother, Patricia Brachman, for her quiet but firm guidance over the years and for opening her home to Karina and I whenever we could find the time to get away. Our quiet mornings sharing blueberry muffins will always be on my mind. Finally, I would like to thank my uncle, Martin Schor, who for as long as I can remember encouraged, and occasionally challenged me to be ambitious and pursue whatever goals I chose to set for myself.

I have one final acknowledgment to offer, and if I wrote another four hundred pages I wouldn't scratch the surface of how much love and appreciation I feel for my wife, Karina Esposito. Karina has offered more love, praise, and just as importantly constructive criticism, than words can describe. She read this dissertation countless times, with a smile, and provided 
the perfect balance of advice and encouragement. She bore the burden of balancing a (more than) part-time job, teaching, taking classes, researching, and cooking so that I could focus on teaching and writing. She was optimistic during the most daunting phases of writing and job searching, consoling during times of tragedy, and she found every possible way to make graduate school a fun, happy place to be. She made me laugh when I was frustrated, and made me focus when I was distracted. On top of all of that, she made progress in her own work, which is brilliant, exciting scholarship. Karina was the central part of this process, every day, and to her I offer the greatest of thanks and all of my love. 


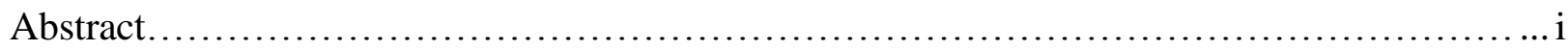

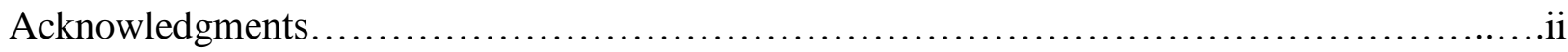

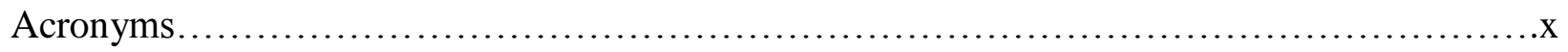

Chapter 1: Introduction: Institutional Decolonization as a Prism for Understanding International

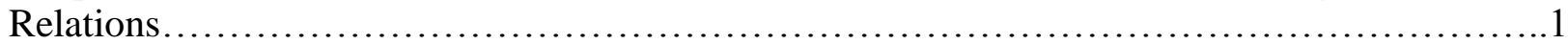

The Cold War and Decolonization.................................................

British Guiana's Significance in the Post-War Period.................................. 4

Institutional Decolonization................................................... 9

Capitalism, Colonialism, and the British Guianese Economy $\ldots \ldots \ldots \ldots \ldots \ldots \ldots \ldots \ldots \ldots \ldots \ldots$

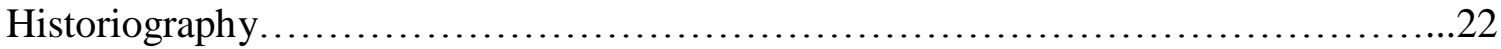

Chapter 2: The Origins of AFL, CIO, and TUC Involvement in Institutional Decolonization....31

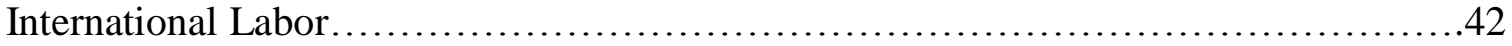

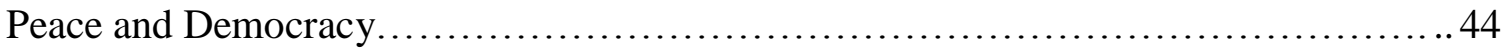

Economic Development, Stability, and Institution Building.........................53

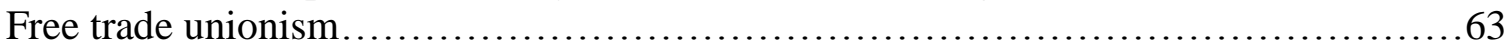

The Impact of International Labor Organizations on AFL, CIO, and TUC Leaders.......66

Chapter 3: Anglo-American Objectives and the Limits of Official Cooperation..................80

AFL-CIO and TUC Debates on Colonialism and Institution-Building..................85

Chapter 4: Economic Emancipation: The Ideological Origins of the People's Progressive Party Challenge to Reformist Trade Unionism............................................... 118

The Clash of Trade Union Philosophies in British Guiana............................125

The People's Progressive Party's Political Objectives.................................139

Conclusion........................................................................... 151

Chapter 5: The First Phase of Institutional Decolonization in British Guiana..................155

The Emergence of a left-coalition opposition.....................................160

Early Institution-Building in the Wake of the PAC Challenge........................171

The Internationalization of Institutional Decolonization...........................178

Institutional Decolonization during the PPP government.............................196

Labor Conflict and the Suspension of the Waddington Constitution....................207

Response to the Suspension and Conclusions...................................225

Chapter 6: Checking the Excesses of Democracy: International Institution-Building in British

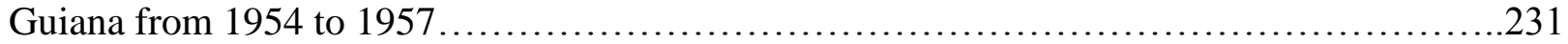

Origins and Background of the Second Phase of Institutional Decolonization in British Guiana..........................................................................237

American Foreign Policy toward British Guiana during the Eisenhower

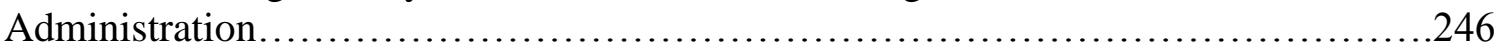




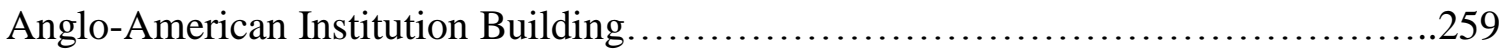

Guianese Activism and Internationalism.....................................278

Chapter 7: The Fracturing of British Guiana, 1957-1961_................................301

The Anglo-American Response to the 1957 Election...............................305

International Labor Developments and American Labor's Expanded Connections in

British Guiana.......................................................... 314

Guianese Trade Union Conflicts and the PPP's Alienation from the Labor Movement.318

Wages Council Debate......................................................... 321

Guianese Appeals for American Funding and Anglo-American Tensions...............327

Labor Relations between the PPP and Government Workers.......................330

The MPCA, BGTUC, and International Relations................................333

Industrial Labor Unrest and Workers Protests in from 1959-1960....................337

Conclusion........................................................... 343

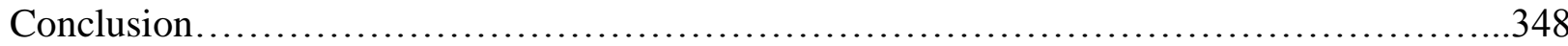

Institutional Warfare and American Intervention..................................348

The Lessons of British Guiana for Post-War United States Foreign Policy..............359

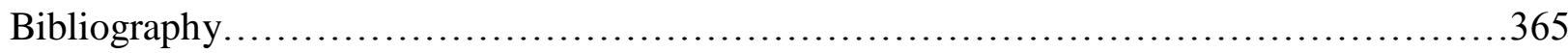




\section{Acronyms}

\begin{tabular}{|c|c|}
\hline AFL & American Federation of Labor \\
\hline AFL-CIO & $\begin{array}{l}\text { American Federation of Labor-Congress of Industrial Organizations (merged in } \\
\text { 1955) }\end{array}$ \\
\hline BGEIA & British Guiana East Indian Association \\
\hline BGLU & British Guiana Labor Union \\
\hline BGTUC & British Guiana Trades Union Council \\
\hline BGWL & British Guiana Workers League \\
\hline BGSWU & British Guiana Sugar Workers Union \\
\hline BTUC & British Trades Union Congress \\
\hline CAC & Colonial Advisory Committee (BTUC) \\
\hline CCL & Caribbean Congress of Labor \\
\hline CIA & Central Intelligence Agency \\
\hline CLC & Caribbean Labor Congress \\
\hline $\mathrm{CIO}$ & Congress of Industrial Organizations \\
\hline Comintern & Communist International \\
\hline FBI & Federal Bureau of Investigation (United States) \\
\hline FOA & Foreign Operations Administration (United States) \\
\hline FTUC & Free Trade Union Committee \\
\hline FUGE & Federation of Unions of Government Employees (British Guiana) \\
\hline GAWU & Guiana Agricultural Workers Union \\
\hline GIWU & Guiana Industrial Workers Union \\
\hline ICA & International Cooperation Administration \\
\hline ICFTU & International Confederation of Free Trade Unions \\
\hline ILO & International Labor Organization \\
\hline JTUC & Joint Trade Union Committee \\
\hline MPCA & Manpower Citizens Association (British Guiana) \\
\hline NSC & National Security Council \\
\hline OAS & Organization of American States \\
\hline ORIT & Inter-American Regional Organization of Workers (Regional Affiliate of ICFTU) \\
\hline PAC & Political Affairs Committee (British Guiana) \\
\hline SPA & Sugar Producers Association (British Guiana) \\
\hline SWFU & Sawmill and Forest Workers Union (British Guiana) \\
\hline SWU & Sawmill Workers Union (British Guiana) \\
\hline UAW & United Auto Workers (United States) \\
\hline UN & United Nations \\
\hline WFTU & World Federation of Trade Unions \\
\hline
\end{tabular}




\section{Chapter 1: Introduction: Institutional Decolonization as a Prism for Understanding International Relations}

"In most countries, the progressive trade union movement is the backbone of the national liberation struggle. Trade unions, by the very nature of their organization and activities must, of necessity, be part of the struggle for self-rule and freedom from foreign control.” Janet Jagan, $1959^{1}$

"Once the crucial phase of the liberation struggle begins to take shape, a group of indigenous union leaders decides to create a national labor movement. The locals desert en masse the previous organization imported from the metropolis. The formation of this union is another way for the urban population to exert pressure on the colonial authorities... The national labor unions born out of the liberation struggle are... above all political and nationalist." Frantz Fanon, The Wretched of the Earth ${ }^{2}$

\section{The Cold War and Decolonization}

Throughout the twentieth century the system of international relations underwent extensive transformations. Competition between world powers, and the impact of industrialization, culminated in two massive world wars from 1914 to 1918 and 1939 to 1945. In part as a consequence of those conflagrations, the distribution of global power shifted away from European empires toward the United States and the Soviet Union, and ambiguously toward European colonies. ${ }^{3}$ American and Soviet policymakers opposed the perpetuation of colonial systems for ideological and strategic reasons; however, the two nations' leaders had irreconcilable ideas of how the modern industrial world should be restructured ${ }^{4}$ Colonial leaders

\footnotetext{
${ }^{1}$ Janet Jagan, “To Working People of Guiana: Join the Struggle for Self-Rule,” Thunder, May 2, 1959, Cheddi Jagan Research Center (hereafter: CJRC).

${ }^{2}$ Frantz Fanon, The Wretched of the Earth (New York: Grove Press, 2004), 73 (originally published in 1961).

${ }^{3}$ Nigel Bolland offers a concise explanation of World War II's impact on the British Empire. See: O. Nigel Bolland, The Politics of Labour in the British Caribbean: The Social Origins of Authoritarianism and Democracy in the Labour Movement (Oxford: James Currey, 2001), 381-383. See also: John Darwin, "Diplomacy and Decolonization," in, Kent Fedorowich and Martin Thomas, eds., International Diplomacy and Colonial Retreat (London: Frank Cass, 2001), 13-18; William Roger Louis, Imperialism at Bay: The United States and the Decolonization of the British Empire 1941-1945 (New York: Oxford University Press, 1978).

${ }^{4}$ Ideology: Daniel Yergin, Shattered Peace: The Origins of the Cold War and the National Security State (Boston: Houghton Mifflin Company, 1977); Michael Hunt, Ideology and U.S. Foreign Policy (New Haven, CT: Yale University Press, 1987); Michael E. Latham, Modernization as Ideology: American Social Science and "Nation Building" in the Kennedy Era (Chapel Hill: The University of North Carolina Press, 2000); John Fousek, To Lead the Free World: American Nationalism and the Cultural Roots of the Cold War (Chapel Hill: The University of
} 
often pursued engagement with the superpowers based on the type of economic and social model they thought would best apply to their newly independent countries. As a result, the Cold War rivals courted colonial leaders, and frequently intervened in decolonizing areas, to expand capitalist or communist systems. The Cold War and decolonization were mutually constitutive expressions of the larger changes in international relationships.

In the British Guiana, the Political Affairs Committee (PAC), which became the People's Progressive Party (PPP) in 1950, attempted to break from the American-led capitalist system. PAC and PPP leaders attempted to establish Guianese socialism as a means of addressing the colony's severe poverty, and their efforts included establishing ties to socialist countries in the Eastern-bloc. ${ }^{5}$ At the same time, opponents of the PAC/PPP exploited connections to British and American labor leaders to oppose the social revolution and institutionalize capitalism and connections to Great Britain and the United States. The combination of internal debates over the structure of society and appeals to Cold War rivals initiated a Cold War conflict in the colony. American and British labor and political leaders were influenced by Cold War ideology and appealed to it; however, at a basic level their opposition to the PAC/PPP was rooted in a desire to integrate the Guiana into the Western system prior to its independence. ${ }^{6}$ This is particularly evident at the institutional level when examining the conflicts between trade unionists in Guiana, Great Britain, and the United States; and it helps to explain why non-state actors played the most important role in British Guiana. The Guianese experience also sheds light on the early Cold War

North Carolina Press, 2000); Frank Ninkovich, The Wilsonian Century: U.S. Foreign Policy Since 1900 (Chicago: University of Chicago Press, 1999). Geo-strategic concerns: John Lewis Gaddis, We Now Know: Rethinking Cold War History (Oxford: Oxford University Press, 1997); Robert A. Pollard, Economic Security and the Origins of the Cold War, 1945-1950 (New York: Columbia University Press, 1985).

${ }^{5}$ Jan Koura and Robert Waters, "Cheddi Jagan and Guianese Overtures to the East: Evidence from the Czech National Archives," Cold War International History Project, e-Dossier No. 54, Wilson Center, 2015.

${ }^{6}$ Though as will be explained in chapter three, British and American policymakers disagreed strongly on which nation's institutional values should shape the Western capitalist system. 
in that it suggests British colonists engaged in a conflict of ideologies before the Cold War began.

The Cold War centered on United States officials' attempt to build and integrate capitalist democracies into an American-led system and Soviet leaders' advocacy for development based on Soviet-styled communism in conjunction with increased Russian influence. ${ }^{7}$ Importantly, scholars note that American and Soviet policymakers feared that the expansion of their rivals' political-economic ideology would manifest in a loss of relative power and represent an existential threat to their own survival. ${ }^{8}$ European empires faced domestic constraints, economic weakness, nationalist movements in colonial territories, and international pressures from state as well as non-state actors that further eroded their ability and, at times, desire to reassert control over colonial territories. ${ }^{9}$ Post-1945 international relations can be understood to a great extent as a period of adjustment in the international structure that Matthew Connelly refers to as a

\footnotetext{
${ }_{7}$ Thomas J. McCormick, America's Half-Century: United States Foreign Policy in the Cold War (Baltimore: Johns Hopkins University Press, 1989); Odd Arne Westad, The Global Cold War: Third World Interventions and the Making of Our Times (New York: Cambridge University Press, 2005); Victoria De Grazia, Irresistible Empire: America's Advance through Twentieth-Century Europe (Cambridge, MA: The Belknap Press of Harvard University Press, 2005); Melvyn P. Leffler and Odd Arne Westad, eds., The Cambridge History of the Cold War, Vol. 1: Origins (Cambridge: Cambridge University Press, 2010); Vladislav M. Zubok, A Failed Empire: The Soviet Union in the Cold War From Stalin to Gorbachev (Chapel Hill: The University of North Carolina Press, 2007); Kathryn C. Statler and Andrew L. Johns, eds., The Eisenhower Administration, the Third World, and the Globalization of the Cold War (Lanham, MD: Rowman \& Littlefield Publishers, Inc., 2006).

${ }^{8}$ Melvyn Leffler, A Preponderance of Power: National Security, the Truman Administration, and the Cold War (Stanford: Stanford University Press, 1992); John J. Mearsheimer, The Tragedy of Great Power Politics (New York: W.W. Norton \& Company, 2001).

${ }^{9}$ The desire to retain empire varied with time and place; however, the broad reappraisal of colonial policy after World War II trended toward decentralization of formal colonial control and eventually toward decolonization. While not an exhaustive list, the following works are most useful in overviewing decolonization's central themes. For a more complete list, see Bibliography. Matthew Connelly, A Diplomatic Revolution: Algeria's Fight for Independence and the Origins of the Post-Cold War Era (Oxford: Oxford University Press, 2002); John Darwin, "Decolonization and the End of Empire," in Robin Winks and William Roger Louis, The Oxford History of the British Empire, Vol. 5 (Oxford: Oxford University Press, 1999); Niall Ferguson, Empire: The Rise and Demise of the British World Order and the Lessons for Global Power (New York: Basic Books, 2002); Cary Fraser, Ambivalent Anti-Colonialism: The United States and the Genesis of West Indian Independence, 1940-1964 (Westport, CT: Greenwood Press, 1994); Ronald Hyam, Britain's Declining Empire: The Road to Decolonisation 1918-1968 (Cambridge: Cambridge University Press, 2006); William Roger Louis, Ends of British Imperialism: The Scramble for Empire, Suez, and Decolonization (London: I.B. Tauris, 2006); Spencer Mawby, Ordering Independence: The End of Empire in the Anglophone Caribbean, 1947-1969 (New York: Palgrave Macmillan, 2012); Jason Parker, Brother's Keeper: The United States, Race, and Empire in the British Caribbean, 1937-1962 (Oxford: Oxford University Press, 2008).
} 
"simultaneous fragmentation and integration of the world community." Importantly, Connelly and Jason Parker demonstrate that the Cold War involved a critical North-South conflict in which actors in the developing world exerted disproportionate influence through nongovernmental organizations. ${ }^{10}$ That international reorientation was complicated by ideological and national rivalry between the United States and Soviet Union for dominance in the revised system.

\section{British Guiana's Significance in the Post-War Period}

Guyana is a small country located between Venezuela, Brazil, and Suriname on the Caribbean coast of South America. Territorially Guyana is slightly smaller than Idaho, has a population of around 735,000 , and as of 2014 is among the poorest countries in the hemisphere with a per capita GDP marginally higher than Bolivia, Nicaragua, and Honduras. ${ }^{11}$ The area that became Guyana when it gained independence from Great Britain in 1966 was previously known as British Guiana beginning in 1815 when the British formally assumed control of the colony after defeating the Dutch in the Napoleonic Wars. ${ }^{12}$

At first glance, British Guiana appears to scholars of United States foreign relations as merely another example of American intervention, an interesting and temporary sideshow for global superpowers during the Cold War. Appearances, however, can be deceiving. The progression toward self-government in British Guiana was not as violent as decolonization in Kenya, India, or Vietnam and as a result it has received much less attention from scholars. ${ }^{13}$

\footnotetext{
${ }^{10}$ Connelly, A Diplomatic Revolution, 10. Parker, Brother's Keeper.

${ }^{11}$ CIA World Factbook, https://www.cia.gov/llibrary/publications/the-world-factbook/geos/gy.html

${ }^{12}$ Stephen G. Rabe, U.S. Intervention in British Guiana: A Cold War Story (Chapel Hill: The University of North Carolina Press, 2005), 15.

${ }^{13}$ In particular, it is noteworthy that there is a considerable amount of scholarship on British Guiana that addresses the colony as part of broader studies of decolonization or American intervention. Placing the Guianese experience in a comparative context allows scholars to illuminate important general concepts; however, these works are inherently limited in their ability to closely analyze the process of decolonization in the colony. See: Sara Abraham, Labour and the Multiracial Project in the Caribbean: Its History and Its Promise (Lanham, MD: Rowman \& Littlefield
} 
Nonetheless, Guiana played a key role in shaping the post-war world. It was the largest British colony in the Caribbean where there was a strong possibility that self-determination would have led to social revolution and close association with the Eastern-bloc. ${ }^{14}$

In British Guiana the PAC represented the earliest, most consistent attempt at peaceful social revolution within the British Empire. PAC and PPP leaders attempted to move toward a Marxist-Leninist development model and established connections with the Eastern bloc to address the extreme poverty that had long plagued the colony's people. The PAC/PPP met constant resistance from reformist Guianese leaders wary of Marxism-Leninism, beginning with the PAC's founding in 1946. At the same time, British and American political and labor leaders and Western international trade unionists responded to the PPP with political intervention and the first attempt at full-scale post-war institution-building. The political, social, and physical conflicts that rocked the colony between 1946 and 1965, and the appeals of competing Guianese labor leaders to both sides of the Cold War divide, evidence an important connection between the Cold War and decolonization. The Guianese experience also provides a clear example of the significant influence of non-state actors on post-1945 international relations.

The British Empire slowly receded in the Caribbean beginning in the late 1930s, creating the conditions for the Cold War's expansion into the region after World War II, and Guianese

\footnotetext{
Publishers, Inc., 2007); Richard J. Barnet, Intervention and Revolution: The United States in the Third World (New York: World Publishing Company, 1968); Bolland, The Politics of Labour in the British Caribbean; Cary Fraser, Ambivalent Anti-Colonialism: The United States and the Genesis of West Indian Independence, 1940-1964 (Westport, CT: Greenwood Press, 1994); Frank Furedi, Colonial Wars and the Politics of Third World Nationalism (London: I.B. Tauris Publishers, 1994); Gerald Horne, Cold War in a Hot Zone: The United States Confronts Labor and Independence Struggles in the British West Indies (Philadelphia: Temple University Press, 2007); Matthew Lange, Lineages of Despotism and Development: British Colonialism and State Power (Chicago: The University of Chicago Press, 2009); Perry Mars and Alma H. Young, eds., Caribbean Labor and Politics: Legacies of Cheddi Jagan and Michael Manley (Detroit: Wayne State University Press, 2004); Mawby, Ordering Independence.

${ }^{14}$ Throughout this dissertation I use the terms Guiana and British Guiana to refer to the colony.
} 
leaders played an important role in the larger Cold War conflict. ${ }^{15}$ The PAC/PPP's most important leader, Cheddi Jagan, was born into poverty on the Guianese plantation at Port Mourant in 1918. Jagan, who was of East Indian descent, used his family's life savings to travel to the United States where he studied from 1936 to 1943. Upon his return, Jagan entered politics and, along with his American-born wife, Janet Rosenberg, helped found the PAC. In 1953 Jagan introduced a proposal that expanded the communist-dominated World Federation of Trade Unions's (WFTU) efforts in colonial territories and, in 1961, he became one of the first colonial leaders to speak at the United Nations (UN). ${ }^{16}$ Leaders of the Manpower Citizens' Association (MPCA), the PAC/PPP's most consistent rival, responded by playing a central role in founding the Caribbean Area Division of the Inter-American Regional Organization of Workers (CADORIT), the local arm of the Anglo-American dominated, staunchly anti-communist, International Confederation of Free Trade Unions (ICFTU). ${ }^{17}$

In 1954 the British Trades Union Congress (TUC) designated the MPCA, a reformist Guianese sugar workers' union, as the first colonial labor organization to be the recipient of a full-scale institution-building program. Colonial leaders and British trade unionists argued that

\footnotetext{
${ }^{15}$ Jason Parker's Brother's Keeper: The United States, Race, and Empire in the British Caribbean, 1937-1962 most effectively explains the West Indian colonies' gradual transition from formal British control to independence within the American sphere of influence.

${ }^{16}$ Jagan and other Caribbean scholars claim he was the first colonial leader to speak directly to the UN General Council. Cheddi Jagan, The West on Trial: My Fight for Guyana's Freedom (New York: International Publishers, 1967), 13-15; J.Y. Mackenzie, Foreign Office to S.E.V. Luke, Esq., Colonial Office, January 2, 1952, CO 968-252, BNA; "Survey of Communism in the West Indies, 1951," undated, CO 968-252, BNA; Secretary of State for the Colonies to Parliament, "British Guiana: Suspension of the Constitution," October 1953, CO 859-772, BNA "History of the PPP," January 1963, CJRC; Basil A. Ince, Decolonization and Conflict in the United Nations: Guyana's Struggle for Independence (Cambridge, MA: Schenkman Publishing Company, 1974), 70.

${ }^{17}$ Luis J. Marcano, Secretary, CADORIT, “Report on CADORIT's Activities,” December 31, 1954, RG 18: International Affairs Department, Staff Files: George Delaney's Files, 1921-1957, Box 11, ORIT 3rd Congress, 1955, George Meany Memorial Archives, Silver Spring, MD (Hereafter GMMA). Caribbean Area Division of ORIT of the ICFTU: Information Bulletin No. 1," February 1953, RG 18-009: International Affairs Department, Staff Files: Serafino Romualdi's Files, 1945-1961, Caribbean Area, 1953-1956, GMMA; Robert Alexander interview with Sheikh Shakoor, June 4, 1953, RG 18-003, International Affairs Department, Jay Lovestone Files, 1944-1973, Box 2, Alexander, Robert, 1953, GMMA; Leo E. Eliazer, Regional Organizer of ORIT in the Caribbean Areas, "Report on British Guiana," RG-18, International Affairs Department, Staff Files: George Delaney's Files, 19211957, ORIT Executive Board Meetings, 1951-1953, GMMA.
} 
without external funding, training, and support in negotiations, the MPCA would collapse, destroying the Guianese labor movement. British assistance aimed at increasing the size and effectiveness of reformist Guianese labor organizations. As organizing improved, the British sought to strengthen structural connections between the unions and employers while institutionalizing reformist trade unionism within the state apparatus-embedding a capitalist system in British Guiana. The precedent-setting program directly taxed British workers and combined their funds with covert aid from the Colonial Office to aid the MPCA. ${ }^{18}$ In 1959 the British Guiana Trades Union Council (BGTUC) became the first colonial trade union delegation received by the Colonial Office and TUC in London for the purpose of discussing territorial development. ${ }^{19}$ The extent of British support for reformist trade unions in Guiana suggests that policymakers, colonial officials, and trade union leaders in the United Kingdom considered the colony among the most important strategic challenges of the late-1950s and early 1960s.

American policymakers and trade union leaders exhibited similar concern about the colony. Serafino Romualdi, the inter-American representative of the American Federation of Labor-Congress of Industrial Organizations (AFL-CIO), acknowledged that beginning in 1951 he did "everything in [his] power" to oppose the Jagan-led PPP after becoming convinced the Guianese leader was a dedicated communist. The AFL and CIO (and later the AFL-CIO) unwaveringly followed Romualdi's lead throughout the 1950s and early 1960s. ${ }^{20}$ In 1961 , just

\footnotetext{
${ }^{18}$ N.A. Mayle, Colonial Office Minute to Mr. Rogers and Mr. Watson, December 23, 1954, CO 859-773, BNA; "Note of Meeting to Discuss Trade Unionism in British Guiana," July 1, 1954, CO 859-773, BNA; N.L. Mayle to Alfred Savage, August 4, 1954, CO 859-773, BNA; N.D. Watson to Sir T. Lloyd and N.L. Mayle, December 16, 1954, CO 859-773, BNA; Trades Union Congress, "Colonial Work of the T.U.C.," June 6, 1956, Marjorie Nicholson Files, Box 15, Trade Unions+Colonies, Trades Union Congress Library, London Metropolitan University, London (Hereafter TUCLC); Rabe, U.S. Intervention in British Guiana, 51-52.

${ }^{19}$ Carroll H. Woods to Department of State, April 8, 1959, 841.00/4-859, General Records of the Department of State, Central Decimal Files, Box 4451, RG 59, NARA II.

${ }^{20}$ Serafino Romualdi, Presidents and Peons: Recollections of a Labor Ambassador in Latin America (New York: Fund \& Wagnalls, 1967), 346. The AFL and CIO were separate organizations until 1955 when they merged to unify the United States labor movement.
} 
three months after the Bay of Pigs fiasco, Senator Thomas Dodd of Massachusetts warned legislators that Cheddi Jagan was "more dangerous than [Fidel] Castro.",21 American concern with controlling Guianese decolonization reached the highest levels of the United States government. Historian Arthur Schlesinger, Jr., Special Assistant to President John F. Kennedy, noted in 1962 that the United States spent more man-hours per capita on British Guiana than any other area. ${ }^{22}$ By 1964 AFL-CIO representatives suggested that British Guiana was among the most strategically important areas of the world and warned TUC leaders that Guiana, Cuba, and Vietnam represented the key areas of potential communist subversion. ${ }^{23}$ Crucially, U.S. policymakers' hostility toward the PAC/PPP followed American labor leaders' opposition to the Jagan-led movement and the AFL-CIO's antagonism to the party was largely a response to appeals from the MPCA.

The PPP's rejection of the Anglo-American post-war system preceded more famous examples of leftist regional movements in Cuba, Chile, and even Guatemala, and there is some evidence that Cuban leaders considered the PPP an important ally in the early 1960s. ${ }^{24}$ Most

\footnotetext{
${ }^{21}$ Thomas Dodd, "Press Release from Statement on the Floor of the Senate," July 17, 1961, The Papers of Alan Grant, Box 15, Dwight D. Eisenhower Presidential Library, Abilene, Kansas (Hereafter, DDEL). In April 1961 a group of Cuban exiles trained and armed by the Central Intelligence Agency (CIA) landed in Cuba with the intention of initiating a counterrevolution to overthrow the Fidel Castro-led revolutionary government in Havana. The operation failed disastrously and generated strong international condemnation. Nonetheless, American policymakers considered the Castro government so threatening to United States interests that plans to subvert the Cuban government and assassinate Castro continued for decades. The John F. Kennedy Presidential Library provides a useful overview of the Bay of Pigs invasion. See: "The Bay of Pigs," John F. Kennedy Presidential Library and Museum: http://www.jfklibrary.org/JFK/JFK-in-History/The-Bay-of-Pigs.aspx, Last Accessed May 3, 2015 .

${ }^{22}$ Memorandum form the President's Special Assistant (Schlesinger) to President Kennedy, March 8, 1962, Foreign Relations of the United States, 1961-1963 (Hereafter FRUS), Volume XII, American Republics, eds., Edward C. Keefer, Louis J. Smith, and Charles S. Sampson (Washington D.C.: Government Printing Office), Document 267. ${ }^{23}$ Report of the $96^{\text {th }}$ Annual Trades Union Congress, September 7-11, 1964, 427, TUC History Online, http://www.unionhistory.info/britainatwork/emuweb/objects/nofdigi/tuc/imagedisplay.php?irn=6016484\&reftable=e catalogue\&refirn=6016378, Last Accessed July 12, 2015.

${ }^{24}$ According to Ricardo Garcia, Cuban Ambassador to Guyana, a man named Osvaldo Cardenas claimed that Che Guevara chose him to assist the PPP government in 1963 during the period of AFL-CIO supported general strikes in the colony. Cardenas claimed that Guevara emphasized Cuba's eternal gratitude for Jagan's support in the early days of the Cuban Revolution and during the Bay of Pigs and October Crisis (Cuban Missile Crisis). According to Cardenas, Jagan even offered Guianese volunteers to fight with the Cuban revolutionaries after the Bay of Pigs
} 
importantly, however, local conflicts in the colony underlay international tensions in part due to the competition between the communist and non-communist blocs. Guianese leaders faced a decision to choose one of two paths forward as the colony moved toward self-government. Both reformist and revolutionary Guianese leaders appealed to external actors for assistance, thus internationalizing the conflict within British Guiana. The Marxist-Leninist-dominated PPP had the strongest support among the Guianese people and attempted to peacefully alter the structures of society to establish an Eastern bloc-oriented socialism in Guiana. Ultimately, the PPP had considerably more domestic support and greater ties to the Eastern bloc than Salvador Allende.

The colony is also significant in that like Chile, British Guiana was progressing toward the establishment of a popularly elected Marxist government before United States intervention exploited local conflicts to topple a democratically elected leader. ${ }^{25}$ The PPP also symbolized the possibility of a regional social revolution nearly a decade before the Cuban Revolution.

\section{Institutional Decolonization}

For such a popular revolution to even get started the colonial-era structures would have to be altered or dismantled. Some of the complex political alliances established in Guiana after World War II challenged the model of unionization the Colonial Office and TUC worked to establish as part of the process of institution-building between 1946 and 1961. Frantz Fanon was an Afro-Caribbean French psychiatrist, philosopher, and revolutionary whose work on the

invasion. Guillermo Batista, Cuban Ambassador to Trinidad and Tobago similarly noted that Guevara sent fuel, food, and printing machinery to Jagan as an expression of solidarity between their movements. See: "Interview by Cuban journalist Ernesto Nunez Jimenz to the late President Cheddi Jagan,” February 1997, CJRC. Robert Waters, Gordon Daniels, and Clem Seecharan have all emphasized the importance of Cheddi Jagan's relationship with Cuba though Cardenas alone suggests the PPP leader offered armed support to Guevara. See: Robert Anthony Waters, Jr. and Gordon Oliver Daniels, "Striking for Freedom? International Intervention and the Guianese Sugar Workers' Strike of 1964," Cold War History, Vol. 10, No. 4, (November 2010): 537-569; Clem Seecharan, Sweetening 'Bitter Sugar': Jock Campbell the Booker Reformer in British Guiana 1934-1966 (Miami: Ian Randle Publishers, 2005), 488-492.

${ }^{25}$ Stephen Rabe notes in his review of the FRUS volume XXXI that American policymakers blocked the democratic election of left-leaning leaders in British Guiana, Bolivia, and Chile in the mid-1960s. Stephen G. Rabe, "Foreign Relations of the United States, 1964-1968: Volume XXXI, South and Central America; Mexico (Review)," The Americas, Vol. 64, No. 2, October 2007. 
psychology of decolonization provides an important framework with which to examine the conflicts in British Guiana. Specifically, Fanon's analysis of trade unions' role in decolonization illuminates the most important aspect of the conflicts that shaped the Guianese path toward political independence, a process I term institutional decolonization.

The term institutional decolonization refers to the process through which colonial structures were contested in the last phase of British colonization and during the transition to political independence in former colonies. ${ }^{26}$ In British Guiana, British, American, and Guyanese trade union and political leaders negotiated, cooperated, and clashed over how post-colonial society should be structured. In addition to colonial officers and State Department officials, other participants in the struggle included international labor organizations, regional labor leaders and politicians, private citizens who helped finance each side, and trade unionists in Eastern Europe.

The concept of institutional decolonization clarifies and adds depth to what Nigel Bolland describes as the institutionalization of trade unions during the final phase of British colonialism in the Caribbean. Bolland argues that the TUC engaged Caribbean labor movements primarily to

\footnotetext{
${ }^{26}$ This dissertation discusses the concept of institutional decolonization as it pertained to the labor movement; however, it should be acknowledged that conflicts regarding Guianese social structures unfolded in various sectors of Guianese society. For example, almost all Guianese schools were run by Christian churches and major People's Progressive Party (PPP) initiatives in 1953 and 1961 regarded the establishment of public schools independent of religious domination as an important aspect of decolonization. Critics accused the PPP of trying to subvert control of educational institutions while party members argued that they did not intend to take over private schools but to create public institutions to provide a Guianese-centered education. See: William Maddox to Department of State, July 30, 1953, 841D.43/7-5053, Central Decimal Files, RG 59, NARA II; Frank Birbalsingh, The People's Progressive Party of Guyana 1950-1992: An Oral History (London: Hansib Publications, 2007). Mohan Ragbeer recalls an interview he conducted with Cheddi Jagan in 1950 wherein Jagan argued that the structure of Guianese schools was "a left-over from British colonialism" and that "independent Guiana will need new institutions." See: Mohan Ragbeer, The Indelible Red Stain: The Destruction of a Tropical Paradise-a Cold War Story, Book 1 (Published by Dr. Mohan Ragbeer, 2011), 253. British Security Reviews suggest that the PPP initiated similar efforts to replace social organizations such as the YMCA and Boy Scouts with the Guyana Union of Youths and Students (GUYS). See: Eastern Caribbean and British Guiana Security Review for Period January 1-March 31, 1956, CO 1035-16, British National Archives, Kew, Richmond, Surrey. (Hereafter BNA). GUYS established correspondence "with like-minded people in the Soviet Union, China, and the People's Democracies" but sought no political affiliations. See: Eastern Caribbean and British Guiana Security Review for Period July 1- September 30, 1956, CO 1035-16, BNA. Jagan argued for similar efforts promoting socialist youth organizations in Guiana and establishing relations with international socialist youth groups in 1961. See: British Guiana Government Information Services, Guiana Diary, "Youth Called on to join Struggle," February 13-19, 1961, F2384, British Guiana, Guiana Diary, 1957to 1962, TUCLC. See also: "History of the PPP," January 1963, CJRC.
} 
protect property interests and reinforce employers' control of workers in preparation for British withdrawal from the West Indies. He suggests that British programs contributed to authoritarian tendencies in theoretically democratic institutions resulting in anti-democratic propensities in post-colonial West Indian governments. ${ }^{27}$ Similarly, Spencer Mawby argues that colonial administrators established various structural frameworks to slow down decolonization and assure independence was ordered in a way beneficial to British objectives. ${ }^{28}$ As Bolland and Mawby suggest, British efforts to build the trade union movement in Guiana aimed at solidifying a capitalist system of labor relations in the colony to protect British interests as the colony advanced toward self-government. While acknowledging that British officials wielded substantially superior power in shaping the nature of colonial labor relations, this dissertation adds that Guianese actors played a major role in internationalizing the colony's institutional decolonization.

The concept of institutional decolonization also draws on John Darwin's Unfinished Empire which argues that decolonization is most accurately understood as "the break-up or dismantling of...a 'globalized' system of imperial domination centered upon Europe.”29 Examining Guianese decolonization through Darwin's prism of systemic control permits a deeper analysis of the challenge to colonial structures that previous scholarship on Guianese decolonization only peripherally addressed due to a focus on Cold War political intervention. The PAC/PPP's ideology is examined in chapter four; however, the most important aspect of the movement was its insistence on breaking from Western economic control rather than integrating

\footnotetext{
${ }^{27}$ Bolland, The Politics of Labour in the British Caribbean, 363-364; 513-515.

${ }^{28}$ Mawby, Ordering Independence, 30.

${ }^{29}$ John Darwin, Unfinished Empire: The Global Expansion of Britain (New York: Bloomsbury Press, 2013), xiii, 388-389.
} 
into an American-led system. ${ }^{30}$ In this sense, PAC/PPP efforts to restructure Guianese

institutions simultaneously rejected colonial control and resisted the possibility of American

expansion of power into the void left after British withdrawal. ${ }^{31}$

Finally, the international dynamics of institutional decolonization are best understood in

the context of Jason Parker's Brother's Keeper, which argues that transnational connections

heavily influenced British Caribbean decolonization. Parker's work discusses the ways non-

governmental relationships eased the transition to independence in most of the West Indies. ${ }^{32}$

This study argues that similar tendencies existed in British Guiana and that some Guianese labor

leaders' connections to American, British, and pro-Western international trade unions improved

their organizations' ability to negotiate with foreign employers. However, the most influential

Guianese leaders rejected the establishment of institutional connections with Anglo-American

trade unions and instead pursed relations with Eastern-bloc organizations. Consequently, heavy-

handed American intervention and domestic conflict shaped Guianese decolonization in contrast

to the relatively smooth transition to independence in the rest of the West Indies. Thus, debates

\footnotetext{
${ }^{30}$ To be clear, PPP leaders publically stated that they would seek admission into the British Commonwealth after independence. See: Janet Jagan, "Comments on the Political Situation,” Thunder, November 4, 1961, CJRC; Transcript of Cheddi Jagan's Meet the Press interview, October 15, 1961, CJRC. Nonetheless, the Jagan-led leftwing of the PPP consistently argued for economic integration into a socialist system rather than the Western capitalist system. See: Cheddi Jagan, "Straight Talk: The Ideological Struggle," Thunder, March, 1957, CJRC; Dr. Cheddi Jagan, "Legislative Council (Elections Amendment)," January 23, 1952, David Dabydeen and Lynne Macedo, eds., Dr. Cheddi Jagan National Assembly Speeches, Volume 2: The Fourth Legislative Council January 1952-April 1953 (Published by the Caribbean Press for the Government of Guyana, 2011), 31-43; Cheddi Jagan, "Seizure of Private Property, Savings: What is the Position?" Thunder, April 29, 1961, CJRC. Jagan's argument for integration into the socialist world included social institutions in addition to economic relationships. In February 1961 he argued for closer relations between Guianese youth movements and socialist international youth organizations. Specifically, he cited Cuba as a "classic example of economic independence." See: British Guiana Government Information Services, Guiana Diary, "Youth Called on to join Struggle," February 13-19, 1961, F2384, British Guiana, Guiana Diary, 1957to 1962, TUCLC.

${ }^{31}$ This dissertation thus contributes to a greater understanding of institutional resistance to American economic power; a topic Alan McPherson suggests requires further inquiry in his conclusion to Anti-Americanism in Latin America and the Caribbean. McPherson, Anti-Americanism in Latin America and the Caribbean, 272-274.

${ }^{32}$ Parker, Brother's Keeper. This dissertation expands on Parker's work by systematically analyzing labor organizations.
} 
regarding the role of trade unions as social institutions led to domestic and international conflicts that shaped decolonization and the Cold War in the British Caribbean.

Analyzing decolonization at the institutional level allows for a deeper analysis of political objectives and ensuing international conflicts more effectively than the examination of political rhetoric or public discourse. For example, PPP leader Cheddi Jagan and MPCA founder Ayude Edun both framed their political ideas as a form of socialism; however, the institutional models with which Jagan and Edun attempted to shape labor relations differed dramatically. ${ }^{33}$ Nationalist leaders' attempts to shape the institutional foundations of society explain more about their aims than requests for foreign aid. The PAC/PPP's unofficial international relationships are more illuminating than their official diplomatic relations with other nations. Cheddi Jagan, for example, requested aid from the United States and Great Britain but never opened to the possibility of permitting existing labor relations to be based on a British or American model. As a result, the PAC/PPP led early efforts to replace Guianese trade unions integrated into Western labor's international structures. PAC/PPP efforts to retain connections to the Eastern-bloc labor international, the WFTU, while resisting integration into the Western-bloc's ICFTU helps explain the reasons American labor leaders became involved in the colony well before United States policymakers expressed concern about the Guianese labor movement. Institutional objectives influenced international relations when the PPP increased political connections to Eastern-bloc to help to transform the labor movement into something approximating the "scientific socialist model.",34

\footnotetext{
${ }^{33}$ Ayude M. Edun, President and founder of MPCA to James Griffiths, May 23, 1950, CO 859-1150, BNA; Cheddi Jagan, "Straight Talk: A Living Wage," Thunder, December 26, 1959, CJRC; Cheddi Jagan, "Bitter Sugar," (B's Printing Service: Georgetown, 1954), CJRC.

${ }^{34}$ Janet Jagan, “The Rights of Workers in the People's Republic of Rumania," Thunder, July 1953, CJRC; Janet Jagan, “Apprenticeship in Rumania,” Thunder, August, 1953, CJRC; Seecharan, Sweetening 'Bitter Sugar,' 556.
} 
An inter-disciplinary perspective allows for a focus on Guianese decolonization at the institutional level that illuminates three important and previously underappreciated aspects of labor conflict in British Guiana. First, political-scientist Kathleen Thalen's study of institutional evolution is useful in identifying the incompatible objectives of the various actors in Guiana. ${ }^{35}$ Thalen notes that political and social institutions can develop for several purposes. British colonial officials, trade unionists, and employers wanted labor institutions in British Guiana to preserve labor relationships and maintain stability to protect British interests. American labor leaders and policymakers expressed similar objectives while hoping to advance United States interests as British control receded. Reformist Guianese leaders in the MPCA and BGTUC agreed and hoped to advance workers' interests within that system of labor relations. ${ }^{36}$ Conversely, the Jagan-led members of the PAC and PPP viewed the labor institutions as a means through which they could alter economic relationships and challenge the dynamics of power relations in the colony.

Second, Thalen's study suggests that institutions can change considerably in subtle ways while superficially remaining consistent, thus allowing for a greater appreciation of institutional change during periods when labor relations seem stagnant. Applying Thalen's framework to Guiana suggests that conservative labor leaders played a more complex role than historians appreciate and did not act as a barrier to advancing trade union objectives even though their efforts failed to address stifling poverty and did not avert the emergence of the PPP. ${ }^{37}$ To be sure,

\footnotetext{
${ }^{35}$ Kathleen Thelen, "How Institutions Evolve: Insights from Comparative Historical Analysis," in James Mahoney and Dietrich Rueschemeyer, eds., Comparative Historical Analysis in the Social Sciences (Cambridge: Cambridge University Press, 2003), 208-235.

${ }^{36}$ Robert Alexander interview with Justin Yee, June 29, 1954, RG 18-003, International Affairs Department, Jay Lovestone Files, 1944-1973, Box 2, Alexander, Robert, 1954, George Meany Memorial Archives, Silver Spring, MD (Hereafter GMMA).

${ }^{37}$ Matthew Lange notes the Guianese plantation system was stronger than in the rest of British Caribbean which contributed to the emergence of a uniquely radical labor movement in the colony. The scope of Lange's work, however, does not allow for discussion of reformists' gains. Matthew Lange, Lineages of Despotism and
} 
the PPP's existence as a radical alternative provided an important motive for employers to embrace reform and the MPCA's successes derived largely from British fears that inaction would lead to political radicalism. Nonetheless, close examination suggests a gradual expansion of the reformist labor movement in British Guiana. Thalen's work also helps explain why most labor leaders who held leadership positions in Guianese trade unions did not insist on structural breaks with the Anglo-American model of labor relations and opposed the PAC/PPP model of labor relations. MPCA leaders, Richard Ishmael in particular, appreciated the small but important advancements in labor relations between 1946 and 1961 and expressed optimism that those changes would meaningfully impact workers over time. In short, they expressed confidence in trade unions within a capitalist society. ${ }^{38}$

Finally, tracing institutional conflicts allows for greater appreciation of the underlying factors shaping the racial split in the labor movement after 1957. Walter Rodney, a Guianese scholar and political activist, noted that colonization shaped employment patterns and contributed to racial tensions in the colony in the nineteenth and early twentieth centuries. Rodney's insights shed light on racial conflicts in the 1950 s as well. ${ }^{39}$ Differences in labor relationships made possible the Anglo-American exploitation of racial tensions discussed by scholars. Even though colonialism embedded racial conflict within Guianese society, the PPP withstood ethnic divisions and external attempts to destroy the movement until the party became the administrating authority against which predominantly Afro-Guianese civil service unions negotiated for wage increases. The PPP's advocacy of strikes to demand wage increases for overwhelmingly East Indian sugar workers negotiating against foreign capitalists stood in stark

Development: British Colonialism and State Power (Chicago: The University of Chicago Press, 2009), 7-8, 117, 130-131.

${ }^{38}$ Thelen, "How Institutions Evolve," 208-235.

${ }^{39}$ Walter Rodney, A History of the Guyanese Working People, 1881-1905 (Baltimore: The Johns Hopkins University Press, 1981), 179-181. 
contrast to their resistance to increasing taxes to raise pay for government employees. Thus, labor relations, rather than race, explain why predominantly Afro-Guianese civil servants bitterly opposed the PPP in the early 1960s.

Matthew Lange, like Stephen Rabe, emphasizes external factors undermining Guianese democracy; however, Guianese leaders independently at times chose to subvert institutional democracy within their organizations. The radical movement pushed forward reforms, but also led to a current of authoritarianism and anti-democratic features within the reformist trade unions, which resulted in institutional dysfunction over the long-term. While Thalen's study suggests that examining Guianese institutional development closely will help appreciate gradual but important changes in labor relations, Lange's work on British Guiana suggests that the period between 1945 and 1961 represented a critical juncture in Guianese history. Lange argues that external intervention in Guiana resulting from Anglo-American Cold War concerns destroyed efforts at change and led to institutional failure after independence. Importantly, Lange argues that absent intervention British Guiana should have been expected, as a directly-ruled colony, to develop effective and lasting institutional foundations for democratic stability. ${ }^{40}$

Four perspectives were most important in shaping the process of institutional decolonization - those of British trade union and political leaders, those of American trade union and political leaders, those of the revolutionary Cheddi and Janet Jagan-led left-of-center Guianese leaders, and those of reformist left-moderate Guianese leaders. ${ }^{41}$ Anglo-American trade unionists and political leaders agreed that British Guiana should be transitioned from a colony to an independent capitalist democracy even though they disagreed on the specifics of institutionbuilding efforts in the 1950s and competed for influence in the post-colonial Caribbean.

\footnotetext{
${ }^{40}$ Lange, Lineages of Despotism and Development, 7-8, 117, 130-131.

${ }^{41}$ Source limitations necessarily determine the extent that other important viewpoints can be examined, most importantly those of Eastern European trade union leaders and members of the WFTU.
} 
Significantly, American policymakers resisted promoting free trade for British Guiana and insisted that liberalized trade with the Eastern-bloc represented a threat to American national security during the Cold War. ${ }^{42}$ Thus, Anglo-American policy aimed at integrating the Guianese economy with the Western capitalist system rather than accepting autonomy for the Guianese people or promoting free trade.

Ultimately, British, American, and Guianese leaders viewed the establishment of specific types of institutionalized labor relations in British Guiana as an opportunity to achieve broader objectives regarding the nature of post-colonial society and Guiana's place within the decolonized post-war international system.

\section{Capitalism, Colonialism, and the British Guianese Economy}

Capitalism and imperialism, closely related in the British experience though not inherently connected, resulted in the concentration of economic power that defined social relations in developed countries and colonies. The primary institutional mechanisms through which capitalist societies maintained stability and democracy were representative political bodies and industrial organizations designed to protect workers' interests. In British Guiana, as in most colonial territories, political representation was severely restricted leaving workers' movements and trade unions as the sole source of mass representation and democratic expression. ${ }^{43}$ While the Colonial Office considered Guianese trade unions weak and thoroughly inadequate throughout the late-colonial period, a far greater percentage of the population was able to express their demands through trade unions or unauthorized industrial action than could participate in

\footnotetext{
${ }^{42}$ Memorandum of Discussion at the 188th Meeting of the National Security Council, March 11, 1954, 188th Meeting of the NSC, March 11, 1954, Dwight D. Eisenhower Papers as President, 1953-61 (Ann Whitman File) NSC Series, Box 5, DDEL.

${ }^{43}$ Restrictions severely limited the voting population in British Guiana before universal suffrage was initiated in 1953; however, even after representative government was expanded British rule inherently limited Guianese political voice. According to Matthew Lange, suffrage in British Guiana included only fifteen percent of the population in 1947 and only forty-five percent even after universal suffrage began in 1953. See: Lange, Lineages of Despotism and Development, 124.
} 
electoral politics before $1950 .{ }^{44}$ Paradoxically, Guianese trade unions' inability to meaningfully address workers' extreme poverty in the 1940s and 1950s convinced many laborers that unions were useless unless they were connected to a political party that could provide financial support and legislative representation as was the custom in the British Caribbean.

Labor relations in British Guiana were a matter of international affairs, and trade union actions were episodes in foreign relations in addition to being the most important type of democratic activity in the colony. Colonialism created an economy in British Guiana overwhelmingly based on exporting raw materials, particularly sugar and bauxite, limiting the ability of the Guianese people to address the colony's intense poverty. ${ }^{45}$ Booker Brothers' McConnell \& Co., the largest sugar company in the colony, consolidated control over the Guianese economy after 1900, particularly between 1920 and 1940, deepening the plantation economy in British Guiana. Nigel Bolland argues that, as a result, "the survival of the plantation system meant the persistence of the monoculture economy, of dependency and foreign control, and consequently of the absence of sustained diversification and development," leaving the population "condemned to poverty and powerlessness." ${ }^{46}$ Booker Brothers, a private sugar company owned and operated by British investors, so thoroughly controlled the Guianese economy that British Guiana was often derisively referred to as Booker's Guiana. Historian Sara Abraham notes that Booker Brothers was responsible for at least $45 \%$ of government revenue and directly or indirectly controlled the employment of up to $80 \%$ of the population in British

\footnotetext{
44 "Development of Trade Unionism in British Guiana," July 1949, CO 111/797/4, BNA; Venn Commission Report, "The Development of Trade Unionism in British Guiana," November 19, 1949, Venn Commission Recommendation: Trade Union Organizations, CO 111/797/5, BNA.

${ }^{45}$ Memorandum by the Minister of State for Colonial Affairs, March 28, 1960, CAB 129/101, BNA; Hilbourne Watson, "Guyana, Jamaica, and the Cold War Project: The Transformation of Caribbean Labor," in Perry Mars and Alma H. Young, eds., Caribbean Labor and Politics: Legacies of Cheddi Jagan and Michael Manley (Detroit: Wayne State University Press, 2004), 104-105.

${ }^{46}$ Bolland, The Politics of Labour in the British Caribbean, 118-120.
} 
Guiana. ${ }^{47}$ Moreover, Inter-American Regional Organization of Labor (ORIT) economic reports suggested that in the early 1950 s over $60 \%$ of the colony's revenue derived from the sugar industry, that $75 \%$ of the population were low income wage-earners, and that the vast majority of wage earners were dependent on the sugar industry. ${ }^{48}$

Similarly, the expansion of American aluminum companies in the bauxite industry limited Guianese workers to employment in raw material extraction. United States labor laws restricted employment to American seamen on ships transporting bauxite, limiting Guianese workers' opportunity to benefit from their country's resources for employment beyond mining. ${ }^{49}$ Bauxite was British Guiana's second largest economic interest and the colony was the world's second largest producer of the ore. However, the Aluminum Company of America (Alcoa) held virtual monopoly over the industry through its subsidiaries the Demerara Bauxite Company, Ltd. (Demba) and Aluminum Company of Canada (Alcan). ${ }^{50}$ Moreover, American policymakers considered control of Guianese bauxite a national security issue and emphasized access to the strategic mineral. ${ }^{51}$ Thus, British and American companies exerted overwhelming influence over the Guianese economy and the majority of the colony's people.

\footnotetext{
${ }^{47}$ Abraham, Labour and the Multiracial Project in the Caribbean, 56.

${ }^{48}$ Ernst Schwarz, ed., "British Guiana: A Colonial Miniature," from Research Department of the Inter-American Regional Organization of Workers, January 1951, Vol. 1, No.1, RG-18: International Department, Serafino Romualdi Files, Box 8, Research Department, 1951-1953, George Meany Memorial Archives, Silver Spring, MD (Hereafter, GMMA); Leo E. Eliazer, Regional Organizer of ORIT in the Caribbean Areas, "Report on British Guiana," RG-18, International Affairs Department, Staff Files: George Delaney’s Files, 1921-1957, ORIT Executive Board Meetings, 1951-1953, GMMA.

${ }^{49}$ A. Vieira, Secretary British Guiana and West Indies Seaman's Union to AFL, October 11, 1951; Serafino Romualdi, Latin American Representative, AFL to A. Vieira, BG and WI Seaman's Union, November 8, 1951; Serafino Romualdi to Willy J. Dorchain, International Transport Federation, November 8, 1951, RG 1-027, Office of the President, George Meany’s Files, 1944-1960, Subjects: ORIT Office, 1949-1957, GMMA.

${ }^{50}$ A. John Cope, Jr., American Consul, Georgetown to Department of State, April 23, 1957, RG 59 122.41D, Box 717, National Archives II, College Park, MD (Hereafter, NARA II); Jagan, The West On Trial, 98-104.

${ }^{51}$ A. John Cope, Jr., American Consul, Georgetown to Department of State, April 23, 1957, RG 59 122.41D, Box 717, NARA II. Jason Parker argues that the rise in Cold War tensions and especially the onset of the Korean War, increased American policymakers' concern with anti-communism and stability in Jamaica as a means of preserving access to bauxite as well. See: Parker, Brother's Keeper, 86. Stephen Rabe argues that the Eisenhower administration was particularly focused on retaining access to strategic materials. See: Stephen G. Rabe, Eisenhower
} 
British and American policymakers argued that exploitation in monopolistic relationships, however, could be countered through other democratic institutions. Specifically, they suggested that trade unions were the lynchpin of international capitalist interests. British policymakers sought to adjust the imperial framework to preserve commercial and political connections while decentralizing authority and, at least in the Caribbean, gradually preparing the colonies for increased self-government and eventually political independence as they assessed the Empire in the decade after World War II. ${ }^{52}$ The key to preserving the benefits of the Empire in new circumstances, they argued, was the establishment of British-modeled institutions and the retention of political and unofficial connections between former colonies and Great Britain. Conversely, United States policymakers sought to expand American influence into colonial territories as British control lessened. Both British and American policymakers argued that the preservation of capitalism in former colonies was important and both pursued policies designed to keep colonies within the Anglo-America Cold War camp. However, the American and British political-economic systems differed in small but important ways, with Britain moving toward a welfare state and the United States slowly drifting away from some of the progressive economic programs of the 1930s. ${ }^{53}$ Moreover, British and American labor leaders long disagreed on the role of trade unions in capitalist society, and political leaders in both countries related to unions differently.

As a result, Anglo-American trade union and political leaders loosely cooperated to promote reformist trade unions in British Guiana. British and American political and labor

and Latin America: The Foreign Policy of Anticommunism (Chapel Hill: The University of North Carolina Press, 1988), 64-65, 69.

52 John Darwin, The Empire Project: The Rise and Fall of the British World-System, 1830-1970 (Cambridge: Cambridge University Press, 2009); Bolland, The Politics of Labour in the British Caribbean, 513-515; Mawby, Ordering Independence; Rabe, U.S. Intervention in British Guiana, 33.

${ }^{53}$ For more on the shift in American liberalism, see: Alan Brinkley, The End of Reform: New Deal Liberalism in Recession and War (New York: Vintage Books, 1995). 
leaders argued that developing colonial institutions to support specific social and politicaleconomic relationships to shape post-colonial societies, and thus their international orientation, was the most important aspect of decolonization. They tended toward agreement on national lines with trade union leaders acting in accordance with official policy rather than toward a program of international labor solidarity. British and American policymakers and labor leaders described defining and developing post-colonial institutions in different ways and, despite shared broad objectives in the early Cold War, they conflicted in their pursuit of decolonizing colonial institutions. Most importantly, colonial officials and TUC leaders expressed strong opposition to allowing American labor practices to shape trade union development in British Guiana. Nonetheless, the TUC reduced its involvement in British Guiana in mid-1957, which increased AFL-CIO influence in the Guianese labor movement.

Guianese labor and political leaders also disagreed on the best way to establish a diversified industrial economy and on how to pursue their foreign relationships. Nationalists sought to develop and strengthen their institutions in preparation for independence based on the type of post-colonial society they hoped to establish. It would be overly simplistic to suggest that Guianese leaders merely appealed to European ideas in imagining an independent Guyana; however, their designs were based on variations of capitalism, socialism, or communism adjusted for local circumstances. Significantly, a number of the colony's key figures in politics and organized labor were educated in English-run schools and several of the most influential leaders obtained college and graduate-level educations in England and the United States. ${ }^{54}$ Thus, Guianese leaders developed political ideologies while studying in Western educational systems

\footnotetext{
${ }^{54}$ Cheddi Jagan attended Howard University in Washington D.C. and dental school at Northwestern University in Chicago in the early 1940s. Richard Ishmael attended Gettysburg College in Pennsylvania. Forbes Burnham and Ashton Chase attended law school in London.
} 
and living for extended periods in Western societies. Those overseas experiences shaped

Guianese perceptions of institutional decolonization.

\section{Historiography}

This dissertation engages scholars who have begun to examine the ways that regional actors influenced events and to challenge the notion that the United States imposed its will on Latin American and Caribbean peoples uninfluenced by local circumstances. It reinforces the notion that regional actors influenced the course of events to a larger degree than earlier scholarship appreciated. As Michael Gambone suggests, regional developments are best understood as a convergence of multi-layered local, national, regional, international dynamics. ${ }^{55}$ While Cold War concerns provided an overarching framework for Guianese decolonization, the consistent American pursuit of regional hegemony was most important in explaining U.S. involvement in the colony's progression toward self-government. ${ }^{56}$ Scholars have long appreciated that the United States exerted control throughout the hemisphere though they disagree on the motives of American actors and the extent to which other countries in the region influenced American foreign policy. Orthodox and some post-revisionist scholars suggest that United States actions in Latin America balanced national interest with an idealistic altruism

\footnotetext{
${ }^{55}$ Michael D. Gambone, Capturing the Revolution: The United States, Central America, and Nicaragua, $1961-1972$ (Westport, CT: Praeger, 2001); Hal Brands, Latin America's Cold War (Cambridge, MA: Harvard University Press, 2010).

${ }^{56}$ The Caribbean, which is the focus of this study, was in a period of transition from British to American control before the World Wars. Nigel Bolland argues that the period of transition began in 1898 and culminated in the 1930s and 1940s. See: Bolland, 3. Similarly, Jason Parker argues that American influence in the region increased with increased immigration and transnational relations between the West Indies and the United States in the late 19th century and official United States policy designed to assume a larger official role in the region during the 1930 s. See: Parker, Brother's Keeper, 6-7, 17, 33-66. Moreover, United States policymakers' pursuit of regional hegemony preceded and continued after the Cold War. See: James Siekmeier, "Latin American Economic Nationalism and United States-Latin American Relations, 1945-1961." The Latin Americanist 52:3 (October 2008): 59-76; Piero Gleijeses, Shattered Hope: The Guatemalan Revolution and the United States, 1944-1954 (Princeton, NJ: Princeton University Press, 1991).
} 
focused on advancing a collective set of regional ideals. ${ }^{57}$ Revisionists and some post-

revisionists counter that U.S. actions are most effectively understood as a form of imperialism based primarily on economic domination frequently maintained through the use of military

force. ${ }^{58}$ While scholars debate the drivers of the United States' hemispheric policy they agree on the consistency of American aims and suggest that decolonization and the Cold War offered a different backdrop that merely reframed long-standing issues. ${ }^{59}$ The merging of the specific Cold War challenges to traditional American policy in the hemisphere was made clear in 1954 when Secretary of State John Foster Dulles informed the National Security Council that his understanding of the Monroe Doctrine excluded foreign ideologies, specifically communism, in the hemisphere. ${ }^{60}$

United States involvement in British Guiana's decolonization demonstrates a continuity of policy based on efforts to integrate the region into an American-dominated neo-liberal

\footnotetext{
${ }^{57}$ Lester D. Langley, America and the Americas: The United States in the Western Hemisphere, $2^{\text {nd }}$ ed. (Athens, GA: The University of Georgia Press, 2010); Stephen J. Randall, Colombia and the United States: Hegemony and Interdependence (Athens, GA: The University of Georgia Press, 1992); Elizabeth A. Cobbs, The Rich Neighbor Policy: Rockefeller and Kaiser in Brazil (New Haven, CT: Yale University Press, 1992); Bradley Lynn Coleman, Colombia and the United States: The Making of an Inter-American Alliance, 1939-1960 (Kent, OH: The Kent State University Press, 2008).

${ }^{58}$ William Appleman Williams, The Tragedy of American Diplomacy (New York: W.W. Norton \& Company, 1959); Walter LaFeber, Inevitable Revolutions: The United States in Central America, 2nd ed. (New York: W.W. Norton and Company, 1993); Rabe, Eisenhower and Latin America; Stephen G. Rabe, The Most Dangerous Area in the World: John F. Kennedy Confronts Communist Revolution in Latin America (Chapel Hill: The University of North Carolina Press, 1999); Greg Grandin, Empire's Workshop: Latin America, the United States, and the Rise of the New Imperialism (New York: Henry Holt and Company, LLC, 2006); Brian Loveman, No Higher Law: American Foreign Policy and the Western Hemisphere Since 1776 (Chapel Hill: The University of North Carolina Press, 2010).

${ }^{59}$ Mark T. Gilderhus, The Second Century: U.S.-Latin American Relations Since 1889 (Wilmington, DE: Scholarly Resources, Inc., 2000); Peter H. Smith, Talons of the Eagle: Latin America, the United States, and the World, 3rd, ed. (New York: Oxford University Press, 2008); Emily S. Rosenberg, Spreading the American Dream: American Economic and Cultural Expansion 1890-1945 (New York: Hill and Wang, 1982); Lars Schoultz, That Infernal Little Cuban Republic: The United States and the Cuban Revolution (Chapel Hill: The University of North Carolina Press, 2009); Alan McPherson, ed., Anti-Americanism in Latin America and the Caribbean (New York: Berghahn Books, 2006), 2; Gerald Horne, Cold War in a Hot Zone: The United States Confronts Labor and Independence Struggles in the British West Indies (Philadelphia: Temple University Press, 2007); Gabriel Kolko, Confronting the Third World: United States Foreign Policy, 1945-1980 (New York: Pantheon Books, 1988); James Siekmeier, "Latin American Economic Nationalism and United States-Latin American Relations, 1945-1961." The Latin Americanist 52:3 (October 2008): 59-76.

${ }^{60}$ Memorandum of Discussion at the 188th Meeting of the National Security Council, Thursday, March 18, 1954, Dwight D. Eisenhower Papers as President, 1953-61, (Ann Whitman File), NSC Series, Box 5, DDEL.
} 
economic system. ${ }^{61}$ As James Siekmeier and others have shown, United States policymakers fervently opposed economic nationalism in the Western Hemisphere. ${ }^{62}$ At the same time, as Marc-William Palen points out, U.S. officials did not consistently advocate a true "Open Door Policy" designed to foster free trade in Latin America. Instead, U.S. policymakers and labor leaders pursued an ever-expanding, pro-United States closed door. ${ }^{63}$ The Cold War reinforced the tendency to limit regional free trade. The National Security Council specifically stated its opposition to restricting the trade of raw materials between the Caribbean and the Soviet Union if those materials would "break certain bottlenecks" in the Soviet economy. ${ }^{64}$ In that context, British colonists attempted to improve their position within the international system and nationalists pursued social, structural, and political-economic changes domestically with the objective of modernizing in their own way, often appealing to the American and Soviet models. ${ }^{65}$ In British Guiana the relative importance of economic, ideological, and strategic concerns varied among the range of actors involved in the process of decolonization, though to the Guianese economics were the heart of the debate.

Several scholars have also emphasized the importance of appreciating the domestic concerns influencing regional leaders rather than viewing them as merely responding to United

\footnotetext{
${ }^{61}$ LaFeber, Inevitable Revolutions; James Siekmeier, The Bolivian Revolution and the United States, 1952 to the Present (University Park, PA: The Pennsylvania State University Press, 2011).

${ }^{62}$ Siekmeier, "Latin American Economic Nationalism and United States-Latin American Relations, 1945-1961."

${ }^{63}$ Marc-William Palen, “The Imperialism of Economic Nationalism, 1890-1913,” Diplomatic History, Vol. 39, No. 1, January 2015, 157-185. Mark Esposito argues that domestic economic concerns tempered United States policymakers' pursuit of unchecked free trade. Even at its peak, the American pursuit of liberalized trade contained safeguards designed to blunt the impact of free trade on the domestic workforce. See: Mark A.T. Esposito, "The UAW., American Trade Policy, and the Transformation of the Global Automobile Industry, 1945-1973," (West Virginia University: Ph.D. Dissertation, 2004), 11.

${ }^{64}$ Memorandum of Discussion at the 188th Meeting of the National Security Council, March 11, 1954, 188th Meeting of the NSC, March 11, 1954, Dwight D. Eisenhower Papers as President, 1953-61 (Ann Whitman File) NSC Series, Box 5, DDEL.

${ }^{65}$ Arnold L. Steinbach, "Changing Concepts and Practices in the International Labor Movement," in Everett M. Kassalow, ed., National Labor Movements in the Postwar World (Evanston, IL: Northwestern University Press, 1963), 46-47.
} 
States policy. ${ }^{66}$ Guianese labor leaders established connections to the AFL-CIO and appealed to American policymakers to advance their own objectives before the United States became involved in the colony. Ultimately, the PAC/PPP's attempt to address extreme poverty and asymmetries of power through social revolution and connections with the Eastern-bloc challenged both short-term and long-term American interests. Guianese leaders' internal disagreements and conflict with colonial authorities led to American involvement through a weak attempt at institution-building cast aside for intervention when the project failed.

In addition to using the prism of institutional decolonization to explain the process of negotiation and conflict in British Guiana between 1946 and 1961, this dissertation makes use of Guianese sources made available on a large scale in the past five years through the Cheddi Jagan Research Center. ${ }^{67}$ It juxtaposes those sources with British and American governmental and trade union records, many previously unexamined, to explain the multifaceted and internationalized conflict over British Guiana’s institutional development. Conflicts between Guianese labor leaders over the nature of post-colonial institutions were internal and emanated outward, suggesting that in at least one way the ideological disagreements that shaped the Cold War unleashed conflict which began between Guianese trade unionists before American, Soviet, and British leaders acknowledged a state of Cold War among the world's most powerful nations. Nonetheless, it is critical to acknowledge that Great Britain and later the United States imposed their will in the colony however much they were influenced by Guianese leaders.

\footnotetext{
${ }^{66}$ Siekmeier, The Bolivian Revolution and the United States. Motives and actions of LA: Alan McPherson, Yankee No!: Anti-Americanism in U.S.-Latin American Relations (Cambridge, MA: Harvard University Press, 2003); Kyle Longley, The Sparrow and the Hawk: Costa Rica and the United States During the Rise of Jose Figueres (Tuscaloosa, AL: The University of Alabama Press, 1997); Eric Paul Roorda, The Dictator Next Door: The Good Neighbor Policy and the Trujillo Regime in the Dominican Republic, 1930-1945 (Durham, NC: Duke University Press, 1998).

${ }^{67}$ The Cheddi Jagan Research Center is privately operated by friends of the late Dr. Cheddi Jagan. Cheddi and Janet Jagan's daughter Nadira Jagan-Brancier runs the center's website which makes available a large cache of the Jagans' speeches and published articles as well as PPP material.
} 
The literature on Guianese decolonization primarily emphasizes the importance of external actors in shaping the colony's transition to political independence and, as a result, focuses on the 1953 suspension of internal self-government and later Anglo-American subversion of the PPP government before the colony gained political independence. ${ }^{68}$ In the earliest study on the subject, Leo Despres identifies important cultural and ideological differences that disrupted Guianese society; however, he suggests that external actors were the decisive factor in the disintegration of a unified nationalist movement. ${ }^{69}$ The Guianese people elected Cheddi Jagan to office in 1992 in the country's first fair elections since the AngloAmerican intervention in 1964 which laid the foundation for Forbes Burnham's dictatorship. Soon after Jagan's return, Cary Fraser and Stephen Rabe wrote highly critical studies arguing that narrow anti-communism drove American policymakers to manipulate the Guianese labor movement and exert pressure on the British government to delay independence until the PPP could be removed from office. American policymakers, they argued, misunderstood Jagan, and the intervention made the colony "collateral damage" as the United States waged the Cold War. ${ }^{70}$

\footnotetext{
${ }^{68}$ Interestingly, several of the important Guianese figures involved in the colony's transition to independence wrote memoirs or participated in oral histories about their experiences. Each provides unique and important insights; however, they disagree considerably on the PPP's ideology and the reasons for British Guiana's violent and troublesome process of decolonization. Cheddi Jagan American-published memoir argues that his socialist/reformist government was a victim of American Cold War aggression. See: Jagan, The West on Trial. Jai Narine Singh, Mohan Ragbeer, and the editors of Forbes Burnham's speeches argue that Jagan's doctrinaire Marxism and dedication to international communism destroyed the unified nationalist movement. See: C.A. Nascimento and R.A. Burrowes, eds., Forbes Burnham, A Destiny to Mould: Selected Speeches by the Prime Minister of Guyana (New York: Africana Publishing Corporation, 1970); Jai Narine Singh, Guyana: Democracy Betrayed (Kingston, Jamaica: Kingston Publishers Ltd., 1996); Ragbeer, The Indelible Red Stain. Wynter Crawford, the radical journalist and politician from Barbados, claimed that the Jagans "almost single handedly spread communism throughout the West Indies." See: Woodville K. Marshall, ed., I Speak for the People: The Memoirs of Wynter Crawford (Kingston: Ian Randle Publishers, 2003), 110-112. Frank Birbalsingh's oral history of the PPP includes interviews with almost all of the key members of the PPP between 1950 and 1966. Birbalsingh's work suggests a reality between the two extremes but hints that the early PPP was a left-coalition with a core of communist-inspired leaders and that ideological disagreements played a significant role in local disagreements. His work does not suggest, however, a particularly internationalist commitment on the part of PPP leaders. See: Frank Birbalsingh, The People's Progressive Party of Guyana 1950-1992.

${ }^{69}$ Leo A. Despres, Cultural Pluralism and Nationalist Politics in British Guiana (Chicago: Rand McNally and Company, 1967).

${ }^{70}$ Fraser, Ambivalent Anti-Colonialism; Rabe, U.S. Intervention in British Guiana, 186.
} 
Similarly, Nigel Bolland and Spencer Mawby argue that British officials pursued policies designed to shape decolonization and institutionalize capitalist labor relations to preserve British interests in the Caribbean. Bolland and Mawby agree that British policies resulted in authoritarian tendencies in the institutions tasked with assuring social democracy, especially West Indian trade unions. ${ }^{71}$ Colin Palmer agrees that colonialism's legacy was the creation of schisms in Guianese society and that British and American actions during decolonization contributed to increasing violence as Guiana progressed toward independence. However, Palmer suggests that Guianese leaders' manipulation of racial conflicts for political gain contributed to the colony's devolution into violence and repressive government. ${ }^{72}$ The fundamental historiographical challenge to these works revolves around Cheddi and Janet Jagan's political orientation and the degree of the PPP's connection to the Eastern-bloc. Robert Waters argues that the depiction of Cheddi Jagan as a socialist victim of overzealous anti-communism too easily dismisses the PPP's Marxist ideology and its attempts to secure connections with Czechoslovakia, Cuba, and the Soviet Union. ${ }^{73}$

The existing literature captures the connections between the Cold War and decolonization, British attempts to shape labor relations, and the importance of colonial structures on racial violence during decolonization, and it is beginning to explain the complexity

\footnotetext{
${ }^{71}$ Bolland, The Politics of Labour in the British Caribbean; Mawby, Ordering Independence.

${ }^{72}$ Colin A. Palmer, Cheddi Jagan and the Politics of Power: British Guiana's Struggle for Independence (Chapel Hill: The University of North Carolina Press, 2010). Perry Mars and Alma Young edited a series of essays that collectively outline an argument similar to Palmer, though they are less critical of Jagan's part in contributing to Guianese violence. See: Perry Mars, Perry and Alma H. Young, eds., Caribbean Labor and Politics: Legacies of Cheddi Jagan and Michael Manley (Detroit: Wayne State University Press, 2004).

${ }^{73}$ Waters and Daniels, "Striking for Freedom?," 537-569; Robert Anthony Waters, Jr., "More Subtle than we Knew: The AFL in the British Caribbean," in Robert Anthony Waters, Jr. and Geert Van Goethem, American Labor's Global Ambassadors: The International History of the AFL-CIO During the Cold War (New York, Palgrave Macmillan, 2013); Jan Koura and Robert Waters, "Cheddi Jagan and Guianese Overtures to the East: Evidence from the Czech National Archives," Cold War International History Project, e-Dossier No. 54, Wilson Center, 2015. See also: Seecharan, Sweetening 'Bitter Sugar'. Christopher Andrew does not label the PPP but notes that Cheddi and Janet Jagan retained connections with the Soviet Embassy and Communist Party of Great Britain beginning in 1947. See: Christopher Andrew, Defend the Realm: The Authorized History of MI5 (New York: Alfred A. Knopf, 2009), 459-460, 477.
} 
of Guianese leaders' relations with both sides of the Cold War divide. However, none of it has adequately tackled the fundamental issue that shaped Guianese decolonization: the debate over the institutions that would shape post-colonial society. Guianese labor leaders' political ideologies influenced, but also grew out of their experiences in seeking improvements for the colony's impoverished workers through the labor movement. Political and trade union ideologies shaped transnational relationships and were the basis of the relationship between the Cold War and decolonization in British Guiana. ${ }^{74}$

Ultimately, British, American, and Guianese leaders viewed the establishment of specific types of institutionalized labor relations in British Guiana as an opportunity to achieve broader objectives regarding post-colonial society and Guiana's place within the decolonized post-war international system. After 1946, a conflict emerged between Guianese labor leaders who supported the idea of decolonization within the existing system and those who interpreted decolonization as a more fundamental break from British and American control, objectives achievable only through greater association with the Eastern-bloc. Guianese leaders played a more important role in late-colonial struggles than scholars realize, and the conflict in the colony's labor movement was considerably internationalized by mid-1950s.

American involvement in British Guiana shifted from institution-building and political intervention to subversion. The CIA and AFL-CIO intervened to exacerbate domestic unrest as a means of undermining the PPP government between 1962 and 1964 at the same time the Kennedy administration pressured British Prime Minister Harold Macmillan to hold new elections based on proportional representation. The new electoral system allowed a coalition

\footnotetext{
${ }^{74}$ Matthew Lange argues that the process of decolonization undermined the establishment of functional postcolonial institutions and resulted in Guyana's long-term underdevelopment. Lange's work is an important bridge between historical studies of decolonization and an examination of Guianese institutions. Lange, Lineages of Despotism and Development.
} 
between the PNC and United Front (UF) to replace the PPP before the colony became independent in 1966 and set the stage for a twenty-seven-year PNC dictatorship in the colony. The relationships the CIA exploited, which are the focus of Rabe's and Fraser's work, grew out of the efforts of reformist Guianese labor leaders to use contacts in British and American trade unions in the 1950s. The PPP's attempt to resist its Anglo-American orchestrated removal, in part through cooperation with Cuba, ended in failure. ${ }^{75}$ Ultimately, disagreements between the Guianese owing largely to the structure of colonial society assured conflict during decolonization; however, the PPP's removal and Burnham's subsequent dictatorship were the result of U.S. intervention to protect American interests. Thus, the internationalization of Guianese trade union struggles contributed to the corruption of the labor movement and the destruction of democracy in Guyana.

The remainder of this dissertation proceeds as follows: Chapter two explores the context, ideology, and objectives that drove AFLAFL-CIO international activities after World War II, arguing that American labor leaders were willing to undermine democracy and selfdetermination abroad to advance pro-American capitalism. Chapter three juxtaposes British and American foreign policies after World War II and argues that both nations' labor and political leaders connected the expansion of reformist trade unions to the preservation of global capitalism. Chapter three also shows that British and American policymakers and trade unionists competed to advance national interests while advancing shared objectives. Chapter four shows that Guianese trade unionists and political leaders clashed over the political-economic system through which they hoped to develop Guiana, and as a result the foreign relationships Guianese leaders pursued. Moreover, this conflict began in the Guianese labor movement before the start of the Cold War. Chapter five suggests that the PAC's founding in 1946 represented a first phase

\footnotetext{
${ }^{75}$ Waters and Daniels, "Striking for Freedom?."
} 
of institutional decolonization during which revolutionary Guianese labor and political leaders rejected the British-imposed model of trade unionism and struggled to break from institutional connections to the West. This first phase culminated in the PPP's electoral victory and ended when the colonial government suspended the Waddington constitution and re-imposed direct rule in the British Guiana.

Chapters six and seven explain Anglo-American institution-building programs in British Guiana and argue that Anglo-American rivalry limited cooperation in the colony during a second phase of institutional decolonization. As a result, reformist Guianese trade unionists appealed to both British and American trade unionists, as well as Western international labor organizations, to counter the PPP's revolutionary program in the colony. Thus, reformist Guianese labor leaders were the driving force behind external involvement in the colony between 1954 and 1961. Together, those chapters show that the internationalization of labor relations paradoxically sustained the reformist labor movement and helped it gain important institutional advancements, while increasing Guianese unionists' dependence on external assistance and contributing to the loss of democracy within those organizations. This dissertation concludes with a brief overview of the third phase of institutional decolonization, the period during which institutional breakdown in the labor movement resulted in U.S.-supported subversion of the elected PPP government between 1962 and 1964. Ultimately, American intervention through relationships developed at the behest of reformist Guianese labor leaders was the decisive factor in removing the PPP and placing Forbes Burnham at the head of the colony's government when Guyana became independent in 1966. 


\section{Chapter 2: The Origins of AFL, CIO, and TUC Involvement in Institutional Decolonization}

The American Federation of Labor (AFL), Congress of Industrial Organizations (CIO), and Trades Union Congress (TUC) pursued activist foreign policies after World War II that promoted democracy, economic development, and international solidarity in the pursuit of global peace and a liberal capitalist international economic system. Anglo-American labor leaders expected those objectives to be mutually reinforcing, and they often were; however, they were also frequently incompatible. As labor's Cold War grew in intensity in the late 1940s and early 1950s, Anglo-American labor leaders increasingly pursued foreign policies that subordinated promoting democracy abroad to imposing liberal capitalism and business-unionism on colonial areas. Thus, British and American trade unions' institution-building efforts in British Guiana in the 1950s and early 1960s were part of a broader effort to integrate colonial unions into a liberal capitalist economic system centered in the U.S. and Great Britain. Despite national rivalry, tactical disagreements, and organizational conflicts, the AFL, CIO, and TUC agreed on the importance of integrating colonial trade unions into the Western system through the labor movement.

The existing scholarship on American labor's post-war foreign policy objectives is best understood as falling into three general schools of thought; orthodox, revisionist, and postrevisionist. The earliest significant studies of American labor's Cold War foreign policy were written in the 1960s and 1970s and varied between praise for American labor's defense of freedom abroad and criticism of the motives, actions, and especially consequences of AFL-CIO international activities. Orthodox labor scholars accepted AFL-CIO leaders' public explanations of policy and encouraged or defended their actions as a form of positive anti-communism. The 
earliest orthodox work, George Lodge's, Spearheads of Democracy, was published for the Council on Foreign Relations in 1962. The author, who was Secretary of Labor in the late 1950s, submitted a draft of his work to several labor leaders for approval before publishing a manuscript that called for greater labor-government cooperation in international relations. Despite its bias, Lodge's work is useful in hinting at the underlying institutional issue at the center of this dissertation. The author criticizes the United States government's ineptitude and American businesses abroad for failing to realize that undermining trade unions in developing countries reinforced arguments for class struggle and missed "the opportunity to build a relationship and an institution which in time of instability and trouble might save its neck." ${ }^{1}$ Active collaboration between the United States government and the AFL-CIO, Lodge argued, was crucial to advancing the political-economic system designed in the United States and, specifically, to combatting the international Communist conspiracy directed from Moscow. ${ }^{2}$

Ronald Radosh's, American Labor and United States Foreign Policy is the foundational revisionist work on American labor's international relations. Radosh argues that American labor leaders accepted a role as junior partners cooperating with the United States government to reinforce the capitalist political economic system and pursue an expansionist foreign policy. Radosh suggests that labor leaders expected American economic expansion to lead to increasing employment, wages, and benefits for American workers. ${ }^{3}$ Furthermore, Radosh suggests that American labor leaders' support for an imperialist United States foreign policy led to labor's adoption of reactionary overseas activities including support for dictatorial leaders who suppressed free trade unions as a means of limiting the forces of social change. Radosh contests

\footnotetext{
${ }^{1}$ George C. Lodge, Spearheads of Democracy: Labor in the Developing Countries (New York: Harper \& Row, Publishers, 1962), vii, xi-xiii.

${ }^{2}$ Lodge, Spearheads of Democracy, 3-12, 53, 55-58, 229, 234-237.

${ }^{3}$ Ronald Radosh, American Labor and United States Foreign Policy (New York: Random House, 1969),4-6, 15, 25, 28,149 .
} 
labor leaders' public statements, which argued that the AFL-CIO's aggressive foreign policy grew out of the post-war threat of expansionist totalitarian Communism emanating from the Soviet Union. The AFL/AFL-CIO, Radosh argues, consistently contributed to an expansionist foreign policy in pursuit of the Open Door ideal, or the free flow of trade and investments, since the early twentieth century. Radosh suggests that anti-communist rhetoric was a guise to increase overseas activities in opposition to revolutionary or nationalist movements that threatened corporate capitalism after World War II. ${ }^{4}$ Significantly, Radosh argues that labor leaders often took aggressive anti-communist positions in advance of official United States policy, including in British Guiana. Nonetheless, he argues that once official policy was determined, the AFL/AFL-CIO frequently became pawns for the Central Intelligence Agency (CIA), State Department, and American corporations who used trade unionists to build institutions overseas to forestall social revolutions. ${ }^{5}$

Philip Taft examines AFL-CIO archives for his work, Defending Freedom, and uses the organizations' materials to defend American labor leaders' expansion of overseas activities after World War II. Taft rejected revisionist criticism of AFL-CIO foreign policy as the work of "conceited politicians" or "lazy and arrogant liberal intellectuals." ${ }^{\circ}$ He praises labor leaders, such as Jay Lovestone, George Meany, Matthew Woll, William Green, Serafino Romualdi, and David Dubinsky for identifying totalitarianism as a "monstrous evil" as well as recognizing the

\footnotetext{
${ }^{4}$ Radosh, American Labor and United States Foreign Policy, 23-25, 72, 373, 375, 435, 452. For more on Western labor leaders' shift toward greater support for the existing social order, see: David J. Saposs, "Ideological Conflicts in the International Labor Movement," in, Everett M. Kassalow, ed., National Labor Movements in the Postwar World (Evanston, IL: Northwestern University Press, 1963).

${ }^{5}$ Radosh, American Labor and United States Foreign Policy, 373, 382, 395, 405.

${ }^{6}$ Philip Taft, Defending Freedom: American labor and Foreign Affairs (Los Angeles: Nash Publishing, 1973), viiviii, 1-2, 251-260. Taft acknowledges that AFL anti-communism was not a manifestation of the Cold War. He suggests that long-standing opposition to Communist unions was based on the assumption that Communist unions rejected the notion that each national union should determine its own philosophy and tactics in favor of global class struggle. He also notes that the AFL-CIO opposed communist totalitarianism because it denied men the right to choose governors, labor organizations, or engage in freedom of association, speech, or the press. See: Taft, Defending Freedom, 159-161, 256.
} 
similarities between Soviet domination of trade unions and German, Spanish, and Italian fascist repression of workers in the 1930s. ${ }^{7}$ Those men, Taft argues, laid the foundation for an aggressive post-war policy of anti-communism designed to promote democracy and defend workers across the world from falling under the control of communist, fascist, or colonial totalitarian governments. ${ }^{8}$ Taft suggests that the CIO joined the AFL in advocating a staunchly anti-communist policy by 1949 in response to the Soviet Unions' antagonism in the World Federation of Trade Unions (WFTU), the international labor organization established in 1945 to unify trade unions across the globe. ${ }^{9}$ Taft's work articulates the AFL-CIO's stated foreign policy objectives; however, it is limited in that it uncritically accepts labor leaders' public statements and organizations' official policies without examining the underlying nature of those programs or their consequences. Perhaps most damaging, Taft defends the AFL-CIO from allegations of complicity with the CIA in carrying out subversive activities overseas, activities which have since been confirmed with the release of classified materials. Nonetheless, Taft made a significant contribution to the historiography in arguing that American labor leaders pursued their own foreign policy objectives rather than merely acting on behalf of agencies within the United States government. ${ }^{10}$

Jon Kofas's The Struggle For Legitimacy argues that anti-communism was the driving force behind AFL/AFL-CIO foreign policy after World War II; however, like Radosh he suggests that American labor leaders' policy in the hemisphere needs to also be understood in the

\footnotetext{
${ }^{7}$ Taft, Defending Freedom, 252-253, 256-257, 259-260.

${ }^{8}$ Taft, Defending Freedom, 1, 2, 5, 68-71, 83-85, 180-181.

${ }^{9}$ Taft, Defending Freedom, 90-92, 100-101.

${ }^{10}$ In addition to Lodge and Taft, see: Bert Cochran, Labor and Communism: The Conflict that Shaped American Unions (Princeton: Princeton University Press, 1977). Bert Cochran argues that the American Communist Party's adherence to Soviet dictates de-legitimized the ideas of the labor left and shaped American labor leaders' views regarding foreign policy.
} 
broader context of consistent opposition to Latin American economic nationalism. ${ }^{11}$ Kofas agrees that the State Department drove labor's foreign policy, suggesting that as a result the United States government was the most important actor in shaping the foreign policies of international organizations to which American labor belonged, especially the Inter-American Regional Organization of Labor (ORIT). ${ }^{12}$ Kofas, however, notes disagreements between American labor leaders and suggests that the CIO occasionally pressured the AFL to implement progressive policies, including the adoption of a position of strong opposition to right-wing dictatorships as a central tenet of ORIT policy. ${ }^{13}$ Other revisionist works expounded on the same ideas, primarily focusing on American labor leaders' negative anti-communism, cooperation with or subordination to agencies within the United States government, and pursuit of a foreign policy that undermined workers and subverted democracy. ${ }^{14}$

Post-revisionist scholars examining Anglo-American labor foreign policy have begun to synthesize earlier efforts. They acknowledge that AFL and CIO leaders supported an expansionist and often self-interested economic policy while emphasizing that anti-communism and the promotion of "free trade unionism" were central to American labor leaders' foreign

\footnotetext{
${ }^{11}$ Jon V. Kofas, The Struggle for Legitimacy: Latin American Labor and the United States 1930-1960 (Tempe: Arizona State University, 1992), 310, 351.

${ }^{12}$ Kofas, The Struggle for Legitimacy, 344.

${ }^{13}$ Kofas, The Struggle for Legitimacy, 300, 351.

${ }^{14}$ For other works suggesting American labor leaders' virulent anticommunism undermined collaborative international labor efforts and/or increasingly allowed the AFL/AFL-CIO to be used as tools of agencies advancing United States foreign policy, see: Gary K. Busch, The Political Role of International Trades Unions (New York: St. Martin's Press, 1983); Michael E. Gordon and Lowell Turner, ed., Transnational Cooperation among Labor Unions (Ithaca: Cornell University Press, 2000); Fred Hirsch and Richard Fletcher, The CIA and the Labor Movement (Nottingham, UK: Spokesman Books, 1977); Judith Stepan-Norris and Maurice Zeitlin, Left Out: Reds and America's Industrial Unions (Cambridge, UK: Cambridge University Press, 2003); Beth Sims, Workers of the World Undermined: American Labor's Role in U.S. Foreign Policy (Boston: South End Press, 1992). Sims importantly describes the relationship between labor and governmental leaders as symbiotic. Ake Wedin, T.L. Johnston, trans., International Trade Union Solidarity: ICFTU 1957-1965 (Stockholm: Bokforlaget Prisma, Publishers, 1974). Wedin argues that AFL-CIO foreign policy was a result of AFL dominance and that CIO leaders tried to act more collaboratively in international affairs. For more on the conflicts between AFL and CIO leadership regarding American labor's foreign policy, see: Alfred O. Hero, Jr. and Emil Starr, The Reuther-Meany Foreign Policy Dispute: Union Leaders and Members View World Affairs (Dobbs Ferry, NY: Oceana Publications, Inc., 1970).
} 
policymaking. While often critical of the outcomes of AFL-CIO policy, some scholars have begun to nuance previous explanations of labor leaders' motives. ${ }^{15}$ Martin Halpern, John Fousek, and Nelson Lichtenstein note the domestic context in which labor leaders developed their foreign policies. Halpern and Fousek argue that labor leaders adopted conservative policies to solidify New Deal gains in the face of an anti-labor backlash in the late 1940s. ${ }^{16}$ Lichtenstein agrees and notes that CIO President Walter Reuther determined to pursue a policy of staunch anticommunism coupled with a program to reinforce and adjust the existing capitalist system that he thought most effectively advanced workers' interests. ${ }^{17}$

Post-revisionist scholarship makes several other contributions that are significant for the purposes of this dissertation. Anthony Carew argues that the Cold War was merely a new context in which long-standing debates over theories of trade unionism were reignited. ${ }^{18}$ His assertion that different interpretations of "free trade unionism" were central to post-1945 conflicts in international labor anticipates the work of scholars like Edmund Wehrle, Geert van Goethem, Dustin Walcher, Robert Waters, Federico Romero, and Victor Silverman, who have begun to examine the role of free trade unionism as an ideological factor in shaping American labor leaders' foreign policies. Silverman also considers the TUC ideal of "voluntaryism," which he suggests was the organization's version of free-labor ideology. ${ }^{19}$

\footnotetext{
${ }^{15}$ On this subject in particular, there is still dissention among scholars.

${ }^{16}$ John Fousek, To Lead the Free World: American Nationalism and the Cultural Roots of the Cold War (Chapel Hill: The University of North Carolina Press, 2000), 147-150, 153-161; Martin Halpern, UAW Politics in the Cold War Era (Albany: State University of New York Press, 1988), 3-6. Edmund Wehrle also notes that CIO policy moderated in response to domestic pressures. See: Edmund F. Wehrle, Between a River \& a Mountain: The AFLCIO and the Vietnam War (Ann Arbor: The University of Michigan Press, 2005), 41.

${ }^{17}$ Nelson Lichtenstein, Walter Reuther: The Most Dangerous Man in Detroit (Urbana, IL: University of Illinois Press, 1995), 103, 181, 253. See also: Fousek, To Lead the Free World, 147-150.

${ }^{18}$ Anthony Carew, “A False Dawn: The World Federation of Trade Unions (1945-1949)," in, Anthony Carew, et al., The International Confederation of Free Trade Unions (New York: Peter Lang, 2000), 183.

${ }^{19}$ Victor Silverman, Imagining Internationalism in American and British Labor, 1939-49 (Chicago: University of Illinois Press, 2000); Wehrle, Between a River \& a Mountain; Walcher, van Goethem, Waters, and Wehrle each contributed to an edited volume in which their explanations of free trade unionism can be found. The volume itself is the most concise and broad explanation of American labor's foreign policy ideology available. See: Robert
} 
Walcher's and Romero's essays in American Labor's Global Ambassadors and

Silverman's Imagining Internationalism in British and American Labor, like Lichtenstein, note

that American labor leaders' sincere belief in the universal applicability of American-style liberal

trade unionism and corporatism contributed to the development of an ideology that justified

activist overseas policies. Specifically, Walcher suggests that American labor leaders embraced

the corporatist political economic system emerging from the New Deal in the United States. ${ }^{20}$

Walcher and Romero suggest that American labor leaders adopted as a viable system to export

the concept of a liberal trade unionism that focused on preserving labor's autonomy and ability

to negotiate within the larger political-economic structure without challenging business' right to

manage. $^{21}$

Silverman argues that British and American views of liberal political economy and trade

unionism precluded state interference in union activities and therefore rejected the Leninist

principle of centralization that contributed to communist methods of unionization. ${ }^{22}$ Despite what

Silverman describes as the TUC's attempt to take the helm of a new postwar system to avoid

war, the concepts of free trade unionism and voluntaryism devolved into narrow anti-

Anthony Waters, Jr. and Geert Van Goethem, American Labor's Global Ambassadors: The International History of the AFL-CIO During the Cold War (New York, Palgrave Macmillan, 2013). Among post-revisionists, Silverman and Kim Scipes' work most closely connects to revisionist arguments. Silverman suggests that state and labor leaders, on both sides of the Cold War divide, imposed the conflict on the rank-and-file from the top and that it was not a matter of differences of trade union philosophy. He suggests that the UN and WFTU, in both creation and disillusionment, symbolized the hope and failure for the establishment of a more equitable world system. See: Silverman, Imagining Internationalism in American and British Labor, 184-186. See also: Kim Scipes, AFL-CIO's Secret War against Developing Country Workers: Solidarity or Sabotage (New York: Lexington Books, 2010).

${ }^{20}$ Michael Hogan first explained the concept of corporate neocapitalism as a product of the New Deal. See: Michael J. Hogan, The Marshall Plan: America, Britain, and the Reconstruction of Western Europe, 1947-1952 (Cambridge, MA: Harvard University Press, 1987); Dustin Walcher, "Reforming Latin American Labor: The AFL-CIO and Latin America's Cold War," in, Waters and van Goethem, American Labor's Global Ambassadors, 124, 126, 129; Federico Romero, "Transnational Labor Politics in the Global Cold War," in, Waters and van Goethem, American Labor's Global Ambassadors, 277.

${ }^{21}$ Silverman, Imagining Internationalism in American and British Labor, 178; Wehrle, Between a River \& a Mountain, 199; Jennifer Luff, Commonsense Anticommunism: Labor and Civil Liberties between the World Wars (Chapel Hill: The University of North Carolina Press, 2012), 3-6.

${ }^{22}$ Silverman, Imagining Internationalism in American and British Labor, 13-14, 29. 
communism by 1949 , which he suggests was the AFL view all along. ${ }^{23}$ Carew is more specific in noting the differences between AFL and TUC ideology. He suggests that the AFL favored a definition of free trade unionism that included emphasizing organizational independence from political parties, government, employers, or churches. The TUC, in contrast, favored a looser definition that merely suggested freedom from external domination and allowed a degree of party-union collaboration similar to that which existed between the TUC and the Labor Party in Great Britain. $^{24}$

Kim Scipes', AFL-CIO's Secret War Against Developing Country Workers, like Silverman, applies a post-revisionist methodology to draw a nearly revisionist conclusion. ${ }^{25}$ Scipes agrees that American labor leaders determined AFL-CIO policy even when policy mirrored or contributed to government policy and programs. Nonetheless, Scipes aggressively criticizes AFL-CIO policy, arguing that it was based on an imperialist attempt to impose American-style "business unionism" on foreign unions. ${ }^{26}$ Like Radosh, Scipes suggests that AFL-CIO policy did not fundamentally change after the Russian Revolution and as a result is not most effectively understood as merely anticommunist. ${ }^{27}$ Scipes insists that AFL-CIO rationalizations of their policy as supportive of freedom of association are "a complete and utter fraud." ${ }^{28} \mathrm{He}$ argues that United States labor leaders were inconsistent in their use of power; however, he concludes that labor imperialism worked in conjunction with the pursuit of

\footnotetext{
${ }^{23}$ Silverman, Imagining Internationalism in American and British Labor, 35, 91, 114-116. Silverman notes some variance among TUC leaders, George Woodcock, for example, seems to have held a view close to that of AFL leadership. See: Silverman, Imagining Internationalism in American and British Labor, 109. Note that other scholars, particularly Wehrle, challenge Silverman's reduction of AFL free trade unionism to mere anticommunism.

${ }^{24}$ Carew, "A False Dawn," 193-194.

${ }^{25}$ Scipes, AFL-CIO's Secret War against Developing Country Workers.

${ }^{26}$ Scipes, AFL-CIO's Secret War against Developing Country Workers, xxii, xxiv, xxix, 1, 25.

${ }^{27}$ Scipes, AFL-CIO's Secret War against Developing Country Workers, xxiv, 27.

${ }^{28}$ Scipes, AFL-CIO's Secret War against Developing Country Workers, 68.
} 
American Empire in a non-democratic, non-transparent manner, and that labor leaders' policies frequently worked against the interests of both American workers and laborers abroad. ${ }^{29}$ Less critically, Edmund Wehrle's Between a River and a Mountain addresses the concept of free trade unionism and rejects the notion that American labor leaders acted as "junior partners" taking orders from the United States government. Wehrle suggests instead that American trade union leaders designed AFL-CIO foreign policy based on labor's objectives and exerted considerable influence in relations with the United States government. He argues that labor leaders consistently pursued a foreign policy that promoted the ideal of trade unions acting as "essential components of democracies- the sole defense of workers against a multitude of threatening interests and institutions" in modern society. ${ }^{30}$ Wehrle acknowledges that various factors contributed to labor's foreign policy; however, he suggests that the most significant was the idea of free trade unionism, which he defines as trade union autonomy and "activist internationalism, a commitment to maintaining the essential autonomy of trade unions and advocacy of aggressive full-employment economics." ${ }^{31}$

Post-revisionists also nuance earlier explanations of the relationship between American labor leaders and United States government agencies. Wehrle suggests anticommunist labor leaders became more prevalent in the CIO after 1947 and AFL and CIO leadership coalesced around an anti-communist policy in the late 1940s despite deep differences regarding tactics.

${ }^{29}$ Scipes, AFL-CIO's Secret War against Developing Country Workers, 138-163.

${ }^{30}$ Wehrle, Between a River \& a Mountain, 3-4, 9. See also: Quenby Olmsted Hughes, "In the Interest of Democracy:" The Rise and Fall of the Early Cold War Alliance Between the American Federation of Labor and the Central Intelligence Agency (Oxford: Peter Lang, 2011), 14, 54. Hughes argues that the AFL, from its founding, conceived an organizational purpose as an institution designed to facilitate capitalism's proper function.

${ }^{31}$ Wehrle, Between a River \& a Mountain, 4. Specifically, Wherle notes that virulent anti-communism resulting from Communist "boring from within" strategies in the 1920s and 1930s led labor leaders to fear "Red Fascism." See: Wehrle, Between a River \& a Mountain, 9, 18. Wehrle also notes that domestic concerns and the expectation of jobs, a change in CIO views of political economy, and anti-colonialism were factors contributing to AFL/AFL-CIO foreign policy. See: Wehrle, Between a River \& a Mountain, 9, 14, 41, 44, 51. Quenby Olmsted Hughes argues that prominent individuals' conviction that trade unions needed to be independent from political control was an important factor in shaping American labor leaders' perception of "free trade unionism." See: Hughes, "In the Interest of Democracy," 183. 
Wehrle notes that the unions' merger in 1955 muted dissention in practice. ${ }^{32}$ Wehrle also suggests that the close relationship between AFL-CIO leaders and the Kennedy and Johnson White House in the 1960s may have contributed to a more aggressive United States foreign policy. ${ }^{33}$ When considered in conjunction with his explanation of free trade unionism, Wehrle convincingly argues that American labor leaders pursued an interventionist, anti-communist foreign policy to further their own objectives rather than as tools of United States government agencies.

Ted Morgan's biography of Jay Lovestone, A Covert Life, expands on Wehrle's suggestion that labor leaders influenced foreign policy in important ways. Morgan suggests that Lovestone, who held a variety of positions within the AFL international apparatus, acted covertly as one of the most influential foreign policymakers in the United States between 1944 and 1974. Lovestone influenced Presidential appointments, Senatorial speeches, and operated covertly overseas before the establishment of the CIA. ${ }^{34}$ Morgan suggests that Lovestone and his AFL associates collaborated closely with the CIA at the highest levels by 1950 at times altering policies with which they disagreed; however, he suggests that AFL influence decreased after 1958. ${ }^{35}$ Hugh Wilford's, The Mighty Wurlitzer further nuances the relationship between American labor leaders and the CIA. Wilford notes that Lovestone's faction in the AFL frequently disagreed and conflicted with official policy and ultimately the CIA-AFL-CIO connection ended when the CIA attempted to exert more control over labor activities than labor

\footnotetext{
${ }^{32}$ Wehrle, Between a River \& a Mountain, 41-42, 44, 58-64.

${ }^{33}$ Wehrle, Between a River \& a Mountain, 4-5, 75.

${ }^{34}$ Ted Morgan, A Covert Life: Jay Lovestone Communist, Anti-Communist, and Spymaster (New York: Random House, 1999), 143, 194, 198, 217, 255, 293.

${ }^{35}$ Morgan, A Covert Life, 217, 326. Morgan's suggestion that AFL Cold War policy diminished in 1958 seems skewed by the nature of his study. Specifically, Lovestone's collaboration with the CIA seemed strained after 1958; however, Edmund Wehrle's work suggests that, and this dissertation concurs, in some ways the AFL increased as a Cold War actor with the ascension of John F. Kennedy and Lyndon Johnson, two Democrats, to the Presidency. For more on the close relationship between AFL leaders and high-level political leaders, see: Hugh Wilford, The Mighty Wurlitzer: How the CIA Played America (Cambridge, MA: Harvard University Press, 2008), 4.
} 
leaders were willing to concede. ${ }^{36}$ Quenby Olmsted Hughes' In the Interest of Democracy is the most thorough examination of the AFL-CIA relationship and more generally the ideological foundations of American labor leaders' anti-communism. Hughes argues that labor-government cooperation was based on shared ideological objectives, as well as the realization that organizational weaknesses could be offset through collaboration, and that the relationship ended when labor leaders' concluded the CIA was attempting to control trade union foreign policy. ${ }^{37}$

Finally, scholars from all three schools address the question of when labor leaders became engaged in the Cold War, an issue that is critical for this study. The scholarship is virtually unanimous in concluding that American labor leaders, particularly in the AFL, became widely engaged in a Cold War before the United States government. American labor leaders frequently deemed foreign unionists or political leaders communist in advance of the United States government and pursued more aggressive policies to combat the perceived threat of communist expansion. ${ }^{38}$ Victor Silverman suggests that the reverse was true in Great Britain, arguing that despite pressure from the Foreign Office and some trade union leaders, rank-and-file concern with economic self-interest and the avoidance of war acted as a counterforce that slowed the TUC's drift into the Cold War. Nonetheless, he suggests that changes in TUC leadership in

\footnotetext{
${ }^{36}$ Wilford, The Mighty Wurlitzer, 9, 51-52, 60-61, 69. Anthony Carew advances a similar argument in a recent article. See: Anthony Carew, "The American Labor Movement in Fizzland: The Free Trade Union Committee and the CIA," Labor History 39 (1998). The CIA relationship with American labor was primarily with the AFL both before and after the AFL-CIO merger. However, the CIO briefly cooperated with the CIA in the early 1950s independently of the AFL.

${ }^{37}$ Quenby Olmsted Hughes, "In the Interest of Democracy:" The Rise and Fall of the Early Cold War Alliance Between the American Federation of Labor and the Central Intelligence Agency (Oxford: Peter Lang, 2011). ${ }_{38}$ Busch, The Political Role of International Trades Unions, 41; Carew, "A False Dawn," 236; Geert van Goethem, "From Dollars to Deeds: Exploring the Sources of Active Interventionism, 1934-1945, in, Robert Anthony Waters, Jr. and Geert Van Goethem, American Labor's Global Ambassadors: The International History of the AFL-CIO During the Cold War (New York: Palgrave Macmillan, 2013), 17; Hero and Starr, The Reuther-Meany Foreign Policy Dispute, 32-33; Scipes, AFL-CIO's Secret War against Developing Country Workers, xxix, 28; Sims, Workers of the World Undermined, 16-17; Taft, Defending Freedom, 52-65; Wedin, International Trade Union Solidarity, 15; Wehrle, Between a River \& a Mountain, 27; Hugh Wilford, "American Labour Diplomacy and Cold War Britain,” Journal of Contemporary History, Vol. 37 (1), 45-65, 2002.
} 
the early 1950s led to closer collaboration between the TUC and Foreign Office in waging the Cold War. ${ }^{39}$

\section{International Labor}

Anti-communism was the defining characteristic of the AFL's international activities no later than 1944 and it was increasingly significant to the Western world's labor internationalism after the establishment of the International Confederation of Free Trade Unions (ICFTU) in December 1949. Nonetheless, anti-communism was not a reflexive policy or an end in itself; it was the dominant theme in Anglo-American labor's foreign policy because it was seen as the most immediate threat to the preservation of the Anglo-American dominated capitalist system labor leaders thought would protect trade union independence and increase material benefits for workers, promote peace and economic growth, and advance American and British national interests. Labor leaders argued that communist trade unions operated based on a theory of trade unionism incompatible with Western labor, a practice that was designed to introduce a revolutionary political economic system that did not protect workers' freedom. Moreover American and British labor leaders argued that communists frequently attempted to infiltrate non-communist unions to turn the organizations into tools of political subversion rather than to collaborate in pursuit of workers' interests. Ultimately, they feared that communist unions would facilitate the expansion of a political-economic system that concentrated economic and political power, subverted workers' independence, spread poverty, and led to military conflict. ${ }^{40}$

\footnotetext{
${ }^{39}$ Silverman, Imagining Internationalism in British and American Labor, 101, 107-109, 114.

${ }^{40}$ Nelson Lichtenstein suggests that American labor leaders, such as Walter Reuther, expected Communist expansion would undermine the American economy, decrease workers' standards of living, lead to reactionary political instability from both ends of the political spectrum, and likely result in a war fought by the working class. See: Lichtenstein, Walter Reuther, 253. See also: Hughes, “In the Interest of Democracy”, 58; Interview with Jesse A. Friedman by James F. Shea and Don R. Kienzle, September 22, 1995, The Foreign Affairs Oral History Collection of the Association for Diplomatic Studies and Training, library of Congress, Manuscript Division, Washington, D.C. 20540 USA (Hereafter FAOHC, LOC).
} 
American and British labor leaders increasingly adopted anti-communism in the late 1940 s and in the 1950 s as a means of preserving the international system, which they expected to decentralize power and increase workers' influence. As a result, they expected that their objectives could only be attained within the Anglo-American-led capitalist system with trade unions designed to perpetuate that system. ${ }^{41}$ Several scholars place their analyses of American labor's foreign policy in this broader structural context. ${ }^{42}$ Ultimately, the TUC and CIO followed the AFL into a Cold War, engaging in institution-building activities designed to subvert potential challenges to the Anglo-American political-economic system or British and American national interests. $^{43}$

Labor leaders representing the AFL, CIO, and TUC disagreed on a wide range of tactical questions regarding their organizations' roles in international labor and the international labor movement's role in post-World War II international relations; however, they agreed that peace, economic stability, democratic principles, workers' rights, and the interests of British and

${ }^{41}$ Cochran, Labor and Communism, 344. For an explanation of the ideological and structural roots of AFL, and after 1955 AFL-CIO, promotion of American-style unionism, see: Walcher, "Reforming Latin American Labor," 124133. Simeon Larson and Bruce Nissen note that among the various theories of organized labor, only Marxist labor theorists advocated a form of trade unionism that sought to alter the political-economic system. After World War II AFL "business unionism," and CIO and TUC "social activist unionism" both supported perpetuation of the existing capitalist system rather than advocating for Socialism or Communism. See: Simeon Larson and Bruce Nissen, eds., Theories of the Labor Movement (Detroit: Wayne State University Press, 1987), 2-7. Similarly, David Saposs, labor scholar and chief economist of the National Labor Relations Board from 1935 to 1940, argued that advances in social legislation and union rights beginning around 1900 and peaking after World War II led to an ideological shift in traditionally Socialist-oriented labor organizations such as the CIO and TUC. As a result, Saposs suggests that the working-class invested in the preservation of capitalism as the means to consolidating or expanding material gains rather than the pursuit of a Socialist society, and established a stronger attachment to national rather than international objectives. See: David J. Saposs, "Ideological Conflicts in the International Labor Movement, in Everett M. Kassalow, ed., National Labor Movements in the Postwar World (Evanston, IL: Northwestern University Press, 1963), 23. Edmund Wehrle notes that Samuel Gompers' view of American labor as a counter to radicalism shaped American labor leaders' ideology through the 1970s. Gompers himself directed this view toward anticommunism after 1917. See: Wehrle, Between a River \& a Mountain, 12.

${ }^{42}$ Gerald Horne, Cold War in a Hot Zone: The United States Confronts Labor and Independence Struggles in the British West Indies (Philadelphia: Temple University Press, 2007); Kofas, The Struggle for Legitimacy; Saposs, "Ideological Conflicts in the International Labor Movement;" Hilbourne Watson, "Guyana, Jamaica, and the Cold War Project: The Transformation of Caribbean Labor," in Perry Mars and Alma H. Young, ed., Caribbean Labor and Politics, Legacies of Cheddi Jagan and Michael Manley (Detroit: Wayne State University Press, 2004).

${ }^{43}$ Despite general unity in anti-communist viewpoint, the AFL stood out in its aggressive anti-communism. TUC and CIO leaders, while consistently anti-communist, tended to advocate positive developmental strategies to combat communism's appeal, rather than negative anti-communist subversion more so than the AFL. 
American workers could only be preserved within the existing capitalist system. ${ }^{44}$ More importantly, they argued that the trade union movement, based on British and American trade union practices, was fundamental to the preservation of the capitalist system and democratic politics. Crucially, instability in the post-war international system, the near assurance that colonies would gain a degree of autonomy, and the appeal of communism to many colonial leaders, convinced many labor leaders that the development or imposition of specific institutional structures was the only safeguard against the collapse of international capitalism, democracy, economic stability, and peace, as well as British and American workers' interests. Thus, Anglo-American trade union leaders engaged in a post-war policy of institution building in colonial areas that was more aggressive than pre-war TUC, AFL, or CIO activities.

\section{Peace and Democracy}

AFL, CIO, and TUC post-war institution-building centered on the theoretically mutually constitutive promotion of peace, economic growth, democracy, and self-determination; however, contradictions in British and American labor foreign policies undermined those ideals in practice. British and American labor leaders consistently emphasized trade unions' and international labor institutions' importance as associations to preserve peace during and after the Second World War. Sidney Hillman of the CIO, who historian Jennifer Luff argues was part of a "cadre of left unionists" that "made up the labor wing of the progressive alliance" in the United

\footnotetext{
${ }^{44}$ The AFL in particular criticized delegates at the World Labor Conference in 1945 of contemplating, "anticapitalist resolutions," such as a TUC proposal that the conference "go on record in support of public ownership (with workers' participation) of key industries, and of State control of private investment." See: "What Happened at the World Labor Conference," Office of the President-George Meany (1948-1960), Box 52, Subjects: World Federation of Trade Unions (1945-1949), George Meany Memorial Archives, Silver Spring, MD (Hereafter GMMA). Five years later the AFL was less critical of the TUC after the TUC moderated its position. An AFL summary of the ICFTU's philosophy described it as a reformist "middle way," supportive of a "mixed economy" rather than socialism and "private enterprise within the welfare state with some degree of nationalization." See: "International Confederation of Free Trade Unions: Its Organization, Objectives, Ideology and Structure," 2 May 1950, Office of the President-Meany (1948-1960), Box 49, Formation, 1949-1950, GMMA. See also: Cochran, Labor and Communism, 341-344.
} 
States during the $1930 \mathrm{~s}$, was one of the most influential men in founding the WFTU in $1945{ }^{45}$

The first of several aims Hillman listed as organizational purposes at the WFTU's founding was its role in contributing to an enduring global peace. ${ }^{46}$ When the ICFTU was founded in 1951 , largely for the purpose of opposing the WFTU, its leaders acknowledged that one of the WFTU's most important objectives was to promote peace even though they determined that it failed as an organization. ${ }^{47}$ Furthermore, in articulating its broad responsibilities and defining its relations with United Nations agencies in the Western Hemisphere, the ICFTU emphasized the importance of workers' self-organization, collective bargaining, and improved standards of living as central to "the responsibilities of the trade union movement of America and the World toward peace founded on justice." ${ }^{48}$

British and American labor leaders emphasized the importance of using trade union activity to preserve peace in their bilateral meetings as well. Richard Walsh, an AFL representative who met with the TUC in 1952, emphasized in his speech that "the first task of the free world is to prevent World War III and not refight World War II." ${ }^{, 49}$ Individual unions explained part of their post-war mission in similar terms. The United Auto Workers (UAW) adopted a resolution in 1953 emphasizing the important role that their organization and other trade unions played in acting as a deterrent to "reactionary isolationists" and "trigger-happy Senators" whose actions could undermine negotiation between nations and result in the use of

\footnotetext{
${ }^{45}$ Luff, Commonsense Anticommunism, 145.

${ }^{46}$ Sidney Hillman, "World Trade Union Conference: Basis for a World Trade Union Federation," February 1945, RG1-027, Office of the President, President's Files, George Meany, 1947-1960, Box 52, Subjects: World Federation of Trade Unions, 1945-1949, GMMA.

47 “International Confederation of Free Trade Unions: Its Organization, Objectives, Ideology and Structure,” May 2, 1950, Office of the President-Meany (1948-1960), Box 49, Formation, 1949-1950, GMMA.

48 "Relation with the UN and Specialized Agencies in the Western Hemisphere," March 27-28, 1951, International Affairs Department, Staff Files, George Delaney’s Files, 1921-1957, ICFTU 1951-1952, GMMA.

${ }^{49}$ Richard Walsh, statement before the TUC, September 1952, RG 18-003, International Affairs Department, Jay Lovestone Files, 1944-1973, Box 10, British Embassy, 1952-1953, GMMA.
} 
force in disagreements between communist and non-communist countries. ${ }^{50}$ Walter Reuther, who was president of the UAW and vice president of the AFL-CIO, echoed the resolution in a speech to the TUC in 1957, arguing that the problem of world peace "transcends every other problem we face." $" 51$

In addressing the second ORIT convention in December 1952, AFL representative William Doherty identified the greatest challenge facing the organization as the "ability to find a way to insure lasting peace and international security as well as economic and social advancement." Doherty argued that peace, through a broadly defined freedom, was possible only with the strength of organized labor, noting that Adolf Hitler's Germany and Benito Mussolini's Italy first asserted dictatorial powers through dissolution of their nation's trade unions. In addition to identifying peace as an ideal, Doherty's speech identified communist dictatorships as the primary threat to peace, arguing that non-communist dictatorships used "identical methods and employ the same basic techniques" as in communist countries. The means of undermining communist dictatorship and preserving post-war peace, Doherty argued, was to "strengthen all instruments of democracy, including the free-trade union movement.” Doherty suggested that grassroots organizing and people's participation in civic enterprises were essential and in their absence "the rise of dictatorship of one form or another is inevitable."52

Doherty’s address illuminated two important conclusions AFL leaders drew regarding foreign policy by 1952. First, in associating dictatorship with the use of communist methods, it insinuated that communism was the source of oppression, rather than totalitarianism. In doing so

\footnotetext{
${ }^{50}$ Resolution Adopted by the UAW-CIO, March 22-27, 1953, FO 371-103575, BNA

${ }^{51}$ The Press Department, Trades Union Congress, "Excerpts from Fraternal Address of Walter P. Reuther," September 3, 1957, RG 18-003: International Affairs Department, Jay Lovestone Files, 1944-1973, Box 11, British Trade Union Congress, 1957, GMMA.

${ }^{52}$ William C. Doherty, Address to the Second ORIT Convention, December 1952, International Affairs Department, Staff Files, George Delaney's Files, 1921-1957, Box 11 (1945-55), ORIT Congress (Second), (Rio de Janeiro, December 1952), 1952-53, GMMA.
} 
it sought to delegitimize communist ideology of local as well as Soviet origin and also discredit the use of "communist methods;" specifically, the use of trade unions for organizing anticapitalist political activities. It also opened the possibility of compromise with right-wing dictatorships as a temporary means of defeating communism since the latter was explained as the root cause of tyranny. To be clear, America labor leaders actively, if inconsistently, opposed right-wing authoritarian regimes that suppressed trade unions. The AFL-CIO refused several requests from the State Department to participate in an International Labor Organization (ILO) conference in Caracas, Venezuela in 1955 in protest to the Perez Jiménez regime's suppression of trade unions ${ }^{53}$ Similarly, American labor leaders' and other members of ORIT issued a statement emphasizing the organization's opposition to military dictatorships that repressed citizens and made it difficult to counter communism in $1957 .{ }^{54}$ Nonetheless, the tendency in American labor circles was to identify communism as the most significant threat to democracy and peace. Secondly, the speech directly asserted that the only means of preserving workers' freedom was institution building, the establishment of trade unions based on AFL methods. Labor leaders, particularly in the AFL, reinforced the notion that trade unions played a crucial role in preserving peace and that doing so was central to their mission; however they acknowledged that peace was unachievable without action and may not be an end in itself. The AFL's views increasingly influenced debates within international labor organizations as American labor leaders tried to work from within the ICFTU and especially ORIT in the early 1950s. An AFL memorandum describing the establishment and ideology of the newly

\footnotetext{
${ }^{53}$ There is an entire folder of material in the State Department records that examines official efforts to convince the AFL-CIO to reverse its position and attend the Caracas Conference, to no avail. See: 398.06-ILO, RG 59, General Records of the Department of State, Central Decimal File 1955-59, Box 1454, National Archives II, College Park, MD (Hereafter, NARA II).

${ }^{54}$ Draft Statement on the Military Dictatorships in Latin America, 1957, RG 18-009, International Affairs Department, Staff Files: Serafino Romualdi’s Files, 1945-1961, Box 5, ORIT, 1957, GMMA.
} 
established ICFTU in 1950 noted that peace and democracy were mutually compatible; however, it argued that pacifism could not adapt to a modern society with constant threats of totalitarianism. International labor organizations, the memorandum argued, needed to use all means possible of advancing democracy which experience taught was the only means of providing for people's spiritual and material needs. ${ }^{55}$ Examination of international organizations founding documents strongly suggests that the AFL's international relations philosophy permeated the ICFTU and especially ORIT. ${ }^{56}$

After the AFL engineered the replacement of TUC General Secretary Vincent Tewson as president of the ICFTU with Omar Becu in early 1953, the AFL News Reporter took pride in claiming that the new leadership would "transform the ICFTU from a dormant debating society into an active and militant organization" to "advance peace, without appeasement." The inclusion of the phrase "without appeasement" is subtle but significant. The qualification acknowledged that preserving peace was less important than pursuing aggressive anti-communist policies from the perspective of AFL leadership. Specifically, the article noted that the new leadership allowed for a shift away from Tewson's strategy of negotiation toward a policy that encouraged active engagement against communism. ${ }^{57}$ Pierre Ferri-Pisani, a French trade unionist who worked closely with Lovestone, Brown, and the AFL's covert Free Trade Union Committee (FTUC), defended American labor's emphasis on aggressive anti-communism and criticized

\footnotetext{
55 "International Confederation of Free Trade Unions: Its Organization, Objectives, Ideology and Structure," May 21950, Office of the President-Meany (1948-1960), Box 49, Formation, 1949-1950, GMMA.

${ }^{56}$ Inter-American Regional Organization of Workers of the International Confederation of Free Trade Unions, "Constitution," RG 18-009, International Affairs Department, Staff Files: Serafino Romualdi’s Files, 1945-1961, Box 7, Miscellaneous, 1955-1956, GMMA.

${ }^{57}$ Phillip Pearl, "ICFTU is Revitalized Under New Leadership," Extract from AFL News Reporter, July 17, 1953, FO 371-103575.
} 
efforts at peaceful coexistence in international labor relations. ${ }^{58}$ Ferri-Pisani criticized the ICFTU, arguing that neutralism was akin to "cowardice" and "pathological indecision." Similarly, George Harrison, Chairman of the AFL-CIO Committee on International Affairs, reminded delegates to a Conference on World Affairs in 1960 that American labor did "not want peace with chains and slavery" in a speech edited by Lovestone and Mike Ross, Director of the AFL-CIO International Affairs Department. Harrison's speech argued that communist expansion would result in "the peace of the prison or the cemetery."60

As mentioned above, Anglo-American labor leaders' foreign policy rhetorically aimed at protecting and advancing democratic principles through international trade union activity after World War II because democracy and peace were deemed mutually constitutive. Regarding trade unions' preservation of democracy, David Dubinsky, one of CIO leaders most responsible for the organization's foreign policy, noted that Communist control of the trade unions in

Czechoslovakia presaged the 1948 Soviet coup d'état in that country. ${ }^{61}$ He argued that, "the catastrophe that has befallen Czecho-Slovakia confirms that once a country falls under the yoke of a totalitarian regime, free unions perish. There can be no democracy without free trade unionism; there can be no bona fide, free, trade unionism without democracy." Dubinsky

\footnotetext{
${ }^{58}$ For more on the FTUC, see: Quenby Olmsted Hughes, "The American Federation of Labor's Cold War Campaign Against 'Slave Labor' at the United Nations," in Robert Anthony Waters, Jr. and Geert van Goethem, American Labor's Global Ambassadors, 23-38.

${ }^{59}$ Ferri-Pisani Pierre, "Memorandum on the Possible Reorientation of the ICFTU," undated, Office of the PresidentGeorge Meany (1948-1960), Box 49, Subjects: Headquarters, 1951-1962, GMMA; Morgan, A Covert Life, (GET PAGES).

${ }^{60}$ George Harrison, “Opening Remarks,” April 1, 1960, RG 18-003, International Affairs Department, Jay Lovestone Files, 1944-1973, Box 68, American Federation of Labor-Congress of Industrial Organizations: Conference on World Affairs, New York City, 1960, GMMA.

${ }^{61}$ Gary Busch describes the communist coup in Czechoslovakia through the union movement in detail. See: Busch, The Political Role of International Trades Unions, 43-48.
} 
concluded that, "Free trade unionism and genuine democracy need each other like a fish needs water or like a human being needs air to breath and live.",62

A report presented to the CIO International Committee in 1950 argued that strengthening free labor abroad was essential "so that we can promote democracy now and save lives later." The report warned that supporting free labor abroad "stands today as the only firm and reliable bulwark against further infiltration of red totalitarianism" and the "double threat of reaction from the Right and subversion from the Left."63 The merged AFL-CIO reiterated similar objectives and emphasized the mutually dependent relationship between trade unions and democratic societies during their first convention in December 1955. Furthermore, the AFL-CIO defined the organization's international role as the pursuit of good relations to foster "and promote enduring peace and freedom" and "to encourage mutually advantageous trade... in order to advance common economic stability and social well-being." 64

Perhaps the most direct and illuminating examples of the difficult and sometimes ambiguous nature of balancing several post-war ideals are two speeches found in Jay Lovestone's files among the records of the AFL-CIO. The first speech is untitled and seems to have been given by an AFL representative, possibly Lovestone, to the TUC in 1954. It acknowledged that the two organizations occasionally clashed in international activities but expressed hope that they had "learned to disagree without being disagreeable." It suggested that

\footnotetext{
${ }^{62}$ David Dubinsky draft of paper, undated, RG 18-003, International Affairs Department, Jay Lovestone Files, 19441973, Box 10, David Dubinsky, 1947-1948, GMMA. See also: George Harrison, “Opening Remarks,” April 1, 1960, RG 18-003, International Affairs Department, Jay Lovestone Files, 1944-1973, Box 68, American Federation of Labor-Congress of Industrial Organizations: Conference on World Affairs, New York City, 1960, GMMA; Ernst Schwarz to Arthur Goldberg, CIO, "Resolution on the CIO and the Self-Determination of the Peoples of LA," August 1952, RG 18-002, International Affairs Department, Series 3, Sub-Series 1, Box 7, GMMA.

${ }^{63}$ Untitled, undated report, International Affairs Department (CIO), Director's Files (Mike Ross), 1945-1955, Subseries 5: CIO International Committees, CIO International Committee Meetings, 1951, GMMA.

${ }^{64}$ George M. Harrison, "Why We Fight for Freedom," New York Times, included in a letter from Albert J. Zack, Director Department of Public Relations, AFL-CIO to Dwight D. Eisenhower, May 25, 1960, AFL-CIO (Merged 12-5-55), Central Files, General File, 1959-1960, Box 943, Dwight D. Eisenhower Presidential Library, Abilene, KS (Hereafter DDEL).
} 
failure to cooperate was suicide and that "above all, we do not want to have [sic] fight a World War III.." ${ }^{, 5}$ The speech illuminates labor leaders' continued fear of military engagement, reinforces the notion that they viewed their role in the post-war world as advancing solidarity between national trade union fronts to avoid conflict, and makes clear that the AFL and TUC disagreed on how to achieve those objectives.

The second speech seems to have been given to the TUC in 1955 by either C.J. Haggarty of the AFL or Lovestone. Lovestone, who was perhaps more influential than anyone else in establishing and implementing the AFL's foreign policy program, almost certainly contributed to or at least approved the speech. The speech outlines the importance of democracy and trade unions' role in upholding it, emphasizing that the AFL could not support non-free unions even if official United States policy was supportive of a dictatorial government. However, the speech cautions that "In the quest for peace, we must be prepared to sup with Satan." After reinforcing the superiority of democratic ideals and demanding caution when "dining with the devil," Lovestone continues, arguing that "Ballerina, prima dona, and concert tours, trade missions and exchange of sundry sorts of delegations, may appear attractive but they are not effective means for reducing international tension. ${ }^{.66}$ While stressing labor leaders' ideals for the post-war world and their willingness to stand for free trade union principles even faced with conflicting policies on the part of their own government, the speech insinuates a willingness to engage in antidemocratic activities when necessary to achieve broader objectives.

Furthermore, members of the AFL-CIO were allied with the Cold War Council, Council on Communist Aggression, and other organizations engaged in promoting psychological warfare

\footnotetext{
${ }^{65}$ AFL to TUC, 1954 , RG 18-003, International Affairs Department, Jay Lovestone Files, 1944-1973, Box 10, British Trades Union Congress, 1948-1949, 1954-1956, GMMA.

${ }^{66}$ AFL speech to TUC, September, 1955 , RG 18-003, International Affairs Department, Jay Lovestone Files, 19441973, Box 10, British Trades Union Congress, 1948-1949, 1954-1956, GMMA.
} 
in the late 1950s and early 1960s. The Cold War Council openly justified its willingness to unite with totalitarian governments. The Council argued that "All totalitarian tyrannies are bad, but only the Communists aim at the destruction of the U.S. and the enslavement of all mankind," while noting that the United States aligned with the Soviet Union to defeat Nazi Germany. Similarly, they argued, cooperation with non-communist dictators may be necessary to combat Communism. ${ }^{67}$ Thus, some American labor leaders were willing to temporarily sacrifice democratic principles abroad to defeat what they viewed as an immediately and existential threat to democracy.

Importantly, labor leaders' views of dictatorship and democracy mirrored those expressed in President Dwight Eisenhower's National Security Council (NSC) and pursued throughout the 1950s during the period under examination in this dissertation. Nelson Rockefeller, Eisenhower's special assistant on foreign affairs, told the NSC that dictators were "a mixed blessing." Rockefeller suggested that authoritarian Latin American leaders effectively combat communism; however, he warned the NSC that it was in the best interest of the United States to back democratic governments. Eisenhower's agreement with Rockefeller's assessment suggests that American labor and governmental leaders shared a belief in promoting regional democracy while expressing a willingness to see democratic principles temporarily compromised to defeat communism. ${ }^{68}$ Furthermore, Stephen Rabe notes that Eisenhower worked with dictatorial governments and even rewarded Latin American dictators who enforced anti-communist

\footnotetext{
67 "What is the Cold War Council," undated pamphlet, Alan Grant Papers, Box 15, miscellaneous, 1961 (3), Oct.Dec., DDEL. In the same folder is a newspaper clipping describing AFL-CIO support for the Freedom Bill and two letters from AFL-CIO unionists offering support for psychological warfare programs.

${ }^{68}$ Memorandum of Discussion at the $237^{\text {th }}$ Meeting of the National Security Council, February $17,1955,237^{\text {th }}$ Meeting of NSC, February 17, 1955, Dwight D. Eisenhower Papers as President, 1953-61, (Ann Whitman File) NSC Series, Box 6, DDEL.
} 
stability. ${ }^{69}$ Lovestone's cryptic speech and the Eisenhower administration's reluctant support of anti-communist dictators are sobering acknowledgments of the contradictions American labor leaders and policymakers faced and the compromises they were willing to make in the pursuit of foreign policy objectives.

\section{Economic Development, Stability, and Institution Building}

Anglo-American labor leaders consistently argued in favor of economic policies and trade agreements designed to promote economic growth and stability overseas; however, their idealism was trumped by motives rooted in protecting their constituents' economic status and combatting communism to preserve liberal, Western-oriented capitalist system and their favorable position within it. ${ }^{70}$ There were notable differences, however, in the economic philosophies of AFL, CIO, and TUC leaders and those dissimilarities contributed to the ideological outlook that shaped overseas activities in the 1950s as well as Guianese political and labor leaders' response to Western international organizations. The AFL's gradual assertion of dominance over American labor's foreign policy and eventually within the ICFTU, ORIT, and the Caribbean Area Division of ORIT (CADORIT), led to a more conservative economic stance that was increasingly hostile to the Guianese labor leaders' socialist tendencies.

Sidney Hillman spoke of the need for international cooperation to industrialize underdeveloped areas, pursue reconstruction after the war, and to "fully utilize the rich resources of the world for the benefit of its people, yielding rising standards of living and real security to

\footnotetext{
${ }^{69}$ Stephen G. Rabe, Eisenhower and Latin America: The Foreign Policy of Anticommunism (Chapel Hill: The University of North Carolina Press, 1988), 85-99.

${ }^{70}$ Robert Waters and Geert Van Goethem note that the AFL-CIO's primary objective was, "to defend and promote the material interests of its members." Waters and van Goethem, American Labor's Global Ambassadors, 6. The AFL in particular had a history of organizational support for United States economic expansion as a means of securing benefits for American workers, even if such expansion undermined worker's rights abroad. See: Kofas, The Struggle for Legitimacy, 251, 294, 296-297, 321-322; Radosh, American Labor and United States Foreign Policy, 4$6,15,25,28,149$.
} 
the men and women of all nations," at the World Trade Union Congress in $1945 .{ }^{71}$ Hillman's speech was not radical, particularly in the context in which it was given--during World War II as an appeal for international trade union cooperation in rebuilding the world and contributing to a lasting peace. Nonetheless, there was criticism within the AFL regarding Hillman's insinuation of international cooperation. In June 1945 Robert Maisel warned AFL President William Green that Hillman's proposal to "provide other credits and facilities" for reconstruction were part of "the economic chess game that we now see being played before our eyes, to make American resources available to Russia and Russia's allies after World War II."72

\section{A comparison of two reports written by CIO Executive Secretary Ernst Schwarz} illuminates the ways in which labor's emerging Cold War contributed to the contradictions CIO leaders faced in balancing economic ideals with Cold War context. Schwarz's first report articulated the difficulties facing transnational labor cooperation in economic development programs in an analysis he wrote for the WFTU Economic and Employment Commission in 1948. In his study, Schwarz acknowledged a split among trade union leaders in the WFTU over the type of economic development programs proposed for needy countries. CIO, TUC, and French trade unionists argued that agricultural development and private foreign investment should form the basis of economic programs to underdeveloped countries. Conversely, Eastern European trade unionists argued that industrialization and self-sufficiency were the central components of economic development in poor countries and those improvements could only be made after colonies gained political independence. ${ }^{73}$

\footnotetext{
${ }^{71}$ Sidney Hillman, "World Trade Union Conference: Basis for a World Trade Union Federation,” February 1945, RG1-027, Office of the President, President's Files, George Meany, 1947-1960, Box 52, Subjects: World Federation of Trade Unions, 1945-1949, GMMA.

${ }^{72}$ Robert Maisel to William Green, April 2, 1945, 52/15 Subjects: World Federation of Trade Unions, 1945-1949, GMMA.

${ }^{73}$ Ernst Schwarz, "Summary of the Deliberations of the $3{ }^{\text {rd }}$ Meeting of the Economic and Employment Commission," June 29, 1948, International Affairs Department (CIO), Director's Files (Mike Ross), 1945-1955,
} 
Bureaucratic debates likely hardened positions in the organization, particularly in respect to the CIO's position alongside the TUC and French union leaders seemingly acting in support of colonialism and emphasizing the importance of private investment. Nonetheless, Schwarz's report suggests that British and American trade union leaders endorsed policies within the WFTU that reinforced the nature of international economic relationships regardless of idealism. It is also significant that Schwarz noted the somewhat isolated American, British, and French position on the issue of economic development when he acknowledged that other countries, including Brazil, China, India, Australia, and Norway “ took a stand somewhere in the middle...but often showed more sympathy toward the views of Eastern European members."74 Schwarz's note suggests that there was sympathy among many international labor leaders for political-economic ideas and international policies that conflicted with British and American aims, including in former British colonies. The expression of starkly contrasting views of economic development in the context of post-war debates regarding the future of industrial modernization and the international system reinforced American and British labor leaders' proclivities toward greater international activity to stabilize the existing system and their position within it.

Schwarz's second report, which he sent Mike Ross in March 1949, was the draft of a plan for economic development in Latin America. Schwarz's proposed plan is striking in the extent to which it deviated from the Western economic development view articulated in his WFTU report from the previous year. Schwarz argued that Latin America's economic underdevelopment was a result of foreign exploitation that subverted regional nations' attempts to diversify their economies and created financial dependencies. Regional development, he argued, could only be

Sub-Series 1: World Federation of Trade Unions: CIO Department Files, 001/36, WFTU: Correspondence, 1948, GMMA.

${ }^{74}$ Ibid. 
obtained through a progressive economic program undertaken by democratic governments in coordination with free labor institutions. Schwarz criticized the "colonial and semi-colonial" nature of Latin American economies, argued in favor of national economic planning that subordinated private investment to public agencies, proposed land reform, and advocated nationalization to develop heavy industry. ${ }^{75}$ ORIT's founding members copied Schwarz's analysis nearly verbatim and included in the discussions during the organization's establishment in March 1951 and an ICFTU report in 1949 echoed the primacy of public good over private profit. $^{76}$

Comparing the Schwarz documents suggests that rivalries and bureaucratic struggles within the WFTU polarized views and discouraged compromise on subjects about which delegates held similar views. Even though Schwarz's proposals were included in discussions at the ORIT founding and similar ideals were expressed in ICFTU resolutions, in practice the Western labor internationals did not emphasize the importance of Schwarz's development program. In practice, the ICFTU and ORIT primarily focused on institution building to confront communism and labor movements that engaged in socialist trade union practices, despite the importance British and American labor leaders placed on economic development.

The uncertainty regarding ORIT's primary purpose further illuminates the complexity of American labor's international activities. ORIT was established, in part, to assist in strengthening trade unionism in developing Latin American nations and advance the goals of regional workers in collaboration with American labor. According to Rutgers professor and labor activist Robert

\footnotetext{
${ }^{75}$ Ernst Schwarz, "A Hemisphere Plan for the Economic and Social Development of the Countries of Latin America," March 15, 1949, International Affairs Department (CIO), Director's Files (Mike Ross), 1945-1955, SubSeries 1: International Committees, 007/16, CIO Latin America Committee, 1949, GMMA.

76 "Statement on Economic and Social Development Program for Latin America," attached to documents pertaining to the establishment of the Inter-American Regional Organization of ORIT, March, 1951, International Affairs Department, Staff Files, George Delaney's Files, 1921-1957, ICFTU 1951-1952, GMMA; "International Confederation of Free Trade Unions: Its Organization, Objectives, Ideology and Structure," May 2, 1950, Office of the President-Meany (1948-1960), Box 49, Formation, 1949-1950, GMMA.
} 
Alexander, ORIT's role was essential because American companies owned and operated many of the corporations exploiting hemispheric workers. Consequently, ORIT and American labor unions pressured United States businesses that were harassing Latin American labor as a means of protecting workers in the United States and the rest of the region. ${ }^{77}$ Alexander's view is significant because it is the clearest expression of his idealism and because he was a central figure in AFL activity in British Guiana in the early 1950s. Nonetheless, Alexander's explanation was expressed in a public forum and as will be discussed in the next three chapters his activities in British Guiana were far more focused on political activity and institution building than economic activities.

William Doherty acknowledged another subtlety in the AFL's position during an address at the second ORIT convention in December 1952. Doherty noted that "the most compelling reason why organized labor in the United States is vitally concerned with preventing a recurrence of economic crises" was because "one nation cannot live in peace and plenty while the rest of the world is plagued with misery and starvation. ${ }^{, 78}$ The AFL vice president's speech was primarily an argument against dictatorship; however, in the context of articulating an aggressive vision for ORIT's opposition to totalitarianism Doherty illuminated a more complicated issue facing international labor. Early Cold War AFL efforts to promote economic advancement abroad were at their core attempts to avoid the recurrence of political radicalism that could lead to military conflict. On their most fundamental level, AFL appeals to avert armed conflagration were attempts to protect American workers. Thus, their support for economic advancement overseas

\footnotetext{
${ }^{77}$ Robert J. Alexander, "Labor and Inter-American Relations," Annals of the American Academy of Political and Social Science, Vol. 334, March 1961, pp. 41-63.

${ }^{78}$ William C. Doherty, Address at the Second ORIT convention, December 1952, International Affairs Department, Staff Files: George Delaney's Files, 1921-1957, Box 11, ORIT Congress (Second), (Rio de Janeiro, December 1952), (1952-1953), GMMA.
} 
was occasionally limited and self-serving however sincere and laudable attempts to prevent a third World War.

Doherty's address to a group of hemispheric labor leaders called for a sound program of industrialization to diversify Latin American economies; however, American labor leaders did not consistently support measures aimed at altering the status of underdeveloped areas when in a position to advocate for policies that could conflict with American workers' interests. Stanley Ruttenberg, director of the CIO's Department of Education and Research, had an opportunity to influence American policymaking when he spoke with the Eisenhower administration's Commission on Foreign Economic Policy in $1953 .{ }^{79}$ Ruttenberg argued for a trade policy that avoided supporting industrialization in the hemisphere's underdeveloped areas and instead emphasized the significance of trade unions to the post-war economy and preservation of American workers' increasing living standards. He suggested that unimpeded "tri-cornered" trade gave the United States access to raw materials, provided underdeveloped areas with dollars for development and purchase of American exports, and also gave underdeveloped areas dollars to spend in Europe allowing Europeans to purchase American manufactured products.

Ruttenberg's focus on creating jobs for American workers led to his advocating a policy that reinforced the existing international economic system and underdevelopment in some parts of the world. $^{80}$

David McDonald, President of the United Steelworkers of America, disagreed with Ruttenberg and suggested that industrialization in underdeveloped areas might not harm

\footnotetext{
${ }^{79}$ For a detailed analysis of the Eisenhower administration's economic policy, see: Rabe, Eisenhower and Latin America, 64-83.

${ }^{80}$ Stanley H. Ruttenberg, Director, Department of Education and Research, CIO, Statement Before the Commission on Foreign Economic Policy, Presented on Behalf of the Congress of Industrial Organizations, October 28, 1953, Hearings-Cong. Of Indus. Org. Stanley H. Ruttenberg, Dir. Dept. of Edu. \& Research-10/28/53, Commission On Foreign Economic Policy: Records, 1953-1954 (Randall Commission), Transcript of Hearings-11/19/53, Box 10, Eisenhower Presidential Library; CIO Proposal to Boost World Trade: Statement for Release, March 15, 1953, RG 18-002, Series 3, Sub-series 1, International Affairs Department, 1945-1971, GMMA.
} 
American workers and may even be beneficial. ${ }^{81}$ The difference between Ruttenberg's and McDonald's views on industrialization in undeveloped areas is significant. Certainly Ruttenberg was acting according to his mandate in advocating for policies in the best interest of his constituents. However, many colonial leaders, including the People's Progressive Party (PPP) in British Guiana, saw the post-war era as an opportunity to improve their country's place in the international economic system, to establish a modern industrial economy, and consequently to increase the quality of life for people often living in dire poverty. PPP leaders understood that complete incorporation into Anglo-American international institutions such as ORIT or the ICFTU, or close relationships with the AFLAFL-CIO and TUC, would result in inconsistent support for the structural changes they sought as their territories moved toward independence.

Boris Shishkin, an AFL economist, spoke to the Eisenhower commission on behalf of AFL President George Meany the same day as Ruttenberg. Meany's statement echoed Ruttenberg's argument for increased efforts at establishing minimum international labor standards and emphasized the importance of American economic assistance to underdeveloped areas for a several reasons. Meany suggested that economic aid could improve living standards and purchasing power in underdeveloped areas, increase American exports, and improve access to raw materials. He also noted that in many cases American aid was actually spent in the United States and sent abroad as commodities that aided domestic job creation. Meany further argued that economic aid and development abroad would increase trade and interconnectedness and undermine communism's appeal; however, he emphasized that his support for freer trade and

\footnotetext{
${ }^{81}$ David McDonald to Members of the Commission on Foreign Economic Policy, "Draft of Commission's Report on the Labor Aspects to our Foreign Economic Policy," December 21, 1953, Drafts of Report-McDonald: Labor Aspects to our Foreign Econ. Policy, Commission on Foreign Economic Poliyc: Records, 1953-1954 (Randall Commission), Memorandums concerning draft of Commission's Report Box 37, DDEL.
} 
economic cooperation was not a response to communism but a sincere belief that economic isolationism stunted growth and created long-term economic decay on a wide scale. ${ }^{82}$

Shifting focus, Ruttenberg also reminded the commission that the CIO joined international trade confederations to assist in building trade unions throughout the world because "Until the workers in various parts of the world are organized into sound, free, democratic trade unions, they will not be able effectively to establish and maintain adequate living standards." Ruttenberg argued that the absence of trade unions depressed wages abroad and made it impossible for even improved mass production techniques in the United States to allow American businesses to compete. ${ }^{83}$ Similarly, McDonald suggested that United States trade policy should contribute to raising wage standards abroad to protect American workers from unfair competition. ${ }^{84}$ Ruttenberg's statement was consistent with CIO discussions earlier in the year. Labor leaders at the CIO's executive board meeting in August 1953 determined that the expansion of free trade unions and expanded economic assistance in underdeveloped areas could increase living standards and "defeat the false totalitarian promise of world Communism." CIO leaders argued that objective could be achieved with expanded trade to assure access to raw materials and foreign markets. ${ }^{85}$ The CIO's foreign policy was, at least by 1953 , focused on expanding trade and assisting economic improvement in underdeveloped areas as a means of

\footnotetext{
${ }^{82}$ Statement by George Meany, Presented by Boris Shishkin, "American Trade Policy in the Free World," October 28, 1953, Hearings-American Fed. of labor Shishkin, Dir. Of Research..., Commission On Foreign Economic Policy: Records, 1953-1954 (Randall Commission), Transcript of Hearings-11/19/53, Box 10, Eisenhower Presidential Library.

${ }^{83}$ Stanley H. Ruttenberg, Director, Department of Education and Research, CIO, Statement Before the Commission on Foreign Economic Policy, Presented on Behalf of the Congress of Industrial Organizations, October 28, 1953, Hearings-Cong. Of Indus. Org. Stanley H. Ruttenberg, Dir. Dept. of Edu. \& Research-10/28/53, Commission On Foreign Economic Policy: Records, 1953-1954 (Randall Commission), Transcript of Hearings-11/19/53, Box 10, DDEL.

${ }^{84}$ David McDonald to Members of the Commission on Foreign Economic Policy, “Draft of Commission's Report on the Labor Aspects to our Foreign Economic Policy," December 21, 1953, Drafts of Report-McDonald: Labor Aspects to our Foreign Econ. Policy, Commission on Foreign Economic Poliyc: Records, 1953-1954 (Randall Commission), Memorandums concerning draft of Commission's Report Box 37, DDEL.

85 “CIO Proposal to Boost World Trade: Statement for Release,” March 15, 1953, 008/28; “CIO Executive Board Meeting Summary,” August 20, 1953, 008/13, GMMA.
} 
improving the American economy and countering the conditions that led poor countries' leaders to look for non-capitalist political-economic systems.

Similarly, a UAW resolution adopted in March 1953 emphasized the need for international labor standards "so that exploitation of weakly organized workers in one country shall not undermine the wage rates and living standards of workers in other countries." The resolution also argued for promoting economic and social betterment for workers abroad primarily because CIO leaders expressed confidence that economic improvement and social justice were the "fundamental answer to the challenge of Communist Russia." ${ }^{\text {" }}$ David Dubinsky discussed the interdependence of labor unions in a 1949 speech and emphasized the need for cooperation in the economic sphere. He noted that trade union internationalism improved "living standards and purchasing power-especially in underdeveloped areas" and that consequently "the prospects for better pay and decent working conditions are enhanced even in countries with stronger economies like the United States."

Ruttenberg's and McDonald's concerns, the UAW resolution, and Meany's and Dubinsky's speeches hint at economic contradictions in American labor's post-war foreign policy. Idealistically, American labor leaders wanted to assist in improving workers' standards of living abroad out of a sense of solidarity; however, they had an obligation to pursue policies that were most advantageous to American workers. In some ways, such as increased wages for workers in undeveloped areas, those policies seemed mutually compatible; however, other economic issues, such as promoting industrial development abroad, held ambiguous and possibly detrimental consequences for American workers. Moreover, economic programs were often

\footnotetext{
${ }^{86}$ Resolution Adopted by the UAW-CIO, March 22-27, 1953, FO 371-103575, BNA.

${ }^{87}$ David Dubinsky, “Labor Internationalism is Part of Social Progressivism at Home,” undated, RG18-003, International Affairs Department, Jay Lovestone Files, 1944-1973, 33/6, Dubinsky, David, 1949, GMMA.
} 
understood as tools for combating communism and contributing to national security rather than as ends in themselves.

As will be seen in subsequent chapters, AFL-CIO leaders opposed Guianese unions whose leaders cooperated with politicians to alter the colony's place in the tri-cornered trade Ruttenberg described. AFL-CIO opposition was not solely, or even primarily a result of the specific challenge to Guiana's position as a provider of raw materials in and of itself; however, concerns regarding the nature of trade relations were an important part of the milieu that shaped American and Guianese viewpoints. American labor leaders saw various challenges to the American-defined system through trade, domestic political-economy, trade union practices, and transnational relations as mutually reinforcing. American labor leaders frequently suggested that deviations from the United States-defined system constituted serious challenges that threatened American power and the prosperity and security of the American workforce.

The Eisenhower Commission agreed with Ruttenberg, recommending that the United States "be party to agreements with other countries to raise standards generally" and that an international conference could be called to address the subject, "the focal point [of which] might be the formulation of a Code of Fair Labor Standards, which would include the right of workers to organize in free trade unions and engage in free collective bargaining." 88 According to President Eisenhower's Committee on Foreign Economic Policy, trade unions were fundamental to economic development and the advancement of American workers' standards of living. An International Labor Organization (ILO) resolution drawn up in 1956 was consistent with Eisenhower's views. The committee, which included the AFL's Latin American representative, Serafino Romualdi, and Mike Ross, argued for the need to establish strong trade unions to help

\footnotetext{
${ }^{88}$ Memorandum from David J. McDonald to Members of the Commission of Foreign Economic Policy, December 21, 1953, Drafts of Report-McDonald: Labor Aspects to our Foreign Econ. Policy, Commission on Foreign Economic Policy: Records, 1953-1954 (Randall Commission), Box 37, DDEL.
} 
businesses increase production in underdeveloped areas. The ILO explained the unions' role in terms similar to the AFL model and concluded that increases in production, rather than social expenditures, were the key to improved living conditions in the developing world. ${ }^{89}$

AFL, CIO, and TUC economic policies were simultaneously idealistic and pragmatic, focused on promoting advancement for workers abroad and protecting workers' interests at home. Idealism was discarded in favor of policies that directly benefited American workers when interests seemingly clashed. Furthermore, Cold War tensions polarized the nature of AFL/AFL$\mathrm{CIO}$ and TUC transnational economic programs. As a result of AFL, CIO, and TUC economic policies some Guianese political and trade union leaders concluded that cooperation with Western labor institutions would inhibit the pursuit of far-reaching and necessary social reforms.

\section{Free trade unionism}

The TUC, CIO, and especially AFL responded to events in British Guiana based on an ideological commitment to "free trade unionism" which they argued was essential to providing a democratic voice for workers in capitalist-democratic systems. It is significant that the AFL/AFL-CIO understanding of free trade unionism was not universally accepted however much it dominated the American labor leaders' worldview. Anthony Carew suggests that the American perspective emphasized the importance of unions' independence from a variety of social institutions, including political parties, while the TUC was more flexible, accepting close connection between political parties and trade unions as long as union imperatives were not subordinated to government, employer, or foreign domination. ${ }^{90}$ Several scholars suggest that the

\footnotetext{
${ }^{89}$ Resolution Concerning Co-operation of the I.L.O. With the Special Delegates of the Presidents of the American Republics, taken from the Sixth conference of the American States Members of the ILO, September 1956, 398.06ILO, Central Decimal Files Box 1459, RG 59, Records of the Department of State, NARA II; Carnegie Endowment for International Peace, December 27, 1956, 398.06-ILO/12-2756, Central Decimal Files Box 1458, RG 59, Records of the Department of State, NARA II.

${ }^{90}$ Anthony Carew, et al., The International Confederation of Free Trade Unions (New York: Peter Lang, 2000), 193-194; Anthony Carew, "Ideology and International Trade Unionism," in Bart De Wilde, ed., The Past and Future
} 
ideal was a rhetorical façade, or at best paradoxical. Beth Sims suggests that AFL and CIO accepted a role as subordinate partners in the United States and undermined independent unions abroad at the same time American labor leaders define free unions as independent of government or business control and committed to democracy and pluralism. ${ }^{91}$ Victor Silverman notes that TUC leaders frequently argued in favor of voluntaryism, which was the notion that individual workers retained the right to choose whether or not to join a union. Silverman suggests that voluntaryism was a variant of free trade unionism and that both the American and British trade union ideologies devolved into narrow anti-communism by $1949 .{ }^{92}$

Given the wealth of scholarly discourse on the subject, it is necessary only to highlight a few aspects of the ideal that relate directly to Anglo-American labor involvement in British Guiana. AFL/AFL-CIO leadership's understanding of free labor was viewed in part through the prism of the pre-war anti-fascist experience. David Dubinsky argued that trade unions were a defense against political radicalism on both the left and the right and that extremism advanced

\footnotetext{
of International Trade Unionism (Ghent: International Conference, May 19-20, 2000), 241, 243. See also: Luff, Commonsense Anticommunism, 6. Willy Buschak argues that the word 'free' had at least three basic meanings; including that trade unions had to be free from governmental influence, guided solely by the interests of their members, and free from party influence. See: Willy Buschak, "The Meaning of the Word 'Free' in Trade Union History," in Bart De Wilde, ed., The Past and Future of International Trade Unionism (Ghent: International Conference, May 19-20, 2000), 272. Quenby Olmsted Hughes explains the influence of prominent American labor leaders' formative experiences in leading them to the conclusion that trade unions needed to be thoroughly independent from political influence. See: Hughes, "In the Interest of Democracy", 183-186. Arnold Steinbach criticized the narrow American interpretation of free trade unionism as a rigid dogma that identified any workers' organization that failed to adopt the AFL-CIO model of unionism as totalitarian, irrespective of local circumstance. See: Arnold L. Steinbach, "Changing Concepts and Practices in the International Labor Movement," in Everett M. Kassalow, ed., National Labor Movements in the Postwar World (Evanston, IL: Northwestern University Press, 1963), 38. See also: "Statement Adopted by the Executive Council of the American Federation of Labor," 4 May 1945,RG1-027, Office of the President, President's Files, George Meany, 1947-1960, Box 52, Subjects: World Federation of Trade Unions, 1945-1949, GMMA; Interview with Bert Seidman conducted with James Shea, September 16, 1994, FAOHC, LOC.

${ }^{91}$ Sims, Workers of the World Undermined. Kim Scipes argued that the AFL/AFL-CIO ideal was, "a complete and utter fraud," and that American labor leaders used the language of freedom to justify intervention and advancement of American Empire. See: Scipes, AFL-CIO's Secret War against Developing Country Workers, 68.

${ }^{92}$ Silverman, Imagining Internationalism in American and British Labor, 35, 91, 114-116.
} 
when unions were undermined. ${ }^{93}$ American labor leaders argued that unions closely connected to political parties were particularly vulnerable to becoming organs of state control in the same way government controlled unions repressed German and Italian workers in the 1930s. ${ }^{94}$ They further argued that governments assumed the role of employers in state dominated economic systems and as a result that unions connected to political parties could not act independently of the state because the party could not negotiate against itself. ${ }^{95}$ The TUC was more ambiguous regarding trade unions' affiliations, generally arguing that they should be "free from outside control by Government, employers, or any other influence which might come between a worker and his union." 96

Colonial political leaders, including in British Guiana, were often drawn from the ranks of organized labor as a result of long-standing colonial structures and limitations on suffrage. In British Guiana, property requirement restricted the vote to several thousand Guianese until to the 1953 election. ${ }^{97}$ Moreover, local politicians operating within a colonial framework could be disregarded in a way that labor leaders could not if they were able to mobilize the workforce in

\footnotetext{
${ }^{93}$ David Dubinsky speech, May (date illegible, likely 1947), RG 18-003, International Affairs Department, Jay Lovestone Files, 1944-1973, Box 10, David Dubinsky, 1947-1948, GMMA. Dubinsky's speech was an attack against the Taft-Hartley Bill in which he accused Senators Taft and Hartley of being the two best recruiting agents for the Communist Party. His intent seems to have been to play off of Cold War fears to oppose domestic anti-labor legislation; however, throughout the rest of the speech he drew close connections between domestic and foreign policy regarding organized labor; and his view that the absence of trade unions led to political reaction seems to have been sincere in the context of his other writings.

${ }^{94}$ Alan Brinkley, The End of Reform: New Deal Liberalism in Recession and War (New York: Vintage Books, 1995), 202-203.

${ }^{95}$ Message to TUC, 1954, RG 18-003, International Affairs Department, Jay Lovestone Files, 1944-1973, Box 10, British Trades Union Congress, 1948-1949, 1954-1956, GMMA; David Dubinsky, "Communists and the Trade Unions,” RG 18-003, International Affairs Department, Jay Lovestone Files, 1944-1973, David Dubinsky, 19471948, GMMA. Cheddi Jagan specifically defended his party against the allegation that the PPP acted as an employer in the capitalist sense in a 1959 Thunder article. Jagan argued that governments and capitalists served fundamentally different purposes and since the state did not exist to exploit surplus labor it was not an employer in the traditional sense. See: Cheddi Jagan, "Straight Talk—Employer-Government and Capitalist," Thunder, December 19, 1959, Cheddi Jagan Research Center (Hereafter: CJRC).

${ }^{96}$ Addendum to "Notes on the Development of Trade Unionism and Labour Relations in the Colonies," revisedApril, 1953, Marjorie Nicholson Files, Box 15, Trade Unions+Colonies, Trade Union Congress Library Collections, London Metropolitan University, London, England (Hereafter TUCLC).

${ }^{97}$ Rabe, U.S. Intervention in British Guiana, 17.
} 
opposition to employers. Consequently, British and especially American labor leaders were suspicious of the development of a politicized labor movement in British Guiana and the connections between politicians and trade unions as the colony progressed toward selfgovernment.

\section{The Impact of International Labor Organizations on AFL, CIO, and TUC Leaders}

In addition to pursuing ideals and broad objectives, American and British labor leaders' shaped their organizations' foreign policies based on experiences with post-war international labor organizations and the nature and consequences of the WFTU-ICFTU rivalry directly impacted decolonization in British Guiana. The TUC and CIO helped establish the WFTU in 1945 to promote global solidarity in the international labor movement. During the waning years of World War II, CIO and TUC officials argued that post-war peace and global economic stability required cooperation between the major national labor fronts in the post-war world including Communist organizations in the Soviet Union and Eastern Europe. CIO and TUC architects of the WFTU expressed a desire to stabilize the global system and advance workers' rights through a worldwide labor organization that participated as members in new international organizations such as the United Nations. ${ }^{98}$

Sidney Hillman emphasized the importance of giving labor representatives a voice at post-war peace settlements and conferences regarding economic reconstruction in a speech at the London Conference in February 1945, which served as the precursor to the establishment of the WFTU. Hillman argued that the emerging WFTU would hasten the end of World War II and assist in establishing "an enduring peace, an economy which will fully utilize the rich resources of the world for the benefit of its people" resulting in improved living standards and

\footnotetext{
${ }^{98}$ Silverman, Imagining Internationalism in American and British Labor, 5; Lewis L. Lorwin, The International Labor Movement: History, Policies, Outlook (New York: Harper \& Brothers, 1953), 205-210.
} 
democratization after the war. However, he cautioned the conference's delegates that "powerful and well organized forces of reaction" opposed the formation of a new international workers' organization. Reactionary victory, Hillman argued, meant that "all we have suffered and fought and died for will have been in vain." Ultimately, Hillman warned that reactionary victory over a unified international workers" organization would result in "economic depression, unemployment and want, the impression of weaker peoples and imperialist aggressions, leading inevitably to a new world war."99

AFL leaders argued that the inclusion of Soviet and Communist unions in the WFTU threatened to subordinate the organization to dictates from the Soviet state and that inclusion of multiple national fronts from one country strengthened the CIO challenge to AFL predominance in the American labor movement. The AFL did not participate in the new international as a result of AFL leaders' concerns. AFL leaders argued that their objective was the "rebuilding and reconstituting a new world order, the reestablishing of agencies of free government, and the resurrecting and resumption of free institutions of labor," suggesting that they would act independently if necessary. ${ }^{100}$ Two tenets defined the AFL position and they resulted in two important conclusions. First, AFL leaders argued that communist ideology necessitated trade unions subordination to the Communist Party and threatened the independence of trade unions. Second, they argued that all communism was Soviet directed and that labor leaders who adhered to communist ideology inevitably used trade union activity to advance Soviet objectives. AFL

\footnotetext{
${ }^{99}$ Sidney Hillman, "World Trade Union Conference: Basis for a World Trade Union Federation," February 1945, RG1-027, Office of the President, President's Files, George Meany, 1947-1960, Box 52, Subjects: World Federation of Trade Unions, 1945-1949, GMMA.

${ }^{100}$ AFL leaders noted that when the International Federation of Trade Unions (IFTU), the previous labor international, established a wartime "Joint Trade Union Committee" aimed at incorporation of Russian unions, the AFL declined to participate despite pressure from the highest levels of the United States government. "What Happened at the London World Labor Conference," RG1-027, Office of the President, President's Files, George Meany, 1947-1960, Box 52, Subjects: World Federation of Trade Unions, 1945-1949, GMMA; "Report from representative in London on Labor Conference," RG1-027, Office of the President, President's Files, George Meany, 1947-1960, Box 52, Subjects: World Federation of Trade Unions, 1945-1949, GMMA.
} 
leaders accepted isolation from the international labor community and a sharpening of the anticommunist issue within American unions as a consequence of non-affiliation in the WFTU. ${ }^{101}$

Geert van Goethem suggests that the division between the AFL and TUC regarding participation in the WFTU was central to postwar developments in international labor. According to van Goethem, the AFL's aim of promoting freedom and democracy was irreconcilable with the TUC's desire to narrowly focus on trade union representation and recognition to defend the interests of British workers internationally. ${ }^{102}$ It is important to consider again the importance of contradictions between AFL ideals and actions; specifically, three factors help illuminate the AFL's post-war ideology and refusal to join the WFTU.

First, the WFTU included a large number of Communist unions and AFL leaders referenced Soviet attempts to infiltrate and manipulate international labor organizations in the 1920s as evidence that Communist unions could not be trusted to engage in collaborative labor efforts rather than political subversion. Lovestone was particularly influential in shaping AFL leaders' interpretations since he was a central figure in debates between American Communists in the 1920s and 1930s. Ultimately, Lovestone's challenge to Joseph Stalin's mandates led to his separation from the party and his renouncing communism. ${ }^{103}$ Some Communist leaders thought that trade unions should be ignored as reactionary elements of capitalism while others thought they should be taken over from within and used as tools of the Communist Party. Both strategies discounted the legitimacy of using trade unions to independently pursue workers' interests.

\footnotetext{
101 “What Happened at the London World Labor Conference," RG1-027, Office of the President, President's Files, George Meany, 1947-1960, Box 52, Subjects: World Federation of Trade Unions, 1945-1949, GMMA.

${ }^{102}$ Van Goethem argues that TUC policies were "flexible and pragmatic" while AFL policies were "inflexible, straightforward, and missionary." Geert van Goethem, "From Dollars to Deeds: Exploring the Sources of Active Interventionism, 1934-1945, in, Waters and van Goethem, American Labor's Global Ambassadors, 16-20. Van Goethem's suggestion is important to the concepts introduced below. AFL leaders sought to expand American-style unionism into British colonies while the TUC, as colonizers, had already established the institutional framework in which colonial unions operated. Thus, they were able to focus narrowly on trade union activity and preserve their systemic preferences.

${ }^{103}$ Morgan, A Covert Life.
} 
Moreover, the representative of the Communist International (Comintern) determined trade union strategy instead of members of the Communist Party in the United States (CPUSA). The Comintern also advocated the use of the Red International as a means of organizing national trade unions in support of international communism from the outside. ${ }^{104}$ During the 1940 s, the AFL pointed to creation of a new labor international while the International Federation of Trade Unions (IFTU) was already in existence as evidence of the subversive nature of the World Trade Unions Conference in 1945. Thus, AFL leaders concluded that the WFTU's purpose was to impose Soviet political philosophy on the international labor movement and "subordinate the American labor movement, its affiliates and membership as well as that of other lands, to the dictates and the will of those who themselves are not free to determine their destiny."

Secondly, the AFL deemed unions under communist systems illegitimate since they were involuntary organizations that acted as subordinate agencies of governments. ${ }^{106}$ The involuntary nature of Soviet unions also clashed with British ideals of voluntaryism, though differences were briefly muted after the WFTU's establishment. ${ }^{107}$ AFL leaders argued that their resistance to the WFTU was a continuation of long-standing opposition to government controlled trade unions that included pre-war Communist organizations as well as Nazi and Fascist controlled labor

\footnotetext{
${ }^{104}$ Hughes, “In the Interest of Democracy,” 24-32, 40-41.

105 "Statement Adopted by the Executive Council of the American Federation of Labor," May 4, 1945, Office of the President-George Meany (1948-1960), Box 52, Subjects: World Federation of Trade Unions (1945-1949), GMMA. See also: "What Happened at the World Labor Conference," Office of the President-George Meany (1948-1960), Box 52, Subjects: World Federation of Trade Unions (1945-1949), GMMA. Anti-communism was clearly the most significant factor in the AFL's rejection of the WFTU. See: Busch, 37.

${ }^{106}$ Luff, Commonsense Anti-Communism, 135; Goulden, 1972, 122. Goulden explains Meany's view of communists as illegitimate. Cited in Scipes, AFL-CIO's Secret War against Developing Country Workers, 29. See also: Interview with Bert Seidman conducted with James Shea, September 16, 1994, FAOHC, LOC. For more on the functioning of trade unions in the Soviet Unions, see: Isaac Deutscher, Soviet Trade Unions: Their Place in Soviet Labor Policy (London: Royal Institute of International Affairs, 1950).

${ }^{107}$ Silverman, Imagining Internationalism in American and British Labor, 5-6. Silverman's work is unique among the scholarship on international labor in that he suggests labor's Cold War began in 1948, after the increase in tensions between the United States and the Soviet Union.
} 
organizations during the 1930s and 1940s. ${ }^{108}$ AFL Vice President William Doherty reminded delegates at the second ORIT convention that his organization was dedicated to "vigorously oppos[ing] any kind of dictatorship-communist, fascist, military or civil, where the privileged few impose their ruthless edicts upon the masses," undermining the freedoms that were the foundation of AFL policy. ${ }^{109}$ AFL leaders argued that the WFTU's theory of unionism would eventually lead to a political system designed to "enslave and enchain workers to the state." 110 Furthermore, AFL leaders voiced strong opposition to a WFTU resolution that they interpreted as accepting the inevitability of a forced labor program in the Soviet Union, suggesting it was an indication of broader Soviet designs to use the organization for the oppression of workers worldwide. ${ }^{111}$ More generally, American labor leaders promoted "business unionism" that aimed at the pursuit of increased material benefits rather than societal transformation and compromise with unions in the WFTU assured a degree of politicization in trade union activities.

Finally, the AFL and CIO were engaged in an intense struggle for control of the United States labor movement and the WFTU's acceptance of representatives from multiple national unions assured the AFL could not claim to be American workers' sole representative in the international sphere. The AFL-CIO conflict was the least significant factor motivating AFL

\footnotetext{
108 "What Happened at the World Labor Conference," Office of the President-George Meany (1948-1960), Box 52, Subjects: World Federation of Trade Unions (1945-1949), GMMA; "Statement Adopted by the Executive Council of the American Federation of Labor," May 4, 1945, Office of the President-George Meany (1948-1960), Box 52, Subjects: World Federation of Trade Unions (1945-1949), GMMA. See also: Geert van Goethem, "From Dollars to Deeds: Exploring the Sources of Active Interventionism, 1934-1945, in, Waters and Van Goethem, American Labor's Global Ambassadors, 12-14.

${ }^{109}$ William C. Doherty, Address at the Second ORIT convention, December 1952, International Affairs Department, Staff Files: George Delaney's Files, 1921-1957, Box 11, ORIT Congress (Second), (Rio de Janeiro, December 1952), (1952-1953), GMMA.

110 "Statement Adopted by the Executive Council of the American Federation of Labor," May 4, 1945, Office of the President-George Meany (1948-1960), Box 52, Subjects: World Federation of Trade Unions (1945-1949), GMMA. 111 "What Happened at the World Labor Conference," Office of the President-George Meany (1948-1960), Box 52, Subjects: World Federation of Trade Unions (1945-1949), GMMA. A thorough explanation of the discussion regarding Soviet "slave labor" can be found in: Hughes, "In the Interest of Democracy”, 97-116; Quenby Olmsted Hughes, "The American Federation of Labor's Cold War Campaign Against 'Slave Labor' at the United Nations," in, Waters and van Goethem, American Labor's Global Ambassadors, 23-38.
} 
opposition to the WFTU; however, AFL leaders concluded that "In terms of domestic labor politics" the CIO's increased prestige "will mean an acute sharpening of the anti-Communist issue within the American unions" as well as "a further widening of the breach between the CIO and AFL which will close the doors to labor unity for perhaps years to come."112 Therefore, territorial struggles contributed to AFL foreign policy and hostility toward the WFTU.

The AFL's red-baiting as a means of delegitimizing the CIO contributed to the enflamed rhetoric of early Cold War domestic political discourse in the United States and increased the AFL's standing as the Cold War intensified. ${ }^{113}$ AFL anti-communism increased the organization's esteem after the CIO withdrew from the WFTU citing the Soviet-domination of the organization that motivated AFL non-participation. As a result, the AFL's domestic status increased in the late 1940s and early 1950s as the NSC emphasized the importance of "destroying the structure of relationships by which leaders of the All-Union Communist Party have been able to exert moral and disciplinary authority" in countries not under communist control, specifically the WFTU. ${ }^{114}$ Consequently, AFL members dominated government-labor programs, including in British Guiana.

The TUC, CIO, and most Western European unions withdrew from the WFTU in early 1949, arguing that the organization was "controlled by communist organizations which themselves are controlled by the Kremlin and Cominform." 115 TUC representatives argued that

\footnotetext{
112 "What Happened at the World Labor Conference," Office of the President-George Meany (1948-1960), Box 52, Subjects: World Federation of Trade Unions (1945-1949), GMMA.

${ }^{113}$ Luff, Commonsense Anticommunism.

114 The National Security Council first articulated this objective in November 1948. It recommitted to the aim in June 1953. Thus, United States policymakers at the highest level countered the WFTU across administrations and regardless of policy party. See: "Statement of Policy by the National Security Council," undated, Foreign Relations of the United States (Hereafter FRUS), 1952-1954, National Security Affairs, Volume II (Washington D.C.: Government Printing Office), 591.

${ }^{115}$ Published statement by British TUC, CIO, and Confederation of Free Trade Unions of the Netherlands, "Free Trade Unions Leave the WFTU," undated, International Affairs Department (CIO) Director's Files (Mike Ross), 1945-1955, Sub-series 1, World Federation of Trade Unions, GMMA; Trades Union Congress International
} 
the WFTU's major policy discussions, particularly regarding the European Recovery Program, were poisoned with propaganda and a "stream of vilification and abuse which has been poured on the British T.U.C., American Labor and leaders of those national centers who are not prepared to become subservient to Communist doctrine and dictation." ${ }^{116}$ According to the TUC, Soviet leaders and the Cominform used WFTU publications and meetings as a platform for communist political propaganda and refusal to cooperate in the pursuit of goodwill and trade unionism resulting in irreparable organizational schisms.

Nigel Bolland contests TUC leaders' public rationalization for leaving the WFTU. Bolland argues that British labor leaders' motives were largely a consequence of the TUC's inability to control the WFTU and the possibility that the international would support colonial labor unions engaged in labor politics outside of acceptable British practices. ${ }^{117}$ Significantly, British trade union leaders concluded that the WFTU was directly opposed to TUC interests when it continued to function after the TUC and a considerable number of national centers withdrew from the organization. TUC leaders justified their position on the assumption that the remaining members of the WFTU were aligned based on their shared Communist viewpoints and accepted as inevitable an intensification of international rivalries. ${ }^{118}$

\footnotetext{
Committee, “Congress Resolution No. 37: Trade Unions in Developing Countries,” July 26, 1966, Marjorie Nicholson Files, Box 8, I.C. Minutes 1965/66 [901], TUCLC. Bernard Morris noted in an article in World Politics in 1956 that the WFTU had an estimated 65 million members in 1953. He argued that about 58.5 million members were from communist-governed countries, 4.5 million members in communist-dominated trade federations in France and Italy, and about 2 million members outside of the communist world, primarily in India and Indonesia. See: Bernard S. Morris, "Communist International Front Organizations: Their Nature and Function," World Politics Vol. 9 No. 1 (October 1956), 76-87.

${ }^{116}$ Published statement by British TUC, CIO, and Confederation of Free Trade Unions of the Netherlands, "Free Trade Unions Leave the WFTU," undated, International Affairs Department (CIO) Director's Files (Mike Ross), 1945-1955, Sub-series 1, World Federation of Trade Unions, GMMA.

${ }^{117}$ Bolland, The Politics of Labour in the British Caribbean, 490.

${ }^{118}$ Memorandum attached to letter from Vincent Tewson, General Secretary of the British Trades Union Congress to Secretaries of all Affiliated Organizations, October 27, 1948, Office of the President-George Meany (1948-1960), Box 52, Subjects: World Federation of Trade Unions (1945-1949), GMMA. For more on the CIO and TUC withdrawal from the WFTU, see: Trades Union Congress Memorandum to the Secretaries of All Affiliated Organizations: World Federation of Trade Unions, 27 October 1948, RG1-027, Office of the President, President's
} 
Western labor leaders concluded that cooperation with Communist trade unions or communist labor leaders was impossible after the WFTU split. American labor leaders, especially in the AFL, conflated Soviet dictatorship with communist ideology and occasionally opposed social reformism and trade union organization closely aligned with political parties under an aegis of anti-communism. As a result, social revolutionary movements that connected trade union and political activity, especially those that were sympathetic to communist ideals, were considered contributors to Soviet imperialism and a direct threat to international capitalism, democracy, and national security. That context, reinforced through experiences in the WFTU, was critical in explaining American, and to a lesser degree British labor responses to trade union conflicts and political developments in British Guiana. Three other important developments in international labor during the period between 1944 and 1949 directly shaped subsequent events in British Guiana.

First, the London Conference offered the initial opportunity for British colonial trade unionists to participate in an international labor conference and the AFL's report on the meeting suggested that "sections of the final resolution gave partial expression to their demands."119 George Lichtblau argues that the TUC's suggested inviting colonial unionists to the conference; however, subsequent events suggest that even if that were true TUC support for colonial

\footnotetext{
Files, George Meany, 1947-1960, Box 52, Subjects: World Federation of Trade Unions, 1945-1949, GMMA; James Carey, President of the International Union of Electrical, Radio, and Machine Workers of the AFL-CIO to Akira Iwai, Secretary General of Sohyo, February 9, 1959, RG 84, Records of the Foreign Service Posts of the Department of State, British Guiana, U.S. Consulate, Classified General Records, 1940-1963, Box 13, NARA II; James Carey, CIO as told to Sidney Shalett, "Why the CIO Quit the World Federation of Trade Unions," undated, International Affairs Department (CIO) Director's Files (Mike Ross), 1945-1955, Sub-series 1, World Federation of Trade Unions, WFTU Withdrawal Letters, 1949, GMMA;

${ }^{119} \mathrm{CIO}$ and TUC leaders organized the London Conference to serve as the basis for founding a labor international that included representation from trade unions around the world regardless of their political orientation. The conference laid the foundation for the WFTU. "Report from Representatives in London on Labor Conference," undated, Office of the President-George Meany (1948-1960), Box 52, Subjects: World Federation of Trade Unions (1945-1949), GMMA.
} 
working-class aspirations was limited. ${ }^{120}$ Nigel Bolland points out that the TUC refused to financially assist colonial unions' participation in the WFTU. ${ }^{121}$ At the same time, Arnold Steinbach argues that Soviet concepts of class struggle and imperialism articulated in the WFTU neatly conflated with nationalist movements in many areas. ${ }^{122}$ Steinbach's suggestion is particularly relevant in examining the Jagan faction in British Guiana where labor-employer conflict was inherently a conflict for power between colonists and colonizers and Cheddi Jagan frequently sought assistance from the WFTU in confronting British imperialism. Bolland argues that the WFTU was an effective advocate for colonial interests and that British labor leaders' expressed considerable fear that colonial unions would choose to align with the WFTU rather than the TUC when the British organization left the international. ${ }^{123}$ Finally, Lichtblau suggests that the WFTU assisted movements in colonial areas seeking quick detachments from colonizers and social transformations to break with the Western political and economic system beginning in the mid-1950s. ${ }^{124}$

Meanwhile, TUC resistance to anti-colonialism in the ICFTU, and TUC, AFL/AFL-CIO, and ICFTU support for affiliated unions in the 1950s alienated colonial labor leaders who wished to organize in a manner inconsistent from the Western model. Moreover, AFL/AFL-CIO, TUC, and ICFTU support for affiliated unions was inherently a political activity in the colonies given the political nature of colonial trade unionism. The competition between the ICFTU and WFTU after 1949 allowed colonial unions to appeal for external support in internal labor conflicts based on ideological affiliation, often by exploiting ideological fears.

\footnotetext{
${ }^{120}$ George Lichtblau, "Communist Labor Tactics in the Colonial and Former Colonial Countries," in Everett M. Kassalow, ed., National Labor Movements in the Postwar World (Evanston, IL: Northwestern University Press, 1963), 54-55.

${ }^{121}$ Bolland, The Politics of Labour in the British Caribbean, 491.

${ }^{122}$ Arnold L. Steinbach, "Changing Concepts and Practices in the International Labor Movement," in Kassalow, ed., National Labor Movements in the Postwar World, 40.

${ }^{123}$ Bolland, The Politics of Labour in the British Caribbean, 496.

${ }^{124}$ Lichtblau, "Communist Labor Tactics in the Colonial and Former Colonial Countries," 93-94.
} 
Second, the formation of the ICFTU and the articulation of its aims led to an increased emphasis on anti-communism in Western labor while simultaneously increasing competition between the TUC and AFL/AFL-CIO. ${ }^{125}$ American and British labor leaders immediately conflicted over leadership in the ICFTU and the AFL orchestrated TUC General Secretary Vincent Tewson's removal as ICFTU President in 1953. Additionally, TUC and AFL leaders expressed differences of opinion regarding the primary objectives of Western international labor activities. The Colonial Office echoed TUC perspectives in reviewing the purpose of the newly formed ICFTU in 1951, noting that that the primary purpose of the organization was "the establishment of a powerful and effective international organization" that was "pledged to the task of promoting the interests of working people throughout the world" rather than merely

\footnotetext{
${ }^{125}$ It is important to acknowledge that the CIO defined its international role more closely with the TUC than the AFL and that it conducted its own activities independent of the AFL. AFL and CIO leaders often disagreed on foreign relations. CIO President Walter Reuther accused Lovestone of trying to "kill the ICFTU" and Meany of falling under Lovestone's "evil influence." See: Minutes of CIO International Committee Meeting, January 7, 1954, RG 18-002, International Affairs Department, Series 3, Sub-Series 1, Box 7, GMMA. Nonetheless, CIO leaders gradually moved closer to the AFL position in foreign policy between 1945 and 1955. By 1951 CIO leaders reported the that the previous July's ICFTU Conference evidenced significant cooperation between the two organizations and that, "no major points of difference arose although on one or two questions, different opinions were exchanged." See: CIO International Committee, Report on ICFTU Milan Congress, 2 December 1951, CIO International Committee Meetings, 1951, CIO International Affairs, GMMA; Ferri-Pisani Pierre, "Memorandum on the Possible Reorientation of the ICFTU," undated, Office of the President-George Meany (1948-1960), Box 49, Subjects: Headquarters, 1951-1962, GMMA. The CIO issued a statement when the organizations merged noting a "unity of viewpoint" regarding foreign policy. Release from CIO, "Statement by AFL and CIO on International Labor Problems," February 25, 1955, RG 18-002, International Affairs Department, Series 3, Sub-Series 1, Box 8, GMMA. Moreover, the Eisenhower administration actively "encourage[d] the Meany element" as opposed to the Reuthers. See: Diary, May 10, 1956, May '56 DIARY — acw (2), Dwight D. Eisenhower Papers as President of the United States, 1953-61 (Ann Whitman File), Ann Whitman Diary Series, Box 8, DDEL. In regards to the case study examined for this dissertation, AFL leaders dominated the American labor's foreign policymaking. For more on the predominance of hard-line AFL anti-communists in the early AFL-CIO, see: Hughes, "In the Interest of Democracy", 188. For more on AFL-CIO conflict in foreign policy, see: "Proof of the Merger Pending," February 26, 1955, John Herling 's Labor Letter, RG 18-009, International Affairs Department, Staff Files, Serafino Romualdi's Files, 1945-1961, Box 4, Lovestone, Jay, 1955, GMMA; Hero and Starr, The Reuther-Meany Foreign Policy Dispute. Quenby Olmsted Hughes notes that CIO leaders, specifically Walter and Victor Reuther, went so far as to hold a secret conference to try and remove Jay Lovestone from the labor movement in an effort to alter AFL foreign policy. See: Hughes, "In the Interest of Democracy", 52-53, 168, 182; Interestingly, Cheddi Jagan claimed to have approached Walter Reuther on multiple occasions hoping that the CIO leader would be less wedded to American labor's policy of subversion in British Guiana and perhaps willing to discuss Jagan's progressive ideas as the basis for a compromise between the leaders. Jagan claims that Reuther was noncommittal and ultimately dismissive of his overtures. See: Cheddi Jagan, "Straight Talk-CIA Controls the Trade Unions," Thunder, 1967. CJRC.
} 
existing to counter the WFTU. ${ }^{126}$ Nonetheless, in examining the trajectory of its international programs after World War II, the TUC International Committee acknowledged in 1966 that "for many of its affiliates" the ICFTU's creation was merely an attempt to "counteract the activities of the WFTU."127 Specifically, AFL leaders interpreted the organization's primary objective as operating "as a militant arm of free labor throughout the world in the fight against Communist slavery." $" 128$

Additionally, AFL influence contributed to a politically conservative ICFTU constitution that differed from previous international organizations most significantly in its dissociation from emphasizing class struggle and the overthrow of the economic system. ${ }^{129}$ Anglo-American governmental influence in the organization also contributed to the ICFTU's minimizing challenges to the existing international system. Several labor leaders argued that the United States and British governments worked through their national trade union fronts to use the ICFTU as an arm of governmental foreign policy.

Richard Deverall, a former UAW education officer and member of the AFL's FTUC, noted in a report to George Meany that, "from the foundation of the ICFTU the American government has financed in one way or another activities of the ICFTU in order to further American foreign policy." Deverall also argued that the British government financed or used American financing to use the ICFTU to "choke off rebellious Communist and/or vigorously nationalist unions in the colonies" and to develop ICFTU unions to "divert nationalist aspirations

\footnotetext{
126 “Conference of Heads of Labour Departments. Colonial Office," September 24-October 5, 1951, Marjorie Nicholson Files, Box 15, Trade Unions+Colonies, TUCLC.

${ }^{127}$ Trades Union Congress International Committee, "Congress Resolution No. 37: Trade Unions in Developing Countries,” July 26, 1966, Marjorie Nicholson Files, Box 8, I.C. Minutes 1965/66 [901], TUCLC.

${ }^{128}$ Philip Pearl, "ICFTU is Revitalized Under New Leadership," extracted from the AFL New Reporter, 17 July 1953, FO 371-103575, British National Archives, Kew, Richmond, Surrey. (Hereafter BNA). See also: J.A. Diack, "Differences Between the American Federation of Labour and the International Confederation of Free Trade Unions," June 27, 1952, FO 371-97656, BNA; Hero and Starr, The Reuther-Meany Foreign Policy Dispute.

${ }^{129}$ Steinbach, "Changing Concepts and Practices in the International Labor Movement," 40.
} 
into activities that are non-political." Deverall noted that the British were frank about their use of the international to suppress development of nationalist demands for independence. ${ }^{130}$ AngloAmerican pursuit of national interests in the ICFTU undermined the organization's efforts to promote international worker solidary and led to skepticism about ICFTU motives among many colonial and Western European labor leaders.

The brief CIO-TUC inclusion in the WFTU exacerbated long-standing tensions between the AFL, CIO, and TUC and struggles for influence over the nature of the ICFTU assured that conflicts continued after the CIO and TUC left the WFTU. Western labor leaders in the ICFTU from countries other than the United States and Great Britain frequently struggled to limit AFL/AFL-CIO and to a lesser extent TUC influence in the organization and independent AngloAmerican overseas labor activities. ICFTU bureaucratic struggles continued throughout the 1950s and 1960s. AFL leaders, including George Meany, discussed leaving the organization to pursue independent activity almost immediately and withdrew from the ICFTU from 1969 to 1982. ${ }^{131}$ AFL alienation from the international labor community reinforced its tendency to act independently in pursuit of business unionism and opposed to the European social reformist style

\footnotetext{
${ }^{130}$ Robert Deverall Report to George Meany, May 1, 1957, Office of the President-George Meany (1948-1960), Box 56, Reports-Lovestone, 1957, Apr., GMMA. For Deverall's background, see: Edmund F. Wehrle, Jr., "Free Labor versus Slave Labor": Free Trade Unionism and the Challenge of War-Torn Asia," in, Waters and Van Goethem, American Labor's Global Ambassadors. Walter Citrine, TUC representative to the World Trade Union Congress in 1945 , vehemently rejected colonial attempts to use the WFTU to advance national liberation movements, colonial socialism, or challenges to British interests. See: Trades Union Congress, "World Federation of Trade Unions, Brief History," RG1-027, Office of the President, President's Files, George Meany, 1947-1960, Box 52, Subjects: World Federation of Trade Unions, 1945-1949, GMMA.

${ }^{131}$ Eric Arnesen, Encyclopedia of U.S. Labor and Working-Class History, Volume 1 (New York: Routledge, 2007), 672-673. The reports of AFL-TUC conflict in the ICFTU, with each union accusing the other of trying to dominate the organization, are voluminous. See: Minutes of the Colonial Advisory Committee, February 4, 1958, Marjorie Nicholson Files, Box 9, ICFTU/TUC, Trade Union Congress Library Collections, London Metropolitan University, London, England. Minutes of CIO International Committee Meeting, January 7, 1954, International Affairs Department (CIO), Director's Files (Mike Ross), 1945-1955, International Committee Meeting, January, 1954; Notes on International Committee Meeting of AFL, GMMA.
} 
of unionism. ${ }^{132}$ Taken together with TUC parochialism in the colonies, the five year period in international labor activity after World War II contributed to conditions that undermined efforts at coordinating institutional decolonization through the ICFTU in the 1950s.

In sum, there were three specific outcomes that grew out of the early Cold War period in international labor that directly impacted the working-class struggle in British Guiana between 1948 and 1965: a strong anti-communist trend in Western labor, a power struggle between American and British labor leaders that minimized cooperative action through an international labor body, and the establishment of two international labor organizations with different views on political economy and colonialism. In British Guiana, the AFL/AFL-CIO, TUC, and ICFTU affiliated with organizations that were strongly anti-communist and that did not associate with the WFTU. Most importantly, the TUC-AFL rivalry occasionally impeded the coordination of British and American labor programs in British Guiana and resulted in inefficient institution building efforts as a whole. ${ }^{133}$

American and British labor leaders expressed a shared desire to build liberal capitalistoriented trade unions connected to the Western international labor movement in British Guiana partially to protect their own nations' interests. Anglo-American trade union leaders argued that pro-Western trade unions would contribute to establishing a non-communist government and improve Guianese workers' conditions and influence based on the ideals of free labor unionism or voluntaryism. However, American labor leaders considered the primary threat to AFL-styled

\footnotetext{
132 "What Happened at the World Labor Conference," undated, Office of the President-George Meany (1948-1960), Box 52, Subjects: World Federation of Trade Unions (1945-1949), GMMA. See also: van Goethem, "From Dollars to Deeds," in, Waters and Van Goethem, American Labor's Global Ambassadors, 16-18.

${ }^{133}$ It is important to acknowledge that TUC relations differed with the AFL and CIO even after the American unions merged in 1955. Some Anglo-American labor programs designed to train Guianese unionists succeeded in part because the proposals originated in the CIO, which eased TUC reservations regarding cooperation with American trade unions. See: Department of State Memorandum of Conversation, "Assistance to British Guiana Trade Unions," March 7, 1960, British Guiana: U.S. Consulate, Georgetown, Classified General Records, 1940-1963, 1957-1963, 560: Economic Affairs, Box 13, RG 84, NARA II.
} 
unions to be political leaders who acted through the labor movement to subvert the capitalistdemocratic system and AFL-CIO efforts aimed at address the political threat as a means of defending Guiana's unions from subversion to a political party. Conversely, the TUC expressed the view that the threat to Western interests in British Guiana was a lack of effective democratic institutions that perpetuated poor conditions for workers, workers' lack of investment in the political-economic system, and a consequent success for radical political leaders. 


\section{Chapter 3: Anglo-American Objectives and the Limits of Official Cooperation}

British policymakers advocated granting colonies' independence more quickly than the United States at times, as was the case in British Guiana. American and British trade unions and governments cooperated to advance liberal capitalism after World War II, especially in contesting the expansion of communism, which was the most direct threat to a liberal capitalist

international system. Both nations' political leaders argued for collaboration with trade unions to build capitalist institutions as a means of pursuing their foreign policies. American policymakers, however, expressed less confidence than the British that institutional structures could effectively safeguard against communism. In British Guiana, American policymakers' determined that the People's Progressive Party's (PPP) Marxist-Leninist proclivities would overwhelm the reformist labor unions and establish a communist beachhead in South America if independence was granted too soon. Thus, American policymakers pressured British officials into delaying Guianese independence until the PPP was removed. At the same time, British officials acknowledged the importance of cooperating with U.S. policymakers in determining the future of British Guiana. Both countries' policymakers and labor leaders pursued national interests in trying to obtain the most advantageous place within the international order. By the 1950 s a dynamic emerged in which British and American officials cooperated diplomatically while engaging in institution-building projects designed to advance national interests in British colonies as they progressed toward self-government and independence.

The Anglo-American alliance during World War II contributed to the emergence of decolonization as a means of strengthening the liberal capitalist international system in which the 
United States and Great Britain exerted the greatest degree of influence. ${ }^{1}$ United States

policymakers advocated the expansion of self-determination to British colonies for ideological, strategic, and most importantly economic reasons and began pressing Great Britain to grant independence to its colonial possessions during the war. British policymakers resisted American pressure; however, they concluded that Britain's economic and strategic interests benefited from ending formal empire after the Suez Crisis in 1956, and as early as 1949 in the West Indies. ${ }^{2}$ At the same time, American policymakers' fear that socialist or communist governments with Eastern-bloc-oriented foreign policies could emerge in former colonial territories weakened long-inconsistent American support for self-determination. United States policymakers adjusted their anti-colonial policy as a response to Cold War developments and frequently pressured British policymakers to delay independence in colonies until circumstances could be altered

\footnotetext{
${ }^{1}$ The most comprehensive background on the emergence of Anglo-American cooperation in establishing a liberal capitalist post-war system is: Randall Bennett Woods, A Changing of the Guard: Anglo-American Relations, 19411946 (Chapel Hill: The University of North Carolina Press, 1990). Carey Fraser examines the Anglo-American pursuit of a liberal economic trading order with a focus on the British Caribbean. See: Cary Fraser, Ambivalent AntiColonialism: The United States and the Genesis of West Indian Independence, 1940-1964 (Westport, CT: Greenwood Press, 1994); Cary Fraser, “The 'New Frontier' of Empire in the Caribbean: The Transfer of Power in British Guiana, 1961-1964," The International History Review, Vol. XXII, September 3, 2000, pp. 583-610. See also: John Gallagher and Ronald Robinson, "the Imperialism of Free Trade," in John Gallagher, The Decline, Revival, and Fall of the British Empire (Cambridge: Cambridge University Press, 1982), 1-18; O. Nigel Bolland, The Politics of Labour in the British Caribbean: The Social Origins of Authoritarianism and Democracy in the Labour Movement (Oxford: James Currey, 2001), 589-590; Charlie Whitham, Bitter Rehearsal: British and American Planning for a Post-War West Indies (London: Praeger, 2002).

${ }^{2}$ Christopher Thorne, Allies of a Kind: The United States, Great Britain, and the War Against Japan, 1941-1945 (Oxford: Oxford University Press, 1978); Ronald Hyam, Britain's Declining Empire: The Road to Decolonisation 1918-1968 (Cambridge: Cambridge University Press, 2006); William Roger Louis, Imperialism at Bay: The United States and the Decolonization of the British Empire 1941-1945 (New York: Oxford University Press, 1978); William Roger Louis, Ends of British Imperialism: The Scramble for Empire, Suez, and Decolonization (London: I.B. Tauris, 2006); Jason Parker, Brother's Keeper: The United States, Race, and Empire in the British Caribbean, 1937-1962 (Oxford: Oxford University Press, 2008); "[Federation]: draft introduction by C Y Carstairs to the report of the Standing Close Association Committee on the arguments in favour of federation," June 21, 1949, CO 318/487/2, no 1, in, British Documents on the End of Empire: Ashton, S.R. and Killingray, David, eds. Series B Volume 6: The West Indies, London: The Stationary Office, 1999. (Hereafter, BDEEP).
} 
more favorably toward American interests. ${ }^{3}$ As a result, the American position shifted toward support for a British policy of slow, closely guided, decolonization. ${ }^{4}$

Anglo-American leaders prioritized the preservation of their alliance during the Cold War and compromised on the details of decolonization to assure their partner's as well as their own objectives were protected. Both nations aimed to retain colonial participation in a liberal capitalist-international system, to protect strategic raw materials, military bases, and ports, to assure stability and to preserve as much democracy as possible in emerging countries. ${ }^{5}$

Nonetheless, British and American leaders subtly disagreed on the future toward which the colonies were to be guided. The most important aspect of Anglo-American tension derived from the British objective of retaining connections and influence in former colonies and United States policies designed to expand American power in decolonizing areas. ${ }^{6}$

Pragmatism guided American and British policymakers toward collaboration in British Guiana. British leaders expressed a strong concern that the imperial withdrawal occur in a dignified manner leaving colonies stable with viable, pro-Western economic and political systems. ${ }^{7}$ American officials acknowledged British objectives including the desire to quickly

\footnotetext{
${ }^{3}$ Fraser, Ambivalent Anti-Colonialism.

${ }^{4}$ Gordon Knox to William Burdett. Contingency Planning for British Guiana, 2 October, 1962, Br. Guiana Briefing Papers 1.8, RG 59, Records of the Department of State, National Archives II, College Park, MD (Hereafter, NARA II).

${ }^{5}$ Preservation of democracy was an important ideological objective but the least significant strategic aim for British and American policymakers and trade union leaders in British Guiana. British officials, for example, openly accepted that the consequence of their actions in the colony after independence would be suppression of political and possibly individual freedoms. See: Note by West Indian Department B: British Guiana: After the Elections, November 1964, CO 1031/4407, Records of the West Indian Department, British National Archives, Kew, Richmond, Surrey. (Hereafter BNA); National Security Council, “U.S. Policy Toward the West Indies," January 25, 1960, West Indies (1); National Security Council, "United States Objectives and Courses of Action with Respect to Latin America, September 3, 1954, Latin America (1), White House Office, National Security Council Staff: Papers, 1948-61, Disaster File, Box 63, Dwight D. Eisenhower Presidential Library, Abilene, KS (Hereafter DDEL).

${ }^{6}$ National Security Council, "U.S. Policy Toward the West Indies,” January 25, 1960, West Indies (1); National Security Council, "United States Objectives and Courses of Action with Respect to Latin America, September 3, 1954, Latin America (1), White House Office, National Security Council Staff: Papers, 1948-61, Disaster File, Box 63, DDEL.

${ }^{7}$ British conversations about Guiana frequently discussed fear of post-colonial instability, to the point of warning about the outbreak of potential post-colonial civil war. Brief for Prime Minister's Visit to Washington, 3 December
} 
leave Guiana given its drain on scarce British resources and minimal strategic significance for Great Britain. ${ }^{8}$ British economic weakness precluded protracted decolonization and limited Britain's ability to financially support colonial and post-colonial Guyana's development. ${ }^{9}$ Moreover, colonial officials expected British Guiana's economy to worsen over time as the population increased. ${ }^{10}$ Nonetheless, the Colonial Office emphasized the importance of establishing economically stability prior to granting political independence. ${ }^{11}$

As a result, colonial officials attempted to incorporate the former British Dominion of Canada into British Guiana's development plans on the premise that the Canadians had substantial investments in Guianese bauxite, and Canadian leaders expressed an interest in exerting influence among former British colonies in the hemisphere. ${ }^{12}$ British documents, however, suggest that colonial officials doubted Canadian cooperation could replace the level of assistance available from the United States. British officials suggested that post-colonial development required financial and material aid from the United States particularly as the Caribbean colonies increasingly drained Britain's diminishing coffers in the early 1960s and as a

1965, FO 371-179146, General Records of the American Department, BNA. American officials also feared instability and violence in the colony. Memoranda from American Consol General Everett Melby to Secretary of State, 05 September 1962, RG 59, Records of the Department of State, NARA II; BNA, CO 1031/4407, Note by West Indian Department B: "British Guiana: After the Elections" November 30, 1964, BDEEP.

${ }^{8}$ Gordon Knox to William. Burdett, Contingency Planning for British Guiana, 2 October, 1962, Br. Guiana Briefing Papers 1.8, RG 59, Records of the Department of State, NARA II; Note from John Hennings of British Embassy, Washington D.C. to Ambler Thomas of Colonial Office, 15 February 1963, CO 1031/4866, Records of the West Indian Department, TNA; Position Paper by William Burdett on Prime Minister MacMillan's Visit to Washington, 20 April 1962, RG 59, Records of the Department of State, National Archives II, College Park, MD; “ [UK interests]: Minute by Lord Perth on 'our basic interests in the Caribbean," November 22, 1961, CO 1031/3278, no 147, BDEEP.

${ }^{9}$ American officials were at least somewhat understanding of Britain's desire to rapidly decolonize British Guiana, given the colony's relative drain on British resources. Secretary's Talks With United Kingdom Ambassador, 14 March 1961, Colonialism and the UN, US-UK Talks-Feb-Mar 61, RG 59, Records of the Department of State, NARA II.

10 "[British Guiana]: letter from Sir A Savage to Sir T Lloyd on the PPP government and the economic situation. Enclosure: notes by the governor," September 13, 1953, CO 1031/119, no 27, BDEEP.

11 "[Federation]: draft introduction by C Y Carstairs to the report of the Standing Close Association Committee on the arguments in favor of federation," June 21, 1949, CO 318/487/2, no 1, in, BDEEP.

${ }^{12}$ British Guiana: Visit to Ottowa, 9 April 1964, CO 1031/4866, Records of the West Indian Department, BNA; Paper for the Defense of Overseas Policy, 21 June 1964, CO 1031/4866, Records of the West Indian Department, BNA. 
result emphasized the importance of cooperating with American policymakers. ${ }^{13}$ Additionally,

British policymakers expressed concern that failing to protect American objectives might result in their partner's intervention in British Guiana after independence. ${ }^{14}$

Therefore, British and American policymakers formed a cooperative diplomatic strategy toward British Guiana despite official assertions that the Colonial Office developed its Guiana policy independently of outside influence. ${ }^{15}$ British officials formulated plans that assumed disagreement with the United States; however, their broad strategy worked in conjunction with American interests in the region. ${ }^{16}$ At the same time, American policymakers acknowledged that political or economic programs designed to shape decolonization in the colony required cooperation with British officials despite the colony’s geographical proximity to the United

\footnotetext{
${ }^{13}$ Memorandum from Secretary of State to Robin Piper: British Guiana: American Aid, 23 December 1964, CO 1031/4867, Records of the West Indian Department, BNA; Brief For Prime Minister's Talks with President Kennedy, Prepared by the Colonial Office, June 1963, CO 1031/4866, Records of the West Indian Department, BNA; "The West Indies Federation: CO brief for Mr Macmillan's meeting with President Kennedy at Bermuda, December 1961, on the question of US aid to the Caribbean, December 15, 1961, CO 1031/3506, no 125, BDEEP. ${ }^{14}$ Paper for Defense/Overseas Official Policy, British Guiana: Political Situation, 21 June 1964, CO 1031/4866, Records of the West Indian Department, BNA; Brief For Prime Minister's Talks with President Kennedy, Prepared by the Colonial Office, June 1963, CO 1031/4866, Records of the West Indian Department, BNA.

${ }^{15}$ Anglo-American collaboration on British Guiana included the establishment of, "an informal U.K.-U.S. Working Party of officials [to review] the situation in the Colony and work out an agreed approach to its problems." British officials discussed internally the impact of colonial policy toward British Guiana on Anglo-American relations. British officials went so far as to suggest that policy toward the colony could not move forward prior to consultation with the United States. See: "British Guiana Independence: memorandum by Mr Maudling for Cabinet Colonial Policy Committee on the arguments for and against moving more quickly to independence," December 15, 1961, CAB 134/1560, CPC (61) 32, BDEEP. See also: "[British Guiana]: letter from Mr Rusk to Lord Home asserting that it is not pobbile for the US 'to put up with an independent British Guiana under Jagan.' Minute by Mr Macmillan," February 20, 1962, PREM 11/3666, BDEEP; "[British Guiana]: letter (reply) from Lord Home to Mr Rusk challenging US policy over British Guiana," February 26, 1962, PREM 11/3666, BDEEP; "[British Guiana]: record by Lord Home of his conversation with Mr Rusk in Geneva," March 12, 1962, PREM 11/3666, BDEEP; "[British Guiana]: note by Mr Fraser to Mr Maudling on his conversations with President Kennedy and US officials in Washington," March 20, 1962, PREM 11/3666, BDEEP; "[British Guiana]: CO briefing note for the AngloAmerican official talks on current situation and the options for UK policy," June 24, 1963, CO 1031/4402, no 40, BDEEP; "[British Guiana]: FO record of a meeting between Mr Macmillan and President Kennedy at Birch Grove House on the current situation in British Guiana," June 30, 1963, PREM 11/4586, ff 33-36, BDEEP. See also: Fraser, "The 'New Frontier' of Empire in the Caribbean," 583-610.

${ }^{16}$ British Guiana: Anglo-U.S. Consultations on Future Co-operation, 14-16 October 1963, CO 1031/4866, Records of the West Indian Department, BNA; Note From Foreign Office to Washington, 24 November 1965, FO 371/179146, General Records of the American Department, BNA; Brief for Prime Minister's Talks with President Kennedy: British Guiana: Talking Points, June 1963, CO 1031/4866, Records of the West Indian Department, BNA; "British Guiana Independence: memorandum by Mr Maudling for Cabinet Colonial Policy Committee on the arguments for and against moving more quickly to independence," December 15, 1961, CAB 134/1560, CPC (61) 32, BDEEP.
} 
States. Consequently, official American policy developed in conjunction with British interests.

Moreover, both nations tried to obscure American involvement in British-Guianese relations to avoid international criticism.

As a result of the delicate, occasionally contentious but necessarily collaborative relationship regarding decolonization in British Guiana, British and American policymakers looked for unofficial channels through which they could pursue their independent aims in the colony. Ultimately, British and American policymakers' objectives merged with their nation's labor leaders' aims, resulting in Anglo-American policymakers' determinations that institutionbuilding in British Guiana was the most effective means of achieving shared, and also their national objectives.

\section{AFL-CIO and TUC Debates on Colonialism and Institution-Building}

British and American labor leaders agreed that colonies' transition to increased selfgovernment and eventually political independence required the development of trade unions acting as institutions in a capitalist democracy. Anglo-American labor leaders opposed the People's Progressive Party (PPP) in British Guiana for three mutually reinforcing reasons. First, Anglo-American labor leaders expressed concern that party's political objectives would lead to close association with international communism and that communist ideology prescribed a role for trade unions that subordinated them to the state. Trade unions' inclusion in the state apparatus with the state as the primary employer, they argued, precluded the possibility of independent worker representation. ${ }^{17}$

\footnotetext{
${ }^{17}$ Message to TUC, 1954, RG 18-003, International Affairs Department, Jay Lovestone Files, 1944-1973, Box 10, British Trades Union Congress, 1948-1949, 1954-1956, George Meany Memorial Archives, Silver Spring, MD (Hereafter GMMA); David Dubinsky, "Communists and the Trade Unions," RG 18-003, International Affairs Department, Jay Lovestone Files, 1944-1973, David Dubinsky, 1947-1948, GMMA; Addendum to "Notes on the Development of Trade Unionism and Labour Relations in the Colonies," revised-April, 1953, Marjorie Nicholson Files, Box 15, Trade Unions+Colonies, Trades Union Congress Library, London Metropolitan University, London (Hereafter TUCLC). See also: Alan Brinkley, The End of Reform: New Deal Liberalism in Recession and War (New
} 
Second, British and American labor leaders opposed the PPP's argument for close collaboration between trade unions and political parties in pursuit of a social transformation. American Federation of Labor (AFL) leaders argued that trade unions should restrict their activities to industrial activity and bargaining for wages and benefits. Conversely, Congress of Industrial Organizations (CIO) and Trades Union Congress (TUC) leaders argued for broader trade union activity that included political activism in support of social reforms. However, the CIO and TUC did not support politically active unionism in colonial areas in the same manner as in the United States and Great Britain. ${ }^{18}$ Thus, the AFL, CIO, and TUC shared a general outlook toward trade unions' role in colonial areas. Finally, Anglo-American trade union leaders argued that the PPP's development of socialist-unionism would result in international associations that challenged British and American national interests. Specifically, British and American labor leaders expressed concern about the PPP's relations with the World Federation of Trade Unions (WFTU) in the context of global competition between the International Confederation of Free Trade Unions (ICFTU) and WFTU.

York: Vintage Books, 1995), 202-203; Jennifer Luff, Commonsense Anticommunism: Labor and Civil Liberties between the World Wars (Chapel Hill: The University of North Carolina Press, 2012), 135. Several PPP leaders expressed interest in learning about the role of Eastern-bloc trade unions, most importantly PPP General Secretary Janet Jagan. See: Janet Jagan, “The Rights of Workers in the People's Republic of Rumania,” Thunder, July 1953, CJRC; Janet Jagan, “Apprenticeship in Rumania,” Thunder, August, 1953, CJRC. Nonetheless, Cheddi Jagan specifically defended his party against the allegation that the PPP acted as an employer in the capitalist sense in a 1959 Thunder article. Jagan argued that governments and capitalists served fundamentally different purposes and since the state did not exist to exploit surplus labor it was not an employer in the traditional sense. See: Cheddi Jagan, "Straight Talk-Employer-Government and Capitalist," Thunder, December 19, 1959, CJRC. For the clearest explanation of how the debate over trade unions' role in the Soviet Union unfolded see: Isaac Deutscher's Soviet Trade Unions. See: Isaac Deutscher, Soviet Trade Unions: Their Place in Soviet Labour Policy (London: Royal Institute of International Affairs, 1950), 33-52.

18 "Conference of Heads of Labour Departments. Colonial Office," September 24- October5, 1951, Marjorie Nicholson Files, Box 15, Trade Unions+Colonies, TUCLC; "Notes on the ICFTU Resolution Regarding Non-SelfGoverning Territories," January 23, 1952, Trade Union Congress 931.9, Box 9, Marjorie Nicholson Files, TUCLC; Minutes from meeting of Conference of heads of Labor Departments, October 5, 1951, Trade Unions and Colonies 932.5, Box 15, Marjorie Nicholson Files, TUCLC; Walter Hood, November 11, 1957, Marjorie Nicholson Files, Box 15, Trade Unions+Colonies, TUCLC; David Dubinsky speech, May 1947, RG 18-003, International Affairs Department, Jay Lovestone Files, 1944-1973, Box 10, David Dubinsky, 1947-1948, GMMA. 
Despite their general agreement regarding the role of trade unions in colonial areas and support for capitalist democracies, the AFL, CIO, and TUC disagreed considerably on the political issue of colonialism. British and American labor leaders' actions regarding European imperialism contributed to the context in which Guianese labor leaders formulated their organizational perspectives and considered international relationships. American labor leaders and other non-British members of the ICFTU after 1949 frequently attacked colonialism and emphasized challenging colonial social and economic structures as a priority for their organizations. Conversely, British trade union leaders generally supported official colonial policy. ${ }^{19}$ Nonetheless, the TUC and AFL/AFL-CIO engaged in inconsistent inter-organizational cooperation in the process of institution building. ${ }^{20}$ All three organizations tried to exert influence over colonial unions through shared methods, training programs, and affiliation to American, British, and international labor organizations, particularly with consideration to future independence.

Sidney Hillman, the first Vice President of the CIO and a close adviser to Franklin Roosevelt, explained why his organization opposed colonialism in a February 1945 speech opening the World Trade Union Conference. Hillman argued that post-war imperialism, regardless of its economic orientation, would lead to the repression of workers' rights as soon as the conflict ended. He warned that with allied victory assured imperialist nations were jockeying for position in the post-war world and "should [reactionary] forces prevail, then all we have

\footnotetext{
${ }^{19}$ The TUC was divided on the issue of colonialism; however, the organization's highest-ranking leaders consistently supported official policy. See: Victor Silverman, Imagining Internationalism in American and British Labor, 1939-49 (Chicago: University of Illinois Press, 2000). ICFTU anti-colonialism was present at the organization's formation and increased throughout the 1950s to the dismay of British officials. Julian Amery of the Colonial Office noted increasing ICFTU anti-colonialism in 1960, suggesting that the TUC and Colonial Office were unsuccessful in using the ICFTU to limit independent American labor activities in colonial territories. See: Julian Amery to Gorell Barnes, January 6, 1960; Colonial Office Minute, January 21, 1960, CO 1031-2952, BNA.

${ }^{20}$ The American organizations unified in 1955; however, policy toward British Guiana was AFL-dominated before the merger. Regardless, both organizations generally agreed on policy toward the colony. Therefore the abbreviation AFL/AFL-CIO is used in this dissertation when referring to policies that include the years prior to the merger.
} 
fought and suffered and died for will have been in vain." Continued imperialism, Hillman suggested, assured future economic crises, oppression, aggression, and inevitably a third world war. ${ }^{21}$ Ernst Schwarz, the CIO's Latin American representative and a member of the ICFTUaffiliated Inter-American Regional Organization of Workers (ORIT) Executive Council, introduced a development plan for Latin America in 1949 that was reiterated at ORIT's founding conference two years later. Schwarz criticized colonial and semi-colonial systems as being economically repressive and socially destabilizing. ${ }^{22}$ Thus, Hillman and Schwarz argued that peace though the expansion of democracy, economic progress, and social stability required decolonization.

The debate surrounding an ICFTU resolution on non-self-governing territories provides the clearest example of AFL, CIO, and TUC views on colonialism and the origins of AngloAmerican labor leaders' support for institution-building projects in colonial territories. In November 1951 the ICFTU executive board adopted a resolution on dependent territories that established a series of measures articulating the organization's support for self-determination and to pressure European governments into ending their empires. ICFTU support for political independence, however, was predicated on the notion that colonies establish "a democratic society" and "uphold the principles of free trade unionism" because free trade unions were "the

\footnotetext{
${ }^{21}$ Sidney Hillman, "World Trade Union Conference: Basis for a World Trade Union Federation," RG1 -027, Office of the President, President's Files, George Meany, 1947-1960, Box 52, Subjects: World Federation of Trade Unions, 1945-1949, GMMA.

${ }^{22}$ Ernst Schwarz, "A Hemisphere Plan for the Economic and Social Development of the Countries of Latin America," 15 April 1949, International Affairs Department (CIO), Director's Files (Mike Ross), 1945-1955, SubSeries 1. CIO International Committees, CIO Latin America Committee, 1949, GMMA; "Statement on Economic and Social Development Program for Latin America," attached to documents pertaining to the establishment of the Inter-American Regional Organization of ORIT, March, 1951, International Affairs Department, Staff Files, George Delaney's Files, 1921-1957, ICFTU 1951-1952, GMMA. Interestingly, the difference between the two documents is the deletion of a single paragraph from Schwarz's general remarks when his report was copied for the ORIT meeting. In the missing paragraph, Schwarz called for releasing Latin America from its "colonial and semi-colonial shackles." The ORIT document includes the "colonial and semi-colonial" phrasing later in the document, but moderates the language, referring only to the need to repair the "colonial and semi-colonial structure" of Latin American economies.
} 
most important force for democratic development. ${ }^{, 23}$ An article in the AFL News Reporter in 1953 further underscored American labor leaders' anti-colonialism. The article noted that AFL pressure to replace the TUC's Vincent Tewson as President of the ICFTU opened the door to the pursuit of a policy to bring about "the end of the evils of colonialism."24

TUC leaders resented American insistence on prioritizing anti-colonialism in the ICFTU in the early 1950s and their hesitation illuminates a central argument of this dissertation. Specifically, the TUC followed the British government's lead and argued for prioritizing the development of strong political-economic institutions in the colonies before independence. TUC leaders insisted that focusing on independence before institutions were firmly established was a course toward chaos. In British Guiana, the TUC's prediction proved tragically accurate, though institutional dysfunction was largely a consequence of politically-focused Anglo-American institution-building. Thus, TUC representatives reserved their position on several aspects of the ICFTU resolution including the insistence on timetables for self-determination, membership of non-self-governing territories in the International Labor Organization (ILO), and support for popular movements for national independence..$^{25}$

Most importantly, the TUC International Committee quoted Oliver Lyttleton, the new Secretary of State for the Colonies, in emphasizing that "in pursuit of self-government, we are seeking as rapidly as possible to build up in each territory the institutions which its circumstances require." Self-government absent the appropriate institutions, they argued, was "fraught with danger" and held the potential for "bad political maneuvering." TUC leaders

\footnotetext{
23 "Resolution Adopted by the ICFTU Executive Board, Brussels, 26-30 November, 1951, On Non-Self-Governing Territories, Marjorie Nicholson Files, Box 9, ICFTU/TUC, TUCLC.

${ }^{24}$ Philip Pearl, "ICFTU is Revitalized Under New Leadership," extracted from the AFL News Reporter, July 17, 1953, FO 371-103575, BNA.

${ }^{25}$ Notes from TUC Executive Board Meeting, International Committee Minute, January 1952, Marjorie Nicholson Files, Box 9, ICFTU/TUC, TUCLC.
} 
emphasized the importance of their role in colonial areas because "in many territories the people are striving to master forms of political and social organization, knowledge and ideas in decades that the West took centuries to develop." Furthermore, TUC representatives warned that a general policy of support for any democratic nationalist movement in colonial areas would "get the ICFTU into real trouble," that it was a direct contradiction of TUC policy, and that "based on experience...the trade union should first be able to build up its industrial strength before embarking on political activity." 26

Despite strong anti-colonial rhetoric, the AFL, CIO, and ICFTU tacitly agreed that political emancipation was a means of achieving social and economic improvement and not necessarily an end in itself. The ICFTU adjusted its resolution in response to TUC objections and included an emphasis on the significance of institution-building. The revised resolution noted that, even though the organization supported self-government as an ultimate aim "account must be taken of the fact that many different degrees of development exist amongst the non-selfgoverning territories" and "intermediate stages may have to be envisaged" to develop modern democratic institutions over time. ${ }^{27}$ While the organization agreed to press for self-determination in colonial areas, ICFTU leaders acknowledged that "one of the factors to bear in mind will be the existence in the non-self-governing territory of a free trade union movement able to guarantee workers' rights." The new resolution prescribed a role for the ICFTU in contributing to creating the "conditions permitting the development of political, economic and social institutions, and particularly a sound free trade union movement" to effectively advocate colonial independence. In pursuit of that objective, the ICFTU agreed to receive requests from non-self-

\footnotetext{
26 "Notes on the ICFTU Resolution on Non-Self-Governing Territories," January 23, 1952, Marjorie Nicholson Files, Box 9, ICFTU/TUC, TUCLC.

27 "Statement on Non-Self-Governing Territories Adopted by the First General Council Meeting at Berlin," July 1-5, 1952, RG1-027, Office of the President, President's Files, George Meany, 1947-1960, Box 49, Subjects: Headquarters, 1951-1960, GMMA.
} 
governing territories regarding their particular challenges, to study the situation, consult the metropolitan trade union, and advocate on the colonial union's behalf through contact with the colonizing country. ${ }^{28}$

Everett Kassalow, Director of Research for the Industrial Union Department of the AFLCIO, concisely articulated this viewpoint when he emphasized in closing a lecture in 1961 that "a strong case can be made for the proposition that an effective trade union movement that gives workers a sense of integration and participation in the great industrial processes of their own society is one of the essential parts of a modern, stable, democratic industrial order." ${ }^{29}$ D.I. Davies expressed a similar view in analyzing British encouragement of colonial labor unions. Davies suggested that the Colonial Office and TUC collaborated to promote trade unions in British territories because, as one trade union adviser explained, workers were going to "organize and act collectively whether Government or employers or anyone else wish to permit it or not" and trade unions would be "led by men more revolutionary" if British trade unions and colonial governments failed to support organizations willing to work within the British system, based on British labor practices. $^{30}$

British policy shifted during the late 1940s and 1950s from defense of the empire to decolonization; however, British policymakers considered both possibilities - preservation of the empire and political independence for their colonies — a means of safeguarding strategic objectives and retaining systemic connections between former colonies and Great Britain. ${ }^{31}$ As a

\footnotetext{
28 "International Confederation of Free Trade Unions: Statement on Non-Self-Governing Territories," July 1-5, 1952, RG1-027, Office of the President, President's Files, George Meany, 1947-1960, Box 49, Subjects: Headquarters, 1951-1960, GMMA.

${ }^{29}$ Everett M. Kassalow, "Factors Affecting the Development of Labor Movements Abroad," September, 1961, Marjorie Nicholson Files, Box 15, Trade Unions+Colonies, TUCLC.

${ }^{30}$ D.I.Davies, “The Politics of the TUC's Colonial Policy,” The Political Quarterly, Vol. 35 (1), 23-34, (1964).

${ }^{31}$ William Roger Louis most effectively argues that decolonization was a strategy to preserve British imperatives after World War II. See: William Roger Louis, Ends of British Imperialism: The Scramble for Empire, Suez, and Decolonization (London: I.B. Tauris, 2006). John Darwin most effectively argues that colonial policy is best
} 
result, the Colonial Office underscored the importance of building colonial trade unions.

Specifically, colonial officials "endorsed the principle that a sound and responsible trade union movement is essential to economic and political progress" at a conference for the heads of Colonial Labor Departments in $1951 .^{32}$

The Colonial Office and TUC cooperated since the 1920s to establish close connections between British and colonial unions, to collect information about colonial trade unions for policy development, and to promote British trade union principles in colonial organizations. Colonial Office-TUC collaboration expanded throughout the late 1940s and into the early 1950s with the establishment of the Commonwealth Advisory Committee in 1945 and increased material assistance, educational training, and TUC advising after 1950. British labor leaders expected supplementary support from international labor through the ICFTU, particularly financially; however, they emphasized that the Colonial Office and TUC would play the most significant role in developing trade unions in British territories. ${ }^{33}$ The Colonial Office concurred and suggested

understood in the context of a British world-system and that decolonization was largely a means of trying to readjust the dynamics of the relationship between colonial territories and Great Britain. See: John Darwin, The Empire Project: The Rise and Fall of the British World-System, 1830-1970 (Cambridge: Cambridge University Press, 2009); John Darwin, "Diplomacy and Decolonization," in, Kent Fedorowich and Martin Thomas, eds., International Diplomacy and Colonial Retreat (London: Frank Cass, 2001), 18-19. For more on British attempts to retain a form of control over the nature of post-colonial Caribbean colonies, see: O. Nigel Bolland, The Politics of Labour in the British Caribbean: The Social Origins of Authoritarianism and Democracy in the Labour Movement (Oxford: James Currey, 2001); Spencer Mawby, Ordering Independence: The End of Empire in the Anglophone Caribbean, 19471969 (New York: Palgrave Macmillan, 2012), 27; Stephen G. Rabe, U.S. Intervention in British Guiana: A Cold War Story (Chapel Hill: The University of North Carolina Press, 2005), 31. For specific reference to British desire to avoid jeopardizing access to potential real estate and oil investments in the Caribbean during the height of debates regarding Guianese independence, see: "[UK interests]: Minute by Lord Perth on 'our basic interests in the Caribbean," November 22, 1961, CO 1031/3278, no 147, BDEEP.

32 "Conference of Heads of Labour Departments. Colonial Office," September24-October 5 October, 1951, Marjorie Nicholson Files, Box 15, Trade Unions+Colonies, TUCLC. See also: "Notes on the TUC's Colonial Work," August, 1950, Marjorie Nicholson Files, Box 15, TUCLC.

33 "Notes on the TUC's Colonial Work," August, 1950, Marjorie Nicholson Files, Box 15, Trade Unions+Colonies, TUCLC. Nigel Bolland discusses aspects of this relationship, arguing that, "The Colonial Office encouraged the participation of the British TUC in its policy of attempting to duplicate the British pattern of trade unions and industrial relations in its colonies." He also points out that TUC leaders such as Walter Citrine were involved in the Caribbean since before World War II. Bolland argues, however, that TUC involvement in the Caribbean colonies was not benign support for trade unionism and that the TUC acted as spies by informing on Caribbean unionists for the Colonial Office. See: Bolland, The Politics of Labour in the British Caribbean, 364, 489. Thus, the TUC's 
that ICFTU involvement in the colonies should focus on directly combatting communism as an auxiliary TUC institution-building. ${ }^{34}$ TUC International Committee analyses of post-war colonial labor programs acknowledged that the TUC and British government jointly "and consciously attempted to shape, within limits, both the developing trade union movements and the conditions under which the trade unions would operate as independence was secured."35

The Colonial Labor Advisory Committee prepared a memorandum for Secretary of State for the Colonies James Griffiths in May 1951 that evaluated the situation regarding colonial trade unions and proposed several recommendations. The committee criticized the failure to effectively establish labor principles and practices amenable to British interests as colonial trade union membership increased. As a result, the committee argued that British trade unionists and colonial officials needed to "pass on to Colonial peoples the protection and experience gained by labor in this country over the past century." Trade union development, according to the committee, was essential to the ultimate objective of British colonial policy, "to guide the colonial territories to responsible self-government within the Commonwealth in conditions that ensure to the people both a fair standard of living and freedom from aggression in any quarter." Freedom of association, wrote the committee, was central. ${ }^{36}$

Members of the Colonial Labor Advisory Committee met with Labor Department heads in the fall of 1951 and articulated a shared understanding of trade unions' fundamental role in the process of establishing the institutional structures central to capitalist democracy. At the meetings' opening session Griffiths insisted that the long-term success of colonial policy

motives were not entirely altruistic and cooperation with the Colonial Office often compromised trade unionists' pursuit of labor internationalism; however, cooperation was understood to be part of a process of institution-building that would ultimately create the structures necessary for colonies to transition to independent capitalist-democracies.

${ }^{34}$ Untitled Colonial Office Report, October 14, 1950, 932.5, Box 15, Marjorie Nicholson Files, TUCLC.

35 Trades Union Congress International Committee, "Congress Resolution No. 37: Trade Unions in Developing Countries,” July 26, 1966, Marjorie Nicholson Files, Box 8, I.C. Minutes 1965/66 [901], TUCLC.

36 "Trade Unions in the Colonies: Memorandum Submitted to the Secretary of State by the Colonial Labor Advisory Committee," May 24, 1951, Trade Unions and Colonies 932.5, Box 15, Marjorie Nicholson Files, TUCLC. 
depended on effectively managing British territories' transition to industrialization and that trade union development was critical to giving colonists a "sense of belonging" as society changed. Speaking on behalf of the Colonial Employers' Federation (CEF), Booker Brothers' chairman, Sir Frederick Seaford, suggested that employers had a responsibility to encourage the development of trade unions to protect business interests. Specifically, Seaford pointed to Bookers' attempts to establish negotiating machinery in British Guiana as an example of British employers' participation in institutional development. ${ }^{37}$

The members of the TUC, the OEF, and Labor Department officials who made up the advisory committee determined that colonial labor officers should encourage trade union development and that the TUC should undertake organization and training. Participants suggested the TUC should directly implement colonial trade union training courses to give the programs the appearance of independence from the Colonial Office. More importantly, the committee agreed that the TUC should strengthen its connections to colonial unions and use its influence and educational programs to moderate potentially radical movements. The committee re-emphasized its expectation that international participation in colonial institution-building through the ICFTU should be complementary and that the TUC would play the primary role in implementing programs. ${ }^{38}$

Regarding TUC activities, Griffiths emphasized that "proper liaison should be maintained with the Colonial Labor Departments" while warning that labor organizations had to avoid being too closely associated with governments. Conference members agreed that government-union connections needed to be limited to avoid abuse by "outside politicians or lawyers who see a

\footnotetext{
${ }^{37}$ Minutes from meeting of Conference of heads of Labor Departments, October 5, 1951, Trade Unions and Colonies 932.5, Box 15, Marjorie Nicholson Files, TUCLC.

${ }^{38}$ Minutes from meeting of Conference of heads of Labor Departments, October 5, 1951, Trade Unions and Colonies 932.5, Box 15, Marjorie Nicholson Files, TUCLC.
} 
union as vehicle for his ambition." 39 Attendees noted that "time was not on our side." They insisted on the critical need for immediate action since "the tide of events was moving rapidly, and might well not allow scope for the organizations and structures which we wished to see develop in Colonial societies to grow up by the slow and pure process of natural evolution."40 Thus, colonial officials, labor leaders, and businessmen engaged in cooperative institutionbuilding in an attempt to establish colonial trade unions that could help colonies transition economically and socially into capitalist democratic territories and retain connections with Great Britain. ${ }^{41}$ In November 1951, Griffiths suggested that the British policy toward its colonies would be to move toward granting dependent territories greater internal self-government and promoting economic and social development to achieve stability in the post-war system. Significantly, he noted: "To that end we are seeking as rapidly as possible to build up in each territory the institutions which its circumstances require." ${ }^{, 42}$

Colonial officials evaluating the effects of TUC-Colonial Office relations concluded that the partnership successfully advanced British objectives and noted that TUC activities in the colonies were "a great advantage" that was "the most important element in the creation of a stable and responsible trade union movement." Furthermore, colonial officials offered "great praise for the work which has already been done," commending TUC efforts to educate colonial unionists and restrained their actions. Despite officials' praise for the collaboration, British labor leaders expressed skepticism regarding early institution-building efforts. TUC leaders criticized

\footnotetext{
${ }^{39}$ Conference members specifically referenced institution-building efforts in British Guiana as an example of how to effectively structure institution-building programs. "Trade Unions in the Colonies: Memorandum Submitted to the Secretary of State by the Colonial Labor Advisory Committee," May 24, 1951, Trade Unions and Colonies 932.5, Box 15, Marjorie Nicholson Files, TUCLC.

${ }^{40}$ Conference of Heads of Labor Departments, September 24-October 5, 1951, Trade Unions and Colonies 932.5, Box 15, Marjorie Nicholson Files, TUCLC.

${ }^{41}$ Minutes from meeting of Conference of heads of Labor Departments, October 5, 1951, Trade Unions and Colonies 932.5, Box 15, Marjorie Nicholson Files, TUCLC.

42 "Notes on the ICFTU Resolution Regarding Non-Self-Governing Territories," January 23, 1952, Trade Union Congress 931.9, Box 9, Marjorie Nicholson Files, TUCLC.
} 
"the timidity of the Colonial Office" and restrictions placed on British trade union activities in the colonies. Additionally, British labor leaders suggested that a lack of foresight and the "obstruction of Administrations and people within the territories" made their activities ineffective. However, British labor leaders suggested developing long-term programs to eliminate the causes of the crises that undermined TUC colonial programs rather than abolishing their efforts. ${ }^{43}$

Despite occasional disagreements between government officials and trade unionists, TUC leaders agreed that their primary objective was protecting British interests, noting that "at no time has any serious conflict arisen between official British policy" and the policy of the TUC. Broadly shared international objectives facilitated close cooperation between trade union officials and the Colonial Office in attempting to develop colonial labor organizations and integrate them into the Western capitalist system once the decision to pursue decolonization was reached in the late 1950s. The TUC, according to Cabinet members, could "check irresponsible nationalism and maintain control in key sectors of the economy" while avoiding charges of perpetuating colonial relationships. ${ }^{44}$

Oliver Lyttleton, who succeeded Griffiths as Secretary of State for the Colonies soon after the joint conference, articulated a crucial and prevalent view during the establishment of an informal organization involving members of the Overseas Employers' Federation (OEF) and the TUC in coordination with the Colonial Office in 1954. Lyttleton explained that the tripartite Colonial Office-OEF-TUC approach to developing colonial trade unions held as a central aim countering the expansion of World Federation of Trade Unions (WFTU) influence in the

\footnotetext{
43 "Colonial Trade Unionism," undated, but appears to be mid-1953, Marjorie Nicholson Files, Box 15, Trade Unions+Colonies, TUCLC.

44 “'Secret' Annex to Cabinet Paper on Policy in Africa," December 21, 1959, RG 1-027, Office of the President, George Meany’s Files, 1944-1960, Box 51, Meetings: Misc., Corr., re ICFTU, 1955-1960, GMMA.
} 
colonies, largely as a result of Soviet domination of the international. Nonetheless, Lyttleton argued that "communism had made the job [of developing trade unions in colonies] urgent" but "the problems would exist without it and communism itself could only be met by developing sound industrial relations.” Therefore, he suggested that material improvements for workers obtained through capitalist trade unions could improve industrial relations and, according to TUC Assistant General Secretary George Woodcock, could "be a much more effective check on the excess of democracy than second chambers or other constitutional devices." ${ }^{45}$ The close relationship between Secretaries of State and the TUC continued under Lyttleton's successor, Alan Lennox-Boyd, as institution-building and decolonization expanded in the late 1950s. ${ }^{46}$ Some OEF leaders disagreed that trade unions were useful as democratic institutions; however, they often supported cooperating with the Colonial Office and TUC to develop organized labor as a tool to increase workers' productivity. According to A.J. Wells, Chief Personnel Officer of Bookers Sugar Estates in British Guiana, industrial and political democracy should be limited and trade union training should be focused on teaching workers their individual responsibilities rather than allowing representation in the decision-making process. Nonetheless, he argued that cultivating trade unions was the "only possible course open to industrial management" and that welcoming employees as associates was beneficial because "If you can influence, control or direct men's thoughts into the right channels...then the action you desire will happen as a matter of course." ${ }^{, 47}$ Thus, Bookers cooperated in British institution-building projects and conducted studies for the Colonial Labor Advisory Committee as a means of

\footnotetext{
${ }^{45}$ Mr. Parry, signed by L.T. Stapleton to Mr. Foggon, "Draft of Notes from establishment of O.E.F.-T.U.C Committee," April 1, 1959, CO 859-1118, BNA.

46 "Background Note for the Secretary of State's Meeting with Sir Vincent Tewson," November 26, 1959, CO 8591119 , BNA.

${ }^{47}$ Address given by A.J. Wells, Chief Personnel Officer of Bookers Sugar Estates, Ltd., British Guiana, at Conference of Employers, September 19, 1955, RG 18-009, International Affairs Department, Staff Files: Serafino Romualdi's Files, 1945-1961, Box 1, Caribbean Area, 1953-1956, GMMA.
} 
perpetuating the dependence of Guianese workers and improving living conditions to improve productivity. ${ }^{48}$ At the same time, historian Clem Seecharan argues that Booker Brothers' Chairman Jock Campbell strongly advocated social reform and expanded industrial democracy as an end in itself. ${ }^{49}$

Moreover, TUC and OEF leaders acknowledged that the weak Guianese economy limited the extent of wage increases and government assistance to the poor, and they expressed fear that continued poverty would renew WFTU influence in the colony. As a result, British labor leaders, colonial officials, and employer representatives in the OEF concluded that the only way to avoid challenges to the political-economic system from disillusioned workers was to train Guianese labor leaders and guide trade unions toward a narrowly industrial focus. ${ }^{50}$ Thus, Colonial officials, British trade union leaders, and British businessmen invested in the colonies hoped to improve workers' conditions as a means of alleviating unrest and stabilizing colonial societies while avoiding the possibility of mass support for socialism, communism, or radical political measures. Colonial Officials, British and colonial employers, and British and colonial labor leaders argued that cooperation was essential; however, they emphasized that collaboration needed to be covert and that the TUC was obliged to play the most important role in organizing and training colonial unions. ${ }^{51}$

\footnotetext{
${ }^{48}$ British Guiana Government Information Services, Guiana Diary, "U.K. Labor Official Arrives in B.G. to Study Industrial Relations," February 6-9, 1956, F2384, British Guiana, Guiana Diary, 1955 Jan to 1957 Jun, TUCLC.

${ }^{49}$ Clem Seecharan, Sweetening 'Bitter Sugar': Jock Campbell the Booker Reformer in British Guiana 1934-1966 (Miami: Ian Randle Publishers, 2005).

50 "Discussions Between Representatives of the Trades Union Congress, the Overseas Employers' Federation, and the Colonial Office," May 24, 1955, Box 40, Marjorie Nicholson Files, TUCLC. In addition to constraints on the Guianese economy, some American labor leaders noted that inflation offset most of the gains sugar workers' were able to secure. Both sides of the issue are explored in a contentious series of letters between Jay Lovestone and Booker Brothers Chairman Jock Campbell in 1954. See: RG 18-003, International Affairs Department, Jay Lovestone Files, 1944-1973, Box 10, British Guiana, 1954, GMMA.

${ }^{51}$ The Colonial Office's expectation of discretion regarding Colonial Office-TUC cooperation in the colonies is most clearly evident in a series of exchanges between colonial officers in 1959. See: Minute by J.S. Bennett, Colonial Office, August 25, 1959; Minute by E. Parry, August 26, 1959, Minute by J.S. Bennett, September 1, 1959, CO 859-1119/, BNA.
} 
In other words, British labor leaders, colonial officials, and employers articulated a clear and firm position that colonies' political independence could only be considered if it was coupled with the establishment of structural mechanisms designed to alleviate poverty and social unrest. The British institution-building project aimed at perpetuating capitalist-democratic social and political-economic systems in former territories, protecting British investments, and preserving connections between former colonies and Great Britain.

Many of the principles articulated in TUC and Colonial Office records are echoed in the constitution for the Inter-American Regional Organization of Workers (ORIT), the regional arm of the ICFTU in the Western Hemisphere. American labor leaders in the American Federation of Labor-Congress of Industrial Organizations (AFL-CIO) wielded the greatest influence in ORIT and operated through the organization to advance American labor's regional objectives. ORIT's constitution defined its objective as promoting "economic development and social progress" because "economic distress will aid Communist aggressors as much as military weakness." ORIT leaders emphasized that support for democratic government was only possible when "people feel they have something worth fighting for." To achieve those objectives, the constitution recommended a complementary program that facilitated full support from regional labor organizations to strengthen the Western Hemisphere's economy. ${ }^{52}$ The ORIT constitution vaguely echoed some of the ideas emphasized in the ICFTU resolution on non-self-governing territories, particularly in regards to supporting institution building. However, the AFL's influence over the organization is evidenced in the emphasis on anti-communism.

Like British policymakers, American government officials pursued policies after World War II designed to establish an integrated and stable international system based on

\footnotetext{
${ }^{52}$ Statement of the Meeting of Foreign Ministers of American Republics by ORIT, March 27, 1951, International Affairs Department, Staff Files, George Delaney's Files, 1921-1957, ICFTU Inter-American Regional Organization of Workers...,1951-1952, GMMA.
} 
modernization through liberal capitalism and democracy, to avoid war and depression, and to preserve national interests. ${ }^{53}$ As a result, American government officials consistently argued that the AFL and CIO had an increased and crucial role in play in post-war foreign relations.

However the American labor-government relationship in international affairs differed from that between the Colonial Office and TUC since the United States did not have colonial possessions. ${ }^{54}$ Nonetheless, American policymakers, like colonial officials, viewed trade unions as institutional mechanisms designed to reinforce a liberal capitalist-democratic system while safeguarding national interests. The State Department established a relationship with American labor leaders based on developing effective inter-American economic cooperation and opposing dictatorships through regional labor unions almost immediately after World War II. ${ }^{55}$ Specifically, the State Department agreed to fund CIO training programs for Latin American

\footnotetext{
${ }^{53}$ National Security Council, "US Objectives and Courses of Action w/Respect to Lain America," September 3, 1954, White House Office, NSC, Disaster Files, Box 63, DDEL. See also: Thomas J. McCormick, America's HalfCentury: United States Foreign Policy in the Cold War (Baltimore: Johns Hopkins University Press, 1989); Odd Arne Westad, The Global Cold War: Third World Interventions and the Making of Our Times (New York: Cambridge University Press, 2005).

${ }^{54}$ Works that speak directly to the relationship between Anglo-American trade unions and the United States and British governments include: Gary K. Busch, The Political Role of International Trades Unions (New York: St. Martin's Press, 1983); Anthony Carew, "The American Labor Movement in Fizzland: The Free Trade Union Committee and the CIA," Labor History 39 (1998); D.I. Davies, "The Politics of the TUC's Colonial Policy;" Fred Hirsch and Richard Fletcher, The CIA and the Labour Movement (Nottingham, UK: Spokesman Books, 1977); Jon V. Kofas, The Struggle for Legitimacy: Latin American Labor and the United States 1930-1960 (Tempe: Arizona State University, 1992); George C. Lodge, Spearheads of Democracy: Labor in the Developing Countries (New York: Harper \& Row, Publishers, 1962); Ted Morgan, A Covert Life: Jay Lovestone Communist, Anti-Communist, and Spymaster (New York: Random House, 1999); Ronald Radosh, American Labor and United States Foreign Policy (New York: Random House, 1969); Beth Sims, Workers of the World Undermined: American Labor's Role in U.S. Foreign Policy (Boston: South End Press, 1992); Robert Anthony Waters, Jr. and Geert Van Goethem, eds., American Labor's Global Ambassadors: The International History of the AFL-CIO During the Cold War (New York, Palgrave Macmillan, 2013); Edmund F. Wehrle, Between a River \& a Mountain: The AFL-CIO and the Vietnam War (Ann Arbor: The University of Michigan Press, 2005); Hugh Wilford, "American Labor Diplomacy and Cold War Britain," Journal of Contemporary History, Vol. 37 (1), 45-65, (2002); Hugh Wilford, The Mighty Wurlitzer: How the CIA Played America (Cambridge, MA: Harvard University Press, 2008).

${ }^{55}$ Philip Murray, President CIO to Nelson Rockefeller, Assistant Secretary of State, August 16, 1945, RG 18-002 Series 3, Sub-series 1, GMMA; Dean Acheson to Jacob Potofsky, January 22, 1946, RG 18-002, Series 3, SubSeries 1, GMMA; Paper Prepared for Philip Murray, September 24, 1948, RG 18-002, Series 3, Sub-series 1, GMMA.
} 
labor leaders so that they could explain "how free, independent trade unions operate in a democracy" based on American labor practices. ${ }^{56}$

An article in the October 1950 State Department Bulletin echoed several of the colonial labor advisors' conclusions. The article, authored by labor official Bernard Weisman, noted that organized labor developed over a long period in industrialized countries and established itself as one of the most important institutions in facilitating liberal capitalist democracy. However, the article warned that "in newer countries, there is an almost frantic haste to bridge within months or years the experience of many centuries." Workers in emerging areas, Weisman suggested, often took on responsibilities for which they were unprepared out of necessity. Furthermore, Weisman argued that the desirability of the situation was irrelevant, asserting that: "it is a fact, and we must try as a nation to face facts and to build upon them the structure which... will be in the best interest of all concerned." $" 57$ The State Department, much like the Colonial Office, accepted as inevitable the progression toward some form of modernity in colonial and undeveloped areas and sought to direct that trajectory through the implementation of specific institutional structures designed to guide development toward capitalism and democracy.

Weisman maintained that cooperation between government and labor in international relations was crucial in the post-war world; however, the American view differed from that of the Colonial Office in important ways. The State Department emphasized advancing a nationalist agenda and especially the importance of confronting the Kremlin's "foremost objective:" taking control of the organized labor movement. According to Weisman, American labor's dynamic influence on American economics and politics necessitated that the AFL-CIO "play a major part

\footnotetext{
${ }^{56}$ Arnold Zempel, Associate Director to Ernst Schwarz, September 22, 1949, RG 18-002, Series 3, Sub-series 1, GMMA.

${ }^{57}$ Bernard Weisman, “Labor's Role in World Affairs," published by the Department of State, October, 1950, RG 18-003, International Affairs Department, Jay Lovestone Files, 1944-1973, GMMA.
} 
in shaping American diplomacy." Moreover, Weisman argued that American labor constituted one of the most potent influences constituting American activity in world affairs. Weisman noted that "the Department of State has no desire to dictate to labor what it should do or try to control what labor does," emphasizing the importance of organized labor's independence in determining the course of action it thought best in international relations. However, Weisman concluded American labor leaders needed to "carry America's message abroad" and discussed the various ways American organized labor representatives advised policymaking and contributed to and supported American foreign policy. ${ }^{58}$ Thus, the State Department formulated a clear expectation of government-labor cooperation in international relations that closely resembled the relationship between the Colonial Office and the TUC.

At the highest level of the United States government, foreign policymakers argued that organized labor was an important part of American foreign policy. President Dwight Eisenhower's reorganization plan establishing the Foreign Operations Administration (FOA) in 1953 further emphasized the need for organized labor to support official policy and was designed to subordinate the AFL and CIO to the State Department in international affairs. ${ }^{59}$ Nonetheless,

\footnotetext{
${ }^{58}$ Bernard Weisman, "Labor's Role in World Affairs," published by the Department of State, October, 1950, RG 18-003, International Affairs Department, Jay Lovestone Files, 1944-1973, GMMA.

${ }^{59}$ The FOA reorganized United States mutual security efforts under the control of the State Department. Governmental and non-governmental actors worked through the FOA to implement a wide variety of projects globally to promote social development, economic growth, and anti-communism in the developing world. See: Letter to Charles B. Brownson, Chairman International Operations Subcommittee, House of Representatives, October 19, 1954, Administration-Organization, 1953-1955 (FOA), Dennis A. FitzGerald Papers, 1945-1969, Box 38, DDEL; Harold E. Stassen, Director, "Report to the President on the Foreign Operations Administration, January 1953 to June 1955," June 30, 1955, Executive Departments and Agencies-Foreign Operations Administration (1), Laurin L. Henry: Papers re Presidential Transitions, 1952-1961, Box 4, DDEL; Dwight D. Eisenhower to John Foster Dulles, April 15, 1955, Executive Departments and Agencies-Foreign Operations Administration (1), Laurin L. Henry: Papers re Presidential Transitions, 1952-1961, Box 4, DDEL; Statement of Rowland R. Hughes, Assistant Director, Bureau of the Budget; Accompanied by William F. Finan, Assistant Director for Management and Organization, Bureau of the Budget; and Statement of Gen. Walter Bedell Smith, Under Secretary of State, Reorganization Plans Nos. 7 and 8 of 1953 (Foreign Operations Administration) (United States Information Agency), Hearings before the Committee on Government Operations House of Representatives, 83rd Congress, 1st Session on H.J. Res. 261 and H.J. Res. 262, June 22, 23, and 24, 1953 (Washington D.C.: Government Printing Office, 1953), 11, 17.
} 
the State Department's expressed expectations for government-labor programs did not emphasize the importance of creating specific institutional structures, which was a key concern for the Colonial Office. Therefore, British and American policymakers held similar but not identical expectations regarding the restructuring of colonial territories as they transitioned to independence. Specifically, the Colonial Office articulated views emphasizing the importance of institutions and American officials expressed a desire to use existing structures to achieve political objectives. ${ }^{60}$ The difference in emphasis between British and American objectives influenced the nature of Anglo-American labor programs in British Guiana, especially as the AFL-CIO supplanted the TUC as the most active external labor organization in the colony. Consecutive American Secretaries of State discussed the importance of State Department cooperation with labor leaders as an important component of post-war diplomacy. Dean Acheson, under Secretary of State from 1945 to 1949, assured Jacob Potofsky, President of the Amalgamated Clothing Workers of America, that the State Department would continue to regularly meet with American trade unionists to discuss foreign developments. ${ }^{61}$ As Secretary of State from 1949 to 1953, Acheson criticized what the nation's lack of commitment to the early Cold War, a struggle that he stated was "just as crucial from the point of view of the continued existence of our way of life" as the Second World War. Acheson argued that successful confrontation with the Soviet Union in the post-war world necessitated "total diplomacy," which included military preparedness and a foreign policy that created "economic, political, social, and psychological conditions that strengthen and create confidence in the democratic way of life." Implementing Acheson's policy, he suggested, required voluntary coordination between all

\footnotetext{
${ }^{60}$ Bernard Weisman, "Labor's Role in World Affairs," published by the Department of State, October, 1950, RG 18-003, International Affairs Department, Jay Lovestone Files, 1944-1973, GMMA.

${ }^{61}$ Dean Acheson to Jacob Potofsky, January 22, 1946, RG 18-002, International Affairs Department, Series 3, SubSeries 1, Box 7, GMMA.
} 
branches of government as well as "business, agriculture, and labor...all of our great national organizations." 62

John Foster Dulles, Acheson's successor, shared his predecessor's interest in cooperation with non-state actors while emphasizing the need for American involvement in colonial areas. ${ }^{63}$ In a November 1953 speech to the CIO, Dulles echoed the view that the success of American foreign policy depended on concurrent action by private citizens and groups; in particular, nongovernmental organizations shared a responsibility to advance the nation's foreign policy. Moreover, his speech emphasized the rapidly increasing importance of the third world to American foreign relations. Dulles argued that "the colonial and dependent areas are the field of most dramatic contest" in international relations. There, Dulles argued, "the policies of the West and those of Soviet imperialism come into headlong collision." The Secretary of State expressed concern at the possibility that Soviet leaders had a strategic plan to exploit nationalist movements with the objective of advancing global communist revolution. Specifically, Dulles quoted from a lecture by Joseph Stalin on Leninism which argued that "the road to victory of the revolution in the West lies through the revolutionary alliance with the liberation movement of the colonies and dependent countries." Dulles' speech, given less than a month after the British alleged a communist conspiracy as the justification for suspending self-government in British Guiana, articulated the ideas behind the FOA and International Cooperation Administration (ICA)

\footnotetext{
${ }^{62}$ Dean Acheson, “The Task of Today’s Diplomacy,” Department of State Publication 3806, March 20, 1950, Marjorie Nicholson Files, Box 45, TUCLC.

${ }^{63}$ For more on the shift in United States foreign policy during the Eisenhower administration that emphasized the developing world, see: Kathryn C. Statler and Andrew L. Johns, eds., The Eisenhower Administration, the Third World, and the Globalization of the Cold War (Lanham, MD: Rowman \& Littlefield Publishers, Inc., 2006).
} 
programs that combined the efforts of American trade unionists and government officials in the colony beginning in $1954 .^{64}$

Dulles's relations with labor leaders, based on a shared pursuit of institution building, included personal meetings with AFL President George Meany and CIO President Walter Reuther. Dulles commended Meany for the ICFTU's role in promoting democratic institutions throughout the world and met with Meany and Reuther to discuss the continuing success of the ICFTU in $1953 .{ }^{65}$ The Secretary also met with Meany, Reuther, and FOA officials to assure smooth operation of government-labor programs in the mid-1950s. ${ }^{66}$ Additionally, the Dulles-led State Department worked with the AFL-CIO to resolve labor disagreements between American companies and foreign workers, cooperated in public relations efforts to improve perceptions of the United States abroad, and requested advice on labor appointees to international diplomatic conferences during the 1950 s. $^{67}$

The Eisenhower administration's National Security Council (NSC) advocated government-labor institution-building in pursuit of American foreign policy as well. The NSC developed broad regional objectives based on hemispheric solidarity in support of United States world policies, orderly development so that states in the region would be effective members of the hemispheric system, reduction of internal Communist or anti-American subversion, and the retention of access to raw materials. To advance those aims, the NSC highlighted the need to

\footnotetext{
${ }^{64}$ John Foster Dulles, “The Moral Initiative," Speech before the annual convention of the Congress of Industrial Organizations, Cleveland, OH, November 18, 1953, RG 18-003, International Affairs Department, Jay Lovestone Files, 1944-1973, Box 33, John Foster Dulles: Secretary of State, 1953-1955, GMMA.

${ }^{65}$ John Foster Dulles to George Meany, August 26, 1953, RG 1-027, Office of the President, George Meany's Files, 1944-1960, Box 15, State Department, 1953-1960, GMMA.

${ }^{66}$ Floyd Springer, Jr., Labor Committee Secretary, FOA to George Meany, June 23, 1955, RG 1-027, Office of the President, George Meany’s Files, 1944-1960, Box 15, Foreign Operations Administration, 1954, Sept. 1955, GMMA.

${ }^{67}$ Robert Murphy, Deputy Undersecretary of State to George Meany, March 16, 1959; Carl W. McCardle, Assistant Secretary of State to George Meany, September 9, 1953, RG 1-027, Office of the President-George Meany (19481960), Box 15, State Department, 1953-1960, GMMA; Francis O. Wilcox, Assistant Secretary of State to George Meany, July 8, 1958, RG 18-009, International Affairs Department, Staff Files, Serafino Romualdi's Files, 1945 1961, Box 5, State Department, 1957, GMMA.
} 
"assist and encourage the formation and development of responsible organized labor movements and leadership in Latin American countries" and the importance of strengthening programs for specialized training in the United States of Latin American labor leaders. ${ }^{68}$

Dulles's stated objectives and United States hemispheric policy are best understood within the context of the broader American Cold War policy aimed at countering Soviet power and containing the expansion of communist influence. Eisenhower's "New Look" national security policy outlined in NSC Document 162/2 noted that underdeveloped and colonial areas contained vast manpower, crucial resources, and significant potential for growth that "would greatly, perhaps decisively, alter the world balance of power to our detriment" if incorporated into the Soviet system. As a result the NSC advocated the orderly development of stable, responsible nations willing and able to participate in defense of the free world. ${ }^{69}$ Thus, Eisenhower's foreign policy depended largely on preserving confidence in the free world's institutions, keeping colonial areas within the Western capitalist system, and defending American national security.

AFL-CIO leaders also influenced United States foreign policy through informationsharing and correspondence with some of the most influential American policymakers in the late 1950s. Meany and Jay Lovestone of the AFL International Affairs Department in particular maintained a broad correspondence with high-ranking United States officials including Secretary of the Navy Arleigh Burke and Senators Thomas Dodd and John F. Kennedy. Meany also contributed to a study of international communist techniques in the labor field for the House of

\footnotetext{
${ }^{68}$ National Security Council, US Objectives and Courses of Action w/Respect to Latin America, September 3, 1954, White House Office, NSC, Disaster Files, Box 63, DDEL.

69 "Note by the Executive Secretary to the National Security Council on Basic National Security Policy, NSC 162/2," October 30, 1953, Foreign Relations of the United States (Hereafter FRUS), 1955-1957, Volume XIX, National Security Policy (Washington D.C.: Government Printing Office).
} 
Representatives Committee on Un-American Activities in June $1956 .{ }^{70}$ American labor leaders helped train Foreign Service workers during the late 1950s and 1960s on international labor issues as well. ${ }^{71}$ Additionally, Eisenhower named Meany and AFL-CIO Vice President George M. Harrison as members of the United States Delegation to the UN General Assembly from 1957 to $1959 .^{72}$ Thus, American labor leaders and government officials developed a consistent and cooperative relationship to advance United States foreign policy.

The Eisenhower administration, like the Colonial Office, expressed appreciation trade unions' cooperation in foreign relations. ${ }^{73}$ George C. Lodge, Assistant Secretary of Labor for International Affairs from 1958 to 1962, wrote an article for Foreign Affairs in July 1959 warning of communists' concentration on union leaders in their subversive efforts, that many foreign unionists were indoctrinated in Moscow, and that American labor's overseas activities were critical in impeding communist efforts. Lodge suggested that American labor leaders' understanding of developing world problems made their training programs and efforts abroad essential to preserving American-style capitalism internationally. ${ }^{74}$ Additionally, a January 1961

\footnotetext{
${ }^{70}$ Arleigh Burke to Jay Lovestone, August 23, 1956; John P. Meagher, Public Services Division, State Department to Jay Lovestone, July 14, 1956; William P. Knowland to Jay Lovestone, April 24, 1956; Thomas Dodd to Jay Lovestone, July 28, 1956; Robert L. King, Assistant to the Vice President to Jay Lovestone, August 1, 1956, RG 18: International Affairs Department, Jay Lovestone Files, 1939-1974, Box 7, GMMA; John F. Kennedy to Jay Lovestone, May 20, 1958, RG 18: International Affairs Department, Jay Lovestone Files, 1939-1974, Box 68, Congressmen and Senators, GMMA; George Meany to Dean Rusk, March 11, 1964, RG 18-002, International Affairs Department, Series 3, Sub-Series 1, Box 7, GMMA; Wilton B. Persons, Deputy Assistant to the President to Senator Clifford P. Case, January 1, 1957, 122-G, 1957, Central Files, General File, GF 122-G, 1955, Box 864, DDEL; J.H. Smith, Jr. to George Meany, December 3, 1957, ICA Chron File, Dec. 1957, James Hopkins Smith, Jr., Papers, 1932-1980, DDEL.

${ }^{71}$ Harold B. Hosking, Director, Foreign Service Institute to William F. Schnitzler, Secretary-Treasurer, AFL-CIO, February 8, 1961; RG 1-038, Box 76, GMMA. Arthur Dukakis, Program Assistant School of Foreign Affairs Foreign Service Institute to William Schnitzler, December 31, 1958, RG 1-027, International Affairs Department, Series 2, Box 15, GMMA.

${ }^{72}$ Special supplement to the New York Times, “U.S. Labor's International Role," May 25, 1960, 126-C American Federation of Labor Congress of Industrial Organ., AFL-CIO, (merged 12-5-55), Central Files, General File, FG 126-C, 1959-60, Box 943, DDEL.

${ }^{73}$ Stephen G. Rabe, Eisenhower and Latin America: The Foreign Policy of Anticommunism (Chapel Hill: The University of North Carolina Press, 1988), 34.

${ }^{74}$ It is also important to note that Lodge defended the American political-economic system itself, suggesting that linguistic burdens associating capitalism with the robber-baron era inadequately described businesses' social
} 
White House press release commended the efforts of American labor organizations in countering the spread of Communism in labor organizations abroad. ${ }^{75}$

Eisenhower's and Dulles's successors strengthened the association between the executive office and American labor leaders. Dean Rusk, Secretary of State for President John F. Kennedy, regularly invited several AFL-CIO leaders to conferences to discuss nongovernmental organizations' role in foreign policy, suggesting at times that Kennedy himself would attend the meetings. ${ }^{76}$ Kennedy's connection to American labor leaders engaged in AFL-CIO international relations originated well before his time as President. Jay Lovestone provided Kennedy with information regarding labor developments while Kennedy was a Senator from Massachusetts and Kennedy assured Lovestone that he would carefully consider AFL-CIO resolutions. ${ }^{77}$ Arthur Schlesinger, Special Assistant to President Kennedy, assured the AFL-CIO's Latin American representative, Serafino Romualdi, that American labor leaders' reports on Latin America provided important background information for presidential speeches. ${ }^{78}$ Moreover, one of Kennedy's final meetings prior to his inauguration was with the AFL-CIO Executive Council. ${ }^{79}$

consciousness in the late 1950s. George C. Lodge, "Labor's Role in Newly Developing Countries," Foreign Affairs, July 1959, White House Office, Office of the Special Assistant for National Security Affairs, OCB Series, Subject Subseries, Box 3, DDEL.

${ }^{75}$ White House Press Release, January 12, 1961, Papers of Alan Grant, Box 15, DDEL.

${ }^{76}$ Dean Rusk to William Schnitzler, Secretary-Treasurer, AFL-CIO, April 14, 1961; George Ball, under Secretary of State to George Meany, January 16, 1962; George Ball to George Meany, June 1, 1962; Dean Rusk to George Meany, April 27, 1962; Dean Rusk to William Schnitzler, April 27, 1962; Dean Rusk to William Schnitzler, May 1, 1963; Dean Rusk to William Schnitzler, February 15, 1965, RG 1-038, Box 76, GMMA. Eisenhower also directly requested information from labor leaders on FOA programs and extended invitations to labor leaders to discuss foreign policy issues with lower-level members of the Executive Branch. See: George Meany to Dwight D.

Eisenhower, June 2, 1960; Dwight D. Eisenhower to George Meany; George Meany to Dwight D. Eisenhower, May 14, 1959, RG 1-027, Office of the President, George Meany's Files, 1944-1960, Box 15, White House, 1953-1960, GMMA.

${ }^{77}$ John F. Kennedy to Jay Lovestone, May 20, 1958, RG 18-003, International Affairs Department, Jay Lovestone Files, 1944-1975, Box 68, Congressmen and Senators, GMMA.

${ }^{78}$ Arthur Schlesinger, Jr., Special Assistant to the President to Serafino Romualdi, March 15, 1961, RG 1-038, Box 61, GMMA.

${ }^{79}$ Garnett D. Horner and Robert E. Clark, "Kennedy Gets Final Briefing By Eisenhower," Star, January 1, 1961, Election Day to January 20-Kennedy Activities, Jan. 1-20, 1961 (1), ), Laurin L. Henry: Papers re Presidential Transitions, 1952-1961, Box 20, DDEL. 
Despite State Department support, AFL-CIO leaders in the early 1950s argued that the United States government failed to adequately utilize American labor's international capabilities and that, as a result, American foreign policy suffered. In a statement before the TUC, Richard Walsh of the AFL argued that his organization was "convinced that foreign policy is no longer to be entrusted solely to the professional diplomats" and that ensuring a democratic foreign policy necessitated labor participation in execution and particularly at the constructive stage. Rather than "wait[ing] for our government to evolve and formulate foreign policy," he argued, "quite often we come forward with proposals to our government and fight for their being adopted." $\$ 0$ Thus, American labor leaders acted aggressively, cooperating with the State Department and other agencies to advance United States foreign policy; however, the AFL-CIO frequently became involved in overseas activities in advance of governmental agencies.

Juxtaposing the views of the Colonial Office and the State Department regarding the role of national trade unions in international relations illuminates two important aspects of British and American policy pertaining to British Guiana between 1946 and 1961. Both governments agreed that their national trade unions contributed a great deal to the implementation of effective foreign policy that building effective unions in developing countries was important to national interests and global stability, and that anti-communism was crucial in the post-war world. The State Department emphasized trade union diplomacy as a way to directly confront communism, which was assumed to be Soviet-influenced, through politically shaped activities. Conversely, the Colonial Office generally argued that unions should focus their efforts toward building strong institutions and working to alleviate the economic and social conditions that led to communism's

\footnotetext{
${ }^{80}$ Richard Walsh, statement before the TUC, September 1952, RG 18-003, International Affairs Department, Jay Lovestone Files, 1944-1973, Box 10, British Embassy, 1952-1953, GMMA.
} 
ideological appeal. Their perspectives were similar and flexible, but the subtle differences were important in determining the nature of their programs in British Guiana. ${ }^{81}$

Most importantly, British influence over institutional structures was an inherent consequence of the colonial relationship and their objective was to guide development in a manner that preserved British influence. Conversely, American attempts to influence postcolonial structures required increased influence in British colonies. Cabinet officials expressed apprehension that American policy directly contradicted British objectives and was designed to "replace their influence and interests by direct US penetration" in some areas of the world. Cabinet members specifically noted that Vice President Richard Nixon, the Senate Foreign Relations Committee, and State Department officials publically expressed the view that colonial retreat should be coupled with American economic and political expansion, particularly through the trade union movement. ${ }^{82}$ Thus, by the end of the 1950s British officials argued that American actions, at times at the cost of Cold War imperatives, were inherently expansionist in the sense that they sought to introduce and impose new ideas on former colonial institutional structures. In other words, American labor leaders and governmental officials, especially in the AFL, articulated a clear and firm position that colonial trade unions should be supported in a process of institution-building. Their objective was to establishment fervently anti-communist unions that operated on the basis of AFL-styled business unionism and acted as structural

\footnotetext{
${ }^{81}$ Similarly, Joey Long argues that American and British attempts to steer decolonization in Singapore clashed at times, particularly over tactics; however, they were also often in harmony in principle. See: S.R. Joey Long, Safe for Decolonization: The Eisenhower Administration, Britain, and Singapore (Kent, OH: The Kent State University Press, 2011). 82 “'Secret' Annex to Cabinet Paper on Policy in Africa," December 21, 1959, RG 1-027, Office of the President, George Meany's Files, 1944-1960, Box 51, Meetings: Misc., Corr., re ICFTU, 1955-1960, GMMA. The Cabinet Paper referenced specifically discussed Africa and British policymakers were more open to increased United States influence in the Caribbean, as Jason Parker notes. See: Parker, Brother's Keeper. Nonetheless, the central issue discussed in the paper was British fear that American policy was based on exaggerating the communist threat and exploiting colonialism to expand American influence through a trade union movement that rejected actual trade union principles, and that was not specific to Africa.
} 
mechanisms designed to perpetuate capitalist-democratic social and political-economic systems in the developing world while expanding American influence and protecting American interests. $^{83}$

British and American trade union leaders also acted to advance their nations' economic, strategic, and geo-political interests when developing and implementing programs to influence the future of British colonies. The TUC and American labor, particularly the AFL, maneuvered for predominance within the Western international labor movement throughout the late 1940s and early 1950s. Officials in the British Foreign Office noted that Phillip Pearl of the AFL wrote an article in the AFL News Reporter regarding TUC General Secretary Vincent Tewson's resignation as head of the ICFTU that "caused the utmost indignation in the TUC" and that a confrontation was imminent for dominance of the organization. ${ }^{84}$ An informal meeting between TUC and AFL-CIO leaders in 1957 suggested that considerable tension remained between the two organizations throughout the $1950 \mathrm{~s} .{ }^{85}$ Both organizations frequently levied accusations that

\footnotetext{
${ }^{83}$ Michael Adamson describes United States use of the Export-Import Bank and World Bank in a manner similar to the process of institutional decolonization discussed in the field of labor relations in this dissertation. Adamson argues that the American use of international financial institutions was designed to strengthen the capitalist world and the United States' position therein. See: Michael R. Adamson, “"The Most Important Single Aspect of Our Foreign Policy'?: The Eisenhower Administration, Foreign Aid, and the Third World," in Kathryn C. Statler and Andrew L. Johns, eds., The Eisenhower Administration, the Third World, and the Globalization of the Cold War (Lanham, MD: Rowman \& Littlefield Publishers, Inc., 2006), 47-72. Stephen Rabe summarizes the Eisenhower administration's Latin America policy as insistence on regional support for the Cold War and opposition to communism, the advancement of free trade and investment, and the preservation of American regional leadership. See: Rabe, Eisenhower and Latin America, 174. Hilbourne Watson argues that AFL-CIO involvement in British Guiana and the West Indies between 1953 and 1964 was based on promoting sovereignty in the region "with the aim of broadening and deepening the global reach of American capital." See: Hilbourne Watson, "Guyana, Jamaica, and the Cold War Project: The Transformation of Caribbean Labor," in Perry Mars and Alma H. Young, eds., Caribbean Labor and Politics: Legacies of Cheddi Jagan and Michael Manley (Detroit: Wayne State University Press, 2004), 91, 100, 105.

${ }^{84}$ The minute incorrectly attributed authorship of the article to George Meany. See: Foreign Office Minute to F.C. Mason, August 7, 1953, FO 371-103575, BNA.

${ }^{85}$ Despite AFL-TUC tension, Hugh Wilford suggests that the AFL and TUC retained a generally fraternal relationship. Specifically, he suggests that American and British labor leaders were inconsistent in addressing the needs of racial minorities and occasionally pursued racist policies, though he notes that rank-and-file British unionists were often critical of American race relations. As a result, Wilford suggests that American labor leaders tempered criticism of the TUC's role in curbing militant non-white colonial workers and the TUC refrained from condemning the treatment of African-American workers. See: Hugh Wilford, "The South and the British Left, 1930-
} 
the other was trying to dominate the ICFTU. American labor leaders expressed concern that the TUC was trying to "carve out a sphere of influence" in British territories while the TUC justified their special connection to colonial unions as the result of a long standing cooperative relationship. ${ }^{86}$ Here again, the different motives of British and American labor leaders in colonial territories is evident, with the TUC trying to retain aspects of an existing institutional connection and American labor leaders trying to replace British influence.

Regarding the ICFTU resolution on non-self-governing territories, the TUC most fervently opposed the ICFTU's suggestion that colonies be placed under United Nations supervision. The TUC argued that such a move would shift control away from Whitehall while failing to put it in the hands of colonists, reinforcing their sense of inferiority and undermining “enlightened colonial policy." ${ }^{87}$ The TUC and Colonial Office expected that trade union work in the colonies was a responsibility reserved for the British trade unionists despite the creation of the ICFTU to advance an international labor program. ${ }^{88}$ There were mild nationalist undertones in the TUC's argument that illuminate the challenges facing national-front trade unions in international institutions, a subtext that contributed to the predominance of independent AFL$\mathrm{CIO}$ and TUC actions rather than the prevalence of ICFTU programs in British Guiana.

1960," in Joseph P. Ward, ed., Britain and the American South: From Colonialism to Rock and Roll (Jackson, MS: University Press of Mississippi, 2001), 172-173.

${ }^{86}$ That sufficient tension between the organizations existed to necessitate an informal meeting is itself illuminating. Notes from an informal meeting of members of the TUC and AFL-CIO, September 9, 1957, Marjorie Nicholson Files, Box 9, ICFTU/TUC, TUCLC. For more on the tension between the AFL-CIO and TUC regarding American activity in British colonies, see: Anthony Carew, ed., The International Confederation of Free Trade Unions (New York: Peter Lang, 2000), 270; Yevette Richards, Maida Springer: Pan-Africanist and International Labor Leader (Pittsburgh: University of Pittsburgh Press, 2000). For more on general tensions between the AFL-CIO and the ICFTU, see: Ake Wedin, T.L. Johnston, trans., International Trade Union Solidarity. ICFTU 1957-1965 (Stockholm: Bokforlaget Prisma, Publishers, 1974). For more on the tension between the AFL and TUC, see: Hugh Wilford, "American Labour Diplomacy and Cold War Britain,” Journal of Contemporary History, Vol. 37 (1), $45-$ $65,2002$.

87 "Notes on the ICFTU Resolution on Non-Self-Governing Territories," 23 January 1952, Marjorie Nicholson Files, Box 9, ICFTU/TUC, TUCLC.

88 “Conference of Heads of Labour Departments. Colonial Office," September 24-October, 5, 1951, Marjorie Nicholson Files, Box 15, Trade Unions+Colonies, TUCLC. 
Nonetheless, the TUC's argument illuminates the significance colonial officials and British labor leaders placed on achieving their version of institution-building prior to granting political independence to colonial territories. British institution-building efforts intended to use trade unions to integrate the Guianese political economy within a British-led liberal capitalist system as formal political control of colonies diminished. Even though reformist Guianese labor leaders eagerly participated in these programs, British institution-building programs inevitably clashed with the objectives of revolutionary Guianese. Thus, institution-building fueled the conflicts at the center of institutional decolonization.

The importance British and American government officials placed on trade unions' role in international relations in the late 1940s and early 1950s went beyond rhetoric. When differences between the AFL and TUC threatened to undermine the nascent ICFTU in 1952, British and American foreign officers met with their respective nation's labor leaders to discuss ways to compromise and preserve the organization. British officials thought it "a pity if the impression remained that the TUC had entered into the Washington talks reluctantly or under government pressure" and that they should "dispel the impression that this had been the case," though it is evident that government officials encouraged TUC leaders to find ways to compromise and collaborate with the AFL. ${ }^{89}$ It is also noteworthy that AFL president George Meany met with members of the British Foreign Office and that the British officials thought the incident important enough to forward details through the chain of command to Foreign Secretary Anthony Eden. ${ }^{90}$ Finally, the incident is illuminating in that the most significant point of disagreement grew out of the AFL's conclusion that the ICFTU was "insufficiently aggressive in

\footnotetext{
${ }^{89}$ J.A. Diack, Head of American Department, British Foreign Office to G.C. Veysey, Minister of Labour and National Service, July 3, 1952, FO 370-97656, BNA.

${ }^{90}$ Foreign Office to J.A. Diack, June 12, 1952, FO 370-97656, BNA.
} 
its anti-communist strategy." ${ }^{91}$ Anglo-American labor cooperation in British Guiana remained limited, in part, as a result of disagreements about the nature of and means to confront the potential communist threat in the colony. Moreover, British officials occasionally used connections in the American labor movement to try and influence State Department policy and encouraged West Indian colonial leaders to do the same. ${ }^{92}$ Thus, British Foreign Office relations with American labor leaders were not solely a matter of conflict resolution; rather, a consistent dialogue existed between American labor leaders and British officials. ${ }^{93}$

It is important to consider that some colonial labor leaders looked forward to strengthening their trade unions on British or American principles and increasing formal connections to those organizations while others expected international labor organizations to act as a forum to advance the cause of political, economic, and social autonomy. The tension between the expectations of the latter group of colonists and those of the TUC became evident as soon as post-war international labor institutions were established. Walter Citrine, the TUC's representative to the WFTU conference in October 1945, criticized an unnamed colonial unionist for suggesting that "his organization was going to join the international because his country wanted their national Independence and he wished to establish Socialism." Citrine emphasized that attempts to use the WFTU as a political international rather than an organization to address practical union activities contributed considerably to the TUC's withdrawal from the organization in $1949 .^{94}$

\footnotetext{
91 J.A. Diack, "Differences Between the American Federation of Labor and the International Confederation of Free Trade Unions," June 27, 1952, FO 370-97656, BNA.

${ }^{92}$ Colonial Office Report to Foreign Office, July 28, 1955; W.H. Braine, British Embassy, Washington D.C. to Foreign Office, August 4, 1955; H.M. Foote, Governor, West Indies to Roger Makins, June 28, 1955 , FO 371114452 , BNA.

${ }^{93}$ Roger Makins to Walter Reuther, June 16, 1953, FO 371-103575, BNA; A.M. Morgan, Labour Attaché, British Embassy to G.C. Wilson, Ministry of Labour and National Service, October 3, 1958, CO 859-1150, BNA.

94 Trades Union Congress, "World Federation of Trade Unions, Brief History," RG1-027, Office of the President, President's Files, George Meany, 1947-1960, Box 52, Subjects: World Federation of Trade Unions, 1945-1949,
} 
Citrine's articulation of the British viewpoint regarding anti-colonialism in the WFTU, and CIO representative Ernst Schwarz's acknowledgment that British and American unionists were isolated within the organization in their support for private development initiatives, illuminate an important aspect of international trade unionism and its relationship to decolonization. ${ }^{95}$ When the TUC and CIO left the WFTU and joined with the AFL in forming the ICFTU they created an institution in which the most conservative elements of the international labor movement played the most significant role. AFL leaders exercised the most influence in the ICFTU and argued that trade unions should act independently of politics and focus on narrow questions of wages and working conditions. Conversely, TUC, CIO, and most Western European trade union leaders argued that trade unions should act as a progressive force for broad social reform while retaining independence from politics. Thus, ICFTU efforts to assist trade unions abroad balanced the trade union ideologies expressed in the leading members' unions but often leaned toward a version of trade unionism closer to the AFL's ideals. Tensions between the viewpoints were consistent and the AFL withdrew from the ICFTU in 1968, in part as a result of the organization's challenge to support for AFL-styled business-unionism abroad. ${ }^{96}$

The WFTU explained the formation of the ICFTU as a new organization doomed to conflict between the "TUC's desire for international Trade Union hegemony, based on the policy of the Foreign Office" and AFL attempts to supplant the TUC through financial domination of

GMMA. The Soviet Union's use of the WFTU as a tool for the dissemination of communist propaganda is widely accepted; however, it is important that Citrine also criticized its politicization by colonial unionists in search of a forum for political, social, and economic reform.

${ }^{95}$ See also: Memorandum from Acting Director European Labor Division, "Comparative Policy Position of the Labor Internationals (ICFTU, IFCTU, WFTU), June 30, 1953, RG 18: International Affairs Department, Staff Files: George Delaney's Files, 1921-1957, Box 11, Labor Internationals, n.d., GMMA.

${ }^{96}$ Ake Wedin, T.L. Johnston, trans., International Trade Union Solidarity. ICFTU 1957-1965 (Stockholm: Bokforlaget Prisma, Publishers, 1974). 
smaller unions; a "fight between rival trade union imperialisms." ${ }^{, 97}$ Regardless of the political motives of the communist-dominated unions the WFTU advocated anti-colonialism and economic development programs designed to alter colonial economic structures far more aggressively than the ICFTU. ${ }^{98}$ The ICFTU constitution defended the freedom of all peoples, "including those in colonial or semi-dependent status to determine or change their own political, social, or economic institutions by democratic means." ${ }^{99}$ Nonetheless, AFL, CIO, TUC, ICFTU, and ORIT leaders all supported the decision to suspend the Guianese constitution in 1953 making clear the limitations of Anglo-American labor's support for colonial autonomy. ${ }^{100}$ Moreover, British socialists acknowledged that the ICFTU tried to assist colonial workers resist oppression; however, they noted that the OEF often impeded ICFTU activities as they were implemented in the colonies. Thus, some British socialists and a number of colonial labor leaders argued that effective pursuit of political independence and socio-economic reform required continued association with the WFTU. ${ }^{101}$

Thus, British, American, and colonial leaders engaged in a struggle for influence over what they determined to be one of the most crucial institutions in determining the nature of postcolonial societies. British and American leaders sought to use trade unions and the labor movement to decolonize Britain's colonies in a manner conducive to their national objectives

\footnotetext{
${ }^{97}$ John Morgan, “Amongst the Opponents of Unity. The Fight Between Trade Union Imperialisms: T.U.C. Versus A.F.L.," copied from the World Trade Union Movement, July 1949, RG1-027, Office of the President, President's Files, George Meany, 1947-1960, Box 52, Subjects: World Federation of Trade Unions, 1945-1949, GMMA.

${ }^{98}$ Colin Palmer, Cheddi Jagan and the Politics of Power: British Guiana's Struggle for Independence (Chapel Hill: The University of North Carolina Press, 2010), 22-27; Bernard S. Morris, "Communist International Front Organizations: Their Nature and Function," World Politics Vol. 9 No. 1 (October 1956), 76-87.

${ }^{99}$ International Confederation of Free Trade Unions News, July 1954, RG 18-009, International Affairs Department Staff Files: Serafino Romualdi's Files, 1945-1961, Box 4, ICFTU, 1957, GMMA.

${ }^{100}$ Luis J. Marcano, Secretary, CADORIT, "Report on CADORIT's Activities," December 31, 1954, RG 18: International Affairs Department, Staff Files: George Delaney's Files, 1921-1957, Box 11, ORIT 3rd Congress, 1955, GMMA; Minutes of the 11th Meeting of the Executive Board of the ICFTU, November 30-December 4, 1953, RG 1-027, Office of the President-George Meany (1948-1960), Box 51, Meetings: Executive Board (Emergency Committee), 1954, Mar., GMMA.

${ }^{101}$ Venture, Journal of the Fabian Colonial Bureau, “A Socialist Commentary on Colonial Affairs,” July 1955, Marjorie Nicholson Files, Box 12, TUCLC.
} 
while strengthening the liberal-capitalist international system. However, the pursuit of national objectives undermined consistent cooperation in institution building between the AFL/AFL-CIO and TUC, and British and American policymakers viewed the conflict over Guiana's institutions as an area where they could pursue national interests while collaborating on a diplomatic level. Most importantly, Guianese leaders disagreed about the meaning of decolonization and some pursued institutional changes irreconcilably opposed to both the British or American models, a conflict that was central to the struggle that shaped Guianese decolonization. 


\section{Chapter 4: Economic Emancipation: The Ideological Origins of the People's Progressive Party Challenge to Reformist Trade Unionism}

The fundamental issue that shaped Guianese decolonization was the debate over the nature of the institutions that would provide the foundation for post-colonial society. Guianese labor leaders' political ideologies influenced but also grew out of their experiences seeking improvements for the colony's impoverished workers through the labor movement. Two general perspectives of labor organization materialized in the colony. One argued for reform through the preservation of existing labor relations, and a second argued for a break with the Western model of trade unionism. Transnational relationships derived from political and trade union ideologies and increased the connection between the Cold War and decolonization in British Guiana. Ultimately, Guianese, British, and American leaders viewed the establishment of specific types of institutionalized labor relations in British Guiana as an opportunity to achieve broader objectives regarding the nature of post-colonial society and Guiana's place within the decolonized post-war international system. After 1946 a conflict arose between Guianese labor leaders who supported the idea of decolonization within the existing system and those who interpreted decolonization as a fundamental break from British and American control, objectives achievable only through greater association with the Eastern-bloc. ${ }^{1}$

There is considerable debate regarding the People's Progressive Party's (PPP) political orientation, especially the ideologies of Cheddi and Janet Jagan, the party's leaders from 1950 to 1999. Several important Guianese involved in the colony's transition to independence wrote memoirs or participated in oral histories about their experiences and each provides unique and

\footnotetext{
${ }^{1}$ In some ways Jagan engaged in the "meaningful counterinterpretation to North American claims of manifest destiny," that Peter Smith explores in United States-Latin American relations in Talons of the Eagle. Peter H. Smith, Talons of the Eagle: Latin America, the United States, and the World, 3rd ed. (Oxford: Oxford University Press, 2008), 396-397.
} 
important insights; however, these works disagree considerably on the PPP's ideology and the reasons for the colony's violent process of decolonization. Cheddi Jagan's autobiography, The West on Trial, published in 1967, argues that the PPP became a victim of American Cold War aggression despite pursuing a socialist-reformist—but non-communist—program. ${ }^{2}$ The West on Trial provides crucial insight into Jagan's background, the context in which Jagan developed his political ideals, and the origins of the PPP's philosophy. Nonetheless, the Jagans were experienced politicians and as a source The West on Trial needs to be understood in perspective. The memoir's publication in the immediate aftermath of Anglo-American intervention reinforced Cheddi Jagan's long-standing assurances to British and American officials that depicted the PPP as a non-communist party. Close examination of Jagan's rhetoric and writings intended for a Guianese audience, however, suggests that the PPP leader connected his country's destiny with that of the international communist movement even if the party was not a disciplined communist organization.

In a Legislative Council debate in 1953 Cheddi Jagan argued that socialism was merely a step on the process toward communism. He criticized as "fools" and "ignoramuses" peers who argued that "socialism is a respectable thing but that communism is the thing which would take away their liberties and freedom. ${ }^{3}$ Three years after the publication of The West on Trial Jagan explained PPP policies as an adaptation of Leninist principles applied with the objective of communist development. Moreover, Jagan placed the Guyanese struggle within the context of a

\footnotetext{
${ }^{2}$ Cheddi Jagan, The West on Trial: My Fight for Guyana's Freedom (New York: International Publishers, 1967).

${ }^{3}$ Dr. Cheddi Jagan, "Undesirable Publications Bill," 1953, David Dabydeen and Lynne Macedo, eds., Dr. Cheddi Jagan National Assembly Speeches, Volume 2: The Fourth Legislative Council January 1952-April 1953 (Published by the Caribbean Press for the Government of Guyana, 2011), 309. See also: Cheddi Jagan, "1956 Congress Speech," Cheddi Jagan Research Center (Hereafter: CJRC). The 1928 Constitution gave the Guianese restricted selfgovernment in the Legislative Council. Between 1928 and 1953, suffrage was severely restricted and based on property ownership. Moreover, nominated members dominated the council and Executive Committee, and the colonial governor exercised reserve power over the legislature. Thus, the representative body was not representative of a democratic political process. See: Colin Palmer, Cheddi Jagan and the Politics of Power: British Guiana's Struggle for Independence (Chapel Hill: The University of North Carolina Press, 2010), 8.
} 
broader international movement to which he suggested the party was "accountable" in $1970 .{ }^{4}$ Even between 1957 and 1961, when the PPP moderated its rhetoric and governing policies, Jagan explained in the party journal that PPP's national liberation struggle was "part and parcel" of the "titanic battle between two systems, capitalism-imperialism on the one hand and socialism—communism on the other." ${ }^{, 5}$ He also criticized Forbes Burnham's sacrifice of "our proletarian, working-class, internationalist outlook for narrow nationalism." ${ }^{6}$ Ultimately, Jagan explained the party's purpose as pursuing socialism with the objective of progressing to the "second stage" wherein society would be based on the principle "to each according to his need, from each according to his ability" once the colony achieved independence. ${ }^{7}$ Thus, The West on Trial provides a critical background into the political ideas of British Guiana's working-class movement; however, it is necessary to evaluate other sources to comprehend the PPP's ideology. Several of Jagan's contemporaries challenged the non-communist depiction of PPP objectives Jagan intimated to British and American officials. They describe the Jagan-led party as doctrinaire in its Marxism and committed to international communism. In editing a volume of Forbes Burnham's speeches, C.A. Nascimento and R.A. Burrowes argue that Cheddi Jagan subordinated nationalist interests to advancing global communism. ${ }^{8}$ Their depiction, however, suffers from a problematic bias since the authors served as public relations officials for the Burnham government, which was in the process of establishing a fraudulent and politically repressive dictatorship in $1970 .{ }^{9}$ Jai Narine Singh, a vice president for the Manpower Citizens Association (MPCA) in the 1940s and early member of the PPP executive committee also

\footnotetext{
${ }^{4}$ Cheddi Jagan, "Lenin in Our Time," 1970, CJRC.

${ }^{5}$ Cheddi Jagan, "Straight Talk: The Ideological Struggle," Thunder, March, 1957, CJRC.

${ }^{6}$ Cheddi Jagan, "1956 Congress Speech,” CJRC.

${ }^{7}$ Cheddi Jagan, "Straight Talk: A Living Wage," Thunder, December 26, 1959, CJRC.

${ }^{8}$ C.A. Nascimento and R.A. Burrowes, eds., Forbes Burnham, A Destiny to Mould: Selected Speeches by the Prime Minister of Guyana (New York: Africana Publishing Corporation, 1970), xix.

${ }^{9}$ Robert Waters clarified Nascimento's position within the Burnham government in an email. Robert Waters to Josh Esposito, March 20, 2015.
} 
describes the Jagan-led party as subordinate to Soviet, and later Cuban mandates in his autobiography which was published in 1996. While Singh played a central role in facilitating Burnham's break from the PPP in 1955, he later split with Burnham in $1958 .{ }^{10}$ Singh, however, remained opposed to the Jagan-led PPP for decades after the division. Thus, the Jagans' Guyanese critics challenge the depiction of the PPP as a non-communist, socialist-nationalist party while suffering from inherent biases.

Two more objective first-hand accounts published in the early 2000s disagree with Jagan's depiction of the PPP in The West on Trial. Wynter Crawford, the radical journalist and politician from Barbados, claims that the Jagans "almost single handedly spread communism throughout the West Indies.” However, Crawford provides few specifics and acknowledges that he never personally discussed communism with the Jagans in any of their meetings. ${ }^{11}$ Most significantly, Frank Birbalsingh's oral history of the PPP includes interviews with almost all of the PPP's influential early leaders. Birbalsingh's work hints that the PPP began as a left-coalition with a core of communist-inspired leaders and that ideological disagreement played a significant role in the party split and subsequent local conflicts. However, Birbalsingh's work does not suggest a particularly internationalist commitment on the part of PPP leaders. ${ }^{12}$

The earliest scholarship evaluating Guianese political ideology drew primarily on American and British archival material with minimal access to Guianese sources, and Jagan's autobiography shaped the narrative. In the late 1960s evidence emerged of Anglo-American

\footnotetext{
${ }^{10}$ Jai Narine Singh, Guyana: Democracy Betrayed (Kingston, Jamaica: Kingston Publishers Ltd., 1996). Mohan Ragbeer claims in his self-published two-volume autobiography to have been an early associate of Cheddi Jagan and describes the PPP as subordinate to Soviet influence as well. See: Mohan Ragbeer, The Indelible Red Stain: The Destruction of a Tropical Paradise-a Cold War Story (Published by Mohan Ragbeer, 2011).

${ }^{11}$ Woodville K. Marshall, ed., I Speak for the People: The Memoirs of Wynter Crawford (Kingston: Ian Randle Publishers, 2003), 110-112.

${ }^{12}$ When he was interviewed for the book in 1986 Jagan described himself and most of the party's early leaders as adherents of Marxist-Leninist ideas as described in the Soviet Union. Frank Birbalsingh, The People's Progressive Party of Guyana 1950-1992: An Oral History (London: Hansib Publications, 2007), 30, 32.
} 
machinations against the Jagan-led PPP earlier in the decade. At the same time, Burnham solidified his hold on an increasingly repressive regime that nationalized major sectors of the economy and pursued an Eastern-bloc oriented foreign policy. ${ }^{13}$ Consequently, contemporary scholars emphasized the external factors destabilizing British Guiana and Burnham's duplicity in diplomatic relations. Rather than criticize intervention's use as a tool of foreign policy, regardless of the Jagans' political ideals, scholars often downplayed the impact of Marxist ideology on the PPP. ${ }^{14}$ The cultural anthropologist Leo Despres is exceptional in emphasizing the importance of the PPP's left-wing Marxism and the party's international connections. He suggests that there existed a "hard core" of extreme Marxists within the Political Affairs Committee (PAC) including the Jagans, Martin Carter, Rory Westmaas, Sidney King, and Brindley Benn, who chose to continue relations with international communists rather than try to advance a nationalist agenda through the conservative labor movement in British Guiana. Nonetheless, Despres concludes that external forces and cultural factionalism were most significant in splitting the Guianese nationalist movement. ${ }^{15}$

Jagan returned to office as a democratic socialist in 1992 after twenty-seven years opposing Burnham's People's National Congress (PNC) autocracy. The disastrous consequences of American intervention and the Burnham dictatorship for the Guianese people, along with a continued lack of access to PPP material, contributed to the perpetuation of the existing

\footnotetext{
${ }^{13}$ Philip Agee, Inside the Company: CIA Diary (New York: Bantam Books, 1975), 174, 416; Arthur M. Schlesinger, Jr., A Thousand Days: John F. Kennedy in the White House (New York: First Mariner Books, 1965), 774-779; Stephen G. Rabe, U.S. Intervention in British Guiana: A Cold War Story (Chapel Hill: The University of North Carolina Press, 2005), 162-168.

${ }^{14}$ Richard J. Barnet, Intervention and Revolution: The United States in the Third World (New York: World Publishing Company, 1968); Thomas Spinner, A Political and Social History of Guyana, 1945-1983 (Boulder, CO: Westview Press, 1984).

${ }^{15}$ Leo A. Despres, Cultural Pluralism and Nationalist Politics in British Guiana, (Chicago: Rand McNally and Company, 1967), 178-188, 197-200. Basil Ince also suggested that the PAC committed itself to pursuing independence through a Marxist-Leninist strategy. Ince also suggests that ideology played a more significant role in the party split that scholars of the era appreciated; however, Ince also concludes that "external influence" was the most important factor. See: Basic Ince, Decolonization and Conflict in the United Nations: Guyana's Struggle for Independence (Cambridge, MA: Schenkman Publishing Company, 1974), 38-44.
} 
interpretation of the party's ideology after the Cold War. Stephen Rabe and Cary Fraser

produced groundbreaking studies of American involvement in Guianese decolonization in the early 2000s and their work remains the most influential scholarship shaping the subject. Their focus on Anglo-American actions in the colony and limited access to Guianese sources resulted in an uncritical treatment of PPP ideology that is consistent with earlier works on the subject.

Rabe and Fraser agree that American policymakers understood events in British Guiana through a Cold War prism and mislabeled Jagan's socialist-democratic ideas as communist. ${ }^{16}$ However, Fraser has since argued for a closer examination of PPP ideology during the period and suggested that the PPP's radical Marxist ideology differed from the social democratic ideas which influenced the rest of the British Caribbean. ${ }^{17}$

The Guianese historian Clem Seecharan introduced the first scholarly counter-narrative in 2005 suggesting that Cheddi Jagan was a doctrinaire Marxist and that party leaders' ideological dogmatism impeded reform efforts in British Guiana. Methodologically, Seecharan's work represents an important advancement in the scholarship since he based much of his analysis on close examination of the PAC Bulletin, the earliest platform in which the eventual PPP leaders explained their political agenda. Consequently, Seecharan is the first scholar to use primary source material to explain PAC/PPP ideology. ${ }^{18}$ Colin Palmer's Cheddi Jagan and the Politics of Power describes the ideological foundations of PPP leadership as a fusion of Marxism and

\footnotetext{
${ }^{16}$ Rabe, U.S. Intervention in British Guiana; Cary Fraser, Ambivalent Anti-Colonialism: The United States and the Genesis of West Indian Independence, 1940-1964 (Westport, CT: Greenwood Press, 1994). Cary Fraser, "The 'New Frontier' of Empire in the Caribbean: The Transfer of Power in British Guiana, 1961-1964," The International History Review, Vol. XXII, September 3, 2000, pp. 583-610. Sara Abraham agrees that the PAC was "not particularly radical;" however, she suggests in her conclusion that research is needed on the "over-dependency of some sections of the left on Marxist-Leninist discourse.” See: Sara Abraham, Labour and the Multiracial Project in the Caribbean: Its History and Its Promise (Lanham, MD: Rowman \& Littlefield Publishers, Inc., 2007 ), 209.

${ }^{17}$ Cary Fraser, "Forward," in Birbalsingh, The People's Progressive Party of Guyana 1950-1992, 13, 15.

${ }^{18}$ Clem Seecharan, Sweetening 'Bitter Sugar': Jock Campbell the Booker Reformer in British Guiana 1934-1966 (Miami: Ian Randle Publishers, 2005). It is worth noting that Janet Jagan wrote a brief response to Seecharan's book. In her response, Mrs. Jagan criticized Seecharan's depiction of Dr. Jagan's intellectual capacity; however, she did not criticize Seecharan's historical interpretation. See:

http://jagan.org/Janet\%20Jagan/JJ\%20Articles/JJ\%20Articles\%202000-2009/2006_1.html\#reply.
} 
Guianese nationalism adapted to circumstances in Guiana in the most focused study of PPP philosophy. Palmer emphasizes that Jagan and other party leaders acted independently of international communists despite the similarities in their political ideology. ${ }^{19}$ Robert Waters introduced the most direct challenge to the traditional narrative after gaining access to previously unexamined archives in former communist countries and considering the PPP's international policies. Waters suggests that the Jagans sought increased economic, political, and social relations with Eastern bloc nations consistently beginning at least by 1951, and that they were willing to engage in political subversion toward that objective. ${ }^{20}$ Recently declassified British intelligence files confirm that the Jagans established contact with Soviet representatives in Washington D.C. as early as 1947 and maintained close contact with the Communist Party of Great Britain. $^{21}$

The most recently available archival material corroborates much of the new research in suggesting that the PPP was a left-coalition before 1955 that included a core of self-described Marxist-Leninist leaders. ${ }^{22}$ PPP leaders explained their movement as part of an international struggle and sought increased association with what they described as socialist countries and

\footnotetext{
${ }^{19}$ Palmer, Cheddi Jagan and the Politics of Power. Perry Mars and Alma Young edited a series of essays commemorating Cheddi Jagan in 2004 that depicts Jagan in as a Marxist-inspired leader more complex than the orthodox interpretation. Taken together their interpretation is similar to Palmer's work. See: Perry Mars and Alma H., Young, eds., Caribbean Labor and Politics: Legacies of Cheddi Jagan and Michael Manley (Detroit: Wayne State University Press, 2004).

${ }^{20}$ Robert Anthony Waters, Jr. and Gordon Oliver Daniels, "Striking for Freedom? International Intervention and the Guianese Sugar Workers' Strike of 1964," Cold War History, Vol. 10, No. 4, (November 2010): 537-569; Robert Anthony Waters, Jr., "More Subtle Than We Knew: The AFL in the British Caribbean," in, Robert Anthony Waters, Jr. and Geert Van Goethem, American Labor's Global Ambassadors: The International History of the AFL-CIO During the Cold War (New York: Palgrave Macmillan, 2013), 165-173; Jan Koura and Robert Waters, "Cheddi Jagan and Guianese Overtures to the East: Evidence from the Czech National Archives," Cold War International History Project, e-Dossier No. 54, Wilson Center, 2015.

${ }^{21}$ Christopher Andrew, Defend the Realm: The Authorized History of MI5 (New York: Alfred A. Knopf, 2009), 459461.

${ }^{22}$ Cheddi Jagan stated in his interview with Frank Birbalsingh in 1986 that the PPP's early leadership was based on "Marxism/Leninism in relation to the Soviet Union and other communist countries." Birbalsingh, The People's Progressive Party of Guyana 1950-1992, 32. See also: Cheddi Jagan, "Lenin in Our Time," 1970, CJRC. Moreover, Moses Bhagwan told Birbalsingh that the PPP was receiving funds from the Russia when he joined the party in 1957. See: Birbalsingh, The People's Progressive Party of Guyana 1950-1992, 115.
} 
international organizations to advance their liberation movement in British Guiana, several of which were communist fronts. Crucially, the Jagan-led left-wing, the ideologically MarxistLeninist members of the PPP, remained unaffiliated with and acted independently of international communist organizations during the period discussed in this dissertation. ${ }^{23}$ Nonetheless, it is clear from thorough examination of party materials that Cheddi Jagan did not differentiate between socialism and communism, arguing that they were theoretically the same and that communism was merely the advanced stage of socialism. ${ }^{24}$ As a result, the PPP's leftwing pursued connections with the World Federation of Trade Unions (WFTU) and Eastern-bloc nations for the purpose of transitioning the colony to socialism and expecting an evolution toward communism while generally governing pragmatically and remaining committed to parliamentary democracy. Ultimately, close examination of the objectives and consequent transnational connections Guianese leaders pursued in attempting to establish Guianese socialism suggests that the Jagan-led PPP sought institutional transformation and increased connections to the Eastern-bloc as a means of achieving economic autonomy.

\section{The Clash of Trade Union Philosophies in British Guiana}

Guianese interpretations of institutional decolonization varied; however, two general views prevailed and labor leaders acted domestically and internationally to establish trade unions that would facilitate their supported style of labor organization. The first most consistently manifested in the policies of the Manpower Citizens' Association (MPCA), a sugar workers' union registered in 1937 that had the largest membership in the Guianese labor movement.

\footnotetext{
${ }^{23}$ Andrew, Defend the Realm, 459.

${ }^{24}$ Dr. Cheddi Jagan, "Undesirable Publications Bill," 1953, Dabydeen and Macedo, eds., Dr. Cheddi Jagan National Assembly Speeches, Volume 2, 309.
} 
MPCA leadership tried to address stifling poverty and oppression of workers through

negotiations with British companies and reform within the existing political-economic system. ${ }^{25}$

MPCA leaders pursued for a form of trade unionism independent of political control that

loosely resembled British and American models of labor organization. MPCA founder Ayude

Edun favored the establishment of a socialist system that permitted a degree of latitude for

private enterprise with unions acting independently of political parties. Importantly, Edun

appealed to Secretary of State for the Colonies James Griffiths to reconfigure Anglo-Guianese

connections as a partnership as the Empire adjusted to the post-1945 world while vehemently

rejecting "Communism and Americanism." ${ }^{, 26}$ Most MPCA leaders in the 1950s, however,

expressed support for a free-market economic ideal and suggested that unions should work to

exact benefits for workers within that system. Rutgers University Economics professor and labor

activist Robert Alexander conducted several hemispheric fact-finding missions for the Free

Trade Union Committee (FTUC), a covert anti-communist branch of the American Federation of

Labor (AFL). ${ }^{27}$ Alexander interviewed Guianese labor leaders including Rupert Tello, at the time

\footnotetext{
${ }^{25}$ Ashton Chase, A History of Trade Unionism in Guyana, 1900 to 1961, with an Epilogue to 1964 (Demerara, Guyana: New Guyana Company, Ltd., 1964), 86, 207.

${ }^{26}$ Ayube M. Edun, President and founder of MPCA to James Griffiths, May 23, 1950, CO 859-1150, British National Archives, Kew, Richmond, Surrey. (Hereafter BNA). Edun's appeal is interesting. It may have been a political maneuver to use British fears of American expansion as a way to exact benefits for the MPCA. More likely, Edun legitimately opposed the American style of capitalism and thought that cooperation with the Colonial Office could institutionalize a system closer to the socialism he rhetorically supported. Thus, his collaboration with colonial officials seems to have been an attempt to exact the farthest-reaching reform possible in the circumstances. For an explanation of Latin American support for "socialism" as a means of resisting American capital, see: Alan McPherson, ed., Anti-Americanism in Latin America and the Caribbean (New York: Berghahn Books, 2006) 20-22.

${ }^{27}$ Jay Lovestone, the most important individual in developing the AFL's international policy, supported Alexander's missions even though he was at times considerably critical of Alexander's analyses. See: Jay Lovestone to Robert Alexander, June 6, 1952 and Jay Lovestone to Robert Alexander, June 10, 1952, RG 18-003, International Affairs Department, Jay Lovestone Files, 1944-1973, Box 2, Alexander, Robert, 1952, George Meany Memorial Archive, Silver Spring, MD (Hereafter GMMA). Serafino Romualdi, the AFL's Latin American representative, held Alexander's views and recommendations in high regard and used them to develop ORIT policies and programs in the early-mid 1950s but changed his view of Alexander later in the decade. See: Serafino Romualdi to Jay Lovestone, July 8, 1954, RG 18-003, International Affairs Department, Jay Lovestone Files, 1944-1975, Box 55, Romualdi, Serafino (Latin America), 1954-1955, GMMA; Serafino Romualdi to Robert Alexander, June 4, 1954, RG 18-003, International Affairs Department, Jay Lovestone Files, 1944-1975, Box 55, Romualdi, Serafino (Latin America), 1954-1955, GMMA. An exchange between Romualdi and Lovestone regarding an Alexander fact-finding
} 
the MPCA Vice President and a member of the National Democratic Party (NDP). Tello, who worked with American and British trade union leaders throughout the 1950s and early 1960s, took care to note that he supported "importation of capital for the development of the country" and free enterprise. Tello emphasized that he opposed nationalization with the possible exception of public utilities and then "only if necessary and wanted.",28

Similarly, Justin Yee, President of the Demerara Electric Company branch of the MPCA, told Alexander that his union hoped to overcome considerable agitation for nationalization through strengthening the union and increasing workers' wages. ${ }^{29}$ Thus, MPCA leaders sought to advocate on workers' behalf while using their organization as a bulwark against party-dominated unionism and left-wing economics in British Guiana. A Legislative Council debate between MPCA President Lionel Luckhoo and PPP leader Cheddi Jagan over the role of trade unions in 1952 illuminates the leaders' contrasting viewpoints. Luckhoo insisted that trade unions should act independently of politics. "Trade unions and politics," Jagan replied, "cannot be put into separate airtight compartments.",30

trip in 1959 suggests that the AFL continued to value Alexander's views while their representative in ORIT disagreed with him considerably by the end of the decade. Romualdi claimed that Alexander's reports were "of little or no value in helping formulate our Latin America policy" while Lovestone deemed them "essential for formulating policy." See: Serafino Romualdi to Jay Lovestone, August 7, 1959 and Jay Lovestone to Serafino Romualdi, August 11, 1959, RG 18-003, International Affairs Department, Jay Lovestone Files, 1944-1975, Box 55, Romualdi, Serafino (Latin America), 1956-1959, GMMA.

${ }^{28}$ Robert Alexander interview with Rupert Tello, June 4, 1953, RG 18-003, International Affairs Department, Jay Lovestone Files, 1944-1973, Box 2, Alexander, Robert, 1953, GMMA. See also: Robert Alexander interview with Richard Ishmael, June 28-29, 1954, RG 18-003, International Affairs Department, Jay Lovestone Files, 1944-1973, Box 2, Alexander, Robert, 1954, GMMA.

${ }^{29}$ Robert Alexander interview with Justin Yee, June 29, 1954, RG 18-003, International Affairs Department, Jay Lovestone Files, 1944-1973, Box 2, Alexander, Robert, 1954, GMMA. See also: Robert Alexander interview with J. Yee and Claude Archer, President Electrical Workers Branch of MPCA, June 3, 1953, RG 18-003, International Affairs Department, Jay Lovestone Files, 1944-1973, Box 2, Alexander, Robert, 1953, GMMA.

${ }^{30}$ Dr. Cheddi Jagan, "Estimates-Labour Department: Thursday February 26, 1948," David Dabydeen, and Lynne Macedo, eds., Dr. Cheddi Jagan National Assembly Speeches, Volume 1: The Fourth Legislative Council December 1947-December 1951 (Published by the Caribbean Press for the Government of Guyana, 2011), 5. See also: Jagan, The West on Trial, 102, 116. 
Alternately then, a second view of Guianese labor organization emerged after World War II in part as reaction to increased poverty and the MPCA's perceived ineffectiveness throughout the 1940s. This idea was to establish a working-class movement which subordinated trade unions to a political party and that pursued political independence as a precursor to structural transformation and the establishment of a socialist society. ${ }^{31}$ Seecharan suggests that Cheddi Jagan consistently supported the view that trades unions' primary purpose was to act as an instrument to destroy the capitalist state. ${ }^{32}$ The movement congealed into the left-coalition PAC in 1946 after Cheddi Jagan resigned from his position as treasurer of the MPCA. ${ }^{33}$ The PAC laid the foundation for the establishment of the PPP in 1950, which effectively acted as an alternative

\footnotetext{
31 "Excerpt from 'What Happened in British Guiana' by Cheddi Jagan,” British Guiana 972.8 (520), Box 44, Marjorie Nicholson Files, Trades Union Congress Library, London Metropolitan University, London (Hereafter TUCLC). See also: Perry Mars and Alma H. Young, "Introduction," in Mars and Young, eds., Caribbean Labor and Politics: Legacies of Cheddi Jagan and Michael Manley, xxvii. For PAC/PPP explanations of their socialist objectives see: Dr. Cheddi Jagan, "Prohibition of Subversive Literature," March 13, 1952, Dabydeen and Macedo, Dr. Cheddi Jagan National Assembly Speeches, Volume 1, 51-52, 59; Dr. Cheddi Jagan, "Motion on Timber Concessions to Cuba," November 4, 1960, David Dabydeen and Lynne Macedo, eds., Dr. Cheddi Jagan National Assembly Speeches, Volume 3: The Legislative Council \& the Senate, February 1959-July 1961 (Published by the Caribbean Press for the Government of Guyana, 2011), 92-102.Cheddi Jagan, "Bitter Sugar," (B's Printing Service: Georgetown, 1954), CJRC; "Radio Debate on B.G.'s 'Economic Realities," January 1-8, 1961, F2384, British Guiana, Guiana Diary, 1957to 1962, TUCLC; Cheddi Jagan, "The New Sugar Agreement," Thunder, February 14, 1952, CJRC; Janet Jagan, "The Rights of Workers in the People's Republic of Rumania," Thunder, July 1953, CJRC; Cheddi Jagan, "PPP Economic Policy—Realistic Plan for Prosperous Future," Thunder, August 5, 1961, CJRC; Cheddi Jagan, "Report by the Premier on the Mission to the United States, Canada, and Puerto Rico, October, 1961," History of British Guiana, Guiana Diary 1957-July to 1962-Jan, F2384, TUCLC; Janet Jagan, "British Guiana: Our Victory," Labor Monthly, October 1961, CJRC; "History of the PPP," January 1963, CJRC; Cheddi Jagan, "The Ideological Struggle," Thunder, March 1967, CJRC; Chase, A History of Trade Unionism in Guyana, 178.

${ }^{32}$ Seecharan, Sweetening 'Bitter Sugar, '132-135.

${ }^{33}$ Cheddi and Janet Jagan founded the PAC in collaboration with Jocelyn Hubbard in 1946. Palmer, Cheddi Jagan and the Politics of Power, 9; Rabe, U.S. Intervention in British Guiana, 27; Maurice St. Pierre, "Dr. Cheddi Jagan: The Making of a Movement Intellectual," in Mars and Young, eds., 21. In discussing the PAC's founding, Cheddi and Janet Jagan and Ashton Chase suggest that Chase was also part of the group of four founders. See: Birbalsingh, The People's Progressive Party of Guyana 1950-1992, 30, 37, 42; Chase, A History of Trade Unionism in Guyana 1900 to 1961, 127; Despres, Cultural Pluralism and Nationalist Politics in British Guiana, 181; Jagan, The West on Trial, 88. Clem Seecharan suggests that Jagan was expelled from the MPCA. See: Seecharan, Sweetening 'Bitter Sugar,' 133, 144.
} 
representative for sugar workers actively opposing MPCA leadership and frequently the union itself. $^{34}$

The PAC/PPP's labor activism grew out of an effort to negotiate against employers who were overwhelmingly foreign with direct consequences on leaders' view of trade union organization. The Guianese people experienced 150 years of British colonial exploitation and the PAC argued that meaningfully improving the lives of Guianese workers necessitated empowering them in a manner beyond legally protecting the right to negotiate with employers. The largest employers in the colony, especially Booker Brothers, effectively controlled the economy, leaving Guianese workers with little effective negotiating power. The MPCA obtained concessions from Booker Brothers in the late 1930s and 1940s; however, PAC/PPP leaders argued that the Guianese would never be able to benefit from their own resources or develop in a manner that benefited the Guianese people rather than foreign employers unless the Guianese themselves controlled the economy. ${ }^{35}$ The only means of decolonizing the colonial economy in the view of many Guianese political activists was to nationalize foreign investment and take control of the state.

\footnotetext{
34 “Twelve Years of the PPP," June, 1961, CJRC; Brindley Benn, "Legacies of Cheddi Jagan," and Maurice St. Pierre, "Dr. Cheddi Jagan: The Making of Movement Intellectual," in Mars and Young, eds., Caribbean Labor and Politics, 11, 21-23; Birbalsingh, The People's Progressive Party of Guyana 1950-1992, 30, 37, 42; O. Nigel Bolland, The Politics of Labour in the British Caribbean: The Social Origins of Authoritarianism and Democracy in the Labour Movement (Oxford: James Currey, 2001), 602-603, 609; Despres, Cultural Pluralism and Nationalist Politics in British Guiana, 183-189; Palmer, Cheddi Jagan and the Politics of Power, 9; Rabe, U.S. Intervention in British Guiana, 27.

${ }^{35}$ For a concise comparison of Burnham and Jagan's economic philosophies see: British Guiana Government Information Services, Guiana Diary, "PNC Revolutionary, Not Communist," October 31-November 6, 1960; "Dr. Jagan Explains PPP Policy to T.U.C., November 7-13, 1960, F2384, British Guiana, Guiana Diary, 1957to 1962, TUCLC. For a scholarly explanation of colonial Socialist ideology and support for nationalization that closely mirrors Jagan's writings, see: David J. Saposs, "Ideological Conflicts in the International Labor Movement," in Everett M. Kassalow, ed., National Labor Movements in the Postwar World (Evanston, IL: Northwestern University Press, 1963), 27-31. See also: Abraham, Labour and the Multiracial Project in the Caribbean, 56.
} 
Consequently Nigel Bolland notes that the PAC stated as its purpose the "abolition of the existing economic system" and its replacement with scientific socialism. ${ }^{36}$ H.J.M. Hubbard, one of the PAC's founders, specifically argued that trade unions needed to engage in political activity to aid in the establishment of a socialist society. ${ }^{37}$ Cheddi Jagan insisted that the social and political-economic reforms necessary to improve the lives of Guiana's workers "must be joined at the industrial and political level outside the legislature." ${ }^{38}$ Ashton Chase was a Trades Union Congress (TUC)-trained labor leader, lawyer, and high-ranking member of the PPP who served as Minister of Labor under the short-lived PPP government in 1953. According to Chase, the PPP's prioritized strengthening and operating in conjunction with Guianese trade unions. As a result, Chase suggested that "the PPP and the trade unions worked together, planned together and struggled together to uproot privilege and a decadent political and economic system."39

Janet Jagan, Cheddi Jagan's wife and confidant, and a leading member of the PPP, took care to note the lessons she learned from trade unionists during a visit to Rumania in 1953 . She specifically noted the "difference in the functions of trade unions existing in capitalist countries and those in the socialist countries. $" 40$ Janet Jagan's report does not show that the PPP copied communist trade union practices; however, it suggests that the party worked toward the development of labor relations that would promote a fundamentally different economic system in Guiana than that which the MPCA supported. Several years later Cheddi Jagan explained to the British Guiana Trades Union Congress (BGTUC) that the PPP expected to assume ownership of the economy as head of a government democratically responsible to the people. Specifically,

\footnotetext{
${ }^{36}$ Bolland, The Politics of Labour in the British Caribbean, 602.

${ }^{37}$ Bolland, The Politics of Labour in the British Caribbean, 476-477.

38 Jagan, The West on Trial, 102, 116.

${ }^{39}$ Chase, A History of Trade Unionism in Guyana 1900 to 1961, 177.

40 Janet Jagan, “The Rights of Workers in the People's Republic of Rumania,” Thunder, July 1953, CJRC; Janet Jagan, "Apprenticeship in Rumania," Thunder, August, 1953, CJRC.
} 
Jagan suggested that a PPP-headed socialist government would coordinate its activities with "subsidiary agencies of a democratic character, such as trade unions" that would help manage industries in addition to arguing with employers. ${ }^{41}$

Colin Palmer argues that PPP ministers "challenged the institutional structures of the imperial regime most sharply with the rhetorical weapons at their command."42 Palmer's penetrating analysis provides a key insight into the PPP's challenge to institutional structures that is critical to understanding the broader Left-coalition's efforts in British Guiana. However, the PPP program was part of broad, active, and consistent efforts to decolonize the labor movement that went far beyond rhetoric and the most important PPP leaders were also active trade unionists. While the party itself was never of singular mind, particularly before 1955 when it acted as a coalition of Left-nationalists, it nonetheless consistently advocated empowering the Guianese and as much as possible breaking the institutional mechanisms through which British and American employers controlled the colony. ${ }^{43}$

\footnotetext{
${ }^{41}$ British Guiana Government Information Services, Guiana Diary, "Dr. Jagan Explains PPP Policy to T.U.C., November 7-13, 1960. Jagan articulated a similar concept in a 1976 address wherein he explained the role of trade unions and democratic centralism in support of scientific socialism. It cannot be assumed that Jagan held identical views twenty years prior; however, the general ideas articulated in his 1976 address are consistent with his earlier writings and the role he proscribed for trade unions is consistent with PAC/PPP relations with organized labor between 1946 and 1953. See: "Trade Unions and National Liberation," An address by Dr. Cheddi Jagan to the Second Triennial National Convention of the National Union of Government \& Federated Workers, October 15, 1976, CJRC. For more on the PPP's conception of party-centered trade unionism, see: Ashton Chase, Guyana a Nation in Transit: Burnham's Role (Guyana: Ashton Chase, 1994), 11; Perry Mars and Alma Young describe Jagan's view of trade unionism as the subordination of the labor movement to the leadership of a particular party. See: Perry Mars and Alma H. Young, "Introduction," in Mars and Young, eds., Caribbean Labor and Politics, xxvii.

${ }^{42}$ Palmer, Cheddi Jagan and the Politics of Power, 29.

${ }^{43}$ Scholarship on Guyanese decolonization generally focuses on Cheddi and Janet Jagan, who were undoubtedly the most influential members of the PPP. Limitations on access to Guyanese sources and the scope of the argument limit the extent to which this dissertation can quantify the impact of other PPP members on organizational policy. Frank Birbalsingh's oral history of the PPP suggests that the Jagans wielded considerable control over Party matters, as Cary Fraser points out in his forward to the volume; however, a number of interviewees disagree with that assertion, suggesting that the PPP was always a complex coalition and that the Jagans did not exercise as much control as is attributed to them, and certainly not before 1955. See: Birbalsingh, The People's Progressive Party of Guyana 19501992. Jai Narine Singh's autobiography also suggests that the PPP contained a core of communist leaders, but that the Party was established as a coalition of Guianese activists who set aside ideological differences in pursuit of a broad program of independence and social reform, and remained so between 1950 and 1955. See: Singh, Guyana: Democracy Betrayed, xxvi.
} 
Beyond ideology, it is important to consider that the PPP's practical needs resulted in close relations with trade unions that became especially important after 1956, when Cary Fraser suggests the Party was confronted a "schizophrenic predicament." Fraser suggests that the PPP "refashioned itself as a moderate political force" to court support from the fundamentally conservative and capitalist East Indian community while simultaneously trying to retain its Marxist ideology as Guianese politics realigned on racial grounds in the late $1950 \mathrm{~s} .{ }^{44}$ The complexity of Guianese politics and the practical realities of governing after 1957 placed the PPP in a position where its most effective means of pushing for radical change was often through associated trade unions rather than political action that could undermine the Party's base of support, create disorder in government, or result in the suspension of self-government.

The contrast between Jagan's vision and the views of American and British labor leaders is stark. David Dubinsky argued that "organized labor has something to say only about the conditions of work and their standards of pay. Organized labor has nothing to say about management of industry, the distribution and price of its products at home, and the disposition of its goods abroad." ${ }^{45}$ Similarly, Walter Hood, responsible for the colonial section of the TUC's International Department, noted in a 1957 list of frequently asked questions prepared for colonial unions that "the primary function of a trade union is to give workers a say in the determination of their wages and conditions of work." 46 TUC leaders' insistence that trade unions limit their activities was less rigid within Great Britain; however, they generally dismissed the notion of political unionism in the colonies.

\footnotetext{
${ }^{44}$ Cary Fraser, in, Birbalsingh, The People's Progressive Party of Guyana 1950-1992, 12.

${ }^{45}$ David Dubinsky speech, May 1947, RG 18-003, International Affairs Department, Jay Lovestone Files, 19441973, Box 10, David Dubinsky, 1947-1948, GMMA.

${ }^{46}$ Walter Hood, November 11, 1957, Marjorie Nicholson Files, Box 15, Trade Unions+Colonies, TUCLC.
} 
In opposing the MPCA's leader, Luckhoo, Cheddi and Janet Jagan articulated views that directly contradicted Dubinsky's and Hood's ideas. Cheddi Jagan argued that "One does not stop at wages and working conditions. We need laws that can put profits and other benefits into the pockets of workers. ${ }^{, 47}$ Janet Jagan, who later became Minister of Labor, Health, and Housing in the PPP government, explained strikes and trade union activity as legitimate forms of civil protest in a manner that conflicted with American and British expectations for industrial colonial unionism. ${ }^{48}$ Even when the PPP moderated its rhetoric while holding office under a restricted constitution in 1958 Janet Jagan argued for close collaboration between politics and unionism, suggesting that the British Labor Party was a viable model for the Guianese. ${ }^{49}$ Importantly, the Jagans most cautious public statements demanded a political role for trade unions greater than what the British were willing to allow in the colony. ${ }^{50}$ Thus, Guianese labor and political leaders found a ready ideological ally in American and British organized labor, and American labor leaders opposed the PAC/PPP on trade union grounds well before the United States government determined the Jagans' PPP was a strategic Cold War threat. Conversely, PAC/PPP leaders sought connections with the WFTU and communist parties who shared their views on the role of trade unions as social institutions.

The PAC and PPP were not communist organizations; however, leaders' Marxist ideals reinforced their experiences fighting for Guianese workers and shaped the manner in which they

\footnotetext{
${ }^{47}$ Dr. Cheddi Jagan, "Ban Against Messrs. Strachan and Smith Con't," October 3, 1952, Dabydeen and Macedo, Dr. Cheddi Jagan National Assembly Speeches, Volume 2, 175.

${ }^{48}$ Janet Jagan, "The Politics of Protest," undated (approximately 1990), Party Life, CJRC.

${ }^{49}$ British Guiana Government Information Services, Guiana Diary, "Minister Speaks on Trade Unions and Politics," June 30-July 3, 1958, F2384, British Guiana, Guiana Diary, 1957to 1962, TUCLC.

${ }^{50}$ Conversations about the possibility of a Guianese labor party occurred regularly in trade union circles; however, the Jagans' position is distinct in that discussions of a British-style labor party were the most centrist of their positions.
} 
hoped to design their post-colonial political institutions. ${ }^{51}$ The evolution of the trade union struggle helps illuminate Cheddi Jagan's conclusion in the 1950s that British and American economic power was the most significant threat to Guianese unions' effectiveness. Sara Abraham argues that the Jagan faction of the PPP expected the resolution of their powerlessness through winning leadership of key national labor unions as did most nationalist parties in the decolonizing Caribbean. ${ }^{52}$ The left-wing of the PAC/PPP viewed the establishment of coordinated trade union-party activity as central to their objective of restructuring Guianese society. However, the PAC and PPP differed from most Caribbean nationalist parties in emphasizing the prioritization of party over union and rejecting the notion of integration into Western international labor organizations. ${ }^{53}$ Given the core PPP leaders' Marxists-Leninist ideology, their conceptualization of the role of trade unions is most effectively understood as simultaneously anti-colonial and consistent with Lenin's argument that the fundamental task of revolutionary movements was to pursue "a gigantic replacement of certain institutions by other institutions of a fundamentally different type." ${ }^{54}$ The PPP's efforts to alter the structure of labor relations coincided with attempts to re-orient educational and youth institutions based on

\footnotetext{
${ }^{51}$ Palmer, Cheddi Jagan and the Politics of Power, 25. See also: Despres, Cultural Pluralism and Nationalist Politics in British Guiana, 185-186.

${ }^{52}$ Abraham, Labour and the Multiracial Project in the Caribbean, 55. Jon Kofas explores the ways hemispheric labor leaders coordinated union strength with governmental support to counterbalance the influence of political, economic, and military elites, as well as powerful external interests. Though his work does not address the Caribbean, the dynamic he describes was a fundamental component of the PPP's pursuit of autonomy, as well as the American resistance to it. See: Jon Kofas, The Struggle for Legitimacy: Latin American Labor and the United States 1930-1960 (Tempe: Arizona State University, 1992).

${ }^{53}$ Waters, "More Subtle Than We Knew," 169-173. J.P. Lachmansingh, for example, had been temporarily expelled from the PPP in August 1951 for acting against a decision of the party's General Council while president of the GIWU. See: Chase, A History of Trade Unionism in Guyana 1900 to 1961, 193.

${ }^{54}$ V.I. Lenin, The State and Revolution, in SWL, London, 1969, cited in Ralph Miliband, Marxism and Politics (Oxford: Oxford University Press, 1977), 139. In an interview with Frank Birbalsingh in 1986, Cheddi Jagan, the leader of the PPP, described himself as a Marxist-Leninist since the 1940s. Most other PPP leaders Birbalsingh interviewed expressed similar sentiments. See: Birbalsingh, The People's Progressive Party of Guyana 1950-1992, 30-32.
} 
socialism and simultaneously to increase affiliation between new organizations and communistled international groups. ${ }^{55}$

Labor leaders' competing trade union ideologies shaped their pursuit of transnational relationships and Guianese involvement in international labor organizations internationalized the conflict. Colonial Office-TUC efforts to help build Guianese trade unions began on a small scale in 1929 as a result of policies designed to train Guianese labor leaders and institutionalize the labor movement. ${ }^{56}$ However, World War II impeded British officials' plans to expand the programs in response to labor unrest in the late 1930s. ${ }^{57}$ Meanwhile, PAC co-founder H.J.M. Hubbard attended the first conference of the WFTU when international labor leaders formed the organization in 1945 in an attempt to facilitate universal workers' solidarity and establish a cooperative relationship between communist and non-communist labor organizations. ${ }^{58}$ Tensions $^{2}$

\footnotetext{
${ }^{55}$ PPP attempts to change the educational system focused on creating public schools rather than relying on the predominantly religious institutions in place. At the same time, party leaders emphasized the need for specific education on socialist principles. William Maddox to Department of State, July 30, 1953, 841D.43/7-5053, Central Decimal Files, RG 59, National Archives and Records Administration, College Park, MD (Hereafter, NARA II); Birbalsingh, The People's Progressive Party of Guyana 1950-1992. Mohan Ragbeer recalls an interview he conducted with Cheddi Jagan in 1950 where Jagan argued that the structure of Guianese schools was, "a left-over from British colonialism," and that, "independent Guiana will need new institutions..." See: Mohan Ragbeer, The Indelible Red Stain: The Destruction of a Tropical Paradise-a Cold War Story, Book 1 (Published by Dr. Mohan Ragbeer, 2011), 253. British Security Reviews suggest that similar efforts were made to replace social organizations, such as the Young Men's Christian Association (YMCA) and Boy Scouts, with the Guyana Union of Youths and Students (GUYS). See: Eastern Caribbean and British Guiana Security Review for Period January 1-March 31, 1956, CO 1035-16, BNA. GUYS established correspondence "with like-minded people in the Soviet Union, China, and the People's Democracies," but sought no political affiliations. See: Eastern Caribbean and British Guiana Security Review for Period July 1- September 30, 1956, CO 1035-16, BNA. Jagan argued for similar efforts promoting socialist youth organizations in Guiana and establishing relations with international socialist youth groups in 1961. See: British Guiana Government Information Services, Guiana Diary, "Youth Called on to join Struggle," February 13-19, 1961, F2384, British Guiana, Guiana Diary, 1957to 1962, TUCLC. See also: "History of the PPP," January 1963, CJRC.

${ }^{56}$ Nigel Bolland most effectively describes British efforts to institutionalize Caribbean labor as a long-term process beginning with Emancipation. See: Bolland, The Politics of Labor in the British Caribbean.

${ }^{57}$ Colonial Advisory Committee, "Colonial Work of the TUC," June 6, 1956, Box 15, Marjorie Nicholson Files, TUCLC; Report of the 78th Annual Trades Union Congress, page 162, October 21, 1946, TUC History Online; "Trade Unions in the Colonies," 1955, Box 15, Marjorie Nicholson Files, TUCLC; Untitled Colonial Office Report, October 14, 1950, Trade Unions and Colonies 932.5, Box 15, Marjorie Nicholson Files, TUCLC. See also: Bolland, The Politics of Labour in the British Caribbean, 383-395.

58 "Statement Adopted by the Executive Council of the American Federation of Labor," May 4, 1945, Office of the President-George Meany (1948-1960), Box 52, Subjects: World Federation of Trade Unions (1945-1949), GMMA. See also: "What Happened at the World Labor Conference," Office of the President-George Meany (1948-1960),
} 
between communist and non-communist labor leaders, disagreement over the future of European colonialism, and debates about the Marshall Plan divided the WFTU. As a result, the TUC and CIO led the non-communist unions out of the organization in 1949 and they established the International Confederation of Free Trade Unions (ICFTU) as an alternative to the WFTU. ${ }^{59}$ PAC/PPP leaders individually and in conjunction with the Guiana Industrial Workers Union (GIWU) retained connections to the WFTU and its loosely affiliated regional organization, the Caribbean Labor Congress (CLC). ${ }^{60}$ The WFTU's anti-colonialism and advocacy for the PPP increased Guianese leaders' support for the communist-led international. ${ }^{61}$ Moreover, a report by Ernst Schwarz, the CIO's representative to the WFTU prior to the split, suggests that in addition to conflicting over political ideology, divisions within the organization

Box 52, Subjects: World Federation of Trade Unions (1945-1949), GMMA. Anti-communism was clearly the most significant factor in the AFL's rejection of the WFTU.

${ }^{59}$ Hilbourne Watson, "Guyana, Jamaica, and the Cold War Project: The Transformation of Caribbean Labor," in Mars and Young, Caribbean Labor and Politics, 99.

60 "Survey of Communism in the West Indies, 1951," undated, CO 968-252, BNA. "History of the PPP," 1963, CJRC; Secretary of State for the Colonies to Parliament, "British Guiana: Suspension of the Constitution," October 1953, CO 859-772, BNA; “The Interest of WFTU in Colonial and Dependent Countries," January 2, 1952, CO 968 252, BNA.; Patrick Renison to British Ambassador to Washington D.C., September 19, 1957, FO 371-126078, BNA; Dave Goodman, Circulation Department, WFTU to Cheddi Jagan, February 5, 1953, KV2-3604, BNA; Dave Goodman, Circulation Department, WFTU to Cheddi Jagan, March 17, 1953, KV2-3604, BNA; Intercepted Telegram from Communist Party Headquarters, London to Cheddi Jagan, May 4, 1953, KV2-3604, BNA; Robert Alexander interview with J.P. Lachmansingh, President of GIWU, June 29, 1954, RG 18-003, International Affairs Department, Jay Lovestone Files, 1944-1973, Box 2, Alexander, Robert, 1954, GMMA; "Extract from British Guiana Sixtieth Political Report covering the period from June 1-June 30, 1954, CO 859-773, BNA; "Eastern Caribbean and British Guiana Security Review," July 1-September 30, 1955, CO 1035-16. See also: Gerald Horne, Cold War in a Hot Zone: The United States Confrtons Labor and Independence Struggles in the British West Indies (Philadelphia: Temple University Press, 2007), 65, 168-169, Chase, A History of Trade Unionism in Guyana 1900 to $1961,105$.

${ }^{61}$ Specifically, the WFTU pressured the Colonial Office, ILO, and United Nations on behalf of the PPP and PPP members. Alfred Savage to Oliver Lyttleton, December 22, 1953, CO 859-772, BNA; Willi Baumgart, General Secretary, WFTU to Postmaster General, Georgetown, British Guiana, April 30, 1953, CO 859-772, BNA; "Observations of the United Kingdom Government on a Complaint by the Trades Union International of the Postal, Telegraph, Telephone and Radio Workers Concerning Alleged Infringement of Trade Union Rights in British Guiana, undated, CO 859-772, BNA; Patrick Renison to British Ambassador to Washington D.C., September 19, 1957, FO 371-126078, BNA; International Labor Office, "Report of the Committee on Freedom of Association," November 16-19, 1954, CO 859-772, BNA; Secretary of State for the Colonies to Officer Administering the Government of British Guiana, December 16, 1954, CO 859-772, BNA. See also: Bolland, The Politics of Labour in the British Caribbean, 490-496; Palmer, Cheddi Jagan and the Politics of Power, 22-27, 99-100; Arnold L. Steinbach, "Changing Concepts and Practices in the International Labor Movement," in Everett M. Kassalow, ed., National Labor Movements in the Postwar World (Evanston, IL: Northwestern University Press, 1963), 40. 
revolved around the type of development to support in underdeveloped areas. Schwarz noted that British and American representatives were alienated within the organization in their support for agricultural development and private foreign investment rather than the industrialization and pursuit of self-sufficiency that Eastern European representatives demanded for poor countries. ${ }^{62}$ Therefore, the WFTU's support for socialist development dovetailed with PAC/PPP objectives. ${ }^{63}$ Meanwhile, MPCA leaders increased their pursuit of institutional connections to the British and American-led international economic system. As the Guianese labor conflict increased in the late 1940s, the TUC increased its support for the MPCA. At the same time, the sugar workers' union affiliated to ICFTU and its regional arm, the Inter-American Regional Organization of Workers (ORIT). ${ }^{64}$ MPCA General Secretary Sheik Shakoor traveled to the United States to meet with American labor leaders to discuss the organization and purpose of ORIT just after its founding. ${ }^{65}$ Shakoor also played an important role in expanding ORIT with the creation of the Caribbean Area Division of ORIT (CADORIT) in 1952, which Jagan opposed

\footnotetext{
${ }^{62}$ Ernst Schwarz, "Summary of the Deliberations of the 3rd Meeting of the Economic and Employment Commission," June 29, 1948, International Affairs Department (CIO), Director's Files (Mike Ross), 1945-1955, Sub-Series 1: World Federation of Trade Unions: CIO Department Files, 001/36, WFTU: Correspondence, 1948, GMMA.

${ }^{63}$ Robert Alexander interview with J.P. Lachmansingh, February 4, 1956, RG 18-003, International Affairs Department, Jay Lovestone Files, 1944-1973, Box 2, Alexander, Robert, 1955, GMMA; Robert Alexander interview with J.P. Lachmansingh, June 29, 1954, RG 18-003, International Affairs Department, Jay Lovestone Files, 19441973, Box 2, Alexander, Robert, 1954, GMMA. See also: Palmer, 26.

64 "For Bread, Peace, and Freedom: Decisions of the First World Congress of the ICFTU," November-December, 1949, International Affairs Department, Staff Files: George Delaney's files, 1921-1957, Box 10, ICFTU InterAmerican Regional Organization of Workers..., 1951-1955, GMMA; "Trade Union Organizations in British Colonies Accepted for Affiliation to ICFTU to July, 1952," ICFTU/TUC 931.9, Box 9, Marjorie Nicholson Files, TUCLC; Robert Alexander interview with Ashton Chase, June 5, 1953, RG 18-003, International Affairs Department, Jay Lovestone Files, 1944-1973, Box 2, Alexander, Robert, 1953, GMMA. The record is unclear regarding whether the MPCA formally affiliated to the ICFTU in 1951 or 1952. However, it is clear that the union participated in ICFTU functions beginning in 1949. See: "International Confederation of Free Trade Unions: Its Organization, Objectives, Ideology, and Structure,” RG 1-027, Office of the President, George Meany, 1948-1960, Box 49, Subjects: Formation, 1949-1950, GMMA.

65 “Third Meeting of the Executive Board," December 17, 1951, January 23-24, 1952, RG 18-International Affairs Department, Staff Files: George Delaney's files, 1921-1957, ICFTU Inter-American Regional Organization of Workers..., 1951-1952, GMMA.
} 
in CLC arguing that it disrupted Caribbean labor unity. ${ }^{66}$ Colonial officials and TUC leaders supported the MPCA's integration into the Western labor organizations and occasionally provided assistance to ease the financial burden on Guianese trade unionists' travels to ICFTU, ORIT, or CADORIT conferences. ${ }^{67}$ Nonetheless, MPCA efforts to resist structural changes to the nature of trade unionism were not directed from the outside and Shakoor and other leaders aggressively opposed the PAC/PPP and GIWU despite a general lack of external international assistance before 1954. ${ }^{68}$ Richard Ishmael, who became MPCA president in 1953, insisted on increasing his organization's integration into ORIT as a result of shared opposition to communism and mutual support for "free trade unionism."69 Ishmael's appeal to the American concept of free trade unionism in particular underscores MPCA leaders' opposition to PAC/PPP trade union ideals. Thus, Guianese labor leaders pursued regional and global integration with

\footnotetext{
${ }^{66}$ Handwritten Colonial Advisory Committee Note, July 11, 1952, West Indies, TUC I, 972/2, Box 40, Marjorie Nicholson Files, TUCLC; Caribbean Area Division of ORIT of the ICFTU: Information Bulletin No. 1," February 1953, RG 18-009: International Affairs Department, Staff Files: Serafino Romualdi's Files, 1945-1961, Caribbean Area, 1953-1956, GMMA; Report of the 82nd Annual Trades Union Congress, pages 210-213, TUC History Online; Luis J. Marcano, Secretary, CADORIT, “Report on CADORIT's Activities,” December 31, 1954, RG 18: International Affairs Department, Staff Files: George Delaney's Files, 1921-1957, Box 11, ORIT 3rd Congress, 1955, GMMA; Robert Alexander interview with Sheikh Shakoor, June 4, 1953, RG 18-003, International Affairs Department, Jay Lovestone Files, 1944-1973, Box 2, Alexander, Robert, 1953, GMMA; Leo E. Eliazer, Regional Organizer of ORIT in the Caribbean Areas, "Report on British Guiana," RG-18, International Affairs Department, Staff Files: George Delaney's Files, 1921-1957, ORIT Executive Board Meetings, 1951-1953, GMMA; Dr. Cheddi Jagan, "Grant to Trades Union Council: Wednesday, November 9, 1949," Dabydeen and Macedo, Dr. Cheddi Jagan National Assembly Speeches, Volume 1, 126-129; Dr. Cheddi Jagan, "Miscellaneous: March 8, 1950," Dabydeen and Macedo, Dr. Cheddi Jagan National Assembly Speeches, Volume 1, 183-184.

${ }^{67}$ Report of the 81st Annual Trades Union Congress, September 5-9, 1949, 140-141, 146-147, TUC History Online, http://www.unionhistory.info/britainatwork/emuweb/objects/nofdigi/tuc/imagedisplay.php?irn=6012016\&reftable=e catalogue\&refirn=6012196, Last Accessed July 12, 2015; Report of the 82nd Annual Trades Union Congress, September 4-8, 1950, 154-155, TUC History Online, http://www.unionhistory.info/britainatwork/emuweb/objects/nofdigi/tuc/imagedisplay.php?irn=6012322\&reftable=e catalogue \&refirn=6012524, Last Accessed July 12, 2015.

${ }^{68}$ W.H. Ingrams to J.H. Peck, "Propaganda and Special Operations in British Guiana," July 13, 1953, CO 1027-14, BNA; Robert Alexander, "What's Wrong with US Policy in Latin America," undated, RG 18-003, International Affairs Department, Jay Lovestone Files, 1944-1973, Alexander, Robert, 1953, GMMA; Robert Alexander interview with Sheikh Shakoor, June 4, 1953, RG 18-003, International Affairs Department, Jay Lovestone Files, 1944-1973, Box 2, Alexander, Robert, 1953, GMMA.

${ }^{69}$ Address by Richard A. Ishmael, General President of the Manpower Citizens' Association, and Delegate to the III Regional Congress of ORIT, April 13-17, 1955, RG 18: International Affairs Department, Staff Files: George Delaney's Files, 1921-1957, Box 11, ORIT 3rd Congress, 1955, GMMA.
} 
transnational organizations as a way to strengthen their movements based on the type of postcolonial society they hoped to establish.

\section{The People's Progressive Party's Political Objectives}

The juxtaposition of Jagan's depiction of PPP ideas with contemporaries' accounts and newly available primary sources suggests that the party acted independently of external forces while using institutional challenges to pursue Soviet-modeled socialist development and integration into the Eastern-bloc. Crucially, most of the core PPP leaders defined themselves as Marxist-Leninists who, though not subordinate to the Soviet Union, interpreted their anticolonial struggle as part of a broader socialist revolution and who hoped to increase affiliation with other socialist or communist countries as a means of achieving economic independence, development, and modernization. As Colin Palmer argues, describing PPP leaders as "'Russian puppets' constitutes a gross misunderstanding of their nationalist aspirations" and a "failure to accord independence of thought and will to colonial subjects;" however, dismissing the extent to which as nationalists they consciously hoped to participate in and integrate with an international socialist movement is to dismiss their aspirations too easily as well. ${ }^{70}$

PPP leaders explained their central objective as improving the lives of Guiana's impoverished population through socialist development and a subsequent change from the colony's position as raw material exporter in the international capitalist system. ${ }^{71}$ Cheddi Jagan

\footnotetext{
${ }^{70}$ Palmer, Cheddi Jagan and the Politics of Power, 25. Despres, Cultural Pluralism and Nationalist Politics in British Guiana, 185-186.

${ }^{71}$ A 1963 PPP pamphlet explained, "The whole reason of being, for the PPP was to lift the living standards of the many," and reaffirmed the Party's commitment to economic emancipation "through a dynamic policy of Socialism." "History of the PPP," January 1963, CJRC. See also: Cheddi Jagan, "Bitter Sugar," (B's Printing Service: Georgetown, 1954), CJRC; Ragbeer, 302. John Darwin argues that conceptually decolonization is most accurately understood as "the break-up or dismantling of... a 'globalized' system of imperial domination centered upon Europe" and that part of that system was a "division of labor between commodity-producing colonials and their industrialized masters." Darwin notes that Soviet-style planning was widely viewed in former colonial areas as the quickest route to economic development and a break from informal economic colonialism. See: John Darwin, "Diplomacy and Decolonization," in, Kent Fedorowich and Martin Thomas, eds., International Diplomacy and
} 
argued that the transition toward political independence was a means of achieving economic autonomy and the ability to marshal capital toward development and industrialization in the interest of Guianese workers rather than as an end in itself. ${ }^{72}$ In addition to giving the Guianese greater control over their own resources, Jagan argued that local investment in industry and diversification of the economy would help the Guianese avoid repercussions emanating from the negative effects of economic cycles in North America. ${ }^{73}$ The PPP's explanation of economic autonomy conflicted with Colonial Office analyses regarding the extension of self-government in the West Indies. A Colonial Office committee debating the possible federation of Caribbean territories in 1949 noted that colonies' dependence on private assistance restricted autonomy as much as governmental loans. However, the report emphasized the usefulness of private investment and concluded that "the way to political independence [was], in short through economic stability and solvency" but not "economic self-sufficiency.",74

Cheddi Jagan acknowledged that industrializing and diversifying the Guianese economy required significant foreign capital investments; however, he feared that Anglo-American financing in the Western Hemisphere during the 1950s would limit development while interest

Colonial Retreat (London: Frank Cass, 2001), 6, 21. The PPP program in British Guiana is most effectively understood in the context of Darwin's explanation.

${ }^{72}$ British Guiana Government Information Services, Guiana Diary, "Dr. Jagan Explains PPP Policy to T.U.C., November 7-13, 1960; “Radio Debate on B.G.'s 'Economic Realities," January 1-8, 1961, F2384, British Guiana, Guiana Diary, 1957to 1962, TUCLC. A. John Cope to Department of State, October 30, 1957, British Guiana: U.S. Consulate, Georgetown, General Records, 1957-1963, Box 47, Record of the Foreign Service Posts of the Department of State, RG 84, NARA II; London Press Conference, October 22, 1953, CJRC; Janet Jagan, “A May Day Review of New Labor Laws," Thunder, May 10, 1958, CJRC. Jagan specifically criticized the John F. Kennedy's Alliance for Progress programs for inhibiting the creation of balanced agricultural-industrial economies in the region. See: Cheddi Jagan, "Straight Talk-Alliance for Progress," Thunder, 1967, CJRC.

${ }^{73}$ Interview with Cheddi Jagan for La Esfera, August 21, 1957, FO 371-126078, BNA; Industrial Newsletter No.1, January 31, 1958, HC 157A-BSS: Economic Conditions, Falkland Islands and Various Countries, TUCLC; Dr. Cheddi Jagan, "Motion on Timber Concessions to Cuba," November 4, 1960, in David Dabydeen and Lynne Macedo, eds., Dr. Cheddi Jagan National Assembly Speeches, Volume 3: The Legislative Council and the Senate: February 1959-July 1961 (Published by the Caribbean Press for the Government of Guyana, 2011), 94-95.

74 "[Federation]: draft introduction by C Y Carstairs to the report of the Standing Close Association Committee on the arguments in favor of federation," June 21, 1949, CO 318/487/2, no 1, BDEEP. 
on loans would accrue to the extent that incoming assistance only served to pay off older debts. ${ }^{75}$

In a speech before the Legislative Council in 1952 he argued that external investors sought to use the colonies as sources of cheap labor while draining them of raw materials. Jagan insisted that the WFTU opposed the perpetuation of indirect forms of exploitation and should be considered a possible ally in Guiana's struggle to end colonial exploitation, suggesting one of the reasons leftwing PPP leaders pursued relations with the communist-dominated international labor organization. ${ }^{76}$ J.P. Lachmansingh, the GIWU President and member of the PPP executive committee, agreed that his union sympathized with the Eastern-bloc international as a result of the WFTU's activities supporting agricultural workers. ${ }^{77}$ Furthermore, Jagan argued that private foreign control of disbursement would direct funds in the interest of investors' profits rather than leaving the Guianese "free to put it, after we have been scientifically advised how to spend it, on the sectors which will generate wealth more rapidly" and end dependence on external funding. ${ }^{78}$ Thus, PAC/PPP leaders and the overwhelming majority of the Guianese Left expressed concern

\footnotetext{
${ }^{75}$ It is significant that the British government was increasingly unable to finance development throughout the 1950s and issued a White Paper in 1957 after a meeting of Commonwealth Prime Ministers emphasizing colonies' need to accumulate capital through domestic savings and resources or through foreign private investment. Between 1958 and 1961 the British government increasingly viewed financing from the United States and international lending agencies as the most effective source of funding for underdeveloped Commonwealth or colonial areas. See: D.J. Morgan, The Official History of Colonial Development, Vol. 3: A Reassessment of British Aid Policy, 1951-1965 (Atlantic Highlands, NJ: Humanities Press, 1980), 13-17. Moreover, Cheddi Jagan appealed for Marshall Plan aid in the early 1950s before it became clear that United States grant money was not available in the Western Hemisphere in the same way as Western Europe or parts of Asia. For Jagan's proposal, see: Dr. Cheddi Jagan, "Drainage and Irrigation, a Colonial Question (Motion)," undated (1952-1953), Dabydeen and Macedo, Dr. Cheddi Jagan National Assembly Speeches, Volume 2, 199-202. Robert Alexander reported in 1953 that American failure to provide a "Marshall Plan for Latin America" was one of the fundamental elements increasing regional appeals to social revolution, particularly since Latin Americans observed United States expenditures in reconstructing Europe and Asia. See: Robert Alexander, "What's Wrong with US Policy in Latin America," undated, RG 18-003, International Affairs Department, Jay Lovestone Files, 1944-1973, Alexander, Robert, 1953, GMMA.

${ }^{76}$ Dr. Cheddi Jagan, "Ban Against Messrs. Strachan and Smith Con't," October 3, 1952, Dabydeen and Macedo, Dr. Cheddi Jagan National Assembly Speeches, Volume 2, 170.

${ }^{77}$ Robert Alexander interview with J.P. Lachmansingh, February 4, 1956, RG 18-003: International Affairs Department, Jay Lovestone Files, 1944-1973, Box 3, Alexander, Robert, 1955, GMMA.

${ }^{78}$ People's Progressive Party Manifesto Programme \& Policy, June 1957, CJRC; Transcript of Cheddi Jagan's Meet the Press interview, October 15, 1961, CJRC.
} 
that political independence without structural reorientation to strengthen working-class influence on political-economic issues would lead to dependence on the British and American economies.

Jagan's ultimate objective, then, was political independence as a means of achieving the economic autonomy and diversification that he expected would break sugar's hold on the economy and allow resources to be used for the benefit of the Guianese people through a program of socialization. ${ }^{79}$ Despite internal disagreements on ideological and foreign policy issues, PPP leaders agreed on the importance of ending foreign domination of the Guianese economy. Even Jai Narine Singh, who along with Lachmansingh and Burnham was most responsible for dividing the PPP in 1955 over ideological disagreements, suggested in his autobiography that he viewed independence as a means of achieving a program of nationalization. ${ }^{80}$ In speaking with Alexander in 1953, Lachmansingh discussed the need for nationalization of some industries as a necessary precursor to development. He argued that the PPP government elected in 1953 would eventually take over public utilities, which would put them in a position to "push electricity out into the countryside, where there is none now" because private companies would lose money in providing services to rural areas. ${ }^{81}$ Thus, Singh and

\footnotetext{
${ }^{79}$ Cheddi Jagan, “Bitter Sugar,” CJRC; Janet Jagan, “British Guiana: Our Victory,” Labour Monthly, October 1961, CJRC; "History of the PPP," January 1963, CJRC; British Guiana Government Information Services, Guiana Diary, "Dr. Jagan Explains PPP Policy to T.U.C., November 7-13, 1960; "Radio Debate on B.G.'s 'Economic Realities,"” January 1-8, 1961; F2384, British Guiana, Guiana Diary, 1957 to 1962, TUCLC. Nigel Bolland and Clive Thomas also argue that the struggle for political independence was closely connected to attempts to alter economic relationships, what Bolland calls the "colonial division of labor." See: Bolland, The Politics of Labour in the British Caribbean, 514; Clive Y. Thomas, The Rise of the Authoritarian State in Peripheral Societies (New York: Monthly Review Press, 1984), 44.

${ }^{80}$ In addition to explaining his support and the PPP's logic for nationalization in the early 1950s, Singh defended the nationalization of bauxite in the 1970s. Significantly, Singh suggested that the nature of international capitalism, specifically the domination of bauxite markets by the Alcoa-Alcan corporation based in the United States, made it impossible for "almost any other country except China, the Soviet Union, and its satellites" to nationalize the bauxite industry. It is important to note that Singh wrote his story in the waning years of the Cold War and his work was published in 1996. Singh's criticism of the Jagan-faction of the PPP was based largely on their support for increased relations with the Soviet Union. See: Singh, Guyana: Democracy Betrayed, 160-164.

${ }^{81}$ Robert Alexander interview with J.P. Latchmansingh, June 4, 1953, RG 18-003, International Affairs Department, Jay Lovestone Files, 1944-1973, Alexander, Robert, 1953, GMMA.
} 
Lachmansingh joined with PAC's left wing in the late 1940s giving the PPP a strong trade union association when the party formed in 1950 .

However, Lachmansingh and Singh's political philosophies fell in between the reformist elements in the MPCA and the left-wing of the PPP. Those leaders sought a form of independence that included significant reforms in Guianese society and a degree of socialism that stopped short of social revolution and preserved rather than reoriented the colony's external connections. Lachmansingh founded the GIWU and, along with Singh, was an early member of the PPP and minister in the PPP government in 1953. Their split from the PPP, seemingly based on disagreements over the structure of post-colonial Guyanese society and the PPP's foreign relations, was a signal event in the internal conflict over the idea of institutional decolonization. ${ }^{82}$ Similarly, Richard Ishmael briefly joined the left-coalition in the early 1950s as member of the PPP but left the party and joined MPCA when he thought the colony was in danger of too significant a break from traditional British political-economic institutions and of falling into too close an association with Eastern Bloc nations. ${ }^{83}$

Moreover, the PAC/PPP philosophy starkly conflicted with the AFL/AFL-CIO and ICFTU policy that "government participates in improving the standard of living and safeguarding working conditions, with private enterprise remaining the chief mode for operating

\footnotetext{
${ }^{82}$ Robert Alexander interview with J.P. Lachmansingh, February 4, 1956, RG 18-003: International Affairs Department, Jay Lovestone Files, 1944-1973, Box 3, Alexander, Robert, 1955, GMMA; Singh, Guyana. Explaining the motives that drove Lachmansingh, and especially Singh, to split from the PPP is a highly contentious endeavor among Guianese who lived through the period. Some saw the split as a betrayal of the PPP based on competing personal ambitions while others suggest that it was based on a sincere disagreement over Guyana's future politicaleconomic and international orientation. See: Birbalsingh, The People's Progressive Party of Guyana 1950-1992.

${ }^{83}$ BRITISH NA DOC. Personal political ambition was clearly important as well; however, this dissertation assumes that such rivalry is inherently present in politics and while important, was not the definitive factor in Guianese politics during decolonization prior to Forbes Burnham's assumption of power in December 1964. Moreover, contemporary accounts of Guianese politicians generated by British and American officials are of limited use in disentangling such questions since they are occasionally clouded with speculative rumors and at times coded racist analysis.
} 
industry and business.” ${ }^{\circledR 4}$ Thus, Anglo-American trade union leaders opposed the political objectives of nationalist leaders who bridged political and industrial activity in addition to objecting to the relationship between the PPP's trade union ideas.

Though Marxist-inspired, much of the PAC's and PPP's economic nationalism resembled that of numerous regional political leaders during the era. Historian Michael Adamson argues that most Latin American countries pursued policies designed "to restructure their economies away from commodity production and mineral extraction that exposed them to external corporate decision making and global financial shocks" after $1945 .{ }^{85}$ United States policymakers and businessmen inconsistently responded to appeals for industrial development in the Third World during President Dwight Eisenhower's administration when American and British development assistance to British Guiana peaked. Eisenhower generally continued the policies outlined in the Truman administration's Hoover Commission Report, for example, which argued against promoting industrial development in the developing world, despite disagreement from Secretary of State John Foster Dulles. ${ }^{86}$ The American National Association of Manufacturers and CIO also opposed promoting industrialization in underdeveloped countries in hearings before the Eisenhower Administration's Commission on Foreign Economic Policy. ${ }^{87}$

\footnotetext{
84 “International Confederation of Free Trade Unions: Its Organization, Objectives, Ideology and Structure," May 2, 1950, Office of the President-Meany (1948-1960), Box 49, Formation, 1949-1950, GMMA.

${ }^{85}$ Michael R. Adamson, “'The Most Important Single Aspect of Our Foreign Policy”?: The Eisenhower Administration, Foreign Aid, and the Third World," in Kathryn C. Statler and Andrew L. Johns, eds., The Eisenhower Administration, the Third World, and the Globalization of the Cold War (Lanham, MD: Rowman \& Littlefield Publishers, Inc., 2006), 55.

${ }^{86}$ John Foster Dulles Memorandum of Conversation with Mr. Stassen, June 7, 1955, Memos of ConversationGeneral-S (3), John Foster Dulles Papers, 1951-59, General Correspondence and Memoranda Series, Box 1, DDEL. ${ }^{87}$ Statement by Henning W. Prentis, Jr., Past President of the National Association of Manufacturers and Chairman of its International Relations Committee, Before the Commission on Foreign Economic Policy, October 29, 1953, Hearings, Nat'l Assn. of Manufacturers 10/29/53; Statement Before the Commission on Foreign Economic Policy, Presented on Behalf of the Congress of Industrial Organizations, by Stanley H. Ruttenberg, Director, Department of Education and Research, CIO, October 28, 1953, Hearings-Cong. Of Indus. Org. Stanley H. Ruttenberg, Dir. Dept. of Edu. \& Research-10/28/53; Commission on Foreign Economic Policy: Records, 1953-1954 (Randall Commission), Transcript of Hearings-11/19/53 (copy 2), Box 10, DDEL.
} 
American lack of support for industrial development in the underdeveloped world reinforced Jagan's preconceptions about Anglo-American economic imperatives. William Maddox, the United States Consul in Trinidad, held responsibility for British Guiana after the State Department controversially closed the American consulate in Guiana in early 1953 as a cost-saving measure. Maddox reported to the State Department on Jagan's criticism of a British development plan for British Guiana in 1954. Jagan argued that the plan attempted to "facilitate imperialist "looting of our raw materials." Most importantly, Jagan argued that the proposal did not discuss industrialization and the repayment of interest necessitated the expenditure of funds that diverted financing from development. Ultimately, Jagan argued that political independence was a "mirage" unless coupled with economic emancipation. Reiterating that autonomy required economic independence that went beyond self-government, Jagan suggested that "Colonial leaders like myself are now increasingly aware that it is possible for an imperialist power to carry on the imperialist control and exploitation of an underdeveloped country without appearing to retain control by constitutional form or by making the territory into a direct and formal colony. $" 88$

Broadly then, the PPP's left- wing pursued a policy designed to limit integration into the global capitalist system and to integrate with socialist countries as a means of increasing their relative economic power. ${ }^{89}$ As early as 1952 Jagan criticized British economic planners for "thinking only in one direction" and failing to consider the possibilities of trade while "markets [were] available in the socialist sector of the world," arguing that "unless we can rearrange the

\footnotetext{
88 "Address by the Honourable Dr. Cheddi Jagan, Premier of British Guiana to the Great Neck Forum," November, 1961, CJRC. Jagan specifically accused Guianese trade unions of perpetuating colonial dependency on a sugar economy and economic imperialism in a speech to the Legislative Council in 1951. See: Dr. Cheddi Jagan, "UKCuba Trade Pact," 1951, Dabydeen and Macedo, Dr. Cheddi Jagan National Assembly Speeches, Volume 1, 333337.

${ }^{89}$ Cheddi Jagan, "Straight Talk: The Ideological Struggle,” Thunder, March, 1957, CJRC.
} 
economy of this Colony and unless we can disturb consciously its present economic fabric, we will never be able to control and make the progress we want." 90 Over time the PPP's left- wing leaders aimed for integration into what Cheddi Jagan referred to as a socialist world system that he suggested in early 1961 "is today challenging capitalism on a world front surpassing it in certain fields. ${ }^{91}$ Expanded trade with the socialist world, however, directly conflicted with American objectives articulated in National Security Council (NSC) document 162/2, which formed the basis of the Eisenhower administration's national security strategy. The NSC argued that limited integration into the American-led capitalist system on the part of colonial or underdeveloped areas directly threatened the system itself and undermined United States national security. ${ }^{92}$ Moreover, the NSC expressed considerable concern at the possibility of expanded trade of strategic materials, such as bauxite, with the Soviet-bloc. ${ }^{93}$ The PPP's access to free trade would have included increased economic arrangements with the Soviet-bloc and as a result directly conflicted with United States national security objectives.

Beyond trading with Eastern-bloc countries, the PPP's left- wing expressed a desire to incorporate aspects of Soviet development plans in British Guiana. In an interview with Robert Alexander, Jagan quoted from a United Nations study suggesting that planned economies, such as in the Soviet Union, were developing faster than undeveloped societies or capitalist

\footnotetext{
${ }^{90}$ Dr. Cheddi Jagan, "Legislative Council (Elections Amendment),” January 23, 1952, Dabydeen and Macedo, Dr. Cheddi Jagan National Assembly Speeches, Volume 2, 31-43.

${ }^{91}$ Cheddi Jagan, "Seizure of Private Property, Savings: What is the Position?" Thunder, April 29, 1961, CJRC. Jagan's argument for integration into the socialist world included social institutions in addition to economic relationships. In February 1961 he argued for closer relations between Guianese youth movements and socialist international youth organizations. Specifically, he cited Cuba as a "classic example of economic independence." See: British Guiana Government Information Services, Guiana Diary, "Youth Called on to join Struggle," February 13-19, 1961, F2384, British Guiana, Guiana Diary, 1957to 1962, TUCLC.

92 "Note by the Executive Secretary to the National Security Council on Basic National Security Policy, NSC 162/2," October 30, 1953, Foreign Relations of the United States, 1952-1954 (Hereafter: FRUS), 1952-1954, Volume XIX, National Security Affairs, Part 1, eds., Lislie A. Rose and Neal H. Peterson (Washington D.C.: Government Printing Office), 577.

${ }^{93}$ Memorandum of Discussion at the 188th Meeting of the National Security Council, March 11, 1954, 188th Meeting of the NSC, March 11, 1954, Dwight D. Eisenhower Papers as President, 1953-61 (Ann Whitman File) NSC Series, Box 5, DDEL.
} 
democracies. ${ }^{94}$ Jagan explained that he opposed foreign exploitation of the country's resources and wished to grow the Guianese economy with internally generated capital. ${ }^{95}$ Consequently, the PPP established closer relations with the WFTU and pursued connections with the Eastern-bloc to assist in the pursuit of socialist development. ${ }^{96}$ On this issue as well, Jagan found the WFTU a strong ideological ally. Perry Mars notes in his essay "Ethno-Politics and the Caribbean Working-Class Project" that the Caribbean movement in which Jagan was a central figure assumed that "successful power struggles are facilitated by international class solidarity through the development of close links with like-minded trade union and political movements abroad."97 Everett Kassalow, Deputy Director of the Office of Labor Affairs for the Foreign Operations Administration (FOA) and a historian, argues that in European territories colonial capital tended to "predominate in [the] major industrial and agricultural ventures," resulting in "the union movement tak[ing] on a kind of anti-foreign, political character as well as an economic one.” Kassalow noted that "even 'routine' economic action against a corporation which is controlled by foreign or colonial capital inevitably has political overtones."98 The PAC and PPP formed as a result of labor struggles becoming politicized when the groups' leaders concluded that industrial action alone insufficiently addressed Guianese poverty. The inability to effectively engage in routine economic action increased Guianese support for the politicization

\footnotetext{
${ }^{94}$ Jagan reiterated his interest in learning how Soviet development might benefit British Guiana and his opposition to free enterprise on Meet the Press in 1961. See: Transcript of Meet the Press, October 15, 1961, CJRC. Wilfried Loth notes that Soviet Union's rapid industrialization and reconstruction stood in contrast to less effective responses to the Great Depression in Western liberal democracies and impressed many observers. In that sense, Jagan's . See: Wilfried Loth, "The Cold War and the social and economic history of the twentieth century," in Melvyn P. Leffler and Odd Arne Westad, eds., The Cambridge History of the Cold War, Volume II: Crises and Détente (Cambridge, MA: Cambridge University Press, 2010), 514.

${ }^{95}$ Robert Alexander interview with Cheddi Jagan, June 5, 1953, RG 18-003, International Affairs Department, Jay Lovestone Files, 1944-1973, Box 2, Alexander, Robert, 1953, GMMA.

${ }^{96}$ The pursuit of financial assistance for development projects also led to close ties with Eastern Bloc nations. History of the PPP," January 1963, CJRC.

${ }_{97}$ Perry Mars, "Ethno-Politics and the Caribbean Working-Class Project: Contributions of Cheddi Jagan and Michael Manley," in Perry Mars and Alma H. Young, eds., Caribbean Labor and Politics, 145.

${ }^{98}$ Everett M. Kassalow, ed., National Labor Movements in the Postwar World (Evanston, IL: Northwestern University Press, 1963), 233.
} 
of labor struggles, particularly when the PAC took the lead in organizing workers in the wake of the violent British response to sugar workers strikes in 1948. Similarly, historian Arnold Steinbach notes that many colonial unionists appealed to the WFTU in part because the affiliated countries, including Communists in the Soviet Union, seemed to appreciate the complex agricultural problems facing their societies more so than unionists in the United States and Great Britain. ${ }^{99}$ Along those lines Jagan noted in an interview with Robert Alexander that British Guiana's first economic priority was agricultural development and the need to break the stranglehold sugar held over the colony. ${ }^{100}$ Therefore, Jagan's appeal to socialism and Sovietstyle development was typical of a wide variety of postcolonial leaders who noted that the Soviet Union industrialized within a generation. ${ }^{101}$

Cheddi Jagan's political-economic ideas were most concisely articulated during a visit to the United States, Canada, and Puerto Rico in 1961. In recounting the trip, Jagan noted that he "stated frankly everywhere that my Government was dedicated to the carrying out of a socialist policy." Clarifying, Jagan stated that he favored "the workers reaping the full fruits of their labor through public ownership of the means of production, distribution and exchange" and that only planning on that basis could rapidly modernize the economy and provide the Guianese people with higher standards of living. Despite temporary circumstances, Jagan noted that, "I believe ideally in the nationalization of all the important means of production, distribution and

\footnotetext{
${ }^{99}$ Arnold L. Steinbach, "Changing Concepts and Practices in the International Labor Movement," in Everett M. Kassalow, ed., National Labor Movements in the Postwar World (Evanston, IL: Northwestern University Press, 1963), 46-47. Steinbach's interpretation is particularly useful because he was familiar with conflicts between Guianese unionists. Steinbach was working for the Department of Labor when he met Rupert Tello in December 1956 during Tello’s International Cooperation Administration-funded visit to Washington D.C. See: International Cooperation Administration, Program and Itinerary: British Guiana-Labor Union Organization and Practices, December 1956, CO 859-1150, BNA.

${ }^{100}$ Robert Alexander interview with Cheddi Jagan, June 5, 1953, RG 18-003, International Affairs Department, Jay Lovestone Files, 1944-1973, Alexander, Robert, 1953, GMMA.

${ }^{101}$ Adamson, “"The Most Important Single Aspect of Our Foreign Policy’?," 56; Robert J. McMahon, "Introduction: The Challenge of the Third World," in Peter L. Hahn and Mary Ann Heiss, Empire and Revolution: The United States and the Third World Since 1945 (Columbus: Ohio State University Press, 2001), 7.
} 
exchange." He directly acknowledged that "we differed from the nations of North America in the way we propose to organize our economic life" while noting that given the colony's dire situation, industrialization necessarily would be "tied to export markets previously explored and secured."

In British Guiana a lack of local capital made external financing for diversification of the economy and industrialization necessary precursors to development. At the same time, institutional development required training and external financial assistance. Jagan consistently stated that he would "seek aid from all possible sources;" however, he was adamant that he would "not accept any aid upon conditions which limit the sovereignty of my people."103 Therefore, the activists who sought to restructure Guianese society and modernize their economy in a manner inconsistent with Anglo-American aims could only do so by developing connections outside the capitalist world. ${ }^{104}$ Still, PPP leaders argued that they did not want to sever political relations with Great Britain after independence and would cooperate with the United States. They argued that their objective was a reorientation of political and economic power that included incorporation into Western political institutions such as the British Commonwealth of

\footnotetext{
102 Cheddi Jagan, "Report by the Premier on the Mission to the United States, Canada, and Puerto Rico, October, 1961," History of British Guiana, Guiana Diary 1957-July to 1962-Jan, F2384, TUCLC; Chase, A History of Trade Unionism in Guyana, 178. Interestingly, in explaining the PPP's rationale for support of social revolution, Chase refers to an argument articulated by Forbes Burnham, who with support from the United States and Great Britain became the authoritarian leader of Guyana. See also: Mawby, Ordering Independence, 82, 201.

${ }^{103}$ Cheddi Jagan, "Report by the Premier on the Mission to the United States, Canada, and Puerto Rico, October, 1961," History of British Guiana, Guiana Diary 1957-July to 1962-Jan, F2384, TUCLC.

${ }^{104}$ Cheddi Jagan directly acknowledged his interest in acquiring knowledge of how the Soviet Union established and operated its planned economy in a 1961 Meet the Press interview. His position was that American capitalist development was not relevant to circumstances in British Guiana in 1961. See: Transcript of Cheddi Jagan's Meet the Press interview, October 15, 1961, CJRC. Wilfried Loth notes that Soviet Union's rapid industrialization and reconstruction stood in contrast to less effective responses to the Great Depression in Western liberal democracies and encouraged many observers to consider the merits of planned economies. Moreover, Loth suggests that anticolonial struggles frequently appealed to a Leninist variant of Marxism. See: Loth, "The Cold War and the social and economic history of the twentieth century," 514-515. See also: Ragbeer, The Indelible Red Stain, $262-263$.
} 
Nations and the Organization of American States (OAS) while allowing state-to-state relations to be based on equality and, as Janet Jagan put it: "to our mutual advantage and benefit."105

Nonetheless, the argument for continued political association with capitalist countries did not suggest integration into the capitalist economic system. PPP leaders also aimed to increase their economic, political, and social connections with communist nations abroad to assist in their objective of non-violent, democratically driven social revolution. ${ }^{106}$ Cheddi Jagan hinted that the PPP thought social revolution and integration with the Eastern-bloc could allow for continued relations with Great Britain and the United States. In a 1952 Legislative Council debate Jagan suggested that it was possible to support "the peaceful coexistence of the capitalist and socialist systems of economy." He argued that his Guianese opponents misunderstood revolution, suggesting that "there are such things as social revolution as people's ideas change." His opponents in the Legislature, he argued, did "not want the people of this Colony to change their ideas at all." Conservatives wanted to "keep the millstone of capitalist ideas tied around their necks as long as they live." ${ }^{107}$ Ultimately, a political and international reorientation required redefining the role of trade unions and other social institutions in British Guiana so that they could act in support of a socialist system rather than as a moderating influence in an AngloAmerican capitalist system. ${ }^{108}$ In British Guiana, the Cold War and decolonization merged in a

\footnotetext{
105 Janet Jagan, "Comments on the Political Situation," Thunder, November 4, 1961, CJRC; Transcript of Cheddi Jagan's Meet the Press interview, October 15, 1961, CJRC.

${ }^{106}$ PPP literature emphasized the Party's internationalism as a key characteristic of its policies and a reason for its success. See: "History of the PPP," CJRC.

${ }^{107}$ Dr. Cheddi Jagan, "Prohibition of Subversive Literature," March 13, 1952, Dabydeen and Macedo, Dr. Cheddi Jagan National Assembly Speeches, Volume 2, 51-52, 59. For a similarly articulated argument in 1960 that places British Guiana in the context of revolutionary international and socialist forces, see: Dr. Cheddi Jagan, "Motion on Timber Concessions to Cuba," November 4, 1960, Dabydeen and Macedo, Dr. Cheddi Jagan National Assembly Speeches, Volume 3, 92-102.

${ }^{108}$ Jagan's view of trade unions' role directly conflicted with ORIT's purpose as stated in its constitution to defend trade unions against subjugation by anti-labor forces. While the PPP did not appear to be anti-labor, the subordination of trade unions directly conflicted with Western trade union practices. See: Inter-American Regional Organization of Workers of the International Confederation of Free Trade Unions, "Constitution," RG 18-009, International Affairs Department, Staff Files: Serafino Romualdi’s Files, 1945-1961, Box 7, Miscellaneous, 1955 -
} 
direct way. Combining socialist nationalization of the economy's commanding heights with institutional reorientation, the left-wing PAC and PPP leaders argued, would facilitate a peaceful social revolution.

\section{Conclusion}

Left-wing PAC and PPP leaders consistently advocated a peaceful progression toward social revolution and a commitment to political democracy between 1946 and 1964 while retaining more popular support than domestic opposition. It is critical to note that PPP leaders did not attempt to subvert the Parliamentary Constitutional process or undermine political democracy when in office in 1953 or between 1957 and 1964. For several months in 1964 the PPP acted outside of democratic institutions and used political violence in an attempt to stay in power after Anglo-American intervention combined with domestic opposition to remove the party from office. ${ }^{109}$ Excepting 1964, however, and despite evidence that the party prepared for a campaign of subversion, PPP leaders generally did not act to undermine democratic principles in Guiana. At the same time, Cheddi Jagan advocated leaving avenues open to private investment if government did not have enough capital to effectively pursue development as long as the Guianese could avoid having "foreign individuals coming here today who will take away

1956, GMMA. Jagan articulated a similar concept in a 1976 address wherein he explained the role of trade unions and democratic centralism in support of scientific socialism. It cannot be assumed that Jagan held identical views twenty years earlier; however, the general ideas articulated in his 1976 address are consistent with his earlier writings and the role he proscribed for trade unions is consistent with PPP relations with organized labor between 1950 and 1965. See: "Trade Unions and National Liberation," An address by Dr. Cheddi Jagan to the Second Triennial National Convention of the National Union of Government \& Federated Workers, October 15, 1976, CJRC. Furthermore, Jagan listed four personal qualifications when he first ran for legislative council in 1947, the second being, "Thorough knowledge of the theory and practice of comparative governments with special emphasis on labor legislation." See: Chase, A History of Trade Unionism in Guyana 1900 to 1961, 125.

${ }^{109}$ On the PPP's attempt to use trade unions as tools of subversion in 1964, see: Waters and Daniels, "Striking for Freedom?" 537-569. Despite expressing admiration for the Cuban Revolution, Janet Jagan promised the people of Guiana that the PPP would not follow Castro's footsteps and would hold regular, free elections. See: British Guiana Government Information Services, Guiana Diary, "PPP Believes in Free Elections," April 24-30, 1961, F2384, British Guiana, Guiana Diary, 1957to 1962, TUCLC. 
salaries, pensions and everything else including profits in the long run." 110 Thus, there is evidence that the PPP intended to pursue peaceful co-existence with the Western-bloc. Nonetheless, the left-wing of the PAC and PPP consistently suggested that compromise on the nature of Guianese society was temporary and they articulated a belief in Marxist-Leninist theory and support for communist development. ${ }^{111}$

Jagan's frank connection of socialism to communism in the 1953 Legislative Council debate is significant. His position does not suggest that he intended to impose communism on British Guiana but that he expected a form of it to evolve from the PPP's establishment of socialism. ${ }^{112}$ As a result, left-wing PAC and PPP leaders attempted to institutionally reorganize the colony to lay the foundations of socialism and a progression toward communist development. Even though PPP leaders constantly sought economic aid from the United States and Great Britain it is far more telling that the party did not pursue institutional connections with the Western-bloc. Despite suggestions from moderate party members that they would accept aid from both the ICFTU and WFTU, for example, there is no evidence that PPP leaders attempted to associate with Western labor institutions at any point. ${ }^{113}$ Cheddi Jagan specifically dismissed the idea of cooperation with "the pro-imperialist" ICFTU or CADORIT in a 1956 speech even as he advocated a temporarily moderated political position within Guiana. ${ }^{114}$ Economic assistance

\footnotetext{
${ }^{110}$ Dr. Cheddi Jagan, “Establishment of B G Rice Development Company,” December 19, 1952, Dabydeen and Macedo, Dr. Cheddi Jagan National Assembly Speeches, Volume 2, 231, 235.

${ }^{111}$ Cheddi Jagan, Straight Talk: A Living Wage, Thunder, December 26, 1959, CJRC; Dr. Cheddi Jagan, “Undesirable Publications Bill," 1953, Dabydeen and Macedo, Dr. Cheddi Jagan National Assembly Speeches, Volume 2, 309.

112 Ashton Chase, the PPP Minister of Labor in 1953, suggested in a 1994 interview that the party attempted to move directly to communism after taking office in 1953. Significantly, Chase suggests that Jagan was not the impetus behind the accelerated push to transform British Guiana but that he nonetheless did not attempt to reign in the party's left-wing. See: Birbalsingh, 44.

113 Chase, A History of Trade Unionism in Guyana.

${ }^{114}$ Cheddi Jagan, “1956 Congress Speech,” CJRC.
} 
for development, even aid that included specific stipulations, did not hold the key to shaping the nature of Guianese society in the same way as institutional structures.

Crucially, United States national security estimates suggested using "all feasible diplomatic, political, economic, and covert measures to counter any threat of a party or individuals directly or indirectly responsive to Soviet control" to inhibit "Soviet capabilities for extending control and influence."115 Thus, the PPP's consideration of increased trade with the Eastern-bloc and Soviet-influenced development qualified as a threat to United States national security and to American policymakers offered a justification for intervention in the early 1960s. American policymakers argued that communist ideas could potentially offer an opportunity for expanded Soviet influence regardless of the relationship between the PPP and Eastern-bloc communists. Moreover, the PPP's pursuit institutional ties to Eastern-bloc international organizations such as the WFTU and efforts to restructure Guianese society complemented party leaders' attempt to expand economic relations into the socialist world. Despite the ultimate decisiveness of Anglo-American intervention, the conflict over British Guiana's institutional structures and political orientation first emerged internally.

The PAC-GIWU challenge to the MPCA and the British-imposed system of labor relations in British Guiana congealed into a left-coalition after the violence at Plantation Enmore in 1948. Available sources limit the extent to which the ideological evolution of left-coalition leaders can be traced; however, some general conclusions emerge from close examination of the existing materials. Most importantly, some of the coalition's leaders argued that challenging the colonial system's structural poverty required a fundamental change to the nature of the Guianese political-economic system and increased connections to the Eastern-bloc. The Guianese left,

\footnotetext{
115 "Note by the Executive Secretary to the National Security Council on Basic National Security Policy, NSC 162/2," October 30, 1953, FRUS, 1952-1954, Volume XIX, National Security Affairs, Part 1, eds., Lislie A. Rose and Neal H. Peterson (Washington D.C.: Government Printing Office), 577.
} 
however, disagreed on the extent to which the movement should seek a break with the Western capitalist system. Moreover, conservative labor leaders advocating reform within the existing colonial structure resisted the left-coalition and acted with the advantage of preferential placement within the colonial system. As a result, an ideological, legal, and physical conflict grounded in disagreements regarding the institutional framework for Guiana began and evolved into what the first Guianese Labor Commissioner, James Ramphal, referred to as a "persistent state of inter-union war."116

${ }^{116}$ James Ramphal, British Guiana Labor Commissioner, "Present and Future Outlook of the Trade Union Movement," June 1954, CO 859-773, BNA. 


\section{Chapter 5: The First Phase of Institutional Decolonization in British Guiana}

Cheddi Jagan's break with the Manpower Citizens' Association (MPCA) and the subsequent formation of the Political Affairs Committee (PAC) marked the beginning of a distinct period of labor conflict in British Guiana in which debates about labor relations became struggles to shape the nature of post-colonial society through institution-building. The first phase of institutional decolonization was grounded in conflicts between Guianese unionists who differed on their expectations for the structure of an autonomous society. British efforts to institutionalize capitalist labor relations exacerbated the internal struggle, as did the slow internationalization of the debate as American and international labor organizations entered the fray. The first phase of institutional decolonization in British Guiana peaked when the People's Progressive Party (PPP) sought to use its electoral victory to alter Guianese institutions and the British government forcibly removed the PPP. The British action exacerbated ideological conflicts within the PPP and initiated the disintegration of the left-coalition and the emergence of racialized politics. Guianese leaders consistently fought over influence within the labor movement, the most important political institution in British Caribbean colonial systems. ${ }^{1}$

The process of negotiation and conflict centered on establishing post-colonial political and social structures in British Guiana, what I term institutional decolonization, began in 1946 when the left-coalition PAC organized to replace the existing political-economic system in British Guiana with a Marxist state. ${ }^{2}$ The PAC challenged colonialism, capitalism, and Guianese

\footnotetext{
${ }^{1}$ Similar conflicts for control of the labor movement shaped decolonization in other parts of the British Caribbean. See: Gerald Horne, Cold War in a Hot Zone: The United States Confronts Labor and Independence Struggles in the British West Indies (Philadelphia: Temple University Press, 2007).; Perry Mars and Alma H. Young, Alma H., eds., Caribbean Labor and Politics: Legacies of Cheddi Jagan and Michael Manley (Detroit: Wayne State University Press, 2004); Jason Parker, Brother's Keeper: The United States, Race, and Empire in the British Caribbean, $1937-$ 1962 (Oxford: Oxford University Press, 2008).

${ }^{2}$ O. Nigel Bolland, The Politics of Labour in the British Caribbean: The Social Origins of Authoritarianism and Democracy in the Labour Movement (Oxford: James Currey, 2001), 602; Clem Seecharan, Sweetening 'Bitter
} 
labor and political leaders who proposed improving workers' wages and conditions within the existing system. PAC leaders used a three-pronged approach to alter the structure of institutionalized labor relations as a precursor to broader structural transformation of Guianese society. They engaged in legislative debates, undertook strike actions, and pursued international connections to the World Federation of Trade Unions (WFTU) and communist parties to generate support for their program. Reformist Guianese labor leaders, colonial officials, and British, American, and Western international trade unionists opposed the left-coalition between 1946 and 1953.

The PAC evolved into the PPP, a multi-racial left-coalition that won a resounding victory in the 1953 elections, which allowed for full internal self-government in the colony for the first time. ${ }^{3}$ The seven-year-long labor conflict erupted as the PPP used its position to alter institutionalized labor relations and met fierce resistance from colonial employers, reformist unionists, and eventually the British military. Ultimately, the period between 1946 and 1953 is best understood as the onset of a twenty-year period of conflict to determine the nature of labor relations in the colony and the institutional structure of post-colonial society.

The PPP's success resulted from its ability to forge a multiracial, left-coalition that brought the most effective Guianese leaders into a single organization designed to advance the interests of Guianese workers. The brief experiment in self-government illuminated the popular support for the PPP and the core PPP leaders' commitment to revolutionary changes in Guianese society. At the same time, the MPCA's resistance to PPP labor policies shed light on the depth of reformist opposition to social revolution. The first phase of institutional decolonization in British Guiana convinced British and American policymakers and labor leaders of the need to pursue

Sugar': Jock Campbell the Booker Reformer in British Guiana 1934-1966 (Miami: Ian Randle Publishers, 2005), 124-130.

${ }^{3}$ Seecharan, Sweetening 'Bitter Sugar', 116-130. 
institution-building as a counter to the PPP. Ultimately, British officials' swift reaction to the PPP in the summer of 1953 disillusioned Guianese leaders and exacerbated ideological schisms, racial tensions, and personal feuds within the left-coalition.

The existing scholarship on the period between 1946 and 1953 focuses primarily on the political dimensions of British intervention to re-impose direct rule in British Guiana after a brief experiment allowing the Guianese full internal self-government and universal suffrage under the Waddington Constitution from April to October 1953. Scholars agree that the PAC/PPP-led militant labor movement emerged as a political force that won support of Guianese people as a result of demands for improved wages and conditions for deeply impoverished workers. The earliest studies on the subject note the radical nature of the left-coalition's leadership and argue that the PPP's challenge to British control created a dilemma for colonial officials only willing to permit self-determination that accepted existing economic relationships.

Leo Despres points out that disagreement between Guianese leaders preceded the PPP's time in government and he suggests that the left-coalition PAC started to fracture as soon as colonial officials proposed constitutional changes in 1949. Despres argues that ideological disagreements between Marxist and non-Marxist members of the coalition struggled to maintain a unified nationalist program while differing on the nature of post-colonial Guiana. ${ }^{4}$ Basil Ince suggests that the constitution's suspension was a reaction to four pieces of legislation designed to collectively alter the nature of labor relations in the colony. Ince suggests that the PPP's challenge to British control forced colonial officials to question the bounds of expanded colonial autonomy even though three of the four bills did not pass in the legislature. Ultimately, he argues that British officials concluded that self-determination did not include permitting colonists to

\footnotetext{
${ }^{4}$ Leo A. Despres, Cultural Pluralism and Nationalist Politics in British Guiana, (Chicago: Rand McNally and Company, 1967), 179-202.
} 
pursue a political-economic system that administrators considered a betrayal of the interests of the people they were charged to govern. ${ }^{5}$

Post-Cold War scholarship emphasizes the destructive consequences of British intervention, specifically the fracturing of the nationalist movement, the rise of the authoritarian Forbes Burnham, and the long-term racial discord that continues to plague Guyana. These works are crucial in highlighting the important failures of interventionist policies; however, they disagree on the motives behind British action. Stephen Rabe argues that British policymakers in London dismissed contrary reports from colonial officials in British Guiana and intervened in response to a perceived communist threat. ${ }^{6}$ Colin Palmer, like Rabe, suggests that colonial officials overreacted to the PPP's rhetoric and the challenge to certain aspects of British control, particularly regarding labor relations, and tried to justify the intervention on baseless claims of impending communist subversion. ${ }^{7}$

Conversely, Clem Seecharan argues that the PPP's left- wing governed with the intention of undermining the Waddington Constitution because party leaders considered it a retrograde attempt to perpetuate capitalist exploitation in the colony. He specifically suggests that the PPP attempted to use the Labor Relations Bill to give the party-supported Guiana Industrial Workers Union (GIWU) the opportunity to act as the vanguard for the advancement of "scientific socialism" in the colony. ${ }^{8}$ Similarly, Robert Waters argues that British officials suspended the Waddington Constitution in response to a wide variety of circumstantial evidence and intelligence reports which together presented a strong case that the PPP intended to move toward

\footnotetext{
${ }^{5}$ Basic Ince, Decolonization and Conflict in the United Nations: Guyana's Struggle for Independence (Cambridge, MA: Schenkman Publishing Company, 1974), 38-41.

${ }^{6}$ Stephen G. Rabe, U.S. Intervention in British Guiana: A Cold War Story (Chapel Hill: The University of North Carolina Press, 2005), 31-46; Sara Abraham, Labour and the Multiracial Project in the Caribbean: Its History and Its Promise (Lanham, MD: Rowman \& Littlefield Publishers, Inc., 2007), 54-60.

${ }^{7}$ Colin Palmer, Cheddi Jagan and the Politics of Power: British Guiana's Struggle for Independence (Chapel Hill: The University of North Carolina Press, 2010), 46-61.

${ }^{8}$ Seecharan, Sweetening 'Bitter Sugar', 207-232, 556.
} 
the establishment of a communist government. ${ }^{9}$ Gerald Horne argues that British opposition to the PPP government revolved around the Guianese attempt to exercise a degree of democracy beyond what British officials accepted in colonial areas. Specifically, Horne suggests that colonial officials reacted in response to the Labor Relations Bill and introduced the defense of the intervention as necessary to counter communism in the colony after the fact. ${ }^{10}$ Spencer Mawby suggests that British officials' response was primarily aimed at the perceived radicalism of Sydney King and Janet Jagan and simultaneous fears in London of colonial anarchy rather than of communist subversion. ${ }^{11}$ While scholars disagree on the specifics of the intervention, they agree that the debate centered on labor relations.

Thorough examination of the labor struggle suggests that British institution-building before 1953 institutionalized reformist trade unions, but did not significantly improve day-to-day life for Guianese workers. In addition to Mawby's and Seecharan's studies, Nigel Bolland's work is most illuminating in placing the era in the context of a broader labor struggle in which colonial officials confronted challenges to existing labor relations through force, "limited concessions, and finally by trying to institutionalize and control the labor movement."12 However, Bolland notes that wartime price and cost-of-living increases offset minor wage gains. Moreover, he suggests that raw material extraction and cheap labor formed the basis of colonial economic systems in the British Caribbean and as a result British efforts to reform the system

\footnotetext{
${ }^{9}$ Robert Anthony Waters, Jr., "More Subtle Than We Knew: The AFL in the British Caribbean," in Robert Anthony Waters, Jr. and Geert van Goethem, American Labor's Global Ambassadors: The International History of the AFLCIO During the Cold War (New York: Palgrave Macmillan, 2013), 172. Importantly, the intelligence records Waters references were only declassified in 2009. See: Christopher Andrew, Defend the Realm: The Authorized History of MI5 (New York: Alfred A. Knopf, 2009), 459-460.

${ }^{10}$ Horne, Cold War in a Hot Zone, 181-191.

${ }^{11}$ Spencer Mawby, Ordering Independence: The End of Empire in the Anglophone Caribbean, 1947-1969 (New York: Palgrave Macmillan, 2012), 87-92.

${ }^{12}$ Bolland, The Politics of Labour in the British Caribbean, 363. See also: Bolland, The Politics of Labour in the British Caribbean, 363-365, 389-390, 392, 490-498. See also: Mawby, Ordering Independence, 30-100; Seecharan, Sweetening 'Bitter Sugar', 207-232.
} 
were insufficient. ${ }^{13}$ As a result, core PPP leaders would have democratically replaced the Manpower Citizens' Association (MPCA) and begun the transition toward peaceful social revolution absent British intervention. Moreover, the transnational trade union relationships established between 1946 and 1953 provided the basis for Anglo-American institution-building and opposition to the PPP after the Waddington Constitution's suspension.

\section{The Emergence of a left-coalition opposition}

In 1953 the left-wing of the PPP challenged the institutions that defined Guianese society, most importantly the colony's labor movement, and established connections to the socialist world in pursuit of social revolution and a reorientation of British Guiana's position in the international economic system. Specifically, the core members of the PPP wanted to use the labor movement to challenge the colony's exploitative economic relations and to establish a framework in which trade unions acted as "subsidiary agencies of a democratic character" within the PPP. ${ }^{14}$ The Jagan-led left-wing of the PPP held the strongest support of the Guianese population from the party's founding in 1950 until after independence; however, a diverse opposition to the PPP emerged based on disagreement with various aspects of the Jagans' program.

Some of the PPP's conservative detractors opposed the party's pursuit of socialism in British Guiana; however, Guianese political leaders were widely sympathetic to socialist principles. Therefore, opposition within the Guianese Left, most importantly regarding the

\footnotetext{
${ }^{13}$ Bolland, The Politics of Labour in the British Caribbean, 389-90.

${ }^{14}$ The clearest explanations of PPP trade union policy are expressed in documents produced after the time period examined in this chapter. However, PPP activities between 1950 and 1953 were consistent with the policies party leaders' later articulated. See: British Guiana Government Information Services, Guiana Diary, "Dr. Jagan Explains PPP Policy to T.U.C., November 7-13, 1960, F2384, British Guiana, Guiana Diary, 1957to 1962, Trade Union Congress Library Collections, London Metropolitan University, London, England (Hereafter TUCLC); "Trade Unions and National Liberation," An address by Dr. Cheddi Jagan to the Second Triennial National Convention of the National Union of Government \& Federated Workers, October 15, 1976, Cheddi Jagan Research Center (Hereafter: CJRC).
} 
relationship between the PPP and trade unions and the party's international orientation, was most significant in shaping internal conflicts in British Guiana during decolonization. Specifically, some members of the Guianese Left pursued social reform through activist unionism to exact benefits for impoverished Guianese workers while refusing to challenge the political-economic system. The PPP's moderate and conservative opponents established relationships with British, American, and Western international labor organizations to support their trade unions in British Guiana.

The Jagan-led movement used a three-pronged approach to challenge the nature of institutionalized labor in British Guiana between 1946 and 1953 and domestic opposition to PAC/PPP pressure ignited the conflicts central to the process of institutional decolonization.

First, PAC/PPP leaders worked with the GIWU to challenge the MPCA for the right to represent sugar workers. Colonial officials and employers in the Sugar Producers' Association (SPA) recognized the MPCA as the bargaining agent for sugar workers since 1937 and sought to alleviate poverty and worker unrest through the union in the 1940s. ${ }^{15}$ Nonetheless, extreme poverty persisted in the colony and the GIWU rapidly won grassroots support between 1946 and 1948. Second, Cheddi Jagan advocated for political changes to support the GIWU and undermine the MPCA and other British-supported trade unions after his election to the Legislative Council in 1947. Finally, the PPP's left-wing pursued international relationships with the WFTU and Eastern-bloc labor organizations to obtain support and training for their movement in British Guiana. ${ }^{16}$

\footnotetext{
${ }^{15}$ Clem Seecharan's biography of Booker Brothers Chairman and Fabian Socialist Jock Campbell is the most extensive study of Bookers' reform efforts. See: Seecharan, Sweeting 'Bitter Sugar.'”

${ }^{16}$ Jan Koura and Robert Waters, "Cheddi Jagan and Guianese Overtures to the East: Evidence from the Czech National Archives," Cold War International History Project, e-Dossier No. 54, Wilson Center, 2015; Christopher Andrew, Defend the Realm: The Authorized History of MI5 (New York: Alfred A. Knopf, 2009), 459-460.
} 
The PAC/PPP pursuit of Marxist modernization and development necessitated a break from or loosening of British Guianese ties to the capitalist world system, a separation that Jagan thought was possible if the PPP could take control of economy through legislative action and especially through party-led trade union activity. Since the MPCA and existing unions simultaneously resisted and appealed to the external capitalist system for assistance, Jagan and the PPP pushed for the establishment of new trade unions and a closer relationship between the unions and the party that could be used to reorient the economic system and establish a Guianese form of communism once the PPP attained power.

Jagan initially pursued political change as a member of the MPCA; however, he left the union in 1946 after a year as treasurer and helped establish the PAC. ${ }^{17}$ The MPCA, the largest union in British Guiana, initially lost the confidence of many sugar workers when evidence emerged in 1939 that the organization's treasurer accepted a bribe from Booker Brothers' McConnell \& Co., the privately owned British sugar company that dominated the Guianese economy. ${ }^{18}$ Most Guianese sugar workers remained skeptical of the union thereafter even though there were no proven subsequent instances of corruption. Additionally, the MPCA's collaborative bargaining techniques and cooperation with sugar employers led to charges of being a corrupt company union that ignored the workers' needs. ${ }^{19}$ Sugar producers acceded to small negotiated benefits for Guianese workers in the 1940s; however, a decline in sugar prices

\footnotetext{
${ }^{17}$ The exact date Jagan left the MPCA is unclear. Jagan suggests 1945 in his autobiography, while Ashton Chase dates the split as 1946 in his history of Guianese unionism. See: Cheddi Jagan, The West on Trial: My Fight for Guyana's Freedom (New York: International Publishers, 1967), 88; Ashton Chase, A History of Trade Unionism in Guyana 1900 to 1961, with an Epilogue to 1964 (Demerara, Guyana: New Guyana Company Ltd., 1966), 126.

${ }^{18}$ For details of Booker Brothers' influence over the Guianese economy, see: Ernst Schwarz, ed., "British Guiana: A Colonial Miniature," from Research Department of the Inter-American Regional Organization of Workers, January 1951, Vol. 1, No.1, RG-18: International Department, Serafino Romualdi Files, Box 8, Research Department, 19511953, George Meany Memorial Archives, Silver Spring, MD (Hereafter, GMMA); Leo E. Eliazer, Regional Organizer of ORIT in the Caribbean Areas, "Report on British Guiana," RG-18, International Affairs Department, Staff Files: George Delaney's Files, 1921-1957, ORIT Executive Board Meetings, 1951-1953, GMMA.; Abraham, Labour and the Multiracial Project in the Caribbean, 56.

${ }^{19}$ Seecharan, Sweetening 'Bitter Sugar', 92-93; Jagan, The West on Trial, 88-89; Chase, A History of Trade Unionism in Guyana, 90, 112.
} 
and employers' considerable power limited material improvements for workers living in dire poverty. At the same time, the part-time and seasonal nature of plantation work exacerbated the MPCA's weakness since laborers were unable to pay union dues in the offseason. Consequently, alternate sugar workers' unions were established throughout the 1940s to pursue a more militant platform; however, most of them were short-lived and financially insolvent. ${ }^{20}$

The Colonial Office Commissioner of Labor in British Guiana, William Bissell, responded to ongoing labor unrest in the 1940s with the support of the British Guiana Trades Union Council (BGTUC). Bissell advocated a policy that encouraged the growth of two craftbased sugar workers' unions that inherently contained a great degree of racial segregation strongly opposed from the Guianese Left. ${ }^{21}$ Bissell argued that the MPCA should represent the overwhelmingly East Indian plantation workers and that the British Guiana Workers League (BGWL) should bargain for the predominantly Afro-Guianese factory workers. Additionally, Bissell attempted to restrict the number of trade unions and limit their activities to industrial matters. Bissell's actions reinforced colonial officials' argument that Guianese workers could effectively negotiate with employers if they developed the necessary institutional structures. However, workers' conditions remained poor throughout the decade and competing unions proliferated. In the late 1940s at least twenty-seven trade unions claimed legitimacy, nine in the sugar industry alone, despite the colony's population reaching only about 400,000. Thus, the GIWU's challenge to the MPCA was representative of broad conflict within the labor

\footnotetext{
${ }^{20}$ Chase, A History of Trade Unionism in Guyana, 112-113.

${ }^{21}$ The Jagan-led left strongly and consistently opposed British attempts to split the Guianese sugar workers into two unions as a result of the racial divisions inherent in such a policy. See: London Press Conference, October 22, 1953, CJRC; Seecharan, Sweetening 'Bitter Sugar', 161.
} 
movement; however, the GIWU was unique in its influence and connection to the left- wing of the PAC and PPP. ${ }^{22}$

Dr. Joseph Prayal (J.P.) Lachmansingh, Amos A. Rangela, and Jane Phillips-Gay founded the GIWU in 1946, establishing a militant union that promoted itself as an alternative to the MPCA. ${ }^{23}$ Cheddi Jagan's election to the Legislative Council in 1947 corresponded with the emergence of the GIWU, and he backed the union through his seat in government. Jagan exercised considerable influence within the union despite not officially holding a position in the organization. ${ }^{24}$ In February 1948 Jagan pressed the Legislative Council to adopt a policy compelling recognition of unions with the greatest membership on plantations where multiple unions existed rather than permitting the Sugar Estates Authorities to choose the union with which they preferred to negotiate. ${ }^{25}$ His efforts directly challenged the SPA's preference of the MPCA over the GIWU on the sugar plantations.

Jagan clarified his criticism of the Labor Department's trade union policy in British Guiana in February 1948. He suggested that both employers and employees would benefit from the development of strong trade unions; however, he criticized the Labor Department's methods of supporting organized labor in British Guiana, specifically on sugar estates. Jagan argued that Bissell was "merely importing [trade union] principles from the United Kingdom and other

\footnotetext{
${ }^{22}$ Venn Commission Report, “The Development of Trade Unionism in British Guiana,” November 19, 1949, Venn Commission Recommendation: Trade Union Organizations, CO 111/797/5, British National Archives, Richmond, Kew, Surrey, UK (Hereafter, BNA). In underscoring the extent to which union proliferation divided Guianese workers, it is noteworthy that some reports suggest the labor force was only about 160,000 and the majority of the population was non-unionized. A 1953 report estimated that 20-25,000 workers in the colony were in unions, of which at that point there were 47 ; consequently, the relatively large number of unions was even more disruptive to strong organization than the report suggests. See: Ingram to Peck, July 13, 1953, CO 1027/14, BNA.

${ }^{23}$ The GIWU was formed in 1946 and registered on April 5, 1948. See: Bolland, The Politics of Labour in the British Caribbean, 607. The establishment of the PAC in 1946, Jagan's election to the Legislative Council in 1947, and the GIWU's founding contributed to a broader shift in working-class politics that congealed into the PPP-led working-class movement in 1950. See also: Seecharan, Sweetening 'Bitter Sugar', 144-145.

${ }^{24}$ Seecharan, Sweetening 'Bitter Sugar', 135-137, 144.

${ }^{25}$ Dr. Cheddi Jagan, “Estimates-Labour Department: Thursday February 26, 1948," David Dabydeen and Lynne Macedo, eds., Dr. Cheddi Jagan National Assembly Speeches, Volume 1: The Fourth Legislative Council December 1947-December 1951 (Published by the Caribbean Press for the Government of Guyana, 2011), 5.
} 
countries without at first trying to fathom the psychology and amenity background of the people of British Guiana." Jagan argued that merely adopting British trade union principles was useless in British Guiana because workers on sugar plantations were held in "a condition which is tantamount to forced labor." Furthermore, Jagan noted that sugar workers' dependence on plantation housing and persistent victimization made it impossible for Guianese workers to negotiate wages and conditions according to British trade union principles. ${ }^{26}$ Addressing the needs of sugar workers, Jagan concluded, required trade unions engaged in practices different than those adapted for the conditions of industrial workers in Great Britain at least until Guianese society was restructured. ${ }^{27}$

Jagan articulated a similar view in 1951 while serving as President of the Sawmill Workers' Union (SWU), a position he held in addition to his seat in the Legislative Council. Jagan argued in the council that an agreement between the SWU and employers in September 1949 guaranteed workers a right to renegotiate wage rates no later than March 1950; however, discussions had still not taken place by early 1951. Jagan accused Bissell of enabling employers' delaying tactics, such as rejecting union proposals while offering no counterproposals as a way to end negotiations. Employer intransigence, Jagan argued, led discontented workers to engage in civil disobedience. Jagan further suggested that the resulting social unrest was a result of failed democratic institutions since trade unions were unable to effectively protect workers in the face of powerful foreign employers. ${ }^{28}$ Ultimately, Jagan argued that the Guianese labor movement needed to be freed from its colonial framework and adjusted to circumstances in the

\footnotetext{
${ }^{26}$ Ibid, 3-4.

27 Jagan reiterated his assertion that Guiana required trade unions designed for the colony's specific circumstances in March, 1950. Dr. Cheddi Jagan, "Estimates-Labour Department: March 3, 1950,” Dabydeen and Macedo, eds., Dr. Cheddi Jagan National Assembly Speeches, Volume 1, 177-178.

${ }^{28}$ Dr. Cheddi Jagan, “Constabulary Amendment Bill: 1951," Dabydeen and Macedo, eds., Dr. Cheddi Jagan National Assembly Speeches, Volume 1, 244-246.
} 
colony. Jagan did not explain exactly what adjustment needed to be made; however, Jagan argued in a 1948 PAC Bulletin that strikes and worker unrest were inevitable in Guiana until the government took control of production and distribution. At that point, the Bulletin argued, capitalism and strikes could be simultaneously eliminated. ${ }^{29}$

The GIWU's founding and Jagan's early political career occurred within the context of significant labor resistance against the colony's two most influential companies, the Demerara Bauxite Company (Demba) and Booker Brothers. Strikes against Demba lasted from April to June 1947 and sugar workers' unrest climaxed in the fatal Enmore strike the following year. ${ }^{30}$ Ashton Chase, a Guianese lawyer whose career began as a trade unionist trained at Oxford through a TUC exchange program most effectively chronicled Guianese labor unrest in the 1940s. Chase also played a significant role in Guianese decolonization struggles as a minister in PPP governments. ${ }^{31}$ Chase suggests that tension between sugar workers and employers increased throughout the 1940s and created the conditions for GIWU inspired strikes in 1948.

The 1948 sugar strikes began in April and occurred on a number of estates in Demerara before culminating on June 16, 1948 when police shot fourteen workers, killing five, on the Enmore Plantation. Striking plantation workers protested an assortment of deep-seated grievances regarding industrial and political issues. Specifically, workers objected to working and housing conditions, changes to the cut-and-load system on sugar estates, inaccurate scales, dissatisfaction with the rules of piece work, and the conduct of rural officials. However, Chase

\footnotetext{
${ }^{29}$ Seecharan, Sweetening 'Bitter Sugar', 132.

${ }^{30}$ Chase, A History of Trade Unionism in Guyana, 126; Palmer, Cheddi Jagan and the Politics of Power, 33; Rabe, U.S. Intervention in British Guiana, 27.

${ }^{31}$ Report of the 80th Annual Trades Union Congress, September 5-9, 1948, TUC History Online, 208, http://www.unionhistory.info/britainatwork/emuweb/objects/nofdigi/tuc/imagedisplay.php?irn=6011671\&reftable=e catalogue\&refirn=6011859, Last Accessed July 13, 2015; Report of the 81st Annual Trades Union Congress, September 5-9, 1949, TUC History Online, 146-147, http://www.unionhistory.info/britainatwork/emuweb/objects/nofdigi/tuc/imagedisplay.php?irn=6011943\&reftable=e catalogue\&refirn=6011956, Last Accessed July 12, 2015.
} 
suggests that the fundamental issue at stake was recognition of the GIWU rather than the SPAbacked MPCA as sugar workers' representative. ${ }^{32}$ In addition to general suspicion that the MPCA was a company union, sugar workers objected to a recently negotiated MPCA agreement with the SPA. The MPCA-SPA compromise allowed for increased wage rates of 7- cents per ton rather than the 40- cents per ton the workers demanded, and workers doubted MPCA leaders' promise that the settlement was temporary. Furthermore, Nigel Bolland argues that the strike evolved into a broader political action critiquing the colonial administration and the capitalist economy when workers passed a resolution requesting Bissell's removal as labor commissioner. ${ }^{33}$ Colonial officials, however, concluded that the strike was primarily a consequence of "Dr. Jagan, a local communist, and other political malcontents" using the GIWU to exploit workers' grievances for political gain. ${ }^{34}$

Workers refused MPCA requests to return to work, continuing the strike with encouragement and material assistance from the Jagans, Lachmansingh, Phillips-Gay, and Rangela. Throughout the strike, the PAC distributed propaganda bulletins at GIWU meetings to encourage workers to continue their efforts against the sugar companies. Jai Narine Singh, who was a Vice President in both the BGLU and MPCA in the early 1940s, joined the Jagans in leading a funeral procession to Georgetown after the strike to protest the use of force. Singh criticized officials and walked out of the official hearings investigating the strike in protest of the committee's impartiality. He also represented some of the victims' families in court and won them compensation for their suffering. Meanwhile, Lachmansingh and the Jagans refused to

\footnotetext{
${ }^{32}$ Chase, A History of Trade Unionism in Guyana, 149-150; Seecharan, Sweetening 'Bitter Sugar', 152-156, 161.

${ }^{33}$ Bolland, The Politics of Labour in the British Caribbean, 606-607.

34 "British Guiana: Commission of Enquiry into the Sugar Industry, Brief for the Minister of State," 1949, CO 111/797/4, BNA.
} 
testify. ${ }^{35}$ The Jagans, Lachmansingh, Singh, and Phillips-Gay gained considerable support among sugar workers as a result of their efforts during and after the strike which in turn strengthened the emerging left-coalition between the GIWU and PAC. ${ }^{36}$

The wave of labor unrest in the late 1940s is most completely understood as simultaneously a form of worker resistance to external employers' exploitation and the onset of conflict between Guianese labor leaders pursuing different notions of trade unionism for an autonomous British Guiana. Evidence supports GIWU claims that employers leveraged their influence over the MPCA to limit aggressive negotiations. MPCA General Secretary Sheik Shakoor and President Richard Ishmael noted in an interview with Robert Alexander in 1954 that the SPA censored the union's periodical, Labour Advocate, pointing out that the SPA even ran advertisements criticizing the union's militancy. Ishmael also noted that SPA advertisements in the Labour Advocate financed MPCA leaders' salaries. ${ }^{37}$ At the same time, Clem Seecharan notes that Booker Brothers Chairman Jock Campbell worked from within his company to advocate gradual reforms throughout the late 1940s and early $1950 \mathrm{~s}^{38}$ Nonetheless, PAC and PPP leaders argued that reforms could not address workers needs and they pushed to establish a

\footnotetext{
${ }^{35}$ Singh, Guyana, xxiv-xxv, 29-37; Chase, A History of Trade Unionism in Guyana,149-150. Notably, Singh, who was a Senior Vice President of the MPCA during the Enmore strike, agrees with Chase that an important motive of the strikers was to gain recognition for the GIWU. He acknowledges the central role the GIWU played during and after the strike, while not discussing, either positively or negatively, the MPCA's actions at the time. Singh's account is also significant in that it fails to mention the Jagans role in the strike and funeral march, hinting at the subjectivity of some aspects of his autobiography.

${ }^{36}$ Bolland, The Politics of Labour in the British Caribbean, 608; Chase, A History of Trade Unionism in Guyana, 140-149; Jagan, The West on Trial, 108-109, Singh, Guyana, 29-37.

${ }^{37}$ Robert Alexander interview with Sheik Shakoor, June 27, 1954, RG 18-003, International Affairs Department, Jay Lovestone Files, 1944-1973, Box 2, Alexander, Robert, 1954, GMMA. Robert Alexander interview with Richard Ishmael, June 27, 1954, RG 18-003, International Affairs Department, Jay Lovestone Files, 1944-1973, Box 2, Alexander, Robert, 1954, GMMA. Sugar workers, as well as American labor leaders, criticized the financial dependence of the MPCA periodical on advertisements from Booker Brothers and other sugar producers. See: Jay Lovestone to George Meany, July 16, 1954, RG 001-027, Office of the President, George Meany (1948-1960), Box 49, Subjects: Free Trade Union Committee, 1950-1958, GMMA.

${ }^{38}$ Seecharan, Sweetening 'Bitter Sugar', 132-163.
} 
political party that could finance a party-trade union relationship independent of employers to provide leverage for workers unavailable within the existing economic framework.

GIWU leaders argued that their organization could aggressively confront the SPA since it was not under employer control and the union's militancy encouraged Bookers' officials and colonial administrators to push for reforms to counter more aggressive demands. Nonetheless, colonial officials and sugar producers refused to recognize the GIWU limiting its effectiveness. The labor struggle continued to move toward the political sphere where the left-coalition leaders hoped to use legislation to allow for changes to union representation that would supplant the MPCA since the SPA declined to recognize the GIWU. At the same time the plantation structure reinforced the mutual dependency between political and trade union leaders when some companies restricted Jagan's access to plantations where sugar workers lived several miles from public roads. ${ }^{39}$ Companies' assertion that private property laws allowed them to inhibit access to individuals effectively isolated sugar workers from their elected representatives and contributed to Jagan's conclusion that effective democratic representation for workers could only be attained through cooperation with a recognized trade union. Sugar workers interpreted the ban as corroboration of Jagan's claim to challenge sugar producers' authority on their behalf and his base of support strengthened. ${ }^{40}$

In an address to the Legislative Council in February 1949, Cheddi Jagan bitterly criticized the British response to the previous year's labor violence and his attack illuminates his increasingly strong conclusion that Guianese unions needed to be free from external control to be effective. Jagan argued that Bissell's attempt to amalgamate Guianese unions beginning in 1945

\footnotetext{
${ }^{39}$ Cheddi Jagan, "Estimates-Legislature: Wednesday February 2, 1949," Dabydeen and Macedo, eds., Dr. Cheddi Jagan National Assembly Speeches, Volume 1, 26.

${ }^{40}$ Mohan Ragbeer, The Indelible Red Stain: The Destruction of a Tropical Paradise-a Cold War Story (Published by Mohan Ragbeer, 2011), 168.
} 
failed and that the only alternative was determining recognized bargaining agents based on union membership. However, Jagan accused Bissell of refusing to accept popular recognition because doing so would empower Guianese leaders who opposed his policies. Furthermore, Jagan criticized Bissell's insistence that trade unions and politics should be clearly separated, arguing that such a policy was inconsistent with trade union politics in Great Britain. Finally, Jagan noted that he proposed meeting with Bissell and Daniel Debidin, the legislative representatives of striking workers in Demerara, the previous year but that Bissell refused. Jagan concluded that Guianese political and labor leaders needed to cooperate to leverage their influence against British control since Bissell ignored struggling workers. Conversely, Bissell argued that preserving institutional machinery was paramount in maintaining effective labor relations. Bissell argued that workers needed to work through their union representatives if the system was going to be successful and that overturning institutional structures disrupted the system itself. ${ }^{41}$

Jagan's speech and his legislative proposal echoing the sugar workers' resolution calling for Bissell's replacement as Commissioner of Labor hint at the difficulty of early British attempts at institution-building particularly on Guianese sugar plantations. Bissell argued that colonial policy should focus on developing effective institutional mechanisms as the foundation of an increasingly politically autonomous colony and that doing so was more important than addressing immediate economic concerns. However, sugar workers were disinclined to delay alleviation of intense poverty in the hope that a future organization colonizers developed would address their needs particularly since existing trade union mechanisms failed to substantially improve workers' conditions. Instead, workers turned to Lachmansingh's GIWU which insisted on immediately resolving workers' poverty.

\footnotetext{
${ }^{41}$ Cheddi Jagan, "Estimates-Legislature: Wednesday February 3, 1949," Dabydeen and Macedo, eds., Dr. Cheddi Jagan National Assembly Speeches, Volume 1, 37-42.
} 
Simultaneously, sugar workers appealed to Jagan who advocated for social change designed to fundamentally alter Guianese society and eliminate the potential for perpetuation of external exploitation in Guiana. In reflecting on the evolution of Guianese politics in 1953, Jagan explained his 1949 legislative proposal as an action in support of the GIWU. He described his movement's broad plan as an attempt to gradually build "a strong and united party and effective trade unions" as part of a process of carrying out a Socialist reconstruction of the country. ${ }^{42} \mathrm{He}$ complemented his legislative actions with trade union activity, becoming president of the SWU in 1949 and aligning politically with Forbes Burnham, head of the BGLU. ${ }^{43}$ In the short term, Jagan tried to use his political position to legislate improvements Guianese unions were unable to negotiate, such as a two-dollar a day minimum wage for sugar workers. He argued that his proposal was necessary because existing mechanisms for collective bargaining were inefficient and the lack of pro-labor legislation left unions impotent in the face of powerful sugar interests. ${ }^{44}$ Thus, the PAC and GIWU formed a left-coalition between 1946 and 1949 that focused on using legislative action and strikes to improve workers' conditions. Most importantly, the Jagan-led left- wing of the PAC-GIWU coalition aimed to lay the foundations of a party-union relationship that would alter the nature of Guianese institutions and bring about a socialist transformation of the colony.

\section{Early Institution-Building in the Wake of the PAC Challenge}

The Colonial Office established the Venn Commission to determine the causes and possible solutions to economic and social unrest in British Guiana in the wake of the violent conclusion to sugar strikes in 1948. In August 1949 strikes broke out as a result of the rivalry

\footnotetext{
42 "Excerpt from 'What Happened in British Guiana' by Cheddi Jagan," British Guiana 972.8 (520), Box 44, Marjorie Nicholson Files, TUCLC.

${ }^{43}$ Horne, Cold War in a Hot Zone, 116-117.

${ }^{44}$ Cheddi Jagan, "Motion-Minimum Wage: Thursday, October, 13, 1949," Dabydeen and Macedo, eds., Dr. Cheddi Jagan National Assembly Speeches, Volume 1, 116-123.
} 
between the MPCA and GIWU and Bissell requested the Venn Commission publish its report arguing that the commission's conclusions would strengthen the government's ability to enforce order and reinforce orthodox labor relations in the wake of the renewed unrest. ${ }^{45}$ The commission released the report in November and outlined several conclusions regarding the development of trade unions in British Guiana. The commission's conclusions illuminate the official British perspective on organized labor's role in the post-war world and the contradictions within their view that reinforced the PAC's left-wing Marxist opposition. ${ }^{46}$ British objectives were two-fold, each objective containing within it humanitarian concerns and practical benefits for the British. First, the commission argued for alleviation of the extreme poverty that caused Guianese discontent. Second, the commission emphasized the need to build stronger mechanisms through which Guianese workers could express their discontent within the colony's existing political-economic structure. $^{47}$

The Venn Commission concluded that poverty drove the colonial crisis; however, it suggested that trade unions' inability to effectively advocate for improvements and political and labor leaders' exploitation of conditions for political advantage directly contributed to social unrest. In assessing the turmoil, the commission drew the critical conclusion that self-interested political leaders' abuse of the union movement led to competition between unions rather than the effective organization of workers necessary to establish a stable labor movement capable of advocating for improvement to wages and working conditions. Despite Bissell's efforts, the commission determined that trade unionism "developed with an emphasis on the political rather than the purely industrial role of labor organization, and ephemeral unions [had] been founded

\footnotetext{
${ }^{45}$ Telegram from British Guiana to Secretary of State for the Colonies, August 31, 1949, CO 111/797/4, BNA. ${ }^{46}$ Colonial Office to G.F. Seel, September 16, 1949; "Venn Commission: Note for Secretary of State," October 1949, CO 111/797/4, BNA.

${ }^{47}$ Venn Commission Report, “The Development of Trade Unionism in British Guiana," November 19, 1949, Venn Commission Recommendation: Trade Union Organizations, CO 111/797/5, BNA.
} 
and exploited by individuals more for selfish political advantage (and cheap publicity) than for the real benefit of the worker." British officials argued that "the GIWU was mainly responsible for provoking the strike on the Plantation Enmore in April, 1948” and that Lachmansingh's "purpose in exploiting this trade union is almost entirely political and personal." Furthermore, the commission noted the possibility that Cheddi Jagan, "the Communist member of the Legislative Council," had been "worming his way into" the BGWL and might win its presidency in the union's upcoming election. ${ }^{48}$ Thus, the Venn Commission concluded that the solution to Guianese unrest and poverty lay in reinforcing the institutional structure of trade unionism in the colony through programs aimed at strengthening the MPCA and guiding its development toward narrowly industrial ends.

The TUC's 1949 annual report suggests that some British labor leaders interpreted the violence in British Guiana differently than the Colonial Office; however, opponents of the official view agreed that Guianese workers needed assistance from the British labor movement. A.L. Cohen of the Union of Shop, Distributive and Allied Workers challenged the Colonial Advisory Committee's (CAC) interpretation and suggested that sugar workers' protests resulted from a desire for increased wages. Cohen noted sugar workers' low pay--25 shillings per week for men and 14 for women--and contrasted their meager wages with reports of considerable profit for Tate \& Lyle, the combine that controlled the sugar plantation at Enmore. Tate \& Lyle, he argued, recorded significant revenues in 1948 followed by record profits of close to five million shillings in 1949. Cohen referred to other presentations at the meeting that confirmed his report who shared his recommended of exposing Tate \& Lyle's "insidious propaganda,"

\footnotetext{
48 "Development of Trade Unionism in British Guiana," July 1949, CO 111/797/4, BNA; Venn Commission Report, “The Development of Trade Unionism in British Guiana," November 19, 1949, Venn Commission Recommendation: Trade Union Organizations, CO 111/797/5, BNA.
} 
combatting the company's anti-nationalization campaign, and assisting workers in defeating "the machination of this sugar combine."49

Cohen seems not to have appreciated that the fundamental question of recognition for the GIWU underlay the strike; however, his conclusion is significant for three reasons. First, it suggests that some British unionists sympathized with colonial unions and encouraged assistance based on ideals of workers' solidarity. Second, it suggests that some British unionists suspected sugar companies of intentionally spreading disinformation about labor unrest in the colonies as a means of discrediting Guianese political and labor leaders in a manner that distorted official perceptions of the nationalist resistance. ${ }^{50}$ Finally, Cohen's recommendation suggests that British unionists' participation in institution-building efforts were based on an oversimplified understanding of colonial issues that encouraged attempts to implement a form of organized labor based narrowly on promoting trade union organization and collective bargaining divorced from political activism. Despite differences of opinion on the sources of conflict, the TUC and Colonial Office cooperated to try and bolster reformist Guianese unions and increase their negotiating effectiveness.

In addition to suggesting a program of institution-building, the Venn Commission recommended introducing emergency restrictions in British Guiana. Specifically, the commission suggested delaying implementation of the International Labor Convention's

\footnotetext{
${ }^{49}$ Report of the 81st Annual Trades Union Congress, September 5-9, 1949, TUC History Online, 371-372, http://www.unionhistory.info/britainatwork/emuweb/objects/nofdigi/tuc/imagedisplay.php?irn=6011943\&reftable=e catalogue\&refirn=6011956, Last Accessed July 12, 2015. In advocating an increased minimum wage for sugar workers in 1949, Cheddi Jagan referenced sugar workers' pay rates that were somewhat higher than those cited in the Cohen's statement. Regardless of the discrepancy, pay rates were extremely low and both men argued that sugar companies could easily afford increased wages for sugar workers. See: Cheddi Jagan, "Motion-Minimum Wage: Thursday, October, 13, 1949," Dabydeen and Macedo, eds., Dr. Cheddi Jagan National Assembly Speeches, Volume 1,116-123.

${ }^{50}$ Frank Furedi argues that officials within the British government also used tactics of discrediting nationalists as a means of undermining movements deemed radical, rather than trying to justify imperialism, with the result being the promotion of nationalism along ethnic lines. See: Frank Furedi, Colonial Wars and the Politics of Third World Nationalism (London: I.B. Tauris Publishers, 1994).
} 
standards concerning Freedom of Association and the Right to Organize that had already been adopted in the United Kingdom. Additionally, the Commission proposed restricting trade union leadership positions to full-time employees in the industry whose workers the union purported to represent. ${ }^{51}$ Commissioners expected the decision to aggravate Guianese workers and provoke resistance in other Caribbean territories and among regional labor organizations since the policy restricted trade union rights. Regardless, the commission determined that allowing registrars to refuse recognition to certain unions, including some those workers preferred benefited workers. The conclusion suggests that the commission prioritized undermining the GIWU and strengthening the MPCA in the short-term as part of a process of long-term institution-building. ${ }^{52}$

Cheddi Jagan criticized the Venn Commission's ruling regarding trade unions and the Legislative Council's inattention to what he deemed the cause of a great deal of labor strife, workers' inability to collectively bargain through the union of their choosing. ${ }^{53}$ He further criticized the Commission's suggestion to recognize several different craft unions within the sugar industry, rather than support an industrial union to represent the entirety of sugar workers, a criticism consistent with the Colonial Office's previous recommendation of minimizing the proliferation of unions. ${ }^{54}$ Finally, the Commission advocated a rule limiting leadership positions in trade unions to workers who had three continuous years working within the industry they proposed to represent. Theoretically the policy aimed at limiting the connections between industrial and political organizing to minimize the corruption of labor organization for political advancement; however, it created a barrier between the workers and the people they most trusted

\footnotetext{
51 "Note of Meeting on $19^{\text {th }}$ May in the Colonial Office," May 19, 1949, CO 111/797/4, BNA.

52 The Venn Commission rejected the GIWU's claim for recognition, arguing that sugar workers should pursue union changes within the MPCA, rather than through the creation of another organization. Chase, A History of Trade Unionism in Guyana, 160.

${ }^{53}$ Dr. Cheddi Jagan, "Venn Commission Report," undated, Dabydeen and Macedo, eds., Dr. Cheddi Jagan National Assembly Speeches, Volume 1, 250-255.

${ }^{54}$ Dr. Cheddi Jagan, "Venn Commission Report," undated, Dabydeen and Macedo, eds., Dr. Cheddi Jagan National Assembly Speeches, Volume 1, 310-312.
} 
as representatives, impeding meaningful democracy in colonial society. ${ }^{55}$ It was also a policy clearly aimed at undermining the PAC's influence since colonial officials accepted close connections between reformist trade unions and nationalist parties in the rest of the Caribbean territories. $^{56}$

Jagan argued that the Commission's proposal was based on conditions in Great Britain, where the trade union movement grew out of centuries of struggle. In British Guiana, he argued, workers did not have the same level of experience and needed to be led; a rare point about which the Legislative Council agreed with Jagan. ${ }^{57}$ Moreover, the proposal of restricting union leadership to consistently employed full-time workers limited leadership positions to sugar workers vulnerable to company victimization if their negotiations pressed for changes sugar producers deemed too substantial and overlooked the fact that many sugar workers were seasonal employees.

The Venn Commission's recommendation of Colonial Office-TUC collaboration reinforced a broader, longer-term effort at institution-building. The Commission's recommendations expanded on more than a decade of cooperative union work for developing colonial areas. The TUC first established relationships with colonial unions before World War II for the purpose of advising, educating, and collecting information to assist colonial workers in pursuing labor organization. ${ }^{58}$ In 1940 the British government passed the Colonial Development

\footnotetext{
${ }^{55}$ Venn Commission Report, “The Development of Trade Unionism in British Guiana," November 19, 1949, Venn Commission Recommendation: Trade Union Organizations, CO 111/797/5, British National Archives, Richmond, Kew, Surrey, UK; "Trade Unions in the Colonies: Memorandum Submitted to the Secretary of State by the Colonial Labor Advisory Committee,” May 24, 1951, Trade Unions and Colonies 932.5, Box 15, Marjorie Nicholson Files, TUCLC.

${ }^{56}$ Horne, Cold War in a Hot Zone; Parker, Brother's Keeper; Waters, "More Subtle Than We Knew."

${ }^{57}$ Dr. Cheddi Jagan, "Venn Commission Report," undated, Dabydeen and Macedo, eds., Dr. Cheddi Jagan National Assembly Speeches, Volume 1, 298-299.

${ }^{58}$ Colonial Advisory Committee, "Colonial Work of the TUC," June 6, 1956, Box 15, Marjorie Nicholson Files, TUCLC. Between 1932 and 1947 trade union organizing in British colonies increased the number of colonial unions from 3 to 939 and the number of organized workers from 83,000 in 1942 to 250,000 in 1947. Nonetheless, official
} 
and Welfare Act, which was updated in 1945, based on the notion that newly established colonial trade unions required the assistance of experienced British trade union advisors. ${ }^{59}$ TUC cooperation with the Colonial Office included training staff members in Colonial Labor Departments since at least 1942 and sending British trade unionists to guide colonial trade unions; however, the war limited the effectiveness of their programs. After 1945 the TUC collaborated with Ruskin College, Oxford, in bringing colonial unionists to England for education and circulating correspondence courses in the colonies. ${ }^{60}$

TUC records indicate that the Colonial Office encouraged British trade unionists to increase their involvement in the Caribbean after the violence at Enmore and offered some governmental financing to advance the programs. A grant from the Colonial Development and Welfare Act financed West Indian courses conducted between August and December 1948 that included the participation of eighteen trade union leaders in the Caribbean. ${ }^{61}$ Colonial officials and British unionists expected that their participation in institution-building activities would assist in the construction of structural mechanisms to alleviate colonial poverty and promote the development of social and political-economic institutions based on British practices and contribute to capitalist-democratic development. ${ }^{62}$ However, as D.I. Davies argues, British efforts at trade union development promoted the diffusion of some TUC practices while guiding organized labor along a moderate path in the colonies. Davies and Spencer Mawby argue that

numbers obscured the significant lack of organization among the rank-and-file, which was the focus of post-war programs. See: Report of the $78^{\text {th }}$ Annual Trades Union Congress, October 21-25, 1946, TUC History Online, 162, http://www.unionhistory.info/britainatwork/emuweb/objects/nofdigi/tuc/imagedisplay.php?irn=6011026\&reftable=e catalogue\&refirn=6011026, Last Accessed, July 13, 2015.

59 "Trade Unions in the Colonies," 1955, Box 15, Marjorie Nicholson Files, TUCLC.

${ }^{60}$ Ashton Chase's education in trade unionism at Oxford was part of this program.

${ }^{61}$ Untitled Colonial Office Report, October 14, 1950, Trade Unions and Colonies 932.5, Box 15, Marjorie Nicholson Files, TUCLC.

${ }^{62}$ Nigel Bolland notes that Colonial Office-TUC cooperation began in 1925, but argues that effective collaboration began in the 1930s. See: Bolland, The Politics of Labour in the British Caribbean, 144, 359. Post-War Colonial Office-TUC collaboration built off of earlier programs, but was more extensive and designed to establish postcolonial institutions, rather than narrowly as organizations aimed at easing labor conflicts inherent in colonial societies. 
TUC programs focused more on moderating potentially challenging colonial movements than assuring political voice and material benefits to colonial workers. ${ }^{63}$ Furthermore, historian Bob Reinalda argues that in "colonies and former colonies trade union policies were often modeled according to the national interests of the mother countries, and as such these top-down policies tended to frustrate local models." ${ }^{, 64}$ Thus, scholarship suggests that the Venn Commission recommendation for countering the GIWU-PAC alliance in British Guiana through institutionbuilding fell into a broader pattern employed throughout the Empire. British institution-building efforts, however, unfolded in an increasingly complex international environment in which international organizations and non-state actors outside of the United Kingdom played an increasing role in colonial affairs.

\section{The Internationalization of Institutional Decolonization}

Cold War conflicts between international labor organizations influenced institutional decolonization in British Guiana as early as 1945 when H.J.M. Hubbard, a founding member of the PAC, attended the first conference of the WFTU. In response to PAC association with the WFTU and its financially independent regionally arm, the Caribbean Labor Congress (CLC), the Colonial Office and TUC encouraged Guianese unions to associate with the International Confederation of Free Trade Unions (ICFTU) and Inter-American Regional Organization of Workers (ORIT). Nigel Bolland explains the Colonial Office's provision of funds for Guianese unions' participation at the ICFTU Conferences as a means to bolster support for the anticommunist crusade through affiliation with the newly-formed anti-communist international organization. He suggests that the TUC previously refused funds to colonial unions for

\footnotetext{
${ }^{63}$ D.I. Davies, “The Politics of the TUC's Colonial Policy," The Political Quarterly, Vol. 35 (1), 23-34, 1964; Mawby, Ordering Independence.

${ }^{64}$ Bob Reinalda, "The Anatomy of the Major Twentieth-Century International Trade Union Federation" in Bart De Wilde, ed., The Past and Future of International Trade Unionism (Ghent: International Conference, May 19-20, 2000), 34-36.
} 
participation in the WFTU even though the TUC helped found the organization. ${ }^{65}$ Moreover,

Bolland argues that TUC pressure on colonial unions to join the ICFTU in response to Cold War politics resulted in a greater politicization of colonial trade unions. Bolland suggests that TUC pressure was largely a reaction against WFTU efforts to support colonial trade unions and the TUC's realization that failure to offer an alternative to the WFTU would result in greater colonial involvement with Eastern bloc and communist unions at the international level. ${ }^{66}$ Colin Palmer also suggests that the WFTU, particularly communists and Eastern bloc representatives, provided the strongest support for colonial nationalists. ${ }^{67}$

The establishment of the ICFTU and debates surrounding whether or not, and how, Guianese unions should align internationally fueled tensions between Guianese unionists and politicians, as well as between the PAC/PPP and the colonial establishment. ${ }^{68}$ Some Guianese labor leaders embraced the new organizations. Hubert Critchlow of the BGLU attended the first congress of the ICFTU in 1949 and the BGLU and MPCA formally joined the ICFTU in July 1952. However, the BGLU did not disaffiliate with the WFTU and according to Critchlow did not pay dues to the ICFTU. ${ }^{69}$ The MPCA also integrated into the Western internationals as one

\footnotetext{
${ }^{65}$ This process is most thoroughly understood in conjunction with Bolland's broader argument that the Colonial Office engaged in a process of securing capitalist property through institutionalization and control of the labor movement in colonial territories. Bolland's identification of British attempts to institutionalize the labor movement is similar, but not identical to the concept of institutional decolonization discussed in this dissertation. Specifically, this dissertation considers institutional decolonization as a process of negotiation and conflict between British, Guianese, and American actors for control of post-colonial social and political-economic mechanisms of power. Bolland's explanation of institutionalization of the labor movement is best understood as part of the broader process discussed herein. See: Bolland, The Politics of Labour in the British Caribbean, 363-366. Cheddi Jagan's speech before the Legislative Council on November 9, 1949 contradicts Bolland, suggesting that the Council loaned money to two Guianese unionists to attend the World Trade Union Conference which established the WFTU. See: Dr. Cheddi Jagan, "Grant to Trades Union Council: Wednesday, November 9, 1949," Dabydeen and Macedo, eds., Dr. Cheddi Jagan National Assembly Speeches, Volume 1, 127.

${ }^{66}$ Bolland, The Politics of Labour in the British Caribbean, 490-496.

${ }^{67}$ Palmer, Cheddi Jagan and the Politics of Power, 22-27.

${ }^{68}$ Bolland argues that the establishment of the ICFTU split labor movements throughout the Caribbean colonies. Bolland, The Politics of Labour in the British Caribbean, 490.

69 "For Bread, Peace, and Freedom: Decisions of the First World Congress of the ICFTU," November-December, 1949, International Affairs Department, Staff Files: George Delaney's files, 1921-1957, Box 10, ICFTU InterAmerican Regional Organization of Workers..., 1951-1955, GMMA; "Trade Union Organizations in British
} 
of the founding members of ORIT. ${ }^{70}$ Conversely, Cheddi Jagan criticized the Colonial

Legislature's decision to contribute funding to send a trade union delegate to the ICFTU

Conference in 1949 arguing that the Council's recent decision to reject increased funds for

education made the trade union expense extraneous. Jagan's opposition to using legislative funds

to support unions' integration into the ICFTU was largely a consequence of ideological support

for the WFTU. Jagan's speech to the Council attacked support for the ICFTU's establishment on the grounds that it split the international labor movement in two to further British and American Cold War objectives in addition to opposing the use of colonists' money to help build the organization. $^{71}$

Jagan then shifted tactics, using the debate over the international conference as a means of advocating for the GIWU. In a November legislative session, Jagan acknowledged Critchlow as the "father of Trade Unionism" in British Guiana; however, he continued to disagree with the principle that the council should support his attendance at the conference. ${ }^{72}$ Jagan suggested that if the government was to fund a trade unionist to attend the conference despite his objections then the unionist chosen should be a representative from the GIWU. He pointed to a United Nations (UN) resolution demanding freedom of association and noted that the SPA still refused

Colonies Accepted for Affiliation to ICFTU to July, 1952," ICFTU/TUC 931.9, Box 9, Marjorie Nicholson Files, TUCLC; Robert Alexander interview with Ashton Chase, June 5, 1953, RG 18-003, International Affairs Department, Jay Lovestone Files, 1944-1973, Box 2, Alexander, Robert, 1953, GMMA; It is also notable that an AFL report on an ICFTU meeting in October 1950 lists the BGLU as a member organization. Thus, it is unclear whether the BGLU affiliated in 1950 or 1951; however, it is evident that the union participated in ICFTU functions beginning in 1949. See: "International Confederation of Free Trade Unions: Its Organization, Objectives, Ideology, and Structure," RG 1-027, Office of the President, George Meany, 1948-1960, Box 49, Subjects: Formation, 19491950, GMMA.

${ }^{70}$ Serafino Romualdi, Presidents and Peons: Recollections of a Labor Ambassador in Latin America (New York: Fund \& Wagnalls, 1967), 346.

${ }^{71}$ Dr. Cheddi Jagan, “Grant to Trades Union Council: Wednesday, November 9, 1949,” Dabydeen and Macedo, eds., Dr. Cheddi Jagan National Assembly Speeches, Volume 1, 126-129; Dr. Cheddi Jagan, "Miscellaneous: March 8, 1950," Dabydeen and Macedo, eds., Dr. Cheddi Jagan National Assembly Speeches, Volume 1, 183-184.

${ }^{72}$ Critchlow also attended the London Conference that was the basis of the WFTU in July 1945. See: Horne, Cold War in a Hot Zone, 57. Jagan suggests that H.M. Hubbard also attending the conference that founded the WFTU. See: Jagan, The West on Trial, 89. 
to acknowledge the GIWU even though the union gained recognition from the Guianese government. The GIWU, he argued, had a legitimate case that it required international assistance to obtain practical recognition denied in the colony. Jagan clearly understood that his motion stood no chance of passing in the council since he referred to the debate as a joke; however, he insisted that he was sincere and wanted his position on the record. ${ }^{73}$

The legislative debate over funding the BGLU shows the importance British officials' placed on cultivating relations between colonial unions and the ICFTU as well as colonial unionists' use of the ICFTU and ORIT to integrate into the Western capitalist system. Official British objectives regarding colonial trade unions included the retention of control as a central objective. In discussing trade unionism in the colonies the Colonial Office concluded in October 1951 that recent legislative proposals regarding colonial union regulations "might in themselves seem to suggest a legalistic and restrictive spirit that was alien to proclaimed liberal ideas about freedom of association;" however, "these proposals implied no shift of policy: they must be viewed simply as a reappraisement [sic] of the measure of guidance and control which might be desirable to promote the growth of an independent, responsible, and effective trade union movement." 74 Thus, in the face of British promotion of ICFTU relations and a general program aimed at controlling colonial trade unions, the PAC increased its efforts to work with the WFTU.

The conflicts shaping institutional decolonization in British Guiana increased after 1950 as Cold War tensions heightened with the onset of the war in Korea and the intense anticommunism of McCarthyism in the United States. In February 1950 colonial officials recommended that employers and workers negotiate to ensure stability and concluded an

\footnotetext{
${ }^{73}$ Dr. Cheddi Jagan, “Grant to Trades Union Council: Thursday, November 19, 1949,” Dabydeen and Macedo, eds., Dr. Cheddi Jagan National Assembly Speeches, Volume 1, 130-132.

74 "Conference of Heads of Labour Departments. Colonial Office," September 24- October5, 1951, Marjorie Nicholson Files, Box 15, Trade Unions+Colonies, TUCLC.
} 
agreement between the SPA, MPCA, and BGWL to increase wages and paid leave for sugar workers. The negotiations revolved around a general view that improved conditions would, according to American Consul Eugene Johnson, "provide an incentive to secure more regular and continuous working of factories, thus increasing the productivity of the industry." ${ }^{, 75}$ Despite Johnson's optimistic outlook, production did not increase significantly and employment for sugar workers stagnated and possibly decreased throughout the year. ${ }^{76}$ Moreover, Jagan suggested that sugar producers offset wage increases with increased prices for local consumption and he continued his push for recognition for the GIWU in the Legislative Council in March. During a debate, Jagan criticized Bissell and the Labor Department for alleging to uphold International Labor Organization (ILO) principles assuring workers the right to organize and have unions recognized while not enforcing that recognition in practice. He warned that encouraging workers to organize and having government recognition of their unions while permitting employers to deal only with unions of their choosing would inevitably lead to continued labor conflict. ${ }^{77}$ In early November the Jagan-backed GIWU instigated a colony-wide strike that resulted in a partial work stoppage that threatened waning production. ${ }^{78}$

In response to the Venn Commission Report and continued division in the Guianese labor movement, the TUC agreed to increase assistance for trade unions in British Guiana at its annual congress in September 1950. British trade unionists sent "a typewriter, duplicating machinery, stencils, ink, duplicating paper, stencil pens and other accessories, stapling machine, [and] filing cabinet" to the BGTUC by January 1951, along with books on "trade union and associated

\footnotetext{
${ }^{75}$ Eugene H. Johnson, American Consul, Georgetown to Department of State, February 3, 1950, 841D.061/2-350, Box 4814, Central Decimal Files, RG 59, National Archives and Records Administration, College Park, MD (Hereafter, NARA II).

${ }^{76}$ Horn, Cold War in a Hot Zone, 180.

${ }^{77}$ Jagan, The West on Trial, 116; Dr. Cheddi Jagan, “Estimates-Labour Department: March 3, 1950," Dabydeen and Macedo, eds., Dr. Cheddi Jagan National Assembly Speeches, Volume 1, 177-178.

${ }^{78}$ Franklin Hale, American Consul, Port-of-Spain to Department of State, November 2, 1950, 841D.062/11-250, Box 4814, Central Decimal Files, RG 59, NARA II.
} 
subjects," pamphlets, and regular publications to allow the BGTUC to start a trade union library. Finally, the TUC worked with Ruskin College to design an updated course in trade union principles for colonial students. ${ }^{79}$ TUC efforts at educational training continued to expand slowly through the establishment of correspondence course with the participation of four Guianese unionists in $1951 .^{80}$

The TUC program for British Guiana fit within a broader restatement of purpose articulated in a May 1951 memorandum from the Colonial Labor Advisory Committee to the Secretary of State for the Colonies. The committee argued that the "central purpose of British colonial policy is to guide the colonial territories to responsible self-government," including assisting colonies to establish trade unions and overcome the reality that their growth was "not matched in understanding of principles and practice." Furthermore, the committee argued that "if a situation arises in which two strong trade unions compete for recognition" it would create "serious difficulties for the territory concerned." Thus, the committee recommended giving colonial officials the authority to reject registration of unions if they determined that existing organizations offered sufficient representation. Such a proposal was anathema to British trade union practices but was deemed necessary in colonies where a multiplicity of unions could render the movement itself useless and was particularly significant in Guiana where the GIWUMPCA dispute was an ongoing conflict on sugar estates. ${ }^{81}$

At a Conference of the Heads of Colonial Labor Departments in October 1951 James Griffiths, Secretary of State for the Colonies, noted that colonial development would result in a

\footnotetext{
${ }^{79}$ Report of the 81st Annual Trades Union Congress, September 5-9, 1949, TUC History Online, 222-223, http://www.unionhistory.info/britainatwork/emuweb/objects/nofdigi/tuc/imagedisplay.php?irn=6011943\&reftable=e catalogue\&refirn=6011956, Last Accessed July 12, 2015.

${ }^{80}$ Report of the 81st Annual Trades Union Congress, September 4-8, 1950, TUC History Online, 210-213, http://www.unionhistory.info/britainatwork/emuweb/objects/nofdigi/tuc/imagedisplay.php?irn=6012244\&reftable=e catalogue\&refirn=6012260, Last Accessed July 12, 2015.

${ }^{81}$ Memorandum submitted to the Secretary of State by the Colonial Labor Advisory Committee, "Trade Unionism in the Colonies," May 24, 1951, Trade Unions+Colonies (932.5), Box 15, Marjorie Nicholson Files, TUCLC.
} 
"revolution that would parallel in some degree the Industrial Revolution of this country" and that the success of British policy depended on how colonial authorities managed those changes to encourage colonists to develop a "sense of belonging" in new societies. Sir Frederick Seaford of Booker Brothers suggested that direct TUC involvement was crucial to preparing colonies for development. While not wanting to "seem to be forcing itself and British methods on colonial unions," attendees recommended "trying to prompt requests for help" and increasing TUC training in colonies rather than through exchange programs in Great Britain. ${ }^{82}$

At the same time the TUC began sending supplies to the MPCA and BGTUC, American labor leaders and the American-dominated ORIT became increasingly involved in the colony. In January 1951 ORIT released its inaugural publication, which began with a report on British Guiana edited by the organization's Assistant Secretary, Ernst Schwarz of the American Congress of Industrial Organizations (CIO). The report noted that 75\% of the Guianese population was "wage-earners of lower income," and another $10 \%$ were independent peasant farmers or civil service and public workers, and that a rapidly developing American-owned bauxite mining industry offered employment possibilities for the future. The report criticized appalling workplace conditions and suggested that "squalor, poverty, and the frequently abominable surroundings no doubt account to a large extent for the low productivity in the industries." The report argued that conditions were unacceptable, particularly since "bauxite is largely used by the United Nations and the United States in the manufacture of war materials" and therefore represented an important aspect of American military preparedness toward the year-old conflict in East Asia. Schwarz concluded that strengthening the trade union movement was the key to improving conditions and he suggested that ORIT particularly support the

\footnotetext{
${ }^{82}$ Minutes of Conference of Heads of Labour Departments, October 5, 1951, Trade Unions+Colonies (932.5), Box 15, Marjorie Nicholson Files, TUCLC.
} 
democratically principled MPCA, which had "collective labor agreements with the employers of the sugar, rice, bauxite, and electric power industries of the colony." ${ }^{.3}$ The ORIT report suggests that American labor leaders considered British Guiana important as early as 1951 at least in part as a result of its production of strategic materials. American opposition to poor labor conditions derived at least partially from the impact of the workplace environment on effective production of bauxite. Most importantly, American Federation of Labor (AFL) and CIO leaders determined that American labor and ORIT needed to increase their involvement in the colony and support for the MPCA to help build a pro-American trade union movement to secure their interests.

Serafino Romualdi, the AFL's long-time Latin American representative, Assistant Secretary of ORIT, and possible CIA operative, visited British Guiana in 1951 and concluded that Cheddi Jagan was subservient to the international Communist movement. ${ }^{84}$ In an article published in the Inter-American Labor News in January 1951 Romualdi criticized PPP-backed wildcat strikes in British Guiana and accused the party of being Communist. In May 1952 Romualdi published a second article in ORIT's Inter-American Labor News accusing the PPP of trying to destroy the MPCA, ORIT's affiliate in British Guiana ${ }^{85}$ Romualdi resolved to work through the MPCA and other affiliated Guianese unions to rid Guiana of Jagan and began

\footnotetext{
${ }^{83}$ Ernst Schwarz, ed., "British Guiana: A Colonial Miniature," from Research Department of the Inter-American Regional Organization of Workers, January 1951, Vol. 1, No.1, RG-18: International Department, Serafino Romualdi Files, Box 8, Research Department, 1951-1953, GMMA. It is also important to acknowledge that American fears of hostile infiltration into the Guianas impeding access to bauxite reserves preceded the Cold War. Bob Moore notes that the State Department adjusted policies toward Suriname (Dutch Guiana) in response to fears of German invasion through Brazil in early 1941. Therefore, the active pursuit of American access to Guianese bauxite is most effectively understood as a consistent policy, rather than a reaction to the Cold War, though the Cold War exacerbated such tensions. See: Bob Moore, "Decolonization by Default: Suriname and the Dutch Retreat from Empire," in, Fedorowich and Thomas, International Diplomacy and Colonial Retreat, 233.

${ }^{84}$ Romualdi, Presidents and Peons, 346.Philip Agee, a former CIA operative, identified Romualdi as a long-time agent of the utmost importance in his memoir. See: Philip Agee, Inside the Company: CIA Diary (New York: Bantam Books, 1975), 69, 214, 245, 641.

${ }^{85}$ Serafino Romualdi, "AFL-CIO Inter-American Representative: Facts on Cheddi Jagan and His CommunistControlled People's Progressive Party of BG: Free Labor's 10 Year Struggle to Preserve Independence," March 1962, RG 1-038, GMMA.
} 
discussing the establishment of the Caribbean Area Division of ORIT (CADORIT) to further the organization's activities in the Caribbean. ${ }^{86}$

Leo Eliazer, Surinam's representative to ORIT and the organization's regional organizer in the Caribbean, visited British Guiana in October and November 1951, met with Sheik Shakoor, General Secretary of the MPCA, and drew up a detailed report on the colony. Importantly, Eliazer noted that American labor activist and Rutgers professor Robert Alexander held Shakoor in high regard suggesting that the MPCA leader used international connections to advance the sugar workers' cause in British Guiana and giving the union an influential connection within the American labor movement. ${ }^{87}$ The ORIT report praised the MPCA's persistent support for sugar workers and attainment of marked improvement for laborers in after World War II warning that "the unrecognized pirate union,” Dr. Lachmansingh's GIWU, represented the greatest obstacle in the way of trade union progress.

Eliazer criticized the "communist” GIWU's relationship with the BGTUC and accused Lachmansingh of exploiting conditions on the sugar estates for political advantage. ${ }^{88}$ Moreover, Eliazer noted that the Lachmansingh "depends on the communist PPP Party with whom his union has an alliance for support to continue mischief-making in the sugar industry until he gets recognition." He also reported that the GIWU “openly applied for affiliation with the London Branch of the Communist Caribbean Labor Congress." As a result of its connections, Eliazer reported that the GIWU had access to two automobiles while the high cost of transportation--up

\footnotetext{
${ }^{86}$ Serafino Romualdi to AFL President William Green, May 16, 1952, RG 027-Office of the President, George Meany’s Files, 1944-1960, Box 58, Reports: Serafino Romualdi, 1948-1955, GMMA; Serafino Romualdi to Francisco Aguirre, Secretary General, ORIT, October 30, 1951, RG 027-Office of the President, George Meany's Files, 1944-1960, Box 58, Reports: Serafino Romualdi, 1948-1955, GMMA.

${ }^{87}$ Robert Alexander interview with Sheikh Shakoor, June 4, 1953, RG 18-003, International Affairs Department, Jay Lovestone Files, 1944-1973, Box 2, Alexander, Robert, 1953, GMMA.

${ }^{88}$ On the issue of "support" Eliazer's report is somewhat ambiguous. The colonial government recognized the GIWU, even if it did not support it, and most other sources suggest the GIWU had more support among sugar workers than the MPCA even if support was unclear in the early $1950 \mathrm{~s}$.
} 
to $45 \%$ of MPCA contributions-- inhibited the MPCA's ability to maintain regular contact with sugar workers spread out across a wide area on Guiana's coast. Eliazer concluded that the financial burden of transportation contributed to the MPCA's failure to effectively confront communist propaganda spread through GIWU organizing. ${ }^{89}$ In addition to indirectly acknowledging the GIWU's superior rank-and-file support, Eliazer offered recommendations for addressing the MCPA-GIWU conflict.

Eliazer emphasized that several steps were undertaken to stabilize the trade union movement and after reiterating that democracy in the economically and geographically important territory depended on ORIT assistance, he offered several suggestions to increase the connections between the Guianese labor movement and ORIT. He noted that the MPCA was expanding to include negotiating rights for bauxite workers to confront what he deemed communist organizing in that industry and that the Federation of Government Unions (FUGE) planned to apply for affiliation to ORIT and the ICFTU. The BGTUC, which applied to affiliate with ORIT and the ICFTU in 1950 but declined when the GIWU joined the BGTUC in 1951, reapplied for affiliation after a meeting with Eliazer. Eliazer further "pledged [his] service at the disposal of the democratic trade union leaders against the communist PPP men." In addition to his own services, Eliazer recommended ORIT provide "two full-time paid organizers of the workers in the democratic trade unions, for a period of five years with all equipments [sic] necessary to undertake the planning and execution of propaganda calculated to improve the standard of living of the masses of workers in addition to the intensification of the organizational, economical, [sic] political and educational activities in the trade unions affiliated to ORIT." He further recommended the provision of two cars and a loud-speaker for organizing,

\footnotetext{
${ }^{89}$ Leo E. Eliazer, Regional Organizer of ORIT in the Caribbean Areas, "Report on British Guiana," RG-18, International Affairs Department, Staff Files: George Delaney's Files, 1921-1957, ORIT Executive Board Meetings, 1951-1953, GMMA.
} 
scholarships for unionists to study for eight months in the United States or Puerto Rico, six to eight tons of newsprint for two years to supply the MPCA for the publication of its journal, and the placement of responsibility for the provisions in the hands of Shakoor who would report to ORIT and the ICFTU regularly. ${ }^{90}$ Thus, ORIT's most important Caribbean leader used the regional arm of the ICFTU to encourage American labor leaders to join the trade union conflict in British Guiana against the left-coalition in the PAC-GIWU within months of the Western international's founding.

Shakoor strengthened the MPCA's connections to American labor when the ORIT executive board invited him to attend its meeting in late 1951 and early 1952 as an observer. The list of high-ranking American labor leaders participating included the soon-to-be AFL President George Meany, Romualdi, and Ernst Schwarz. Board members discussed the expansion of ORIT's influence into the British West Indies through a regional organization, a process already underway as a result decisions made at a conference in Trinidad in 1951 attended by Assistant General Secretary of the TUC, George Woodcock. Attendees also praised the cooperation between ORIT, the AFL and CIO, and the State Department in collaborating to strengthen miners' movements in British Guiana through negotiations with American industrialists. The negotiations "represented a great deal of money for all of [those] countries" but "did not bring comparable social and economic benefits to the workers." The report notes that increased profits merely "served to increase the wealth of the capitalists of the countries benefited." 91 Thus, in 1952 labor struggles in British Guiana became increasingly internationalized as the AFL, CIO,

\footnotetext{
${ }^{90}$ Leo E. Eliazer, Regional Organizer of ORIT in the Caribbean Areas, "Report on British Guiana," RG-18, International Affairs Department, Staff Files: George Delaney’s Files, 1921-1957, ORIT Executive Board Meetings, 1951-1953, GMMA.

91 "Third Meeting of the Executive Board," December 17, 1951, January 23-24, 1952, RG 18-International Affairs Department, Staff Files: George Delaney's files, 1921-1957, ICFTU Inter-American Regional Organization of Workers..., 1951-1952, GMMA.
} 
TUC, ORIT, ICFTU, and State Department involvement in the colony; however, their participation in industrial disputes failed to effectively addressing the needs of Guianese workers.

Eliazer and Romualdi's visits to British Guiana, Shakoor's attendance at the ORIT meeting, and the connections established and conclusions drawn from those experiences is considerable. First, the entrance of American trade union leaders into the labor struggle in British Guiana provided a small financial base for the MPCA that, in addition to TUC assistance, allowed the organization to engage the more widely supported and financially sound GIWU despite a lack of support among sugar workers for the MPCA. ${ }^{92}$ Second, the ORIT program directly contradicted at least one aspect of TUC assistance; specifically, ORIT refused to contribute to a trade union library "until the unions themselves indicate their willingness to make use of local books and periodicals." The disagreement between ORIT and the TUC on a seemingly insignificant matter foreshadowed a larger lack of coordination between international trade unionists' activities in British Guiana throughout the 1950s. Third, the connections American labor leaders' established in British Guiana through ORIT beginning in 1951 formed the basis of American involvement in the colony for the next fifteen years. ${ }^{93}$

At the same time ORIT leaders engaged the Guianese trade union movement, the WFTU offered an alternative for Guianese trade unionists disinclined to affiliate with the ICFTU and ORIT. Cheddi Jagan expressed a firm conviction that the WFTU was "ready to fight for colonial people all over the world.” British withdrawal from the WFTU, Jagan argued, indicated a

\footnotetext{
${ }^{92}$ It is unclear where the GIWU obtained its funding. J.P. Lachmansingh was financially well-off and association with the PPP contributed to GIWU funds; however, it is possible money was obtained elsewhere, including from the WFTU or Eastern-bloc countries.

${ }^{93}$ Leo E. Eliazer, Regional Organizer of ORIT in the Caribbean Areas, "Report on British Guiana," RG-18,
} 1951-1953, GMMA. 
International Affairs Department, Staff Files: George Delaney’s Files, 1921-1957, ORIT Executive Board Meetings,

1951-1953, GMMA. 
rejection of the organization's "going too far in the sense that it was beginning to investigate conditions" that "carried to their logical conclusion they would have exposed the rottenness" of British imperialism. As a result, the Jagan-led PPP continued cooperation with the organization after the TUC and CIO withdrew in $1949 .{ }^{94}$ Jagan also traveled to East Germany in 1951 where he toured factories and trade union resorts to learn "how workers were building socialism, the constructive role they played, the social and economic benefits they secured and the direct participation of workers in management and control of factories and production. ${ }^{95}$ Jagan's appeal to Eastern European trade unions and the WFTU as a guide for Guianese institutionbuilding aimed at breaking the colony's economy from foreign capitalist control. However, the PPP's attempt to establish labor relations on an Eastern-bloc model conflicted with British and American conceptions of institutional development for the colony while Guianese association with communist organizations directly challenged Cold War imperatives.

J.Y. Mackenzie of the Foreign Office contacted the Colonial Office to express his department's concern that in November 1951 a Guianese delegate to the WFTU conference in Berlin suggested the organization set up a new colonial department. ${ }^{96}$ The delegate, Cheddi Jagan, had his proposal seconded by a delegate from Trinidad before WFTU members agreed to the plan. ${ }^{97}$ Foreign Office records also noted that leading speakers at the conference advised the organization to increase involvement in Latin America and that the Soviet delegate directed that

\footnotetext{
${ }^{94}$ Dr. Cheddi Jagan, "Ban Against Messrs. Strachan and Smith Con't," October 3, 1952, David Dabydeen and Lynne Macedo, eds., Dr. Cheddi Jagan National Assembly Speeches, Volume 2: The Fourth Legislative Council January 1952-April 1953 (Published by the Caribbean Press for the Government of Guyana, 2011), 165-166; See also: Dr. Cheddi Jagan, "Ban Against Messrs. Strachan and Smith," October 2, 1952, Dabydeen and Macedo, eds., Dr. Cheddi Jagan National Assembly Speeches, Volume 2, 159-163.

${ }^{95}$ Jagan, The West on Trial, 122.

${ }^{96}$ J.Y. Mackenzie, Foreign Office to S.E.V. Luke, Esq., Colonial Office, January 2, 1952, CO 968-252, BNA.

97 "Survey of Communism in the West Indies, 1951," undated, CO 968-252, BNA. "History of the PPP," 1963, CJRC; Secretary of State for the Colonies to Parliament, "British Guiana: Suspension of the Constitution," October 1953, CO 859-772, BNA; Chase, A History of Trade Unionism in Guyana, 105.
} 
the WFTU provide unions in colonial and dependent territories more support. ${ }^{98}$ An AFL-CIO report on the conference claimed that the WFTU platform was part of Soviet policy designed to undermine the Truman administration's Point Four program. American labor leaders suggested that WFTU members inaccurately interpreted Point Four as an attempt to insert American technicians into key positions in developing economies to protect American investments and profits and secure access to raw materials. The American report suggests that WFTU delegates agreed to the organization of trade union conferences in Latin America in addition to the creation of a Colonial Department. ${ }^{99}$ Thus, British policymakers interpreted the WFTU conference as a threat to their control of colonial unions and American labor leaders explained WFTU programs as a direct threat to American foreign policy objectives.

Juxtaposing Shakoor's and Jagan's international activities in late-1951 offers an important reflection on the emerging conflict within the Guianese trade union movement. Guianese labor leaders advocated two irreconcilably opposed objectives and aggressively courted international support for their positions. Shakoor and the MPCA represented a reformist labor movement that sought to improve workers' conditions through negotiations within a capitalist system and his organization pursued integration into Western labor institutions to achieve that aim. Conversely, the Jagan-led left-coalition that made up the PPP advocated replacing the capitalist system and appealed for closer relations with the Eastern-bloc to advance their program. Significantly, Jagan's central role in the proceedings suggests that he was an

\footnotetext{
98 "The Interest of WFTU in Colonial and Dependent Countries,” January 2, 1952, CO 968-252, BNA.

99 "WFTU General Council Meeting in Berlin, Nov. 15-21, 1951, RG 18-International Affairs Department, Staff Files: George Delaney's Files, 1921-1957, WFTU, 1945-1952, GMMA. The Foreign Office was initially unclear on the formation of the Colonial Bureau, but considered Jagan's role in its establishment important when details were brought to light. See: Secretary of State for the Colonies to Parliament, "British Guiana: Suspension of the Constitution," October 1953, CO 859-772, BNA.
} 
important force behind the WFTU's increased involvement in colonial areas and Shakoor also requesting Western assistance.

The discussion between Mackenzie and S.E.V. Luke of the Colonial Office illuminated the British debate about the role the United States should play in the process. Mackenzie suggested to Luke that cooperation with the State Department and possibly Federal Bureau of Investigation (FBI) would be advisable to help confront perceived communist infiltration into colonial territories though the WFTU. ${ }^{100}$ Luke disagreed, suggesting that Mackenzie avoid consulting with the State Department in lieu of a meeting with John Shaw of the British Security Service. In Luke's analysis, there were a remarkably small number of local politicians who had communist contacts and sympathies given the economic condition of the region; however, even those who held communist views in British Guiana were not members of the Communist Party. $^{101}$

Christopher Andrew's authorized history of MI5, Defend the Realm, confirms the Colonial Office analysis of communism in British Guiana. Andrew notes that British intelligence agencies knew that Cheddi Jagan made contact with Soviet representatives in Washington D.C. in 1947 and maintained contact with the British Communist Party since 1948, but they carefully noted that no evidence suggested that Jagan's movement was directed from the outside. ${ }^{102}$ Two generally consistent themes throughout the 1950s and early 1960 are evident in this early exchange of views between the Foreign Office and Colonial Office regarding the WFTU in 1951. First, the Foreign Office encouraged greater collaboration with the United States to the chagrin of colonial officials who opposed such cooperation. Second, colonial officials explained

\footnotetext{
${ }^{100}$ J.Y. Mackenzie, Foreign Office to S.E.V. Luke, Esq., Colonial Office, January 2, 1952, CO 968-252, BNA.

${ }^{101}$ S.E.V. Luke, Colonial Office to J.Y. Macknezie, Foreign Office, January 15, 1952, CO 968-252, BNA.

${ }^{102}$ Christopher Andrew, Defend the Realm: The Authorized History of MI5 (New York: Alfred A. Knopf, 2009), 459-460.
} 
Guianese communism as a uniquely interpreted ideology pursued by local leaders and adapted to local conditions rather than an infiltration directed from the Soviet Union.

International maneuvering for control of labor relations in British Guiana continued in 1952 as discussions regarding the future of the colony continued to shift toward increased selfgovernment and eventual political independence. TUC reports show that British trade unionists' completed an initial program to supply equipment to the MPCA during the year. In June ORIT formed a Caribbean Division (CADORIT) discussed the previous year, with representation from the MPCA. ${ }^{103}$ MPCA General Secretary Sheik Shakoor served on CADORIT's administrative committee giving the reformist sugar workers' union a position of influence within the regional labor movement. At the same time Cheddi Jagan joined the Jamaican Marxist politician and labor leader Richard Hart in leading protests against the new organization. Jagan and Hart argued that CADORIT intentionally displaced the CLC to undermine trade union unity in the Caribbean. ${ }^{104}$

Guianese businessmen entered the fray when the Georgetown Chamber of Commerce President E.J. Haywood requested the establishment of an Employers Federation and Labor Relations Committee to serve as negotiating machinery under the premise that it would ensure industrial peace. Oliver Littleton, Secretary of State for the Colonies, denied the request on the grounds that British Guiana had satisfactory machinery for the resolution of industrial

\footnotetext{
${ }^{103}$ Handwritten Colonial Advisory Committee Note, July 11, 1952, West Indies, TUC I, 972/2, Box 40, Marjorie Nicholson Files, TUCLC; Caribbean Area Division of ORIT of the ICFTU: Information Bulletin No. 1," February 1953, RG 18-009: International Affairs Department, Staff Files: Serafino Romualdi's Files, 1945-1961, Caribbean Area, 1953-1956, GMMA.

${ }^{104}$ Luis J. Marcano, Secretary, CADORIT, “Report on CADORIT's Activities,” December 31, 1954, RG 18: International Affairs Department, Staff Files: George Delaney's Files, 1921-1957, Box 11, ORIT 3rd Congress, 1955, GMMA.
} 
disputes. ${ }^{105}$ On July 31 Jagan introduced a bill to the Legislative Council that called for new regulations to reduce jurisdictional disputes between competing unions based on United States and Canadian laws ensuring recognition to the organization with the majority membership. The motion aimed at giving the GIWU legislative backing to displace the MPCA and even though it failed, the proposal served as a template for PPP proposals in $1953 .{ }^{106}$

Jagan continued his efforts at facilitating connections between the Guianese labor movement and the Eastern-bloc in October when he engaged in a two-day debate in the Legislative Council regarding a Colonial Office ban on entrance into the colony of Billy Strachan and Ferdinand Smith, two communist Jamaican labor leaders. ${ }^{107}$ Colonial officials argued that Smith and Strachan's attempt to visit British Guiana proved that the WFTU implemented Jagan's proposal to increase regional activities since Smith was appointed to the World Secretariat of the WFTU and was chief of the organization's Colonial Bureau. ${ }^{108}$ The Colonial Office defended the ban on Smith and Strachan's as a response to attempted communist infiltration; however, it also served as a reaction against the emergence of inter-colonial labor organizing in the West Indies that fell outside of what British officials deemed acceptable trade unionism. The mutually pursued relationship between the WFTU and West Indian trade union leaders fueled colonial officials' fears of militant organizing and its connection to international communism. Ironically, the Colonial Office reports identified Jagan's proposal as the impetus for

\footnotetext{
${ }^{105}$ David Jones to Oliver Littleton, Secretary of State for the Colonies, November 4, 1952; Telegram from the Secretary of State for the Colonies to British Guiana, November 6, 1952; Telegram from British Guiana to the Secretary of State for the Colonies, November 8, 1952, CO 1031/922, BNA.

${ }^{106}$ George Woodcock Papers, "B.G. Constitution, 1954," handwritten note, British Guiana 972.8 (520), Box 44, Marjorie Nicholson Files, TUCLC; Dr. Cheddi Jagan, “Trade Unions Collective Bargaining," undated, Dabydeen and Macedo, eds., Dr. Cheddi Jagan National Assembly Speeches, Volume 2, 269-270.

${ }^{107}$ In addition to colonial officials allegations that Strachan and Smith were communists, Martin Carter and Brindley Benn, two key members of the left-wing within the PPP described the men as communists in their interviews with Frank Birbahlsingh. See: Birbalsingh, The People’s Progressive Party of Guyana 1950-1992, 54, 64.

${ }^{108}$ Secretary of State for the Colonies to Parliament, "British Guiana: Suspension of the Constitution," October 1953, CO 859-772, BNA.
} 
increased WFTU activity in the region while criticizing trade union organizing between three West Indian labor leaders as a form of external infiltration. ${ }^{109}$

Jagan's objection to the ban is significant because his defense of the men refuted the British claim that the WFTU was merely a communist-front organization and criticized the Legislative Council's financial support for Guianese unionists attending ICFTU meetings. Jagan contrasted the Council's treatment of Serafino Romualdi, an American citizen who traveled freely around British Guiana the previous year while representing ORIT, with the ban on WFTU representatives Strachan and Smith who were both British subjects. Jagan argued that the Legislative Council inhibited Guianese unionists' ability to develop their own institutions and join with the international organization they determined most directly acted in their interests while forcing an cooperation with organization that he claimed was controlled by the State Department. Moreover, he criticized the Legislature's refusal to overturn sugar estate bans on trade union organizers and suggested that the two issues evidenced a legal effort to impede workers' organization. $^{110}$

Thus, throughout 1952 Guianese employers and trade unionists introduced legislation to increase their ability to influence negotiating machinery when a new Constitution allowing for full internal self-government went into effect the following April. Meanwhile, reformist trade unionists continued their cooperation with the TUC, ICFTU, ORIT, and CADORIT. TUC support went to the unions willing to base their activities on British-approved trade union

\footnotetext{
${ }^{109}$ Secretary of State for the Colonies to Parliament, "British Guiana: Suspension of the Constitution," October 1953, CO 859-772, BNA.

${ }^{110}$ Dr. Cheddi Jagan, "Ban Against Messrs. Strachan and Smith,” October 2, 1952, Dabydeen and Macedo, eds., Dr. Cheddi Jagan National Assembly Speeches, Volume 2, 159-163; Dr. Cheddi Jagan, "Ban Against Messrs. Strachan and Smith Con't," October 3, 1952, Dabydeen and Macedo, eds., Dr. Cheddi Jagan National Assembly Speeches, Volume 2, 164-176.
} 
methods; however, the supplies and educational literature the TUC sent to the MPCA did not address the practical problems facing sugar workers.

At the same time, sugar companies continued to victimize workers organizing for the GIWU. Sugar companies evicted GIWU branch secretaries from company-owned housing during a 1952 strike for recognition, a practice that Sydney King, one of the PPP's early leaders, suggested was regularity during union protests. ${ }^{111}$ In summarizing his supporters' "fight for trade unionism" in 1953, Jagan argued that sugar companies continued to victimize workers hoping to align with the GIWU and GIWU activists between 1950 and 1953. He suggested that the GIWU lost members after 1950 despite popularity with sugar workers as a result of union leaders restriction from company property and workers' fear of being removed from company housing for supporting the union. ${ }^{112}$ TUC efforts to strengthen preferred Guianese unions complemented sugar companies' heavy-handed tactics which included exerting official influence to utilize police action against strikers. Together, British efforts aimed at strengthening trade unions willing to confine their activities to industrial matters, accept limited improvements to wages and conditions through collective bargaining, minimize agitation, and associate with the ICFTU rather than the WFTU.

\section{Institutional Decolonization during the PPP government}

The first phase of the struggle for institutional decolonization in British Guiana culminated in the period between April 27, 1953 when the PPP won eighteen of twenty-four seats in the House of Assembly in the colony's first election under the new Waddington Constitution, and October 8, 1953 when the British suspended the Constitution and re-imposed

\footnotetext{
${ }^{111}$ Sydney King, forward to Cheddi Jagan, "Waddington Constitution Exposed," 1952, CJRC.

112 "Excerpt from 'What Happened in British Guiana' by Cheddi Jagan,” British Guiana 972.8 (520), Box 44, Marjorie Nicholson Files, TUC Library, London Metropolitan University, London, England; Dr. Cheddi Jagan, "Venn Commission Report," undated, Dabydeen and Macedo, eds., Dr. Cheddi Jagan National Assembly Speeches, Volume 1, 310-312.
} 
direct rule in British Guiana. The Waddington Constitution granted universal suffrage to Guianese over the age of twenty-one and allowed internal self-government to the elected Guianese in a lower House of Assembly while reserving veto powers for the newly appointed governor, Alfred Savage. ${ }^{113}$ The constitution also created an upper house comprised of appointed as well as elected representatives designed to act as a check on the elected lower house.

Secretary of State for the Colonies Oliver Lyttleton warned that the composition of the Executive Council gave both ministers and unofficial members "styled as ministers" a great deal of influence over government business. At times, he suggested, situations could arise in which "a member's private business activities, his financial interest in particular companies or schemes, and his activities and interests as an official of a trade union" could conflict with public duties. ${ }^{114}$

Thus, despite the considerable progress toward self-government, PPP leaders noted the limits on democracy and the subtle ways the new constitution preserved colonial economic relationships. Sydney King and Cheddi Jagan criticized the document as "a changed form of oppression" that refused to countenance economic changes to the structure of Guianese society. King argued that the constitution was a "British lie" written "to fool the people into thinking that their elected representatives could now control the country."115 Jagan agreed with King because "a representative of Bookers sitting on the Executive Council with me, a representative of the people," will not "be framing a similar type of legislation." He further criticized the constitution for allowing the Colonial Secretary to oversee foreign trade, which he suggested gave colonial officials considerable influence to retain the colonial economic framework. ${ }^{116}$ Jagan's two-day

\footnotetext{
${ }^{113}$ Rabe, U.S. Intervention in British Guiana, 31-32.

${ }^{114}$ Appendix of report by Oliver Lyttleton filed in George Woodcock Papers, May 2, 1953, British Guiana 972.8 (520), Box 44, Marjorie Nicholson Files, TUC Library, London Metropolitan University, London.

${ }_{115}$ Sydney King, forward to Cheddi Jagan, "Waddington Constitution Exposed," 1952, CJRC.

${ }^{116}$ Text of Cheddi Jagan Speech on Adult Suffrage in Legislative Council, January 17, 1952, printed in Cheddi Jagan, "Waddington Constitution Exposed," 1952, CJRC.
} 
attack on the constitution in the Legislative Council revolved around his determination to wrest economic control of the colony as a means of directing development away from sending profits abroad and toward improving the lives of Guianese people through establishing a socialism in British Guiana. The Waddington Constitution reinforced to PPP leaders the need for institutional changes to shift the balance of power over Guianese economics.

At the same time, Colin Palmer notes that investors' fear of the PPP government weakened the colonial economy as depositors withdrew their holdings from the Government's Savings Bank. ${ }^{117}$ In response to the financial crisis, Savage explained to the PPP ministers that external economic assistance would be withheld if investors or international lending agencies thought the government was communist. ${ }^{118}$ Thus, while communism was the superficial threat, the subtext was that external financing of development was predicated on a degree of control over British Guiana's fiscal policies and political-economic structure. Investors would not invest in projects likely to lose money and businesses did not want to allocate resources likely to be nationalized. Left-wing PPP leaders argued that such concerns structurally constricted the freedom of action necessary for development in the interests of the Guianese people. Colonial Officials, tasked with establishing a stable, capitalist-oriented, and reasonably democratic society that would transition to independence as early as the mid-1950s interpreted the PPP's plans as a direct threat to each of their objectives. Jagan and King's criticisms of the constitution as an impediment to Guianese acquisition of economic power is the backdrop in which the leftcoalition sought to gain influence over the colony's economic structure through coordinated efforts between the GIWU and PPP toward institutional reconstruction of Guianese society.

\footnotetext{
${ }^{117}$ Palmer, Cheddi Jagan and the Politics of Power, 32-33.

${ }^{118}$ Palmer, Cheddi Jagan and the Politics of Power, 21, 32-33.
} 
The PPP won an overwhelming majority of seats in the April election despite the MPCA's aggressive anti-PPP campaign and several months of tangible gains negotiated for sugar workers through MPCA collective bargaining. Throughout early 1953 the MPCA issued election guides warning Guianese not to vote for PPP candidates while arguing that the leftcoalition party was acting out orders directed from the Soviet Union. The MPCA used Cheddi Jagan's participation in WFTU conferences as evidence to support the claim of PPP subordination to "Russian imperialist masters." MPCA election guides included crass personal slanders but directed most of their vitriol at the alleged devotion of PPP candidates subordinate to international Communists or naiveté that allowed them to be manipulated as part of an international conspiracy. ${ }^{119}$ After the PPP assumed office the GIWU applied for affiliation to the WFTU; however, the application was withdrawn as a result of political developments in Guiana in October. ${ }^{120}$ Importantly, MPCA campaign material and the public discourse surrounding the election influenced British and especially American interpretations of Guianese politics for the rest of the 1950s.

Political developments, however, comprised only a part of the broader struggle to shape the institutional nature of Guianese society and labor struggles centered on the debate continued throughout and after the campaign. MPCA leaders negotiated what Robert Alexander referred to as "some real gains" including \$3 million for sugar workers in late 1952 and an agreement that assured laborers most of the added profits from increased sugar prices in the United Kingdom in early 1953. MPCA President Lionel Luckhoo also participated in the first ICFTU World Congress for Plantation Workers negotiated wage increases for rice workers after he took over

\footnotetext{
1191953 Election Campaign Pamphlet issued by the MPCA, April 1953, British Guiana 972.8 (520), Box 44, Marjorie Nicholson Files, TUC Library, London Metropolitan University, London, England.

${ }^{120}$ Patrick Renison to British Ambassador to Washington D.C., September 19, 1957, FO 371-126078, BNA.
} 
the position in early $1953 .{ }^{121}$ Nonetheless, inflation offset the benefits of small advances in wage rates and the oppressive conditions under which workers labored in the colony remained unchanged. ${ }^{122}$ Shakoor and MPCA Vice-President Rupert Tello continued negotiations with the rice board arguing for modifications to the wage scale in June 1953 but eventually conceded that foul weather undermined crop production and precluded immediate changes to workers' pay. ${ }^{123}$ Minor work stoppages occurred in June and July before they were settled through government intervention. ${ }^{124}$ Thus, despite some gains, the colony's dire poverty left many workers discontented with the MPCA.

MPCA-negotiated improvements expanded beyond the agricultural sector as well. In June 1953 Justin Yee and Claude Archer of the Electrical Workers Branch of the MPCA noted negotiated improvements in their industry since 1950, including overtime pay; however, they explained to Alexander that they continued to face difficulties in organizing since employers refused to support a closed shop. Yee and Archer also hinted at future employer-MPCA collaboration to counter the PPP. The unionists suspected that employers regretted their dismissal of MPCA demands since workers responded with support for the PPP. Yee and Archer expected PPP agitation to increase with the introduction of legislation to demand recognition of new unions similar to the proposal Jagan introduced the previous year.

\footnotetext{
${ }^{121}$ Caribbean Area Division of ORIT of the ICFTU: Information Bulletin No. 1," February 1953, RG 18-009: International Affairs Department, Staff Files: Serafino Romualdi’s Files, 1945-1961, Caribbean Area, 1953-1956, GMMA; "Report on the First World Congress of Plantation Workers," March 13-14, 1953, RG 1-027, Office of the President-George Meany, 1948-1960, Box 49, Headquarters, 1951-1960, GMMA; Robert Alexander to Jay Lovestone, June 9, 1953, RG 18-003, International Affairs Department, Jay Lovestone Files, 1944-1973, Box 2, Alexander, Robert, 1953, GMMA.

${ }^{122}$ Alexander made note of the problem of inflation, but did not address the impact devalued money would have on the recently renegotiated wage rates. See: Robert Alexander to Jay Lovestone, June 9, 1953, RG 18-003, International Affairs Department, Jay Lovestone Files, 1944-1973, Box 2, Alexander, Robert, 1953, GMMA.

${ }^{123}$ Caribbean Area Division of ORIT Information Bulletin, June 1953, RG 18-009: IAD Staff Files, Serafino Romualdi’s Files, 1945-1961, Caribbean Area, 1953-1956, GMMA.

${ }^{124}$ Palmer, Cheddi Jagan and the Politics of Power, 33.
} 
Yee and Archers' opposition to the PPP's anticipated legislation is important. The MPCA's electrical union leaders suggested a bill recognizing new unions would lead to perpetual changing of bargaining agents and workers shifting union loyalties as new leaders made promises to encourage desertion from existing trade unions. Yee and Archer's fears mirrored TUC criticisms that Guianese labor unrest and the introduction of new unions weakened the institutional stability necessary for effective trade union negotiation with employers. MPCA-TUC reproaches discounted the possibility that a new union could effectively bargain and retain worker loyalty while highlighting the difficulty of retaining workers' support in a colony with deep poverty and little leverage with which to negotiate. ${ }^{125}$ Moreover, as Yee noted in an interview with Alexander the following year, many workers left the MPCA and joined the BGLU after the PPP won office. They hoped that affiliation with a union led by Ashton Chase, the PPP Minister of Labor would prove effective at obtaining the check-off where MPCA efforts had failed. ${ }^{126}$ Thus, as the PPP established itself in office, it became clear that the primary issue facing Guianese society was addressing the question of worker representation, especially on the sugar estates.

Beyond domestic issues, the PPP's election gave pro-WFTU trade unionists an opportunity to increase overt connections to the Eastern-bloc international and in early 1953 the PPP sent delegates to the Vienna Convention of the WFTU. ${ }^{127}$ The Legislative Council passed a subversive literature ban on February 27, 1953, two months before the elections to block WFTU literature from entering British Guiana; however, Cheddi Jagan arranged for materials to

\footnotetext{
${ }^{125}$ Robert Alexander interview with J. Yee and Claude Archer, President Electrical Workers Branch of MPCA, June 3, 1953, RG 18-003, International Affairs Department, Jay Lovestone Files, 1944-1973, Box 2, Alexander, Robert, 1953, GMMA.

${ }^{126}$ Robert Alexander interview with J. Yee, President Demerara Electric Company Branch of MPCA, June 29, 1954, RG 18-003, International Affairs Department, Jay Lovestone Files, 1944-1973, Box 2, Alexander, Robert, 1954, GMMA.

${ }^{127}$ Chase, A History of Trade Unionism in Guyana, 105.
} 
continue to be sent secretly into the colony through early $1953 .{ }^{128}$ It is unclear the extent to which the bill inhibited PPP-WFTU correspondence; however, British intelligence concluded that the PPP was no longer receiving WFTU material in mid-May. Nonetheless, British intelligence sources expected that the WFTU was preparing to send new supplies in the wake of the PPP's electoral victory and the PPP government moved to repeal the ban on subversive literature once in office. ${ }^{129}$

WFTU involvement in British Guiana went beyond the distribution of literature. Colonial officials accused Eric Huntley, a member of the PPP General Council and postal worker with connections to the WFTU, of authoring a controversial memorandum on British Guiana farm workers in the United States and distributing “communist literature." Huntley's political organizing and his participation in a protest during Princess Mary’s visit to British Guiana resulted in the decision to remove him from his civil service position. Governor Savage orchestrated Huntley's firing after he was absent without leave for two days to participate in PPP organizing on sugar estates. ${ }^{130}$ In response, WFTU General Secretary Willi Baumgart wrote a letter of protest to the Guianese Postmaster General in April 1953 criticizing the decision to cause Huntley to "lose his base of existence" for engaging in "a primary democratic right of freely asserting his opinion." ${ }^{131}$ The WFTU affiliated Trades Union International of the Postal, Telegraph, Telephone and Radio Workers followed with the submission of a complaint to the

\footnotetext{
${ }^{128}$ Dave Goodman, Circulation Department, WFTU to Cheddi Jagan, February 5, 1953, KV2-3604, BNA; Dave Goodman, Circulation Department, WFTU to Cheddi Jagan, March 17, 1953, KV2-3604, BNA.

${ }^{129}$ Intercepted Telegram from Communist Party Headquarters, London to Cheddi Jagan, May 4, 1953, KV2-3604, BNA.

${ }^{130}$ Alfred Savage to Oliver Lyttleton, December 22, 1953, CO 859-772, BNA.

${ }^{131}$ Willi Baumgart, General Secretary, WFTU to Postmaster General, Georgetown, British Guiana, April 30, 1953 , CO 859-772, BNA.
} 
Director General of the ILO in August. ${ }^{132}$ Huntley's case is further evidence of the developing relationship between the left-coalition and the WFTU.

American labor leaders sent Alexander to British Guiana in the wake of the PPP's victory fearing the possibility that communists where in the process of taking control of a British colony. Alexander's studies and AFL analyses played an important role in shaping American views on British Guiana after the State Department closed the United States consulate in Georgetown in early 1953 content to save money. Thereafter, Washington officials obtained information on British Guiana from the consul in Trinidad. ${ }^{133}$ Alexander's letter to Jay Lovestone summarizing his findings drew several important conclusions. Alexander informed Lovestone that the MPCA was "our organization" in contrast to the BGLU and FUGE which associated with the WFTU and the PPP. The Jagans, Alexander suggested, were communists but the PPP was not a disciplined Communist Party. Alexander concluded that the State Department's decision to remove the Consulate was "suicidal" given the dire situation in a key area of the Caribbean and that Lovestone should discuss the situation with the State Department, which Stephen Rabe notes Lovestone apparently did. Alexander also noted that he hoped to see the Assistant Secretary of Latin American Affairs when he returned. ${ }^{134}$

The closing of the consulate directly impacted the MPCA since Guianese labor leaders opposed to the PPP used the office of the Vice Consul to obtain information about Janet Jagan's past in the United States and to obtain educational films for the MPCA library. The lost connection likely contributed to Alexander's suggestion that the ICFTU should increase financial

\footnotetext{
132 “Observations of the United Kingdom Government on a Complaint by the Trades Union International of the Postal, Telegraph, Telephone and Radio Workers Concerning Alleged Infringement of Trade Union Rights in British Guiana, undated, CO 859-772, BNA.

${ }^{133}$ Robert Alexander to Jay Lovestone, June 9, 1953, RG 18-003, International Affairs Department, Jay Lovestone Files, 1944-1973, Box 2, Alexander, Robert, 1953, GMMA.

${ }^{134}$ Ibid; Rabe, U.S. Intervention in British Guiana, 38. For more on Alexander's criticism of the withdrawal of the Consulate, see: Robert Alexander, "What's Wrong with US Policy in Latin America," undated, RG 18-003, International Affairs Department, Jay Lovestone Files, 1944-1973, Alexander, Robert, 1953, GMMA.
} 
support for the MPCA. ${ }^{135}$ Alexander reinforced Eliazer's conclusion from 1951 that the MPCA's organizational difficulties derived from financial weakness. He suggested that MPCA leaders risked losing their recently purchased car due to the ICFTU's failure to provide promised funds to pay for it. Without the automobile, Alexander noted, MPCA leaders organizational efforts would be severely restricted. ${ }^{136}$ Alexander's final conclusion is significant since it suggests ORIT and ICFTU assistance to affiliated Guianese unions was limited in the early 1950s and MPCA leaders viewed American labor representatives as a conduit through which they could obtain material resources.

Alexander compiled a series of interviews in June 1953, and an examination of several of those conversations helps explain the prism through which American labor leaders understood British Guiana's trade union conflict and its relationship to political development in the colony throughout the 1950s and early 1960s. Rupert Tello, Vice President of the MCPA, emphasized his commitment to free enterprise and an opposition to the GIWU, which he suggested was able to call frequent walk-off strikes because it did not pay strike benefits. If Tello's criticism is accurate it belies the fact that the GIWU compelled sugar workers cooperation without always being able to offer financial incentives and therefore that the GIWU was, as it claimed, supported more than the MPCA among sugar workers. ${ }^{137}$ Moreover, Tello's statement confirmed to Alexander that the MPCA was committed to perpetuating the free market capitalism that American labor leaders were hoping to spread as part of their version of institutional decolonization in British Guiana.

\footnotetext{
${ }^{135}$ Robert Alexander interview with Sheikh Shakoor, June 4, 1953, RG 18-003, International Affairs Department, Jay Lovestone Files, 1944-1973, Box 2, Alexander, Robert, 1953, GMMA.

${ }^{136}$ Robert Alexander, "What's Wrong with US Policy in Latin America," undated, RG 18-003, International Affairs Department, Jay Lovestone Files, 1944-1973, Alexander, Robert, 1953, GMMA; Robert Alexander interview with Sheikh Shakoor, June 4, 1953, RG 18-003, International Affairs Department, Jay Lovestone Files, 1944-1973, Box 2, Alexander, Robert, 1953, GMMA.

${ }^{137}$ Robert Alexander interview with Rupert Tello, June 4, 1953, RG 18-003, International Affairs Department, Jay Lovestone Files, 1944-1973, Box 2, Alexander, Robert, 1953, GMMA.
} 
Conversely, Cheddi Jagan expressed to Alexander a hesitation to foreign development projects and argued that the Guianese should consider the possibility of establishing a planned economy similar to the Soviet Union. Jagan referenced a recent UN report to suggest that the Soviet Union's development outpaced that of capitalist democracies. Jagan noted that the PPP did not plan immediate nationalization but suggested that the party would consider nationalization of sugar and bauxite if such a policy seemed beneficial in the future. He further criticized the ICFTU's attempts to remove WFTU affiliated organizations from the CLC, to which the PPP belonged. ${ }^{138}$ Jagan did not claim to be a communist; however, his articulation of an economic development plan and international labor relations suggested that the direction in which the PPP planned to take the colony conflicted with American labor leaders' regional objectives

GIWU President J.P. Lachmansingh told Alexander that the PPP government, in which he was a minister, had an international position best understood in trade union terms. The government, he suggested, "sympathized more with the WFTU than with the ICFTU" though it received no funding from either organization and had loyalties only to British Guiana. Lachmansingh further noted that the GIWU was not opposed to working with the ICFTU; however, he suggested that when the ICFTU had come to British Guiana, they never met with him. ${ }^{139}$ Ashton Chase's work on Guianese unionism supports Lachmansingh's position and suggests that PPP leaders "supported the point of view that in the interest of unity the unions should avoid affiliating to either the WFTU or the ICFTU" so that they could be more flexible

\footnotetext{
${ }^{138}$ Robert Alexander interview with Cheddi Jagan, June 5, 1953, RG 18-003, International Affairs Department, Jay Lovestone Files, 1944-1973, Box 2, Alexander, Robert, 1953, GMMA.

${ }^{139}$ Robert Alexander interview with Dr. Latchmansingh, June 4, 1953, RG 18-003, International Affairs Department, Jay Lovestone Files, 1944-1973, Box 2, Alexander, Robert, 1953, GMMA
} 
and "willing to accept aid from both."" 140 The possibility of GIWU cooperation with the ICFTU is unclear. Eliazer claimed to have met with Lachmansingh for four hours during his ORIT visit in 1951 contrary to Lachmansingh's suggestion that ORIT and ICFTU officials ignored his organization. More importantly, it is uncertain whether Lachmansingh and the GIWU would or could have cooperated with the ICFTU and ORIT given their connection to the PPP, whose goals were incompatible with the purpose of the Western labor organizations. Chase and Lachmansingh represented the center-left part of the PPP's left-coalition and evidence suggests that the party's left-wing wielded considerably more influence in 1953.

In Alexander's interview with Hubert Critchlow, Critchlow suggested that the PPP refused to pay his pension if he spoke against the Party. ${ }^{141}$ The conflict between Critchlow and the Jagans ran deeper than mere ideological positions and reached back to a 1945 debate on universal suffrage which political scientist David Hinds suggests was undermined by ethnic rivalries. Critchlow opposed universal suffrage which would have given the East Indian population an electoral majority since and altered political influence in the colony since most East Indians remained disenfranchised in the mid-1940s. ${ }^{142}$ The extent to which Alexander understood the complexities of Guianese politics is unclear; however, his conclusions were confident and carried considerable weight among American labor leaders assessing policy toward British Guiana. Critchlow's assertion in particular convinced American labor leaders that the PPP sought to subvert trade unions' independence to pave the way for authoritarian forms of government. Thus, Alexander's interview with the founder of British Guiana's first trade union reinforced American labor leaders' views that the PPP sought to destroy free labor.

\footnotetext{
${ }^{140}$ Chase, A History of Trade Unionism in Guyana, 213.

${ }^{141}$ Robert Alexander interview with Hubert Critchlow, June 4, 1953, RG 18-003, International Affairs Department, Jay Lovestone Files, 1944-1973, Box 2, Alexander, Robert, 1953, GMMA

${ }^{142}$ David Hinds, Ethno-Politics and Power Sharing in Guyana: History and Discourse (Washington, D.C.: New Academia Publishing, 2011), 3.
} 
Finally Alexander turned to Commissioner of Labor William Bissell for an evaluation of Guianese labor relations. Bissell suggested that workers failed to appreciate the usefulness of organized labor unconnected to the Legislative Assembly and that as a result pro-government unions undermined the MPCA. He emphasized the need to build unions and the machinery for collective bargaining and also suggested, in what is a revealing expression of colonial thought, that Guianese workers had a tendency for dependence on government in the same way masters had previous cared for slaves or indentured servants. ${ }^{143}$ Bissell, the colonial authority on Guianese organized labor, confirmed to American labor leaders that establishing an institutional framework for post-colonial Guiana depended on active efforts to support the MPCA against more popular unions acting in collaboration with the PPP.

\section{Labor Conflict and the Suspension of the Waddington Constitution}

The PPP continued advocating the introduction of trade union methods designed to aid Guiana's transition to socialism throughout the summer of 1953 while the TUC prepared to further its assistance to affiliated unions in the colony. In a speech to the World Congress of Women in Copenhagen in June, excerpted in the PPP's periodical Thunder, Janet Jagan took care to note the lessons she learned from trade unionists during a visit to Rumania, specifically the "difference in the functions of trade unions existing in capitalist countries and those in the socialist countries." 144 The following month she further explained the benefits of Rumanian socialism and contrasted the shocking differences between workers' standard of living in the socialist republic with that of workers in British Guiana. ${ }^{145}$ Perhaps taking note of Jagan's

\footnotetext{
${ }^{143}$ Robert Alexander interview with William Bissell, June 5, 1953, RG 18-003, International Affairs Department, Jay Lovestone Files, 1944-1973, Box 2, Alexander, Robert, 1953, GMMA.

${ }^{144}$ Janet Jagan, “The Rights of Workers in the People's Republic of Rumania,” Thunder, July 1953, CJRC.

${ }^{145}$ Janet Jagan, “Apprenticeship in Rumania,” Thunder, August 1953, CJRC.
} 
writing the TUC allocated $\$ 3,000$ toward an organizing campaign in British Guiana in July, though the money seems not to have been disseminated in the colony. ${ }^{146}$

Colin Palmer's Cheddi Jagan and the Politics of Power provides the most detailed explanation of negotiations and conflict between the SPA, GIWU, and PPP between June and October 1953. Palmer notes that on June 13, Aston Chase, the PPP Minister of Labor, met with W.A. Macnie, managing director for the SPA and recommended that the SPA recognize the GIWU, claiming that his office was overwhelmed with complaints from sugar workers who distrusted MPCA leadership. J.P. Lachmansingh, GIWU President and PPP Minister of Health, met informally with Macnie on July 13, warning him that some PPP and GIWU leaders hoped to gain recognition through industrial action rather than negotiation even though Lachmansingh opposed that strategy. On July 20 the SPA's board of directors agreed that recognition of a PPP sponsored union was inevitable, though they preferred an "amalgamation" of the MPCA and GIWU similar to the policy Bissell suggested consistently since 1945. On July 21, Chase formally requested recognition of the GIWU apparently disregarding the suggestion of combining the MPCA and GIWU, a request the SPA responded to on August 20. Palmer suggests that the SPA's response included a reassertion of the demand for amalgamation. ${ }^{147}$ Clem Seecharan argues that the SPA proposal agreed to recognize the GIWU the field workers who made up the majority of the plantation workforce with the understanding that the MPCA would continue to represent sugar factory workers. ${ }^{148}$

\footnotetext{
${ }^{146}$ In the TUC report, money that was distributed to Caribbean unions specified the unions to which funds were directed. The reference to British Guiana offers only that funds were allocated. See: Vincent Tewson, "Statement on British Guiana," September 6, 1954, Report of the 86th Annual Trades Union Congress, September 6-10, 1954, TUC History Online, 232, http://www.unionhistory.info/britainatwork/emuweb/objects/nofdigi/tuc/imagedisplay.php?irn=6013468\&reftable=e catalogue\&refirn=6013481, Last Accessed July 12, 2015.

${ }^{147}$ Palmer, Cheddi Jagan and the Politics of Power, 34-35.

${ }^{148}$ Seecharan, Sweetening 'Bitter Sugar', 218.
} 
While the SPA, PPP, and GIWU discussed the representation of sugar workers throughout the summer, British officials monitored developments in the colony. In July 1953 W.H. Ingrams, Advisor on Overseas Information sent a top secret report to J.H. Peck in which he described the political situation in British Guiana. Ingrams argued that the PPP program was extremely left-wing in a manner that would be "acceptable to Communist tactics and ideology," but that the Party did not openly advocate communism, unity with the Soviet Union to progress toward socialism, or even secession from the Commonwealth. However, based on Jagan's Legislative Council speeches Ingrams expected the PPP to advocate for immediate selfgovernment, secession from the Commonwealth, and close relations with the Soviet Union as time passed and the Party failed to achieve its objectives. While commending the achievements of institution-building in British Guiana, Ingrams suggested that the Jagans and the PPP exerted considerable influence over a number of important unions, including the colonial trade union center BGTUC, giving the communist voice "fairly effective control in the major trade unions." He concluded that covert activities were "inevitable in the interests of the people themselves quite as much as in ours" and that "if we believe in the necessity and rightness of guiding people to self-government, we must also believe in the rightness of establishing as firmly as we can the way of life which we consider valuable as offering in the long run the best sort of life to the individual.” Ingrams's recommendations included assisting trade unions and developing a covert front organization to combat Guianese communism. ${ }^{149}$

British intelligence reports disagreed on the extent of communism in British Guiana, though the Special Branch (MI5) emphasized that the PPP's international communist contacts suggested a communist core at the center of the PPP. MI5 reports noted foreign newspaper

\footnotetext{
${ }^{149}$ W.H. Ingrams to J.H. Peck, "Information Work in British Guiana in the Light of the Communist Threat," July 13, 1953, CO 1027-14, BNA.
} 
articles suggesting that Janet Jagan was a Moscow-trained agent and intercepted letters from Caribbean Communists, such as Desmond Buckle, congratulating the Jagans on establishing a communist government in $1953 .{ }^{150}$ British intelligence reports determined that the PPP was divided into communist and non-communist leadership severely strained along ideological lines. A May 1953 report from the Security Liaison Office in Jamaica to the Director General of MI5 divided the PPP into "Communist" and "Moderate "self-government"” sections that hinted at the possibility of manipulating ideological differences within the Guianese leadership to establish a government amenable to British objectives. ${ }^{151}$ The contents of the report drew from information from the commissioner of police in British Guiana. The account formed the basis of the Colonial Office interpretation of Guianese leaders until the late 1950s, and Foreign Office and American views into the 1960s. ${ }^{152}$ On July 7 the Secret Intelligence Service (SIS) informed Governor Savage that a message from Sydney King to the WFTU confirmed his collaboration with international communists and in mid-July colonial officials agreed that it might be necessary to suspend the constitution. ${ }^{153}$

In a report titled "Propaganda and Special Operations in British Guiana," Ingrams acknowledged that Soviet communist connections were incidental and that anti-communist programs needed to be designed to meet domestic challenges. He suggested that the most effective program of "political warfare" against domestic "political extremism" would be to find

\footnotetext{
${ }^{150}$ Letter to M.J.E. Bagot, MI5, May 29, 1953, KV2-3604, BNA; Intercepted letter from Desmond Buckle to Cheddi Jagan, May 21, 1953, Letter to M.J.E. Bagot, MI5, May 29, 1953, KV2-3604, BNA.

${ }^{151}$ Security Liaison Officer to Director General, May 22, 1953, Letter to M.J.E. Bagot, MI5, May 29, 1953, KV23604 , BNA. The officer's analysis is very similar, though not entirely identical to the explanations of the PPP's ideological orientation provided in Birbalsingh's oral history of the PPP.

152 [British Guiana]: intelligence report for April 1953 by WA Orrett, Commissioner of Policy, British Guiana, on the general election and the prospects for internal security [Extract], May 5, 1953, CO 1031/128, no 22, BDEEP.

${ }^{153}$ Mawby, Ordering Independence, 88; [British Guiana]: minute by JW Vernon, Principal, CO, West Indian Dept 'B', on the justification for intervention to remove the PPP government, September 16, 1953, CO 1031/119, BDEEP. The Special Branch, or MI5, was responsible for security within the United Kingdom. See: mi5.gov.uk. Last Accessed, July 20, 2015. The SIS, or MI6, was responsible for accumulating foreign intelligence for the British government. See: sis.gov.uk, Last Accessed, July 20, 2015. Thus, the correspondence between the PPP and suspect agencies in the United Kingdom triggered surveillance from both British intelligence agencies.
} 
and exploit the ideological line that divided the members of the PPP and launch a propaganda campaign designed to "meet the threat of British Guiana falling under Communist influence or control." 154 Ingrams suggested that the program "might be used for advising and guiding any non-governmental operations." Since the MPCA did not conform to PPP policy, Ingrams advocated increased support for the MPCA, which he noted was affiliated to ORIT and the ICFTU "with no practical advantage to be gained" from the relationship. He argued that "what is really necessary is that the British TUC itself should take a much more direct interest in the Caribbean Trade Unions." Ingrams's emphasized that "If there is scope for organizing trade unions or for guiding existing unions it seems highly desirable to try to interest TUC direct (and not via ICFTU) from inside the colony." 155 Thus, in July 1953 British intelligence officials began planning to use the MPCA as a weapon in a program of political warfare against the GIWU and PPP.

Colonial governor Alfred Savage agreed with Ingrams's "penetrating analysis of the background situation" in British Guiana, though he suggested that Ingrams underestimated the PPP's efforts to subvert the Constitution and some specific leaders use of their position to “further the Communist cause in every way possible." ${ }^{156}$ R.H. Young, an Assistant Public Relations Adviser in the Colonial Office, wrote to Savage on August 27 emphasizing that the most effective way to counter communist infiltration was a program designed to convince colonists of the benefits of affiliation with Great Britain rather than to attack Communism since few Guianese leaders admitted to being communists. ${ }^{157}$ Young's suggestions hinted at the

\footnotetext{
${ }^{154}$ W.H. Ingrams to J.H. Peck, “Propaganda and Special Operations in British Guiana,” July 13, 1953, CO 1027-14, BNA.

${ }^{155}$ W.H. Ingrams to J.H. Peck, “Propaganda and Special Operations in British Guiana,” July 13, 1953, CO 1027-14, BNA.

${ }^{156}$ Alfred Savage to Colonial Office, August 24, 1953, CO 1027-14, BNA.

${ }^{157}$ R.H. Young to Alfred Savage, August 27, 1953, CO 1027-14, BNA.
} 
possibility of building political opposition within British Guiana, though the most direct means of offering political resistance to the PPP and simultaneously convincing the Guianese of the practical benefits of maintaining relations with Great Britain was through the pro-British trade unions. Labor unrest erupted two days after Young's telegram before Savage could implement a program to counter the PPP. Meanwhile, William Maddox, the American Consul in Port-ofSpain, Trinidad, reported to the State Department on July 30 that exploitation of differences of ideological viewpoints within the PPP was a development that "will be watched closely," particularly the schism between Forbes Burnham and PPP leadership. ${ }^{158}$

Maddox's assessment confirmed Robert Alexander's conclusion that the disagreement between Burnham and Jagan may be "the rock upon which the bark of the PPP splits.",159 Maddox's report was an evaluation of PPP efforts to reform the secondary educational system that is outside the scope of this dissertation; nonetheless, brief attention to his criticism of the program is illuminating. Maddox discussed the "well-known" communist tendencies of leading Party members, specifically Brindley Benn, as well as the incorporation of Eastern European publications in Guianese schools. More telling, however, is Maddox's conclusion that "the prescription of a Government-approved text-book for a course in Civics will ensure that young students receive inculcation in P.P.P. doctrines - nationalist, anti-imperialist, and socialist, even when not communist." ${ }^{160}$ Alfred Savage expressed a similar fear that "the foundations of society are being attacked insidiously almost without check," specifically criticizing the establishment of

\footnotetext{
${ }^{158}$ William Maddox to Department of State, July 30, 1953, 841D.43/7-5053, Central Decimal Files, Box 4814, RG 59, NARA II.

${ }^{159}$ Robert Alexander to Jay Lovestone, June 9, 1953, RG 18-003, International Affairs Department, Jay Lovestone Files, 1944-1973, Box 2, Alexander, Robert, 1953, GMMA.

${ }^{160}$ William Maddox to Department of State, July 30, 1953, 841D.43/7-5053, Central Decimal Files, Box 4814, RG 59, NARA II.
} 
a Pioneer Youth Movement as a PPP alternative to the Boy Scouts, Girl Guides, and YMCA. ${ }^{161}$ Thus, a great deal of Anglo-American opposition to the PPP derived from a general hesitation toward the decolonization of Guianese institutions in a manner that challenged Anglo-American objectives with potential economic socialization and international communist associations the most aggressive forms of institutional reorganization. PPP leaders noted this dynamic in a pamphlet entitled "History of the PPP" which suggested that the labor bill and educational reforms were the two issues that most angered "the former ruling clique.",162

Thus by late-August 1953 the PPP increasingly pressured for the establishment of a reorganized system of labor relations based on party-led trade unions that could assist in moving toward the establishment of socialism in the colony. British officials from several agencies watched uneasily considering how they might act to strengthen the institutions designed to counter social revolution in British Guiana. In this context of labor unrest and conflict between the colonial administration, British economic interests, and Guianese nationalists for control of the institutions of organized labor, the left-coalition of Guianese leaders began an aggressive push in August 1953 that coordinated industrial protest and legislative action in an attempt to break the labor movement from external control.

On August 31, the GIWU called a strike, the goals of which were initially unclear and not negotiated prior to the walk-off. Participants and scholars struggled to explain the GIWU's motives; however, they generally agree that Sydney King, the PPP Minister for Communications and Works, attended a GIWU meeting on August 30 and played a central role in initiating the

\footnotetext{
${ }^{161}$ [British Guiana]: letter from Sir A Savage to Sir T Lloyd on the PPP government and the economic situation. Enclosure: notes by the governor, September 13, 1953, CO 1031/119, no 27, BDEEP.

162 "History of the PPP," January 1963, CJRC.
} 
strike. ${ }^{163}$ King occupied an important position within the PPP as one of the most left-leaning party members and an acknowledged communist. Clem Seecharan suggests that after speaking with King the only logical explanation behind his actions seemed to be as a means of keeping the PPP focused on the class struggle at a time when racial issues threatened to undermine the party's unity. Seecharan also suggests that King's instigation of the strike may have been an effort to continue waging a struggle against the institutional framework of colonial capitalism. ${ }^{164}$ The SPA accused the strike of being politically motivated since negotiations with Chase toward a settlement were ongoing and it is noteworthy that Chase criticized the decision to strike as illconceived "extreme left-adventurism" within the PPP in a 1994 book. ${ }^{165}$ Colin Palmer suggests that GIWU leaders' decision resulted from overconfidence that they could force a showdown to win their demands without compromising because they had PPP support. ${ }^{166}$ In response, the SPA immediately began mobilizing opposition to the strike in British Guiana and London through the West India Committee while refusing Savage's request that the sugar producers resume the scuttled negotiations with Chase. ${ }^{167}$

According to Ashton Chase, strike leaders articulated two goals, better wages and working conditions for Guianese workers and unconditional recognition of the GIWU for all

\footnotetext{
${ }^{163}$ Despres, Cultural Pluralism and Nationalist Politics in British Guiana, 208; Palmer, Cheddi Jagan and the Politics of Power, 35.

${ }^{164}$ Seecharan, Sweetening 'Bitter Sugar', 219-220.

165 Ashton Chase, Guyana a Nation in Transit: Burnham's Role (Guyana: Ashton Chase, 1994), 11. In an interview with Frank Birbalsingh Chase described the PPP program in 1953 as an "amateurish" attempt to "jump straight from colonialism to communism." See: Birbalsingh, The People's Progressive Party of Guyana 1950-1992, 44. Eric Huntley also criticized the decision to strike in a 1994 interview. Huntley suggests that the PPP's continued involvement in trade union affairs after its election, particularly its actions leading the 1953 strike, stood in contrast to the relationship between trade unions and politics in the rest of the British Caribbean colonies. See: Birbalsingh, The People's Progressive Party of Guyana 1950-1992, 75.

${ }^{166}$ Palmer, Cheddi Jagan and the Politics of Power, 35.

${ }^{167}$ [British Guiana]: outward telegram no 21 from Mr. Lyttleton to Sir A Savage on intervention to remove the PPP government and the introduction of emergency powers, September 24, 1953, CO 1031/119, no 29, BDEEP; Palmer, Cheddi Jagan and the Politics of Power, 36.
} 
field and factory workers formerly represented by the MPCA in mid-September. ${ }^{168}$ Palmer, however, suggests that the GIWU did not include recognition in its initial list of demands when they were presented on September 5, though he acknowledges it was clearly the central issue. William Christensen of the State Department's Office of British Commonwealth and Northern European Affairs cabled his superior, Hayden Raynor, on September 18 and noted that PPP ministers offered different reasons for the strike. According to Christensen, Lachmansingh suggested the strike was for recognition while King insisted it was a disagreement over working conditions. ${ }^{169}$ Colonial Office and State Department officials expressed considerable suspicion that the PPP instigated the strike as a means of subverting the Waddington Constitution as a result of the union's uncertainty over the purpose of a strike called with active negotiations and tentative compromises underway. ${ }^{170}$

Meanwhile, the MPCA did not comment on the unrest until September 17 when they criticized GIWU failure to follow trade union procedures and for encouraging disorder. ${ }^{171}$ MPCA leaders defended their previous collective bargaining agreements arguing that the sugar industry could not sustain more drastic wage increases and criticized the strike as a blatant effort for recognition of a rival organization. Maddox reported on the MPCA position to the State Department in mid-September and noted his worry over the involvement of GIWU leaders who

\footnotetext{
${ }^{168}$ Chase, A History of Trade Unionism in Guyana 1900 to 1961, 208.

${ }^{169}$ William Christensen to Hayden Raynor, September 18, 1953, 841D.062/9-1853, Central Decimal Files, Box 4814, RG 59, NARA II; William Maddox to Department of State, September 10, 1953, 841D.062/9-1853, Central Decimal Files, Box 4814, RG 59, NARA II.

${ }^{170}$ Most scholars disagree that the PPP actively sought to undermine the Waddington Constitution; however, Seecharan suggests that likely was one of the party's objectives. See: Seecharan, Sweetening 'Bitter Sugar', 207$232,556$.

${ }^{171}$ William Maddox to Department of State, September 25, 1953, 841D.062/9-2353, Central Decimal Files, Box 4814, RG 59, NARA II.
} 
were also ministers in the PPP government. ${ }^{172}$ Palmer notes that Savage's efforts to end the strike failed because of PPP-GIWU collaboration in forcing the issue of unqualified recognition and the SPA's refusal to concede to GIWU demands until the strike was ended. ${ }^{173} \mathrm{He}$ suggests that GIWU tactics, particularly initiating the strike while negotiations were ongoing, divided the PPP since some party leaders, including Chase and Lachmansingh disagreed with the strike. Moreover, Palmer suggests that the turmoil and the union's inconsistent explanations for the strike convinced domestic opponents that the strike was communist inspired and not based on trade union issues. ${ }^{174}$

Colonial officials concluded in mid-September that the constitutional suspension they began discussing in July was necessary since "an important section of the People's Progressive Party" was "trying to turn the territory into a Republic completely independent of the United Kingdom with a Communist political bias and leaning towards Russia rather than the West in international affairs." J.W. Vernon of the Colonial Office argued that the PPP was "increasing their hold over labor through the trade unions they control" to achieve their subversive objective and he elaborated on possible justifications for suspension while acknowledging that the action itself was undemocratic. Vernon suggested that intervention could be justified based on five broad ideas. First he suggested that financial consequences derived from the PPP's economic policy justified colonial intervention to "protect them from their own folly." Second, Vernon suggested that PPP policies obstructed raw material exports and thus were an international issue requiring the governor to intervene. Third, he suggested that British failure to act would encourage "communism in other B.W.I. territories would have serious repercussions." Forth, he

\footnotetext{
${ }^{172}$ William Christensen to Hayden Raynor, September 18, 1953, 841D.062/9-1853, Central Decimal Files, Box 4814, RG 59, NARA II; William Maddox to Department of State, September 10, 1953, 841D.062/9-1853, Central Decimal Files, Box 4814, RG 59, NARA II.

${ }^{173}$ Palmer, Cheddi Jagan and the Politics of Power, 36-37.

${ }^{174}$ Palmer, Cheddi Jagan and the Politics of Power, 42-43.
} 
argued that "the appearance of an overtly communist regime in British Guiana and its use as a communist centre would embarrass the U.K." and inhibit relations with the United States and in the Western Hemisphere. Finally, Vernon insisted that the establishment of a communist government would undermine "law, order, justice and democratic rights as we know them." Vernon concluded that the sugar strike "may well provide an opportunity" to justify suspension of the constitution and that "there can be no doubt any such opportunity should be vigorously seized." Failure to intervene, he argued, would make it "necessary to take action on a matter which is trivial in itself but which is felt to be the 'sticking point' beyond which Ministers cannot be allowed to go."175 Thus, the Colonial Office began searching for an incident to justify the PPP's removal and the re-imposition of direct rule in British Guiana as PPP efforts gain control of institutionalized labor peaked in intensity.

On September 22, several other unions joined the sugar workers walking off of their jobs in sympathy strikes while Savage worried that the protests would continue to spread to workers in other occupations throughout the colony. ${ }^{176}$ Significantly, Cheddi Jagan, Chief Minister of the government and head of the PPP, and Forbes Burnham, the second highest-ranking member of the party, led the sympathy strikers. Writing from Trinidad, however, Maddox noted that "Reports generally agree that large numbers of sugar workers had to be threatened and cajoled to join the strike." ${ }^{177}$ Most Guianese news sources during the early 1950s were financed by sugar companies or the PPP and the objectivity of reports making it out of the colony is open to question; however, American policymakers depended on Guianese news sources since there was no consul in British Guiana and British officials often intentionally offered only limited

\footnotetext{
${ }^{175}$ [British Guiana]: minute by JW Vernon, Principal, CO, West Indian Dept 'B', on the justification for intervention to remove the PPP government, September 16, 1953, CO 1031/119, BDEEP.

${ }^{176}$ Horne, Cold War in a Hot Zone, 184.

${ }^{177}$ William Maddox to Department of State, September 23, 1953, 841D.062/9-2353, Central Decimal Files, Box 4814, RG 59, NARA II.
} 
information about the colony. Consequently, American officials operated under the assumption that the PPP was using force to mobilize workers in the colony and reports to that end reached at least Secretary of State John Foster Dulles. Dulles sent Maddox copies of United States labor law on September 28 when it became clear that the PPP leaders planned to introduce legislation to achieve the institutional changes the strike failed to produce. ${ }^{178}$

PPP leaders, United States government officials, and American labor leaders' responded to the crisis consistently with their overall objectives. Janet Jagan argued that the MPCA's failure to push for more drastic improvements evidenced their position as a "company union" insufficiently militant in its demand for workers' rights and thus had to be replaced. The GIWU and BGTUC agreed that conditions on sugar estates were deplorable and that more effective negotiating was necessary. ${ }^{179}$ Additionally, PPP leaders argued that trade unionists should be appointed to chair committees in its government rather private citizens who were likely to be employed by influential businesses as a means of weighing policy in favor of the working class, procuring meaningful social change, and creating a balanced legislative environment. ${ }^{180}$ William Christenson warned the State Department that the thought of the strikes generating instability in the rest of the Caribbean was "disturbing to contemplate." Christenson also expressed concern about the financial impact of unrest on British Guiana. ${ }^{181}$

American labor leaders expressed concern regarding the failure to follow accepted negotiating practices and more importantly the attempt to try and force the SPA to recognize the

\footnotetext{
${ }^{178}$ William Maddox, American Consul General, Port of Spain to Department of State, 18 September 1953, 841D.062/9-1853, Central Decimal Files, Box 4814, RG 59, NARA II; John Foster Dulles to William Maddox, September 28, 1953, 841D.06/9-2853, Central Decimal Files, Box 4814, RG 59, NARA II

179 "History of the PPP", Forward by Brindley Benn, January 1963, CJRC; Chase, A History of Trade Unionism in Guyana, 202. Colin Palmer also suggests that the purpose of the strike was to demand improved conditions, rather than wage increases and that there was no attempt to negotiate before the strike was called. See: Palmer, Cheddi Jagan and the Politics of Power, 35

${ }^{180}$ Chase, A History of Trade Unionism in Guyana, 202.

${ }^{181}$ William Christensen to Hayden Raynor, September 18, 1953, 841D.062/9-1853, Central Decimal Files, Box 4814, RG 59, NARA II.
} 
GIWU as the sole negotiating agent of workers which would displace the MPCA and directly challenge ORIT and American labor influence in the colony. American labor leaders also expressed concern that the relationship between the GIWU and PPP government did not allow for trade unions' independence. The president of the GIWU, for example, Dr. Lachmansingh, held the position of Minister of Health and Housing and was a ranking member of the PPP. Moreover, Lachmansingh had been temporarily expelled from the PPP in August 1951 for acting against a decision of the party's General Council while president of the GIWU, further calling into question the independence of his union from the PPP. ${ }^{182}$ PPP leaders argued that attempts to establish a unified, decolonized Guianese movement to increase pressure on the sugar producers for improved working conditions necessitated the removal of the existing union. However, efforts to remove the MPCA generated instability, which conflicted with the interests of the United States government while both the removal of an ORIT affiliated organization and the system of trade union-government relations the PPP pursued conflicted with the aims of American organized labor. Failure to force capitulation from the SPA by the time the strike was called off on September 24 drove the PPP to pursue the legislative action that was used as the justification for British suspension of the constitution on October 9.

The PPP proposed a Labor Relations Bill similar to Cheddi Jagan's proposed legislation introduced in 1949 and 1952 as a result of the impasse between the GIWU and sugar producers. ${ }^{183}$ PPP leaders argued that the bill was based on the 1935 Wagner Act that was the basis of labor law in the United States; however, Cheddi Jagan noted in hindsight that the bill differed from American legislation in that it did not incorporate the "Taft-Hartley portion" of

\footnotetext{
${ }^{182}$ Chase, A History of Trade Unionism in Guyana, 193. Colin Palmer also discusses the "delicate tightrope" Chase was forced to walk balancing his loyalty to the PPP, the government, and the GIWU, suggesting that it was impossible for him to remain entirely impartial. See: Palmer, Cheddi Jagan and the Politics of Power, 36-38. ${ }_{183}$ George Woodcock, hand written note from Constitutional Commission, 1954, British Guiana 972.8 (520), Box 44, Marjorie Nicholson Files, TUCLC; London Press Conference, October 22, 1953, CJRC.
} 
amendments that altered American labor relations in $1947 .{ }^{184}$ More importantly, as Colin Palmer notes, the bill deviated considerably from British trade union practices. ${ }^{185}$ The manner in which the bill was proposed and the legislation's implications on government-labor relations led to dysfunction in the Guianese government and solidified British and American labor leaders' opposition. George Woodcock, Assistant General Secretary of the TUC, noted that the PPP introduced the bill without consulting the trade unions or employers, presented the legislation with no discussion, and proposed it as a consequence of the failed GIWU strike. ${ }^{186}$ Robert Alexander was exceptional among labor leaders in the 1950s in comparing the American and Guianese legislation favorably; however, he interpreted the PPP's legislative tactics as evidence of a militant plot to take control of the labor movement. ${ }^{187}$

Ashton Chase authored the legislation and on September 24 Chase and Burnham moved to suspend the Standing Rules and Orders of the House to allow the bill to be introduced and passed on the same day. Sir Eustance Woolford, Speaker of the House, refused the motion and ruled that the proposal would follow normal legislative procedures. When Burnham suggested that normal procedures on his particular request were to submit the proposal to the House, Woolford refused and insisted "that is the case in ordinary matters" but "in the case of this bill he did not think hasty action was advisable." In response, Burnham and most of the PPP ministers and other party representatives walked out of the proceedings in protest to the ruling and proceeded to rally a crowd of several thousand who had gathered outside the building. ${ }^{188}$ The

\footnotetext{
184 “Excerpt from 'What Happened in British Guiana' by Cheddi Jagan,” British Guiana 972.8 (520), Box 44, Marjorie Nicholson Files, TUCLC.

${ }^{185}$ Palmer, Cheddi Jagan and the Politics of Power, 43.

${ }^{186}$ George Woodcock, handwritten note from Constitutional Commission, 1954, British Guiana 972.8 (520), Box 44, Marjorie Nicholson Files, TUCLC.

${ }^{187}$ Robert Alexander, "Communist Power Cracks in British Guiana," RG 18-003, International Affairs Department: Jay Lovestone Files, 1944-1973, Box 3, Alexander, Robert J., 1955, GMMA

${ }^{188}$ Cheddi Jagan was absent from the proceedings that day, thus Burnham's assumption of authority over the PPP. It is noteworthy that Jagan was not present and surprising that no one has offered an explanation to explain his
} 
noise from the ensuing protests forced the legislature to suspend its activities for the remainder of the day and instability resulting from the shutdown worried American officials that the recent tensions could erupt into a more widespread crisis. ${ }^{189}$ On September 29 the Standing Rules were suspended and the debate over the bill began in the legislature. ${ }^{190}$

On September 24, the day the PPP walked out of the legislature, Oliver Lyttleton, Secretary of State for the Colonies, wrote to Savage expressing his conviction that the PPP was "seeking a one party totalitarian control of the country and a link-up with Russia which we obviously cannot contemplate." Lyttleton argued that reports of the mid-September sympathy strikes "complete[d] the justification for immediate action" and that "I have decided this latest development makes a break inevitable and that we must now act against" the PPP ministers. He suggested Savage "place the dangerous leaders of the PPP under restraint and raid their premises for incriminating documents" as soon as adequate forces were available to maintain law and order. ${ }^{191}$ Lyttleton wrote a memorandum to the Colonial Office on September 25, which he sent on September 30, to make arrangements for troops and to prepare the legal justification for emergency powers necessary to secure British Guiana after a suspension of the constitution in early October. ${ }^{192}$ Thus, the British officials decided to suspend the constitution in British Guiana before the Labor Relations Bill was introduced in the House of Assembly and the suspension order was coupled with a directive from Lyttleton to detain PPP leaders and curtail civil liberties.

whereabouts given that the Labor Relations Bill was the culmination of the PPP's program. Regardless of how the party's objectives are interpreted, it is obvious that party members appreciated the magnitude of the bill even if they did not expect the extent of the British reaction.

${ }^{189}$ William Maddox to Department of State, September 25, 1953, 841D.062/9-2553, Central Decimal Files, Box 4814, RG 59, NARA II. See also: Chase, A History of Trade Unionism in Guyana, 209-211.

${ }^{190}$ William Maddox to Department of State, October 2, 1953, 841D.06/10-253, Central Decimal Files, Box 4814, RG 59, NARA II.

${ }^{191}$ [British Guiana]: outward telegram no 21 from Mr. Lyttleton to Sir A Savage on intervention to remove the PPP government and the introduction of emergency powers, September 24, 1953, CO 1031/119, no 29, BDEE.

${ }_{192}$ Memorandum by the Secretary of State for the Colonies, September 30, 1953, CAB/129/63, BNA. 
The bill itself generated further controversy that is illuminating in its implications in the debate for institutional decolonization in British Guiana after 1953. Maddox pointed out that, despite similarities between American labor practices and the bill's proposed methods for recognizing unions, the legislation appropriated considerably more discretionary powers in the hands of the Minister of Labor, Ashton Chase, than what was permitted under the American model. The bill also proposed giving more power to the Minister than Jagan's proposed 1952 bill which vested discretionary powers in the hands of a British official, the Commissioner of Labor. In light of the fact that three of the six ministers retained positions as presidents of trade unions and a forth was an active protagonist in the strikes, Maddox informed the State Department that impartiality and neutral enforcement "could hardly be expected." ${ }^{\prime 93}$ Passage of the bill, Maddox concluded, "would almost certainly" result in "the establishment or consolidation of PPP controlled trade unions in every major occupation." ${ }^{, 194}$

Leo Despres argues in Cultural Pluralism and Nationalist Politics in British Guiana that the bill effectively gave the Minister of Labor, and thus the PPP, "control of the whole trade union movement," and the Marxists within the party access to the Guianese masses necessary "to control the nationalist movement almost completely." ${ }^{195}$ Stephen Rabe disagrees with criticisms of the bill and argues in U.S. Intervention in British Guiana that even if the bill sought the replacement of the MPCA with the GIWU, it was democratically sound. Moreover, Rabe argues that bill's requirement of a $65 \%$ vote of workers for certification of a union, rather than the $51 \%$ required in the United States, made the bill more rigid than American law. ${ }^{196}$ In confronting

\footnotetext{
${ }^{193}$ William Maddox to Department of State, September 25, 1953, 841D.062/9-2553, Central Decimal Files, Box 4814, RG 59, NARA II.

${ }^{194}$ William Maddox to Department of State, October 2, 1953, 841D.062/10-253, Central Decimal Files, Box 4814, RG 59, NARA II.

${ }^{195}$ Despres, Cultural Pluralism and Nationalist Politics in British Guiana, 207-208.

${ }^{196}$ Rabe, U.S. Intervention in British Guiana, 39.
} 
WFTU allegations in the United Nations, however, the British government suggested that the bill compelled employers to recognize all unions supported by $52 \%$ of workers in an industry. ${ }^{197}$ Cheddi Jagan suggested that the bill varied in the percentage of votes required to achieve union recognition between $52 \%$ and $65 \%$ in a statement to the London press; however, he did not explain the discrepancy. ${ }^{198}$

The TUC also opposed the content of the Labor Relations Bill. George Woodcock argued that the bill was objectionable to British trade union principles particularly in its empowerment of the Minister of Labor to determine who was classified as a worker for purposes of the ballot to determine recognition. Woodcock also argued that the bill's justification of mechanisms to determine jurisdictional disputes between "rival unions" obscured that its purpose was to replace the MPCA, which he noted was an established and not a rival union. He further argued that the bill's claims to be based on United States labor legislation ignored that American labor laws did not permit jurisdictional strikes for recognition where a union was already recognized. Finally, Woodcock pointed out that United States law limited the length of strikes and allowed national security imperatives to be used to end labor protest. ${ }^{199}$

It is significant that, as Jagan noted, the PPP's bill did not include the Taft-Hartley amendments that altered United States labor law in 1947 and which American labor leaders referred to as a "slave labor law."200 Nelson Lichtenstein suggests in The Most Dangerous Man in Detroit that the 1935 Wagner Act on which the Guianese bill was loosely based was possibly the most radical piece of legislation in United States history — and as Jagan noted the American

\footnotetext{
${ }^{197}$ Observations of the United Kingdom Government on a Complaint by the World Federation of Trades Unions Alleging Violation of Trades Union Rights in British Guiana, undated (1954), CO 859-772, BNA.

${ }_{198}$ Cheddi Jagan and Forbes Burnham, "Statement to the Press in London," October 22, 1953, CJRC.

${ }^{199}$ George Woodcock, handwritten note from Constitutional Commission, 1954, British Guiana 972.8 (520), Box 44, Marjorie Nicholson Files, TUCLC.

${ }^{200}$ Jennifer Luff, Commonsense Anticommunism: Labor and Civil Liberties between the World Wars (Chapel Hill: The University of North Carolina Press, 2012), 218.
} 
labor law was altered in $1947 .{ }^{201}$ Moreover, as Jennifer Luff argues in Commonsense

Anticommunism, most unionists in the United States supported the Wagner Act; however, many influential labor leaders across the political spectrum expressed skepticism at the degree of state oversight in the legislation. Many labor conservatives, she argues, offered only tentative support for the bill or opposed aspects of it outright. At the same time, the general public's support for the Wagner Act was inconsistent. ${ }^{202}$ Considering the broader context of the United States law suggests that it is misleading to reduce American policymakers' and labor leaders' opposition to the Guianese bill to merely a simplistic attack on the PPP. In fact, similarities between the Guianese bill and the Wagner Act may have acted to reinforce some American labor leaders' suspicions that the PPP was moving toward an unacceptable centralization of authority in the state. Thus, the PPP's trade union ideology reinforced American preconceptions about its political orientation.

Most importantly, the PPP's bill was passed in a colonial territory in a Cold War context rather than at the height of the depression in the United States and Anglo-American objections to the bill are most effectively understood in that context. As Gerald Horne notes in Cold War in a Hot Zone even though the bill was democratically-based and democratically-proposed, the concept of colonial democracy was the "ultimate oxymoron" and the Colonial Office never intended the introduction of the Waddington Constitution to be the advent of complete selfgovernment in British Guiana. ${ }^{203}$ Thus, the bill was objectionable to British and American trade union leaders because it assumed a degree of self-determination and labor militancy beyond what

\footnotetext{
${ }^{201}$ Nelson Lichtenstein, Walter Reuther: The Most Dangerous Man in Detroit (Urbana, IL: University of Illinois Press, 1995), 50.

${ }^{202}$ AFL leaders' reluctance in supporting the Wagner Act also derived from a desire to protect the organization's preeminence, and that of craft unionism generally, in American organized labor. Luff, Commonsense Anticommunism, 143-155, 162-164, 166, 189-190.

${ }^{203}$ Horne, Cold War in a Hot Zone, 183.
} 
was acceptable to British and American officials while attempting to establish a form of trade unionism that differed considerably from British or American trade union practices. In other words, it sought to decolonize labor institutions from the capitalist-British model of labor relations rather than decolonize Guianese society within the British model.

The Labor Relations Bill was eventually introduced on September 29 and passed on October 8; however, the culmination of tensions and fear of communist infiltration in the British Guianese government resulted in the landing of British soldiers and suspension of the Constitution the following day. ${ }^{204}$ Within two weeks British and American government officials began discussing how to strengthen the MPCA and initially suggested working through the ICFTU. ${ }^{205}$ The intervention, rationalized in a 1954 White Paper as necessary to stop a communist takeover of the colony, was in part a response to fear of communist expansion into British Guiana; however, it was more broadly a reluctance to grant independence to a territory without first establishing the structural mechanisms through which the British could retain post-colonial control.

\section{Response to the Suspension and Conclusions}

PPP actions during their 133 days in office in 1953 are most effectively understood as the culmination of a seven-year-long effort to alter the institutional basis of organized labor in British Guiana. PPP leaders' actions were consistent with the program left-leaning Guianese leaders' undertook beginning in 1946 and were not a momentary spurt of overzealous activity by newly empowered colonial ministers. The Guianese left pursued a form of institutional reorganization, which necessitated a fundamental break from the Colonial Office's instilled trade

\footnotetext{
${ }^{204}$ Lily Ramcharan. “Cold War in British Guiana 1953-1966: The Trade Union Dimension,” The Round Table, Vol. 94, No. 1, 113-128, January 2005.

${ }^{205}$ Memorandum of Conversation, Sir Archibald Gordon, Labor Counselor, British Embassy and Daniel Horowitz Labor Advisor, Bureau of European Affairs, October 20, 1953, 841D.062/10-2053, Central Decimal Files, Box 4814, RG 59, NARA II.
} 
union practices as a precursor to the establishment of Guianese socialism. PPP leaders pursued a cooperative but party centered relationship with trade unions that retained connections to the WFTU and did not affiliate with the ICFTU or ORIT. Their pursuit of institutional reorganization and the development of a unity between the House of Assembly and militant minded labor organizations was a necessity in their push for deeper reforms. However, not all of the left-coalition agreed with the methods employed in seeking to supplant the MPCA in 1953 and schisms emerged within the PPP based on leaders' seeming attempt to subordinate the trade union movement to the party.

Such a unification of party, government, and labor, however, was anathema to American labor leaders and British officials. The combination of the emerging government-labor relationship based on an explicitly stated intention to pursue social revolution convinced American officials observing the situation that there existed an existential threat to the capitalist system in British Guiana. While the United States government was not party to the suspension, Maddox approvingly speculated that Savage would consider instituting a state of emergency by September $23 .{ }^{206}$ Thus, American labor leaders opposed what they deemed to be subversion of independent labor and both labor leaders and American government officials concluded that the PPP was a threat to foreign capital investment and democratic government.

The TUC's role in the aftermath of the constitution's suspension is significant. The Colonial Office aggressively sought cooperation from British labor and implored them to play a larger role in the colony in July 1953; however, British officials' expectations for the TUC role in British Guiana drifted toward the pursuit of political subversion rather than institutionbuilding. In October Oliver Lyttleton reminded Vincent Tewson of the TUC's objection to the

\footnotetext{
${ }^{206}$ Cabinet Minute, October 6, 1953, CAB/195/11, BNA; William Maddox to John Foster Dulles, September 23, 1953, 841D.062/9-2353, Central Decimal Files, Box 4814, RG 59, NARA II.
} 
Labor Bill's proposed empowerment of the Minister of Labor and PPP contacts with the WFTU when he asked TUC General Secretary to nominate one of the three members of the Commission of Inquiry appointed to investigate the crisis and determine the Colonial Office's course of action in British Guiana. Lyttleton's direct appeal to the TUC underscores the importance the Colonial Office placed on the TUC's role in decolonization. ${ }^{207}$ The TUC also indirectly supported the suspension on October 29 when the General Council issued a circular to all affiliated unions opposing Cheddi Jagan's attempt to speak to trade unionists in London. The circular articulated several points of opposition to the PPP government including ministers' affiliation with the WFTU and the Labor Relations Bill. TUC leaders also dismissed the Caribbean Labor Congress through which Jagan reached out to British unions as a communist-controlled organization. ${ }^{208}$ Discussions in the State Department also tended toward the conclusion that the situation in British Guiana necessitated "a special effort...to strengthen the anti-communist trade union forces as a major part of strengthening of democratic forces in opposition to the Communists." State Department officials determined that "it is imperative that the Manpower Citizens Association be strengthened" and that "outside assistance might best take the form of assignment by the British TUC of a competent representative, preferably under ICFTU auspices to work directly with the non-communist trade union forces in Guiana." Lincoln Gordon, Chief of the United States Mutual Security Agency mission in the United Kingdom, suggested he meet with Sir Arthur Deakin of the British Transport Workers to discuss the matter when Deakin was in Washington for the International Transport Workers meeting. ${ }^{209}$ William Christensen met with

\footnotetext{
${ }^{207}$ Cabinet Minute by Oliver Lyttleton, October 13, 1953, CAB/195/11, BNA.

${ }^{208}$ Report of the 86th Annual Trades Union Congress, September 6-10, 1954, TUC History Online, 232, http://www.unionhistory.info/britainatwork/emuweb/objects/nofdigi/tuc/imagedisplay.php?irn=6013468\&reftable=e catalogue\&refirn=6013481, Last Accessed July 12, 2015.

${ }^{209}$ Memorandum of Conversation, "British Guiana Labor Situation," October 20, 1953, 841D.062/10-2053, Central Decimal Files, Box 4814, RG 59, NARA II.
} 
James Barry of the Bureau of the Budget on November 13 to begin discussions of funding Foreign Operations Administration (FOA) programs in the colony at the request of Archie Campbell of the British Embassy. Christensen suggested that the Joint Chiefs of Staff "highly valued" the strategically important Caribbean region and that technical assistance could help counter communism in the volatile area. ${ }^{210}$ Thus, in late 1953 both the Colonial Office and State Department encouraged the TUC to increase its role in institutional decolonization in British Guiana while working to increase American influence in the colony.

In November, the TUC issued a second circular to affiliated unions reserving judgment on the colonial policy in Guiana but criticizing the PPP "which had no scruples in seeking to subject trade unions to their own political ends" and appointing Assistant General Secretary George Woodcock to the Commission of Inquiry. ${ }^{211}$ The PPP's attempt at institutional reorganization through domestic labor relations and international associations contributed to the TUC's ambiguous response to the regressive policy toward British Guiana in London. In discussing the suspension with Winston Churchill on October 13, Lyttleton assured the Prime Minister that opposition from the Labor Party in the House of Commons "would not be united in condemning the action which the Government had taken in this matter" because of PPP policy toward the trade union movement and association with the WFTU. ${ }^{212}$ Thus, the PPP's trade union policies impacted British domestic politics and shaped the response from the Labor Party toward the regressive actions of colonial officials.

\footnotetext{
${ }^{210}$ Memorandum of Conversation, November 13, 1953, 841D.00 TA/11-1353, Central Decimal Files, Box 4814, RG 59, NARA II.

${ }^{211}$ Vincent Tewson, "Statement on British Guiana," September 6, 1954, Report of the 86th Annual Trades Union Congress, September 6-10, 1954, TUC History Online, 232, http://www.unionhistory.info/britainatwork/emuweb/objects/nofdigi/tuc/imagedisplay.php?irn=6013468\&reftable=e catalogue\&refirn=6013481, Last Accessed July 12, 2015.

${ }^{212}$ Cabinet Minute on British Guiana, October 13, 1953, CAB/128/26, BNA.
} 
Conversely, American trade unionists had been actively involved in British Guiana throughout 1953 and thought their government was remiss in underappreciating the potential for communist subversion in the colony, Maddox's discussions with the State Department notwithstanding. It is also significant that the GIWU remained the strongest union in the colony despite early TUC, Colonial Office, AFL, ICFTU, and ORIT financing for programs designed to strengthen the MPCA.

Ultimately, the PPP's ascension and the conflicts that led to the suspension of the constitution in 1953 are best understood as part of institutional decolonization. Guianese leaders conflicted over the nature of their increasingly autonomous society and sought to establish the institutional structures that would fortify the social and political-economic institutions necessary for the type of post-colonial system they envisioned for the territory. A left-coalition led efforts to institutionally restructure the colony intending to break from Anglo-American control through the establishment of socialism in British Guiana and increased affiliation with Eastern-bloc countries and international organizations abroad. Their objective was to establish mechanisms that could be used as the base for social revolution in the colony.

Domestic opponents of the PPP worked to build institutions based on British or American models to establish a capitalist-democratic system in which their organizations could exact reforms from employers. Simultaneously, British and American policymakers and labor leaders, especially in the Colonial Office and AFL, sought to establish British-modeled trade unions and integrate colonial unions into Western-capitalist international labor organizations. A period of conflict between Guianese leaders and external actors unfolded between 1946 and 1953 that culminated when the PPP assumed office and began the process of institutional decolonization on its terms. Domestic opponents and British officials resisted the left-coalition's efforts by 
forcefully removing the PPP government from power and dissolving left-led trade unionism in British Guiana. Pointedly, Oliver Lyttleton admitted to Prime Minister Winston Churchill on October 13 that there was no threat of a Communist coup and that the constitution was suspended "to secure law \& order while Comm. Ministers were removed." ${ }^{213}$ Thus, the Colonial Office's fear was not that the PPP was about to directly impose a communist government in British Guiana, but that the institutions holding Guianese society together were incapable of inhibiting the PPP from progressing toward that end with popular support over time.

The first phase of institutional decolonization that began with the expansion of Colonial Office-TUC programs and the establishment of the PAC in 1946 ended when colonial officials realized the institutional structures they established in coordination with the MPCA and likeminded colonists were not a strong enough bulwark to stop the push for the greater social changes advanced by the left-coalition of Guianese leaders. The suspension of the Waddington Constitution disrupted left-coalition efforts at joining legislative and trade union activity to restructure Guianese society and set the stage for the second phase of institutional decolonization in British Guiana between 1954 and 1957.

${ }^{213}$ Cabinet Minute by Oliver Lyttleton, October 13, 1953, CAB/195/11, BNA. 


\section{Chapter 6: Checking the Excesses of Democracy: International Institution-Building in British Guiana from 1954 to 1957}

The paradoxical effort to establish democratic institutions for the purpose of changing the will of the Guianese people shaped Anglo-American institution-building projects in British Guiana between 1954 and 1957. The Guianese labor movement made progress toward establishing functional capitalist-democratic trade unions despite Anglo-American efforts to use institution-building to expand their respective nations' influence and weaken Jagan. Nonetheless, the Jagan faction of the People's Progressive Party (PPP) achieved electoral victory in August 1957. Anglo-American labor leaders and policymakers lamented the election's outcome; however, British and American interpretations of the institution-building effort differed. Colonial officials and British trade union leaders considered the programs a qualified success while American political and labor leaders concluded that institution-building efforts were a failure. Consequently, Colonial Office and TUC activities in British Guiana differed from American activities in the colony after August 1957.

George Woodcock, Assistant General Secretary of the Trades Union Congress (TUC), was one of three members of the Robertson Commission that investigated the Waddington Constitution's suspension in October 1953. Woodcock played a critical role in designing and implementing British development efforts in Guiana between 1954 and 1957. His retrospective explanation of colonial trade unions as "effective checks on the excess of democracy" illuminates the purpose and negative consequences of Anglo-American involvement in the Guianese labor movement during the second phase of institutional decolonization in British

Guiana. ${ }^{1}$ A British-appointed interim government administered British Guiana between October

\footnotetext{
${ }^{1}$ Mr. Parry, signed by L.T. Stapleton to Mr. Foggon, "Draft of Notes from establishment of O.E.F.-T.U.C Committee," April 1, 1959, CO 859-1118, British National Archives, Kew, Richmond, Surrey, (hereafter BNA). British and American discussions regarding the outcome of elections in British Guiana on August 12, 1957 provide
} 
1953 and August 1957 and during that time myriad international actors carried out programs designed to strengthen moderate, pro-Western trade unions and counter the popular appeal of the left-wing of the PPP. Institution-building efforts aimed at strengthening the foundations of democracy and capitalism in British Guiana; however, as Philip Rogers of the Colonial Office bluntly acknowledged, the primary objective of colonial policy in British Guiana after October 1953 was "to go hard at it and smash [the PPP] completely."2

Therefore, Woodcock's emphasis on the Guianese labor movement's role in protecting British interests in preparation for Guianese independence rather than as an expression of democratic voice in a capitalist society conformed to widely-held British plans regarding the most effective means of decolonizing colonial institutions. The institution-building project in British Guiana reinforced Secretary of State for the Colonies James Griffiths' late-1951 statements arguing that British colonial policy aimed at "as rapidly as possible build[ing] up in each territory the institutions which its circumstances require" to give colonial peoples " a sense of belonging" in preparation for self-government. ${ }^{3}$ Ultimately, the Colonial Office engaged in institution-building to establish a capitalist-democratic political-economic system that protected British interests in British Guiana in the long-term; however, the promotion of democracy was contingent on the preservation of Britain's economic, strategic, and political interests.

\footnotetext{
the most direct acknowledgement that Anglo-American programs between 1954 and 1957 were designed as mechanisms through which Guianese popular opinions could be altered. See: British Embassy, Washington D.C. to Foreign Office, August 16, 1957, FO 371-126078, BNA; Colonial Office to A.N. McCleary, Foreign Office, August 20, 1957, FO 371-126078, BNA.

${ }^{2}$ Colonial Office Minute, Philip Rogers to Lloyd, October 16, 1953, CO 1031/1171, British Documents on the End of Empire: S.R. Ashton and David Killingray. eds., Series B Volume 6: The West Indies (London: The Stationary Office, 1999), 64. See also: Stephen Rabe, U.S. Intervention in British Guiana: A Cold War Story (Chapel Hill: The University of North Carolina Press, 2005); Colin A. Palmer, Cheddi Jagan and the Politics of Power: British Guiana's Struggle for Independence (Chapel Hill: The University of North Carolina Press, 2010).

3 "Notes on the ICFTU Resolution Regarding Non-Self-Governing Territories," January 23, 1952, Trade Union Congress 931.9, Box 9, Marjorie Nicholson Files, Trade Union Congress Library Collections, London Metropolitan University, London, England (Hereafter TUCLC); Minutes from meeting of Conference of heads of Labor Departments, October 5, 1951, Trade Unions and Colonies 932.5, Box 15, Marjorie Nicholson Files, TUCLC.
} 
Analysis of TUC records heretofore unexamined and their juxtaposition with previously scrutinized materials suggests that Guianese unionists aggressively courted Western support and drove the process of institution-building in British Guiana to a greater degree than is represented in the existing scholarship. Close reading of the TUC materials also suggests that the literature does not adequately quantify the gains moderate unionists made within the existing politicaleconomic system between 1954 and 1957. Nonetheless, international efforts did not alleviate Guiana's poverty rapidly enough to undermine the PPP's electoral support. At the same time, increased transnational connections slowly alienated pro-Western trade union leaders from workers even as international relationships financially and legally stabilized the movement. Consequently, the PPP returned to the head of government after elections in August 1957 and the strengthened trade union movement turned to anti-democratic practices to oppose the PPP.

The second phase of institutional decolonization in British Guiana that took place between 1954 and 1961 was the most important period in determining the colony's future. During the seven year period, Guianese trade union leaders and Anglo-American trade unionists, government officials, and employers established important legislative and procedural advances that strengthened the reformist labor movement in the colony. At the same time, MPCA leaders' exclusion of PPP members from participation in the union, and the AFL-CIO's short-sighted institution-building tactics, contributed to alienating an anti-democratic reformist labor movement from its constituents in British Guiana. Meanwhile, the PPP's inability to work from within the sugar union fueled the drive for an alternative union and political action to replace the MPCA. Thus, the third phase of institutional decolonization that unfolded between 1962 and 1964 was a direct result of failed institution-building in the second half of the 1950s. 
Nonetheless, most scholarly historical studies of British Guiana's decolonization focus on the 1953 suspension of the Waddington Constitution and covert American subversion of the PPP government between 1961 and 1964. The political scientist Matthew Lange points out there is a strong correlation between the nature of colonial rule and long-term development, political inclusivity, and stability in post-colonial societies. Specifically, Lange argues that directly ruled colonies such as British Guiana tended to establish effective bureaucratic and institutional structures. Guyana, Lange argues, is exceptional as a consequence of radical changes to the colony's trajectory during the last two decades of colonial rule, what this dissertation refers to as the process of institutional decolonization. ${ }^{4}$ Throughout the second half of the 1950s British and American labor, political, and business leaders cooperated to build the Guianese trade union movement in order to establish the institutional framework for a capitalist, democratic postcolonial Guiana. Anglo-American leaders further aimed to integrate the Guianese labor movement into the Western liberal capitalist system in order to protect British and American interests.

The historiography on the period between 1954 and 1959 explores the objectives of various parties involved in Guianese decolonization; however, it focuses on external efforts to counter popular support for Cheddi Jagan and the PPP. The most prominent study, Stephen Rabe's U.S. Intervention in British Guiana, argues that British and American policymakers' interpreted Jagan's anti-colonial Marxism through a Cold War prism and determined to destroy the PPP. ${ }^{5}$ Similarly, Colin Palmer notes in Cheddi Jagan and the Politics of Power that the Robertson Commission, which investigated the Waddington Constitution's suspension, recommended a period of "marking time in the advance toward self-government" to pursue

\footnotetext{
${ }^{4}$ Matthew Lange, Lineages of Despotism and Development: British Colonialism and State Power (Chicago: The University of Chicago Press, 2009), 7-8, 117, 130-131.

${ }^{5}$ Rabe, U.S. Intervention in British Guiana, 47-51.
} 
social and economic development and undermine Jagan's popularity. ${ }^{6}$ Palmer echoes Rabe's argument and suggests that various groups attempted to build power and oppose the Cheddi Jagan-led faction of the PPP between 1953 and 1960. ${ }^{7}$ Spencer Mawby's Ordering Independence agrees with Rabe and Palmer that anti-communism shaped British interpretations of Jagan's Marxism; however, Mawby notes that British trade unionists also opposed Jagan and the PPP out of a fear of disorderly decolonization. ${ }^{8}$ Thus, Mawby argues that the Colonial Office and TUC cooperated to decelerate decolonization and transition colonies to independence in a manner that protected British imperatives. ${ }^{9}$

Clem Seecharan expands on Rabe's argument, pointing out that Booker Brothers chairman Jock Campbell aggressively opposed the PPP and tried to establish an anti-Jagan alternative to the party between 1953 and 1956. However, Seecharan differs from Rabe and Palmer in arguing that Campbell agreed to work with Cheddi Jagan after the 1957 election and that Jagan's doctrinaire Marxism undermined Campbell's reform efforts leading to conflict between the PPP and British and American officials. ${ }^{10}$ Seecharan's analysis of Booker Brothers' efforts to support the Manpower Citizens' Association (MPCA) on the sugar estates is important in acknowledging that institution-building efforts brought together employers, trade unions, and government agencies. British-owned businesses shared broad objectives with the Colonial Office and TUC in institution-building, though employers were inconsistent in supporting institution-

\footnotetext{
${ }^{6}$ Palmer, Cheddi Jagan and the Politics of Power, 146.

${ }^{7}$ Palmer, Cheddi Jagan and the Politics of Power, 135-155. The PPP was a Left-coalition; however, two distinct factions emerged within the party after the 1953 British intervention. Cheddi and Janet Jagan led one faction while Forbes Burnham led the other. The factions split the party in January 1955 and both claimed to be the legitimate PPP. The Burnham-faction became the People's National Congress (PNC) after the Jagan-faction's dominant victory in the 1957 election.

${ }^{8}$ Spencer Mawby, Ordering Independence: The End of Empire in the Anglophone Caribbean, 1947-1969 (New York: Palgrave Macmillan, 2012), 92.

${ }^{9}$ Mawby, Organizing Independence, 30.

${ }^{10}$ Clem Seecharan, Sweetening 'Bitter Sugar': Jock Campbell the Booker Reformer in British Guiana 1934-1966 (Miami: Ian Randle Publishers, 2005), 207-210.
} 
building efforts. The close association hints at the conservative nature of British programs that failed to address Guianese workers' fundamental needs. In addition to British actors, American trade unionists and foreign operations officials, as well as representatives of the Western international labor organizations - the International Confederation of Free Trade Unions (ICFTU), Inter-American Regional Organization of Workers (ORIT), and Caribbean Area Division of ORIT (CADORIT) —also contributed to Guianese institution-building between 1954 and 1957.

Rabe suggests that, despite broadly shared objectives, colonial officials expressed considerable reservations regarding American influence in British Guiana before the Suez Crisis and Cuban Revolution ultimately undermined Anglo-American cooperation. ${ }^{11}$ Anglo-American competition in British Guiana was consistent with broader rivalry for post-colonial influence during the Eisenhower administration that complicated cooperative efforts in British colonies, particularly in labor movements, as Joey Long argues in Safe for Decolonization. ${ }^{12}$ Nonetheless, Anglo-American power struggles did not preclude cooperation in British Guiana. Ultimately, the increased American role in British Guiana after 1953 is most effectively contextualized as part of a broader expansion of United States influence in the Caribbean that began in the 1930s and increased considerably during the mid-1950s. Carey Fraser's Ambivalent Anti-Colonialism, Gerald Horne's Cold War in a Hot Zone, and Jason Parker's Brother's Keeper all have considered the dynamics shaping the West Indies' transition from British colonies to independent nations within what Parker refers to as an "American Lake." " Joey Long argues that a similar

\footnotetext{
${ }^{11}$ Rabe, U.S. Intervention in British Guiana, 56.

${ }^{12}$ S.R. Joey Long, Safe for Decolonization: The Eisenhower Administration, Britain, and Singapore (Kent, OH: The Kent State University Press, 2011), 99-100.

${ }^{13}$ Cary Fraser, Ambivalent Anti-Colonialism: The United States and the Genesis of West Indian Independence, 1940-1964 (Westport, CT: Greenwood Press, 1994); Gerald Horne, Cold War in a Hot Zone: The United States Confronts Labor and Independence Struggles in the British West Indies (Philadelphia: Temple University Press,
} 
process unfolded in Singapore where American and British officials and labor leaders clashed at times over tactics while agreeing on broad objectives as United States influence expanded in the 1950s. ${ }^{14}$

Most importantly, Palmer argues that the PPP's Guianese opponents advocated limitations on political advancement and civil liberties even more aggressively than did British officials. ${ }^{15}$ Palmer's analysis challenges Rabe's depictions of anti-Jagan unionists as “timid” and "lethargic," characterizations that TUC records suggest obscure the assertiveness of Guianese who courted external support and worked for improvements within the context of a British model of unionism. ${ }^{16}$ Nonetheless, Palmer suggests that the Colonial Office lamented Jagan's expanded influence on sugar estates as early as mid-1955. ${ }^{17}$ The Jagans gained followers throughout the period. However, the PPP's political influence did not translate into a trade union presence because of Anglo-American support for the MPCA, and MPCA leaders' anti-democratic measures within the union.

\section{Origins and Background of the Second Phase of Institutional Decolonization in British Guiana}

The second phase of institutional decolonization in British Guiana began with the suspension of the Waddington Constitution in October 1953 as a way for the Colonial Office to remove suspected communists from government and regain control of the Guianese labor movement after trade union conflict disrupted the colony. Colonial Officials described the suspension as an opportunity to address the poverty and weak institutional structures that allowed the PPP to win political power and radically challenge the Guianese social order. Two

2007), 84, 176; Jason Parker, Brother's Keeper: The United States, Race, and Empire in the British Caribbean, 1937-1962 (Oxford: Oxford University Press, 2008), 40.

${ }^{14}$ Long, Safe for Decolonization.

${ }^{15}$ Palmer, Cheddi Jagan and the Politics of Power, 138-140.

${ }^{16}$ Rabe, U.S. Intervention in British Guiana, 51.

${ }^{17}$ Palmer, Cheddi Jagan and the Politics of Power, 148. 
days after the suspension Governor Alfred Savage argued that a new constitution needed to be implemented and that the next phase of British rule should be of constructive progress rather than "marking time."18 The Robertson Commission appropriated the phrase marking time to argue in favor of a period of pause in the advance toward self-government; however, it too emphasized that the interim government's purpose was to promote social and political development to alter the views of the Guianese electorate. Thus, the official British objective between the October 1953 suspension and the 1957 elections was to provide time for institution building to develop a capitalist system economically and politically connected to the British Commonwealth as British Guiana advanced toward self-government. ${ }^{19}$

Colonial authorities levied a series of authoritarian measures to cripple the PPP in October 1953, including restricting freedom of speech and movement, while establishing an interim government designed to work in coordination with Anglo-American development and institution-building projects. ${ }^{20}$ The State Department and Colonial Office pushed to considerably increase British and American labor involvement in developing a pro-Western labor movement in the colony beginning in late 1953. Anglo-American trade union leaders traveled to British Guiana in early 1954 to evaluate the situation and in mid-1954 a variety of British and American institution-building programs began to take form. The American Federation of Labor (AFL) and Congress of Industrial Organizations (CIO) trained, financed, and advised Guianese trade union leaders independently as well as in coordination with the United States government. Most

\footnotetext{
${ }^{18}$ Palmer, Cheddi Jagan and the Politics of Power, 56.

${ }^{19}$ Palmer, Cheddi Jagan and the Politics of Power, 146-148.

${ }^{20}$ Rabe, U.S. Intervention in British Guiana, 49-51; Palmer, Cheddi Jagan and the Politics of Power, 55-57, 63-74.
} 
significantly, the TUC made British Guiana the first colony in which it undertook a full-scale institution-building effort. $^{21}$

British and American-led institution building projects in British Guiana were cautiously cooperative from their inception. Immediately following the suspension of the Waddington Constitution, Lincoln Gordon, Chief of the United States Mutual Security Agency mission in the United Kingdom, suggested allowing the TUC to take the lead in creating pro-Western trade unions aligned with the ICFTU and its hemispheric affiliate, ORIT. ${ }^{22}$ British and American institution-building tactics differed and aimed to advance national interests resulting in interunion rivalry between the AFL-CIO and TUC. British government officials broadly criticized American institution-building projects in colonial areas in the late-1950s, suggesting that AFLCIO activities impeded trade union development. British trade unionists and government officials alleged American labor leaders' international agenda was an extension of official American policy as defined in the State Department and pursued through the Central Intelligence Agency (CIA). Most importantly, British officials accused American labor leaders of using bribery to build up privileged local leaders rather than constructing organized labor movements from the bottom up. ${ }^{23}$ Nonetheless, Anglo-American cooperation in British Guiana persisted despite British disagreement with AFL-CIO methods and anxiety regarding expanded American influence in British Guiana at the institutional level.

\footnotetext{
${ }^{21}$ Report of the 87th Annual Trades Union Congress, September 5-9, 1955, TUC History Online, 231, http://www.unionhistory.info/britainatwork/emuweb/objects/nofdigi/tuc/imagedisplay.php?irn=6013876\&reftable=e catalogue\&refirn=6013759, Last Accessed July 12, 2015.

${ }^{22}$ Cabinet Minute by Oliver Lyttleton, October 13, 1953, CAB/195/11, BNA; Memorandum of Conversation, "British Guiana Labor Situation," October 20, 1953, 841D.062/10-2053, Central Decimal Files, Box 4814, RG 59, National Archives II, College Park, MD (Hereafter: NARA II).

23 “'Secret' Annex to Cabinet Paper on Policy in Africa," December 21, 1959, RG 1-027, Office of the President, George Meany's Files, 1944-1960, Box 51, Meetings: Misc., Corr., re ICFTU, 1955-1960, George Meany Memorial Archives, Silver Spring, MD (Hereafter, GMMA). The "U.K. Eyes Only" Cabinet Paper is focused on addressing conflicting AFL-CIO and TUC interests in Africa and within the ICFTU; however, the criticism leveled at American trade union policy is relevant in that its focus in British Guiana heavily relied on individual leadership programs similar to those criticized in Africa.
} 
In addition to British and American collaboration, the suspension of the Waddington constitution led to a flurry of activity as Guianese activists and British employers responded to the crisis and labor unrest continued unabated. On October 10 the PPP initiated work stoppages on several sugar estates in protest of the suspension and the strikes lasted several weeks. ${ }^{24}$ Within days of its removal the PPP began printing and distributing handbills and propaganda through underground channels and initiated a program of civil resistance that led to the arrest of several prominent party members. ${ }^{25}$ Booker Brothers chairman Jock Campbell introduced several Guianese politicians to Labor and Conservative Party leaders in late October with assistance from the Colonial Office. Campbell suggested publicizing the exchange in London would help organize an "opposition" to counter the PPP. ${ }^{26}$ PPP contact with the World Federation of Trade Unions (WFTU) continued until Governor Alfred Savage banned all entry and distribution of WFTU publications on December $16^{27}$

Most importantly, conflicts between Guianese unionists persisted as they had in the late 1940s in what British Guiana’s first Guianese Labor Commissioner James Ramphal referred to as a "continuous state of inter-union war." 28 The British Guiana Trade Union Council (BGTUC) disbanded in October 1953 citing communist infiltration and reorganized in early 1954 without the participation of the British Guiana Labor Union (BGLU) or Guiana Industrial Workers' Union (GIWU). The BGLU and GIWU, two of the most important unions in the colony, refused to affiliate as a result of the reformed BGTUC's clause disallowing association with the

\footnotetext{
${ }^{24}$ [British Guiana]: $52^{\text {nd }}$ political report by Sir A Savage on military intervention and its immediate aftermath, October 31, 1953, CO 1031/128, no 44, BDEEP.

${ }^{25}$ Janet Jagan, “The Politics of Protest,” undated, Party Life, Cheddi Jagan Research Center (hereafter CJRC).

${ }^{26}$ Colonial Office Minute, November 2, 1953, CO 1031-781, BNA.

27 Annex to letter from Ministry of Labor and National Service to A. McM. Webster, Colonial Office, July 1, 1954, CO 859-772, BNA; Palmer, Cheddi Jagan and the Politics of Power, 63-65.

${ }^{28}$ James Ramphal, British Guiana Labor Commissioner, "Present and Future Outlook of the Trade Union Movement," June 1954, CO 859-773, BNA.
} 
Caribbean Labor Congress (CLC) or WFTU. ${ }^{29}$ The MPCA continued pressing the Sugar Producers' Association (SPA) for a minimum weekly wage throughout November though no agreement was reached. ${ }^{30}$ MPCA General Secretary Sheik Shakoor traveled to Trinidad and met with Frank Walcott, Chairman of CADORIT, to discuss the situation in British Guiana in late December 1953. CADORIT officials noted the MPCA's failure to secure workers' support and determined that the union's weakness derived from conservatism in the face of considerable poverty. Rather than overhauling the MPCA or suggesting policy changes, CADORIT produced 10,000 pamphlets commending the MPCA's aim of helping workers obtain economic security and political freedom in an attempt to help the Guianese sugar union gain grassroots support. ${ }^{31}$

CADORIT likely understated the MPCA's weakness and inefficiency in late 1953. Colin Palmer notes that increases in cost-of-living surpassed sugar workers' modest wage gains between 1938 and 1954 providing evidence that material conditions for workers declined over time despite the MPCA's officially recognized position as workers' bargaining agent. ${ }^{32}$ Palmer argues that MPCA leaders' policy proposals further undermined the union's efforts to win the support of sugar workers. Palmer notes that the MPCA was part of the Joint Trade Union Committee (JTUC) along with the British Guiana Headmen's Union, the British Guiana Sugar Estates Clerks Association, and the British Guiana and West Indies Sugar Boilers Union. The JTUC ostensibly acted as the unified representative of the colony's 33,000 sugar estate workers in the early 1950s; however, the JTUC argued for policies that disempowered its constituency

\footnotetext{
${ }^{29}$ Robert Alexander interview with Ashton Chase, June 29, 1954, RG 18-003, International Affairs Department, Jay Lovestone Files, 1944-1973, Box 2, Alexander, Robert, 1954, GMMA; British Guiana Government Information Services, Guiana Diary, “Another Step Towards Labor Unity,” May 29-June 1, 1955, F2384, British Guiana, Guiana Diary, 1955 Jan to 1957 Jun, TUCLC.

${ }^{30}$ Alfred Savage, Governor of British Guiana to Oliver Lyttleton, Secretary of State for the Colonies, November 22, 1953, CO 1031-64, BNA.

${ }^{31}$ Luis J. Marcano, Secretary ORIT, "Report on the Activities of the Caribbean Area Division of ORIT Since the Christmas Report," undated (early 1954), RG 18-009, International Affairs Department, Staff Files: Serafino Romualdi's Files, 1945-1961, Box 1, Caribbean Area, 1953-1956, GMMA.

${ }^{32}$ Palmer, Cheddi Jagan and the Politics of Power, 107-111.
} 
despite negotiating for minor improvements to workers' material conditions. Specifically, the JTUC argued for property or income restrictions to determine suffrage as a means of limiting sugar workers' influence in electoral politics. The JTUC's policy aimed at undermining the PPP after the Waddington Constitution's suspension in 1953. Thus, as Colin Palmer argues, the MPCA was not merely cautious in advancing workers' interests, its leaders consciously acted against them. ${ }^{33}$

Anglo-American efforts to strengthen the MPCA and pro-Western trade unions beginning in 1954 benefited from several changes in Guianese labor leadership and the GIWU's considerable loss of influence after the PPP's removal. ${ }^{34}$ First, the Colonial Office promoted Ramphal to Commissioner of Labor after repeated demands for "Guianization" of official positions despite skepticism that his East Indian background compromised his impartiality. ${ }^{35}$ Notwithstanding colonial officials' initial uncertainty, Ramphal advocated a form of Guianese organized labor based on British trade unionism, encouraged educational exchanges between Guianese and British trade unionists, and won George Woodcock's approbation for his overall cooperation with the TUC. ${ }^{36}$

Second, Rupert Tello, former president of the MPCA, ascended to the position of General Secretary in the BGTUC in 1955 and assumed a position in the interim government. ${ }^{37}$ Governor Ralph Grey acknowledged in 1960 that the TUC and Colonial Office exaggerated Tello's local

\footnotetext{
${ }^{33}$ Palmer, Cheddi Jagan and the Politics of Power, 140-141.

${ }^{34}$ Robert Alexander, "Communist Power Cracks in British Guiana," RG 18-003, International Affairs Department: Jay Lovestone Files, 1944-1973, Box 3, Alexander, Robert J., 1955, GMMA.

35 "Note of Meeting to Discuss Trade Unionism in British Guiana," July 1, 1954, CO 859-773, BNA.

${ }^{36}$ James Ramphal, British Guiana Labor Commissioner, "Present and Future Outlook of the Trade Union Movement," June 1954, CO 859-773, BNA; "Notes of Discussion with George Woodcock," February 7, 1955, CO 859-773, BNA.

${ }^{37}$ Rupert Tello to Serafino Romualdi, undated (early 1956), RG 18-009, International Affairs Department, Staff Files, Serafino Romualdi’s Files, 1945-1961, Box 5, T, 1956, GMMA.
} 
stature. ${ }^{38}$ However, Tello played a central role in establishing connections between the BGTUC and the TUC, AFL-CIO, ORIT, and CADORIT. More significantly, Tello convinced British and American trade union leaders and government officials of his prominence in the Guianese labor movement and his shared views regarding the importance of capitalist development and free enterprise. ${ }^{39}$ Anglo-American officials' trust allowed Tello to influence international interpretations of Guianese labor and political developments and use his overseas connections to pursue his own political objectives between 1954 and 1957.

Finally, Richard Ishmael became the MPCA's new president in early 1954. Ishmael, an East Indian Guianese educated at Gettysburg College in the United States, was an early member of the PPP who claimed that he left the party as a result of Cheddi Jagan's communist views. ${ }^{40}$ Rabe notes that British officials regularly criticized Ishmael as an opportunist maneuvering for a future political position. However, as Colin Palmer suggests, Ishmael was an aggressive advocate of Guianese workers during the early part of his career. ${ }^{41}$ British officials' and rival Guianese leaders' criticisms obscured Ishmael's activism as head of the MPCA between 1954 and 1957 as well as the advancements the MPCA secured for sugar workers. As a result scholars fail to fully appreciate the importance of the MPCA's policy shift after the August 1957 elections and the paradoxical effect of external assistance on the MPCA's strength. Most importantly, superficial analyses of Ishmael inaccurately suggest that weak leadership undermined the MPCA

\footnotetext{
${ }^{38}$ Ralph Grey to Angus MacKintosh, July 5, 1960, CO 1031-3421, BNA. See also: Rabe, 51.

${ }^{39}$ Robert Alexander interview with Rupert Tello, June 4, 1953, RG 18-003, International Affairs Department, Jay Lovestone Files, 1944-1973, Box 2, Alexander, Robert, 1953, GMMA.

${ }^{40}$ Richard Ishmael, "The Situation as it is in British Guiana," undated, RG 18-001, International Affairs Department, Country Files, 1945-1971, Box 17, British Guiana, GMMA.

${ }^{41}$ Rabe, U.S. Intervention in British Guiana, 51; Palmer, Cheddi Jagan and the Politics of Power, 107, 133, 136137.
} 
and fail to appreciate that the union's limitations were a reflection of the unequal distribution of power in Guiana and sugar workers' support for radical change. ${ }^{42}$

Ramphal suggested in 1954 that Ishmael was driven to overhaul the union, convinced that "the whole internal organization [was] rotten," and that Ishmael's tenure represented a "new phase in the history of the MPCA." ${ }^{43}$ In June 1954 Robert Alexander compiled Guianese analyses of Ishmael's initial impact as head of the MPCA and his interviews suggested that the new MPCA president was an aggressive leader who engaged sugar workers on the plantations, held illegal meetings, severely criticized sugar producers, and pressed the SPA for considerable improvements to working conditions. ${ }^{44}$ Jane Phillips-Gay, Secretary of the GIWU, the MPCA's rival union, dismissed Ishmael's chance at wooing workers from her organization and criticized his motives as self-serving. Nonetheless, Phillips-Gay acknowledged that Ishmael was active in traveling the country meeting with workers. ${ }^{45}$ At least some sugar workers expressed confidence in his willingness to fight on their behalf and to serve as a break from previously suspect MPCA leadership. Several workers Alexander interviewed suggested that they would return to the MPCA if Ishmael's reform efforts succeeded, despite their general skepticism of the union. ${ }^{46}$

J.P. Lachmansingh, President of the GIWU, noted that Ishmael attacked sugar producers so aggressively that the SPA censored him in the union's journal, the Labor Advocate. ${ }^{47}$ MPCA

\footnotetext{
42 "Extract of a Report by the Minister of State," October 28, 1954, CO 859-773, BNA.

43 James Ramphal, British Guiana Labor Commissioner, "Present and Future Outlook of the Trade Union Movement," June 1954, CO 859-773, BNA.

${ }^{44}$ Robert Alexander Report on Venezuela, Trinidad, and British Guiana, July 6, 1954, RG 18-003, International Affairs Department, Jay Lovestone Files, 1944-1973, Box 2, Alexander, Robert, 1954, GMMA.

${ }^{45}$ Robert Alexander interview with Jane Phillips-Gay, Secretary of GIWU, June 29, 1954, RG 18-003, International Affairs Department, Jay Lovestone Files, 1944-1973, Box 2, Alexander, Robert, 1954, GMMA.

${ }^{46}$ Robert Alexander interview with Tambay, sugar worker, June 28, 1954; Robert Alexander interview with Fordyce, worker, June 28, 1954; Robert Alexander interview with group of sugar workers, June 28, 1954, RG 18003, International Affairs Department, Jay Lovestone Files, 1944-1973, Box 2, Alexander, Robert, 1954, GMMA; James Ramphal, British Guiana Labor Commissioner, "Present and Future Outlook of the Trade Union Movement," June 1954, CO 859-773, BNA.

${ }^{47}$ Robert Alexander interview with J.P. Lachmansingh, President of GIWU, June 29, 1954, RG 18-003, International Affairs Department, Jay Lovestone Files, 1944-1973, Box 2, Alexander, Robert, 1954, GMMA.
} 
General Secretary Sheik Shakoor confirmed that Ishmael wrote inflammatory articles against the SPA in the Labor Advocate that angered sugar producers who were allowed through contract to censor articles in the periodical. ${ }^{48}$ At the same time, colonial officials expressed concern that Ishmael's aggressive tactics disrupted relations with the SPA. ${ }^{49}$ Alfred Thorne, editor of the Guiana Graphic, described Ishmael as a rash leader who "alienated employers." ${ }^{50}$ Eventually Shakoor, Tello, and other MPCA leaders called for Ishmael's suspension as a result of his efforts to rapidly reform the union. ${ }^{51}$ Shakoor retreated from his position when Ishmael agreed to moderate his methods. Nonetheless, Ishmael continued to use tactics that colonial officials and TUC leaders considered irrationally aggressive. ${ }^{52}$ Ultimately, Ishmael's tenure as MPCA President changed the nature of MPCA leadership and contributed to the organization's growth in the mid-1950s.

Ishmael, however, included a political objective for the MPCA that dovetailed with British aims to undermine the PPP. Ishmael admitted that he pursued the MPCA's presidency to obtain the opportunity to build the organization into an effective mechanism through which to defeat his former party. Nonetheless, Ishmael told Alexander that he was willing to cooperate with the PPP's non-communist members and he suggested that the MPCA needed grassroots

\footnotetext{
${ }^{48}$ Robert Alexander interview with S.M. Shakoor, June 27 and June 29, 1954; Robert Alexander interview with Richard Ishmael, June 27, 1954, RG 18-003, International Affairs Department, Jay Lovestone Files, 1944-1973, Box 2, Alexander, Robert, 1954, GMMA.

49 "Extract from British Guiana Sixtieth Political Report covering the period from June 1-June 30, 1954, CO 859773 , BNA. Tello suggests that Ishmael's writings also unsettled Serafino Romualdi. See: Rupert Tello to Serafino Romualdi, July 29, 1956, RG 18-009: International Affairs Department Staff Files: Serafino Romualdi's Files, 19451961, Box 4, I, 1956, GMMA.

${ }^{50}$ Robert Alexander interview with Alfred Thorne, Editor of Guiana Graphic, February 1, 1956, RG 18-003: International Affairs Department, Jay Lovestone Files, 1944-1973, Box 3, Alexander, Robert, 1955, GMMA.

${ }^{51}$ Robert Alexander interview with S.M. Shakoor, June 27 and June 29, 1954; Robert Alexander interview with Richard Ishmael, June 27, 1954, RG 18-003, International Affairs Department, Jay Lovestone Files, 1944-1973, Box 2, Alexander, Robert, 1954, GMMA

${ }^{52}$ Robert Alexander interview with S.M. Shakoor, June 27 and June 29, 1954; Robert Alexander interview with Richard Ishmael, June 27, 1954, RG 18-003, International Affairs Department, Jay Lovestone Files, 1944-1973, Box 2, Alexander, Robert, 1954, GMMA.
} 
support to make external assistance effective. ${ }^{53}$ Crucially, Ishmael supported British trade union methods. Thus, British and American efforts to strengthen the MPCA coincided with the emergence of a new leader who shared their vision of institution-building and who had tentative support from sugar workers.

\section{American Foreign Policy toward British Guiana during the Eisenhower Administration}

The U.S. policy of institution-building in British Guiana between 1954 and 1957 was torn between the guided expansion of democratic mechanisms within Guianese society and the development of a capitalist labor movement based on business unionism. In contrast to the Truman administration, which focused its attention on Europe and Asia, President Eisenhower and his advisors were increasingly concerned with Latin America. ${ }^{54}$ High-ranking American officials discussed British Guiana at a National Security Council (NSC) meeting on October 8, 1953. According to CIA director Allen Dulles, the British suspended the Guianese constitution in response to the election of a communist party in the colony. ${ }^{55}$ William Christensen, the Charge d'affaires in Trinidad and Tobago, expressed concern about the British suspension of the Waddington Constitution in a report to the State Department in November. Specifically, Christensen noted his apprehension about instability in the Caribbean, which the Joint Chiefs of Staff prioritized in national security projections. ${ }^{56}$

\footnotetext{
${ }^{53}$ Robert Alexander interview with Richard Ishmael, June 27, 1954, RG 18-003, International Affairs Department, Jay Lovestone Files, 1944-1973, Box 2, Alexander, Robert, 1954, GMMA.

${ }^{54}$ Rabe, U.S. Intervention in British Guiana, 176.

${ }^{55}$ Memorandum of Discussion at the 165th Meeting of the NSC, October 7, 1953, 162nd Meeting of the NSC September 17, 1953, Dwight D. Eisenhower Papers as President, 1953-61, (Ann Whitman File), NSC Series, Box 4, Dwight D. Eisenhower Presidential Library, Abilene, Kansas (Hereafter, DDEL). Several lines of the transcript are redacted.

${ }^{56}$ Memorandum of Conversation, William H. Christensen and James Barry, Inter-Division Bureau of the Budget, 13 November 1953, 841D.00 TA/11-1353, Central Decimal Files, Box 4814, RG 59, Records of the Department of State, NARA II; Interview with Clint A. Lauderdale conducted with Charles Stuart Kennedy, 16 August 1994, FAOHC, LOC.
} 
Meanwhile, United States diplomats supported the British use of force against the PPP in international forums. An NSC report emphasized the importance of regional diplomatic measures since several Latin American countries thought the question of colonialism more pressing than allegations of communist infiltration in British Guiana. Consequently, American diplomats "took further steps to impress on Latin American officials" that the alleged communist conspiracy in British Guiana posed a critical threat to the hemisphere. ${ }^{57}$ United States representatives at an Organization of American States (OAS) meeting in Caracas the following March pushed through an anti-communist measure in anticipation of involvement in the Guatemalan coup in June while pointedly abstaining from a vote on an anti-colonial resolution that every Latin American Republic adopted. ${ }^{58}$ Similarly, American diplomats supported the British refusal to allow the United Nations to debate the intervention. ${ }^{59}$

The importance of strategic resources, specifically bauxite, considerably influenced the Eisenhower administration's policy toward British Guiana throughout the 1950s. Bauxite, the ore used to produce aluminum, was essential to a wide variety of civilian industries but most importantly to military preparedness in the early Cold War. ${ }^{60}$ British representatives in the Foreign Office noted that the Eisenhower administration impressed on them the considerable American concern with controlling access to Guianese raw materials, though British officials

\footnotetext{
${ }^{57}$ Second Progress Report on NSC 144/1, United States Objectives and Course of Action with Respect to Latin America, November 20, 1953, Foreign Relations of the United States 1952-1954 (Hereafter FRUS), Volume IV, The American Republics, 1952-1954, eds., N. Stephen Kane and William F. Sanford, Jr. (Washington D.C.: Government Printing Office), 26.

${ }^{58}$ Memorandum of Discussion at the 188th Meeting of the National Security Council, March 18, 1954, 188th Meeting of the NSC March 11, 1954, Dwight D. Eisenhower Papers as President, 1953-61, (Ann Whitman File), NSC Series, Box 5, DDEL; Rabe, 54; Nick Cullather, Secret History: The CIA's Classified Account of Its Operations in Guatemala, 1952-1954, $2^{\text {nd }}$ ed. (Stanford: Stanford University Press, 2006), 40.

${ }^{59}$ Ashton and Killingray, eds., 64.

${ }^{60}$ Tyler Priest argues that the procurement of strategic raw materials including Caribbean bauxite drove United States policy in the late 1940s and early 1950s. See: Tyler Priest, "Banking on Development: Brazil in the United States' Search for Strategic Minerals, 1945-1953”, The International History Review, Vol. 21, No. 2 (Jun., 1999), pp. 297-330.
} 
noted the Colonial Office's wariness of permitting an "American foothold" in the West Indian colonies. $^{61}$

In addition to concerns about American access to resources, the NSC acknowledged that increased trade of strategic items "would break certain bottlenecks in the development of Soviet war potential." ${ }^{62}$ A secret evaluation of International Cooperation Administration (ICA) programs in British Guiana noted that the colony "held important deposits of strategic raw materials" that would represent a serious national security threat if traded to the Soviet Union. The report also noted that its proximity to the Panama Canal made British Guiana geographically significant. ${ }^{63}$ The reports collectively suggest that the Eisenhower administration expected a communist or communist-friendly government in British Guiana to trade strategic materials to the Soviet Union and increase the military potential of American's Cold War rival. ${ }^{64}$ Moreover, historian Michael Adamson points out that the Soviet Union pursued an economic offensive in the developing world that focused on using technical assistance, trade, and financial aid to

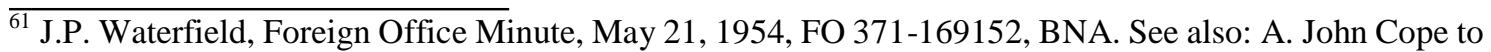
Department of State, 23 April, 1957, 122.41D, Central Decimal Files, Box 717, RG 59, Records of the Department of State, NARA II.

${ }^{62}$ Memorandum of Discussion at the 188th Meeting of the National Security Council, March 11, 1954, 188th Meeting of the NSC, March 11, 1954, Dwight D. Eisenhower Papers as President, 1953-61 (Ann Whitman File) NSC Series, Box 5, DDEL.

${ }^{63}$ International Cooperation Administration, Office of the Assistant to the Director for Evaluation, "Evaluation of Caribbean Overseas Territories Program," July 23, 1959, British Guiana: US Consulate, Georgetown, Classified General Records, 1957-1963, Box 13, Records of the Foreign Service Posts of the Department of State, RG 84, NARA II.

${ }^{64}$ Memorandum of Discussion at the 188th Meeting of the National Security Council, March 11, 1954, 188th Meeting of the NSC, March 11, 1954, Dwight D. Eisenhower Papers as President, 1953-61 (Ann Whitman File) NSC Series, Box 5, DDEL; National Security Council, “U.S. Policy Toward the West Indies," January 25, 1960, West Indies (1); National Security Council, "Progress Report on United States Objectives and Courses of Action with Respect to Latin America by the Operations Coordinating Board," February 3, 1955; National Security Council, "United States Objectives and Courses of Action with Respect to Latin America, September 3, 1954, Latin America (1), White House Office, National Security Council Staff: Papers, 1948-61, Disaster File, Box 63, DDEL. CIA Director Allen Dulles referred to the NSC reports collectively as "the Bible of U.S. policy both here and abroad. See: Memorandum of Discussion at the 224th Meeting of the National Security Council, November 15, 1954, 224th Meeting of NSC, November 15, 1954, Dwight D. Eisenhower Papers as President, 1953-61 (Ann Whitman File) NSC Series, Box 6, DDEL. For more on American policymakers' concerns regarding access to raw materials, see: Robert J. McMahon, "Introduction: The Challenge of the Third World," in Peter L. Hahn and Mary Ann Heiss, Empire and Revolution: The United States and the Third World Since 1945 (Columbus: Ohio State University Press, 2001), 3-4.
} 
expand Soviet influence beginning in $1953 .{ }^{65}$ The PPP's pursuit of economic and technical assistance from the Eastern-bloc and an expressed desire for trade with the socialist world made British Guiana a critical area of concern for American policymakers. ${ }^{66}$

Geopolitical threats and fear of material improvements to the Soviet military were not the only factors shaping American policymakers response to British Guiana. Harold Stassen, Director of the Foreign Operations Administration (FOA), wrote to President Eisenhower in June 1955 arguing that the FOA played an important role in developing economic and social institutions in the underdeveloped world as a means of protecting the American economy. Stassen argued that increasing national output in the United States required "a great increase in imports of foreign materials" as well as locating "new markets for some products where domestic demand is relatively inelastic." ${ }^{, 67}$ While British Guiana represented a small market, access to Guianese materials, from the perspective of American policymakers, could prove to be critical to the United States economy over time. ${ }^{68}$

United States policymakers also considered British Guiana a potential source of economic opportunity throughout the Eisenhower administration. Throughout the 1950s there were persistent attempts to determine the colony's mineral and resource wealth as the United States anticipated the expansion of economic opportunities in the decolonizing British Caribbean. Investors expressed interest in a wide range of possibilities, from exploiting yet to be

\footnotetext{
${ }^{65}$ Michael R. Adamson, “'The Most Important Single Aspect of Our Foreign Policy’?: The Eisenhower Administration, Foreign Aid, and the Third World," in Kathryn C. Statler and Andrew L. Johns, eds., The Eisenhower Administration, the Third World, and the Globalization of the Cold War (Lanham, MD: Rowman \& Littlefield Publishers, Inc., 2006), 55-57.

${ }^{66}$ Jan Koura and Robert Waters, "Cheddi Jagan and Guianese Overtures to the East: Evidence from the Czech National Archives," Cold War International History Project, e-Dossier No. 54, Wilson Center, 2015.

${ }^{67}$ Harold E. Stassen, Director, "Report to the President on the Foreign Operations Administration, January 1953 to June 1955," June 30, 1955, Executive Departments and Agencies-Foreign Operations Administration (1), LaurinL. Henry: Papers re Presidential Transitions, 1952-1961, Box 4, DDEL; Harold Stassen to All FOA Missions, September 1955, Administration-Organization, 1953-1955 (FOA), Dennis A. FitzGerald Papers, 1945-1969, Box 38, DDEL.

${ }^{68}$ See: McMahon, "Introduction: The Challenge of the Third World," in Hahn and Heiss, Empire and Revolution, 23.
} 
discovered offshore oil deposits to expanding into untapped markets for egg crate sales. ${ }^{69}$

Secretary of State John Foster Dulles expressed optimism about the mineral wealth and future economic benefits the United States could attain from increased relations with the colony. Dulles encouraged attempts to locate strategic materials, such as uranium, and labeled exploratory studies on potential fisheries as "urgent.",70 Thus, while strategic concerns ultimately trumped specific economic issues in British Guiana, as James Siekmeier argues, United States policymakers viewed economic nationalism "as both more prevalent and dangerous than communism" during the Cold War and staunch opposition to economic nationalism both pre-and post-dated the post-World War II superpower rivalry. ${ }^{71}$

Most significantly, Eisenhower administration officials argued for a perpetuation of informal American empire in the Western hemisphere through ideological expansion. In March 1954 John Foster Dulles clarified his interpretation of the Monroe Doctrine to the NSC while explaining the background of the anti-communist resolution he advocated at the OAS meeting in Caracas. With the Guatemalan crisis in which CIA-backed opponents of President Jacobo Arbenz ultimately forced him to flee very much on his mind, Dulles argued that the resolution

\footnotetext{
${ }^{69}$ See: Oil: A. John Cope to Department of State, 2 July 1957, 841D.2553/7-257, Central Decimal Files, Box 4451, RG 59, NARA II, Interview with Theodore J.C. Heavner conducted with Charles Stuart Kennedy, 28 May 1997, The Foreign Affairs Oral History Collection of the Association for Diplomatic Studies and Training, Library of Congress, Manuscript Division, Washington, D.C. 20540 USA (Hereafter FAOHC, LOC); egg crates: Juan Colon, Shellmar Products Corporation to U.S. Consulate, Georgetown, 30 April 1952, 510.2, Records of the Foreign Service Posts of the Department of State, RG 84, British Guiana, 1940-52, Box 46, NARA II.

${ }^{70}$ See: sugar: John Foster Dulles to American Consul, Port of Spain, 16 July 1954, 841D.318/7-1654, Central Decimal Files, Box 4814, RG 59, NARA II; rice: John Foster Dulles to American Consul, Georgetown, 24 May 1957, 841D.2317/5-2457, Central Decimal Files, Box 4451, RG 59, NARA II; fishing: John Foster Dulles to American Consul Georgetown, 6 September 1958, 841D.245/10-2458, Central Decimal Files, Box 4451, RG 59, NARA II; George Aiken, Study Mission in the Caribbean Area 1957: Report to Committee on Foreign Relations, United States Senate, 20 January 1958, 841D.062/1-2059, Records of the Foreign Service Posts of the State Department, British Guiana, Classified General Records, 1940-63, Box 13, RG 84, NARA II. Attempts to locate other strategic minerals included, uranium: A. John Cope to Department of State, 23 August 1955, 841D.2546/82355, Central Decimal Files, Box 4451, RG 59, NARA II; A. John Cope to Department of State, 29 July 1958, 841D.2546/7-2958, Central Decimal Files, Box 4451, RG 59, NARA II. Jagan also noted that iron ore deposits found on the Venezuela-Guyana border were considered possibly the largest in the world. See: Jagan, 159.

${ }^{71}$ James Siekmeier, "Latin American Economic Nationalism and United States-Latin American Relations, 19451961.” The Latin Americanist 52:3 (October 2008): 59-76.
} 
expanded the American assertion of influence in the Western Hemisphere to include outlawing foreign ideologies in the American Republics. ${ }^{72}$ The Caracas Declaration of Solidarity, signed on March 28, argued that "the domination or control of the political institutions of any American state by the international communist movement extending to this hemisphere the political system of an extra continental power" constituted an existential threat to every country in the region. ${ }^{73}$ Crucially, the declaration confirmed that American efforts to counter subversion could not be considered intervention since the threat of communist control of political institutions in the American republics was tantamount to external aggression against the United States. ${ }^{74}$ Thus, the declaration provided a legal justification for a wide array of American programs aimed at controlling the direction of Guianese labor unions. ${ }^{75}$

Moreover, despite Eisenhower's skepticism, Vice President Richard Nixon and Allen Dulles convinced the NSC that specific U.S. domestic legislation should be aimed at countering subversives in labor unions because such legal justifications could assist in "combatting Communist control of labor unions in foreign countries." ${ }^{, 76}$ On August 6 the NSC articulated its commitment to countering communism's "creeping expansion" in the hemisphere through AFL-

\footnotetext{
${ }^{72}$ Memorandum of Discussion at the 188th Meeting of the National Security Council, Thursday, March 18, 1954, Dwight D. Eisenhower Papers as President, 1953-61, (Ann Whitman File), NSC Series, Box 5, DDEL.

${ }^{73}$ Avalon Project at Yale Law School, "Caracas Declaration of Solidarity," March 28, 1954, Lillian Goldman Law Library. http://avalon.law.yale.edu/20th_century/intam10.asp (accessed January 9, 2015).

${ }^{74}$ Memorandum of Discussion at the 188th Meeting of the National Security Council, Thursday, March 18, 1954, Dwight D. Eisenhower Papers as President, 1953-61, (Ann Whitman File), NSC Series, Box 5, DDEL.

${ }^{75}$ The following year George Meany pursued a similar measure in the ICFTU, winning support for a policy against affiliates having contact with communist organizations. See: Anthony Carew, "Charles Millard, A Canadian in the International Labor Movement: A Case Study of the ICFTU 1955-61,” Labour/Le Travail, 37 (Spring 1996), 121148.

${ }^{76}$ Memorandum of Discussion at the 188th Meeting of the National Security Council, Thursday, March 18, 1954, 188th Meeting of the NSC March 11, 1954, Dwight D. Eisenhower Papers as President, 1953-61, (Ann Whitman File), NSC Series, Box 5, DDEL.
} 
CIO-FOA programs for economic growth, political support, and covert operations, specifically in Latin America. ${ }^{77}$

NSC officials argued throughout 1954 for continued support for NSC 162/2, which argued that underdeveloped countries needed to be guided toward "orderly development into more stable and responsible nations" within the Western capitalist system through "all feasible measures." United States policymakers perceived a revolution of rising expectations in the Third World. NSC members argued that failure to harness that revolution would result in underdeveloped nations and former colonies being absorbed into the Soviet system and tipping the world balance of power against the United States. ${ }^{78}$ Thus, United States policymakers concluded that national security, economic growth, and ideological expansion could be achieved in British Guiana through cooperation with conservative elements of the American labor movement.

The relationship between the AFL, CIO, and the United States government in foreign policy evolved in the early 1950s as the State Department attempted to exert greater influence over labor leaders' involvement in foreign countries. ${ }^{79}$ A number of prominent labor leaders argued that Eisenhower administration officials abused arbitrary powers in labor-government programs and deemphasized labor organizations' role in foreign operations creating a schism between government officials and labor leaders in $1953 .{ }^{80}$ However, as Stephen Rabe argues in

\footnotetext{
${ }^{77}$ Memorandum of Discussion at the 209th Meeting of the National Security Council, Thursday, August 5, 1954, 209th Meeting of the NSC, August 5, 1954, Dwight D. Eisenhower Papers as President, 1953-61, (Ann Whitman File), NSC Series, Box 5, DDEL.

78 "Note by the Executive Secretary to the National Security Council on Basic National Security Policy, NSC 162/2," October 30, 1953, FRUS, 1952-1954, Volume XIX, National Security Affairs, Part 1, eds., Lislie A. Rose and Neal H. Peterson (Washington D.C.: Government Printing Office), 577.

${ }^{79}$ The AFL and CIO were independent national labor councils that merged in 1955.

80 “Another Unionist Declines U.S. Job," New York Times, December 31, 1953; "Meany Quits Stassen Agency; Charges It Sidetracks Labor," New York Times, December 12, 1953; Normal Walker, "CIO Director Rejects Post Offered by Ike," Washington Post, December 31, 1953, Executive Departments and Agencies-Foreign Operations Administration (2), Laurin L. Henry: Papers re Presidential Transitions, 1952-1961, Box 4, DDEL; Jerry Kluttz,
} 
Eisenhower and Latin America, the Eisenhower administration continued previous

administrations' consultation with labor leaders such as George Meany and Serafino Romualdi and secretly financed international labor programs that dovetailed with State Department aims. The administration also encouraged the advancement of United States foreign policy objectives through international labor organizations, most importantly ORIT. ${ }^{81}$ Eisenhower policymakers initiated a foreign policy program that called for increased AFL-CIO involvement in foreign operations, a policy that several members of the administration including Secretary of State Dulles and FOA Director Stassen reflected on positively in $1955 .{ }^{82}$ Nonetheless, the Eisenhower administration decreased the direct influence of the AFL and CIO in policymaking through bureaucratic reorganization aimed at increasing the institutionalized nature of labor-government cooperation in foreign operations to assure that AFL-CIO overseas programs were subordinated to State Department policy.

The Eisenhower administration policy included Dulles's renewal of State Departmentlabor relationships in August 1953, the appointment of James Mitchell as Secretary of Labor in early October 1953, and Stassen's re-establishment of the FOA Office of Labor Affairs in early $1954 .{ }^{83}$ Improved relations between labor leaders and government official increased government-

“Stassen's Firing Power Backfires, Hill Aides Find, Washington Post, September 15, 1953; "FOA Reorganization Planned for Oct. 1," The Washington Daily News, September 6, 1953, Personnel-FOA Aptitude Test, ), Laurin L. Henry: Papers re Presidential Transitions, 1952-1961, Box 11, DDEL

${ }^{81}$ Stephen G. Rabe, Eisenhower and Latin America: The Foreign Policy of Anticommunism (Chapel Hill: The University of North Carolina Press, 1988), 34.

${ }^{82}$ John Foster Dulles Memorandum of Conversation with Mr. Stassen, June 7, 1955, Memos of ConversationGeneral-S (3), John Foster Dulles Papers, 1951-59, General Correspondence and Memoranda Series, Box 1, DDEL; J.H. Smith, Jr. to George Meany, December 3, 1957, ICA Chron File, Dec. 1957, James Hopkins Smith, Jr., Papers, 1932-1980, DDEL.

${ }^{83}$ Harold E. Stassen, Director, "Report to the President on the Foreign Operations Administration, January 1953 to June 1955," June 30, 1955, Executive Departments and Agencies-Foreign Operations Administration (1), Laurin L. Henry: Papers re Presidential Transitions, 1952-1961, Box 4, DDEL; "Stassen Will Name Union Aide for F.O.A.," New York Times, May 29, 1954; "Labor Regains Foreign Aide Role As Chiefs Take Posts Under Law," New York Times, July 19, 1954; “9 Appointed On board to Advise FOA," Washington Post, December 3, 1953, Executive Departments and Agencies-Foreign Operations Administration (2), Laurin L. Henry: Papers re Presidential Transitions, 1952-1961, Box 4, DDEL. 
labor cooperation beginning in 1954. Dulles met with Meany and CIO President Walter Reuther to discuss international relations in August and Mitchell's appointment was the impetus for improved relations between the Department of Labor and American labor leaders. ${ }^{84}$ Meanwhile, Mitchell wrote to Meany in late November 1953 to explain that he viewed the Department of Labor's responsibilities in international relations as among its most important duties and stated his intention to reactivate the Department of Labor Trade Union Advisory Committee on International Affairs. ${ }^{85}$ Discussions at the CIO convention in November 1953 further underscored the shift in Executive policy toward greater official collaboration between the American labor movement and the United States government in foreign relations. ${ }^{86} \mathrm{CIO}$ delegates noted that American foreign operations programs severely de-emphasized labor participation in the early 1950s; however, Dulles suggested that policymakers would renew an alliance with trade unions in the international sphere during his address to the convention. The Eisenhower administration's increased participation with American trade unions coincided with a shift in program emphasis toward less developed areas. ${ }^{87}$ Secretary Dulles specifically

\footnotetext{
${ }^{84}$ John Foster Dulles to George Meany, August 26, 1953, RG 1-027, Office of the President, George Meany's Files, 1944-1960, Box 15, State Department, 1953-1960, GMMA; For an concise overview of Mitchell's tenure, including expansion and strengthening of the Department of Labor and improved relations with Meany and Reuther, see: Henry P. Guzda, "James P. Mitchell: Social Conscience of the Cabinet," Monthly Labor Review, August 1991, 2329.

${ }^{85}$ James Mitchell to George Meany, November 27, 1953, RG 1-027, Office of the President, George Meany's Files, 1944-1960, Box 52, Subjects: Trade Union Advisory Committee, Department of Labor, 1950-1953, GMMA. ${ }^{86}$ Letter to Charles B. Brownson, Chairman International Operations Subcommittee, House of Representatives, October 19, 1954, Administration-Organization, 1953-1955 (FOA), Dennis A. FitzGerald Papers, 1945-1969, Box 38, DDEL. The emphasis on official Executive policy and official collaboration is significant since covert associations between American labor leaders and the Central Intelligence Agency were ongoing in the early 1950s. See:

${ }^{87}$ For more on the shift in United States foreign policy during the Eisenhower administration that emphasized the developing world, see: Kathryn C. Statler and Andrew L. Johns, eds., The Eisenhower Administration, the Third World, and the Globalization of the Cold War (Lanham, MD: Rowman \& Littlefield Publishers, Inc., 2006).
} 
emphasized the importance of State Department relations with American organized labor in stemming the spread of communist ideas into colonial and underdeveloped areas of the world. ${ }^{88}$ At the same time, cooperation between labor leaders and policymakers in foreign operations changed under the Eisenhower administration's 1953 Reorganization Plan number seven that created the FOA as the State Department's administrative arm for U.S. foreign assistance to developing countries. The plan centralized programs to ensure conformity to State Department objectives and coordination with official policy established through the recommendations of the Security Council to the President. ${ }^{89}$ Congressional debates on the plan's ratification acknowledged that appropriation requests from the FOA and its participants could influence policymaking in small ways and give labor leaders an indirect avenue through which they could help formulate policy decisions. However, the reorganization established a clear line of authority that increased the State Department's influence over foreign policy based on what Undersecretary of State General Walter Bedell Smith called “a certain amount of willing subordination" to the Secretary of State. ${ }^{90}$ Edwin Martin, Special Assistant to the Secretary for Mutual Security Affairs, also acknowledged that the FOA "while independent, is subject to the

\footnotetext{
${ }^{88}$ The 15th Constitutional Convention of the Congress of Industrial Organizations, November 16-20, 1953, FO 371 103575, BNA; John Foster Dulles, "The Moral Initiative," Speech before the annual convention of the Congress of Industrial Organizations," November 18, 1953, RG 18-003, International Affairs Department, Jay Lovestone Files, 1944-1973, Box 33, John Foster Dulles: Secretary of State, 1953-1955, GMMA; Harold E. Stassen, Director, "Report to the President on the Foreign Operations Administration, January 1953 to June 1955," June 30, 1955, Executive Departments and Agencies-Foreign Operations Administration (1), Laurin L. Henry: Papers re Presidential Transitions, 1952-1961, Box 4, DDEL.

${ }^{89}$ Letter to Charles B. Brownson, Chairman International Operations Subcommittee, House of Representatives, October 19, 1954, Administration-Organization, 1953-1955 (FOA), Dennis A. FitzGerald Papers, 1945-1969, Box 38, DDEL; Harold E. Stassen, Director, "Report to the President on the Foreign Operations Administration, January 1953 to June 1955," June 30, 1955, Executive Departments and Agencies-Foreign Operations Administration (1), Laurin L. Henry: Papers re Presidential Transitions, 1952-1961, Box 4, DDEL; Dwight D. Eisenhower to John Foster Dulles, April 15, 1955, Executive Departments and Agencies-Foreign Operations Administration (1), Laurin L. Henry: Papers re Presidential Transitions, 1952-1961, Box 4, DDEL.

${ }^{90}$ Statement of Rowland R. Hughes, Assistant Director, Bureau of the Budget; Accompanied by William F. Finan, Assistant Director for Management and Organization, Bureau of the Budget; and Statement of Gen. Walter Bedell Smith, Under Secretary of State, Reorganization Plans Nos. 7 and 8 of 1953 (Foreign Operations Administration) (United States Information Agency), Hearings before the Committee on Government Operations House of Representatives, $83^{\text {rd }}$ Congress, ${ }^{\text {st }}$ Session on H.J. Res. 261 and H.J. Res. 262, June 22, 23, and 24, 1953 (Washington D.C.: Government Printing Office, 1953), 11, 17.
} 
control and supervision and domination of the State Department." ${ }^{91}$ Several labor leaders criticized the State Department's influence in labor programs and argued that subordination to government officials compromised the independence of AFL-CIO actions. ${ }^{92}$

Nonetheless, Undersecretary of State for Administration Donald Lourie noted that educational exchange programs involving "direct face-to-face communication and contact between the people and institutions of the United States" and other countries were more integral to foreign relations than complex, large-scale operations. He suggested that person-to-person programs were particularly effective because they delegated significant portions of administration to private organizations such as the AFL and CIO. ${ }^{93}$ Robert Murphy, Deputy Undersecretary of State, echoed Lourie's view and noted that "more and more labor has come to accept and play its role in the development of the institutions of democracy the world over."94 Harold Stassen suggested that the FOA planned to "maximize a people-to-people relationship parallel to the government-to-government relationship" while "expanding support for voluntary non-governmental organizations." 95 FOA head Stassen also argued that as programs gave new attention to the need for economic, social, and institutional reforms in underdeveloped areas and

\footnotetext{
${ }^{91}$ Statement of Hon. Donold B. Lourie, Under Secretary of State For Administration; Accompanied by Edwin M. Martin, Special Assistant to the Secretary for Mutual Security Affairs, et. al., Reorganization Plans Nos. 7 and 8 of 1953 (Foreign Operations Administration) (United States Information Agency), Hearings before the Committee on Government Operations House of Representatives, 83rd Congress, 1st Session on H.J. Res. 261 and H.J. Res. 262, June 22, 23, and 24, 1953 (Washington D.C.: Government Printing Office, 1953), 58.

${ }^{92}$ FOA Labor Affairs Progress Reports, 1955, Office of the President-George Meany (1948-1960), Box 15, State Department: Foreign Operations Administration, Handbook, Labor Committee, 1955, GMMA.

${ }^{93}$ Statement of Hon. Donald B. Lourie, Undersecretary of State for Administration, Reorganization Plans Nos. 7 and 8 of 1953 (Foreign Operations Administration) (United States Information Agency), Hearings before the Committee on Government Operations House of Representatives, 83rd Congress, 1st Session on H.J. Res. 261 and H.J. Res. 262, June 22, 23, and 24, 1953 (Washington D.C.: Government Printing Office, 1953), 41.

${ }^{94}$ Foreign Operations Administration Labor Committee Memorandum, January 31, 1955, RG 1-027, Office of the President-George Meany (1948-1960), Box 15, State Department: Foreign Operations Administration, Documents, 1955, GMMA.

${ }^{95}$ Harold Stassen to All FOA Missions, September 1955, Administration-Organization, 1953-1955 (FOA), Dennis A. FitzGerald Papers, 1945-1969, Box 38, DDEL; See Also: MSA Press Release, January 15, 1952, AdministrationOrganization, 1953-1955 (FOA), Dennis A. FitzGerald Papers, 1945-1969, Box 38, DDEL.
} 
that "the problems of labor have received increased attention." 96 Thus, labor leaders assumed an increasing role in foreign operations programs, were able to use FOA funding to enhance their international operations, and influenced policymaking through foreign operations channels; however, coordination with official policy limited the independence of AFL-CIO programs. Changes in foreign operations programs in the mid-1950s illuminate the increased significance United States policymakers placed on involvement in underdeveloped countries. The Eisenhower administration assumed increasing responsibility for perpetuating the international capitalist system and, as Michael Adamson argues, restoring "the liberal international political economy" that existed prior to World War I. ${ }^{97}$ FOA and International Cooperation Administration (ICA) programs were conceived as temporary measures designed to advance underdeveloped economies as a means of countering communism's appeal and limiting Soviet influence in the third world; however, Adamson suggests that "promoting global capitalism" was the long-term objective. ${ }^{98}$ Furthermore, Adamson argues that the Eisenhower administration used foreign aid programs to address perceived threats to national security, rather than to promote economic development. However, Adamson suggests that the Eisenhower administration's policy ultimately "strengthen[ed] the institutional basis for liberalizing the

\footnotetext{
${ }^{96}$ Harold E. Stassen, Director, "Report to the President on the Foreign Operations Administration, January 1953 to June 1955," June 30, 1955, Executive Departments and Agencies-Foreign Operations Administration (1), Laurin L. Henry: Papers re Presidential Transitions, 1952-1961, Box 4, DDEL.

${ }^{97}$ Harold Stassen to All FOA Missions and All FOA Washington Employees, August 1, 1953, AdministrationOrganization 1953-1955 (FOA), Dennis A. FitzGerald Papers, 1945-69, Box 38, DDEL; See also: Randall Bennett Woods, A Changing of the Guard: Anglo-American Relations, 1941-1946 (Chapel Hill: The University of North Carolina Press, 1990). Carey Fraser examines the Anglo-American pursuit of a liberal economic trading order with a focus on the British Caribbean. See: Fraser, Ambivalent Anti-Colonialism.

${ }^{98}$ Statement of Hon. Harold E. Stassen, Director for Mutual Security, Reorganization Plans Nos. 7 and 8 of 1953 (Foreign Operations Administration) (United States Information Agency), Hearings before the Committee on Government Operations House of Representatives, 83rd Congress, 1st Session on H.J. Res. 261 and H.J. Res. 262, June 22, 23, and 24, 1953 (Washington D.C.: Government Printing Office, 1953), 118-119; Edwin Bock to Charles Ascher, October 13, 1953, Miscellaneous, 1953-1954, Laurin L. Henry: Papers re Presidential Transitions, 19521961, Box 10, DDEL.
} 
international political economy." "99 American-dominated international financial institutions, and U.S. economic policies, gradually pressured developing world countries into reducing public spending and accepting greater privatization. Nonetheless, FOA and ICA programs failed to strengthen the democratic institutions necessary to complement financial liberalization.

As such, AFL-CIO policies designed and implemented through the FOA inherently addressed State Department objectives while often advancing American labor leaders’ international objectives. A wide range of FOA programs in British Guiana began in May 1954 and continued under the ICA when it replaced the FOA in 1955. Significantly, Eisenhower explained to Secretary Dulles that the ICA was necessary because the FOA was "regarded by many as merely a temporary unit of Government, established solely to meet certain short-term economic and military requirements." The ICA, Eisenhower noted, reflected the recognition that "the functions and the need for cooperative development of economic and military strength among the free nations are continuing and integral parts of the fabric of our international relations."

Despite Eisenhower's ideals, scholars and contemporaries generally agree that the administration's foreign aid programs failed to promote effective economic development in the Third World. ${ }^{101}$ Likewise, the FOA, ICA, and later the American Institute of Free Labor Development (AIFLD), failed to solidify a position for reformist, pro-U.S. trade unions in British Guiana. Dennis FitzGerald, Deputy Director of the FOA and the most consistent administrator in its successor organizations, argued that FOA officials thought that the State Department looked

\footnotetext{
${ }^{99}$ Adamson, "The Most Important Single Aspect of Our Foreign Policy”," in Statler and Johns, eds., The Eisenhower Administration, the Third World, and the Globalization of the Cold War. For a broad overview of the Eisenhower administration's foreign economic policy, see: Burton I. Kaufman, Trade and Aid: Eisenhower's Foreign Economic Policy, 1953-1961 (Baltimore: The Johns Hopkins University Press, 1982).

${ }^{100}$ Dwight D. Eisenhower to John Foster Dulles, April 15, 1955, Executive Departments and Agencies-Foreign Operations Administration (1), Laurin L. Henry: Papers re Presidential Transitions, 1952-1961, Box 4, DDEL.

${ }^{101}$ Adamson, "'The Most Important Single Aspect of Our Foreign Policy'?," in Statler and Johns, eds., The Eisenhower Administration, the Third World, and the Globalization of the Cold War.
} 
upon the aid agencies "as just a kind of convenient device by which you avoided the whole responsibility for anything that went wrong" while "order[ing] it to do what the State Department wanted done." FitzGerald also reflected that the administration's perspective on technical assistance grew increasingly cynical by the late $1950 \mathrm{~s} .{ }^{102}$ FOA and ICA programs in British Guiana overwhelmingly targeted development in PPP strongholds to undermine the Jagans' support. Nonetheless, institution-building programs in the field of organized labor provided crucial funding to the MPCA and later the BGTUC. Tello's and Ishmael's participation in ICA programs between 1954 and 1957 established important connections between Guianese and American trade unionists that played a central role in the third phase of Guianese institutional decolonization after 1962. Connections between Guianese and American trade unionists remained after the ICA suspended its programs in British Guiana after elections in 1957 returned the PPP to power and the initial contract to run operations through the University of Maryland expired. $^{103}$

\section{Anglo-American Institution Building}

British and American labor and political leaders and their representatives in international labor organizations initiated a variety of institution-building projects in British Guiana beginning in mid-1954, intensifying in early 1955, and drawing down between 1957 and 1958 after failing to alter the colony's political outlook. ${ }^{104}$ British officials resisted American influence over British Guiana's institutional development, complicating attempts to coordinate institution-

\footnotetext{
${ }^{102}$ Interview with Dennis FitzGerald by Dr. Thomas Soapes, May 26, 1976, DDEL.

${ }^{103}$ International Cooperation Administration, "Evaluation of Caribbean Overseas Territories Program," July 23, 1959, Box 13, British Guiana U.S. Consulate, Georgetown, Classified General Records, 1940-1963, RG 84, Records of the Foreign Service Posts of the Department of State, NARA II; A. John Cope, Jr. to Department of State, April 26, 1957, 122.4132/4-2657, Box 717, Central Decimal Files, Box 717, RG 59, Records of the Department of State, NARA II; Patrick Renison to Alan Lennox-Boyd, August 23, 1957, FO 371-126078, BNA.

${ }^{104}$ International Cooperation Administration, Office of the Assistant to the Director for Evaluation, "Evaluation of Caribbean Overseas Territories Program," July 23, 1959, British Guiana: US Consulate, Georgetown, Classified General Records, 1957-1963, Box 13, Records of the Foreign Service Posts of the Department of State, RG 84, NARA II.
} 
building efforts. However, financial weakness limited British capabilities and American financial strength increasingly allowed the AFL-CIO and State Department to influence British Guiana in the mid-1950s. Moreover, colonial officials reappraised policies in British Guiana at the same time the Suez Crisis exposed British vulnerability on the international stage. However, as Stephen Rabe argues, British retreat from institution building in British Guiana began at the same time as the Suez Crisis and was not a consequence of the debacle. ${ }^{105}$

A variety of important developments unfolded in British Guiana between 1954 and 1957 before institution-building efforts tapered off. Among the most important were the MPCA's acquisition of a check-off system on sugar estates, the affiliation of several Guianese unions with ORIT, CADORIT, and the ICFTU, and the development of important relationships between proWestern Guianese leaders and British and American trade union and political leaders. Authoritarian British rule in Guiana limited opposition to Western institution-building efforts between 1954 and August 1957. Nonetheless, the Jagan faction of the PPP, with brief assistance from the WFTU, resisted Anglo-American institution building and sought to advance its representatives in Guianese trade unions.

At a session of the ORIT Executive Committee in January 1954, committee members passed a resolution condemning colonial administrators' slow and insufficient efforts to improve working and living conditions in British Guiana. ORIT representatives suggested that inaction created an opening for communists to use the banner of anti-colonialism to "deform the will of non-independent peoples" in the Western Hemisphere. The committee resolved to provide greater assistance and help create the conditions necessary for self-government. ${ }^{106}$ Anglo-

${ }^{105}$ Rabe, U.S. Intervention in British Guiana, 58-60.

${ }^{106}$ ORIT: 7th Session of the Executive Committee, "Resolution on Colonialism in the Western Hemisphere and Communist Penetration," January 24-28, 1954, RG 18-003, International Affairs Department, Serafino Romualdi Files, Box 7, ORIT: Executive Committee, 1952-1954, GMMA. 
American labor leaders supported the Colonial Office's decision to suspend the Waddington Constitution as a necessary measure that provided the opportunity to improve Guianese economic and social conditions and build viable, pro-Western trade unions, though the AFL-CIO and Western international labor organizations occasionally criticized British institution-building efforts as ineffective. ${ }^{107}$ Thus, regional labor leaders articulated a commitment to strengthening pro-Western trade unions and integrating them into ORIT.

At the same time, the WFTU defended Guianese leaders who advocated lessened Guianese integration into the Western system. The Waddington Constitution's suspension eliminated the possibility of direct affiliation of the PPP-aligned GIWU to the WFTU; however, the limited but important relationship between the left-wing of the PPP and the communist labor international continued into 1954. British officials expressed deep concern regarding WFTU support for the PPP in international forums and moderate Guianese leaders continued to warn that the WFTU's influence in the colony represented a formidable threat. ${ }^{108}$

In March 1954 the WFTU filed a complaint against the British government to the Secretary General of the United Nations (UN) alleging that British actions in British Guiana violated trade union rights and were part of a general attack on the rights and freedoms of the Guianese population. ${ }^{109}$ Specifically, the WFTU criticized British censorship of the organization's literature sent to the colony. The British government generally considered

\footnotetext{
${ }^{107}$ Luis J. Marcano, Secretary, CADORIT, “Report on CADORIT’s Activities,” December 31, 1954, RG 18: International Affairs Department, Staff Files: George Delaney's Files, 1921-1957, Box 11, ORIT 3rd Congress, 1955, GMMA; Minutes of the $11^{\text {th }}$ Meeting of the Executive Board of the ICFTU, November 30-December 4, 1953, RG 1-027, Office of the President-George Meany (1948-1960), Box 51, Meetings: Executive Board (Emergency Committee), 1954, Mar., GMMA; Robert Alexander to Jay Lovestone July 6, 1954, RG 1-027, Office of the President-George Meany (1948-1960), Box 15, State Department: Foreign Operations Administration, Handbook, Labor Committee, 1955, GMMA.

${ }^{108}$ Patrick Renison to British Ambassador to Washington D.C., September 19, 1957, FO 371-126078, BNA; Palmer, Cheddi Jagan and the Politics of Power, 99-100.

${ }^{109}$ International Labor Office, "Report of the Committee on Freedom of Association," November 16-19, 1954, CO 859-772, BNA.
} 
"blanket" banning of literature in its territories indefensible and specific legislation in British Guiana only allowed for individual pieces of literature to be withheld; however, officials made an exception in the case of WFTU publications entering the colony. Colonial governor Alfred Savage's December 1953 ban on WFTU material argued that WFTU literature was Soviet propaganda and not trade union material, echoing former MPCA General Secretary and Legislative Council Member Lionel Luckhoo's 1952 subversive literature law. ${ }^{110}$ Oliver Lyttleton, Secretary of State for the Colonies, supported the measure despite Prime Minister Winston Churchill's skepticism regarding the measure's necessity. ${ }^{11}$

British officials also contested the WFTU's allegation that Savage's censorship violated Guianese unions' right to affiliate with the international organization of their choosing since no Guianese union was formally affiliated to the WFTU. ${ }^{112}$ However, colonial officials and TUC leaders cited informal connections between the WFTU and colonial unions as evidence of communist infiltration and used them to justify actions against the unions. ${ }^{113}$ Finally, colonial officials argued that British Guiana's colonial status precluded the protection of trade union rights under International Labor Organization (ILO) rules. ${ }^{114}$ However, a retrospective TUC report noted that the Colonial Office and TUC established the Commonwealth Advisory Committee in 1937 "to improve the conditions of workers in the colonies, in part through the application of the ILO Conventions." ${ }^{, 15}$ Therefore, British officials created a circular and paradoxical defense that rationalized inhibiting all Guianese connections with the WFTU as a

\footnotetext{
${ }^{110}$ Palmer, Cheddi Jagan and the Politics of Power, 99.

${ }^{111}$ Colonial Office Minute, May 7, 1954, CO 859-772, BNA; Palmer, Cheddi Jagan and the Politics of Power, 64.

112 Colonial Office Minute, July, 1954, CO 859-772, BNA.

${ }^{113}$ Colonial Office Minute, May 7, 1954, CO 859-772, BNA.

114 "Extract from British Guiana Sixtieth Political Report covering the period from June 1 -June 30, 1954, CO 859773, BNA.

${ }^{115}$ Trades Union Congress International Committee, “Congress Resolution No. 37: Trade Unions in Developing Countries,” July 26, 1966, Marjorie Nicholson Files, Box 8, I.C. Minutes 1965/66 [901], TUCLC.
} 
means of minimizing Eastern-bloc contacts and assuring Guianese unions' integration into Western labor organizations.

Delegates at the ILO convention in November 1954 dismissed the WFTU's complaint arguing that Savage's ban was a political action undertaken to deal with local circumstances and not a violation of trade union rights. ${ }^{116}$ Nonetheless, several Guianese unions continued their loose association with the communist-international. In early 1954 the GIWU sent a message of support to Jacobo Arbenz in Guatemala at the urging of the WFTU and the BGLU requested that the reformed BGTUC rescind its ban on unions affiliated to the WFTU. ${ }^{117}$ Ultimately the failed protest in the UN weakened the positions of the GIWU and the WFTU in British Guiana. ${ }^{118}$ Despite the WFTU's diminished influence in the colony, British and American labor leaders expressed concern that the communist international was intensifying its programs. Anglo-American institution-building increased as a result of suspicions that the WFTU was using relationships between communist parties and democratic trade unions in underdeveloped countries to promote Soviet foreign policy. ${ }^{119}$ Serafino Romualdi, the AFL representative to ORIT, visited British Guiana for four days in April 1954 to determine the state of trade unionism in the colony and reported his findings to George Meany and ICFTU General Secretary J.H. Oldenbroek. Romualdi noted that various forms of assistance from the ICFTU, ORIT, TUC, AFL, and United States Information Service (USIS) helped the MPCA survive in the midst of the

\footnotetext{
${ }^{116}$ Secretary of State for the Colonies to Officer Administering the Government of British Guiana, December 16, 1954, CO 859-772, BNA.

${ }^{117}$ Robert Alexander interview with J.P. Lachmansingh, President of GIWU, June 29, 1954, RG 18-003, International Affairs Department, Jay Lovestone Files, 1944-1973, Box 2, Alexander, Robert, 1954, GMMA; "Extract from British Guiana Sixtieth Political Report covering the period from June 1-June 30, 1954, CO 859-773, BNA.

118 "Eastern Caribbean and British Guiana Security Review," July 1-September 30, 1955, CO 1035-16.

${ }^{119}$ Foreign Operations Administration, Office of Labor Affairs, "Revised FY 1955 Labor Programs for Underdeveloped Areas,” August 13, 1954, RG 1-027, Office of the President, George Meany’s Files, 1944-1960, Box 15, State Department: Foreign Operations Administration, 1953-1954 Aug., GMMA; “Colonial Trade Unionism, Draft" undated (1955/1956); TUC Pamphlet, "What the TUC is Doing," Spring 1956, Trade Unions and Colonies 932.5, Box 15, Marjorie Nicholson Files, TUCLC.
} 
colony's political turmoil and in the face of challenges from the rival GIWU. Romualdi strongly urged, as did George Woodcock of the TUC who visited British Guiana the previous week, that ORIT or the ICFTU provide a trade union advisor to help build the movement among the rankand-file. Romualdi criticized the "second string individuals" leading the anti-communist labor movement and concluded that there remained a dire need for external training of Guianese unionists since almost the entire labor force of the colony still supported leaders suspected of being communists. ${ }^{120}$ Romualdi's contemporaries in the Western international labor movement also took action in British Guiana. CADORIT Secretary Ken Sterling and Charles Millard, acting National Director of the Steelworkers' Union of Canada, traveled to British Guiana to facilitate affiliation between the British Guiana Mine Workers' Union and the Canadian union in early $1954 .^{121}$

High-ranking American policymakers finalized plans for operations in British Guiana while Romualdi visited the colony. On April 23 Secretary of State John Foster Dulles explained FOA plans to send Guianese trainees to Puerto Rico in a letter to William Maddox, the American Consul General in Trinidad tasked with overseeing British Guiana. ${ }^{122}$ The British and American governments agreed to terms for the initiation of a variety of technical assistance programs in June, though Dulles noted that FOA personnel began cooperating with interested Guianese prior to the official agreement. FOA programs began immediately and according to Dulles were "well underway" by August. ${ }^{123}$ The State Department expected technical assistance in British Guiana

\footnotetext{
${ }^{120}$ Serafino Romualdi to J.H. Oldenbroek, April 6, 1954, RG 1-027, Office of the President, George Meany's Files, 1944-1960, Box 58, Reports: Serafino Romualdi, 1948-1955, GMMA.

121 "Extract from British Guiana Sixtieth Political Report covering the period from June 1-June 30, 1954, CO 859773 , BNA.

${ }^{122}$ John Foster Dulles to William Maddox, Department of State Instruction, April 23, 1954, 841D.00-TA/4-2354, Central Decimal Files, Box 4814, RG 59, NARA II; John Foster Dulles to William Maddox, June 18, 1954, 841D.00-TA/6-1854, Central Decimal Files, Box 4814, RG 59, NARA II.

${ }^{123}$ John Foster Dulles to American Consulate, Barbados, August 25, 1954, 841D.00-TA-8-2554, Central Decimal Files, Box 4814, RG 59, NARA II; Foreign Operations Administration, "American Universities in Technical
} 
to continue until June 30, 1959 but allowed for early termination with thirty days-notice depending on local developments. ${ }^{124}$ The initial FOA programs ignored institution-building and complemented Colonial Office plans to use economic development to undermine the PPP's appeal. However, Romualdi and Ernst Schwarz, the CIO's Latin American representative, helped draft a labor program for British Guiana as FOA programs expanded in the colony in early 1955. $^{125}$

At the same time FOA programs began in late June 1954, Robert Alexander returned to the United States from a fact-finding trip in Latin America. Alexander sent a copy of his findings to Jay Lovestone and Lovestone forwarded the report Free Trade Union Committee (FTUC), the AFL's covert anti-communist arm. Alexander argued that the suspension of the Waddington Constitution created an opportunity to build the MPCA because "the fight to displace the PPP will be decided in the trade union field" and that it was crucial to move quickly in strengthening the PPP's opponents. Alexander warned that international support for anti-PPP trade unions since the suspension was insufficient and time was being wasted. He encouraged the AFL and ORIT to provide financial assistance to the MPCA since the union's finances were dependent on Booker Brothers' advertising. Alexander argued that the MPCA required financial independence from Booker Brothers to initiate a militant union campaign and gain workers' support. Finally,

Cooperation," RG 1-027, Office Of the President, George Meany's Files, 1944-1960, Box 15, State Department: Foreign Operations Handbook, Labor Committee, 1955, GMMA.

${ }^{124}$ Roger Mekins, British Ambassador to John Foster Dulles, June 29, 1954, 841D.00-TA/6-2954, Central Decimal Files, Box 4814, RG 59, NARA II; John Foster Dulles to Roger Mekins, June 29, 1954, 841D.00-TA/6-2954, Central Decimal Files, Box 4814, RG 59, NARA II.

${ }^{125}$ Foreign Operations Administration Labor Committee, Subcommittee Meeting, January 14, 1955, RG 18-007, International Affairs Department (CIO), Director's Files (Mike Ross), 1945-1955, Agencies Sub-Series 4: Foreign Operations Administration, Box 3, FOA Labor Committee: Minutes, 1955, GMMA. Two-thirds of the \$25 million allocated for technical assistance to British Guiana between 1954 and 1956 was for economic development. See: Report to Congress on the Mutual Security Program for the Six Months Ended December 31, 1954, RG 1-027, Office Of the President, George Meany's Files, 1944-1960, Box 15, State Department: Foreign Operations Handbook, Labor Committee, 1955, GMMA. 
Alexander recommended that the FTUC send propaganda that emphasized anti-communism while providing material on how to run a trade union. ${ }^{126}$

British planning for Guianese institution-building increased in the summer of 1954 as well. Alfred Savage informed the Colonial Office in June that he considered the development of non-communist, pro-British trade unionism a matter "of paramount importance." Savage warned of vulnerability in the sugar industry; however, he suggested that the industry was open to British influence since the MPCA and GIWU remained insolvent. ${ }^{127}$ After consulting Woodcock and Romualdi, Savage concluded that Guianese unions required the presence of British trade union leadership and in June he requested that the TUC supply an exceptionally respected unionist to advise Guianese unions for an extended period. ${ }^{128}$ Acting on his advice, representatives of the Colonial Office approached the TUC to discuss expanding efforts in the field of organized labor in June. Five members of the Colonial Office met with Woodcock on July 1 to deliberate on how to most effectively build Guianese trade unionism. ${ }^{129}$ Woodcock and colonial officials outlined general ideas for a program of assistance and established a formal agreement for cooperation in July. $^{130}$

British institution-building in Guiana expanded to include employers later in the summer. In August the new Secretary of State for the Colonies, Alan Lennox-Boyd, held a series of talks with the TUC and Overseas Employers' Federation (OEF) in which he encouraged increased non-governmental cooperation in developing colonial trade unions and underscored the

\footnotetext{
${ }^{126}$ Robert Alexander Report on Venezuela, Trinidad, and British Guiana, July 6, 1954, RG 18-003, International Affairs Department, Jay Lovestone Files, 1944-1973, Box 2, Alexander, Robert, 1954, GMMA.

${ }^{127}$ Alfred Savage to P. Rogers, June 18, 1954, CO 859-773, BNA; Alfred Savage to Alan Lennox-Boyd, July 28, 1954, CO 859-773, BNA.

${ }^{128}$ Alfred Savage to P. Rogers, June 18, 1954, CO 859-773, BNA.

${ }^{129}$ P. Roger, Colonial Office Minute, June 15, 1954 and P. Roger, Colonial Office Minute, June 26, 1954, CO 859-

773, BNA; "Note of Meeting to Discuss Trade Unionism in British Guiana," July 1, 1954, CO 859-773, BNA.

${ }^{130}$ M. Phillips, Colonial Office Minute, July 22, 1954, CO 859-773, BNA; "Note of Meeting to Discuss Trade Unionism in British Guiana," July 1, 1954, CO 859-773, BNA.
} 
importance of colonial institution-building. ${ }^{131}$ Colonial Office, TUC, and OEF collaboration in supporting the MPCA between 1954 and 1957 contributed considerably to the process of institution building. Together, British governmental, business, and workers' organizations cooperated to protect British investors and promote pro-British capitalism in British Guiana.

In contrast to the FOA's emphasis on organized labor's acceptance of official policy, N.D. Watson of the Colonial Office emphasized the importance of allowing the TUC to act independently of British policy even if TUC autonomy occasionally led to decisions with which that the Colonial Office disproved. ${ }^{132}$ The TUC sometimes exercised its independence in implementing the program as was the case when British trade unionists rejected Savage's suggestion of encouraging amalgamation between the GIWU and MPCA. At the same time, the Colonial Office consistently coordinated efforts with Woodcock and TUC General Secretary Vincent Tewson. Moreover, colonial officials developed covert means to provide financing for TUC expenses through the Colonial Development and Welfare Act. TUC leaders described the relationship with the British officials as beneficial; however, Woodcock and Tewson emphasized the need to obscure connections between their organization and the Colonial Office. Specifically, Woodcock and Tewson argued that the PPP and British trade unionists opposed to the project would use evidence of collaboration with the colonial office to undermine the program. ${ }^{133}$ Thus, the TUC and Colonial Office coordinated their efforts and trade unionists' plan did not challenge broad governmental objectives despite rhetoric to the contrary.

\footnotetext{
${ }^{131}$ N.L. Mayle to Alfred Savage, August 4, 1954, CO 859-773, BNA.

132 N.D. Watson, Colonial Office Minute, October 12, 1954, CO 859-773, BNA.

${ }^{133}$ N.A. Mayle, Colonial Office Minute to Mr. Rogers and Mr. Watson, December 23, 1954, CO 859-773, BNA; "Note of Meeting to Discuss Trade Unionism in British Guiana," July 1, 1954, CO 859-773, BNA; N.L. Mayle to Alfred Savage, August 4, 1954, CO 859-773, BNA; N.D. Watson to Sir T. Lloyd and N.L. Mayle, December 16, 1954, CO 859-773, BNA; Trades Union Congress, "Colonial Work of the T.U.C.," June 6, 1956, Marjorie Nicholson Files, Box 15, Trade Unions+Colonies, TUCLC; Rabe, U.S. Intervention in British Guiana, 51-52.
} 
TUC leaders expressed agreement with their counterparts in the Colonial Office, as well as American labor leaders and policymakers, that the PPP's removal created an opportunity to build Western institutions in British Guiana. ${ }^{134}$ In July the TUC General Council agreed to make Guiana the first territory to receive direct financial assistance from British trade unionists, initiating what it considered its "most important major attempt to help an individual union," the "special effort made to establish an effective trade union in the British Guiana sugar industry."135 The TUC General Council allocated $£ 3,000(\$ 8,600)$ to support organizing efforts in British Guiana, giving the colony a third of all financial aid distributed for colonial territories as part of a larger prioritization of the Caribbean area. ${ }^{136}$ TUC leaders justified the effort by arguing that British West Indian trade unions were the most advanced in the colonies. More importantly, the General Council expressed a desire to use institution-building in British Guiana as a model for the rest of the Empire. ${ }^{137}$ According to Stephen Rabe, TUC funding for the MPCA totaled about $\$ 15,000$ when it was distributed in the first six months of 1955 . $^{138}$

At its meeting in December, the Council offered to send Andrew Dalgleish, a retired TUC official with experience advising colonial unions in Africa and the Middle East, to advise Guianese unions. The TUC offered to pay Dalgleish's expenses and agreed to provide further funding for MPCA organization. ${ }^{139}$ TUC leaders coordinated their decision with the highest

\footnotetext{
${ }^{134}$ Report of the 87th Annual Trades Union Congress, September 5-9, 1955, TUC History Online, 232, http://www.unionhistory.info/britainatwork/emuweb/objects/nofdigi/tuc/imagedisplay.php?irn=6013877\&reftable=e catalogue \&refirn=6013760, Last Accessed July 12, 2015.

${ }^{135}$ Trades Union Congress, "Colonial Work of the T.U.C.," June 6, 1956, Marjorie Nicholson Files, Box 15, Trade Unions+Colonies, TUCLC; British Guiana Government Information Services, Guiana Diary, "British T.U.C. Official Arrives on Aid Survey," January 25-28, 1955, F2384, British Guiana, Guiana Diary, 1955 Jan to 1957 Jun, TUCLC; Kenedon Steins, American Vice Consul, Port-of-Spain to Department of State, February 11, 1955, 841D.062/2-1155, Box 4451, RG 59, Central Decimal File, 1955-1959, NARA II.

${ }^{136}$ N.L. Mayle to Alfred Savage, August 4, 1954, CO 859-773, BNA.

${ }^{137}$ Trades Union Congress, “Colonial Work of the T.U.C.," June 6, 1956, Marjorie Nicholson Files, Box 15, Trade Unions+Colonies, TUCLC.

${ }_{138}^{138}$ Rabe, U.S. Intervention in British Guiana, 52.

${ }^{139}$ TUC Press Release, January 3, 1955, CO 859-773, BNA; British Guiana Government Information Services, Guiana Diary, "British T.U.C. Official Arrives on Aid Survey," January 25-28, "British T.U.C. Delegate Arrives to
} 
ranking colonial officials. After coming to a decision, Tewson assured Lennox-Boyd that Dalgleish was an extraordinary choice for "the most difficult mission which we have ever asked a person to undertake." ${ }^{140}$ Meanwhile, George Woodcock sent a detailed explanation to N.L. Mayle in the Colonial Office and assured him that the General Council would determine the allocation of TUC funding in British Guiana. Thus, TUC leaders limited the degree to which the Guianese unions, or even Dalgleish, could challenge official objectives. Woodcock also reassured Mayle that Dalgleish would stay in touch with British officials in Guiana while remaining "at arms-length" to avoid appearing too closely associated with the British appointed Guianese government. ${ }^{141}$ Tewson, Woodcock, and Lennox-Boyd met again on January 10 to discuss the TUC's plans for British Guiana before Woodcock left for the colony to initiate the program. $^{142}$

British and American efforts to build the Guianese trade union movement intensified in early 1955 in conjunction with Ishmael's re-election as President of the MPCA and Shakoor's resignation as General Secretary. ${ }^{143}$ Woodcock and Dalgleish visited British Guiana in January to gather information and finalize the TUC program. Initially, the TUC provided funding for the General Secretary and an Assistant General Secretary of the MPCA and helped organize six Regional Officers. ${ }^{144}$ The Colonial Office encouraged efforts to institutionalize the labor movement's participation in government as well. Specifically, Governor Savage established a

Give Advice,” and “£3,000 British T.U.C. Grant for MPCA,” February 21-March 1, 1955, F2384, British Guiana, Guiana Diary, 1955 Jan to 1957 Jun, TUCLC; Rabe U.S. Intervention in British Guiana, 52.

${ }^{140}$ Vincent Tewson to Alan Lennox-Boyd, December 16, 1954, CO 859-773, BNA.

${ }^{141}$ George Woodcock to N.L. Mayle, December 23, 1954, CO 859-773, BNA.

${ }^{142}$ N.L. Mayle to Mr. Stacpoole, January 11, 1955, CO 859-773, BNA.

${ }^{143}$ British Guiana Government Information Services, Guiana Diary, "Mr. R. Ishmael Re-elected President of M.P.C.A.,” February 22-25, “M.P.C.A. General Secretary Tenders Resignation,” March 2-5, 1955, F2384, British Guiana, Guiana Diary, 1955 Jan to 1957 Jun, TUCLC.1955, F2384, British Guiana, Guiana Diary, 1955 Jan to 1957 Jun, TUCLC.

${ }^{144}$ Secretary of State for the Colonies to Alfred Savage, March 13, 1955, CO 859-773, BNA; British Guiana Government Information Services, Guiana Diary, "T.U.C. Advisor Returns to B.G.," November 17-20, 1955, F2384, British Guiana, Guiana Diary, 1955 Jan to 1957 Jun, TUCLC; TUC Pamphlet, "What the TUC is Doing," Spring 1956, Trade Unions and Colonies 932.5, Box 15, Marjorie Nicholson Files, TUCLC. 
labor advisory board that included various trade unions and important unionists, including Ashton Chase, the former PPP Minister of Labor. In doing so, the Colonial Office expressed hope that it could coordinate colonial policy, legislative efforts, and the TUC's support for the MPCA into a systemically strong capitalist labor movement. ${ }^{145}$

During his visit Woodcock explained the TUC plan to the BGTUC and met with the SPA, Chamber of Commerce, and Shipping Association, arguing that employers could only avoid legislative interference in labor problems if the colony developed strong trade unions. The sugar producers acknowledged that they would have difficulty securing cooperation from some estate managers but agreed to support the program. However, the Chamber of Commerce and Shipping Association resisted Woodcock's proposal and the Shipping Association refused to negotiate with the Forbes Burnham-led BGLU. ${ }^{146}$ Moreover, N.L. Mayle lamented in a letter to Alfred Savage that the Guianese press "misinterpret[ed]" British actions as merely anticommunist. $^{147}$

During his extended visits to British Guiana in 1955 and 1956 Dalgleish advised Guianese unionists to focus on industrial questions and refrain from political connections. ${ }^{148}$ Dalgleish also met with Robert Alexander to discuss the MPCA's progress, keeping the AFL-

\footnotetext{
${ }^{145}$ Colonial Office to Alfred Savage, January 18, 1955, CO 859-773, BNA.

146 "Notes of Discussion with George Woodcock," February 7, 1955, CO 859-773, BNA.

${ }^{147}$ N.L. Mayle to Alfred Savage, January 10, 1955, CO 859-773, BNA. A series of letters between Savage and the Colonial Office in London suggest that Savage interpreted the misunderstanding at least in part as a result of Woodcock's participation in the program, though ultimately he suggests Woodcock was well-received. Suspicion of Woodcock among many Guianese was a consequence of his participation on the Robertson Commission that investigated, and justified, the suspension of the Waddington Constitution. See: CO 859-773, BNA.

${ }^{148}$ British Guiana Government Information Services, Guiana Diary, "British T.U.C. Official Arrives on Aid Survey," January 25-28, "British T.U.C. Delegate Arrives to Give Advice," February 21-March 1, 1955, "British T.U.C. Advisor says B.G. Trades Unions Earnest but Weak," March 2-5, "T.U.C. Advisor Returns to B.G.," November 17-20, 1955, "British T.U.C. Advisor Returns for M.P.C.A. Annual Meeting," February 2-5, 1956, "British T.U.C. Advisor Leaves for U.K.," June 9-12, 1956, F2384, British Guiana, Guiana Diary, 1955 Jan to 1957 Jun, TUCLC; Kenedon Steins, American Vice Consul, Port-of-Spain to Department of State, February 11, 1955, 841D.062/2-1155, Box 4451, RG 59, Central Decimal File, 1955-1959, NARA II; TUC Annual Report, 1956, 223.
} 
CIO informed as to the TUC's plans and analysis of the situation. ${ }^{149}$ The MPCA used British funding and advice to create regional offices and invite applications for a five-week training course in industrial relations conducted through the University College of the West Indies. ${ }^{150}$ Kenedon Steins, the American Vice Consul in Trinidad, reported optimistically on the TUC effort to the State Department, though he expressed minor concern that TUC assistance might be "bungled by mismanagement" or backfire as a result of excessive interference in MPCA affairs. ${ }^{151}$

The TUC General Council discussed its program in British Guiana at the TUC Annual Meeting in September 1955. Woodcock explained his study's conclusions and the TUC plans for British Guiana, noting that institution-building depended on organizational efforts and training more so than financial aid. However, Woodcock suggested that seasonal fluctuations in the Guianese labor force and the wide dispersal of plantations made the sugar industry an exception to general policy and he suggested that there could be no expectation of financial stability for unions dependent on plantation employment. The General Council accepted Woodcock's assessment; however, some members in attendance disagreed with his analysis. W.P. Blair of the Electrical Trades Union argued that the TUC's financial support of the MPCA amounted to taking sides in a dispute between rival unions and that doing so was harmful to the trade union movement in British Guiana as well as in Great Britain. Blair cited the Robertson Commission report, which acknowledged the legitimacy of several GIWU accusations against the MPCA, specifically its weakness and subservience to employers. Blair argued that workers were justified

\footnotetext{
${ }^{149}$ Robert Alexander to Jay Lovestone, February 14, 1956, RG 18-003: International Affairs Department, Jay Lovestone Files, 1944-1973, Box 3, Alexander, Robert, 1955, GMMA.

${ }^{150}$ British Guiana Government Information Services, Guiana Diary, "Reorganization of Labor Movement Planned by M.P.C.A.," March 2-5, 1955, F2384, British Guiana, Guiana Diary, 1955 Jan to 1957 Jun, TUCLC; Robert Alexander to Jay Lovestone, February 14, 1956, RG 18-003: International Affairs Department, Jay Lovestone Files, 1944-1973, Box 3, Alexander, Robert, 1955, GMMA.

${ }^{151}$ Kenedon Steins, American Vice Consul, Port-of-Spain to Department of State, February 11, 1955, 841D.062/21155, Box 4451, RG 59, Central Decimal File, 1955-1959, NARA II.
} 
in supporting the GIWU and that the Council erred in choosing the MPCA as the organization on which to build an effective trade union movement. Nonetheless, the TUC agreed to allocate British funds for MPCA field officers and organizational equipment with the objective of displacing the GIWU and establishing a viable sugar union aligned with British labor. ${ }^{152}$ Like the TUC, the AFL-CIO expanded its efforts in British Guiana in early 1955. The FOA Office of Labor Affairs developed a labor program for British Guiana in January in consultation with Romualdi and Schwarz. ${ }^{153}$ While emphasizing the need for immediate attention, the program articulated short-term and long-term objectives, beginning with a six to eight week labor seminar in Georgetown financed through the FOA. American labor leaders insisted on including a clause in the proposal calling for coordination with the TUC and possibly the Colonial Welfare and Development Board. The FOA program also stressed the need for Schwarz's and Romualdi's participation as lecturers at the seminar. ${ }^{154}$ FOA labor officials anticipated using the seminar to assist American labor leaders in selecting Guianese unionists for further training in the United States. ${ }^{155}$ The planned person-to-person exchange was part of the broader FOA labor program expected to directly counteract communist influence and infiltration

\footnotetext{
${ }^{152}$ Report of the 87th Annual Trades Union Congress, September 5-9, 1955, TUC History Online, 2015.231-232, 474-475, http://www.unionhistory.info/britainatwork/emuweb/objects/nofdigi/tuc/imagedisplay.php?irn=6013877\&reftable=e catalogue\&refirn=6013760, Last Accessed July 12.

${ }^{153}$ Foreign Operations Administration, Labor Committee, Subcommittee Memorandum, "Labor Program for British Guiana," January 7, 1955, RG 18-007, International Affairs Department (CIO), Director's Files (Mike Ross), 19451955, Agencies Sub-Series 4: Foreign Operations Administration, Box 7, FOA Labor Committee: Documents, $1954-$ 1955, GMMA; Eugene Clay to Alfred Savage, January 10, 1955, CO 859-773, BNA; FOA Labor Affairs Progress Reports, 1955, Office of the President-George Meany (1948-1960), Box 15, State Department: Foreign Operations Administration, Handbook, Labor Committee, 1955, GMMA.

${ }^{154}$ A. Campbell to Colonial Office, February 4, 1955, CO 859-773, BNA; N.L. Mayle to Alfred Savage, March 9,1955, CO 859-773, BNA.

${ }^{155}$ Ibid; “'Informal' Proposed Labor Program for British Guiana," addressed to Dr. Ernst Schwarz and forwarded to Serafino Romualdi, January 12, 1955, RG-18: International Affairs Department, Serafino Romualdi Files, Box 4, Labor Department, 1957, GMMA.
} 
in developing countries. ${ }^{156}$ Eugene Clay, the FOA's Director for the Northern Division of Latin America, forwarded the proposal to Savage, on January $10{ }^{157}$

Despite the appeal for cooperation and initial optimism about the program, colonial officials' expressed strong reluctance to allowing increased American influence over the development of colonial institutions and general concern about conflicting British and American interests in the colony. ${ }^{158}$ On April 12, N.L. Mayle questioned the proposal's desirability as a result of the "American influence that will be exercised over the proposed course."159 LennoxBoyd forwarded a summary of Mayle's concerns to Savage on May 10 and suggested that the Colonial Office needed to see the final proposal before officially contacting the TUC. ${ }^{160}$ Mayle's detailed response to Savage on May 16 noted the Colonial Office's "extreme apprehension about the risk of possible influence of American lecturers in the trade union field in British Guiana." Mayle noted that the Colonial Office did not want to jeopardize relations with the FOA and acknowledged that flatly rejecting the labor program was unlikely from an official perspective because of the importance of preserving strong Anglo-American diplomatic relations. Woodcock shared Mayle's position on behalf of the TUC. ${ }^{161}$

Mayle was adamant that trade union training should remain "firmly in British hands;" however, he suggested calling on the FOA to provide necessary financing. He emphasized the

\footnotetext{
${ }^{156}$ Foreign Operations Administration, Labor Advisory Committee, Committee Document, May 25, 1954, RG 18007, International Affairs Department (CIO), Director's Files (Mike Ross), 1945-1955, Agencies Sub-Series 4: Foreign Operations Administration, Box 7, FOA Labor Committee: Documents, 1954-1955, GMMA.

${ }^{157}$ William Maddox, American Consul General, Port-of-Spain to Department of State, June 7, 1955, 841D.06/60755, Box 4451, RG 59, Central Decimal File, 1955-1959, NARA II; N.L. Mayle to Mr. Radford and Mr. Watson, Colonial Office Minute, April 12, 1955, CO 859-773, BNA.

${ }^{158}$ W.H. Braine, Colonial Office Minute sent to A. Campbell, Colonial Attaché, British Embassy, Washington, February 16, 1955, CO 859-773, BNA; N.L. Mayle to Alfred Savage, March 9,1955, CO 859-773, BNA. Joey Long argues that similar Anglo-American tensions characterized British and American involvement with trade unions in Singapore between 1951 and 1957. See: Long, Safe for Decolonization, 99-100.

159 N.L. Mayle to Mr. Radford and Mr. Watson, Colonial Office Minute, April 12, 1955, CO 859-773, BNA.

${ }^{160}$ Telegram from Oliver Lyttleton, Secretary of State for the Colonies to Sir Alfred Savage, May 10, 1955, CO 859773, BNA.

${ }^{161}$ N.L. Mayle to Alfred Savage, May 16, 1955, CO 859-773, BNA; Rabe, U.S. Intervention in British Guiana, 56.
} 
need for British trade unionists to use the seminar as a means of developing the Guianese unions based on British trade union methods and suggested that Schwarz and Romualdi might participate for a limited time as visiting speakers while the TUC provided the primary lecturers. Mayle also suggested that the Colonial Office would approve the program after adjustments addressed British concerns and if it eliminated the proposal to send Guianese unionists to the United States or Great Britain after the seminar. ${ }^{162}$ Specifically, Mayle and Woodcock argued that the additional expense involved in sending Guianese unionists to Great Britain could be inhibiting since the TUC was already financing a program in British Guiana.

More importantly, Mayle suggested that Guianese unionists needed to remain in the colony to effectively build their organizations from the ground up, a criticism that is illuminating since it was echoed inside the FOA. ${ }^{163}$ George Delaney, International Representative of the AFL, argued that FOA labor programs would be more efficient if American trade unionists worked in other countries. Moreover, Delaney suggested that bringing foreign unionists to the United States mirrored communist methods in addition to being ineffective. ${ }^{164}$ Similarly, Dennis FitzGerald, Deputy Director of the FOA, argued in an oral history taken in 1976 that the Eisenhower administration's emphasis on training foreign technicians in the United States rather than sending American technicians to foreign countries inhibited FOA and ICA programs' effectiveness. ${ }^{165}$ The tactical disagreement created minor tension between British and American officials as well as between some American trade unionists and United States government officials. Nonetheless, efforts to advance the program continued and compromises allowed it to move forward.

\footnotetext{
162 N.L. Mayle to Alfred Savage, May 16, 1955, CO 859-773, BNA.

${ }^{163}$ N.L. Mayle to Alfred Savage, March 9, 1955, CO 859-773, BNA.

${ }^{164}$ Foreign Operations Administration Labor Committee, Labor Committee Meeting Summary Minutes, January 25, 1955, RG 18-007, International Affairs Department (CIO), Director's Files (Mike Ross), 1945-1955, Agencies SubSeries 4: Foreign Operations Administration, Box 3, FOA Labor Committee: Minutes, 1955, GMMA.

${ }^{165}$ Interview with Dennis FitzGerald by Dr. Thomas Soapes, May 26, 1976, DDEL.
} 
Mayle's response to the FOA labor program on behalf of the Colonial Office is illuminating in several additional ways. It suggests that British officials expected to retain influence in post-colonial areas through institutional structures while acknowledging Britain's financial limitations in the process of decolonization. TUC leaders echoed official concerns acknowledging the need for programs to counter WFTU influence while expressing fear that lack of funds enfeebled their efforts. Specifically, TUC leaders expressed concern that inconsistent funding led to incomplete programs that irritated colonial labor and made matters worse. ${ }^{166}$ Furthermore, Mayle's response suggests that American institution-building efforts in colonial territories inherently extended American influence through institutional mechanisms. Colonial officials suggested pursuing a two-pronged effort with the TUC program focused on institutionbuilding and the FOA education program helping undermine Communist and WFTU influence in the colony. ${ }^{167}$ Financial issues and debates about trade union methods continued as AngloAmerican institution-building evolved in the late 1950s and early 1960s. Over time, Guianese unionists became caught in the middle, expressing a desire to perpetuate British trade union practices while increasingly dependent on American financial assistance.

American officials expressed sympathy for British concerns and Dulles instructed American representatives in the Caribbean to refrain from initiating the program until the TUC sent assurances that they did not view the project "as an intrusion on its functions by the U.S. Government." Dulles expected that adjustments to the program after further consultations with British officials and ORIT representatives and he sent an updated version of the proposal

\footnotetext{
166 “Colonial Trade Unionism, Draft” undated (1955/1956), Trade Unions and Colonies 932.5, Box 15, Marjorie Nicholson Files, TUCLC.

${ }^{167}$ A. Campbell to Colonial Office, February 4, 1955, CO 859-773, BNA.
} 
addressing Mayle's concerns in May. ${ }^{168}$ American involvement in British Guiana advanced in other areas while officials discussed the details of the FOA proposal. In April USIS finalized plans to build a reading room in the basement of the old consulate to provide material, including trade union films and literature. British officials agreed to the program despite strong apprehension about its being directed from Trinidad rather than by officials involved in the dayto-day affairs of the Guianese, as well as the possibility that Guianese confronted with American wealth would become disillusioned with their own situation. ${ }^{169}$

After an Executive Order replaced the FOA with the ICA in May 1955, William Maddox, the American Consul General in Trinidad, informed the State Department that Savage placed "great value" on the project and encouraged that the plan move forward. Maddox agreed with State Department plans to identify left-wing PPP activists and exclude them from training. However, he acknowledged that there would be a possible advantage to "including an 'insecure' person or so in the seminar," suggesting that the Consul general considered the possibility that institution-building programs could spread American labor ideals. ${ }^{170}$ Maddox's tentative acknowledgement that the trade union movement might benefit from collaboration between Guianese leaders of opposing political views represented a rare occasion in which an American official suggested engagement with the PPP's left-wing. Nonetheless, American government officials and policymakers in some circles echoed Maddox's hesitant recommendation of cooperation with the PPP several times in the ensuing years, suggesting that American governmental officials did not fully agree about how to most effectively confront Cheddi Jagan

\footnotetext{
${ }^{168}$ Department of State Instruction to Port-of-Spain and USOM, Georgetown, 'Proposed Seminar in Workers' Education in British Guiana," May 27, 1955, 841D.06-5-2755, Box 4451, RG 59, Central Decimal File, 1955-1959, NARA II; Rabe, U.S Intervention in British Guiana, 56.

${ }^{169}$ William Maddox to Department of State, April 13, 1955, 122.413/4-1355, Box 717, RG 59, Central Decimal File, 1955-1959, NARA II.

${ }^{170}$ William Maddox to Department of State, June 7, 1955, 841D.06/6-755, Box 4451, RG 59, Central Decimal File, 1955-1959, NARA II; “Proposed Seminar in Workers' Education in British Guiana,” May 27, 1955, 841D.06-52755, Box 4451, RG 59, Central Decimal File, 1955-1959, NARA II.
} 
in the late 1950s. Just as significantly, there is no evidence that American labor leaders shared Maddox's perspective or considered working with members of the PPP. Thus, American labor leaders' opposed Cheddi Jagan earlier and more definitively than government officials and used their influence in the United States to promote opposition leaders. Ultimately, AFL-CIO pressure contributed to the Kennedy administration's conclusion to support covert action and diplomatic pressure to remove Jagan beginning in $1962 .{ }^{171}$

Stassen cabled FOA operatives on June 24 and explained that development needed to be coordinated with Dalgleish since the TUC held primary responsibility for implementing the labor program. Additionally, Dalgleish was also expected to commit to a full-time teaching role during the seminar. ${ }^{172}$ Woodcock assured the United States Labor Attaché in Trinidad that the TUC would approve cooperation; however, he disagreed with the FOA proposal that ORIT should participate in selecting the program's candidates. Woodcock argued that Dalgleish and Ramphal were most familiar with the local situation in British Guiana and should be responsible for determining the participants. ${ }^{173}$ The ICA eventually implemented the proposed FOA program in 1956; however, as early as September 1955 Dulles expressed a "lack of interest in the Caribbean" and the State Department committed to gradually "tapering off" aid programs in the British West Indies. ${ }^{174}$

Thus, British and American labor and political leaders collaborated in pursuing institution-building in British Guiana despite British concerns about expanding American

\footnotetext{
${ }^{171}$ Memorandum from the President's Special Assistant (Schlesinger) to President Kennedy, June 21, 1962, FRUS, 1961-1963, Volume XII, American Republics, eds., Edward Keefer, Harriet Dashiell Schwar, and W. Taylor Fain III (Washington D.C.: Government Printing Office), 278.

${ }^{172}$ Harold Stassen to Port-of-Spain, June 24, 1955, 841D.06/6-2455, Box 4451, RG 59, Central Decimal File, $1955-$ 1959, NARA II.

${ }^{173}$ Seaborn P. Foster, U.S. Labor Attaché, London to John Foster Dulles, June 27, 1955, 841D.06/6-2755, Box 4451, RG 59, Central Decimal File, 1955-1959, NARA II.

${ }^{174}$ Department of State, Memorandum of Conversation, "U.S. Assistance in the British Caribbean," September 29, 1955, 841E.00/9-2955, Box 4451, RG 59, Central Decimal File, 1955-1959, NARA II.
} 
influence over Guianese institutional structures and disagreements regarding the most effective tactics to employ in the colony. The TUC most consistently worked to build Guianese trade unions but financial limitations restricted the extent of solely British programs. American trade union leaders campaigned for greater involvement in the colony but American government officials constrained AFL-CIO efforts to allow the TUC to play the primary role in the colony and to preserve diplomatic collaboration with Great Britain. Moreover, American government officials hoped to achieve political objectives through economic development programs with minimal investment in the field of organized labor. ${ }^{175}$

\section{Guianese Activism and Internationalism}

British and American institution-building efforts focused on strengthening selected Guianese unions and institutionalizing the colony's labor movement. Consequently, British and American programs tried to increase grassroots support for the MPCA through improved organization while training unionists to effectively negotiate with employers for improved wages, benefits, and working conditions. Moreover, institution-building efforts provided the MPCA with financial stability with the expectation that the union's fiscal independence would increase as membership grew.

Anglo-American institution-building efforts contained a final and crucial feature, the integration of Guianese trade unionists into Western international labor organizations. Several Guianese labor leaders enthusiastically cooperated with the Anglo-American institution-building efforts, particularly in seeking integration with the ICFTU, ORIT, and CADORIT. In early April

\footnotetext{
${ }^{175}$ FOA/ICA development programs were more substantial and estimates suggest that American aid reached \$1 million between 1954 and the August 1957 elections. See: BNA. Stephen Rabe argues that "the Eisenhower administration mainly talked about British Guiana;" however, "it did deploy technical assistance money to influence one area of the colony's life-labor relations.” See: Rabe, U.S Intervention in British Guiana, 56. While United States technical assistance was given to support anti-PPP unions and influencing labor relations was a high priority for American policymakers, as Rabe suggests, the vast majority of FOA and ICA money was dispersed to development projects in the 1950s. There is little evidence that United States financial assistance for Guianese unions reached significant levels before 1962.
} 
1954, as Anglo-American institution-building efforts began in British Guiana, the MPCA sent Richard Ishmael and Rupert Tello to a CADORIT conference in Trinidad. Ishmael also attended an ORIT conference in Costa Rica later that month and an ICFTU conference in May. ${ }^{176}$

BGTUC President A.T. Gibson joined the MPCA members at the Trinidad conference. ${ }^{177}$

Guianese labor leaders' use of international connections in early 1954 remained consistent between 1954 and 1957 and considerably influenced the labor movement's development during the period. However, Guianese labor leaders engaged in local struggles as well in seeking to develop their organizations.

Ishmael, the MPCA president, used his connections to the American labor movement to offset the costs of travel to the ORIT conference in Costa Rica in 1954. During the meeting, Ishmael appealed to regional trade unionists for greater assistance for workers in British Guiana though his speech focused on themes of particular concern to American trade union leaders. ${ }^{178}$ Ishmael acknowledged that aid from the ICFTU and ORIT strengthened his organization and emphasized his pride in the MPCA's association with "the free trade union movement and the free world against the unrelenting and viscous onslaught of world communism." However, Ishmael suggested that assuaging Caribbean workers' frustrations and defeating communism's appeal required greater assistance from international trade union organizations to facilitate

\footnotetext{
${ }^{176}$ British Guiana Government Information Services, Guiana Diary, "M.P.C.A. Selects Representatives for ORIT Talks," March 2-5, 1955, F2384, British Guiana, Guiana Diary, 1955 Jan to 1957 Jun, TUCLC; British Guiana Government Information Services, Guiana Diary, “Hon’ble R.C. Tello Re-elected President of B.M.U.," April 7-10, 1955, F2384, British Guiana, Guiana Diary, 1955 Jan to 1957 Jun, TUCLC; “A Note on MPCA Developments," April 1955, CO 859-773, BNA.

${ }^{177}$ British Guiana Government Information Services, Guiana Diary, "Labor Leaders for Trinidad Conference," April 3-6, 1955, F2384, British Guiana, Guiana Diary, 1955 Jan to 1957 Jun, TUCLC.

${ }^{178}$ Robert Alexander to Serafino Romualdi, April 11, 1955 and Asela Hernandez, ORIT Secretary to Robert Alexander, April 18, 1955 (translated by author), RG 18-009, International Affairs Department, Staff Files, Serafino Romualdi’s Files, 1945-1961, Box 3, Alexander, Robert J., 1955, GMMA.
} 
Guianese unions' integration into a Western labor network. ${ }^{179}$ Dalgleish assumed some of Ishmael's duties in the MPCA to facilitate Guianese participation in the 1954 international conference and Ishmael's subsequent visits to Great Britain and the United States. ${ }^{180}$

Ishmael and Tello's efforts contributed to the ICFTU and CADORIT decision to hold a conference of Sugar and Plantation Workers in British Guiana in early August that was widely attended and lauded by regional labor leaders. The conference examined plantation workers' social and economic status while stressing the importance of collaborative efforts between workers, managers, and employers in supporting the capitalist system. ${ }^{181}$ Having increased connections with Western labor internationals, the MPCA claimed responsibility for a one-day strike on the sugar estates in the fall of 1955 to generate support among field workers. BGLU president Forbes Burnham suggested that the strike was a "clever success" since workers began walking off the job before the MPCA issued a strike call. ${ }^{182}$ Regardless of whether the MPCA initiated or reacted to the walk-off, the union enhanced its image as a result of the protest. Moreover, the MPCA's international connections increased and its fiscal and organizational position slowly improved in late 1955.

While MPCA leaders increased cooperation with international labor organizations and British and American institution-building projects, the GIWU's left-coalition collapsed and

\footnotetext{
179 Address by Richard A. Ishmael, General President of the Manpower Citizens' Association, and Delegate to the III Regional Congress of ORIT, April 13-17, 1955, RG 18: International Affairs Department, Staff Files: George Delaney's Files, 1921-1957, Box 11, ORIT $3^{\text {rd }}$ Congress, 1955, GMMA.

${ }^{180}$ British Guiana Government Information Services, Guiana Diary, "British T.U.C. Advisor to Serve on M.P.C.A. Sub-Committee," May 13-16, 1955, F2384, British Guiana, Guiana Diary, 1955 Jan to 1957 Jun, TUCLC; British Guiana Government Information Services, Guiana Diary, "M.P.C.A. President Returns from I.C.F.T.U. Conference,” June 14-17, 1955, F2384, British Guiana, Guiana Diary, 1955 Jan to 1957 Jun, TUCLC.

${ }^{181}$ British Guiana Government Information Services, Guiana Diary, 'O.A.G. Opens Plantation Workers' Conference,” August 5-8, 1955, F2384, British Guiana, Guiana Diary, 1955 Jan to 1957 Jun, TUCLC; Chairman’s Report of Activities of CADORIT, January 1-December 31, 1955, RG 18-009, International Affairs Department, Staff Files, Serafino Romualdi's Files, 1945-1961, Box 3, Caribbean Area of ORIT, 1958, GMMA.

${ }^{182}$ Robert Alexander interview with Richard Ishmael, February 3, 4, 6, 1956; Robert Alexander interview with Forbes Burnham, February 5, 1956, RG 18-003: International Affairs Department, Jay Lovestone Files, 1944-1973, Box 3, Alexander, Robert, 1955, GMMA.
} 
altered the nature of decolonization efforts among organized labor. In February 1955 the PPP split into two factions, one led by Cheddi and Janet Jagan and the other by Forbes Burnham. Conflicts over political ideology, personal rivalry between Burnham and the Jagans, racial tensions inherent in the considerably segregated nature of Guianese employment, and British attempts to create a schism in the party all contributed to the division. ${ }^{183}$ Regardless of the reasons, the separation led to British and especially American support for the Burnham faction and increasingly intensified racial politics. ${ }^{184}$ American labor leaders were among the most consistent and most vocal of Burnham's Anglo-American political supporters; however, they wavered in their views of Burnham in the context of the Guianese labor movement. Robert Alexander reported to Jay Lovestone in February 1956 that Burnham "is someone with whom we can work," a view generally unchallenged in American labor circles. Nonetheless, American labor leaders strongly supported Rupert Tello's faction in the BGTUC, a block of labor leaders

\footnotetext{
${ }^{183}$ There is evidence in British intelligence records that the Special Service played a role in encouraging the split; however, there is no definitive evidence as to the extent of British influence in the PPP's schism. Moreover, any British or American meddling merely exacerbated tensions that existed since at least 1950. See: Colonial Office to A.N. McCleary, Foreign Office, August 20, 1957, FO 371-126078, BNA; Palmer, Cheddi Jagan and the Politics of Power, 58-59. Eric Huntley suggested in his interview with Frank Birbalsingh that someone from the CIA visited Burnham in the company of British trade unionists and encouraged his decision to split from Jagan. See: Birbalsingh, The People's Progressive Party of Guyana 1950-1992, 77.

184 "Eastern Caribbean and British Guiana Security Review," July 1-September 30, 1955, CO 1035-16, BNA; Robert Alexander, "Communist Power Cracks in British Guiana," RG 18-003, International Affairs Department: Jay Lovestone Files, 1944-1973, Box 3, Alexander, Robert J., 1955, GMMA; British Guiana Government Information Services, Guiana Diary, "Jagans Ousted From Top Posts on PPP Executive," February 10-13, 1955, "Two Rival Factions of P.P.P. Hold Congresses," March 26-29, 1955, F2384, British Guiana, Guiana Diary, 1955 Jan to 1957 Jun, TUCLC; Robert Alexander interview with Eric Huntley, February 4, 1956, RG 18-003: International Affairs Department, Jay Lovestone Files, 1944-1973, Box 3, Alexander, Robert, 1955, GMMA; Nigel O. Bolland, The Politics of Labour in the British Caribbean: The Social Origins of Authoritarianism and Democracy in the Labour Movement (Oxford: James Currey, 2001), 625; Leo A. Despres, Cultural Pluralism and Nationalist Politics in British Guiana (Chicago: Rand McNally and Company, 1967), 213-216; Cheddi Jagan, The West on Trial: My Fight for Guyana's Freedom (New York: International Publishers, 1967), 202-212; David Hinds, Ethno-Politics and Power Sharing in Guyana: History and Discourse (Washington, D.C.: New Academia Publishing, 2011), 6-7; Horne, Cold War in a Hot Zone, 204-205; Palmer, Cheddi Jagan and the Politics of Power, 57-59; Rabe, U.S. Intervention in British Guiana, 53.
} 
who conflicted with what CADORIT leaders referred to as the "Burnham-Ishmael-[Andrew]

Jackson block." 185

Most significantly, differences of political ideology and international alignment split the

PPP and decimated the left coalition's efforts in the organized labor movement. GIWU President

J.P. Lachmansingh aligned the union with the PPP's Burnham faction, which Burnham portrayed

as a center-left coalition opposed to association with the Eastern-bloc. Burnham's faction, which

became the People's National Congress (PNC) after the 1957 elections, claimed that the Jagan

faction was made up of doctrinaire Marxists committed to international communism rather than

Guianese nationalism. The GIWU continued to exist until at least 1959; however, the majority of

sugar workers remained loyal to the Jagan faction of the PPP. ${ }^{186}$ Despite the support, the Jagan

faction had no labor organization with which to organize sugar workers and lost further ground

in the labor movement when Cheddi Jagan resigned as president of the Sawmill Workers' Union

(SWU) amidst controversy in late $1955 .{ }^{187}$ As a result, the Jagan faction shifted strategies and

\footnotetext{
${ }^{185}$ Rabe, U.S. Intervention in British Guiana, 57-58; Robert Alexander to Jay Lovestone, February 14, 1956, RG 18003: International Affairs Department, Jay Lovestone Files, 1944-1973, Box 3, Alexander, Robert, 1955, GMMA; CADORIT Information Bulletin, October 1956, RG 18-009: International Affairs Department Staff Files: Serafino Romualdi's Files, 1945-1961, Box 1, Caribbean Area, 1953-1956, GMMA. Tello also disagreed strongly with Burnham's attempt to affiliate the BGTUC to the PNC. See: A. John Cope to Department of State, August 15, 1958, 841D.062/8-1558, Central Decimal Files, Box 4814, RG 59, NARA II.

${ }^{186}$ Robert Alexander interview with J.P. Lachmansingh, February 4, 1956, RG 18-003: International Affairs Department, Jay Lovestone Files, 1944-1973, Box 3, Alexander, Robert, 1955, GMMA; Patrick Renison to Secretary of State for the Colonies, "Report of the Proceedings of the Registrar of Trade Unions," September 29, 1959, CO 859/1151, BNA. The Burnham-faction of the PPP publicly argued that their split with the Jagan-faction grew out of disagreement over the desire of some party members to prioritize "an international reputation for being communists" at the expense of the nationalist struggle. See also: Forbes Burnham, "Where do we go from here?" Thunder, April 16, 1955 in C.A. Nascimento R.A. Burrowes, eds., Forbes Burnham, A Destiny to Mould: Selected Speeches by the Prime Minister of Guyana (New York: Africana Publishing Corporation, 1970), 3-8.

187 "Eastern Caribbean and British Guiana Security Review," October 1-December 31, 1955, CO 1035-16; Robert Alexander, "Communist Power Cracks in British Guiana," undated (June 1956); Robert Alexander to Jay Lovestone, February 14, 1956; Robert Alexander interview with Alfred Thorne, Assistant Professor of Economics at University of Puerto Rico, January 28, 1956; Robert Alexander interview with Mr. Adams, Labor Inspector, February 5, 1956; Robert Alexander with Rupert Tello, February 4-5, 1956; Robert Alexander interview with Eric Huntley, February 4, 1956, RG 18-003: International Affairs Department, Jay Lovestone Files, 1944-1973, Box 3, Alexander, Robert, 1955, GMMA.
} 
encouraged workers to join the MPCA while organizing efforts to have PPP men ascend to prominent positions in the organization. ${ }^{188}$

Colonial officials expressed considerable concern about the possibility of Jagan faction integration with the MPCA. Savage's letters to Lennox-Boyd altered between warnings that the Jagans were infiltrating the MPCA with Ishmael's assistance to dismissals of the reports as rumors promoted by the Burnham faction. ${ }^{189}$ Rivalry between MPCA leadership and the Jagan faction contributed to a political disconnect between union leadership and the rank-and-file in the sugar industry. Despite conflict over control of the union, the MPCA and PPP pursued some similar domestic policies. In November 1956, for example, the MPCA requested the Governor initiate a plan to acquire sugar companies' unused land for redistribution to ease the frustrations of impoverished workers. ${ }^{190}$ Cheddi Jagan's writings argued for similar land redistribution and Jagan advocated those policies in the Legislative Council early in his political career. ${ }^{191}$ The PPP split did not alter Anglo-American efforts to build the MPCA since the GIWU retained its sympathy for the WFTU and it was unclear whether Lachmansingh would be able to command the support of sugar workers absent an alliance with Jagan. ${ }^{192}$

The BGTUC continued its reorganization while the MPCA and TUC collaborated to build a sugar union and the GIWU disintegrated. The BGTUC promoted a fifteen minute weekly

188 "Note on the Relations of the People's Progressive Party with Trade Unions in the Sugar Industry," undated (1959), CO 1031-3421, BNA.

189 "Extract from Labour Advocate, British Guiana," March 20, 1955; Alfred Savage to Alan Lennox-Boyd, March 22, 1955; "A Note on MPCA Developments," April 1955; Alfred Savage to Alan Lennox-Boyd, April 4, 1955, CO 859-773, BNA; "Eastern Caribbean and British Guiana Security Review," July 1-September 30, 1955, CO 1035-16.

${ }^{190}$ British Guiana Government Information Services, Guiana Diary, "M.P.C.A. Calls for Action to Ease Employment Situation,” November 24-27, 1956, F2384, British Guiana, Guiana Diary, 1955 Jan to 1957 Jun, TUCLC. Mr. Eccles of the OEF suggested that Ishmael's land redistribution plan was an attempt to "cash in on" a proposal put forth by Lionel Luckhoo. See: Minutes of a meeting between representatives of the TUC, OEF, and Colonial Office, January 3, 1957, CO 859-1150, BNA.

${ }^{191}$ Cheddi Jagan, "Bitter Sugar,” (B’s Printing Service: Georgetown, 1954), CJRC.

${ }^{192}$ Robert Alexander, "Communist Power Cracks in British Guiana;” Robert Alexander interview with J.P. Lachmansingh, February 4, 1956, RG 18-003: International Affairs Department, Jay Lovestone Files, 1944-1973, Box 3, Alexander, Robert, 1955, GMMA. 
radio broadcast to explain its purpose and functions beginning in late November 1955 and obtained affiliation to the ICFTU on January 1, 1956, after the MPCA joined the BGTUC. ${ }^{193}$ Moreover, the BGTUC grew considerably, increasing from a five-union membership in April 1955 to twenty-five unions and up to 21,000 members in early 1956 . The union held an eight-day training conference for its expanded membership in February $1956 .{ }^{194}$ Nonetheless, Tello requested that Romualdi send education and propaganda material to counter "subversive literature" infiltrating the colony. He also pleaded for financial assistance claiming that his organization had no funding and that he personally paid ORIT and ICFTU affiliation fees. Moreover, Tello noted that TUC funds were allocated for the MPCA and that ICFTU assistance was slow in forthcoming. Consequently, Tello warned that the BGTUC required American aid to address its fragile financial position. ${ }^{195}$ Romualdi contacted John D. Connors, Director of the AFL-CIO Department of Education to request the American union send propaganda material to Tello, though Romualdi suggested that Tello write to the ICFTU directly to obtain financial

\footnotetext{
${ }^{193}$ British Guiana Government Information Services, Guiana Diary, "Educational Program Being Sponsored by T.U.C.," November 17-20, 1955, "B.G.T.U.C. Affiliated with I.C.F.T.U.," December 27-31, 1955, "B.G.T.U.C. Affiliated to I.C.F.T.U.," February 14-17, 1956, F2384, British Guiana, Guiana Diary, 1955 Jan to 1957 Jun, TUCLC.

${ }^{194}$ Tello, the BGTUC General Secretary, claimed an increase from five unions and 5,000 workers to twenty-five unions and 21,000 workers; however, statistics regarding union membership in Guiana during the period under study were frequently inflated. See: Rupert Tello to Serafino Romualdi, undated (early 1956), RG 18-009, International Affairs Department, Staff Files, Serafino Romualdi's Files, 1945-1961, Box 5, T, 1956, GMMA; British Guiana Government Information Services, Guiana Diary, "T.U.C. Plan Eight-Day Training Course for Trade Unionists," F2384, British Guiana, Guiana Diary, 1955 Jan to 1957 Jun, TUCLC.

${ }^{195}$ Rupert Tello to Serafino Romualdi, undated (early 1956), RG 18-009, International Affairs Department, Staff Files, Serafino Romualdi's Files, 1945-1961, Box 5, T, 1956, GMMA. Conflict between the AFL-CIO and TUC in the ICFTU made it difficult for the international to effectively engage with colonial labor movements. See: Notes from an informal meeting of members of the TUC and AFL-CIO, September 9, 1957, Marjorie Nicholson Files, Box 9, ICFTU/TUC, TUCLC. For more on the tension between the AFL-CIO and TUC regarding American activity in British colonies, see: Anthony Carew, ed., The International Confederation of Free Trade Unions (New York: Peter Lang, 2000), 270; Yevette Richards, Maida Springer: Pan-Africanist and International Labor Leader (Pittsburgh: University of Pittsburgh Press, 2000). For more on general tensions between the AFL-CIO and the ICFTU, see: Ake Wedin, T.L. Johnston, trans., International Trade Union Solidarity: ICFTU 1957-1965 (Stockholm: Bokforlaget Prisma, Publishers, 1974).
} 
aid. ${ }^{196}$ Tello followed Romualdi's advice and the ICFTU sent $\$ 1000$ to the BGTUC in late 1956 or early $1957 .{ }^{197}$

Meanwhile, Ishmael initiated a plan in early 1956 to further rehabilitate the MPCA's improving image among workers and expressed hope that assistance from the ICFTU, ORIT, TUC, and AFL-CIO would provide the leverage needed to achieve substantial concessions from employers. ${ }^{198}$ The MPCA President instigated a strike for wage concessions and purposefully antagonized the SPA at the negotiating table causing discussions to fail. He then requested assistance from TUC and AFL-CIO associates in compiling studies countering SPA claims that the sugar industry could not afford wage increases. Ishmael informed Robert Alexander of his plan in advance of its implementation and Alexander wrote to Jay Lovestone suggesting that the AFL-CIO inform British Guiana's new governor, Patrick Renison, that the American labor movement supported the strike. ${ }^{199}$ John Wall of the TUC Economic and Research Department was sent to British Guiana at the MPCA's request in August to testify on the sugar workers' behalf. ${ }^{200}$ Despite Wall's assistance, the Committee of Enquiry ruled in favor of a ten percent cost of living increase in sugar workers' wages retroactive to January 1, a compromise

\footnotetext{
${ }^{196}$ Serafino Romualdi to John D. Connors, February 23, 1956, RG 18-009, International Affairs Department, Staff Files, Serafino Romualdi's Files, 1945-1961, Box 5, T, 1956, GMMA; Serafino Romualdi to Rupert Tello, February 23, 1956, RG 18-009, International Affairs Department, Staff Files, Serafino Romualdi's Files, 1945-1961, Box 5, T, 1956, GMMA.

${ }^{197}$ A. John Cope, Jr. to Department of State, July 29, 1957, Box 4814, RG 59, Central Decimal File, 1955-1959, NARA II.

${ }^{198}$ The MPCA changed its name to the Sugar and General Workers Union in early 1956 at the behest of the TUC despite Ishmael's objections. The new name was only in place for a brief time before the union re-appropriated the name Manpower Citizens' Association. This dissertation will continue to refer to the MPCA for purposes of clarity, since the unions were structurally and functionally identical and sugar workers understood the unions to be the same. See: TUC Pamphlet, "What the TUC is Doing," Spring 1956, Trade Unions and Colonies 932.5, Box 15, Marjorie Nicholson Files, TUCLC; Robert Alexander interview with Richard Ishmael, February 4-6, 1956, RG 18003: International Affairs Department, Jay Lovestone Files, 1944-1973, Box 3, Alexander, Robert, 1955, GMMA.

${ }^{199}$ Robert Alexander to Jay Lovestone, February 14, 1956, RG 18-003: International Affairs Department, Jay Lovestone Files, 1944-1973, Box 3, Alexander, Robert, 1955, GMMA.

${ }^{200}$ Report of the 89th Annual Trades Union Congress, September 2-6, 1957, TUC History Online, 225, http://www.unionhistory.info/britainatwork/emuweb/objects/nofdigi/tuc/imagedisplay.php?irn=6014436\&reftable=e catalogue\&refirn=6014319, Last Accessed July 12, 2015.
} 
significantly closer to the SPA's proposed seven percent increase than the MPCA's demand of a twenty-five percent raise. ${ }^{201}$

Anglo-American institution-building efforts in British Guiana expanded and evolved in 1956 while Guianese labor leaders increased their collaboration with regional labor organizations. In April, the ICA held the trade union seminar that the FOA initially proposed in 1955. A variety of Guianese, American, and British speakers gave lectures and forty Guianese students participated in the meetings. ${ }^{202}$ At the same time, the TUC continued its role in British Guiana as part of a broad effort to expand its role in decolonizing British territories. ${ }^{203}$ Despite British and American efforts, regional labor leaders expressed skepticism regarding the effectiveness of Anglo-American institution-building.

CADORIT leaders met in Barbados in April and discussed the ways Caribbean trade unions could confront potential communist threats in the region while advancing workers' interests. BGTUC General Secretary Rupert Tello, who served on CADORIT's administrative committee, suggested that the ICFTU should work through Caribbean labor leaders rather than the TUC to make international participation in the Caribbean labor movement more effective. Tello further proposed that CADORIT should reorganize into a "more independent organization.” Most interestingly, Tello criticized external financing of Guianese unions as ineffective. In British Guiana, he argued, "persons who got no help were able to build real trade unions, while those who got help had not been able to do so" because external funding weakened

\footnotetext{
${ }^{201}$ British Guiana Government Information Services, Guiana Diary, "Sugar Dispute Enquiry Committee Forward Report to H.E.," September 5-8, 1956; "Sugar Workers Recommended for 10\% Cash Increase," September 13-16, 1956, F2384, British Guiana, Guiana Diary, 1955 Jan to 1957 Jun, TUCLC.

${ }^{202}$ British Guiana Government Information Services, Guiana Diary, "International Trade Union Seminar Opens in Georgetown on April 23," April 6-9, 1956, "U.S. Industrial Relations Director to Lecture at Trades Union Seminar," April 30-May 3, 1956, "Six-Week Trade Union Seminar Ends," June 1-4, 1956, F2384, British Guiana, Guiana Diary, 1955 Jan to 1957 Jun, TUCLC.

${ }^{203}$ Trades Union Congress, "Colonial Work of the T.U.C.," June 6, 1956, Marjorie Nicholson Files, Box 15, Trade Unions+Colonies, TUCLC.
} 
workers' sense of investment in their unions. Suriname's Leo Eliazer, who was also a member of ORIT's Executive Board, agreed with Tello and suggested that it might be possible to develop a regional labor federation independent of ORIT and the ICFTU through which Caribbean unionists could build their organizations. ${ }^{204}$

Despite appeals for regional solidarity and loosened ties with the heavily AngloAmerican influenced Western international labor movement, fear of communism and personal rivalries reinforced Caribbean labor's connections to ORIT and the ICFTU. At the same meeting, Eliazer suggested that communist influence in neighboring British Guiana threatened Suriname and he pressured Romualdi to provide funds promised for use in confronting regional communism. Tello echoed Eliazer's fear of communism and appears to have tentatively accepted CADORIT involvement in British Guiana, hinting at Shakoor's "green-light[ing]" activities in the colony. ${ }^{205}$

More significantly, Tello appealed to ORIT to intervene in the BGTUC's July elections when it appeared he might lose his position as General Secretary. Tello wrote to Romualdi and ORIT General Secretary Luis Alberto Monge warning that, if Romualdi or Robert Alexander could not convince Ishmael to alter his nomination of the "communist" Andrew Jackson, Jackson could win the election. Jackson's election, Tello argued, would lead to a communist takeover of the Guianese labor movement. ${ }^{206}$ Jackson, who was initially left off the BGTUC ballot under

\footnotetext{
${ }^{204}$ British Guiana Government Information Services, Guiana Diary, “T.U.C.'s General Secretary to Attend One-Day Conference in Trinidad," April 14-17, 1956, F2384, British Guiana, Guiana Diary, 1955 Jan to 1957 Jun, TUCLC; Minutes of the 5th Meeting of the Administrative Committee of CADORIT, April 20-21, 1956, RG 18-009: International Affairs Department, Staff Files: Serafino Romualdi's Files, 1945-1961, Box 1, Caribbean Area, 19531956, GMMA.

${ }^{205}$ Minutes of the $5^{\text {th }}$ Meeting of the Administrative Committee of CADORIT, April 20-21, 1956, RG 18-009: International Affairs Department, Staff Files: Serafino Romualdi’s Files, 1945-1961, Box 1, Caribbean Area, 19531956, GMMA.

${ }^{206}$ Rupert Tello to Serafino Romualdi, August 15, 1956, RG 18-009: International Affairs Department Staff Files: Serafino Romualdi's Files, 1945-1961, Box 5, T, 1956, GMMA. Moreover, Tello was a key information source for State Department information regarding Guianese trade unions. See: A. John Cope, American Consul, Georgetown
} 
suspicious circumstances, won the right to have his name added after contesting the BGTUC ballot in the Guianese courts. Romualdi pressured Ishmael, arguing that Jackson's participation in a 1953 WFTU conference and in strikes against the MPCA, as well as his association with the Jagans, were evidence that his "election would be a blow to free trade unionism." Tello adamantly affirmed in a letter to Romualdi that his concern was not personal but sincere fear for the BGTUC. The validity of Tello's claims is unclear; however, it is significant that Romualdi's information about developments in British Guiana was gleaned almost entirely from Tello and Alexander. Romualdi copied nearly verbatim from Tello's letter — at Tello's request— in writing to encourage Ishmael to withdrawal Jackson's nomination. ${ }^{207}$

While the connection between Jackson and the Jagan faction is not certain, in August 1956 the Jagan faction registered the British Guiana Sugar Workers Union (BGSWU) rather than continue seek integration into the MPCA. ${ }^{208}$ It is possible that the Jagan faction interpreted the BGTUC elections as proof of corruption within the labor movement and concluded that

to Department of State, January 24, 1957, 841D.062/1-2457, Box 4814, RG 59, Central Decimal File, 1950-1954, NARA II.

${ }^{207}$ Rupert Tello to Serafino Romualdi, July 29, 1956; Luis Alberto Monge and Serafino Romualdi to Richard Ishmael, August 6, 1956; Luis Alberto Monge and Serafino Romualdi to Rupert Tello, August 6, 1956; Richard Ishmael to Luis Alberto Monge and Serafino Romualdi, August 8, 1956; Serafino Romualdi to Richard Ishmael, August 20, 1956; RG 18-009: International Affairs Department Staff Files: Serafino Romualdi's Files, 1945-1961, Box 4, I, 1956, GMMA.

208 "Note on the Relations of the People's Progressive Party with Trade Unions in the Sugar Industry," undated (1959), CO 1031-3421, BNA. Jackson is an interesting figure and a useful prism through which to understand the complexity of Guianese politics. Some of his contemporaries, such as Tello and Romualdi, accused him of working with Jagan. While definitive evidence is lacking, it is unlikely that Jagan and Jackson were closely aligned. Jackson regularly clashed with the PPP government as head of the Postal Workers' Union and government employees union, FUGE. See: British Guiana Government Information Services, Guiana Diary, "Post Office Workers Strike," March 6-9, 1958, F2384, British Guiana, Guiana Diary, 1957 Jan to 1962 Jun, TUCLC. Jackson also testified at the United Nations in opposition to the PPP's Labor Relations Bill in 1963. See: Andrew Jackson to United Nations Special Committee on the Situation with Regard to the Implementation of the Declaration on the granting of Independence to Colonial Countries and Peoples, 1963. GMMA, 17/01. Conversely, his unions are described in much of the scholarship as aligned with Burnham on narrowly racial grounds. Lange, Lineages of Despotism and Development, 131. Close examination of the records suggests that Jackson and the civil service unions clashed with the Guianese government since before the PPP took office and that the conflict between the PPP and civil services grew out of those industrial disputes. The dispute then took on racial dynamics after the PPP failed to meet government workers demands after assuming office. 
integration into the MPCA would be impossible. Regardless, the possibility of rapprochement within the labor-left decreased considerably with the founding of the BGSWU.

Romualdi's intercession did not convince Ishmael to withdraw his nomination of

Jackson; however, Tello won the election and immediately traveled to Great Britain, Canada, and the United States to study Modern Labor Practices after the election. ${ }^{209}$ The United Steelworkers of America welcomed Tello as a guest during his two weeks in Canada, and during a three week visit to the United States Romualdi introduced him to high-ranking members of the AFL-CIO. The ICA organized Tello's visit and gave him the opportunity to meet with a variety of representatives of the United States government during his three-week course. ${ }^{210}$ During his travels, Tello arranged for Monge and Harry Pollak of the AFL-CIO Department of International Affairs to visit British Guiana in 1957. ${ }^{211}$ Meanwhile, the BGTUC's new President, Joseph Pollydore, also left British Guiana after the election and traveled to an ORIT seminar in Mexico City. ${ }^{212}$ Tello's travels, like the FOA proposal in 1955, elicited fear of increased American influence in British Guiana among colonial officials. Patrick Renison commented in a letter to the Colonial Office that despite Tello's "good impression” in the United Kingdom “some of the gilt has been rubbed off in the U.S." Renison "fear[ed] this is almost inevitable when ICFTU,

\footnotetext{
${ }^{209}$ British Guiana Government Information Services, Guiana Diary, “Elected President of B.G.T.U.C.," September 29-October 2, 1956; General Secretary of B.G.T.U.C. Leaves on U.K. Study Course,” October 11-14, 1956, F2384, British Guiana, Guiana Diary, 1955 Jan to 1957 Jun, TUCLC.

${ }^{210}$ Serafino Romualdi to Rupert Tello, November 6, 1956, RG 18-009: International Affairs Department Staff Files: Serafino Romualdi's Files, 1945-1961, Box 5, T, 1956, GMMA; CADORIT Information Bulletin, October 1956, RG 18-009: International Affairs Department Staff Files: Serafino Romualdi's Files, 1945-1961, Box 1, Caribbean Area, 1953-1956, GMMA; D. Williams, Colonial Attaché to F.D. Jakeway, Colonial Office, January 22, 1957, CO 859-1150, BNA; United States Department of Labor, Office of International Labor Affairs, Program and Itinerary, British Guiana Labor Union Organization and Practice, undated, CO 859-1150, BNA; Rabe, U.S. Intervention in British Guiana, 57.

${ }^{211}$ Memorandum to George Brown, Serafino Romualdi, Luis Alberto Monge, Rupert Tello, and Harry Pollak, February 16, 1957, RG 18-009: International Affairs Department Staff Files: Serafino Romualdi's Files, 1945-1961, Box 4, International Department, 1956, GMMA.

${ }^{212}$ British Guiana Government Information Services, Guiana Diary, “T.U.C. Names Delegate to International Seminar,” June 1-4, 1956, F2384, British Guiana, Guiana Diary, 1955 Jan to 1957 Jun, TUCLC.
} 
CADORIT, etc. are able to be so much more free with their money and promises than can be the TUC and the unions in the U.K.",213

Discussions at the CADORIT conference, Romualdi's involvement in the BGTUC elections, and BGTUC leaders' post-election travels illuminate several important dynamics that influenced the process of institutional decolonization in British Guiana during the mid-1950s. First, Caribbean labor leaders collaborated at a regional level to confront perceived communist threats in their territories and to undercut labor rivals. British and American labor and political leaders occasionally encouraged opposition to left-leaders; however, they did not impose such hostility on the Caribbean labor movement. Second, Caribbean trade unions used AFL-CIO funding and associations as leverage to undermine labor rivals and perceived communists, both overtly and covertly, often levying allegations of communist associations against rivals to exploit American anti-communism.

Third, CADORIT leaders worked with Western international labor organizations and Anglo-American trade unions but did not express confidence in institution-building projects organized and financed from sources external to the region. Caribbean labor leaders regularly argued that developing grassroots support for labor organizations was the key to trade unions' success even as those organizations became dependent on British and American funding. Forth, British and American labor organizations and Western internationals rapidly integrated newly elected labor leaders into training programs with the objective of transposing Western labor practices in the colony, suggesting that institution-building programs were dynamic and adaptable. Fifth, several issues plagued Anglo-American training programs in the mid-1950s beginning with Tello's fear that external involvement in Guianese unions could create financial dependency. Internationalizing the Guianese labor movement also removed key labor leaders

${ }^{213}$ Patrick Renison to F. Kennedy, Colonial Office, December 31, 1956, CO 859-1150, BNA. 
from British Guiana for extended periods at crucial points in time, in Tello's case immediately after a contested election. ${ }^{214}$ Finally, British officials expressed considerable concern at the influx of American influence while accepting the need for cooperation with the United States government and the AFL-CIO in confronting challenges to British interests from left-wing Caribbean trade unionists. Anglo-American rivalry influenced Caribbean decolonization at both the diplomatic and non-governmental level.

Legislative actions in British Guiana beginning on December 20, 1956 initiated the process toward new general elections in August 1957 and a return to partial self-government under the Renison Constitution. ${ }^{215}$ The imminent political change increased the significance of institution-building efforts and British attempts to establish the MPCA and Anglo-American elements in the BGTUC at the center of the Guianese labor movement. Nineteen members of the TUC, OEF, and Colonial Office met on January 3, 1957 to evaluate the institution-building effort in British Guiana and to consider its future in light of the coming Guianese elections. George Woodcock complimented Booker Brothers efforts to cooperate with the MPCA's Regional Officers in building union membership on the sugar estates and supported Ishmael's request for a check-off as an exceptional measure to address the union's financial difficulties. However, Mr. Eccles, speaking on behalf of the OEF, contested the establishment of a check-off with the MPCA as a result of Ishmael's “unreasonable dealings," though Eccles thought it possible to have a check-off with smaller estate unions. The committee expressed general apprehension at the prospect of solidifying Ishmael's position, suggesting that he too aggressively challenged the

\footnotetext{
${ }^{214}$ Similarly, Richard Ishmael traveled to the United States in early 1958 after a manipulated and contested election in the MPCA. See: A. John Cope, Jr. to Department of State, May 28 1958, 841D.062/5-2858, Box 4814, RG 59, Central Decimal File, 1955-1959, NARA II. For other instances of Ishmael and Tello's absence from important debates within the BGTUC, see: A. John Cope to Department of State, August 15, 1958, 841D.062/8-1558, Central Decimal Files, Box 4814, RG 59, NARA II.

${ }^{215}$ British Guiana Government Information Services, Guiana Diary, "Bill Providing for General Elections Introduced in Legco," December 22-31, 1956, "Legco approves Bill making provision for general elections," January 29-February 1, 1957, F2384, British Guiana, Guiana Diary, 1955 Jan to 1957 Jun, TUCLC.
} 
SPA's interests. At the same time, committee members reaffirmed the importance of preserving the MPCA given the likelihood that the Jagan faction of the PPP would win a majority at the polls later in the year. ${ }^{216}$

Despite suggesting that the MPCA had developed "as well as could be expected," Woodcock doubted the union would withstand the political attacks he expected during the electoral process. Woodcock argued that "if by the end of the year the MPCA still exist[s] it would be a real victory." Eccles suggested that the MPCA's position deteriorated since Woodcock's visit making its position in advance of the election even more precarious than the TUC realized. A TUC report in May confirmed that the MPCA claimed only fifteen percent of sugar workers as members of the union despite institution-building efforts. ${ }^{217}$ Woodcock and Eccles agreed that Ishmael's antagonizing estate managers and disunity in the labor movement resulting from conflict between Ishmael and Tello most significantly inhibited the Guianese trade unions' effective development. Regardless, British and American labor leaders and government officials widely agreed that Tello was the most effective trade union leader in the colony.

Ironically, given his support for Tello, Woodcock noted that the Ishmael-Tello rivalry originated with Tello's maneuvers in 1953 and that Ishmael was justified in his hostility. Specifically, Tello formed a breakaway union and re-started the BGTUC against TUC advice after he lost his position in the MPCA to Ishmael in 1953. Furthermore, Tello's position in the interim government compromised his reputation among sugar workers. Woodcock suggested that Tello might be more effective working for CADORIT rather than in British Guiana as a result of his weakened prestige. Eccles disagreed, arguing that Tello was too "responsible and

\footnotetext{
${ }^{216}$ Minutes of a meeting between representatives of the TUC, OEF, and Colonial Office, January 3, 1957, CO 8591150, BNA.

${ }^{217}$ Minutes of a meeting between representatives of the TUC, OEF, and Colonial Office, January 3, 1957, CO 8591150, BNA.
} 
experienced" to lose to an organization "preaching the doctrines of American trade unionism," echoing the consistent British fear of American ideas taking hold in the colony. In his final analysis, Woodcock reiterated Tello's theme at the CADORIT meeting the previous April and recommended against financial assistance for the BGTUC with the expectation that aid would encourage "laziness and incompetence" from the "weak and incompetent organization." Despite Woodcock's skepticism, the TUC General Council expressed satisfaction with reports of the MPCA's development and wage and benefit increases for sugar workers in early 1957. As a result, the TUC continued to send $£ 220$ grants to the Guianese union throughout the year. ${ }^{219}$

The TUC, OEF, and Colonial Office meeting illuminates one additional aspect of the British institution-building project in Guiana as it stood in 1957 prior to the election that has not been previously addressed. Specifically, it suggests that TUC leaders attempted to directly influence Guianese politics. Discussions regarding Tello suggest that TUC representatives encouraged his participation in the Legislative Council and that Woodcock offered general advice on how he should act in his position. Despite reservations, the TUC supported Tello's dual participation in politics and organized labor rendering inconsistent claims that the British union did not support connections between trade unions and politics in the colonies. Colonial officials and TUC leaders cited labor-party connections as a central aspect of their argument against the PPP and TUC support for Tello suggests that British labor leaders accepted colonial unionists' involvement in politics if they advanced British objectives. ${ }^{220}$

\footnotetext{
${ }^{218}$ Minutes of a meeting between representatives of the TUC, OEF, and Colonial Office, January 3, 1957, CO 8591150, BNA.

${ }^{219}$ Report of the 89th Annual Trades Union Congress, September 2-6, 1957, TUC History Online, 225, http://www.unionhistory.info/britainatwork/emuweb/objects/nofdigi/tuc/imagedisplay.php?irn=6014436\&reftable=e catalogue\&refirn=6014319, Last Accessed July 12, 2015. For more on the cooperative relationship between Booker Brothers, the Colonial Office, and the TUC in reforming and stabilizing British Guiana between 1953 and 1957, see: Seecharan, Sweetening 'Bitter Sugar'.

${ }^{220}$ Similarly, in 1960 Governor Ralph Grey lamented that sugar workers supported Ishmael "in purely trade union matters" and the PPP politically. Grey's disappointment that sugar workers did not support Ishmael in political as
} 
In addition to trade union vulnerability, the persistence of sugar workers' strikes suggests that ongoing tension between workers and employers contributed to instability in Guianese labor relations. Ishmael planned a colony-wide strike of sugar workers to protest unemployment on sugar estates and low wages among factory workers after winning re-election in the MPCA in February 1957. The MPCA president rescinded the strike call on February 12 or 13 at the behest of Commissioner of Labor Ramphal, perhaps hinting at Ishmael's turn toward a slightly less aggressive stance in labor relations. Despite the reversal, workers on at least two estates struck and police dispersed striking workers at Skelton using tear gas and a Greener gun, injuring thirteen. In the aftermath of the violence, the MPCA held a 48-hour strike across the colony and strikers at Skelton reassembled to strike for three additional weeks. More telling, an estate colonial official noted that workers at Skelton had "one of the best management/labor relationships of any estate." Intelligence reports noted that no political parties were involved in the strikes; however, both the Jagan and Burnham factions aggressively criticized the colonial government in the aftermath of the violence. Thus, institution-building efforts failed to alter severely depressed conditions and intelligence officials feared that political attacks against the colonial government, SPA, and MPCA would increase as the election neared. ${ }^{221}$

The TUC sent its representative to Trinidad, Martin Pounder, to British Guiana in May to evaluate the MPCA and assist the Guianese sugar workers in negotiating with the SPA in an attempt to achieve a negotiating victory for an anti-Jagan group prior to the election. The negotiations resulted in the MPCA's acceptance, under protest, of a seven and one-half percent

\footnotetext{
we as trade union matters belies the inconsistency of British arguments against the politicization of trade unions. See: "Note on the Relations of the People's Progressive Party with Trade Unions in the Sugar Industry," undated (1959), CO 1031-3421, BNA.

${ }^{221}$ Extract from British Guiana Intelligence Report, February 1957; Extract from Despatch No. 200 from British Guiana, March 13, 1957; Extract From Report by the Local Intelligence Committee, February 1957; CO 1031-2388, BNA; A. John Cope to Department of State, February 15, 1957, 841D.062/2-1557, Box 4814, RG 59, Central Decimal File, 1955-1959, NARA II.
} 
increase in the cost-of-living allowance and the colony's first sickness benefit plan. Nonetheless, the MCPA petitioned the governor to increase the sugar's local selling price to support a more substantial wage increase. Pounder suggested the union grew slightly as a result of intermittent wage gains, increasing its membership from just over 1,600 in 1955 to about 4,600 in mid$1957 .^{222}$ British intelligence reports suggested that sugar workers reacted positively to the increase and that "the atmosphere on the estates is better than it has been for some time." Of greater concern to colonial officials were reports that the Jagan faction abandoned its plan to build the BGSWU after an ineffective year of organization in order to return to a strategy of "penetrating" the MPCA. ${ }^{223}$ Most significantly, the MPCA obtained a check-off system in the early summer, automatically enrolling sugar workers in the union. ${ }^{224}$

Thus, two years of institution-building helped the MPCA achieve notable advances. However, efforts to build a strong sugar workers' union remained incomplete. Criticisms of the MPCA are accurate in noting the organization's conservatism and inability to overcome planters hold on the economy to meaningfully address workers' dire poverty. However, scholarly condemnation of the union underappreciates the significance of precedent-setting advances such as the colony's first sickness benefit plan and the initiation of a check-off system on the sugar estates. $^{225}$ The BGSWU's failure to gain popularity among sugar workers suggests that the MPCA gained at least some support as a mechanism for negotiating with employers. Ishmael's position in particular was uncertain and somewhat paradoxical. British employers and trade

\footnotetext{
${ }^{222}$ Reports of the wage increase ranged from $4 \frac{1}{2}$ to $71 \frac{1}{2}$ percent; however, most reports cite the higher figure. See: Extract from a Report by the Local Intelligence Committee, May 1957; Reuter Press Release, undated; S.A. Ogilvie, "B.G. Sugar: Special Edition,” December 1957, 1031-2388, BNA; British Guiana Government Information Services, Guiana Diary, "Sugar Workers Get Million Dollar Wage Increase,” May 13-16, 1957, F2384, British Guiana, Guiana Diary, 1955 Jan to 1957 Jun, TUCLC.

${ }^{223}$ Extract from a Report by the Local Intelligence Committee, May 1957, 1031-2388, BNA.

${ }^{224}$ A. John Cope to Department of State July 16, 1957, Box 13, RG 84, Classified General Records, NARA II.

${ }^{225}$ The check-off system was introduced just after the election. See: Extract from OEF Newsletter, August 22, 1957, CO 859-1150, BNA; S.A. Olilvie, "B.G. Sugar: Special Edition,” December, 1957, CO 1031-2388, BNA.
} 
union leaders did not think he was the "responsible" leader they needed to head the sugar workers union and either believed or accused him of using his position in the MPCA merely as a means of political advancement. However, the tactics that led British leaders to view Ishmael as irresponsible improved the union's standing among sugar workers.

While the TUC continued its efforts to build the MPCA, American labor leaders and Western labor internationals increased their support for the BGTUC and Tello. Luis Alberto Monge and Harry Pollak visited British Guiana in late March and early April 1957, traveling with Tello and appearing on Radio Demerara to express support for BGTUC. Monge assured listeners that ORIT supported the Guianese workers and planned to “intensify [ORIT's] support to our friends in British Guiana," following through with a six-hundred dollar donation from ORIT for the BGTUC in late-summer $1957 .{ }^{226}$ Pollak assured the Guianese that he would discuss the colony's problems with American labor leaders and "seek means to assist the trade union movement in the area" while assuring workers that their situation could best be improved through the establishment of a trade union movement free from political control. ${ }^{227}$ Moreover, the United Steelworkers of America donated a public address system to the BGTUC and the ICFTU and ORIT made small monetary contributions to assist the union in achieving financial stability. $^{228}$

A. John Cope, the former ICA representative and newly appointed American Consul in British Guiana, reported optimistically to the State Department that Guianese unions continued to make considerable gains in prestige and effectiveness and had improved substantially in the

\footnotetext{
226 "Union Call” No. 66, March 28, 1957, CO 859-1150, BNA; A. John Cope, Jr. to Department of State, July 29 , 1957, Box 4814, RG 59, Central Decimal File, 1955-1959, NARA II.

${ }^{227}$ British Guiana Government Information Services, Guiana Diary, "Pollak Calls for Trade Union Movement free from Political Control," April 3-6, 1957, F2384, British Guiana, Guiana Diary, 1955 Jan to 1957 Jun, TUCLC.

${ }^{228}$ A. John Cope to Department of State, July 29, 1957, 841D.062/7-2957, Box 4814, RG 59, Central Decimal File, 1955-1959, NARA II.
} 
previous year. ${ }^{229}$ However, Cope warned the State Department that the Jagan faction continued to challenge Western influence in the Guianese labor movement and cited the SWFU's recent suspension of its Acting General Secretary, Patrick Alleyne, a Jagan faction candidate for the Legislative Council in the August elections. Alleyne requested assistance from the CLC in a letter aggressively criticizing "American penetration in the trade union movement through the ICFTU, CADORIT, and the AFL-CIO under the guise of financial and moral support" and sending greetings to a WFTU affiliated organization. Alleyne argued in his defense that the Executive Council of the SFWU approved the letter and that his suspension was an attempt to undermine his candidacy in the August elections. Crucially, Cope turned to Tello for information and Tello explained that Alleyne was acting on Cheddi Jagan's behalf, noting that Jagan had been General President of the SWFU from 1950 to 1956. Tello informed Cope that "leftist sources" in Brussels provided information suggesting that Communists previously agreed to use the CLC to fund Jagan as a reward for his commitment to the Communist cause. ${ }^{230}$

It is unclear whether Tello passed along accurate information or used the situation as an opportunity to solidify his own position, particularly since Alleyne's letter also strongly criticized the BGTUC. Nonetheless, the Alleyne letter incident provides further evidence that Tello served as a crucial source of information for American trade union leaders and government officials. Regardless of his motivations or the legitimacy of his claims, the BGTUC General Secretary exercised a considerable influence on American interpretations of Guianese politics and organized labor, especially since American officials thought the British withheld

\footnotetext{
${ }^{229}$ A. John Cope to Department of State July 16, 1957, Box 13, RG 84, Classified General Records, NARA II. Cope worked for the ICA before taking a position as Consul in British Guiana and gained some familiarity with the colony through ICA programs.

${ }^{230}$ A. John Cope to Department of State, July 30, 1957, 841D.062/7-3057, Box 4814, RG 59, Central Decimal File, 1955-1959, NARA II.
} 
information. ${ }^{231}$ Secondly, the letter suggests that the PPP continued to seek cooperation with international labor organizations that were not part of the ICFTU, ORIT, or CADORIT increasing the internationalization of the trade union conflict in British Guiana.

The PPP won a majority of seats in the August elections, eliciting concern from American officials who felt that despite some collaboration British officials were not entirely cooperative in joint efforts to oppose Jagan before the election. Under-Secretary of State Robert Murphy ominously warned the British Ambassador that the United States would protect its interests in the Western Hemisphere despite a general reluctance to interfere in British territories. The guarded conversation further hinted that British officials intervened to build anti-Jagan parties and noted that British and American development projects prioritized undermining the Jagan faction of the PPP with economic progress a secondary concern. ${ }^{232}$ Conversely, colonial officials expressed concern at the extent of American influence in mid-1957 while criticizing the TUC's resistance to Colonial Office pressure for the British union play a larger role in the colony. ${ }^{233}$

Ultimately, TUC, Colonial Office, AFL-CIO, FOA/ICA, ICFTU, ORIT, and CADORIT institution-building efforts in British Guiana between 1954 and 1957 were somewhat effective in developing capitalist-oriented, moderately democratic trade unions. This conclusion is significant because the institutional foundations for a functioning society existed in an embryonic stage in 1957 despite colonialism's repressive nature and ongoing conflict between Guianese who disagreed about the colony's future political-economic and international orientation. The

\footnotetext{
${ }^{231}$ British Embassy, Washington D.C. to Foreign Office, September 5, 1957, FO 371-126078, BNA.

${ }^{232}$ British Embassy, Washington D.C. to Foreign Office, August 16, 1957, FO 371-126078, BNA. Part of the transcript of the conversation between the British ambassador and Murphy is redacted. The conversation relating to the redacted portion related to Murphy's acknowledgment of cooperation and his questioning of whether the British "were satisfied that all that was possible had been done to build up forces opposed to Jagan before the election." See also: Palmer, Cheddi Jagan and the Politics of Power, 146.

${ }^{233}$ Colonial Office Minute, January 13, 1960 (referencing conversation from 1957), CO 1031-2952, BNA.
} 
seeds of ethnic violence, bureaucratic dysfunction, and repressive government existed; however, the colony was predisposed as late as 1957 toward economic development, political democracy, and stability. As Lange suggests, developmental reforms during the 1950s were limited;

however, important advances in institutional development took place between 1954 and $1957{ }^{234}$ Nonetheless, important precedents in labor legislation and collective bargaining did not alleviate sugar workers' considerable poverty. The MPCA and BGTUC experienced improved organization, small increases in membership, and minor improvements in funding, and obtained some concessions from employers. However, the unions were financially unstable and dependent on external assistance, were weakened as a result of leaders' personal rivalries, and did not fundamentally alter the impoverished conditions under which Guianese workers' labored. As a result, workers supported a change in union leadership by late 1957 . While the PPP continued to seek its own external connections to strengthen affiliated unions, evidence in British and American archives does not suggest that there was substantial CLC and WFTU support for the PPP during the period. When the PPP returned to power after the August 1957 elections, the PPP continued to seek a union with which to gain support and engaged in legislative struggles that shaped the labor movement between 1957 and 1964. However, it primarily focused on obtaining external assistance for development and improving economic connections abroad since its base of support and transnational labor connections were eroded.

The PPP victory in 1957 increased the Americanization of external influence in British Guiana and the global and regional context in which it occurred was important. British and American institution-building programs in British Guiana stalled in early 1957. While American labor unions increased their involvement in the colony in response to the election, the TUC dismissed colonial officials' irritated appeals to re-establish British trade union connections in

\footnotetext{
${ }^{234}$ Lange, Lineages of Despotism and Development, 7-8, 130-131.
} 
the colony. ${ }^{235}$ Moreover, British policymakers embraced full-scale decolonization after the Suez Crisis in 1956 and the Cuban Revolution challenged United States hegemony in the Caribbean after $1959 .{ }^{236}$ As a result, American policymakers' increasingly aggressive pursuit of American objectives at the diplomatic level complemented the slow Americanization of development and institution building in British Guiana throughout the 1950s that portended a transition from British to American hegemony in the colony.

\footnotetext{
${ }^{235}$ International Cooperation Administration, "Evaluation of Caribbean Overseas Territories Program," July 23, 1959, Box 13, British Guiana U.S. Consulate, Georgetown, Classified General Records, 1940-1963, RG 84, Records of the Foreign Service Posts of the Department of State, NARA II; A. John Cope, Jr. to Department of State, April 26, 1957, 122.4132/4-2657, Central Decimal Files, Box 717, RG 59, Records of the Department of State, NARA II; Patrick Renison to Alan Lennox-Boyd, August 23, 1957, FO 371-126078, BNA.

${ }^{236}$ Rabe, U.S. Intervention in British Guiana, 47.
} 


\section{Chapter 7: The Fracturing of British Guiana, 1957-1961}

British Guiana's institutional decolonization changed as a result of domestic labor conflicts and changes to Anglo-American institution-building between 1957 and 1961 in ways that laid the foundation for the violence that rocked the colony from 1962 to 1965 . British and American institution-building between 1954 and 1957 contributed to the establishment of important precedents in Guianese trade union development; however, advancements only incrementally helped impoverished workers while generating negative side-effects that worsened the situation for others. In part, sugar workers' continued impoverishment contributed to the reelection of the People's Progressive Party (PPP) when the Colonial Office implemented the Renison Constitution, named for the colonial governor Patrick Renison, establishing restricted self-government in British Guiana in August 1957.

At the same time, the PPP's efforts to work through the Manpower Citizens' Association (MPCA) underlay union president Richard Ishmael's adoption of an authoritarian position within the organization. Moreover, racial tensions increased dramatically as the predominantly East Indian PPP assumed the position of employer to the colony's public sector unions- the vast majority of whom were Afro-Guianese. Thus, conflict between the PPP and MPCA, and tensions between the PPP and Afro-Guianese over labor relations, fractured Guianese society between 1957 and 1961. Ultimately, Central Intelligence Agency (CIA) financing of anti-PPP forces in 1962 and 1963 prolonged tense protests and allowed social unrest to be driven toward violence for political purposes.

The most important developments in Guianese institutional decolonization between 1957 and 1961 involved the colony's trade unionists, political leaders, and workers, rather than British or American trade unionists in the colony. Four overlapping trends best explain these changes. 
First, the PPP continued to pursue socialism in British Guiana, while Cheddi Jagan moderated some of the party's tactics in response to the Renison Constitution's restrictions on Guianese autonomy. ${ }^{1}$ Second, disagreements regarding trade unions' institutional role and the appropriate international orientation of the Guianese labor movement led to a significant increase in conflict between leadership of the MPCA and the PPP. MPCA President Richard Ishmael undermined democracy within the union while the PPP used a variety of methods to displace the union's leadership and eventually replace the organization altogether. Third, the PPP's position as head of government placed the party in opposition to the predominantly Afro-Guianese civil service workers in ongoing debates over government employees' wages and working conditions. As a result, government workers became politicized against the PPP, which contributed to increasing racial tensions within the colony. Finally, general labor unrest led to workers' movements to unionize throughout the colony and the struggles for recognition increased Guianese trade union connections to the American Federation of Labor-Congress of Industrial Organizations (AFLCIO). Ultimately, the return of partial self-government in British Guiana contributed to moving trade union conflicts into the political sphere, and governmental debates regarding the labor movement shaped British and American analyses of Guianese politics.

British and American policymakers interpreted the PPP's election differently; however, at the highest levels policymakers agreed to oppose the PPP's attempt at social revolution and to prepare to suspend the constitution should the PPP pursue a course similar to that which it followed in $1953 .^{2}$ At the same time, British and American officials in Guiana and in the International Cooperation Administration (ICA) suggested working with the PPP government as

\footnotetext{
${ }^{1}$ Cheddi Jagan, “Straight Talk: A Living Wage," Thunder, December 26, 1959, Cheddi Jagan Research Center (Hereafter: CJRC).

${ }^{2}$ Harold Macmillan Personal Minute, August 12, 1957, FO 371-126078, British National Archives, Kew, Richmond, Surrey, (hereafter BNA). See also: E.W.A. Scarlett, to D. Williams, Colonial Attaché, Washington D.C., August 23, 1957, FO 371-126078, BNA.
} 
a way to encourage Jagan to moderate the party's policy further while alleviating the poverty that underlay support for the party. ${ }^{3}$ Perhaps most importantly, institution-building programs floundered as the Trades Union Congress (TUC) retreated from its role in the colony and disagreement between the TUC and AFL-CIO in the International Confederation of Free Trade Unions (ICFTU) impeded collaborative programs to develop the Guianese labor movement. As a result, the MPCA and BGTUC grew increasingly reliant on the AFL-CIO for support, and the American labor leaders became progressively more dependent on reformist Guianese trade unionists in their opposition to the PPP.

The Guianese labor movement continued to grow between 1957 and 1961 in part as a result of Anglo-American trade union and government efforts to strengthen a capitalist-oriented labor movement in British Guiana. More importantly, Guianese labor leaders and workers persistently struggled to establish functional trade unions and achieved significant successes even though conflict undermined the labor movement as a whole. Nonetheless, the depth of poverty resulting from colonialism and from the asymmetries of power between Guianese workers and foreign capital was too severe for a moderately successful capitalist labor movement to reform rapidly enough to generate popular support for the unions, particularly when the PPP promoted more drastic change.

Close examination of the conflict within the labor movement over British Guiana's institutional framework and analysis of PPP materials suggest that the PPP continued its pursuit of social revolution, and that the party's governing strategy centered on advancing toward selfgovernment while altering institutionalized labor relations. Nonetheless, scholarship on the

\footnotetext{
${ }^{3}$ International Cooperation Administration, Office of the Assistant to the Director for Evaluation, "Evaluation of Caribbean Overseas Territories Program," July 23, 1959, British Guiana: US Consulate, Georgetown, Classified General Records, 1957-1963, Box 13, Records of the Foreign Service Posts of the Department of State, RG 84, National Archives II, College Park, MD (Hereafter: NARA II).
} 
period between 1957 and 1961 focuses on examining the colony's political developments and emphasizes PPP moderation, though scholars disagree on the reasons the party's governing methods differed from 1953.

Leo Despres argues that the PPP temporarily cooperated with the Colonial Office out of necessity after Cheddi Jagan concluded that the party could not pursue social revolution until it became head of an independent government. As a result, Despres suggests that the PPP adopted a conciliatory position designed to solidify its support among East Indians and pursue selfgovernment. ${ }^{4}$ Similarly, Clem Seecharan argues that Jagan remained committed to breaking the capitalist system in British Guiana. Seecharan suggests that the Jagans' uncompromising Marxism impeded reform efforts advanced by the Colonial Office and Booker Brothers chairman Jock Campbell despite the party's restrained rhetoric. ${ }^{5}$ Robert Waters and Gordon Daniels's study of the 1964 strike also suggests that the PPP's moderation between 1957 and 1964 was a change in tactics meant to bide time until British withdrawal, and that it did not constitute a change in party leaders' ideology or in their objective of establishing communism in British Guiana. ${ }^{6}$

Conversely, Stephen Rabe argues that Cheddi Jagan attempted to cooperate with British and American officials while pursuing social change. More importantly, Rabe notes that British and American interpretations of the August 12, 1957 election differed considerably. Rabe suggests that, after the election, British officials tended toward a reevaluation of the 1953 suspension of the Waddington Constitution and acknowledged the possibility that permitting the

\footnotetext{
${ }^{4}$ Leo A. Despres, Cultural Pluralism and Nationalist Politics in British Guiana, (Chicago: Rand McNally and Company, 1967), 222-226.

${ }^{5}$ Clem Seecharan, Sweetening 'Bitter Sugar': Jock Campbell the Booker Reformer in British Guiana 1934-1966 (Miami: Ian Randle Publishers, 2005), 207-208, 236, 243-245, 249.

${ }^{6}$ Robert Anthony Waters, Jr. and Gordon Oliver Daniels, "Striking for Freedom? International Intervention and the Guianese Sugar Workers' Strike of 1964," Cold War History, Vol. 10, No. 4, (November 2010): 537-569.
} 
Jagan government to succeed or fail on its own may have more effectively served British interests. On the other hand, Rabe argues that American policymakers continued to uphold the notion that the suspension was necessary. Assessments of the newly elected government, Rabe suggests, reflected the differing interpretations of 1953. British officials prepared to work with a seemingly moderated Jagan-led government and American officials recommitted to the AngloAmerican policy of undermining the PPP pursued since October 1953. ${ }^{7}$ Similarly, Colin Palmer argues that Cheddi Jagan retained his Marxist values but did not attempt to govern as a Marxist leader from 1957-1961, allowing for the possibility of cooperation between the Colonial Office and the PPP. ${ }^{8}$

\section{The Anglo-American Response to the 1957 Election}

British and American government officials, labor leaders, and businesses invested in Guiana argued that a labor movement dominated by the left wing of the Cheddi and Janet Jaganled PPP most directly threatened capitalism in the colony after the suspension of the Waddington Constitution in 1953. As a result, an array of British, American, and international labor leaders engaged in institution-building to undermine the Jagan-led faction of the PPP and the party's prospects for electoral victory as the colony advanced toward self-government. Ultimately, Anglo-American institution-building programs in British Guiana between 1954 and 1957 intended to establish a liberal capitalist-oriented labor movement to protect British and American strategic and economic interests and promote political democracy in Guyana after independence. ${ }^{9}$ Employers' reluctant and limited cooperation with the MPCA obscured and

\footnotetext{
${ }^{7}$ Stephen G. Rabe, U.S. Intervention in British Guiana: A Cold War Story (Chapel Hill: The University of North Carolina Press, 2005), 61-67.

${ }^{8}$ Colin Palmer, Cheddi Jagan and the Politics of Power: British Guiana's Struggle for Independence (Chapel Hill: The University of North Carolina Press, 2010), 152-153.

${ }^{9}$ International Cooperation Administration, Office of the Assistant to the Director for Evaluation, "Evaluation of Caribbean Overseas Territories Program,” July 23, 1959, British Guiana: US Consulate, Georgetown, Classified
} 
restricted the improvements achieved for unionized workers on sugar estates and increased the dependency of Guianese unions on external financial assistance. At the same time, gains for unionized sugar workers frequently came at the expense of displaced field workers. The MPCA's inability to substantially improve the lives of rural East Indians despite institutional advancement reinforced the tendency of Guianese sugar workers to look to the PPP for political alleviation of their impoverished condition.

At the same time, lack of cohesion between British and American labor leaders in the ICFTU undermined organization's usefulness as a labor international. Reformist Guianese labor leaders trying to establish trade unions to support a capitalist economic system needed external assistance to finance their stagnated movement and pressure employers, whose influence over the Guianese economy and society was nearly absolute. However, the AFL-TUC conflict in the ICFTU made it necessary for Guianese labor leaders to spend a great deal of time traveling to England and the United States to obtain assistance the ICFTU failed to provide. British and American uncertainty about whether to channel assistance to the Guianese unions through the ICFTU exacerbated the problem and resulted in several of the most significant Guianese trade unionists traveling to Western Europe and throughout Latin America rather than organizing on the sugar plantations. Moreover, the Inter-American Regional Organization of Workers (ORIT) and Caribbean Area Division of the Inter-American Regional Organization of Workers (CADORIT), the ICFTU's regional associations, achieved limited success in assisting the Guianese labor movement. Regional labor leaders attributed ORIT's and CADORIT's 
shortcomings to the organizations' subordination to the AFL-CIO and TUC. ${ }^{10}$ Ultimately, employers' resistance to substantive changes in labor relations made the internationalization of the labor struggle in British Guiana necessary. However, reliance on external trade unions disrupted grassroots organizing and weakened the local nature of the labor movement while leaving Guianese trade unions financially dependent on outside assistance.

The August 1957 elections that replaced the interim government with the Renison Constitution laid bare institution-building's failure to achieve British and American political objectives. ${ }^{11}$ The new constitution served as a moderate advance toward Guianese selfgovernment which Colin Palmer suggests was effectively closer to re-establishing an authoritarian Crown colony than providing meaningful autonomy in British Guiana. Under the new government, fourteen of the twenty-eight seats in the Legislative Council were elected positions and the remaining fourteen were divided between eleven members nominated by the governor and three ex officio members. Palmer argues that the equal balance of elected representatives and appointed positions in the Executive Council and the governor's reserve veto powers constituted a continuation of the period of politically "marking time." Despite British and American attempts to use institution building projects to increase support for the PPP's opposition and British gerrymandering of electoral districts prior to the August 12 election, the Jagan faction of the PPP won nine of the fourteen seats contested and the Burnham faction won

\footnotetext{
${ }^{10}$ Minutes of the 5th Meeting of the Administrative Committee of CADORIT, April 20-21, 1956, RG 18-009: International Affairs Department, Staff Files: Serafino Romualdi’s Files, 1945-1961, Box 1, Caribbean Area, 19531956, George Meany Memorial Archives, Silver Spring, MD (Hereafter, GMMA).

${ }^{11}$ S.R. Ashton and David Killingray argue that the period of marking time "failed conspicuously in its efforts to command public support, to generate economic growth or to reduce the PPP's political influence." British Documents on the End of Empire: S.R. Ashton and David Killingray. eds., "Series B Volume 6: The West Indies" (London: The Stationary Office, 1999), 364 (Hereafter: BDEE); International Cooperation Administration, Office of the Assistant to the Director for Evaluation, "Evaluation of Caribbean Overseas Territories Program," July 23, 1959, British Guiana: US Consulate, Georgetown, Classified General Records, 1957-1963, Box 13, Records of the Foreign Service Posts of the Department of State, RG 84, NARA II.
} 
three. ${ }^{12}$ After the election, the Forbes Burnham-led faction ended its claim to represent the PPP and formed the People's National Congress (PNC).

American officials, as Rabe and Palmer suggest, expressed considerable discontent about the Jagan faction's electoral victory and criticized British policies between 1953 and 1957 while threatening intervention if American interests were challenged. ${ }^{13}$ Domestic politics also influenced the State Department's response to the Guianese election. As Chester Pach notes in The Eisenhower Administration, the Third World, and the Globalization of the Cold War, contentious debates and appropriations struggles regarding foreign aid programs shaped American politics throughout the 1950s. ${ }^{14}$ In the environment of broad foreign policy debates, the British Embassy reported to the Foreign Office on August 17 that American government officials were "embarrassed politically in view of the Foreign Aid debate and the amount of technical assistance" committed to British Guiana between 1954 and $1957 .{ }^{15}$ Nonetheless, an ICA report analyzing the situation in British Guiana in 1959 suggests that American officials held a more complex view than the State Department. The report argues that Cheddi Jagan "can be dealt with as a Communist leader who is presently friendly and whose economic and social policies are acceptable, whose freedom of action is circumscribed by British authority, and who appears to be independent of ties to Russian Communism." It is important to note that the ICA report concluded that assisting "the British government in its efforts to encourage the continuation of the present comparatively moderate political and economic trend of the Jagan

\footnotetext{
${ }^{12}$ Palmer, Cheddi Jagan and the Politics of Power, 150-152; See also: Rabe, U.S. Intervention in British Guiana, 61.

${ }^{13}$ British Embassy, Washington D.C. to Foreign Office, August 16, 1957, FO 371-126078, BNA.

${ }^{14}$ Chester J. Pach, Jr., Introduction to Kathryn C. Statler and Andrew L. Johns, eds., The Eisenhower Administration, the Third World, and the Globalization of the Cold War (Lanham, MD: Rowman \& Littlefield Publishers, Inc., 2006), xiii-xiv.

${ }^{15}$ British Embassy, Washington D.C. to Foreign Office, August 17, 1957; Colonial Office to A.N. McCleary, Foreign Office, August 20, 1957, FO 371-126078, BNA.
} 
Government" was "essential to our overall political and security objectives." ${ }^{16}$ Carroll Woods, who became the American Consul in British Guiana in September 1958, similarly encouraged a substantial increase in ICA programs in the colony in September 1959. Woods warned the State Department that ICA programs between 1954 and 1959 were insufficient in combatting Guianese social maladies, including unemployment and malnutrition. Significantly, Woods warned that Cheddi Jagan was "openly flirting" with the "Soviet bloc with approval [of the] majority [of the] electorate."17 Thus, at least some departments of the United States government advocated cooperation with the PPP during the 1957-1961 government; however, American officials did not agree on the extent to which Cheddi Jagan posed a direct threat to United States interests by engaging the Soviet Union.

As Rabe notes, British colonial officials and investors expressed a moderation in their opposition to the now Jagan faction-dominated PPP; however, British policy was also inconsistent. Close reading of a note from newly appointed Prime Minister Harold Macmillan to Colonial Secretary Alan Lennox-Boyd suggests that the official British policy toward the colony in 1957 mirrored British policy in 1953. Macmillan instructed Boyd to keep American officials closely informed with developments in British Guiana since United States defense of British policy in 1953 was critical "in keeping the other Latin Americans quiet." Crucially, Macmillan argued that retaining open lines of communication was imperative in case a similar suspension became necessary in $1957 .{ }^{18}$ The Prime Minister's note suggests a British policy of limiting Guianese autonomy and a willingness to use force if challenged even if the Colonial Office

\footnotetext{
${ }^{16}$ International Cooperation Administration, Office of the Assistant to the Director for Evaluation, "Evaluation of Caribbean Overseas Territories Program,” July 23, 1959, British Guiana: US Consulate, Georgetown, Classified General Records, 1957-1963, Box 13, Records of the Foreign Service Posts of the Department of State, RG 84, NARA II.

${ }^{17}$ Carroll H. Woods to Department of State, September 18, 1959, 841D.00TA/9-1859, General Records of the Department of State, Central Decimal Files, Box 4451, RG 59, NARA II.

${ }^{18}$ Harold Macmillan Personal Minute, August 12, 1957, FO 371-126078, BNA. See also: E.W.A. Scarlett, to D. Williams, Colonial Attaché, Washington D.C., August 23, 1957, FO 371-126078, BNA.
} 
employed more conciliatory rhetoric. The Colonial Office's cooperative posture and the difference between 1953 and 1957 were attributable to the limited nature of the 1957 constitution. As Palmer argues, the Renison Constitution included constitutional safeguards reserving power in the governor's hands to render impossible a PPP attempt to pursue policies similar to 1953, and British officials took pains to impress that point on the State Department. ${ }^{19}$

The PPP's rhetoric between 1957 and 1961 suggests that the party's leaders understood the constitution's limitations and calculated their actions in a manner that contributed to British willingness to cautiously work with the newly elected government. In 1959, Cheddi Jagan noted in the PPP's journal, Thunder, that the party remained committed to socialism with the objective of progressing into the "second stage" wherein society would be based on the principle "to each according to his need, from each according to his ability." Nonetheless, Jagan assured readers that as elected socialists the PPP had to accept temporary limitations. Specifically, Jagan noted that socialism could not be implemented immediately and that because of colonialism "the PPP is in office but not in power." ${ }^{20}$ Jagan's views articulated in 1959 remained consistent with his earlier explanation of socialism as a stage on the process toward inevitable communism. ${ }^{21}$

Even so, a close examination of the PPP's attempts to institutionally alter labor relations suggests that the party's moderation between 1957 and 1961 is overstated. In his autobiography, The West on Trial, Jagan noted the limitations the Rension Constitution placed on the PPP. Jagan also describes Renison's encouragement of "talking out" issues on which PPP ministers and

\footnotetext{
${ }^{19}$ Palmer, Cheddi Jagan and the Politics of Power, 153; British Embassy, Washington D.C. to Foreign Office, August 17, 1957; Colonial Office to A.N. McCleary, Foreign Office, August 20, 1957; Alan Lennox-Boyd to Harold Macmillan, August 21, 1957, FO 371-126078, BNA.

${ }^{20}$ Cheddi Jagan, Straight Talk: A Living Wage, Thunder, December 26, 1959, Cheddi Jagan Research Center (Hereafter: CJRC). Jagan explained the party's limited short-term policy of a "unified national front" and with local capitalists as part of a continued struggle for revolution in a 1956 speech at the PPP Congress. See: Cheddi Jagan, "1956 Congress Speech," CJRC.

${ }^{21}$ Dr. Cheddi Jagan, "Undesirable Publications Bill," 1953, David Dabydeen and Lynne Macedo, eds., Dr. Cheddi Jagan National Assembly Speeches, Volume 2: The Fourth Legislative Council January 1952-April 1953 (Published by the Caribbean Press for the Government of Guyana, 2011), 309.
} 
British-appointed members of the legislative bodies disagreed as a tactic the governor regularly employed to impede the introduction of controversial legislation. Crucially, Jagan lists legislation aimed at polling sugar workers to determine union recognition as among the "fundamental issues" undermined through Renison's process of talking out. ${ }^{22}$ There is no evidence of a labor bill in archival records, likely as a result of Rension's killing the proposal before a one could be introduced. However, if the PPP attempted to pursue the issue as Jagan suggests, then the party moved to introduce legislation that Jagan described in the same way as the controversial Labor Relations Bills that preceded the British suspension of the Waddington Constitution in 1953 and that initiated massive American-funded strikes in 1963. Therefore, Jagan acknowledged that the PPP moderated its actions while still pursuing social revolution and the moderation to which the party leader referred was less significant than even close examination of legislative records suggests.

Regardless of the PPP's commitment to social revolution, Jagan convinced colonial officials of the party's willingness to govern moderately. Renison informed Secretary Boyd that he believed in Jagan's sincere desire to establish a responsible government. Renison told Boyd that PPP leaders understood that they could not pursue radical or fundamental changes to the structure of the Guianese social or political-economic system at the time. ${ }^{23}$ Boyd wrote to Renison on August 23 explaining three policymaking priorities in the colony emphasizing "the ultimate responsibility of H.M.G. of both the legitimate interests of Commonwealth and United States governments and legitimate outside economic interests" and the importance of preserving British authority to protect those interests. Boyd suggested that Renison should cooperate with Jagan while limiting the Guianese leader's leverage in governing. Boyd suggested, for example,

${ }^{22}$ Cheddi Jagan, The West on Trial: My Fight for Guyana's Freedom (New York: International Publishers, 1967), 225.

${ }^{23}$ Patrick Renison to Alan Lennox-Boyd, August 16, 1957, FO 371-126078, BNA. 
that Renison nominate members to the Executive Council acceptable to Jagan while insisting that the governor should not allow Jagan himself to nominate members for the council. ${ }^{24}$ Most importantly, Renison constantly worked to build the colony's trade union movement as an institutional bulwark against the possibility that the PPP would try to restructure Guianese society after independence. ${ }^{25}$ Thus, the Prime Minister and Foreign Office did not fundamentally alter their policy toward the PPP. Some colonial officials and British employers in Guiana cooperated with Cheddi Jagan based on the assumption that the new government's power was sufficiently limited and that an institutional framework would develop to protect British interests. $^{26}$

While colonial officials continued to jealously guard their prerogatives in shaping colonial affairs, information-sharing with United States policymakers in 1957 suggests a growing acceptance of the expanding American role in the Caribbean. ${ }^{27}$ As Stephen Rabe suggests, British policymakers did not discuss the suspension of the Waddington Constitution in 1953 with American officials. ${ }^{28}$ Between 1953 and 1957 British officials staunchly refuted the notion of American influence over policymaking toward British Guiana while courting American support for colonial policies. Despite attempts to cooperate in institution building, American officials expressed disappointed with a perceived dearth of shared information though British officials

\footnotetext{
${ }^{24}$ Alan Lennox-Boyd to Patrick Renison, August 23, 1957, FO 371-126078, BNA; Patrick Renison to Alan LennoxBoyd, August 16, 1957, FO 371-126078, BNA.

${ }^{25}$ Patrick Renison to Fred Kennedy, Colonial Office, December 2, 1958, CO 859-1150, BNA.

${ }^{26}$ Patrick Renison to Alan Lennox-Boyd, August 14, 1957, FO 371-126078, BNA; International Cooperation Administration, Office of the Assistant to the Director for Evaluation, "Evaluation of Caribbean Overseas Territories Program," July 23, 1959, British Guiana: US Consulate, Georgetown, Classified General Records, 1957-1963, Box 13, Records of the Foreign Service Posts of the Department of State, RG 84, NARA II.

27 Jason Parker most effectively describes the expansion of American influence in the British West Indies beginning in the 1930s, particularly outside of British Guiana. See: Jason Parker, Brother's Keeper: The United States, Race, and Empire in the British Caribbean, 1937-1962 (Oxford: Oxford University Press, 2008).

${ }^{28}$ Rabe, U.S. Intervention in British Guiana, 43-44.
} 
suggested that there was no such disconnect. ${ }^{29}$ Nonetheless, the decision to increase exchange of information did not entirely alter British parochialism and Colonial Office representatives carefully avoided giving American officials the impression that increased in shared information were tantamount to consultation on questions of colonial policy. ${ }^{30}$ Ultimately, Anglo-American collaboration on questions of policy toward British Guiana increased at the highest-levels while colonial officials continued to resist American influence.

British and American policymakers and labor leaders re-evaluated the purpose and methods of institution building programs as a result of the PPP's victory in the 1957 election. In early September British and American policymakers discussed how to move forward with institution-building efforts in light of the PPP's victory. On September 4 the British Colonial Attaché and the British ambassador in Washington D.C. met with Robert Murphy, Deputy under Secretary of State for Political Affairs, to continue Anglo-American discussions regarding the Guianese elections. British officials noted that one of the primary American concerns was Janet Jagan's appointment as Minister of Labor for the new government and the possibility that she would use her position to strengthen the Guiana Industrial Workers' Union's (GIWU) links to the communist-dominated World Federation of Trade Unions (WFTU) ${ }^{31}$ The American concern belies a lack of understanding of the Guianese labor movement. The GIWU broke from the Jagan faction of the PPP in conjunction with the PPP's split in January 1955 and Renison's response to an inquiry from the British ambassador in Washington strongly refuted the alleged claims of GIWU-WFTU connections. ${ }^{32}$ Nonetheless, the appointment of the PPP's General Secretary as

\footnotetext{
${ }^{29}$ British Embassy, Washington D.C. to Foreign Office, September 5, 1957, FO 371-126078, BNA.

${ }^{30}$ E.W.A. Scarlett, to D. Williams, Colonial Attaché, Washington D.C., August 23, 1957; Alan Lennox-Boyd to Patrick Renison, October 4, 1957; R.W. Jackling, Economic Minister at British Embassy to H.A.A. Hankey, British Embassy, Washington, D.C., October 10, 1957, FO 371-126078, BNA.

${ }^{31}$ British Embassy, Washington D.C. to Foreign Office, September 5, 1957, FO 371-126078, BNA.

${ }^{32}$ Patrick Renison to British Ambassador to Washington D.C., September 19, 1957, FO 371-126078, BNA.
} 
Minister of Labor suggests that the PPP placed paramount importance on using the structures of government to address workers' needs and increase the party's ability to shape the Guianese labor movement. The American response to Jagan's appointment is evidence that the State Department considered the labor movement the heart of the struggle to determine the nature of Guianese independence.

\section{International Labor Developments and American Labor's Expanded Connections in British}

\section{Guiana}

Tensions between British and American labor leaders further disrupted Guianese institution building. AFL and TUC leaders disagreed about trade union methods since the early twentieth century and each advocated international agendas that advanced their nations' interests, which led to long-term tension and occasional conflict between the unions that increased with the onset of the Cold War. The slow evolution of colonial policy toward decolonization increased the AFL-CIO's influence in British colonies and amplified tensions between the unions as the 1950s progressed. AFL-CIO-TUC cooperation in British Guiana was unique given the acute Anglo-American trade union rivalry in Africa; however, the impact of trade union conflict influenced British Guiana in two ways. ${ }^{33}$

\footnotetext{
${ }^{33}$ British and American trade union leaders' rivalry was between the AFL and TUC even though the AFL and CIO merged in 1955. TUC discussions about the rivalry singled out the AFL and noted points of agreement with Walter Reuther, President of the CIO; however, AFL-CIO foreign policy was generally driven by AFL leadership. See: Notes from an informal meeting of members of the TUC and AFL-CIO, September 9, 1957, Marjorie Nicholson Files, Box 9, ICFTU/TUC, TUCLC. Some Anglo-American labor programs designed to train Guianese unionists succeeded in part because the proposals originated in the CIO, which eased TUC reservations regarding cooperation with American trade unions. See: Department of State Memorandum of Conversation, "Assistance to British Guiana Trade Unions," March 7, 1960, British Guiana: U.S. Consulate, Georgetown, Classified General Records, 19401963, 1957-1963, 560: Economic Affairs, Box 13, RG 84, NARA II. For more on the tension between the AFL-CIO and TUC regarding American activity in British colonies, see: Anthony Carew, ed., The International Confederation of Free Trade Unions (New York: Peter Lang, 2000), 270; Yevette Richards, Maida Springer: Pan-Africanist and International Labor Leader (Pittsburgh: University of Pittsburgh Press, 2000). For more on general tensions between the AFL-CIO and the ICFTU, see: Ake Wedin, T.L. Johnston, trans., International Trade Union Solidarity. ICFTU 1957-1965 (Stockholm: Bokforlaget Prisma, Publishers, 1974). For more on the tension between the AFL and TUC, see: Hugh Wilford, "American Labour Diplomacy and Cold War Britain," Journal of Contemporary History, Vol. 37 (1), 45-65, 2002.
} 
First, AFL-CIO conflict with the TUC undermined the establishment of an effective internationally-supported institution building program operated through the ICFTU. Specifically, lack of British and American cohesion in the ICFTU impeded organizational unity and sense of shared purpose while administrative disagreements diverted attention from institution building efforts in underdeveloped areas. ${ }^{34}$ Second, AFL-CIO-TUC tension limited cooperation between British and American efforts in Guiana before the TUC conceded AFL-CIO predominance in the colony after 1957 . The AFL-CIO's ascension resulted in a change to institution building tactics. AFL-CIO policy focused on supporting individual Guianese trade union leaders and using relationships with Guianese unions to support political objectives rather than emphasizing broadbased institution building at the grassroots level and the pursuit of economic achievements.

General international disagreements in the ICFTU further disrupted collaborative AFLCIO-TUC involvement in British Guiana. In November 1957 Charles Millard, ICFTU Director of Organization, proposed that the TUC should aid colonies through the ICFTU as a way to end the AFL-CIO's policy of independently aiding colonial unions. ${ }^{35}$ CIO President Walter Reuther expressed general agreement with the policy of ending national unions' independent activities, particularly after the ICFTU altered its rules to allow AFL-CIO Executive Council members to

\footnotetext{
${ }^{34}$ For a thorough explanation of TUC perspectives on ICFTU ineffectiveness, see: Trades Union Congress International Committee, “Congress Resolution No. 37: Trade Unions in Developing Countries,” July 26, 1966, Marjorie Nicholson Files, Box 8, I.C. Minutes 1965/66 [901], TUCLC. Colonial Office and TUC policy in the late 1950s was to use the ICFTU to influence the American trade union movement and discourage independent AFLCIO international activities, though Julian Amery of the Colonial Office suggested that the policy was unsuccessful. See: Julian Amery to Gorell Barnes, January 6, 1960, CO 1031-2952, BNA.

${ }^{35}$ Minutes of International Committee 2 (1957-58), "International Confederation of Free Trade Unions," November 26, 1957, Marjorie Nicholson Files, Box 9, ICFTU/TUC, Trade Union Congress Library Collections, London Metropolitan University, London, England (Hereafter TUCLC).
} 
participate in ICFTU Executive Board meetings. Nonetheless, Reuther suggested that exceptions could be made if independent activities were conducted within the ICFTU's framework. ${ }^{36}$

Labor historian Anthony Carew suggests that George Meany, president of the AFL-CIO, and Jay Lovestone, the most influential member of the AFL-CIO's International Affairs Department, dismissed Millard's call for ending independent activities despite a weak commitment to accede to working through the ICFTU. ${ }^{37}$ At the same time, the TUC continued to operate autonomously. Together, AFL-CIO and TUC actions suggest that advancing national interests superseded appeals to international solidarity for British and American labor leaders. ${ }^{38}$ Moreover, ORIT policies in Latin America and the AFL-CIO's influence in the organization increased tensions between American trade union leaders and the international labor movement. ${ }^{39}$ Nonetheless, the AFL-CIO-TUC efforts in British Guiana were not as contentious as was the case in other parts of the world and Lovestone even rejected a request for aid from Rupert Tello of the British Guiana Trade Union Council (BGTUC) in 1958 citing the AFL-CIO's agreement not to independently intervene in the colony. ${ }^{40}$

Guianese-American trade union relationships increased outside of institution building projects in the mid-1950s as well, and individual American unions became involved in the colony as part of an effort to expand organizing internationally. Not all Guianese labor struggles unfolded in a Cold War context. Rather, some Guianese unions peacefully integrated into the

\footnotetext{
${ }^{36}$ Minutes of an informal meeting between members of the AFL-CIO and TUC, September 9, 1957; Walter Reuther to Vincent Tewson, General Secretary TUC, December 16, 1957, Marjorie Nicholson Files, Box 9, ICFTU/TUC, TUCLC.

${ }^{37}$ Anthony Carew, "Charles Millard, A Canadian in the International Labor Movement: A Case Study of the ICFTU 1955-61,” Labour/Le Travail, 37 (Spring 1996), 121-148.

${ }^{38}$ Commonwealth Advisory Committee Minute, "TUC and ICFTU Assistance to Trade Unions in British Dependent Territories," April 2, 1958, Marjorie Nicholson Files, Box 9, ICFTU/TUC, TUCLC.

${ }^{39}$ J.H. Oldenbroek, General Secretary, ICFTU to Jim Bury, Assistant Secretary, ORIT, June 17, 1958;

"Memorandum on ORIT-ICFTU Relationships," June 17, 1958, RG 18-003, International Affairs Department, Serafino Romualdi Files, Box 4, ICFTU, J.H. Oldenbroek, 1958, GMMA.

${ }^{40}$ A.M. Morgan, Colonial Office to G.C. Wilson, Minister of Labor and National Service, Overseas Department, October 3, 1958, CO 859-1150, BNA.
} 
Western international system. On October 15, 1957 Nick Zonarich and George Rattinger of the United Steelworkers of America (USW) visited British Guiana in the company of Ken Sterling of CADORIT. The trade union leaders met with officials of the British Guiana Mine Workers Union (BGMWU) at Mackenzie. ${ }^{41}$ USW representatives had experience in Guiana, having donated a public address system to the BGTUC in 1956 and visited the colony in March 1957. Zonarich's public criticism of mineworkers' wages during his March visit initiated a backlash from the Demerara Bauxite Company (Demba), a member of the Aluminum Limited Group of Companies based in Canada and the United States. ${ }^{42}$ In response to Zonarich's criticism, Demba representatives appealed to A. John Cope, the American Consul in Georgetown, condemning Zonarich for inaccurately suggesting that Demba paid sub-standard wages. In addition to suggesting that Zonarich's reproach undermined "the most happy employer-employee relationships within the colony," Demba's appeal accused the American unionist of aiding local communists, a criticism that resonated with Cope and the American Consul suggested that United States government officials should impress on American unionists the delicacy of Guianese labor relations to discourage similar statements during future visits. ${ }^{43}$

Hugh Roach, Public Relations Officer for Demba, leveled similar condemnations of Zonarich and Sterling in October when he accused the men of agitating for strike action among miners with no significant complaints. Roach argued that increasing miners' wages would

\footnotetext{
${ }^{41}$ A. John Cope, Jr., American Consul, Georgetown to Department of State, October 28, 1957, 841D.061/10-2857, Central Decimal Files, Box 4451, RG 59, NARA II.

${ }^{42}$ A. John Cope, Jr. to Department of State, July 29, 1957, Box 4814, RG 59, Central Decimal File, 1955-1959, NARA II; A. John Cope, Jr. to Department of State, April 5, 1957, 841D.061/4-557, Central Decimal Files, Box 4451, RG 59, NARA II.

${ }^{43}$ Demba officials also accused the United Steelworkers of attempting to use the fabricated issue of low wages as a way to undermine manufacturing of aluminum in British Guiana because it would compete with American steel. A. John Cope, Jr. to Department of State, April 5, 1957, 841D.061/4-557, General Records of the Department of State, Central Decimal Files, Box 4451, RG 59, NARA II.
} 
disrupt the existing wage pattern in the colony and lead to runaway inflation. ${ }^{44}$ Nonetheless, the BGTUC-sponsored radio program "Union Call” assured the Guianese that Zonarich and the USW expressed strong interest in establishing close association with Caribbean labor unions particularly in the bauxite mining industry. The program cited Zonarich's agreement to purchase a high powered motor boat to assist the BGMWU in organizational efforts as evidence of the USW's increased support for Guianese bauxite workers. ${ }^{45}$ Thus, the motives driving American trade union involvement in British Guiana varied; however, individual unions, as opposed to the national front AFL-CIO, built relationships emphasizing industrial matters rather than narrow Cold War objectives. Ultimately, efforts to integrate Guianese unions into the Western international system continued to increase the internationalization of labor struggles in the colony after the PPP's election in 1957.

\section{Guianese Trade Union Conflicts and the PPP's Alienation from the Labor Movement}

The Colonial Office, TUC, and Overseas Employers' Federation (OEF) expressed considerable skepticism that the MPCA would survive the political attacks expected to emerge during the 1957 election. ${ }^{46}$ The MPCA withstood the PPP's political attacks more effectively than British officials predicted in mid-1957 largely as a result of President Richard Ishmael's anti-democratic measures to retain control of the union. Martin Pounder of the TUC visited British Guiana in December and reported to the General Council that institution building efforts successfully solidified the MPCA, that membership increased considerably, and that the sugar workers' union was prepared to be financially self-sufficient. In evaluating the union's progress the council noted that the MPCA won a ten-percent wage increase, an additional eight-day pay

\footnotetext{
${ }^{44}$ A. John Cope, Jr., American Consul, Georgetown to Department of State, October 28, 1957, 841D.061/10-2857, General Records of the Department of State, Central Decimal Files, Box 4451, RG 59, NARA II.

${ }^{45}$ Transcript of "Union Call," October 24, 1957, CO 859-1150, BNA.

${ }^{46}$ Minutes of a meeting between representatives of the TUC, OEF, and Colonial Office, January 3, 1957, CO 8591150, BNA.
} 
bonus during the second half of 1957, and that the colony's first sickness benefit scheme began on January 1, 1958. Moreover, the MPCA was able to fund three full-time field officers and fifteen part-time assistants to aid in expanding the union's influence. ${ }^{47}$ TUC leaders determined that the MPCA was "in better shape than ever before" and Governor Patrick Renison argued that the MPCA was "as good as almost any Union in the Caribbean" a year later. ${ }^{48}$

Nonetheless, conflict for control of the MPCA intensified after the PPP's victory in the August elections and colonial officials acknowledged that Ishmael manipulated the union to exclude PPP influence in late 1957. In October Ishmael attempted to remove three PPP members from the MPCA on the grounds that they no longer worked in the sugar industry. ${ }^{49}$ In January 1958 MPCA leaders rejected Balram Singh Rai's nomination to contest the union's presidency as a result of his membership in the PPP. The BGTUC supported the MPCA leaders' decision and passed a series of resolutions aimed at undermining the PPP's attempts to gain influence in the MPCA. ${ }^{50}$ Consequently, Ishmael won an uncontested election to retain his position as MPCA president after removing Rai from the ballot. MPCA leaders amended the union's rules allowing Ishmael to retain the presidency for three years after expressing fears that PPP members might ascend to positions of prominence in the MPCA. MPCA rules were altered further in February to complicate the admission of persons not directly employed in sugar industries as a way to avoid including PPP leaders in the union. BGTUC leaders effectively endorsed the MPCA's policies when General Secretary Rupert Tello dismissed complaints about the new MPCA rules raised in

\footnotetext{
${ }^{47}$ S.A. Olilvie, "B.G. Sugar: Special Edition," December, 1957, CO 1031-2388, BNA; Report of the 90th Annual Trades Union Congress, September 1-5, 1958, 237-238, TUC History Online, 237-238, http://www.unionhistory.info/britainatwork/emuweb/objects/nofdigi/tuc/imagedisplay.php?irn=6014714\&reftable=e catalogue \&refirn=6014597, Last Accessed July 12, 2015.

${ }^{48}$ Patrick Renison to Fred Kennedy, December 2, 1958; Fred Kennedy to Patrick Renison, November 20, 1958, CO 859-1150, BNA.

49 "Note on the Relations of the People's Progressive Party with Trade Unions in the Sugar Industry," undated (1959), CO 1031-3421, BNA.

${ }^{50}$ Ibid. British Guiana Government Information Services, Guiana Diary, "T.U.C. to Counter Political Infiltration," January 13-16, 1958, F2384, British Guiana, Guiana Diary, 1957 Jan to 1962 Jun, TUCLC.
} 
the BGTUC. ${ }^{51}$ Thus, anti-PPP trade union leaders used their organizations as an institutional barrier to exclude PPP members from participation in the established labor movement.

The PPP took a dual approach in responding to Ishmael's maneuvers. First, Janet Jagan appealed to the ICFTU in protest of the election. The American Consul in British Guiana, A. John Cope, informed the State Department of Jagan's appeal and speculated that she also contacted the WFTU. Cope's personal comments noted that only "the irregular electoral procedure of the MPCA" kept PPP members Balram Singh Rai and Abdul Sallim from winning the union's election. Nonetheless, Cope dismissed Jagan's protest as an attempt to embarrass the MPCA and BGTUC, exacerbate personal tensions between Tello and Ishmael, and facilitate future PPP domination of the trade union movement. ${ }^{52}$ Cope's comments illuminate a rationalization for anti-democratic measures as a necessary tactic to preserve democratic institutions and United States' interests in British Guiana that permeated American activities in the colony.

Second, PPP leaders encouraged workers to withdraw permission for automatic deduction of dues as part of the check-off system supporting the MPCA. Cope warned the State Department that the PPP also renewed efforts to build the British Guiana Sugar Workers' Union (BGSWU) which was registered the previous year in an attempt to give the party a union to rival the MPCA. ${ }^{53}$ Despite the PPP's efforts the MPCA experienced a twenty percent increase in membership in the first five months of 1958 to bring its enrollment to 11,500 . The PPP returned to a policy of encouraging qualified members to run for MPCA office despite the new rules

\footnotetext{
${ }^{51}$ A. John Cope to Department of State, August 15, 1958, 841D.062/8-1558, Central Decimal Files, Box 4814, RG 59, NARA II.

${ }^{52}$ A. John Cope, Jr. to Department of State, May 28 1958, 841D.062/5-2858, Box 4814, RG 59, Central Decimal File, 1955-1959, NARA II.

${ }^{53}$ A. John Cope, Jr. to Department of State, July 15, 1958, 841D.062/7-1558, Central Decimal Files, Box 4814, RG 59, NARA II.
} 
designed to prevent their success in 1959. Colonial officials suggested that the PPP's tactical shift proved that their effort to form a new union failed. ${ }^{54}$ It is also possible that the PPP shifted its policy in response to Renison's scuttling Jagan's attempt to reintroduce a labor relations bill since the MPCA would remain the sugar workers' official representative in the absence of legislation to force recognition of a PPP-aligned union. Thus, the PPP's attempt to work through the existing institutional structure was rejected damaging the quickly disintegrating possibility of cooperation between the colony' most popular political party and anti-communist Guianese leaders. Meanwhile, MPCA leaders continued to work to strengthen the union's institutional role while the struggle for control of the sugar union unfolded when Ishmael met with the Sugar Producers' Association (SPA) in November 1957 to negotiate production targets for $1958 .^{55}$

\section{Wages Council Debate}

On March 22, 1958 Forbes Burnham introduced a proposal in the legislature to establish a wages council in the sugar industry. If established, a wages council would give the government considerable influence in setting workers' pay rates. Supporters argued that the MPCA ineffectively bargained on behalf of deeply impoverished Guianese sugar workers. Opponents countered that empowering the government in wage debates interfered with collective bargaining practices, undermined free trade unionism, and threatened the institutional structure of a postcolonial liberal capitalist democracy. Burnham's proposal initiated a debate in the Executive Council that lasted until 1961. The wages council debate, which Cope suggested originated with

\footnotetext{
54 "Note on the Relations of the People's Progressive Party with Trade Unions in the Sugar Industry," undated (1959), CO 1031-3421, BNA.

${ }^{55}$ British Guiana Government Information Services, Guiana Diary, “S.P.A., M.P.C.A. Discussing 1958 Sugar Target," November 1-8, 1957, F2384, British Guiana, Guiana Diary, 1957 Jan to 1962 Jun, TUCLC. The MPCA and SPA engaged in a similar process of negotiating production targets for 1959. See: British Guiana Government Information Services, Guiana Diary, “Sugar Production Target Set at 280,000 Tons," November 24-30, 1958, F2384, British Guiana, Guiana Diary, 1957 to 1962, TUCLC.
} 
GIWU President and Burnham advisor J.P. Lachmansingh, is important to understanding Guianese institutional decolonization between 1958 and 1961 for two reasons.

First, the bill's introduction was misattributed to Janet Jagan and used as evidence of the PPP's attack on trade unionism independent of PPP influence. The error reinforced the notion that the PPP uncompromisingly sought the destruction of Guianese trade unions and persisted even after the mistake was corrected. Janet Jagan received criticism for the bill's discussion even when officials correctly identified Burnham as the original proponent of the legislation. Cope informed the State Department that Burnham realized the proposal was a mistake in July and attributed the continued conversation to PPP attempts to destroy the MPCA, thus absolving Burnham of blame for the implications of his proposal on labor relations. ${ }^{56}$ Similarly, some colonial officials were unclear of the bills' origins as late as 1960 which suggests that factual inaccuracies muddled analysis of the debate. ${ }^{57}$

Significantly, the mistake was partially attributable to information passed from Rupert Tello to contacts in the Colonial Office and forwarded to the TUC. ${ }^{58}$ Tello also used the allegation of "Dr. and Mrs. Jagan's move to destroy the trade unions by means of their proposed wages council" as the justification for requesting financial assistance from the USW during his ICA-USW-supported "Foreign Leader" tour of the United States in the summer of $1958 .{ }^{59}$ Tello argued that the BGTUC needed money to support organizational efforts rather than previously emphasized educational missions to confront the alleged threat emanating from the PPP. While appealing for American assistance, Tello assured colonial officials he sought to protect the

\footnotetext{
${ }^{56}$ A. John Cope, Jr. to Department of State, July 15, 1958, 841D.062/7-1558, Central Decimal Files, Box 4814, RG 59, NARA II.

${ }^{57}$ Ralph Grey to Ambler Thomas, February 22, 1960, CO 1031-3421, BNA.

${ }^{58}$ C.C. Gibbs, Colonial Office to Marjorie Nicholson, International Department of the Trades Union Congress, November 19, 1958; C.C. Gibbs to Marjorie Nicholson, January 8, 1959, CO 859-1150, BNA.

${ }^{59}$ A.M. Morgan, Colonial Office to G.C. Wilson, Minister of Labor and National Service, Overseas Department, October 3, 1958; Fred Kennedy to Patrick Renison, November 20, 1958, CO 859-1150, BNA.
} 
integrity of British trade unionism in Guiana. ${ }^{60}$ Crucially, Tello and Burnham debated the proposed wages council from opposing positions in the BGTUC Executive Council; therefore, Tello was not misinformed regarding the proposal's origin but intentionally mislead British and American officials and trade unionists. At the same time, Burnham's motives in proposing the bill were also suspect and several colonial officials, including Renison, were under the impression that the proposal was a political maneuver intended to undermine the PPP government. ${ }^{61}$ In a discussion with Ralph Grey, who replaced Renison as governor in 1960, Burnham suggested that his objective was to embarrass the PPP for supporting higher wages in the sugar industry while failing to raise wages in the aftermath of the Postal Workers' strike in early $1958 .{ }^{62}$ It is likely that Burnham, like Tello, was insincere in his explanation since he supported the wages councils in the BGTUC after Cope's report. Moreover, Burnham resubmitted the proposal in 1959 after the initial bill lapsed. ${ }^{63}$

The debate about a wages council offers a second insight into institutional decolonization in addition to the impact of the bill's association with Janet Jagan. Specifically, it sheds light on the challenges Guianese political leaders faced in balancing support for trade unions as institutions and advocacy of measures that most effectively addressed workers' grievances. The PPP campaign manifesto opposed wages councils that empowered the Governor to rule on pay disagreements between workers and employers. However, the party's opposition derived from the notion that a British governor could hold power over wage rates and did not inherently oppose a PPP-led government taking charge of ruling on workers' pay. ${ }^{64}$

\footnotetext{
${ }^{60}$ C.C. Gibbs to Marjorie Nicholson, November 19, 1958, CO 859-1150, BNA.

${ }^{61}$ Patrick Renison to Fred Kennedy, Colonial Office, December 2, 1958, CO 859-1150, BNA.

${ }^{62}$ Ralph Grey to Ambler Thomas, February 22, 1960, CO 1031-3421, BNA.

${ }^{63}$ A. John Cope to Department of State, August 15, 1958, 841D.062/8-1558, Central Decimal Files, Box 4814, RG 59, NARA II; Patrick Renison to Fred Kennedy, March 12, 1959; Fred Kennedy to Patrick Renison, March 18, 1959; British Guiana Executive Council Notes, April 3, 1959, CO 859-1150, BNA.

${ }^{64}$ People's Progressive Party Manifesto Programme \& Policy, June, 1957, CJRC.
} 
After Burnham introduced the proposal, Janet Jagan supported the motion and argued that sugar workers' wages lagged behind other businesses in the colony that were less profitable than sugar production despite the MPCA's collective bargaining efforts. Jai Narine Singh, a former member of the PPP who joined Burnham and Lachmansingh in initiating the PPP split in 1955, introduced a minimum wage bill for sugar workers to address what he considered the MPCA's failure to raise wages to a livable rate to counter the proposed wages council. Singh's proposal suggests that regardless of their disagreement on the efficacy of a wages council Guianese leaders of opposing political viewpoints acknowledged that the MPCA ineffectively served sugar workers despite the union's gains. ${ }^{65}$ Nonetheless, some members of the Executive Council suggested that the MPCA's successful negotiations placed sugar workers in a relatively advantageous position compared to workers in other industries with slightly higher wages but little means of increasing them in the future. ${ }^{66}$

Janet Jagan disagreed, arguing that the MPCA efforts were futile, and that workers only joined the union because of the check-off system, which assured non-union workers would lose their jobs if they opted out of the organization. Moreover, she criticized the tendency to evaluate sugar workers' wages based on hourly rates since most field laborers did not work an eight-hour day year round and much plantation employment was task-work. Jagan also noted that studies suggested sugar workers made less than $80 \%$ of urban workers' weekly wages, less than half of bauxite workers, and that unemployment among sugar workers was higher than in other areas of the economy. ${ }^{67}$ Nonetheless, there was unified hostility to the wages council proposal outside of the PPP even though the bill originated with the PNC. Opposition derived from the notion that

\footnotetext{
${ }^{65}$ British Guiana Executive Council Notes, April 3, 1959, CO 859-1150, BNA.

${ }^{66}$ Extract from the unconfirmed minutes of Executive Council, February 17, 1960, CO 1031-3421, BNA

${ }^{67}$ Extract from the unconfirmed minutes of Executive Council, February 17, 1960, CO 1031-3421, BNA; Janet Jagan, “A May Day Review of New Labor Laws,” Thunder, May 10, 1958, CJRC.
} 
voluntary machinery existed to address wage issues in the sugar industry eliminating the need for a wages council. The BGTUC and SPA collectively opposed the measure and received strong support from Renison and the Guianese Commissioner of Labor James Ramphal. ${ }^{68}$

Janet Jagan, in her capacity as Minister of Labor, solicited the BGTUC's views on the council after Burnham's proposal. Upon receiving word of the BGTUC's vehement opposition and of Renison's and Ramphal's disapproval Jagan allowed the bill to lapse without deliberation. ${ }^{69}$ Nonetheless, the debate over a wages council in the sugar industry did not end with the expiration of Burnham's 1958 proposal. According to Cope, BGTUC leaders were not as unified in their opposition to the council as their report to Jagan suggested. Cope informed the State Department that BGTUC disagreement on the issue of a wages council was so severe that union leadership concluded it was impossible to submit an organizational position and ended the conversation. Tello aggressively opposed the bill during the July meeting and likely submitted the response to Jagan; however, the BGTUC General Secretary left the colony and was not present during the final discussion in August. ${ }^{70}$

The wages council debate continued when Burnham introduced the bill again in $1959 .^{71}$ Tello wrote a letter protesting Jagan's proposed appointments to the wages council on July 13 and followed with an appeal to Renison for a meeting to protest the councils on July $23 .^{72}$ Subsequently Tello wrote to Harry Pollak, Associate Inter-American representative of the AFL-

\footnotetext{
${ }^{68}$ Patrick Renison to Fred Kennedy, Colonial Office, December 2, 1958, CO 859-1150, BNA; Extract from Barbados Employers' Confederation Newsletter, September 30, 1958, CO 859-1150, BNA; Ralph Grey to Ambler Thomas, February 22, 1960, CO 1031-3421, BNA; A. John Cope, Jr. to Department of State, July 15, 1958, 841D.062/7-1558, Central Decimal Files, Box 4814, RG 59, NARA II; A. John Cope to Department of State, August 15, 1958, 841D.062/8-1558, Central Decimal Files, Box 4814, RG 59, NARA II.

${ }^{69}$ Patrick Renison to Fred Kennedy, Colonial Office, December 2, 1958, CO 859-1150, BNA.

${ }^{70}$ A. John Cope to Department of State, August 15, 1958, 841D.062/8-1558, Central Decimal Files, Box 4814, RG 59, NARA II.

${ }^{71}$ Fred Kennedy to Patrick Renison, March 18, 1959; British Guiana Executive Council Notes, April 3, 1959, CO 859-1150, BNA.

${ }^{72}$ Rupert Tello to Janet Jagan, July 13; Rupert Tello to Patrick Renison, July 23, 1959, RG 18-009: International Affairs Department, Staff Files: Serafino Romualdi's Files, 1945-1961, Box 3, Caribbean Area Division of ORIT, 1959, GMMA.
} 
CIO and warned him of Janet Jagan's appointment of H.J.M. Hubbard as Chairman of the proposed wages council. Hubbard, Tello insisted, was "a great believer in the Soviet way of life" and staunch supporter of the PPP. ${ }^{73}$ Moreover, the BGTUC officially informed the government of its general opposition to the appointment of nominated legislators to the wages council in late July. ${ }^{74}$ While records suggest that Janet Jagan and the PPP supported the notion of a wages council, Ralph Grey noted that neither Jagan nor the PPP pushed for the council when legislators resisted and he suggested the party's held a nuanced position on empowering the government to address employer-employee debates. Grey also "wonder[ed] whether there is not something in [Janet Jagan's] story that the wages are not adequate" though he concluded the Legislative Council did not have adequate information to draw such a conclusion. ${ }^{75}$

Meanwhile, colonial officials attempted to use the debate to aid the SPA in countering MPCA demands to increase wages in the sugar industry. Negotiations stalled in June 1959 when the MPCA demanded a $\$ 4$ million increase in sugar workers' pay and the SPA countered with an offer of $\$ 750,000$. Renison warned MPCA leaders through Commissioner of Labor Ramphal that failure to agree to arbitration and compromise would suggest a failure of negotiating machinery and be used as a justification for the PPP's imposition of a wages council. ${ }^{76}$ Renison's use of the wages council debate to pressure the MPCA on behalf of the sugar producers suggests that the nature of the colonial political-economy impeded the effectiveness of trade unions and contributed to the extent of sugar workers' impoverishment. Ironically, the MPCA's inability to

\footnotetext{
${ }^{73}$ Rupert Tello to Harry Pollak, July 24, 1959, RG 18-009: International Affairs Department, Staff Files: Serafino Romualdi’s Files, 1945-1961, Box 3, Caribbean Area Division of ORIT, 1959, GMMA.

${ }^{74}$ British Guiana Government Information Services, Guiana Diary, "T.U.C. Protest Appointment of Legislators to Wages Councils,” July 24-31, 1959, F2384, British Guiana, Guiana Diary, 1957to 1962, TUCLC.

${ }^{75}$ Ralph Grey to Ambler Thomas, February 22, 1960, CO 1031-3421, BNA; Dr. Cheddi Jagan, "Industrial Disputes Tribunal," November 25, 1959, in David Dabydeen and Lynne Macedo, eds., Dr. Cheddi Jagan National Assembly Speeches, Volume 3: The Legislative Council and the Senate: February 1959-July 1961 (Published by the Caribbean Press for the Government of Guyana, 2011), 59.

${ }^{76}$ Patrick Renison to Colonial Office, June 23, 1959, CO 1031-3421, BNA.
} 
negotiate more aggressively left the union open to the charges of weakness that underlie PPP support for the wages councils while the question of wages councils limited the possibility of the MPCA taking a firmer stance against the SPA. Therefore, the institutional framework of labor relations in the colony considerably impeded the MPCA's effectiveness as a bargaining agent for workers.

Thus, Guianese trade union leaders and government officials responsible for labor relations disagreed considerably on the institutional mechanisms that would most effectively address sugar workers' impoverished conditions. Opponents of the wages council, however, framed the debate as an attack on free trade unionism and convinced British and especially American officials that the councils could only be interpreted as a PPP attempt to subvert the colony’s embryonic democratic institutions.

\section{Guianese Appeals for American Funding and Anglo-American Tensions}

Anglo-American rivalry in British Guiana’s institutional decolonization continued in 1958 and Cope warned the State Department of British "anti-American” attitudes when three members of Parliament visited the colony in May 1958. Specifically, the British MPs feared American influence in the trade union movement and allegedly encouraged Guianese unionists to appeal directly to the TUC rather than working with American unionists or regional affiliates of the ICFTU. Cope argued that the TUC offered inadequate assistance and as a result American trade union assistance remained necessary. ${ }^{77}$

Ishmael and Tello increased their efforts to appeal to the AFL-CIO and ICA as American influence expanded in the Guianese trade union movement. Ishmael traveled in the United States and Canada from May through August receiving training on American trade union organization

\footnotetext{
${ }^{77}$ A. John Cope to Department of State, May 27, 1958, 841D.062/5-2758, Central Decimal Files, Box 4814, RG 59,
} NARA II. 
and practices through the ICA. ${ }^{78}$ While he remained in the United States Ishmael was elected vice-president of the BGTUC and he held the position concurrently with his role as president of the MPCA. At the same time, the PPP publically presented a moderated position on trade unionism in the colony. In addressing the BGTUC annual conference on June 29 Janet Jagan argued that trade unions could not exist apart from political life but suggested that the PPP based its views of unionism on the relationship between the British Labor Party and TUC. ${ }^{79}$ Her advocacy of political unionism was consistent with PPP policy since its founding; however, it is noteworthy that she appealed to British unionism to justify the PPP's position rather than reiterating an appeal for labor organization along socialist lines.

The contentious labor issues driving conflict between the PPP and conservative members of the Guianese labor movement contributed to schisms within the BGTUC throughout 1958. In addition to conflicts regarding the wages council debate, Cope noted that some members attempted to repeal the BGTUC's clause barring unions' affiliation to the WFTU or CLC but that the motion was defeated. More significantly, trade unionists disagreed on questions of political affiliation for trade unions. Numerically there was support in the BGTUC for affiliating the union with the PNC, a move which Burnham advocated strongly as a delegate to the BGTUC in the summer of 1958. However, there other members proposed joining the PPP or establishing a Labor Party and union leaders prevented a motion from being passed to propose affiliation to any party on August $10 .^{80}$

\footnotetext{
${ }^{78}$ British Guiana Government Information Services, Guiana Diary, "M.P.C.A. President Back from I.C.A. Course," September 1-7, 1958, F2384, British Guiana, Guiana Diary, 1957 Jan to 1962 Jun, TUCLC; A. John Cope, Jr. to Department of State, May 28 1958, 841D.062/5-2858, Box 4814, RG 59, Central Decimal File, 1955-1959, NARA II.

${ }^{79}$ British Guiana Government Information Services, Guiana Diary, "Minister Speaks on Trade Unions and Politics," June 30-July 3, 1958, F2384, British Guiana, Guiana Diary, 1957to 1962, TUCLC; A. John Cope to Department of State, August 15, 1958, 841D.062/8-1558, Central Decimal Files, Box 4814, RG 59, NARA II.

${ }^{80}$ A. John Cope to Department of State, August 15, 1958, 841D.062/8-1558, Central Decimal Files, Box 4814, RG 59, NARA II.
} 
Cope's appraisal of the PNC's sway in the BGTUC likely overstated the party's influence as evidenced in a report from Carroll Woods, Cope's replacement as American Consul, to the State Department in November. Woods noted that Burnham lost a November 14 bid for reelection for the presidency of the British Guiana Labor Union (BGLU) which also removed him from a position of direct influence in the BGTUC. Samuel Walker, a waterfront worker, won the position as Burnham's replacement. ${ }^{81}$ In addition to illuminating the limits to Burnham's influence in the labor movement, the BGLU election was also significant in that it suggests the union was relatively institutionally sound and independent of powerful political figures and external organizations in late-1958. As an important member of the BGTUC, the democratic nature of the BGLU suggests that some Guianese trade unions were growing in strength and functionality at the grassroots level, even if improvements remained gradual in the late-1950s.

In the midst of internal debates, the BGTUC looked to American trade unions to address an ongoing financial crisis owing to the inability of affiliated unions to provide funds to the congress. Tello and Wendall Bobb of the BGTUC Executive Council attended an international conference of the USW in September 1958 at the American union's invitation. Tello used the conference as an opportunity to request financial assistance from the AFL-CIO through Serafino Romualdi, the AFL-CIO's inter-American representative. At the same time the BGTUC, with Cope's support, appealed to the AFL-CIO to fund a lecture tour of the United States that provided the opportunity to solicit further funding for the organization. ${ }^{82}$

Colonial officials noted Tello's attendance at the conference, his request, and his assurance that he was "anxious not to have the British way of doing things in British Guiana

\footnotetext{
${ }^{81}$ Carroll H. Woods to Department of State, November 19, 1958, 841D.062/11-1958, Central Decimal Files, Box 4814, RG 59, NARA II.

${ }^{82}$ A. John Cope to Department of State, September 12, 1958, British Guiana: U.S. Consulate, Georgetown, Classified General Records, 1940-1963, 1957-1963, 560: Economic Affairs, Box 13, RG 84, NARA II.
} 
distorted by too much American influence. ${ }^{" 83}$ According to A.M. Morgan of the Colonial Office, Tello used the threat of the PPP destroying Guianese trade unions through the wages council to justify his appeal for funding. While Tello expressed appreciation for the TUC's educational efforts and a desire to continue building Guianese unions in the British tradition, he acknowledged that the TUC could not provide the funding the BGTUC required. Importantly, Tello also noted that he could not apply for funding through the ICA, since as a United States government entity an application needed to be submitted through the Minister of Labor, Janet Jagan. Thus, Tello used connections with Romualdi and the Labor Attaché in Washington D. C. to obtain funding for a three-week long "Foreign Leader" tour of the United States. ${ }^{84}$ Tello's increased relations with the United States disturbed colonial officials who voiced their concerns to Renison and Marjorie Nicholson, one of the leading figures in the TUC International Department. ${ }^{85}$ Nonetheless, Tello and the BGTUC grew closer to the AFL-CIO and increasingly networked within the United States while warning American unionists of alleged PPP attempt to destroy free trade unions in British Guiana.

\section{Labor Relations between the PPP and Government Workers}

Trade union conflict outside of the sugar industry increased after the 1957 elections as well and tensions between the PPP and government workers influenced Guianese institutional decolonization as much as any facet of the late-colonial period. The transport workers' strike in November 1957 portended a shift in labor conflict that resulted in disaster for the colony. On November 23 transport workers walked off the job to protest newly imposed working conditions and the attitude of an unpopular marine superintendent. The Transport Workers Union (TWU),

\footnotetext{
${ }^{83}$ A.M. Morgan, Colonial Office to G.C. Wilson, Minister of Labor and National Service, Overseas Department, October 3, 1958; C.C. Gibbs to Marjorie Nicholson, November 19, 1958, CO 859-1150, BNA.

${ }^{84}$ A.M. Morgan, Colonial Office to G.C. Wilson, Minister of Labor and National Service, Overseas Department, October 3, 1958, CO 859-1150, BNA.

${ }^{85}$ C.G. Gibbs to Mr. Scarlett, November 19, 1958, CO 859-1150, BNA.
} 
which Cope referred to as the most financially powerful union in the colony, initiated negotiations with the Transport and Harbor Department to settle workers' grievances. Most importantly, Cope noted that Forbes Burnham, leader of the PNC, rallied to enlarge the strike to embarrass the PPP government which was on record as favoring improved conditions for transport workers. $^{86}$

Burnham's exploitation of the transport workers' strike represents a crucial turning point in British Guiana's institutional decolonization, after which trade unions increasingly struck to undermine governmental authority rather than to negotiate on workers' behalf. Institution building programs between 1954 and August 1957 employed tactics designed to build a structural framework to promoted stability and, to a lesser extent, a functional democracy despite the political objectives that motivated those efforts. Jagan, Burnham, and other Guianese leaders used labor unrest to protest colonial policies as well as wages and working conditions throughout the late 1940s and early 1950s; however, their demonstrations were not aimed at subverting an elected government of their peers. After the transport workers' strike in December 1957 Guianese trade unions gradually became tools of political subversion directed against other Guianese leaders rather than foreign employers or the colonial government.

Moreover, trade union developments exacerbated the racial animus that grew steadily since the PPP split. Increased conflict between Afro-Guianese and Guianese of East Indian descent was partially a consequence of the Burnham and Jagan factions' use of racial political discourse prior to the 1957 elections. However, Walter Rodney, the Guianese historian and political activists assassinated during the Burnham dictatorship, argued in A History of the Guyanese Working People that colonial employment patterns and laws were most significant in

\footnotetext{
${ }^{86}$ A. John Cope, Jr. to Department of State, December 4, 1957, 841D.062/12-457, Box 4814, RG 59, Central Decimal File, 1955-1959, NARA II.
} 
segregating Guianese society. ${ }^{87}$ As a result of colonial employment patters the majority of rural

Guianese, especially field workers in the sugar industry were East Indian while the urban

population and the overwhelming majority of civil servants were Afro-Guianese. After the 1957

elections employment patterns shaped tensions between the PPP government and primarily Afro-

Guianese civil service employees increasing trade union conflict and racial schisms. ${ }^{88}$

In mid-November 1958 government workers struck again for several days in response to

a disagreement with the PPP government over the conclusions drawn by the Whitley Council, an arbitrating body established to examine inequities in government employees' salaries. The PPPaccepted the council's decisions excepting the provision that government workers' pay raises be implemented retroactively to January 1, 1957, which party leaders claimed the government could not afford. The strike ended when the PPP agreed to have the matter adjudicated and adhere to the recommendations of an independent committee. ${ }^{89}$

The Whitley Council was established in 1955 in response to government workers' disaffection with low wages; therefore, ongoing conflict between civil service workers and the

\footnotetext{
${ }^{87}$ Walter Rodney, A History of the Guyanese Working People, 1881-1905 (Baltimore: The Johns Hopkins University Press, 1981), 179-181.

${ }^{88}$ In 1960 Angus MacKintosh of the Colonial Office noted that the since taking office in 1957 the PPP consistently took a firm stance against raising wages for civil servants while aggressively advocating wage increases for sugar workers. See: Angus MacKintosh to Ralph Grey, June 8, 1960, CO 1031-3421, BNA. British officials and sugar companies, as well as the pre-Ishmael MPCA, generally argued that the sugar industry in British Guiana was subsidized and could not afford higher wages while remaining competitive on the world market. MacKintosh's suggestion that the Jagans were able to appreciate fiscal limitations for civil servants while ignoring the same for sugar workers implied that the PPP gave preferential treatment to one class and one race of workers over another. Conversely, the PPP argued that sugar producers could, in fact, afford higher wages and that sugar workers were paid less than civil servants. Two months after the transport workers' strike ended, postal employees went on strike against the government to demand higher wages. See: British Guiana Government Information Services, Guiana Diary, "Post Office Workers Strike," March 6-9, 1958, F2384, British Guiana, Guiana Diary, 1957 Jan to 1962 Jun, TUCLC. Perhaps most importantly, PPP leaders consistently argued that striking against private capitalists was fundamentally different than striking against the people's representatives in government.

${ }^{89}$ Carroll H. Woods to Department of State, November 26, 1958, 841D.062/11-2658, Central Decimal Files, Box 4814, RG 59, NARA II; Carroll H. Woods to Department of State, December 3, 1958, British Guiana: US Consulate, Georgetown, General Records, 1943-1960, Box 50, Records of the Foreign Service Posts of the Department of State, RG 84, NARA II; British Guiana Government Information Services, Guiana Diary, “Appendix to Guiana Diary: Text of a Statement Issued by the Chief Secretary," November 25, 1958, F2384, British Guiana, Guiana Diary, 1957to 1962, TUCLC.
} 
Guianese government predated the PPP's resumption of office in August $1957 .{ }^{90}$ Thus, the PPP inherited a contentious situation that it could not effectively confront. Underlying racial tensions exacerbated and amplified in response to continuing tension between civil servants and the government. Burnham's increasing mobilization of primarily Afro-Guianese civil servants against the PPP and later American-backed urban strikes were therefore an exploitation of an ongoing labor conflict. The CIA began funding anti-PPP movements in British Guiana sometime between 1959 and 1962 through AFL-CIO connections with Guianese public service unions established in the 1950s. ${ }^{91}$ The extent to which CIA and AFL-CIO influence exacerbated conflicts between Afro-Guianese civil servants and the PPP government is unclear. However, it is important to note that the tensions between public servants and the Guianese government were considerable regardless of external meddling and preceded any attempt at covert manipulation while acknowledging that American subversion clearly prolonged and made increasingly violent unrest in the early 1960s. ${ }^{92}$

\section{The MPCA, BGTUC, and International Relations}

Tensions between civil service unions and the government challenged the PPP's influence among government workers, a group already inclined toward support for the PNC. At the same time, the MPCA continued to build on its institutional strength. The check-off system increased the MPCA's membership to just fewer than 26,000 by March 1959, impressing colonial officials who noted the organization's relative strength compared to other colonial trade

\footnotetext{
${ }^{90}$ Ibid; British Guiana Government Information Services, Guiana Diary, “U.K. Barrister to assist FUGE,” January 16-23, 1960, F2384, British Guiana, Guiana Diary, 1957to 1962, TUCLC.

${ }^{91}$ Rabe, U.S. Intervention in British Guiana, 62; Philip Agee, Inside the Company: CIA Diary (New York: Bantam Books, 1975), 415.

92 Janet Jagan, “British Guiana: Our Victory,” Labour Monthly, October 1961, CJRC.
} 
unions. ${ }^{93}$ Meanwhile, MPCA leaders negotiated an increase of one-third for manual sugar workers' pensions with the funds derived from the previous year's sugar profits. ${ }^{94}$

In March 1959 MPCA President and BGTUC Vice President Richard Ishmael, BGTUC General Secretary Rupert Tello, BGTUC President Cecil Cambridge, and BGTUC Executive Council member Wendell Bobb embarked on an international tour that began with participation at an ICFTU conference in Geneva. ${ }^{95}$ Subsequently, the Guianese trade unionists visited the TUC General Council in Great Britain. The BGTUC delegation appealed to senior officials in the Colonial Office for development assistance and a plan to address the colony's substantial unemployment with assistance from the TUC. ${ }^{96}$ The mission is also important in that it provides further evidence that the TUC continued to support political activity for anti-PPP Guianese unions despite rhetoric opposing political activities for colonial labor organizations. Most importantly, the BGTUC mission was the first of its kind received by the Colonial Office, reinforcing the significance the TUC and Colonial Office placed on supporting pro-British Guianese trade unions. ${ }^{97}$ Thus, colonial officials and British labor leaders worked through the BGTUC rather than the PPP despite an official policy of cooperation with the Jagan-led government.

The BGTUC leaders left London for the United States on April 11 where they rendezvoused with Forbes Burnham who had been traveling to several American cities

\footnotetext{
${ }^{93}$ Colonial Office Minute, March 12, 1959, CO 859-1151, BNA.

${ }^{94}$ British Guiana Government Information Services, Guiana Diary, “Sugar Workers’ Pensions Increased by OneThird," March 16-23, 1959, F2384, British Guiana, Guiana Diary, 1957to 1962, TUCLC.

${ }^{95}$ Carroll H. Woods to Department of State, April 8, 1959, 841.00/4-859, General Records of the Department of State, Central Decimal Files, Box 4451, RG 59, NARA II.

${ }^{96}$ Carroll H. Woods to Department of State, April 8, 1959, 841.00/4-859, General Records of the Department of State, Central Decimal Files, Box 4451, RG 59, NARA II; Report of the 91th Annual Trades Union Congress, September 7-11, 1959, 237-238, TUC History Online, 253, http://www.unionhistory.info/britainatwork/emuweb/objects/nofdigi/tuc/imagedisplay.php?irn=6014990\&reftable=e catalogue\&refirn=6014874, Last Accessed July 12, 2015.

${ }^{97}$ Report of the 91th Annual Trades Union Congress, September 7-11, 1959, 237-238, TUC History Online, 253, http://www.unionhistory.info/britainatwork/emuweb/objects/nofdigi/tuc/imagedisplay.php?irn=6014990\&reftable=e catalogue\&refirn=6014874, Last Accessed July 12, 2015.
} 
encouraging private investment in British Guiana and criticizing the PPP government as communist and anti-democratic. The BGTUC delegation joined Burnham's request for private investment and appealed for funds to support their labor activities. Woods warned the State Department that the meeting of Guianese delegations in Washington D.C. provided "further evidence of the very thin line between the PNC and the assertedly [sic] non-political" BGTUC. ${ }^{98}$ Connections to American labor offset the cost of Guianese labor leaders' campaigning. The USW covered part of the BGTUC leaders' expenses in traveling to the United States and Romualdi assisted Tello in procuring further funding from the AFL-CIO for lodging in Washington D.C. ${ }^{99}$

Several State Department officials organized a meeting with Tello, Bobb, and AFL-CIO representatives at the American union's request on April 14. The memorandum of conversation from the meeting notes that the AFL-CIO was "squiring" the "British Guiana Trade Unionists around the U.S." The conversation appears to have been short and centered on political issues, such as Tello's fear of political parties infiltrating Guianese unions. Interestingly, despite his opposition to the PPP Tello encouraged the State Department officials to extend assistance to Cheddi Jagan when he visited the United States later in the year. Tello noted his disagreement with Jagan's political orientation but emphasized that Guiana needed assistance to confront poverty and deprivation and he suggested that the PPP would benefit more from continued economic strife than from economic improvements. ${ }^{100}$ After the meeting at the State Department, Ishmael, Tello, Cambridge, and Bobb made a final stop in Canada to visit Canadian trade

\footnotetext{
${ }^{98}$ Carroll H. Woods to Department of State, April 8, 1959, 841.00/4-859, General Records of the Department of State, Central Decimal Files, Box 4451, RG 59, NARA II.

${ }^{99}$ Rupert Tello to Harry Pollak, March 19, 1959; Serafino Romualdi to Rupert Tello, March 26, 1959, RG 18-009: International Affairs Department, Staff Files: Serafino Romualdi’s Files, 1945-1961, Box 3, Caribbean Area Division of ORIT, 1959, GMMA.

${ }^{100}$ Memorandum of Conversation, April 14, 1959, 841D.062/4-1459, Central Decimal Files, Box 4814, RG 59, NARA II.
} 
unionists prior to their return to British Guiana where ORIT was opening a week-long training seminar in Georgetown. ${ }^{101}$

In addition to AFL-CIO and USW assistance, contributions from leading businesses including Booker Brothers and Demerara Bauxite eased the financial burden of sending the four men on a trip to Europe and the United States for over a month. ${ }^{102}$ The cost left to the BGTUC is unclear; however, the assistance of British employers and American trade unionists suggests a continuing effort on the part of non-governmental Anglo-American organizations to integrate the Guianese labor movement into the Western capitalist system. The BGTUC's and MPCA's increased appeals for American funding and dedication to traveling internationally after the 1957 election suggests that anti-PPP trade union leaders did not expect to be able to defeat PPPsupported labor activists at the grassroots level.

Ironically, the reformist labor movement's increasing appeals for outside funding conflicted with Tello's and Ishmael's previous warnings that external financing of Guianese unions would prove counterproductive and the extent of international travel undermined the local involvement that initially gained Ishmael supporters on the sugar plantations. ${ }^{103}$ In 1953 Ishmael's opponents begrudgingly acknowledged that he tirelessly traveled around the colony to sugar plantations; however, by the late 1950s British officials consistently criticized his failure to

\footnotetext{
${ }^{101}$ John A. Ballew, Labor Attaché, U.S. Embassy, Ottawa to Department of State, April 13, 1959, 841D.062/4-1359, Central Decimal Files, Box 4814, RG 59, NARA II; ORIT Office, Mexico City to William F. Schnitzler, AFL-CIO alternate member of ORIT Executive Committee, October 28, 1959, RG1-027, Office of the President, George Meany's Files, 1944-1960, Box 49, Subjects: ORIT: Executive Committee, 1955-1960, GMMA.

${ }^{102}$ Carroll H. Woods to Department of State, May 26, 1959, British Guiana: U.S. Consulate, Georgetown, Classified General Records, 1940-1963, 1957-1963, 560: Economic Affairs, Box 13, RG 84, NARA II.

${ }^{103}$ Minutes of the 5th Meeting of the Administrative Committee of CADORIT, April 20-21, 1956, RG 18-009: International Affairs Department, Staff Files: Serafino Romualdi's Files, 1945-1961, Box 1, Caribbean Area, 1953 1956, GMMA; Robert Alexander interview with Richard Ishmael, June 27, 1954, RG 18-003, International Affairs Department, Jay Lovestone Files, 1944-1973, Box 2, Alexander, Robert, 1954, GMMA.
} 
travel outside of Georgetown while he was in British Guiana. ${ }^{104}$ Moreover, despite the BGTUC's considerable efforts at international diplomacy in mid-1959, including sponsoring several ORIT visits to the colony, the union inconsistently participated in Guianese workers' aggressive efforts to unionize. ${ }^{105}$ In the midst of labor disputes in British Guiana, for example, Tello was named CADORIT's representative to the International Plantation Workers' Confederation. ${ }^{106}$ Tello led a six-man Guianese delegation that included Ishmael to the conference in Barbados on September 17 while strikes in the colony persisted. ${ }^{107}$

\section{Industrial Labor Unrest and Workers Protests in from 1959-1960}

Guianese workers' aggressive attempts to unionize and improve wages and conditions continued while Guianese leaders internationalized the debate over the nature of post-colonial trade unionism. On July 15 workers at Matthew's Ridge walked off in protest against the African Manganese Company's low wages, poor living facilities, and failure to recognize the BGMWU as miners' bargaining agent. Substantial unrest resulted in a call for the riot squad to quell hostilities after an attempt to dynamite the main building. The strike led to negotiations aimed at addressing workers' grievances and at the urging of the Department of Labor the initiation of discussions for recognition of the BGMWU on the estate. ${ }^{108}$ The Motor Transport Workers and Municipal Employees Union also negotiated wage increases in late $1959 .{ }^{109}$ While the unrest at

\footnotetext{
${ }^{104}$ Robert Alexander interview with Jane Phillips-Gay, Secretary of GIWU, June 29, 1954, RG 18-003, International Affairs Department, Jay Lovestone Files, 1944-1973, Box 2, Alexander, Robert, 1954, GMMA.

${ }^{105}$ For a description of various ORIT visits in the first half of 1959, see: ORIT, "General Secretary's Report to Conference,” August 1959, RG1-027, Office of the President, George Meany’s Files, 1944-1960, Box 49, Subjects: ORIT: Executive Committee, 1955-1960, GMMA.

106 ORIT, “General Secretary's Report to Conference,” August 1959, RG1-027, Office of the President, George Meany’s Files, 1944-1960, Box 49, Subjects: ORIT: Executive Committee, 1955-1960, GMMA.

${ }^{107}$ British Guiana Government Information Services, Guiana Diary, "Delegation to Plantation Workers' Talks," September 16-23, 1959, F2384, British Guiana, Guiana Diary, 1957to 1962, TUCLC.

${ }^{108}$ Carroll H. Woods to Department of State, July 27, 1959, British Guiana: U.S. Consulate, Georgetown, Classified General Records, 1940-1963, 1957-1963, 560: Economic Affairs, Box 13, RG 84, NARA II.

${ }^{109}$ British Guiana Government Information Services, Guiana Diary, "Motor Transport Workers Granted Wage Increase, October 1-15, 1959; "Municipal Employees Strike," November 23-30, 1959, F2384, British Guiana, Guiana Diary, 1957to 1962, TUCLC.
} 
Matthew's Ridge calmed, tension continued between civil service employees and the PPP government. Clerks picketed the Public Works Department on September 17 protesting delays in wage increases. ${ }^{110}$ On September 20 the TWU passed a resolution requiring its Executive to work with the Federation of Unions of Government Employees (FUGE) to demand a four-dollara-day minimum wage for all government employees retroactive to January $1 .{ }^{111}$ In response, Cheddi Jagan announced a proposal on September 22 to increase minimum wages while refusing immediate pay increases and abolishing leave passes for some categories of civil servants. ${ }^{112}$

Meanwhile, the MPCA continued negotiating precedent-setting agreements with the SPA. Ishmael, Ramphal, and representatives from Booker Brothers and Demba agreed to the introduction of an eight-hour workday with minimum wages for field workers on September 17, along with cost-of-living increases retroactive to January 1, 1959, and the introduction of a pension scheme that would begin on January $1,1960 .{ }^{113}$ Nonetheless, MPCA gains came with an important consequence, namely that the union accepted the "stabilization of the labor force." The SPA policy created a smaller labor force of regular workers who enjoyed negotiated benefits while leaving significant numbers of sugar workers with diminishing amounts of casual employment and no protection under MPCA-SPA agreements. ${ }^{114}$ The reduction of employment opportunities on sugar estates coincided with a general labor crisis resulting from increases in population that far surpassed new employment opportunities. The colony's rising population

\footnotetext{
${ }^{110}$ British Guiana Government Information Services, Guiana Diary, "P.W. D. Workers protest Salaries increase delay," September 16-23, 1958, F2384, British Guiana, Guiana Diary, 1957to 1962, TUCLC.

${ }^{111}$ British Guiana Government Information Services, Guiana Diary, "T.W.U. demand four dollar a day minimum wage," September 16-23, 1958, F2384, British Guiana, Guiana Diary, 1957to 1962, TUCLC.

112 British Guiana Government Information Services, Guiana Diary, "New Proposals for Civil Servants," September 16-23, 1958, F2384, British Guiana, Guiana Diary, 1957to 1962, TUCLC. Support for minimum wage laws was consistent with PPP campaign positions. See: People's Progressive Party Manifesto Programme \& Policy, June, 1957, CJRC.

${ }^{113}$ British Guiana Government Information Services, Guiana Diary, "Improved conditions for Sugar Workers," September 16-23, 1959, F2384, British Guiana, Guiana Diary, 1957to 1962, TUCLC.

114 "Note on the Relations of the People's Progressive Party with Trade Unions in the Sugar Industry," undated (1959), CO 1031-3421, BNA; Angus MacKintosh to Ralph Grey, June 8, 1960, CO 1031-3421, BNA.
} 
represented an ongoing problem. Political scientist Matthew Lange notes, for example, that British Guiana's labor force increased by 100,000 while jobs increased by 10,000 between 1946 and $1960 .^{115}$

The BGTUC's acceptance of British employers' funding also contributed to a split in the BGTUC in May. Andrew Jackson, a PNC representative in the Legislative Council and head of the Post Office Workers Union and FUGE, cited the acceptance of employers' funds as part of the reason for the withdrawal of the unions he led from the BGTUC. Carroll Woods suggested in his report to the State Department that Jackson's personal feud with the Postmaster General also contributed to his decision. ${ }^{116}$ Nonetheless, anti-PPP unions relied increasingly on external financing as British Guiana moved closer to self-government. AFL-CIO funding and diplomacy increased Tello's and the BGTUC's profile in the United States while the ICFTU agreed to begin an ongoing program of assistance through the International Solidarity Fund (ISF) to assist BGTUC organizing in July $1959 .{ }^{117}$

Ongoing conflict between civil service workers and the PPP government superseded tensions between Jackson and the BGTUC. The BGTUC intervened on FUGE's behalf when 10,000 government workers struck again on December 2, 1959 after negotiations with the government broke down. Workers returned to work on December 17 having accepted the government's terms on the condition that the issue would be submitted to the Whitley Council.

\footnotetext{
${ }^{115}$ Matthew Lange, Lineages of Despotism and Development: British Colonialism and State Power (Chicago: The University of Chicago Press, 2009), 7-8, 117.

${ }^{116}$ Carroll H. Woods to Department of State, May 26, 1959, British Guiana: U.S. Consulate, Georgetown, Classified General Records, 1940-1963, 1957-1963, 560: Economic Affairs, Box 13, RG 84, NARA II.

${ }^{117}$ Report of the 91th Annual Trades Union Congress, September 7-11, 1959, 237-238, TUC History Online, $205-$ 206 ,

http://www.unionhistory.info/britainatwork/emuweb/objects/nofdigi/tuc/imagedisplay.php?irn=6014990\&reftable=e catalogue\&refirn=6014874, Last Accessed July 12, 2015; Report of the 94th Annual Trades Union Congress, September 3-7, 1962, 237-238, TUC History Online, 220, http://www.unionhistory.info/britainatwork/emuweb/objects/nofdigi/tuc/imagedisplay.php?irn=6015826\& reftable=e catalogue\&refirn=6015708, Last Accessed July 12, 2015.
} 
At the request of the BGTUC, the TUC sent Lawrence Sapper, a full-time trade union official in London, to assist FUGE in their negotiations in January. ${ }^{118}$ Sapper spent two weeks advising the civil service unions and helping prepare their case which centered on pay anomalies and protested conditions of service. ${ }^{119}$ Even as Sapper advised Guianese labor leaders some members of the TUC suggested that British trade union involvement needed to be reduced as decolonization progressed. Walter Hood, head of the colonial section of the TUC's International Department, argued in a meeting with the OEF and Colonial Office that British trade unions could only intervene in colonial affairs at the invitation of colonial unions as British territories approached independence. Colonial officials meeting with Hood in 1960 requested British trade unionists' increased participation in institution-building and suggested that the TUC's involvement in colonial affairs remained stagnant since mid-1957. Hood countered the reproach and argued that the OEF was the only party in the talks that would retain direct influence in colonies after independence and therefore should be most involved in the decolonization. ${ }^{120}$ British and American cooperation in supporting reformist, anti-PPP trade unionists continued in March 1960 as the British government discussed a return to full internal selfgovernment in British Guiana the following August. ${ }^{121}$ British diplomats, ICA workers, and American trade unionists developed plans to send roughly half a dozen Guianese trade unionists to Puerto Rico and the United States for intensive training to follow-up on a seminar given in Georgetown. Plans also called for sending either a British or American unionist to British Guiana for a year to assist the anti-PPP unions that were expected to be "the only effective opposition to

\footnotetext{
${ }^{118}$ British Guiana Government Information Services, Guiana Diary, “U.K. Barrister to Assist FUGE," January 1623, 1960, F2384, British Guiana, Guiana Diary, 1957to 1962, TUCLC.

${ }^{119}$ Report of the 92th Annual Trades Union Congress, September 5-9, 1960, 237-238, TUC History Online, 228, http://www.unionhistory.info/britainatwork/emuweb/objects/nofdigi/tuc/imagedisplay.php?irn=6015267\&reftable=e catalogue\&refirn=6015150, Last Accessed July 12, 2015.

120 "Note of discussion with T.U.C. and O.E.F. Officials on $17^{\text {th }}$ December," December 17, 1959; Colonial Office Minute, January 13, 1960, CO 1031-2952, BNA.

${ }^{121}$ Memorandum by the Minister of State for Colonial Affairs, March 28, 1960, CAB 129/101, BNA.
} 
the pro-Communist line" of the PPP. ${ }^{122}$ Robert Buchanan, the Canadian Executive Secretary of the International Journalists and Writers' Union, traveled to British Guiana on behalf of the AFL-CIO in May and presented the BGTUC with a $\$ 4,500$ station wagon as a gift from ORIT. ${ }^{123}$ The TUC assisted Oxford University and Ruskin College in holding a series of week-long summer schools for colonial unionists, including from British Guiana, during July and early August. ${ }^{124}$

Guianese labor leaders also made changes in anticipation of the following year's election. In May the TWU passed a resolution overturning a forty-year-old rule and allowing the union's executive members to simultaneously hold positions in political parties for the first time. ${ }^{125} \mathrm{On}$ June 25 Woods opened the BGTUC annual conference with a speech discussing the ICA's considerable efforts to build the Guianese labor movement. His speech expanded into an explanation of the "neighborly" motives that shaped American policy toward the Caribbean appealing to Guianese workers to increase their connections to the United States. ${ }^{126}$ In June Richard Ishmael won re-election as President of the BGTUC and Tello retained his position as General Secretary though Colonial Office reports suggest that Tello's influence declined beginning in $1959 .{ }^{127}$ Additionally, the BGTUC passed a resolution permitting the Executive

\footnotetext{
${ }^{122}$ Department of State Memorandum of Conversation, “Assistance to British Guiana Trade Unions," March 7, 1960, British Guiana: U.S. Consulate, Georgetown, Classified General Records, 1940-1963, 1957-1963, 560: Economic Affairs, Box 13, RG 84, NARA II.

${ }^{123}$ British Guiana Government Information Services, Guiana Diary, “Canadian Trade Unionist's Visit,” May 16-23, 1960, F2384, British Guiana, Guiana Diary, 1957to 1962, TUCLC.

${ }^{124}$ Report of the 92th Annual Trades Union Congress, September 5-9, 1960, 237-238, TUC History Online, 165, http://www.unionhistory.info/britainatwork/emuweb/objects/nofdigi/tuc/imagedisplay.php?irn=6015267\&reftable=e catalogue\&refirn=6015150, Last Accessed July 12, 2015.

${ }^{125}$ British Guiana Government Information Services, Guiana Diary, "Trade Unionists May now Engage in Politics," May 24-June 7, 1960, F2384, British Guiana, Guiana Diary, 1957to 1962, TUCLC.

${ }^{126}$ British Guiana Government Information Services, Guiana Diary, “US Consul Opens TUC Conference,” June 2430, 1960, F2384, British Guiana, Guiana Diary, 1957to 1962, TUCLC.

${ }^{127}$ British Guiana Government Information Services, Guiana Diary, "TUC Elections," June 24-30, 1960, F2384, British Guiana, Guiana Diary, 1957to 1962, TUCLC; Angus MacKintosh to Ralph Grey, June 8, 1960, CO 10313421, BNA. Ralph Grey suggested that Tello was never quite as significant locally as the TUC or Colonial Office assumed in response to a Colonial Office inquiry regarding Tello. Specifically, Grey suggested that Ishmael was "of
} 
Council to take whatever stand it deemed advisable to procure a national minimum wage of four dollars per day, a rate that the PPP government previously rejected. ${ }^{128}$ Ishmael and Tello led the union on a picket line in protest against Kirpalini Brothers in November as a result of the firm's failure to respect prescribed minimum wages again seeking to gain support from rank-and-file workers. ${ }^{129}$

Guianese connections with international labor expanded when Ishmael and Tello received appointments to the Executive Committee of the Caribbean Congress of Labor (CCL), which replaced CADORIT as the regional arm of Western international labor on September 25, 1960. ${ }^{130}$ In October the TUC General Council sent a representative to assist the MPCA in its negotiations with the SPA. The negotiations resulted in a wage increase, severance pay, and a pension scheme for sugar workers. Moreover, the agreement established a minimum wage rate for sugar workers that exceeded the rate for unskilled government employees for the first time. ${ }^{131}$ The compromise built on important precedents in the sugar industry's labor relations and was possible in part as a result of British Guiana's record sugar production in $1960 .{ }^{132}$ The PPP-led government, however, deemed the pension scheme unacceptable and blocked its introduction in

much more consequence" than Tello by mid-1960. Nonetheless, Grey praised Tello's contributions to the Guianese trade union movement. See: Ralph Grey to Angus MacKintosh, July 5, 1960, CO 1031-3421, BNA. Regardless of the likelihood that Tello's stature was inflated internationally relative to his local importance, this dissertation shows that his influence with British and especially American trade union leaders and political officials is understated in the scholarship. Ultimately, Tello's international connections allowed him to exert considerable influence in Guianese trade union and political debates.

${ }^{128}$ British Guiana Government Information Services, Guiana Diary, “\$4 Minimum Wage Sought,” June 24-30, 1960, F2384, British Guiana, Guiana Diary, 1957to 1962, TUCLC.

${ }^{129}$ British Guiana Government Information Services, Guiana Diary, “T.U.C. Pickets Firm on Minimum Wage Count," November 21-27, 1960, F2384, British Guiana, Guiana Diary, 1957to 1962, TUCLC.

${ }^{130}$ Serafino Romualdi to Dan Benedict, Director of Education, ORIT, September 26, 1960, RG 18-001, International Affairs Department, Country Files, 1945-1971, Box 17, British Guiana, GMMA.

${ }^{131}$ Report of the 93th Annual Trades Union Congress, September 4-8, 1961, 237-238, TUC History Online, 229, http://www.unionhistory.info/britainatwork/emuweb/objects/nofdigi/tuc/imagedisplay.php?irn=6015548\&reftable=e catalogue\&refirn=6015431, Last Accessed July 12, 2015.

${ }^{132}$ In 1960334,441 tons of sugar was produced in British Guiana as compared to 306,361 tons in 1959 and 195,651 tons in 1950. See: British Guiana Government Information Services, Guiana Diary, "Record Sugar Production in 1960," December 19-31, 1960, F2384, British Guiana, Guiana Diary, 1957to 1962, TUCLC. See also: "The Booker Group Review of the Year 1961," HC 157A-B55: Falkland Islands + Various Countries, Economic Conditions, TUCLC. 
July $1961 .^{133}$ Thus, the MPCA's internationalization increased its bargaining power and institutional position despite the tenuous support of Guianese sugar workers and the direct opposition of the workers-supported PPP.

\section{Conclusion}

The Guianese labor movement was inherently political since its founding and AngloAmerican labor leaders' support for Guianese trade unions exacerbated the tendency toward using trade unions for political objectives. Institution-building efforts between 1954 and 1957 were designed to achieve political objectives through the establishment of a functionally sound trade union movement; however, when the project failed to achieve its objective the labor movement became increasingly corrupted and utilized to directly attack the elected PPP government. Thus, institution-building efforts worsened the inherent weakness in the Guianese trade unions. In turn, the politicization of labor organization that was an important aspect of British and American labor leaders' criticism of the PPP became more predominant.

Moreover, because of its anti-PPP nature, the institution-building program lessened the possibility of true nation building through diplomacy and compromise between Guianese of differing views. It is possible that no compromise would have been reached regardless since there is evidence that the PPP received funding from the Eastern bloc, which likely inhibited their willingness to strike agreements as well. ${ }^{134}$ Nonetheless, the PPP accurately interpreted external involvement in the trade union movement as part of a program to destroy their party. ${ }^{135}$

\footnotetext{
133 “The Booker Group Review of the Year 1961," HC 157A-BSS: Economic Conditions, Falkland Islands and Various Countries, TUCLC. The PPP noted in its campaign manifesto that a pension scheme in the sugar industry was “absolutely necessary.” See: People's Progressive Party Manifesto Programme \& Policy, June, 1957, CJRC. ${ }^{134}$ Two important PPP leaders during the period suggested in interviews with Frank Birbalsingh that Russian funds partially supported the PPP at least by 1957. See: Birbalsingh, The People's Progressive Party of Guyana 19501992, 115, 124.

${ }^{135}$ History of the PPP, January 1963, CJRC.
} 
Anglo-American support for anti-democratic trade union practices to keep PPP leaders out of the MPCA reinforced PPP suspicions and further undermined the possibility of compromise between Guianese leaders. British and American officials and trade union leaders explained their ideological compromise as necessary to establish the representative institutions they argued were ideal and necessary to achieve long-term Anglo-American objectives, most importantly the establishment of liberal-capitalist, democratic post-colonial societies. As a result, the Guianese labor movement remained institutionally dysfunctional and anti-democratic, while inconsistently representing Guianese workers. Moreover, the movement was highly internationalized. British, American, and possibly Eastern-bloc imperatives shaped the internal debates between Guianese over how to design post-colonial society. Since the colony was institutionally dysfunctional, conflict was nearly assured when the British government agreed to return full internal self-government and external trade autonomy to British Guiana in August $1961 .^{136}$

At the same time, TUC involvement in the colony decreased between 1957 and 1961 leading British some officials to lament the lack of British trade union involvement and growing American influence in the Caribbean. While colonial officials expressed understanding that the United States would play a larger role in the region as colonies became independent they encouraged the TUC to take an active interest in protecting British commercial influence after independence. ${ }^{137}$ Nonetheless, some colonial officials argued that institution-building efforts

\footnotetext{
${ }^{136}$ Memorandum by the Minister of State for Colonial Affairs, March 28, 1960, CAB 129/101, BNA.

${ }^{137}$ Gordon G. Booth, United Kingdom Trade Commissioner to Cyril Drucker, United Kingdom Board of Trade, August 2, 1961; D.E.F. Carter, Colonial Office to G.G. Gibbs, Colonial Office, August 10, 1961, CO 1031-2952, BNA.
} 
proved a success and that the primary issue facing Caribbean trade unions was maintaining newly established standards. ${ }^{138}$

The TUC's reasons for retreat were threefold. First, British labor leaders prioritized the ICFTU's long-term viability and cooperation with the OEC in colonial areas undermined the organization's claim to support workers in the international labor body. Second, the TUC, like the British Empire, was financially weakened after World War II and labor leaders' argued that cutting colonial programs was a practical necessity. Finally, TUC leaders noted that the advancement of self-government inherently demanded decreased TUC involvement in colonial areas. Nonetheless, the OEF and Colonial Office consistently expressed hope that the TUC would continue to play an important role in the colonies instead of delegating an increased role to the ICFTU. British policymakers and businesses appeals suggest that they expected decolonization to establish political independence but preserve traditional pro-British capitalism in the region. ${ }^{139}$ Moreover, the TUC's withdrawal hinted that the American expansion of influence continued to erode British power prior to the West Indian colonies independence. ${ }^{140}$ Ultimately, the TUC's diminished colonial influence suggested that American labor's tactical objectives increasingly determined the nature of external involvement in Guianese institution building during the last phase of decolonization.

Thus, the structure and racial composition of Guianese socio-economics, British and American support for anti-democratic pro-Western unions, and the PPP's efforts to incorporate trade unions into a social revolution combined to create an inescapable conflict. This conflict, between the PPP and anti-PPP trade union movement, proved crucially important when full

\footnotetext{
${ }^{138} \mathrm{Mr}$. Parry and L.T. Stapleton, Colonial Office Minute, April 1, 1959, CO 859/1118, BNA.

${ }^{139}$ CO1031/2952; J.S. Bennett, Colonial Office Minute, August 1959, CO 859/1118, BNA; Note of Discussion with TUC and OEF Officials, December 17, 1959, CO 859/1118, BNA.

${ }^{140}$ For more on the expansion of United States influence in the Caribbean in the 1950s, see: Parker, Brother's Keeper.
} 
internal self-government was established as a precursor to independence in $1961 .{ }^{141}$ Because of the AFL-CIO's assumption of the primary role among external trade unions between 1957 and 1961, reformist, anti-PPP trade union leaders turned to American unionists more so than the TUC when unrest broke out in 1962 and 1963. The AFL-CIO and CIA used the unrest and American labor leaders' connections to exacerbate conflicts and destabilize the PPP government, and objective that dovetailed with the aims of some elements in the anti-PPP labor. Despite TUC efforts to stabilize the government and compartmentalize labor struggles apart from politics, diplomatic efforts at the highest levels of the American and British governments agreed to remove the PPP through electoral changes.

Most importantly, the actions of Guianese trade unionists after 1957 proved most significant in fueling the colony's unrest after 1961. The MPCA increasingly had difficulty balancing its role as an organization representing Guianese workers and its opposition to the PPP, though the union continued to obtain important concessions for sugar workers. At the same time predominantly Afro-Guianese urban unions mobilized politically against the PPP largely as a consequence of ongoing disagreements over civil servants' wages. Politicians and external actors manipulated the racial aspects of urban opposition to the PPP; however, it is critical to acknowledge that the labor issues underlying resentment originated organically. Each of the participants in labor unrest increasingly looked to the outside for assistance, as did the PPP after 1961, continuing the internationalization of Guianese decolonization.

\footnotetext{
${ }^{141}$ Cheddi Jagan explained in 1960 that the PPP policy would be to treat trade unions as "subsidiary agencies of a democratic character" working under the government that would help manage industries in addition to arguing with employers. British Guiana Government Information Services, Guiana Diary, "Dr. Jagan Explains PPP Policy to T.U.C., November 7-13, 1960, F2384, British Guiana, Guiana Diary, 1957to 1962, TUCLC. Jagan articulated a similar concept in a 1976 address wherein he explained the role of trade unions and democratic centralism in support of scientific socialism. It cannot be assumed that Jagan held identical views twenty years earlier; however, the general ideas articulated in his 1976 address are consistent with his earlier writings and the role he proscribed for trade unions is consistent with PPP relations with organized labor between 1950 and 1965. See: "Trade Unions and National Liberation," An address by Dr. Cheddi Jagan to the Second Triennial National Convention of the National Union of Government \& Federated Workers, October 15, 1976, CJRC.
} 


\section{Conclusion}

“'Time was not in [sic] our side.' The tide of events was moving rapidly, and might well not allow scope for the organizations and structures which we wished to see develop in Colonial societies to grow up by the slow and sure process of natural evolution and 'learning by experience." Minutes of a confidential conference of heads of labor departments, Colonial Office, October 5, 1951. ${ }^{1}$

\section{Institutional Warfare and American Intervention}

Ultimately, British Guiana’s political dysfunction beginning in 1962 directly resulted from the colony's failure to establish an institutionally functional system of labor relations during the late colonial period. Internal labor conflicts began in 1946 between social revolutionary labor leaders and reformists as well as between the revolutionaries and colonial officials. The trade union conflict became internationalized throughout the 1950s, was complicated as a result of racially divided employment demographics after 1957, and exploded in $1962 .^{2}$ Social breakdown resulted from 150 years of colonial labor relationships that segregated society and contributed to endemic racial tensions, local ideological disagreements that motived perpetual struggle between Guianese, and American intervention that aimed at exploiting the situation to remove the People's Progressive Party (PPP). ${ }^{3}$

Between 1962 and 1964 internationalized efforts to shape the colony's post-colonial labor relations devolved into political violence. Between 1946 and the late 1950s British officials

\footnotetext{
${ }^{1}$ Minutes from meeting of Conference of heads of Labor Departments, October 5, 1951, Trade Unions and Colonies 932.5, Box 15, Marjorie Nicholson Files, Trades Union Congress Library Collection, London Metropolitan University, London, United Kingdom (Hereafter TUCLC).

${ }^{2}$ James Ramphal, British Guiana Labor Commissioner, "Present and Future Outlook of the Trade Union Movement," June 1954, CO 859-773, BNA.

${ }^{3}$ Labor unrest led to even more destruction in 1964; however, as Robert Anthony Waters and Gordon Oliver Daniels show, the PPP played a more significant role in the latter strike despite Cheddi Jagan's attempts to quell the violence. Waters and Daniels also point out the important support the PPP received from Cuba in 1964. See: Robert Anthony Waters, Jr. and Gordon Oliver Daniels, "Striking for Freedom? International Intervention and the Guianese Sugar Workers' Strike of 1964," Cold War History, Vol. 10, No. 4, (November 2010): 537-569. There is some evidence that PPP-Cuban relations were cultivated immediately after the Castro-led revolution removed Fulgencia Batista in 1959. See: "Interview by Cuban journalist Ernesto Nunez Jimenz to the late President Cheddi Jagan," February 1997, Cheddi Jagan Research Center (Hereafter CJRC).
} 
and trade unionists worked to establish capitalist-democratic institutions in British Guiana that were integrated into an Anglo-led system. The Trades Union Congress's (TUC) retreat in the colony in 1957 signified the beginning of a shift toward increased American influence over colonial developments. ${ }^{4}$ As a result, American labor leaders' wielded substantial influence in the colony when the PPP won elections to determine the government expected to lead the colony to independence in early 1962. At the same time, the Kennedy administration exerted increasing influence over British policy in Guiana and pressured Prime Minister Harold Macmillan to delay the colony's exit from the empire. ${ }^{5}$

The British-led attempt at guiding Guiana toward self-government resulted in a quandary when economic and political institutions conflicted. Guianese trade unions, particularly the Manpower Citizens' Association (MPCA), won benefits for workers and set important legislative and collective bargaining precedents between 1954 and 1961. At the same time, mechanization and stabilization of the workforce in the sugar industry led to record profits and the Guianese experienced one of the most prosperous years in the colony's history in $1961 .^{6}$ Nonetheless, industrial changes displaced many East Indian sugar workers and poor weather the following

\footnotetext{
${ }^{4}$ The transition to an American-led international system had begun earlier and some British officials continued to express reluctance even after 1961. Nonetheless, in British Guiana colonial officials and British policymakers expressed regrettable acquiescence to the American leading role after 1960. Randall Bennett Woods, A Changing of the Guard: Anglo-American Relations, 1941-1946 (Chapel Hill: The University of North Carolina Press, 1990); Cary Fraser, Ambivalent Anti-Colonialism: The United States and the Genesis of West Indian Independence, 19401964 (Westport, CT: Greenwood Press, 1994); Cary Fraser, "The 'New Frontier' of Empire in the Caribbean: The Transfer of Power in British Guiana, 1961-1964," The International History Review, Vol. XXII, September 3, 2000, pp. 583-610.

${ }^{5}$ Memorandum of Conversation at Birch Grove, England, June 30, 1963, Document 295, Vol. 12, 1961-63, Foreign Relations of the United States (Hereafter FRUS); Stephen G. Rabe, U.S. Intervention in British Guiana: A Cold War Story (Chapel Hill: The University of North Carolina Press, 2005), 116-118.

${ }^{6}$ Stephen Rabe suggests that Cheddi Jagan's economic policies between 1957 and 1961 paved the way for economic growth. Conversely, Clem Seecharan attributes economic improvement to agreements between sugar producers and the MPCA that increased production. See: Clem Seecharan, Sweetening 'Bitter Sugar': Jock Campbell the Booker Reformer in British Guiana 1934-1966 (Miami: Ian Randle Publishers, 2005), 449-456; Rabe, U.S. Intervention in British Guiana, 76. See also: Robert Anthony Waters, Jr. and Gordon Oliver Daniels, "Striking for Freedom? International Intervention and the Guianese Sugar Workers' Strike of 1964," Cold War History, Vol. 10, No. 4, (November 2010): 541.
} 
year undermined sugar productivity. ${ }^{7}$ Moreover, improvements for the primarily Afro-Guianese urban laborers did not keep pace with advances on the sugar estates. The economic situation reinforced the racialized political rhetoric Guianese politicians increasingly employed after the PPP split in 1955. The predominantly East Indian sugar workers attributed economic improvement to PPP policies while remaining receptive to the party's appeal for more radical change to offset the consequences of increasing productivity for displaced workers. Conversely, most Afro-Guianese interpreted economic developments as evidence of PPP favoritism for East Indians.

Racial strife played a major role in political debates in 1961 and ethnicity determined voting patterns far more than any other factor. When the polls closed on August 21 the vast majority of East Indians had voted for the PPP and the majority of Afro-Guianese for the Forbes Burnham-led People's National Congress (PNC). ${ }^{8}$ Importantly, some sugar workers continued to support the reformist MPCA while casting ballots for the social revolutionary PPP. ${ }^{9}$ In addition to racialized politics, however, the vast majority of East Indians had no economic motives to shift party loyalties. Burnham's PNC articulated a political ideology similar to the PPP's expressed views but specifically appealed to an Afro-Guianese constituency. The only other party of note, the Peter D'Aguiar-led United Force (UF), remained a relatively minor party whose conservative capitalist positions did not appeal to generate support among the colony's

\footnotetext{
7 "Booker Group Review of the Year, 1961," Published by Booker Brothers, McConnell \& Co. Limited, Economic Conditions, Falkland Island and Various Countries, HC 157A-B55, TUCLC. The Booker Group Review of the Year, 1961 offers a detailed analysis of Guiana's sugar industry and political environment that extends from 1960 through 1962 with projections to 1964. It is unclear why the review has "1961" in its title.

${ }^{8}$ Leo A. Despres, Cultural Pluralism and Nationalist Politics in British Guiana, (Chicago: Rand McNally and Company, 1967), 169-176, 228-244; Colin Palmer, Cheddi Jagan and the Politics of Power: British Guiana's Struggle for Independence (Chapel Hill: The University of North Carolina Press, 2010), 204; Rabe, U.S. Intervention in British Guiana, 79-80.

${ }^{9}$ Leo Despres suggests that PPP policies between 1957 and 1961 intentionally impeded some aspects of the MPCA reform program to undermine support for the union. See: Despres, Cultural Pluralism and Nationalist Politics in British Guiana, 243-244.
} 
laborers. Therefore, the PPP's victory divided the Guianese racially and exacerbated the "perpetual state of inter-union war" about which James Ramphal warned colonial officials in $1954 .^{10}$

However, the struggle in the labor movement during the early 1960s differed from earlier trade union conflicts in ways that contributed to political breakdown and violence. The dispute over labor relations devolved into a multifaceted conflict based on three separate dynamics. First, the social revolutionary PPP and the reformist MPCA struggled for control of labor institutions in the sugar industry as a result of ideological disagreements. Second, the East Indian-dominated PPP conflicted with Afro-Guianese labor leaders and workers positioned against the party and who aligned with the PNC. Finally, the CIA and AFL-CIO worked through local opponents of the PPP to undermine the Guianese government.

Stephen Rabe demonstrates that United States intervention in British Guiana in 1962 and 1963 made a mockery of the colony's right to self-determination and played a significant part in impeding state formation in addition to directly putting in power a dictatorial and oppressive kleptocracy under Forbes Burnham. Rabe also shows that the Kennedy administration pressured British Prime Minister Harold Macmillan into replacing the first-past-the-post electoral system in British Guiana with a system of proportional representation to create the conditions for the removal of the popularly elected PPP government. ${ }^{11}$ American participation was the decisive factor in removing the Jagan-led PPP; however, as Robert Waters argues, the American role was

\footnotetext{
${ }^{10}$ James Ramphal, British Guiana Labor Commissioner, "Present and Future Outlook of the Trade Union Movement," June 1954, CO 859-773, British National Archives, Kew, Richmond, Surrey. (Hereafter BNA). ${ }^{11}$ Rabe, U.S. Intervention in British Guiana, 186. See also: Cary Fraser, "The 'New Frontier' of Empire in the Caribbean: The Transfer of Power in British Guiana, 1961-1964," The International History Review, Vol. XXII, September 3, 2000, pp. 583-610.
} 
"more subtle than we knew."12 The Central Intelligence Agency (CIA) and the American Federation of Labor-Congress of Industrial Organizations (AFL-CIO) were only part of the complex debate over the nature of British Guiana's post-colonial labor organizations that tore apart British Guiana beginning in 1962. Piero Gleijeses notes in his analysis of the Americanbacked coup in Guatemala there was no "convenient villain" singularly controlling events on the ground. ${ }^{13}$ Similarly, the CIA/AFL-CIO role in British Guiana was part of a diverse combination of events and actors throughout the world but centered on local conflict within the colony. Three specific issues addressed throughout this dissertation contributed to the institutional failure that the CIA and AFL-CIO exploited in 1962 and 1963.

First, colonialism created racially divided employment demographics that placed the predominantly Afro-Guianese government workers against the PPP once the party became the administrating authority in 1957. Racial tensions preceded the PPP's founding and several factors, including Anglo-American meddling, contributed to racializing Guianese politics. ${ }^{14}$ Nonetheless, when the PPP assumed the responsibility of governing it created an impossible situation for the working class party. The PPP advocated on behalf of sugar workers negotiating against foreign capitalist employers while being forced to bargain against wage increases for civil servants since the increased pay would come from taxing other workers in the colony. ${ }^{15}$

\footnotetext{
${ }^{12}$ Robert Anthony Waters, Jr., "More Subtle Than We Knew: The AFL in the British Caribbean," in, Robert Anthony Waters, Jr. and Geert Van Goethem, American Labor's Global Ambassadors: The International History of the AFL-CIO During the Cold War (New York, Palgrave Macmillan, 2013), 165-173.

${ }^{13}$ Piero Gleijeses, Shattered Hope: The Guatemalan Revolution and the United States, 1944-1954 (Princeton, NJ: Princeton University Press, 1991), 7.

${ }^{14}$ There is some evidence in British intelligence records that the Special Service attempted to exploit ideological and racial differences to split the PPP. See: Colonial Office to A.N. McCleary, Foreign Office, August 20, 1957, FO 371-126078, BNA; Palmer, 58-59. Eric Huntley suggested in his interview with Frank Birbalsingh that someone from the CIA visited Burnham in the company of British trade unionists and encouraged his decision to split from Jagan. See: Frank Birbalsingh, The People's Progressive Party of Guyana 1950-1992: An Oral History (London: Hansib Publications, 2007), 77.

${ }^{15}$ The PPP also put a price freeze on domestic sugar in late 1957 and justified the policy as a necessary measure to keep sugar workers from profiting at the expense of urban laborers. MPCA President Richard Ishmael criticized the
} 
Civil service unions' demands for increased wages preceded the PPP's assumption of power; however, once Cheddi Jagan took the reins of government the unions turned their disillusion against the party. ${ }^{16}$ The racialized nature of the dispute intensified the divisions between East Indians and Afro-Guianese but it remained a class dispute at its core.

The first major strike against the PPP in February 1962 began in response to a PPP budget that included a compulsory savings plan designed to generate necessary development capital for the government. The budget was democratically constructed, practical if unappealing, and not at all radical. ${ }^{17}$ There is definitive evidence that the AFL-CIO and CIA supported antiPPP demonstrators, though the extent of American assistance is strongly contested. ${ }^{18}$

Nonetheless, protests cannot be divorced from the broader context. Civil service workers had been in conflict with the administrating authorities in Georgetown for eight years. In October 1961 government workers requested a hearing from the Whitley Council in attempt to negotiate a pay increase and apparently received no response prior to the protests. ${ }^{19}$ Thus, the 1962 strikes are most effectively understood as a complex demonstration in which different motives drove various actors. The disillusionment grew largely out of a long-term sense of frustration toward

policy as a scheme to undermine sugar workers' support for the MPCA. See: Seecharan, Sweetening 'Bitter Sugar', 453.

${ }^{16}$ The Federation of Unions of Government Employees, for example, aligned with the PPP before 1957. Robert Alexander to Jay Lovestone, June 9, 1953, RG 18-003, International Affairs Department, Jay Lovestone Files, 19441973, Box 2, Alexander, Robert, 1953, George Meany Memorial Archives, Silver Spring, MD (Hereafter GMMA). 17 "Booker Group Review of the Year, 1961," Published by Booker Brothers, McConnell \& Co. Limited, Economic Conditions, Falkland Island and Various Countries, HC 157A-B55, TUCLC. See also: Rabe, U.S. Intervention in British Guiana.

${ }^{18}$ Memorandum Prepared for the 303 Committee, March 17, 1967, Foreign Relations of the United States, 19641968, Volume XXXII, Dominican Republic; Cuba; Haiti; Guyana, 1964-1968, eds., Daniel Lawler and Carolyn Yee (Washington D.C.: Government Printing Office), Document 421.Stephen Rabe argues that the Kennedy administration encouraged and the CIA supported the protesters. Robert Waters and Gordon Daniels acknowledge American involvement but argue that it was more limited than Rabe suggests. See: Rabe, U.S. Intervention in British Guiana, 89-93; Waters and Daniels, "Striking for Freedom?," 561.

${ }^{19}$ C.A. Nascimento and R.A. Burrowes, eds., Forbes Burnham, A Destiny to Mould: Selected Speeches by the Prime Minister of Guyana (New York: Africana Publishing Corporation, 1970), 30. 
several administrations in Georgetown that did not increase pay for civil servants. ${ }^{20}$ At the same time, Burnham and other political leaders clearly used workers' disappointment to further their own political objectives and the CIA and AFL-CIO likely took advantage of the disturbances to prolong unrest and destabilize the PPP. While it is possible that the CIA contributed to the timing of the strike in addition to providing funds for protesters, it is important to acknowledge that underlying domestic tensions were structural and had been gesticulating since the Interim government — and indirectly for over a century.

Second, ideological differences created an immutable struggle between the PPP's social revolutionary intentions as the head of an elected government and the largest union in the colony. The conflict between PPP leaders and the MPCA that began when Jagan left the union in 1945 exploded after the PPP's election in 1961. The PPP formed the Guiana Sugar Workers' Union in 1961, which became the Guiana Agricultural Workers' Union (GAWU), and in 1963, the party again introduced a Labor Relations Bill designed to legally replace the MPCA with the partyaffiliated organization. ${ }^{21}$ Brindley Benn, a member of the PPP executive council and Minister of Natural Resources openly stated that his party remained committed to removing MPCA president Richard Ishmael after the elections. ${ }^{22}$

Ishmael immediately traveled to the United States in response to the election and received a warm welcome from the AFL-CIO. Importantly, Ishmael intimated to AFL-CIO representatives in a "very confidential" conversation that he would support efforts to delay

\footnotetext{
20 "Report of the commission of Inquiry into the Disturbances in British Guiana in February 1962" (London: Her Majesty's Stationary Office, 1962).

${ }^{21}$ Everett K. Melby, American Consul, Georgetown to State Department, October 20, 1961, British Guiana: US Consulate, Georgetown, Classified General Records, 1957-1963, Box 13, Records of the Foreign Service Posts of the Department of State, RG 84, NARA II. "Booker Group Review of the Year, 1961," Published by Booker Brothers, McConnell \& Co. Limited, Economic Conditions, Falkland Island and Various Countries, HC 157A-B55, TUCLC.

${ }^{22}$ Peter Pimperanl, "Here and There," Sunday Argosy, October 15, 1961, RG18-001, International Affairs Department, Country Files, 1945-1971, Box 17, GMMA.
} 
independence until Jagan could be removed from office. ${ }^{23}$ The MPCA president's trip corresponded with Cheddi Jagan's official visit as head of state in what proved to be a fateful meeting with President John F. Kennedy. ${ }^{24}$ By the time the two men returned to Guiana the Kennedy administration determined against offering development aid to Jagan and presumably the AFL-CIO agreed to increase support for the MPCA. ${ }^{25}$ The MPCA president also appealed for aid from the ICFTU and the international labor organization forwarded the request to the AFLCIO. ${ }^{26}$ While Ishmael and Jagan engaged in international diplomacy, sugar workers continued to struggle for small improvements and to cope with displacement in British Guiana. The result was a clash between the democratically supported political party pursuing social revolution with increased ties to the Eastern bloc and the legally entrenched and anti-democratic reformist trade union that advocated capitalism and had integrated into the Western system.

Compromise between the PPP and MPCA was impossible because as Osmond Dyce, Secretary Treasurer of the American-affiliated Caribbean Congress of Labor (CCL) explained, "The problem in British Guiana is not just another question of one union raiding the other. It involves a fundamental struggle between two systems of trade unionism and must be treated as such." ${ }^{27}$ Time had passed too rapidly for Anglo-American officials, labor leaders, and employers to construct a democratically-run reformist labor movement amenable to Western interests in the sugar industry. In 1963 the MPCA struck against the PPP in opposition to a proposed Labor

\footnotetext{
${ }^{23}$ Richard Ishmael, "The Situation as it is in British Guiana," undated (early October 1961), RG18-001, International Affairs Department, Country Files, 1945-1971, Box 17, GMMA.

${ }^{24}$ Arthur M. Schlesinger, Jr., A Thousand Days: John F. Kennedy in the White House (New York: First Mariner Books, 1965), 775-776.

${ }^{25}$ There is evidence of AFL-CIO involvement in strikes in British Guiana in February 1962 though the extent of that aid is debated. See: Rabe, U.S. Intervention in British Guiana, 89-93; Waters and Daniels, "Striking for Freedom?," 561.

${ }^{26}$ Richard Ishmael to Omar Becu, General Secretary of the International Confederation of Free Trade Unions, October 24, 1961, RG18-001, International Affairs Department, Country Files, 1945-1971, Box 17, GMMA. ${ }^{27}$ Osmond Dyce, Secretary Treasurer CCL Report on Trade Union Situation in British Guiana, Oct. 28, 1961, RG18-001, International Affairs Department, Country Files, 1945-1971, Box 17, GMMA.
} 
Relations Bill providing the CIA and AFL-CIO with the opportunity to exploit the unrest by financially supporting protests against the PPP. ${ }^{28}$

Third, the conflict over Guianese labor institutions was internationalized throughout the 1950s. Immediately after the PPP's re-election in August 1961 labor leaders on both sides of the ideological debate turned to outside actors for assistance rather than negotiating internally. External appeals suggest that the internationalization of the Guianese labor struggle contributed to an institutional breakdown before the unrest began in 1962. The motives of Guianese labor leaders and rank-and-file workers merged with the objectives of external actors to frame the conflict after the PPP's election. Striking workers could prolong their protests since they had financial support; however, the strikes' aims evolved to address concerns of external actors as well as Guianese workers.

The AFL-CIO's displacement of the TUC as the most influential external actor in the Guianese labor movement was crucial in shaping the MPCA-PPP conflict in 1963. Specifically, American labor leaders' emphasis on removing the PPP took precedence over the TUC's efforts to salvage labor relations and solidify a functional movement that would reduce the appeal of social revolution. Most importantly, the MPCA and British Guiana Trades Union Congress (BGTUC) continued to strike despite TUC mediation and the PPP's compromise on all of the major points of protest. ${ }^{29} \mathrm{CIA}, \mathrm{AFL}-\mathrm{CIO}$, and some Guianese labor leaders' aim of subverting the PPP government supplanted Guianese reformist trade unions' opposition to the bill's provisions as the justification for the strike. The attempt to integrate the Guianese labor

\footnotetext{
${ }^{28}$ Robert Waters and Gordon Daniels, "The World's Longest General Strike: The AFL-CIO, the CIA, and British Guiana," Diplomatic History, Vol. 29, No. 2, 279-307.

${ }^{29}$ The BGTUC's ability to strike depended on outside financing. As Colin Palmer notes, 77\% of the BGTUC's funding the previous year originated outside the colony. See: Palmer, Cheddi Jagan and the Politics of Power, 252.
} 
movement into the Western system for mutual benefit degenerated into a symbiotic relationship that allowed the MPCA and CIA to collaborate in a policy of overthrowing the PPP in 1963.

Ultimately, both internal and external factors contributed to institutional dysfunction. The series of strikes that destabilized the PPP government are most effectively understood as a third phase of conflict in the process of institutional decolonization in which dysfunctional labor relations led to systemic collapse in British Guiana. However, the context and small differences between the various strikes illuminate an important complexity. The 1962 strikes, as Rabe and Palmer note, were irrational if understood as a response to the PPP financial plan; however, the budget debate became a tangible symbol of more deeply-held disagreements between the PPP and the Afro-Guianese community. As Robert Waters and Gordon Daniels note, the budget's austerity measures fell hardest on urban Afro-Guianese laborers and it is significant that the MPCA played virtually no role in the strike. ${ }^{30}$ Conversely, the BGTUC easily mobilized urban workers, many of whom had been engaged in conflicts with the government in Georgetown for since 1954. Thus, broad disillusionment between Afro-Guianese workers and the PPP played the most significant role in generating a backlash to the budget initiating the strike, which the CIA then used to mobilize anti-PPP sentiment. ${ }^{31}$ The unrest in 1962 was far from unexpected, new, or external in origin, though the ongoing turmoil and extent of destruction increased as a result of American involvement.

Similarly, the 1963 Labor Relations bill was, like the 1953 bill, designed to give sugar workers the opportunity to choose the union of their choice. Western labor leaders acknowledged

\footnotetext{
${ }^{30}$ Waters and Daniels, "Striking for Freedom?," 541.

${ }^{31}$ Memorandum Prepared for the 303 Committee, March 17, 1967, Document 421, FRUS, 1964-1968, Volume XII, American Republics (Washington D.C.: Government Printing Office).
} 
as much and noted that the MPCA would not win a referendum among sugar workers. ${ }^{32}$

Nonetheless, the bill was coupled with the GAWU's campaign encouraging workers to withdraw from the MPCA and the PPP's attempt to decertify the MPCA and fourteen other unions. ${ }^{33}$ At the same time the Labor Relations Bill again codified provisions that would have allowed the PPP to exercise considerable influence over the process of certifying unions. Reformist labor leaders in the MPCA and BGTUC rejected empowering the government in such a manner in addition to their ideological opposition to the relationship between the PPP and GAWU. BGTUC president Brentnol Blackmon warned AFL-CIO president George Meany that the bill would act as a "beachhead for the subversion of all democratic institutions on the continent." ${ }^{34}$ Federation of Unions of Government Employees (FUGE) president and PNC General Secretary Andrew Jackson also protested the bill and specifically warned the United Nations (UN) that he did not think the bill was similar to the American Wagner Act regardless of the PPP's protestations. ${ }^{35}$

Reformist labor leaders' resistance to the Labor Relations Bills in 1953 and 1963 resulted from two factors. First, the PPP's 1963 bill targeted a broader section of the workforce. Waters and Daniels note that the PPP created competing civil service and mining unions in addition to creating the GAWU. ${ }^{36}$ Second, American funding supported the strikers, encouraged Guianese unionists to continue protesting, and shifted the discourse from criticism of the bill's provisions to a referendum on the PPP government. Nonetheless, it is important to acknowledge that even

\footnotetext{
${ }^{32}$ Osmond Dyce, Secretary Treasurer CCL Report on Trade Union Situation in British Guiana, Oct. 28, 1961, RG18-001, International Affairs Department, Country Files, 1945-1971, Box 17, GMMA.

${ }^{33}$ Report of the 96th Annual Trades Union Congress, September 7-11, 1964, TUC History Online, 265-267, http://www.unionhistory.info/britainatwork/emuweb/objects/nofdigi/tuc/imagedisplay.php?irn=6016404\&reftable=e catalogue\&refirn=6016290, Last Accessed July 12, 2015.

${ }^{34}$ B. Brentnol Blackmon to George Meany, April 29, 1963, RG18-001, International Affairs Department, Country Files, 1945-1971, Box 17, GMMA.

${ }^{35}$ Andrew Jackson to United Nations Special Committee on the Situation with Regard to the Implementation of the Declaration on the Granting of Independence to Colonial Countries and Peoples, 1963, RG18-001, International Affairs Department, Country Files, 1945-1971, Box 17, GMMA.

${ }^{36}$ Taken together the PPP's program of institution-building suggests a strong effort to create a labor movement closely aligned with but subordinate to the party. See: Waters and Daniels, "Striking for Freedom?," 542.
} 
though American funding allowed the strikes to continue the protesters themselves were Guianese and they were motivated to strike for domestic reasons. Thus, the unrest in Guiana already existed and the conditions were ripe for Anglo-American manipulation. Finally, the 1964 strikes, as Waters and Daniels have shown, were primarily a PPP effort to generate support for the government in advance of elections designed to remove the party from power and very likely were undertaken with Cuban aid. ${ }^{37}$ Ultimately, the labor conflicts that undermined Guiana were internationalized but grounded in domestic disputes.

There was a substantial capitalist, pro-Western current in Guianese politics; however, parties based on those ideals only acquired a small amount of support. The MPCA made considerable gains in negotiating benefits and securing a large base of membership between 1954 and 1961 and evidence suggests that Ishmael achieved as much as was possible in extracting concessions from the Sugar Producers' Association (SPA). Indeed, the SPA frequently considered his demands irrational and his positions nearly undermined any cooperation between the union and employers in the late 1950s. ${ }^{38}$ Nonetheless, the depth of poverty and asymmetries of power in employer-employee relations meant that reform within the existing system could not effectively addressed workers' demands rapidly enough to undermine support for a popular leader offering fundamental systemic changes, especially after racial conflict distorted the political environment. Some sugar workers continued to support both the MPCA and PPP; however, many shifted allegiance to the GAWU and the PPP retained overwhelming grassroots loyalty among East Indians. The colony's institutional framework collapsed when the MPCA joined unions of urban workers uncompromisingly opposed to the PPP.

\footnotetext{
${ }^{37}$ Waters and Daniels, "Striking for Freedom?".

${ }^{38}$ Ralph Grey to Everett Melby, October 17, 1961, British Guiana: US Consulate, Georgetown, Classified General Records, 1957-1963, Box 13, Records of the Foreign Service Posts of the Department of State, RG 84, NARA II.; Ralph Grey to Angus MacKintosh, July 5, 1960, CO 1031-3421, BNA.
} 
Diplomacy between the PPP and United States could have resolved tensions enough to minimize American intervention absent the Cuban revolution, which polarized American foreign policy and emboldened the PPP. Nonetheless, such an accord was unlikely to resolve labor conflicts since the ongoing conflict to determine the nature of Guyana's post-colonial institutions persisted. American, British, and Guianese political and labor leaders were too committed to the outcome of the trade union struggle to compromise and the issue at stake was more fundamental than diplomatic or trade agreements that could vacillate over time. The structure of Guyana's institutions would determine the political-economic system on which post-colonial society would be based, and the nature of the political-economic system would shape transnational relations more than superficial diplomatic overtures.

\section{The Lessons of British Guiana for Post-War United States Foreign Policy}

The Anglo-American manipulation of Guianese sovereignty achieved American goals. It is clear that the aims of policymakers and labor leaders in the United States were secured as an outcome of intervention in the colony in 1962 and 1963. Self-determination and democracy were powerful ideals but remained the least important objectives for the United States government and AFL-CIO in hemispheric relations. The short-term objective of removing Jagan from office came to pass when Commonwealth Secretary Duncan Sandys imposed a system of proportional representation and held elections in December $1964 .{ }^{39}$ The new electoral system allowed a coalition between the PNC and UF to head the government when Guyana became independent two years later despite the PPP's accrual of the plurality of votes. ${ }^{40}$

In the long-term the Eisenhower administration made clear that it intended to secure access to Guianese raw materials, strictly limit the colony's trade outside the Western sphere,

\footnotetext{
${ }^{39}$ Rabe, U.S. Intervention of British Guiana, 78

${ }^{40}$ Palmer, Cheddi Jagan and the Politics of Power, 238-239; Rabe, U.S. Intervention of British Guiana, 137-138; Seecharan, Sweetening 'Bitter Sugar', 594.
} 
and vigorously oppose the entrance of communist ideas into the hemisphere. ${ }^{41}$ In 2014 the Guyanese economy remains based on agricultural and extractive industries and is supported with investments from the Inter-American Development Bank. Sixty-six percent of the colony's export trade is to the United States, Canada, and Great Britain. Though its imports are more diversified, Guyana brings in more goods from the United States than from any other country. Raw material extraction, liberalized finance, and trade with the United States have not addressed the country's needs and it remains among the poorest nations in the hemisphere. ${ }^{42}$ Guyana, as Stephen Rabe notes, was in many ways a casualty of American aims, though as this dissertation shows it was a victim of colonialism and a complex process of institutional decolonization most of all.

It is possible absent American-funded subversion the PPP would have been forced to moderate its policies to accommodate the political views of the substantial reformist presence in British Guiana. It is also conceivable that the growing relationship between the PPP and Cuba would have encouraged Cheddi Jagan to push more aggressively for a transition to socialism

\footnotetext{
${ }^{41}$ J.P. Waterfield, Foreign Office Minute, May 21, 1954, FO 371-169152, BNA; A. John Cope to Department of State, 23 April, 1957, 122.41D, Central Decimal Files, Box 717, RG 59, Records of the Department of State, NARA II; Memorandum of Discussion at the 188th Meeting of the National Security Council, March 11, 1954, 188th Meeting of the NSC, March 11, 1954, Dwight D. Eisenhower Papers as President, 1953-61 (Ann Whitman File) NSC Series, Box 5, Dwight D. Eisenhower Presidential Library, Abilene, KS (Hereafter DDEL); Memorandum of Discussion at the 188th Meeting of the National Security Council, March 11, 1954, 188th Meeting of the NSC, March 11, 1954, Dwight D. Eisenhower Papers as President, 1953-61 (Ann Whitman File) NSC Series, Box 5, DDEL; National Security Council, “U.S. Policy Toward the West Indies," January 25, 1960, West Indies (1); National Security Council, "Progress Report on United States Objectives and Courses of Action with Respect to Latin America by the Operations Coordinating Board," February 3, 1955; National Security Council, "United States Objectives and Courses of Action with Respect to Latin America, September 3, 1954, Latin America (1), White House Office, National Security Council Staff: Papers, 1948-61, Disaster File, Box 63, DDEL. CIA Director Allen Dulles referred to the NSC reports collectively as "the Bible of U.S. policy both here and abroad." See: Memorandum of Discussion at the 224th Meeting of the National Security Council, November 15, 1954, 224th Meeting of NSC, November 15, 1954, Dwight D. Eisenhower Papers as President, 1953-61 (Ann Whitman File) NSC Series, Box 6, DDEL; Memorandum of Discussion at the 188th Meeting of the National Security Council, Thursday, March 18, 1954, Dwight D. Eisenhower Papers as President, 1953-61, (Ann Whitman File), NSC Series, Box 5, DDEL; Avalon Project at Yale Law School, "Caracas Declaration of Solidarity," March 28, 1954, Lillian Goldman Law Library. http://avalon.law.yale.edu/20th_century/intam10.asp (accessed January 9, 2015).

${ }^{42}$ Central Intelligence Agency World Factbook, https://www.cia.gov/library/publications/the-worldfactbook/geos/gy.html, Last Accessed, July 21, 2015.
} 
regardless of domestic sentiments. At the same time, it is likely that the PPP's domestic opponents would have had to accept considerable socialization and an Eastern-bloc oriented, if neutral foreign policy. It is equally imaginable that ideological disagreements and racial tensions would have exploded without external involvement; however, the possibility of cooperation would have continued to exist in a way it did not once external actors made the determination to subvert the PPP. Most importantly, the Guianese could have struggled together as citizens of an independent nation to determine their own future absent the interference of Cold War actors.

The most recently available evidence suggests that the PPP's Marxist-Leninist leaders began working toward the establishment of a socialist-communist society connected to the Eastern-bloc in 1946 through the institutional transformation of the colony while expecting to retain cordial relations with the United States and Great Britain. ${ }^{43}$ The actions undertaken by the left-wing of the PPP suggest that a Jagan-led government would have provided a strategic challenge and perhaps a direct threat to American interests as the National Security Council (NSC) and American labor leaders defined them. While it is unclear the extent to which the PPP received support from the Eastern-bloc, it is possible that similar criticisms could be levied toward communist involvement as well. ${ }^{44}$ Perhaps most importantly, the PPP's removal paved the way for the dictatorial Burnham government and oppression thereafter. In light of new evidence, critics of American foreign policy toward British Guiana should emphasize the destructive tendencies of intervention as a tool of foreign policy and urge the re-evaluation of its

\footnotetext{
${ }^{43}$ Socialism and communism are clearly very different; however, PPP leaders and materials often conflated the two. See: Cheddi Jagan, "Straight Talk: The Ideological Struggle," Thunder, March, 1957, CJRC; Cheddi Jagan, Straight Talk: A Living Wage, Thunder, December 26, 1959, CJRC; Dr. Cheddi Jagan, "Undesirable Publications Bill," 1953, David Dabydeen and Lynne Macedo, eds., Dr. Cheddi Jagan National Assembly Speeches, Volume 2: The Fourth Legislative Council January 1952-April 1953 (Published by the Caribbean Press for the Government of Guyana, 2011), 309.

${ }^{44}$ Waters and Daniels make a strong case that Cuban involvement in the colony reached significant levels in 1964. See: Waters and Daniels, "Striking for Freedom?," 537-569. Moses Bhagwan suggests that the PPP received funding from Russia at least by 1957. See: Birbalsingh, The People's Progressive Party of Guyana 1950-1992, 115.
} 
far too frequent use rather than suggest that American intelligence misread Cheddi Jagan's intentions. PPP policies were designed to pursue what party leaders thought was in the best interest of the Guianese people and the party had popular support even though it also faced considerable domestic opposition.

Thus, there are three key questions for scholars of American foreign policy that provide the opportunity for future research. The first is whether United States labor leaders' and officials' pursued policies that were in the best interest of American citizens. A considerable amount of information about Guiana came from AFL-CIO leaders who in turn gleaned information from a select few colonial trade unionists. Much recent research considers American labor's foreign relations and there is room for much more research evaluating whether AFL-CIO activities advanced or degraded Americans' interests. There is also a need to evaluate whether the NSC and State Department defined foreign policy objectives in a manner that benefited ordinary Americans.

The second question is whether or not the costs of intervention were worth the price of achieving American objectives. The Guyanese people, most importantly, paid a heavy price as a consequence of United States intervention. More fundamentally, interventionist policies are corrosive to international relations and seem to be self-perpetuating. External interference in Guiana's domestic disputes compromised principles of self-determination and negatively impacted the domestic situation in the United States. In conceding that it is acceptable to outlaw ideas, as Dulles argued that it was in defining his notion of the Monroe Doctrine, policymakers reinforced a logic that justified restricting intellectual freedom within the United States as well. Finally, scholars have the opportunity to evaluate whether institution-building efforts could have succeeded if they were implemented more effectively. Some aspects of institution-building 
succeeded, and it would be useful to pursue further studies to examine those programs more systematically. It is worth considering whether a collaborative international program could have benefited the Guianese and simultaneously achieved Anglo-American interests.

Perhaps most importantly, this dissertation uses the prism of institutional decolonization to argue that the British colonies' transition to independence was a complex and internationalized process involving a plethora of state and non-state actors debating the structure of post-colonial Guyana. Labor leaders played a central role in the process of negotiating the nature of post-colonial institutions and their ideologies and objectives influenced international relationships. Transnational connections exacerbated ideological disagreements and resulted in a web of symbiotic relationships that ensconced the progression toward self-government in the Cold War. At the same time, the ideological debates unfolding in decolonizing areas created the ground on which the Cold War conflict raged. Nonetheless, the Cold War and decolonization were merely superficial manifestations of a phase of adjustment in international relations. The underlying struggle between promoting self-determination and securing Anglo-American interests preceded the period and continues to the preset day.

In the end, American labor leaders and the various agencies of the U.S. government involved in British Guiana achieved their objectives more than any other actor in the struggleother than Forbes Burnham, who came to power as a result of the chaos. Regardless, American labor's support of neo-liberal foreign policy contributed to its demise in the United States. Moreover, Guyana remains an impoverished country that is the source of a variety of transnational criminal activities, including narcotics and sex trafficking, and forced labor of children. ${ }^{45}$ Thus, failed institution-building, and outright political subversion, contributed to the

\footnotetext{
${ }^{45}$ CIA World Factbook, Guyana, https://www.cia.gov/library/publications/the-world-factbook/geos/gy.html, Last Accessed, July 21, 2015.
} 
devolution of the colony into a country that represents a destabilizing force in the region, despite the preservation of American economic interests. British suppression of Guianese selfdetermination destabilized a fragile domestic situation in the colony. Rather than facing the challenges of developing a nation through difficult discussions and compromise, Guianese leaders used external support and anti-democratic practices to advance their objectivesprecluding domestic state-building. Most importantly, institutional decolonization in Guyana culminated in the failed promise of a multi-racial coalition of Guyanese citizens cooperating to develop the country based on the will of the people. Debates about how to structure post-colonial Guyana devolved into a violent, internationalized conflict that created racial discord which continues to permeate Guyanese politics. In this Cold War episode, there were no winners. 


\section{Bibliography}

\section{Unpublished Primary Sources:}

\section{United States:}

United States Department of State. Central Decimal Files, 1950-63. Record Group 59. National Archives II. College Park, MD.

United States Department of State. Central Decimal Files, 1963-1969. Record Group 59.

National Archives II. College Park, MD.

United States Department of State. Records of the Foreign Service Posts of the Department of State, Record Group 84. National Archives II. College Park, MD.

Dwight D. Eisenhower Presidential Library, Abilene, KS:

White House Central Files, Records of the President

White House Central Files, Official File, ICA

White House Office, National Security Council Staff: Papers

Ann Whitman Files, Dulles-Herter Series

Ann Whitman Files, National Security Council Series

John Foster Dulles Papers

Christian A. Herter Papers

Harold Stassen Papers

Dennis A. Fitzgerald Papers

Alan Grant Papers

Laurin L. Henry Papers

Kheel Center, Cornell University, Ithaca, NY, Papers of Serafino Romualdi, Inter-American Representative of the AFL-CIO.

The University of Vermont, Burlington, VT, Special Collections, Senator George D. Aiken Papers.

National Labor College. Record Group 1-Office of the President 1940-1980. George Meany Memorial Archives. Silver Spring, MD.

RG 1-026: George Meany Papers, 1935-1960

National Labor College. Record Group 18-International Affairs Department- 1945-1971. George Meany Memorial Archives. Silver Spring, MD.

RG 18-001: Country Files, 1945-1971

RG 18-002: CIO International Affairs Department, Director's Files, Mike Ross, 19451955

RG 18-003: Jay Lovestone Files, 1939-1974 
RG 18-005: Staff Files, George Delaney’s Files, 1921-1957

RG 18-007: International Labor Organizations Activities, 1946-1985

RG 18-009: Staff Files, Serafino Romualdi’s Files, 1945-1961

\section{United Kingdom:}

The National Archives, Kew, Richmond, Surrey, Colonial Office:

Series 111, Records of the West Indian Department, 1949

Series 852, Records of the Economic Department, 1960-62

Series 859, Records of the Social Service Departments, 1954-65

Series 951, Records of the British Guiana Constitutional Commission, 1950-51

Series 968, Records of the Colonial Office and Commonwealth Office: Defense

Department and Successors, Original Correspondence, 1952

Series 1027, Records of the Information Department, 1953, 1963-65

Series 1031, Records of the West Indian Department (WIS File Series), 1948-67

Series 1035, Intelligence and Security Departments (ISD Series), 1954-65

The National Archives, Kew, Richmond, Surrey, Foreign and Commonwealth Office, Series 141, Colonial Administration Records, 1960-1962.

The National Archives, Kew, Richmond, Surrey, Foreign Office, Series 371, Political Departments, General Correspondence, 1906-1966

The National Archives, Kew, Richmond, Surrey, Records of the Security Service, Personal Files (PF Series), 1947-1961.

TUC Library Collections, London Metropolitan University, London, The Marjorie Nicholson Papers, 1935-1997.

TUC Library Collections, London Metropolitan University, London, Series 901, International Committee, 1958-1966.

TUC Library Collections, London Metropolitan University, London, Series 932.5,Trade Unions and the Colonies, 1951-1972.

TUC Library Collections, London Metropolitan University, London, Series 932.9, Colonial Advisory Committee Minutes, 1954-1966.

TUC Library Collections, London Metropolitan University, London, Series 972, West Indies, 1926-1980.

TUC Library Collections, London Metropolitan University, London, Series 972.8, British

Guiana, 1954-1975. 


\section{Published Primary Sources:}

United States Department of State. Foreign Relations of the United States, 1947-68, Washington, D.C.: Government Printing Office, 1996-2005.

Reorganization Plans Nos. 7 and 8 of 1953 (Foreign Operations Administration) (United States Information Agency), Hearings before the Committee on Government Operations House of Representatives, 83rd Congress, 1st Session on H.J. Res. 261 and H.J. Res. 262, June 22, 23, and 24, 1953, Washington D.C.: Government Printing Office, 1953.

The Foreign Operations Administration End-Use Control Program, Hearings Before a Subcommittee of the Committee on Government Operations House of Representatives 83rd Congress, Second Session, June 17, 18, and 23, 1954, Washington D.C.: Government Printing Office, 1954.

British Documents on the End of Empire:

Ashton, S.R. and Killingray, David, eds. Series B Volume 6: The West Indies, London: The Stationary Office, 1999.

Dabydeen, David and Macedo, Lynne eds. Dr. Cheddi Jagan National Assembly Speeches, Volume 1: The Fourth Legislative Council December 1947-December 1951, Published by the Caribbean Press for the Government of Guyana, 2011.

Dabydeen, David and Macedo, Lynne eds. Dr. Cheddi Jagan National Assembly Speeches, Volume 2: The Fourth Legislative Council January 1952-April 1953, Published by the Caribbean Press for the Government of Guyana, 2011.

Dabydeen, David and Macedo, Lynne, eds. Dr. Cheddi Jagan National Assembly Speeches, Volume 3: The Legislative Council \& the Senate, February 1959-July 1961, Published by the Caribbean Press for the Government of Guyana, 2011.

\section{Online Archival Sources:}

Avalon Project at Yale Law School, Lillian Goldman Law Library, http://avalon.law.yale.edu/. Central Intelligence Agency Electronic Reading Room, http://www.foia.cia.gov/.

Central Intelligence Agency World Factbook: Guyana, 2014, https://www.cia.gov/library/publications/the-world-factbook/.

Cheddi Jagan Research Center, http://www.jagan.org/.

Library of Congress, The Foreign Affairs Oral History Collection of the Association for Diplomatic Studies and Training, http://memory.loc.gov/ammem/collections/diplomacy/.

Trades Union Congress History Online, http://www.unionhistory.info/reports/. 


\section{Memoirs, Autobiographies, Diaries, and Interviews}

Agee, Philip. Inside the Company: CIA Diary, New York: Bantam Books, 1975.

Birbalsingh, Frank. The People's Progressive Party of Guyana 1950-1992: An Oral History, London: Hansib Publications, 2007.

Jagan, Cheddi. The West on Trial: My Fight for Guyana's Freedom, New York: International Publishers, 1967.

Marshall, Woodville K., ed. I Speak for the People: The Memoirs of Wynter Crawford, Kingston: Ian Randle Publishers, 2003.

Nascimento, C.A. and Burrowes, R.A., eds. Forbes Burnham, A Destiny to Mould: Selected Speeches by the Prime Minister of Guyana, New York: Africana Publishing Corporation, 1970.

Ragbeer, Mohan. The Indelible Red Stain: The Destruction of a Tropical Paradise-a Cold War Story, Published by Mohan Ragbeer, 2011.

Romualdi, Serafino, Presidents and Peons: Recollections of a Labor Ambassador in Latin America, New York: Funk \& Wagnalls, 1967.

Schlesinger, Arthur M., Jr. A Thousand Days: John F. Kennedy in the White House, New York: First Mariner Books, 1965.

Singh, Jai Narine. Guyana: Democracy Betrayed, Kingston, Jamaica: Kingston Publishers Ltd., 1996.

\section{Secondary Sources:}

Abraham, Sara, Labour and the Multiracial Project in the Caribbean: Its History and Its Promise, Lanham, MD: Rowman \& Littlefield Publishers, Inc., 2007.

Alexander, Robert J. "Labor and Inter-American Relations," Annals of the American Academy of Political and Social Science, Vol. 334, March 1961, pp. 41-63.

Anderson, David. Histories of the Hanged: The Dirty War in Kenya and the End of Empire, New York: W.W. Norton \& Company, 2005.

Andrew, Christopher. Defend the Realm: The Authorized History of MI5, New York: Alfred A. Knopf, 2009.

Arnesen, Eric. Encyclopedia of U.S. Labor and Working-Class History, Volume 1, New York: Routledge, 2007. 
Barnet, Richard J. Intervention and Revolution: The United States in the Third World, New York: World Publishing Company, 1968.

Bell, Wendell. "Equality and Social Justice: Foundations of Nationalism in the Caribbean," Caribbean Studies, Vol. 20 No. 2 (1980), 5-36.

Bolland, O. Nigel. The Politics of Labour in the British Caribbean: The Social Origins of Authoritarianism and Democracy in the Labour Movement, Oxford: James Currey, 2001.

Brands, Hal. Latin America's Cold War, Cambridge, MA: Harvard University Press, 2010.

Brinkley, Alan. The End of Reform: New Deal Liberalism in Recession and War, New York: Vintage Books, 1995.

Busch, Gary K. The Political Role of International Trades Unions, New York: St. Martin's Press, 1983.

Carew, Anthony. "The American Labor Movement in Fizzland: The Free Trade Union Committee and the CIA," Labor History 39 (1998).

Carew, Anthony. "Charles Millard, A Canadian in the International Labor Movement: A Case Study of the ICFTU 1955-61,” Labour/Le Travail, 37 (Spring 1996), 121-148.

Carew, Anthony, ed. The International Confederation of Free Trade Unions, New York: Peter Lang, 2000.

Chase, Ashton. A History of Trade Unionism in Guyana 1900 to 1961, with an Epilogue to 1964, Demerara, Guyana: New Guyana Company Ltd., 1966.

Chase, Ashton. Guyana a Nation in Transit: Burnham's Role, Guyana: Ashton Chase, 1994.

Cobbs, Elizabeth A. The Rich Neighbor Policy: Rockefeller and Kaiser in Brazil, New Haven, CT: Yale University Press, 1992.

Cochran, Bert. Labor and Communism: The Conflict that Shaped American Unions, Princeton: Princeton University Press, 1977.

Coleman, Bradley Lynn. Colombia and the United States: The Making of an Inter-American Alliance, 1939-1960, Kent, OH: The Kent State University Press, 2008.

Connelly, Matthew. A Diplomatic Revolution: Algeria's Fight for Independence and the Origins of the Post-Cold War Era, Oxford: Oxford University Press, 2002.

Cullather, Nick. Secret History: The CIA's Classified Account of Its Operations in Guatemala, 1952-1954, 2nd ed., Stanford: Stanford University Press, 2006. 
Darwin, John. The Empire Project: The Rise and Fall of the British World-System, 1830-1970, Cambridge: Cambridge University Press, 2009.

Darwin, John. Unfinished Empire: The Global Expansion of Britain, New York: Bloomsbury Press, 2013.

Davies, D.I. "The Politics of the TUC's Colonial Policy," The Political Quarterly, Vol. 35 (1), 23-34, 1964.

De Grazia, Victoria. Irresistible Empire: America's Advance through Twentieth-Century Europe, Cambridge, MA: The Belknap Press of Harvard University Press, 2005.

Despres, Leo A. Cultural Pluralism and Nationalist Politics in British Guiana, Chicago: Rand McNally and Company, 1967.

Deutscher, Isaac. Soviet Trade Unions: Their Place in Soviet Labour Policy, London: Royal Institute of International Affairs, 1950.

Esposito, Mark A.T. "The UAW., American Trade Policy, and the Transformation of the Global Automobile Industry, 1945-1973,” West Virginia University: Ph.D. Dissertation, 2004.

Fanon, Frantz. The Wretched of the Earth, New York: Grove Press, 2004.

Fedorowich Kent and Thomas, Martin, eds. International Diplomacy and Colonial Retreat, London: Frank Cass, 2001.

Ferguson, Niall. Empire: The Rise and Demise of the British World Order and the Lessons for Global Power, New York: Basic Books, 2002.

Fousek, John. To Lead the Free World: American Nationalism and the Cultural Roots of the Cold War, Chapel Hill: The University of North Carolina Press, 2000.

Fraser, Cary. Ambivalent Anti-Colonialism: The United States and the Genesis of West Indian Independence, 1940-1964, Westport, CT: Greenwood Press, 1994.

Fraser, Cary. “The 'New Frontier' of Empire in the Caribbean: The Transfer of Power in British Guiana, 1961-1964,” The International History Review, Vol. XXII, September 3, 2000, pp. 583610.

Furedi, Frank. Colonial Wars and the Politics of Third World Nationalism, London: I.B. Tauris Publishers, 1994.

Gaddis, John Lewis. We Now Know: Rethinking Cold War History, Oxford: Oxford University Press, 1997. 
Gallagher, John. The Decline, Revival, and Fall of the British Empire, Cambridge: Cambridge University Press, 1982.

Gambone, Michael D. Capturing the Revolution: The United States, Central America, and Nicaragua, 1961-1972, Westport, CT: Praeger, 2001.

Gleijeses, Piero. Shattered Hope: The Guatemalan Revolution and the United States, 1944-1954, Princeton, NJ: Princeton University Press, 1991.

Gordon, Michael E. and Turner, Lowell. Transnational Cooperation among Labor Unions, Ithaca, NY: Cornell University Press, 2000.

Grandin, Greg. Empire's Workshop: Latin America, the United States, and the Rise of the New Imperialism, New York: Henry Holt and Company, LLC, 2006.

Guzda, Henry P. "James P. Mitchell: Social Conscience of the Cabinet," Monthly Labor Review, August 1991, 23-29.

Hahn, Peter L. and Heiss, Mary Ann. Empire and Revolution: The United States and the Third World Since 1945, Columbus: Ohio State University Press, 2001.

Halpern, Martin. UAW Politics in the Cold War Era, Albany: State University of New York Press, 1988.

Harmer, Tanya. Allende's Chile and the Inter-American Cold War (Chapel Hill: The University of North Carolina Press, 2011).

Hinds, David. Ethno-Politics and Power Sharing in Guyana: History and Discourse, Washington, D.C.: New Academia Publishing, 2011.

Horne, Gerald. Cold War in a Hot Zone: The United States Confronts Labor and Independence Struggles in the British West Indies, Philadelphia: Temple University Press, 2007.

Hughes, Quenby Olmsted. "In the Interest of Democracy:” The Rise and Fall of the Early Cold War Alliance Between the American Federation of Labour and the Central Intelligence Agency, Oxford: Peter Lang, 2011.

Hunt, Michael. Ideology and U.S. Foreign Policy, New Haven, CT: Yale University Press, 1987.

Hyam, Ronald. Britain's Declining Empire: The Road to Decolonisation 1918-1968, Cambridge: Cambridge University Press, 2006.

Ince, Basil A. Decolonization and Conflict in the United Nations: Guyana's Struggle for Independence, Cambridge, MA: Schenkman Publishing Company, 1974. 
Iriye, Akira. Global Community: The Role of International Organizations in the Making of the Contemporary World, Berkeley: University of California Press, 2002.

Khan, Yasmin. The Great Partition: The Making of India and Pakistan, New Haven: Yale University Press, 2007.

Kassalow, Everett M., ed. National Labor Movements in the Postwar World, Evanston, IL: Northwestern University Press, 1963.

Kaufman, Burton I. Trade and Aid: Eisenhower's Foreign Economic Policy, 1953-1961, Baltimore: The Johns Hopkins University Press, 1982.

Kofas, Jon V. The Struggle for Legitimacy: Latin American Labor and the United States 19301960, Tempe: Arizona State University, 1992.

Kolko, Gabriel. Confronting the Third World: United States Foreign Policy, 1945-1980, New York: Pantheon Books, 1988.

Koura, Jan and Waters, Robert. "Cheddi Jagan and Guianese Overtures to the East: Evidence from the Czech National Archives," Cold War International History Project, e-Dossier No. 54, Wilson Center, 2015.

LaFeber, Walter. America, Russia, and the Cold War, 1945-2000, 9th ed. Boston: McGraw Hill, 2002.

LaFeber, Walter. Inevitable Revolutions: The United States in Central America, 2nd ed., New York: W.W. Norton and Company, 1993.

Lange, Matthew. Lineages of Despotism and Development: British Colonialism and State Power, Chicago: The University of Chicago Press, 2009.

Langley, Lester D. America and the Americas: The United States in the Western Hemisphere, 2nd ed., Athens, GA: The University of Georgia Press, 2010.

Larson, Simeon and Nissen, Bruce, eds. Theories of the Labor Movement, Detroit: Wayne State University Press, 1987.

Latham, Michael E. Modernization as Ideology: American Social Science and "Nation Building” in the Kennedy Era, Chapel Hill: The University of North Carolina Press, 2000.

Leffler, Melvyn. A Preponderance of Power: National Security, the Truman Administration, and the Cold War, Stanford: Stanford University Press, 1992.

Leffler, Melvyn P. and Westad, Odd Arne. The Cambridge History of the Cold War, Vols. 1-3, Cambridge: Cambridge University Press, 2010. 
Lichtenstein, Nelson. Walter Reuther: The Most Dangerous Man in Detroit, Urbana, IL: University of Illinois Press, 1995.

Lodge, George C. Spearheads of Democracy: Labor in the Developing Countries, New York: Harper \& Row, Publishers, 1962.

Long, S.R. Joey. Safe for Decolonization: The Eisenhower Administration, Britain, and Singapore, Kent, OH: The Kent State University Press, 2011.

Longley, Kyle. The Sparrow and the Hawk: Costa Rica and the United States During the Rise of Jose Figueres, Tuscaloosa, AL: The University of Alabama Press, 1997.

Loveman, Brian. No Higher Law: American Foreign Policy and the Western Hemisphere Since 1776, Chapel Hill: The University of North Carolina Press, 2010.

Louis, William Roger. Imperialism at Bay: The United States and the Decolonization of the British Empire 1941-1945, New York: Oxford University Press, 1978.

Louis, William Roger. Ends of British Imperialism: The Scramble for Empire, Suez, and Decolonization, London: I.B. Tauris, 2006.

Luff, Jennifer. Commonsense Anticommunism: Labor and Civil Liberties between the World Wars, Chapel Hill: The University of North Carolina Press, 2012.

Mahoney, James and Rueschemeyer, Dietrich, eds. Comparative Historical Analysis in the Social Sciences, Cambridge: Cambridge University Press, 2003.

Mars, Perry and Young, Alma H., eds. Caribbean Labor and Politics: Legacies of Cheddi Jagan and Michael Manley, Detroit: Wayne State University Press, 2004.

Mawby, Spencer. Ordering Independence: The End of Empire in the Anglophone Caribbean, 1947-1969, New York: Palgrave Macmillan, 2012.

McCormick, Thomas J. America's Half-Century: United States Foreign Policy in the Cold War, Baltimore: Johns Hopkins University Press, 1989.

McPherson, Alan. Yankee No!: Anti-Americanism in U.S.-Latin American Relations, Cambridge, MA: Harvard University Press, 2003.

McPherson, Alan, ed. Anti-Americanism in Latin America and the Caribbean, New York: Berghahn Books, 2006.

Mearsheimer, John J. The Tragedy of Great Power Politics, New York: W.W. Norton \& Company, 2001.

Miliband, Ralph. Marxism and Politics, Oxford: Oxford University Press, 1977. 
Morgan, D.J. The Official History of Colonial Development, Vol. 3: A Reassessment of British Aid Policy, 1951-1965, Atlantic Highlands, NJ: Humanities Press, 1980.

Morgan, Ted. A Covert Life: Jay Lovestone Communist, Anti-Communist, and Spymaster, New York: Random House, 1999.

Morris, Bernard S. "Communist International Front Organizations: Their Nature and Function," World Politics Vol. 9 No. 1 (October 1956), 76-87.

Nederveen Pieterse, Jan P. Empire \& Emancipation: Power and Liberation on a World Scale, New York: Praeger, 1989.

Ninkovich, Frank. The Wilsonian Century: U.S. Foreign Policy Since 1900, Chicago: University of Chicago Press, 1999.

Palmer, Colin. Cheddi Jagan and the Politics of Power: British Guiana's Struggle for Independence, Chapel Hill: The University of North Carolina Press, 2010.

Parker, Jason. Brother's Keeper: The United States, Race, and Empire in the British Caribbean, 1937-1962, Oxford: Oxford University Press, 2008.

Pollard, Robert A. Economic Security and the Origins of the Cold War, 1945-1950, New York: Columbia University Press, 1985.

Porter, Bernard. The Absent-Minded Imperialists: Empire, Society, and Culture in Britain, Oxford: Oxford University Press, 2004.

Priest, Tyler. "Banking on Development: Brazil in the United States' Search for Strategic Minerals, 1945-1953", The International History Review, Vol. 21, No. 2 (Jun., 1999), pp. $297-$ 330.

Rabe, Stephen G. Eisenhower and Latin America: The Foreign Policy of Anticommunism, Chapel Hill: The University of North Carolina Press, 1988.

Rabe, Stephen G. The Most Dangerous Area in the World: John F. Kennedy Confronts Communist Revolution in Latin America, Chapel Hill: The University of North Carolina Press, 1999.

Rabe, Stephen G. U.S. Intervention in British Guiana: A Cold War Story, Chapel Hill: The University of North Carolina Press, 2005.

Radosh, Ronald. American Labor and United States Foreign Policy, New York: Random House, 1969.

Ramcharan, Lily. "Cold War in British Guiana 1953-1966: The Trade Union Dimension," The Round Table, Vol. 94, No. 1, 113-128, January 2005. 
Randall, Stephen J. Colombia and the United States: Hegemony and Interdependence, Athens, GA: The University of Georgia Press, 1992.

Richards, Yevette. Maida Springer: Pan-Africanist and International Labor Leader, Pittsburgh: University of Pittsburgh Press, 2000.

Rodney, Walter. A History of the Guyanese Working People, 1881-1905, Baltimore: The Johns Hopkins University Press, 1981.

Roorda, Eric Paul. The Dictator Next Door: The Good Neighbor Policy and the Trujillo Regime in the Dominican Republic, 1930-1945, Durham, NC: Duke University Press, 1998.

Rosenberg, Emily S. Spreading the American Dream: American Economic and Cultural Expansion 1890-1945, New York: Hill and Wang, 1982.

Schoultz, Lars. That Infernal Little Cuban Republic: The United States and the Cuban Revolution, Chapel Hill: The University of North Carolina Press, 2009.

Scipes, Kim. AFL-CIO's Secret War against Developing Country Workers: Solidarity or Sabotage, New York: Lexington Books, 2010.

Seecharan, Clem. Sweetening 'Bitter Sugar': Jock Campbell the Booker Reformer in British Guiana 1934-1966, Miami: Ian Randle Publishers, 2005.

Siekmeier, James. The Bolivian Revolution and the United States, 1952 to the Present, University Park, PA: The Pennsylvania State University Press, 2011.

Siekmeier, James. "Latin American Economic Nationalism and United States-Latin American Relations, 1945-1961." The Latin Americanist, 52:3, October 2008, 59-76.

Silverman, Victor. Imagining Internationalism in American and British Labor, 1939-49, Chicago: University of Illinois Press, 2000.

Smith, Peter H. Talons of the Eagle: Latin America, the United States, and the World, 3rd ed., Oxford: Oxford University Press, 2008.

Spinner, Thomas. A Political and Social History of Guyana, 1945-1983, Boulder, CO: Westview Press, 1984.

Statler, Kathryn C. and Johns, Andrew L., eds. The Eisenhower Administration, the Third World, and the Globalization of the Cold War, Lanham, MD: Rowman \& Littlefield Publishers, Inc., 2006.

Thomas, Clive Y. The Rise of the Authoritarian State in Peripheral Societies, New York: Monthly Review Press, 1984. 
Thorne, Christopher. Allies of a Kind: The United States, Great Britain, and the War Against Japan, 1941-1945, Oxford: Oxford University Press, 1978.

Ward, Joseph P., ed. Britain and the American South: From Colonialism to Rock and Roll, Jackson, MS: University Press of Mississippi, 2001.

Waters, Robert and Daniels, Gordon. "The World's Longest General Strike: The AFL-CIO, the CIA, and British Guiana," Diplomatic History, Vol. 29, No. 2, 279-307.

Waters, Robert Anthony, Jr. and Daniels, Gordon Oliver. "Striking for Freedom? International Intervention and the Guianese Sugar Workers' Strike of 1964," Cold War History, Vol. 10, No. 4, November 2010: 537-569.

Waters, Robert Anthony, Jr. and Van Goethem, Geert. American Labor's Global Ambassadors: The International History of the AFL-CIO During the Cold War, New York, Palgrave Macmillan, 2013.

Wedin, Ake and Johnston, T.L., trans., International Trade Union Solidarity: ICFTU 1957-1965, Stockholm: Bokforlaget Prisma, Publishers, 1974.

Wehrle, Edmund F. Between a River \& a Mountain: The AFL-CIO and the Vietnam War, Ann Arbor: The University of Michigan Press, 2005.

Westad, Odd Arne. The Global Cold War: Third World Interventions and the Making of Our Times, New York: Cambridge University Press, 2005.

Whitham, Charlie. Bitter Rehearsal: British and American Planning for a Post-War West Indies, London: Praeger, 2002.

Wilford, Hugh. “American Labour Diplomacy and Cold War Britain,” Journal of Contemporary History, Vol. 37 (1), 45-65, 2002.

Wilford, Hugh. The Mighty Wurlitzer: How the CIA Played America, Cambridge, MA: Harvard University Press, 2008.

Williams, Brackette F. Stains on My Name, War in My Veins: Guyana and the Politics of Cultural Struggle, Durham: Duke University Press, 1991.

Williams, William Appleman. The Tragedy of American Diplomacy, New York: W.W. Norton \& Company, 1959.

Winks, Robin and Louis, William Roger. The Oxford History of the British Empire, Vol. 5, Oxford: Oxford University Press, 1999.

Woods, Randall Bennett. A Changing of the Guard: Anglo-American Relations, 1941-1946, Chapel Hill: The University of North Carolina Press, 1990. 
Yergin, Daniel. Shattered Peace: The Origins of the Cold War and the National Security State, Boston: Houghton Mifflin Company, 1977.

Zubok, Vladislav M. A Failed Empire: The Soviet Union in the Cold War From Stalin to Gorbachev, Chapel Hill: The University of North Carolina Press, 2007. 